

\section{California \\ Range Brushlands \\ and \\ Browse Plants}




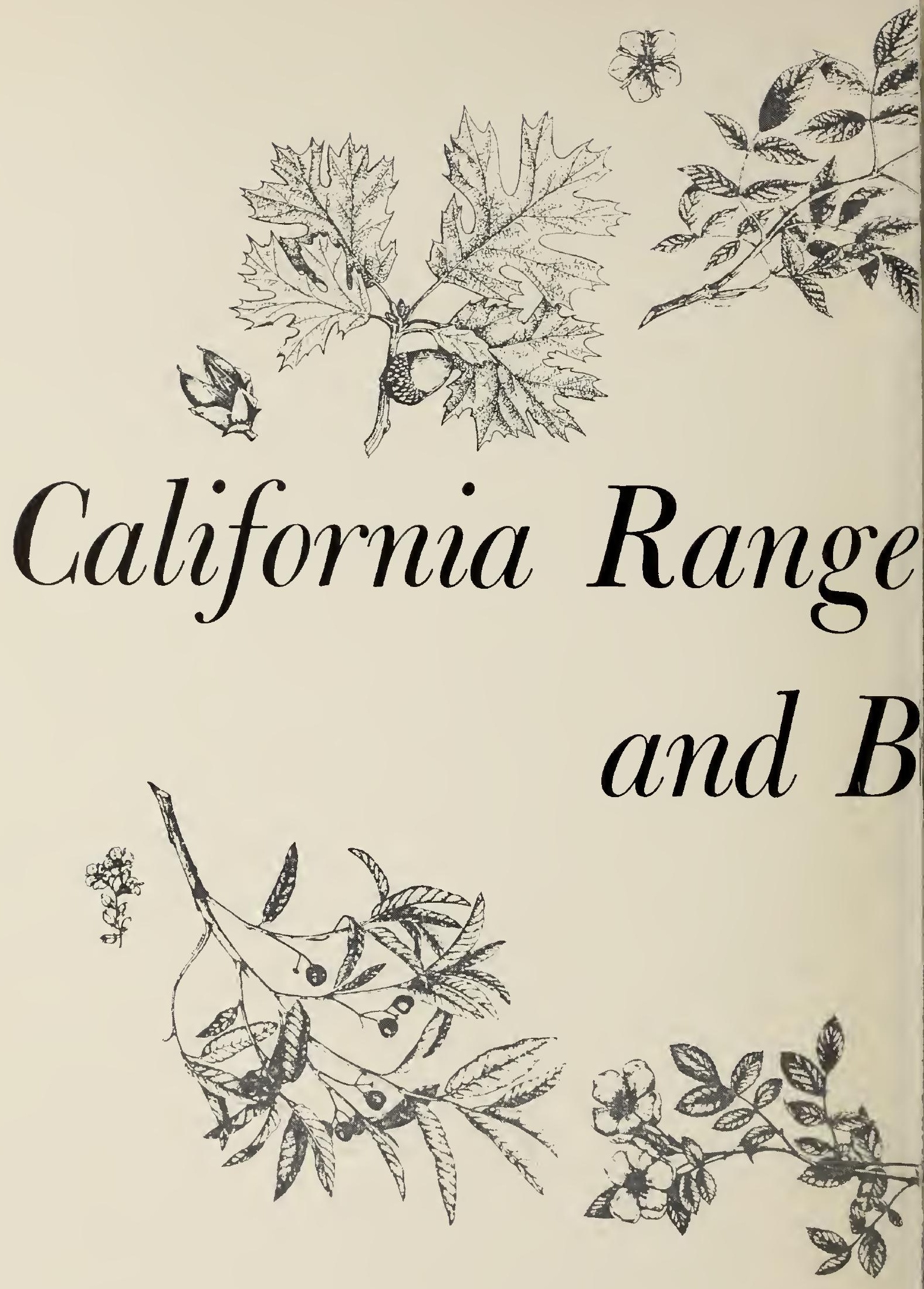

UNIVERSITY OF GALIFORNIA - DIVISION OF AGRIGULTU ( AI,IFORNIAAGRIGULTURAI, EXPERIMENT STATION E EXTE 

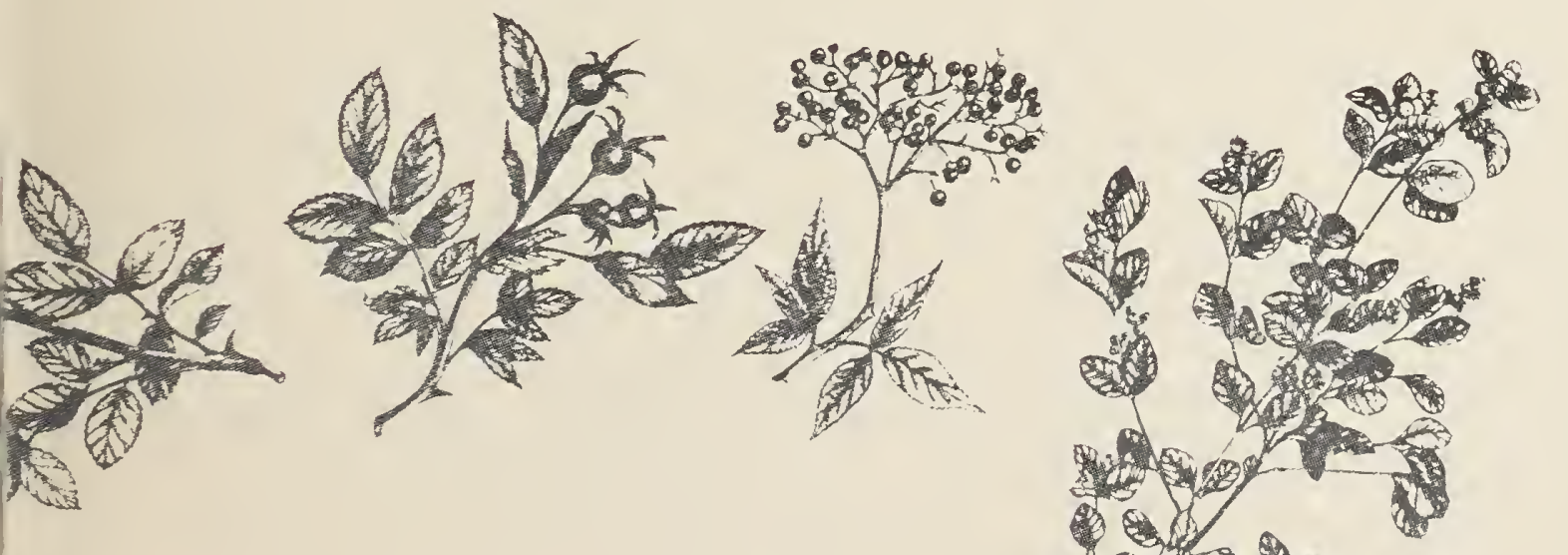

AL SCIENCES

; I O N E R VICE

LIBRARY

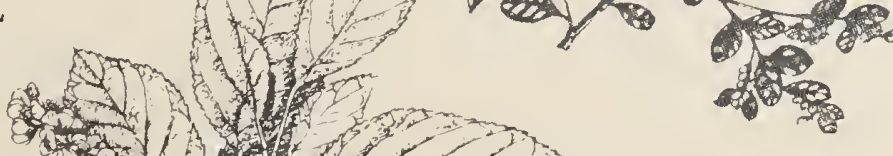




\section{Contents}

\section{PART I. BIOLOGICAL AND MANAGE- MENT CONSIDERATIONS}

Major lrushland communities............

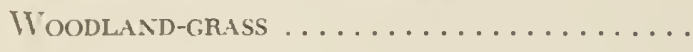

Cilaparral

TIMIBER CHAPARRAL . . . . . . . . . .

SAgEBrusi

Desert SHRub

Classification of California brushland soils

Livestock and big game; their reliance on browse.......................

Beef Cattle, Sileep, and Goats.........

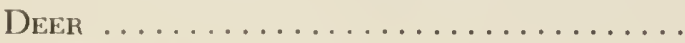

Prong-horn ANtelope $\ldots \ldots \ldots \ldots \ldots \ldots$

Otiler Big-game Animals.

Competition for forage between livestock and big game.

Conipetition Between Livestock and DeER

Conpetition BETWEeN LIVESTOCK AND

A.Ntelope . . . . . . . . . . . . .

CoM PETITION BETWEEN LIVESTOCK AND

Othen Big-game Animals...........

Economic and Social Aspects

Nutritional levels and trends of browse plants.

Seasonal Cinanges in Chemical Composition of Thiree Plant Groups..........

Diets of Four Animal Groups..........

Nutritional Requirements ...........

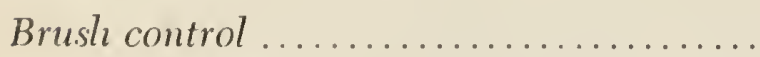

Acreage wilere Brusil Control Is Feasible

Estimate of Success in Range Improve-

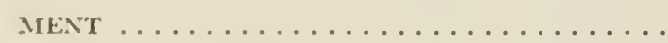

InCREASEd Grazing Capacity Based ON Potential Brusilland Converion......

Brush planting of depleted areas .........

Brushland improvement ................

Sitlection of Surtabide Sitris. . . . . . . . .

Bresil Rearovat, of Control, Burning.....

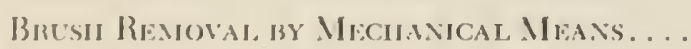

Bresil Rranowal witi Cimincals. . . . . .

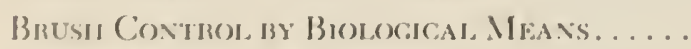

Minch Methom of Control? . . . . . . . .

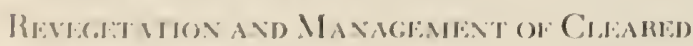

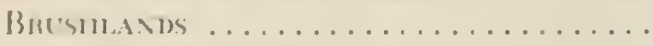

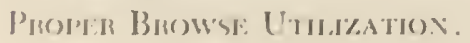

PAGE

1

2

3

5

6

7

7

9

9

11

13

15

15

15

16

17

17

17

18

20

21

21

22

25

26

26

27

28

28

29)

30)

31

32

\section{PART II. APPRAISAL OF BROWSE SPECIES}

Palatability and utilization of browse plants

PAGE

Over-all ratings of browse species ........

Principal browse families ...............

Recognition Key .....................

Discussion of individual browse species...

Cypress Fayily (Cupressaceae).........

Junipers (Juniperus) ................

Gnetum Family (Ephedraceae).........

Ephedra (Ephedra)................

Willow Family (Salicaceae) ...........

Willows (Salix)...................

Aspens, poplars, cottonwoods (Populus). .

Birch Family (Betulaceae) ............

Alders $($ Alnus $) \ldots \ldots \ldots \ldots \ldots \ldots \ldots \ldots$

Birches (Betula)...................

Hazelnuts, filberts (Corylus) . . . . . . . . .

OAK oR Beech Family (FAgaceae)........

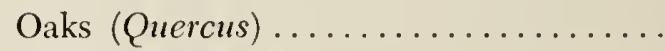

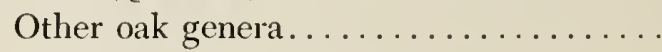

Elm Family (Ulmaceae)...............

Buckwheat family (Polygonaceae)......

Goosefoot or Saltbush Family (ChenopoDiACEAE) $\ldots \ldots \ldots \ldots \ldots \ldots \ldots \ldots$

Saltbushes or shadseales (Atriplex)......

Winter fat (Eurotia) . . . . . . . . . . . . . .

Hop-sage (Grayia)................

Greasewood (Sarcobatus) .............

Molly (Kochia)

LaUrel Family (Lauraceae) . . . . . . . . 70

Poppy Family (Papaveraceae)......... $7 \mathrm{l}$

Saxifrage Family (Saxifragaceae)....... 71

Currants and gooseberries (Ribes)....... 72

Mockorange (Philadelphus)........... 74

Rose Fanily (Rosaceae)............. 75

Bitterbrush (Purshia) .............. 75

Momtain-malogany (Cercocarpus)...... 78

Serviceberry (Amelanchier)........... S1

Chamise (Adlemostoma)............ \$2

Cliffrose (Comania)............... 8.5

Black bush (Coloogyme)............. 86

Sicrra mountain misery (Chamachatia)... 87

Cherries and plims (Prmms)......... \&S

$\operatorname{Roses}(\operatorname{Ros} a) \ldots \ldots \ldots \ldots \ldots \ldots \ldots \ldots . \ldots \ldots$

Toyon (Ileteromeles).............. 92

Other rosaceous species........... 92 
Pea or Legune Family (Leguminosae)....

Redbud (Cercis)...................

Deerweed (Lotus) ..................

Pickeringia (Pickeringia) ............

Caltrops Fanily (Zygophyllaceae)......

Box Family (Buxaceae) ...............

Sumac or Cashew Fanily (ANacardiaceae)

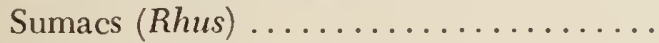

Maple Family (Aceraceae).............

HoRse-ChestNut FaMily (HipPoCASTANACEAE) $\ldots \ldots \ldots \ldots \ldots \ldots \ldots \ldots$

Buckthorx FaMily (RhaMnaceae).......

Ceanothus (Ceanothus)...............

Buckthorns (Rhamnus)..............

Grape Family (Vitaceae).............

Cacao or Sterculia Family (SterculiACEAE) ...................... 116

Oleaster Family (Elaeagnaceae)....... 117

SilkTASSEl F Fimily (GarryacEAE) ........ 118

Dogwood Family (Cornaceae).......... $\quad 119$

Dogwoods (Cornus) . . . . . . . . . . . . 119

Heather Faimily (ERICACEAE)........... . 121

Manzanitas (Arctostaphylos) .......... 122

Huckleberry, blueberry (Vaccinium).... $\quad 124$

Salal (Gaultheria) ................. $\quad 126$

Madrone (Arbutus) ................ 127

Ash or Olive Family (Oleaceae)........ 128

Ash (Fraxinus) .................. 128

Phacelia or Waterleaf Family (HydroPHYLLACEAE) .................... 129

Mint Fanilly (Lablatae).............. 130

Nightshade Familly (Solanaceae) ....... 132

HoNeysuckle F AMilly (CAPRifoliaceae) . . . 132

Elderberries (Sambucus) ............. 132

Snowberries (Symphoricarpos) ........ 135

Honeysuckle (Lonicera)............. 136

Sunflower Family (Compositae)........ 137

Sagebrushes (Artemisia)............. 137

Rabbitbrushes (Chrysothamnus)........ 140

Baccharis (Baccharis) ............. 142

Horsebrushes (Tetradymia).......... 143

Conifers ........................ 144

Tabular summation ratings of browse species................... $\quad 146$

Long-range suggestion for browse improvement ................. 149

LITERATURE CITED ............. 151 INDEX OF RANGE BROWSE PLANTS 157

\section{This manual provides information on the} techniques of converting wild brushlands to grass or of extending desirable browse species where this is suitable. It will be especially helpful if you are among these readers:

- Stockmen and sportsmen who desire additional information on the relative usefulness and identity of the browse plants growing on their ranges or on brushlands where they hunt or seek other forms of recreation.

- Range technicians and range appraisers who are chiefly concerned with the management, evaluations, and general welfare of the state's wild range lands; and

- Students of range management and related fields whose knowledge of ecology, browse values, and taxonomy of the browse plants is an essential part of their training.

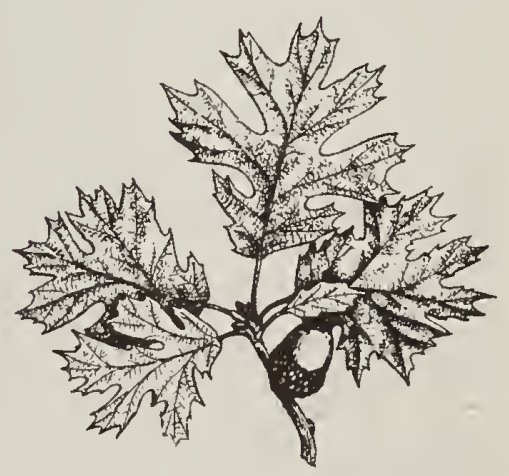




\section{Acknowledgments}

The anthors take plcasure in acknowledging the assistance and suggestions of those who contributed in one way or another to this work. NED A. Surnu compiled useful information on brushland management and individual browse species while pursuing graduate work at the University of California. The late Mrs. Patricia R. Haskey drew the key illustrations. To Miss Aida Montien thanks are expressed for the graphic illustrations and the pen-and-inkdrawings of individual species. The distribution maps of species were mostly prepared by Mrs. R. W. EMbreE. The map showing locations of the major brushland arcas of coastal ranges and Sierra Nevada foothills of the state was provided through the courtesy of A. E. Wieslander, retired, and Clark H. Gleason of the Pacific Southwest Forest and Range Experiment Station, U. S. Forest Service. To Helen R. Sampson special gratitude is expressed for her painstaking cooperation in preparing and checking the work maps on distribution of the individual species, for mounting the figures and checking the descriptions, and for proofreading. Among the colleagues who read parts or all of the manuscript and who offered constructive suggestions the following were especially helpful: J. R. BENTley, H. H. Biswell, L. T. Burcham, Annetta Carter, IV. L. Colivell, D. R. Cornelius, F. P. Cronemiller, IV. P. Dasilani, R. A. Gardner, C. H. Gleason, H. F. Heady, J. L. Hiehle, A. L. Hormay, E. C. Hjersman, H. R. Leach, W. F. Longhurst, R. M. Love, E. C. Nord, Vic. Osterly, C. R. Quick, A. M. Schultz, James Street, Mrs. H. K. Sharsimti, R. D. Taber, A. E. Wieslander, and E. J. Woolfolk.

The photographs on pages 3,5 col. 2, 6, 86, and 104, and the map on page 3 were supplied by the U. S. Forest Service.

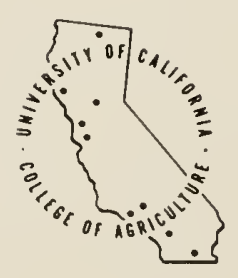

тне acthols: Arminu IV. Sampson is Professor of Forestry, Emeritus, and Plant Ecologist, Emerilus, in the Agricultural Experiment Station, Bcrkeley; Beryt. S. Jespersen, formerly Botanist with the Soil-Vegetation Survey of the Pacific Southwest Forest and Range Experiment Station, is Staff Botamist, Garden Department, Sumset Magazime, Lane Magavine Company, Menlo Park, Callifornia.

\section{NOVEMBER, 1963}

This manual is one of a series published hy the University of California Ditision of Agricularal Sciences and sold al a price which refurns omly a portion of the production cost. By this means it is possible to moke available publicotions which, due to relatively high

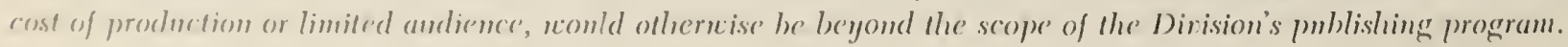




\section{California \\ Range Brushlands and \\ Browse Plants}




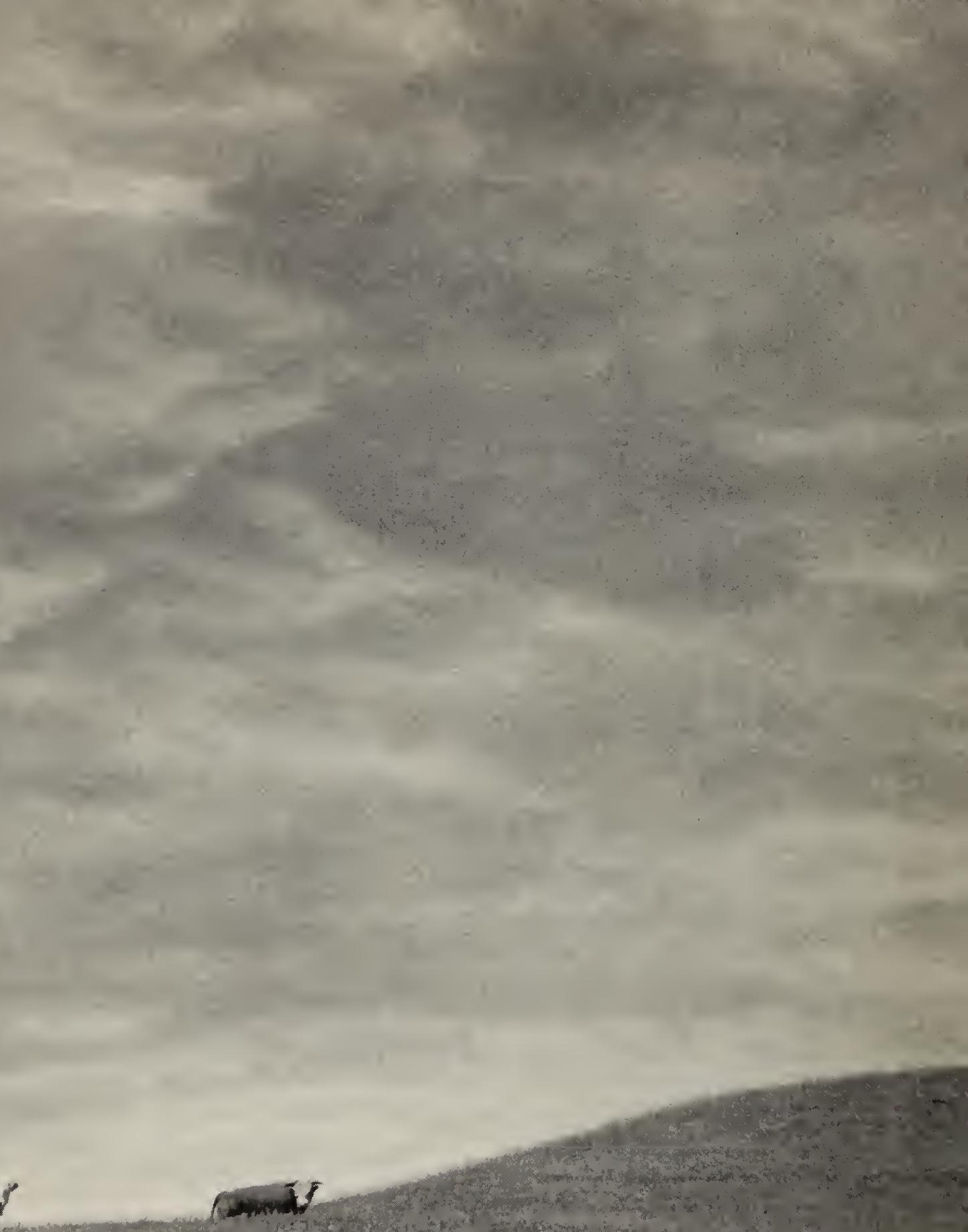

\section{ats}

and

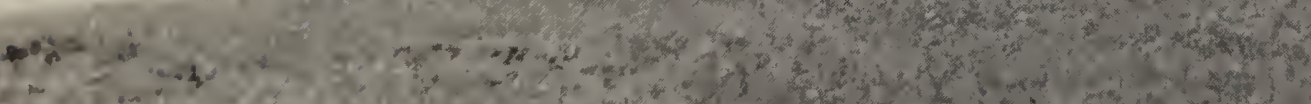

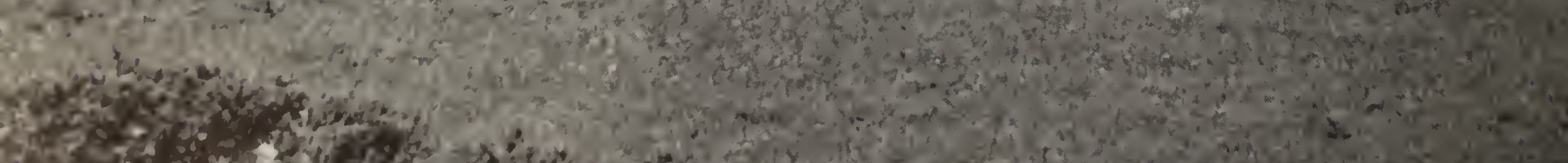
C.

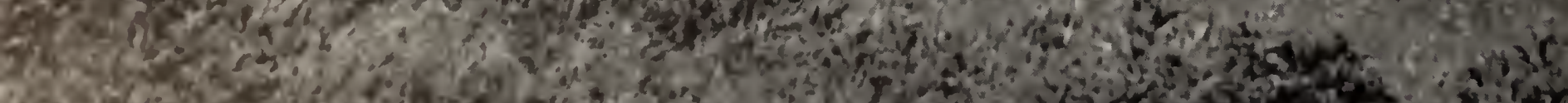

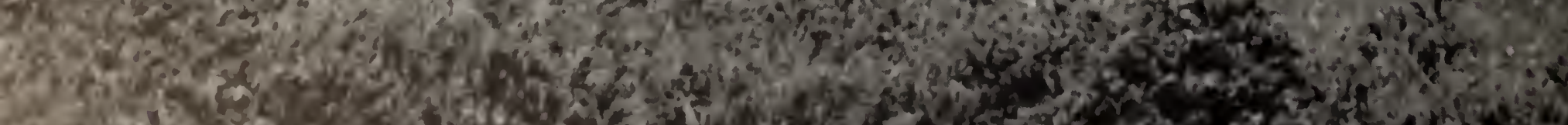

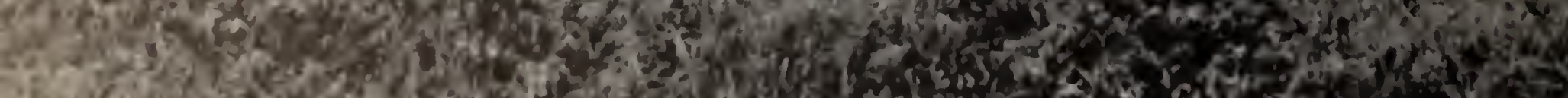
Fon

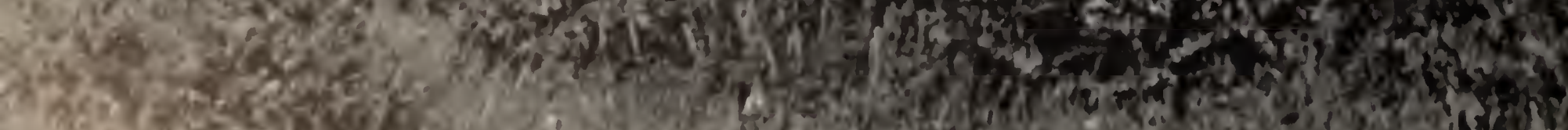

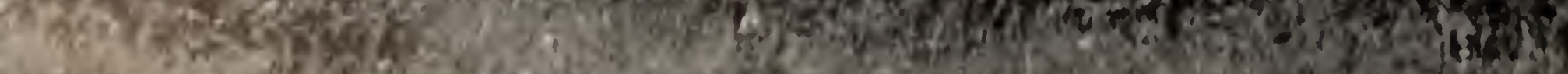

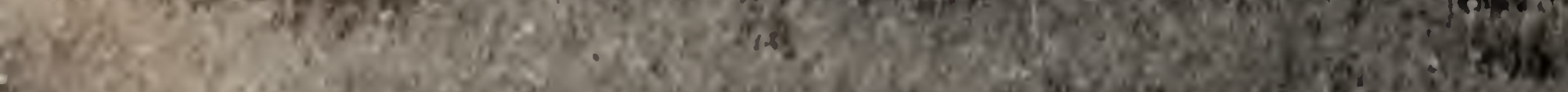
S.

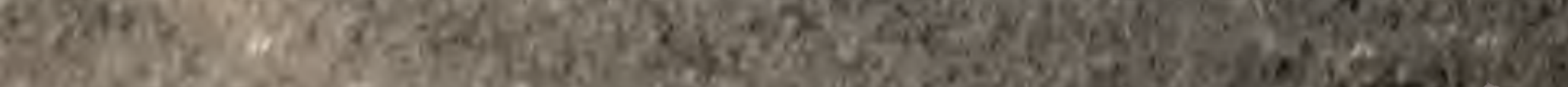




\section{PART I. BIOLOGICAL AND MANAGEMENT CONSIDERATIONS}

A LaRge proportion of the California FoOthills supports brushy vegetation. Some brush stands are so dense that they exclude most understory vegetation; others are more open and support an undercover of grasses and forbs (broadleaved herbs such as dandelion and cow parsnip). In some localities the brush is low in palatability while in others valuable browse species are abundant. In many areas the herbaceous vegetation has decreased measurably as a result of invading brush.

In this manual, "brush" is used as a collective term and refers to stands or fields of shrubby woody plants or low-growing trees, regardless of whether some of the components are cropped or not. On the other hand, "browse" refers to woody plants of all life forms which have palatable parts that are eaten by livestock or biggame animals.

Although grass, together with various forbs, provides the largest volume of forage that grows naturally on California ranges, browse is an important constituent of the food supply in many places. Browse for some kinds of domestic stock is somewhat seasonal, but for deer and antelope it provides most of the diet throughout the year $^{(23 \pi)}$. Cattle and sheep crop the leafy sprouts, as on recently burned areas, more closely than the current twig growth of unburned stands, from early spring to early summer. After midsummer the leaves and stems of most species decline in palatability and nutrition. Even so, late in the summer, after the annual grass and forb cover has dried up, a bordering stand of palatable browse mav provide nutrients such as protein, and vitamin A for livestock that are deficient in the herbaceous forage.

Stockmen differ in their appraisal of brushlands largely because of differences in quality of the brush species present and the local grazing management practices. Sheep and goat growers have higher regard for brush areas than cattlemen because their animals browse much more extensively than do cattle.

Many brush areas are in need of being opened up, especially when:

- They impede the movement of livestock through the stands and thus prevent full utilization of the area.

- They are so dense as to crowd out grasses and forbs which otherwise would grow well on the site.

- The shrubs are decadent or "high-lined," so the forage is largely unavailable to browsing animals.

- Most of the brush stand is low in palatability.
On brushy lands of various kinds several agencies ${ }^{43,70,}$ ${ }^{78,83,145)}$ have demonstrated that opening up of dense brushfields, followed by good management, may greatly improve grazing for livestock and deer. Another technique under investigation is that of planting superior brush species on ranges where they have been destroyed by overbrowsing $^{(163)}$. Also chemical spraying may be used to favor desirable species by lessening competition.

Improvement of brushlands largely depends on our information and techniques for replacing undesirable brush stands with a desirable grass cover, and on our knowledge of how to regenerate and maintain a depleted useful brush cover. Success in either of these procedures is essentially based upon sound ecological principles $^{(15,13,84,157)}$.

\section{Major Brushland Communities}

A knowledge of the nature of the brushland communities of California is helpful in understanding the various problems of brush management. The term "plant community" implies the aggregation of a specific life form of plants, such as shrubs, grass, or forest, having mutual relations among themselves and with their environment.

The most extensive brushlands are found in the foothills of the coastal ranges and the Sierra Nevada, where they comprise a discontinuous cover from slightly above the valley floor to the lower limits of the commercial coniferous forests, mostly between elevations of 500 to 4,000 feet. This zone includes wide variations in topography, climate, and soils. More restricted brushlands extend into the commercial forest zone.

The Pacific Southwest Forest and Range Experiment Station has divided the wildlands of the State into three broad vegetal belts ${ }^{(150,161)}$ : the rolling grasslands of the lower foothills; the woodland-grass which lies immediately above; and the chaparral which occupies extensive areas of the rougher lands bordering on the woodland below and the commercial coniferous forest above. (See photographs on pages 2,3 .) The land units occurring within each of these major belts, including their acreage, are listed in the table below (data compiled by the $\mathrm{Pa}$ cific Southwest Forest and Range Experiment Station ${ }^{(158,}$ ${ }^{161)}$ and by Jensen ${ }^{(80)}$ and Sampson and Burcham ${ }^{(128)}$ ).

Brushfields of varying extent occur in each of the three major belts. The diagrammatic map of the foothill brushlands on page 3 shows that brush occurs virtually throughout the length of the State west of the Sierra 


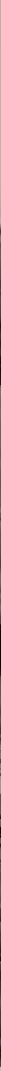

The wildlands of California are divided into three zones:

The rolling grasslands of the lower foothills. Shown here is grassland in Tulare County, with occasional live oak trees. The dominant vegetation consists of slender wild oats (Avena barbata) and redstem filaree (Erodium cicutarium). This area had been utilized lightly.

Nevada and Mojave Desert. The brush problem of the foothill ranges centers in an area of some 20 million acres. About 55 per cent (11 million acres) of this problem area is largcly dominated by brush, the rest is dominated by mixtıres of hardwood trees, brush, and grass.

Table 1
KIND OF RANGE

Primary foothill range:

Grass

Woodland-grass

7.5

Secondary foothill range:

Chaparral

Woodland

Minor conifers

8.5

2.0

1.5

0.5

12.5

Mountain range: $\dagger$

Pine-fir-redwood t

Woodland-chaparral

Criss

3.9

0.6

0.4

4.5 .3
Coastarl sagebrush

Siage-lorush-juniper

The woodland-grass belt above the grassland, San Joaquin Experimental Range. In the foreground annual grasses and forbs compose the cover; in the background blue oak, interior live oak, and Digger pine with understory of ceanothus, manzanita, and coffeeberry prevail.

Discussion of the foothill range problem is sometimes confusing because of statements about " 10 million acres or thercabouts" of brushland in California ${ }^{(s)}$. This figure is apparently based on data compiled in a study of timber areas and vegetation types in California ${ }^{(1.58)}$ that includes only the true chaparral, some of which is located in the timber zone. It does not include the coastal sagebrush, Great Basin sagebrush, various noncommercial hardwoods, or the 24 million acres of desert, all of which may be designated as "brush," depending on how the term is used. Further, it does not include the 7 $1 / 2$ million acres classified as woodland-grass, where chaparral has increased in abundance in recent years.

The individual brushland communities are discussed under five headings: woodland-grass; chaparral; timberland chaparral; sagebrush, and desert shrub.

\section{WoODLAND-Grass}

This community occupics the lowest clevations of the bruslyy vegetation. It comprises some $7 \frac{1}{2}$ million acres and forms a discontinuous zone on the lower slopes of the eoastal ranges, the Klamath Mountains, the Sierra Nevada, and southward into the peninsular ranges of southern California, between clevations of about 500 to 2,500 feet but cxtending upwards into higher clevations on warner slopes. The topography is mostly gentle and many areas have deep, fairly fertile soils. Average ammual rainfall is 15 to 40 inches, with little fog; the growing season is 7 to 10 months, with diry hot summers and wet, moderately cold winters. 


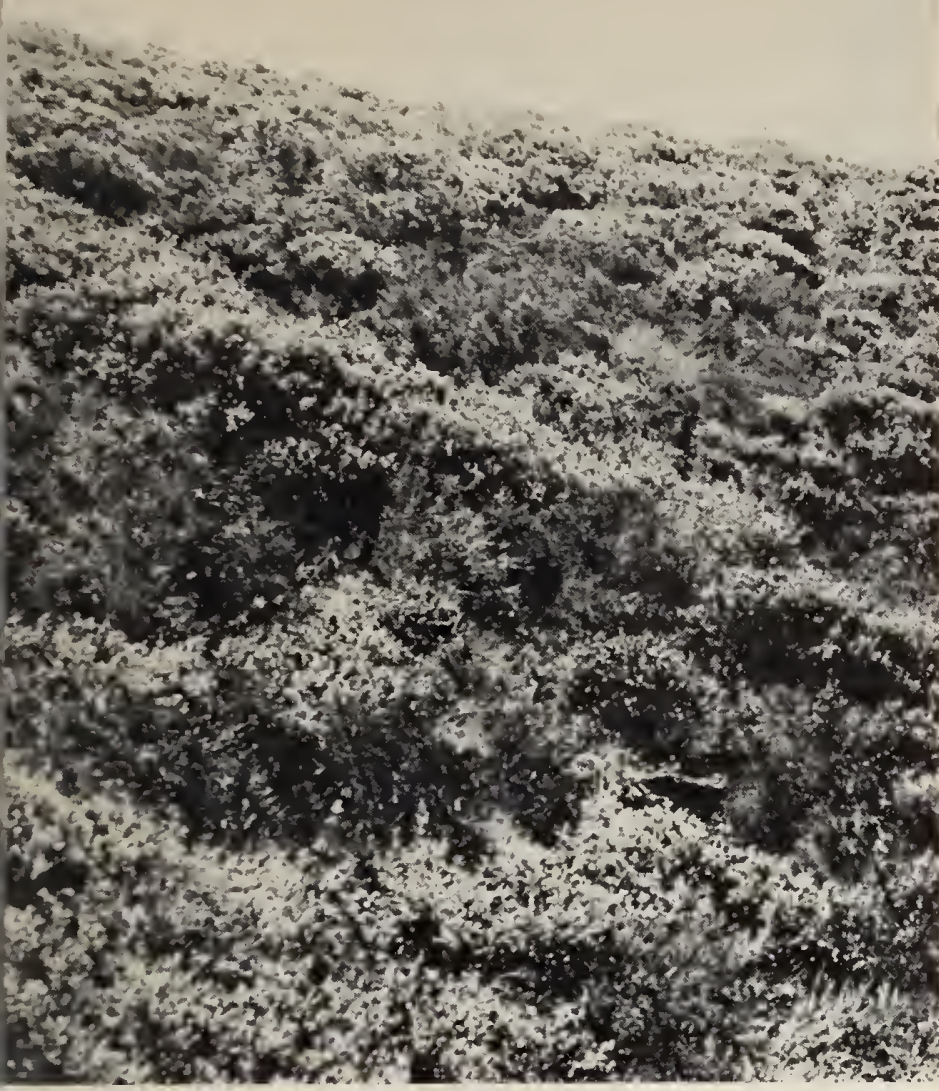

The chaparral region. The area shown here is in Shasta County. The chaparral is composed of a mixture of chamise and manzanita. The area is rocky, the soil thin and infertile. It is a poor site for conversion to grass.

Common tree species in the woodland-grass region are coast live oak (Quercus agrifolia), valley white oak $(Q$. lobata), canyon live oak (Q. chrysolepis), interior live oak (Q. wislizenii), blue oak (Q. douglasii), and Oregon white oak ( $Q$. garryana). These trees give the characteristic aspect to much of the woodland-grass and foothill woodland. Other common trees are Digger pine (Pinus sabiniana), madrone (Arbutus menziesii), and California buckeye (Aesculus californica). Common shrubs are: dwarf interior live oak (Quercus wislizenii var. frutescens), wedgeleaf ceanothus (Ceanothus cuneatus), chaparral whitethorn (C. leucodermis), western mountain-mahogany (Cercocarpus betuloides), manzanitas (Arctostaphylos spp.), California coffeeberry (Rhamnus californica), hollyleaf redberry (R. crocea var, ilicifolia), western redbud (Cercis occidentalis), and California yerba santa (Eriodictyon californicum).

Many of the above listed species provide good feed for sheep, goats, and deer, and some are palatable to cattle. The foothill woodland-grass and the chaparral are much intermingled in the lower elevations. The herbaceous understory, as well as the open grasslands of this zone, consist largely of early-maturing exotic (Mediterranean) annuals, such as fescues (Festuca spp.), bromes (Bromus spp.) wild oats (Avena spp.), and filaree (Erodium spp.) bur clover (Medicago hispida), and various less palatable forbs. The foothill woodland-grass affords better possibilities of conversion to grass than does any other brushland community, partly because fewer woody species sprout when cut or burned ${ }^{(15,126)}$, and because the soils generally are deeper and more fertile. (See photos on page 4$)$. When once the seed from mature plants is eliminated and the seed source in the soil is exhausted, recurrence of brush is limited to invasion from distant areas.

\section{Chaparral ${ }^{*}$}

This community occurs west of the Sierra Nevada summit and Mojave Desert. It occupies dry slopes and ridges of thin soils between elevations of about 1,000 and 4,000 feet over an area of some 11 million acres, including the coastal sagebrush association and the minor coniferous elements. The summers are hot and dry, the winters moderately cold, annual rainfall ranges from 15 to 40 inches.

The most characteristic and widely distributed chaparral species is chamise (Adenostoma fasciculatum). Other common species are California scrub oak (Quercus dumosa), scrub interior live oak (Q. wislizenii var. frutescens), leather oak $(Q$. durata), California coffeeberry (Rhamnus californica), hollyleaf redberry (R. crocea var.

\footnotetext{
- Chaparral is from the Spanish word chaparro, an evergreen oak. In the more common usage chaparral is any dense thicket of stiff or thorny shrubs or dwarf trees. A collective term applied in western United States to the shrubby "hard" brush.
}

Distribution of major brushland areas of the Coast Ranges and Sierra Nevada foothills. The shaded area shows the extent of the zone, some 20 million acres, which is the main area of brush problems, outside of commercial timber areas. The darker shaded area covers 9 million acres of cover types containing mixtures of hardwood, trees, brush, and grass (woodland-chaparral, woodland-grass, and woodland). The lighter shaded area comprises 11 million acres of cover types made up predominantly of brush species (chaparral, coastal sagebrush, and minor conifers).

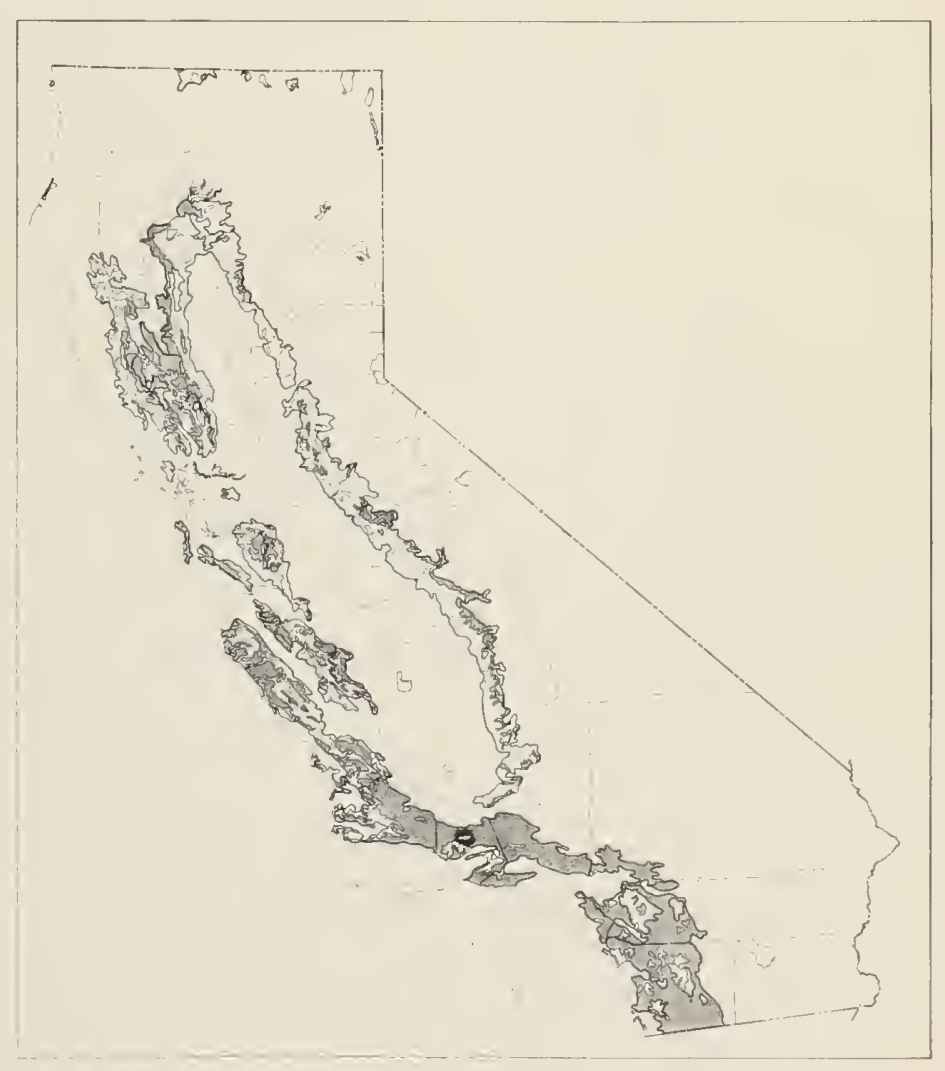


ilicifolia), western redbud (Cercis occidentalis), ceanothus (Ceanothus spp.), California yerba santa (Eriodictyon californicum), manzanitas (Arctostaphylos spp.), and chaparral pea (Pickeringia montana), and California laurel (Umbellularia californica).

Chaparral varies greatly in composition, size, and appearance from onc arca to another and even within the same species; plants may be from less than 2 feet to more than 10 feet in height, and range from compact shrubs to tree-like. Frequently chaparral forms nearly pure stands but it also grows in association with the coniferous forest. Typically, the chaparral element has leaves that arc relatively small, thick, wax-coated, simple, and evergreen, called sclerophyll. These plants have extensive root systems and can endure long, hot, and drv summers. Many species sprout when cut or burned; others reproduce only by seed (upper photo on page 5). The composition of the chaparral also differs perceptibly from one climatic region and soil type to another. From Shasta County northward, for example, manzanita and ccanothus predominate; from Shasta County to Los Angeles County, chamise, ceanothus, and scrub oaks are most abundant; from Orange to Riverside counties southward, poison-oak (Rhus diversiloba), wild buckwheat (Eriogonum spp.) and yerba santa (Eriodictyon spp.) are common, but they do not displace the dominants.

In contrast to sclcrophyll chaparral are the closely associated units of deciduous shrubby species that occupy the moister canyons, draws, bottom lands, and protected pockets and flats of the chaparral. These shrubs have relativcly large and thin leaves, somewhat succulent nonthoriny stems, and rather restricted root systems. At the lower elevations of the chaparral common species are alders (Alnus spp.), California buckeye (Aesculus californica), elderberries (Sambucus spp.), flannel bush (Fremontia californica), wild cherries (Prunus spp.), poison oak (Rhus diversiloba), squaw bush ( $R$. trilobata), and willows (Salix spp.). At higher elevations, as in the ponderosa pine timber zone, common species are deerbrush ceanothus (Ceanothus integerrimus), common snowberry (Symphoricarpos albus), dwarf maple (Acer glabrum), thimbleberry (Rubus parviflorus), wild roses (Rosa spp.), and western mountain-mahogany (Cercocarpus betuloides).

The question is often asked: How stable is the chaparral cover? On the foothill ranges of California, chaparral species occur in two characteristic situations. The one situation is where they are typical associates of what is essentially the primary succession, and are associated with pioneer plants in habitats where the soil mantle is in the early stages of development. Such locations have shallow, typically infertile soils overlying fractured bedrock. Soils of this nature usually reflect the influence of chaparral as a soil-forming factor. Here the chaparral persists through the different stages of plant succession, even in the subclimax and climax (lower photo page 5, col. 1). The second characteristic situation is where the chaparral occurs in secondary successions on disturbed areas. This cover change to chaparral occurs where a relatively well-developed plant cover in a more advanced stage of succession has been partly or wholly destroyed by fire, overgrazing, clearing, accelerated erosion, or the like, and is replaced by plants in a different stage of succession. Most of these latter areas have deep and relatively fertile soils, well suited to forage production. These secondary successions frequently occur on

\section{The woodland-grass region can sometimes be converted to agricultural use}

In foreground, fertile cultivated flat where the brush has been removed The hills support nearly al pure stand of chamise which occupies thin infertile soil. A sizeable acreage of reasonably level woodland-grass area has been converted to agricultural land. Other units have provided sites for homes and even factories.
Shrub and grass mixture on the San Joaquin Experimental Range. Chaparral whitethorn, left, is in full bloom. Associated woody species are blue oak, Digger pine, wedgeleaf ceanothus, hollyleaf redberry, California coffeeberry, Mariposa manzanita, and annual grasses and forbs.

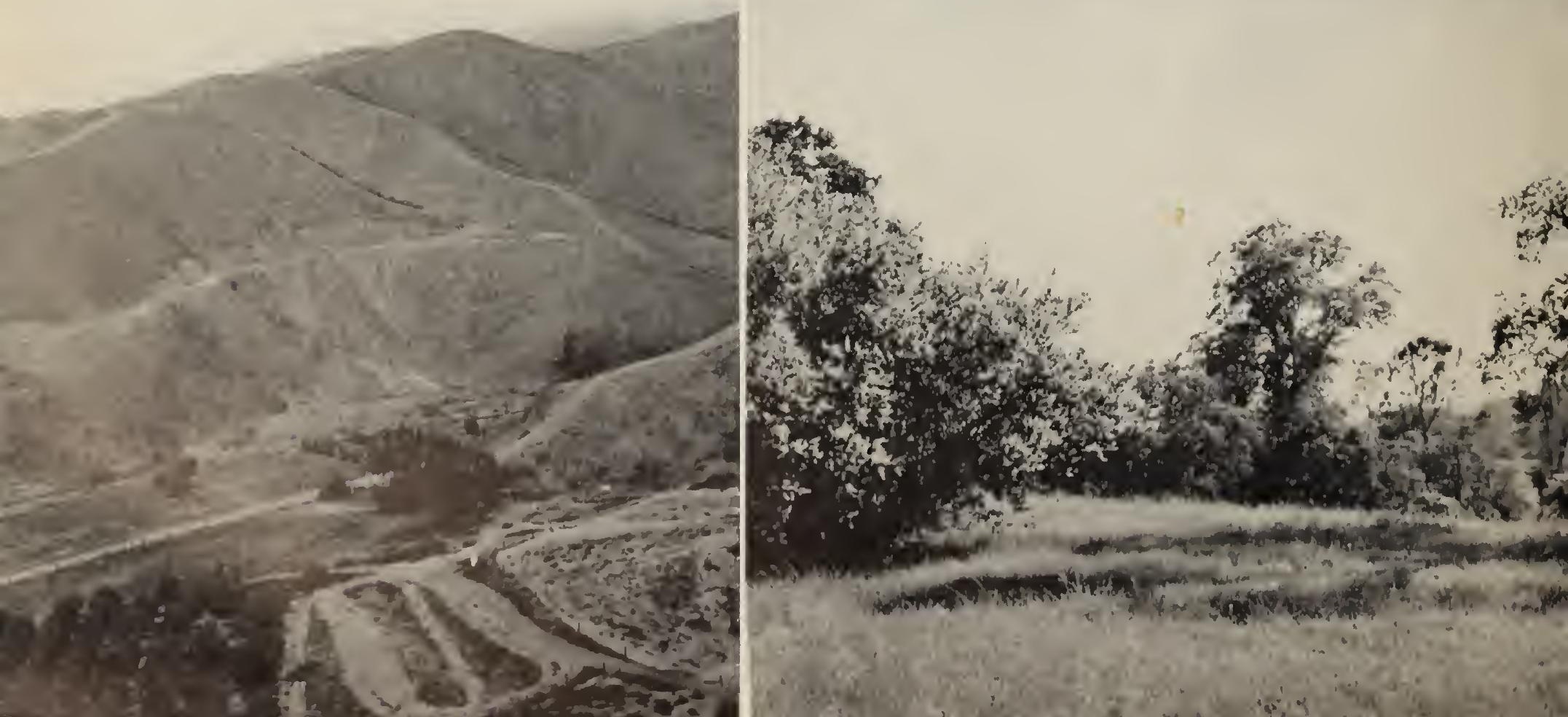




\section{SAGEBRUSH}

This community consists of two associations, the California Great Basin sagebrush and the coastal sagebrush.

The California Great Basin sagebrush is an extension of the Great Basin sagcbrush association to the north and cast. In California it occupies an area of some 3.9 million acres. It occurs on the Modoc Plateau as far west as Siskivou Countr in the north, and along the western cdges of the Mojave Descrt, southward into San Diego Countr. The elcrational range in the north is betwecn 4,000 and 5,500 feet and in the sonth 6,000 to 7,000 feet. Rainfall ranges from 5 to 15 inches and the summers are ncarly as hot as in the desert shrub area ${ }^{(108)}$. The shrubs are mostly low-growing and dcep-rooted, with reduced lcaf surface, and xerophytic in character. Dominant spccics arc big sagcbrush (Artemisia tridentata), black sagebrush (A. arbuscula var, nova), junipers (Juniperus spp.), rabbithrushes (Chrysothammus spp.), saltbushes (Atriplex spp.), curllcaf mountain-mahogany (Cercocarpus ledifolius), bitterbrush (Purshia tridentata), gray horschrush (Tetradymia canescens), shortspine horsebrush (T. spinosa), and saltbushes (Atriplex spp.) (photo below). The color tone is predominantly gray.

The mnderstory vegetation is composed largcly of percnnial grasses, such as wheatgrasses (Agropyron spp.), Indian ricegrass (Oryzopsis hymenoides), wildryes (Elymus spp.), bluegrasses (Poa spp.), and fescues (Festuca spp.). There arc many inconspicuous forbs.

Foragc values are somewhat higher than in the conifcrous woodland. It provides good summer and fall forage for livestock and is exceptionally valuable as winter range for deer and antelope.

The coastal sagebrush association, generally regarded as a segment of the chaparral, occurs along the coast from San Francisco Bay into Lower California, mostly below 3,000 feet elevation, and occupies about 2 million acres. A large proportion of the plants arc subshrubs, similar in this respect, and in drought-endurance, to spccies of the Great Basin sagebrush. The dominants are coast sagebrush (Artemisia californica), white, black, and purple sages (Salvia apiana, S. mellifera and S. leucophylla), California buckwheat (Eriogonum fasciculatum), chaparral broom (Baccharis pilularis var. consanguinea), laurel sumac (Rhus laurina), lemonadebcrry ( $R$. integrifolia), and sawtooth golden bush (Haplopappus squarrosus). Scattered perennial grasses occur throughout the area, the most common being needlegrasses (Stipa spp.), melicgrasses (Melica spp.), fescues (Festuca spp.), and bromes (Bromus spp.). Sandy beaches and duncs occur along the entire coast. Annual rainfall ranges from 10 to 18 inehes over the main area but is only 5 to 10 inches in southern California. Temperatures are mild and the community is essentially frost-free ${ }^{(105)}$.

The grazing values of this assoeiation, like those of the chaparral, are inversely proportional to the density of the brush. Grazing capacity is relatively low. Recreation and homesites are becoming increasingly important uses, in many localities far exceeding the grazing values.

The coastal sagebrush elcment has mostly gray leafage, thus giving the cover much the same color-cast as the Great Basin sagebrush.

Sagelurush in the interior provide forage for livestock and a winter range for deer and antelope; on the coast it is becoming important for recreational uses

This site in the Inyo National Forest, 7,900 feet above sea level, is typical for the low-growing, decp-rooted, dense bitterbrush-sagebrush association. Average age of forest or sagebrush stand 26 vears.

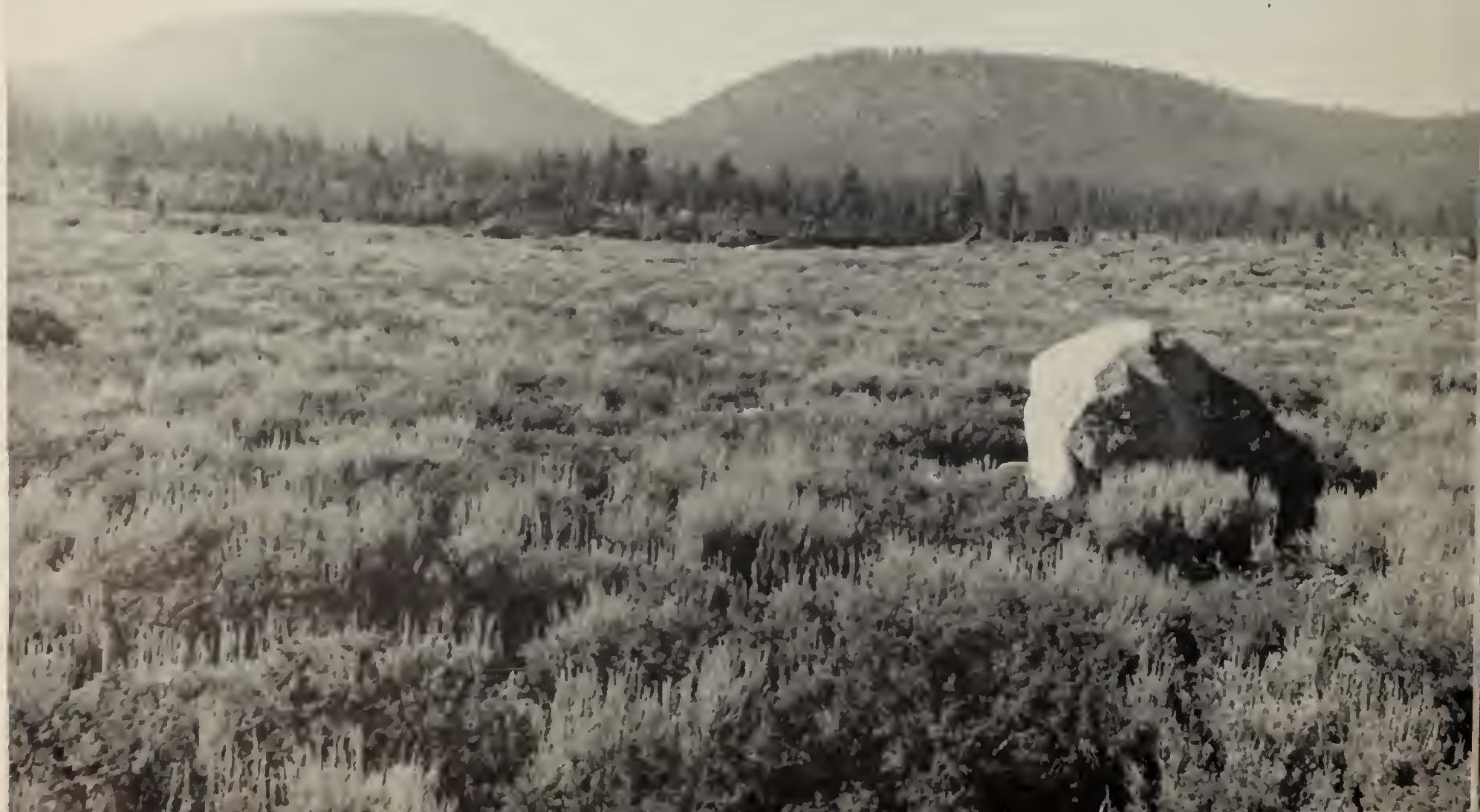




\section{Desert Shrub}

The desert shrub is the most xeric of all the brushland communities. It is found in the Mojave and the Colorado deserts and extends northward into Owens and Death valleys. This area encompasses some 24 million acresnearly one-fourth of the area of the State. Desert shrub occurs from well below sea level in the Colorado Desert and Death Valley to 4,000 feet elevation in Owens Valley. Precipitation ranges from 2 to 10 inches a year, with occasional summer showers at the higher elevations where precipitation is greater. The shrubs have many characteristics of extremely xerophytic vegetation, such as deep or widely spreading root systems, reduced leafsurface, and tissues that can store water. Unlike other brushland communities, the shrubs are usually spaced from 10 to 30 feet apart.

Creosote bush (Larrea divaricata), which extends over hundreds of square miles and in places forms nearly pure stands, is the outstanding dominant plant (upper photo on the right). Associated shrubs are burro-weed (F ranseria dumosa), rubber rabbitbrush (Chrysothamnus nauseosus), ocotillo (Fouquieria splendens), and such cacti as Echinocereus engelmannii, Opuntia bigelovii, and $O$. echinocarpa. The understory is composed of a scattered cover of big galleta (Hilaria rigida), desert saltgrass (Distichlis stricta), threeawns (Aristida spp.) and gramagrasses (Bouteloua spp.). Annual and perennial forbs are common. On mesas and slopes of the Mojave Desert and southern Owens Valley open stands of Joshua tree (Yucca brevifolia), together with California and Utah junipers (Juniperus spp.), called Joshua tree-woodland by some botanists ${ }^{(103)}$, accent the dry conditions (lower photo on the right). Where the mesas and flats are poorly drained and the soil underlain with hardpan, the dominants are saltbushes (Atriplex spp.), winter fat (Eurotia lanata), spiny hop-sage (Grayia spinosa), and broom snakeweed (Gutierrezia sarothrae). The water courses support honey mesquite (Prosopis chilensis), desert-willow (Chilopsis linearis), and desert ironwood (Olneya tesota).

This community contributes little forage, since water shortage restricts grazing to the winter months.

\section{Classification of California Brushland Soils*}

Brushland communities occupy many divergent soil series and soil types, as would be expected in view of the many combinations of plant forms-grass, broad-leaved trees, and coniferous forests-where brush occurs.

Most of the soils falling into the category of "brushland soils" are upland soils. Nearly all valley soils in the intermediate-to-high rainfall zone are cultivated, hence the brush cover, if formerly present, has been removed. The upland soils in the intermediate-to-high rainfall zone comprise more than 50 per cent of the area of the State, or more than 50 million acres.

\footnotetext{
- This section was contributed by R. Earl Storie, Professor of Soil Science and Soil Technologist in the Agricultural Experiment Station, University of California, Berkeley.
}

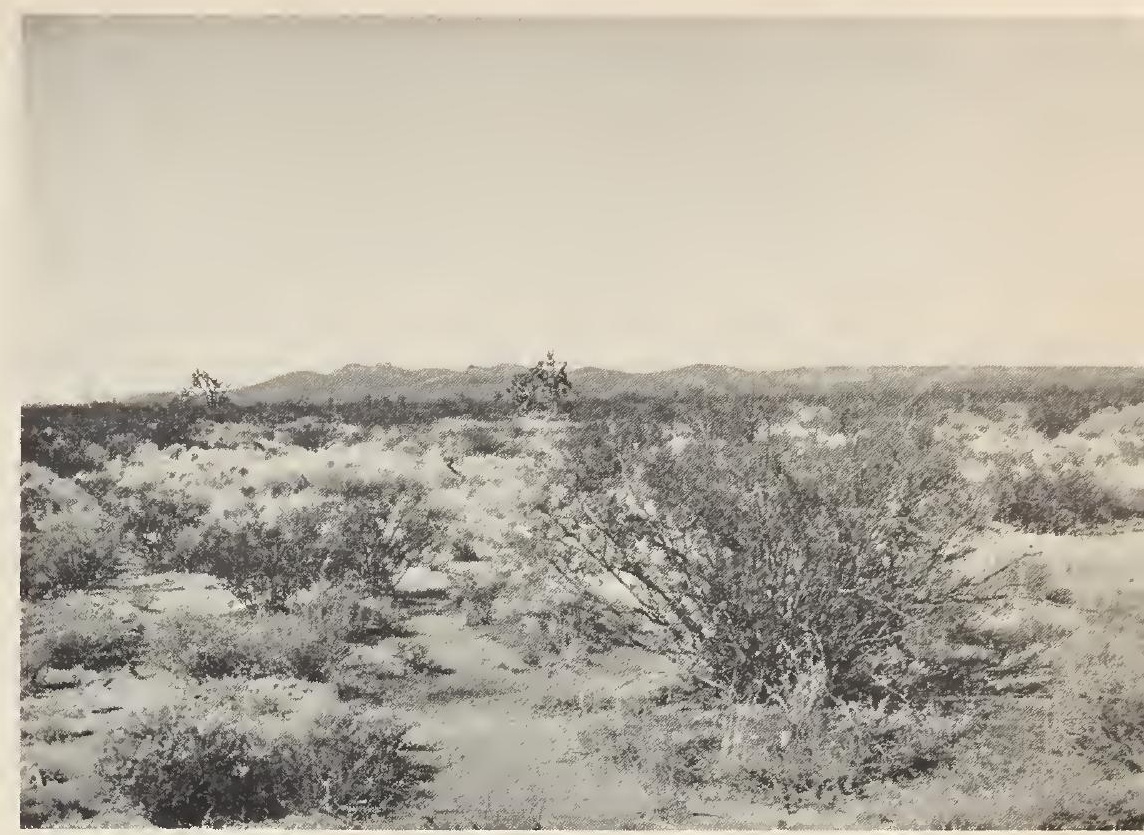

Creosote bush, shown here in San Bernardino County, is dominant in the desert-shrub region. It grows in association with broom snakeweed (Gutierrezia sarothrae), saltbushes, rabbitbrush, and scattered patches of grasses.

\section{The desert shrub area extends over almost one- fourth of California; it has little grazing value.}

More picturesque are Spanish bayonet (Yucca baccata) on left and Joshua tree (Y. brevifolia) on right, also in San Bernardino County. Scattered about are white burrobrush (Hymenoclea salsola), annual grasses, and forbs.

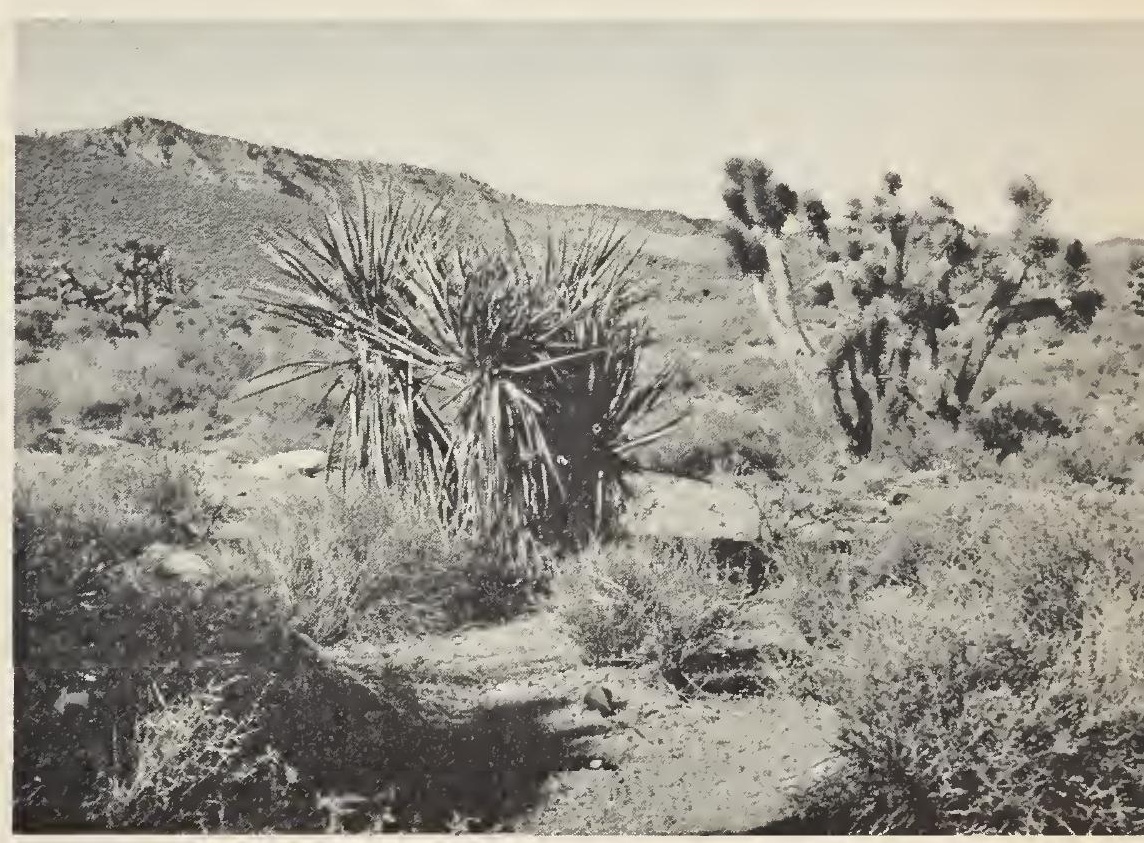

The upland soils are classed in four main categories, and are shown as such on the Generalized Soil Map of California ${ }^{(139)}$. They are as follows:

Ex-Residual soils of very shallow depth to bedrock, usually stony, and variable in color and reaction. They are called lithosol soils. Four lithosol soils are described in the drawing page 8: (1) Maymen stony loam; (2) Henneke stony clay; 


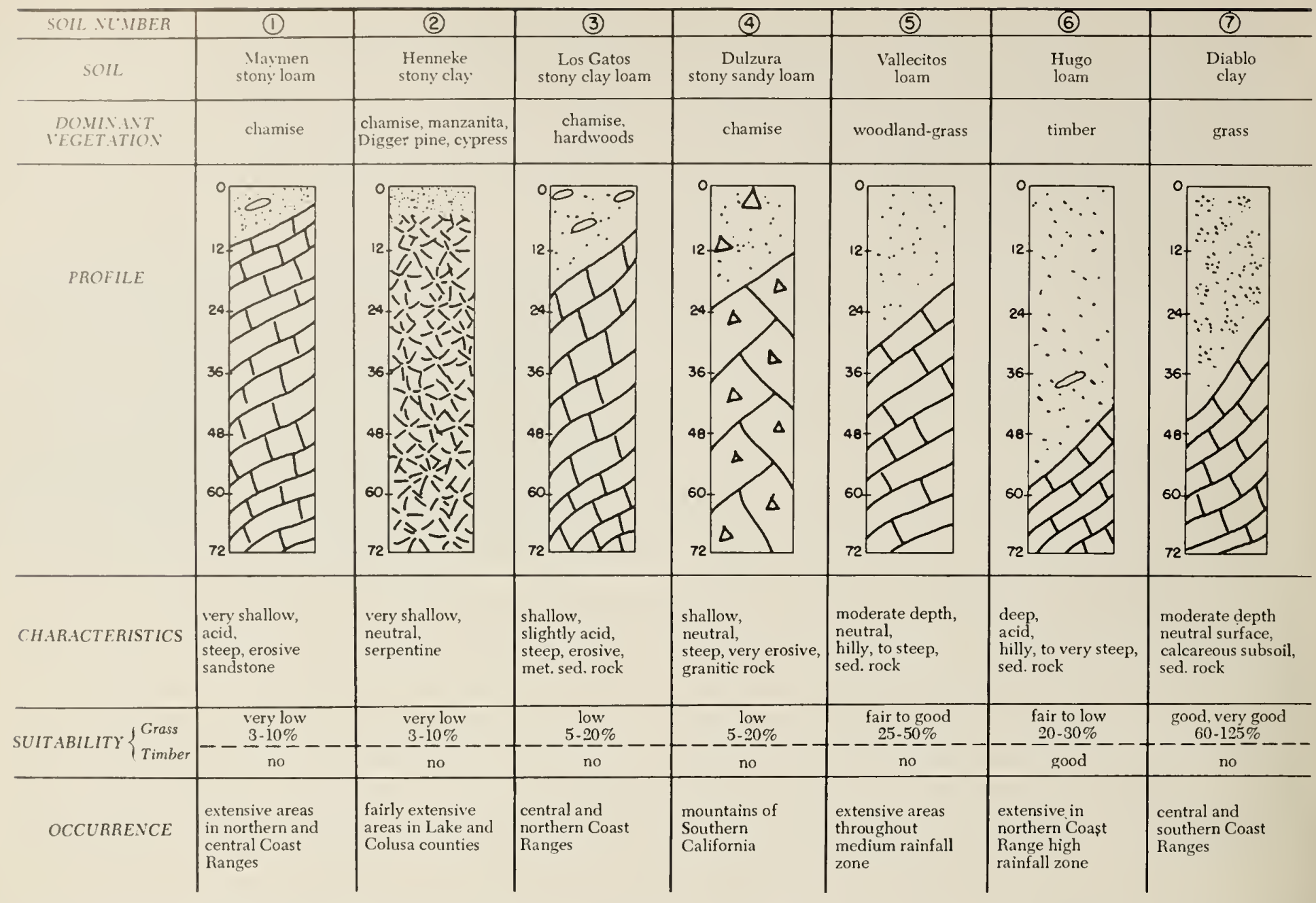

The characteristics of the upland soils, comprising more than 50 per cent of the area of the State. Some are predominantly chaparral soils while others are much better adapted to growing forest or grass.

(3) Los Gatos stony clay loam; and (4) Dulzura stony sandy loam. The four dominant soil types of this group comprise about $13 \frac{1}{2}$ million acres, or 13.5 per cent of the State. Altogether, the "Ex" group of soils comprise about 25 per eent of the upland group. Over this entire area of lithosol soils chamise is the dominant vegetation, but spccies of manzanita are eommon on some of them. The Maymen and the Henneke soils are distinctly low in potential production chiefly because of their shallow phase. The Los Gatos and Dulzura soils are likewise low for grass production.

En-Residual soils of medium to fairly shallow depth to bedrock. These are brownish soils of neutral, slightly acid or basic reaction, and are often referred to as Noncalcic Brown soils. The Vallecitos loam soil is one of the dominant soil types (drawing, above). These residnal soils comprise abont $15 \%$ million acres. Altogether, this is 28 per cent of the upland soil group. 'l'hey normally have a cover of woodland-grass or shrub-grass and are fair to moderately good for grass production. Brush types have probably encroached on some 5 per cont of this group of soils. Cliamise appears to be the dominant vegretation on some very badly croded lands of this type.

Ea-Residual soits of good depth to bedrock, acid reaction. Soil No. 6, Hngo loam, in the drawing above, is ithustrative of this group. These timberland podzolic soils comprise about $201 \frac{1}{2}$ inillion acress or 38 per cent of the upland soils gromp. Brush ocens to some extent as mulderstory vegetation, and oreasionally invades logged-over areats. C.lianise also appears to the the dominant vegetation on some very badly eroded lands of this type. This soil is excellent for timber growth, but fair to poor for grass production.

Esc-Residual soils of moderate depth to bedrock, variable reaction. These are the dark colored grassland soils belonging to the prairie, chernozem, and rendzina Great Soil Groups of the world. These soils comprise about 4.8 million acres, or 9 per cent of the upland area in California. Diablo clay soil, No. 7 in the drawing above, is represcntative of this group. These soils normally have a good grass cover and seldom support brush species. They respond well to grassland management.

As pointed out earlier, there is urgent need for information on both the vegetation and the underlying soils as a basis for management of wildland, be it for improvement of forage, timber, or watershed. To date only a sinall portion of the wild lands have been elassified aeeording to the standards set up for the soil-vegetation survey ${ }^{(1000,}{ }^{001)}$. The studies have proven useful in elassifying soils for their greatest and most permanent usefulness, sueh as "forest soils," "grassland soils," "ehaparral soils," or combinations of these covers. Beeause of the great importance of planning in advanee whieh brush areas are most suitable for conversion to grass, a soilvegetation survey should precede essentially all such plans for forage improvement. 


\section{Livestock and Big Game; Their Reliance} on Browse

Since browse provides food in varying amounts for both domestic grazing animals and big game, it seems appropriate to state the populations of these animals as an indication of demand for range forages of all kinds. On big-game range, there is evidence that overutilization of choice browse areas has shown close correlation with local deer populations ${ }^{(192)}$.

\section{Beef Cattle, Sheep, and Goats \\ History and Distribution}

Range livestock production in California began in 1769, when the first Spanish colonists introduced 200 cattle and horses from Lower California into what is now San Diego County. Sheep and other domestic animals were brought in soon thereafter by Spanish missionaries and spread rapidly over the State. Livestock seemed to thrive everywhere and their numbers increased rapidly.

According to the U. S. census, California in 1955 had 2,349,000 beef cattle, 2,012,000 sheep and lambs, and 43,000 goats $^{(20,137)}$. The graph below indicates that livestock population fluctuated rather widely between 1850 and 1950. The highest beef cattle population recorded was in 1910 and the highest reliable sheep and lamb population in 1930. According to Burcham ${ }^{(22)}$ livestock census data for the State were not reliable until early in this century because only animals found on farms were recorded ${ }^{(28,20,30)}$. Also, it was difficult to compare livestock populations of individual counties because, until 1907, county boundaries changed and new counties were created.

As early as 1890 the ranges of California, and most of the entire IVest, were fully stocked and in many localities already deteriorated by overgrazing. Because of excessive livestock numbers, unfavorable markets, periodic protracted droughts, and failure to provide supplemental feeds, the livestock populations in the carly years of range grazing fluctuated widely. Since about $1900 \mathrm{popu}-$ lation variations have been influenced most by market values of meats, wool, and hides, and by cost of opera-

Livestock population trends in California, 1850 to 1950. Source: Burcham $^{(22)}$.

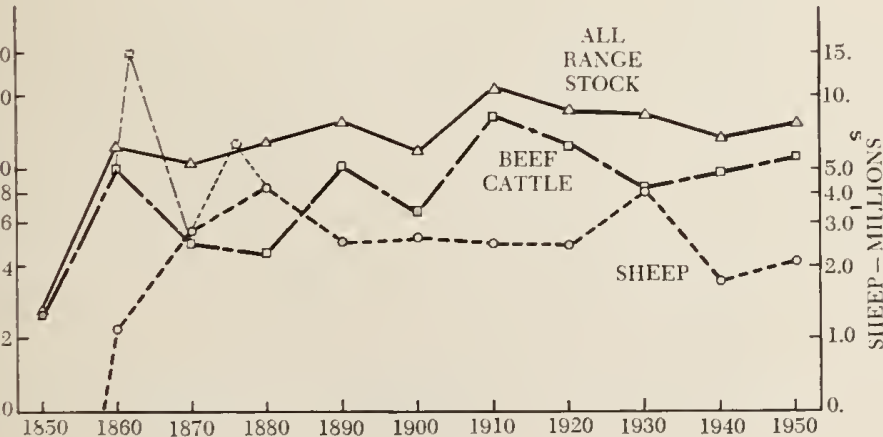

tion. Since 1885 the populations of beef cattle have far exceeded those of sheep, except in 1930 when the numbers of cattle and shcep were nearly equal (graph bclow).

The San Joaquin Valley contains approximately oncthird of the cattle of the State. While cattle production is of first importance in the northern counties, these areas contain only about 10 per cent of the total number of cattle in California (map below).

The principal sheep counties are in northern and central California, the largest number of sheep being found in Sacramento Valley. Howevcr, there are considerable concentrations of sheep in San Joaquin Vallcy, the northern coast countics, and the northeast counties of Modoc and Shasta (map on page 10).

\section{Observations of Browsing by Cattle}

The extent to which cattle browse on woodland-grass range is influenced by many factors, notably the accessibility and palatability of the woody species, and whether the grass cover has reached maturity. Obervations as to the amount of time that cattle spend browsing on range where palatable herbaceous vegetation is adequately available should provide an indication of the value of the browse fecd. Such a time study was conducted by Kenneth A. Wagnon, Department of Animal Husbandry,

The largest numbers of cattle of all kinds are found in the San Joaquin Valley. Dairy cattle have largely replaced beef cattle in the vicinity of large cities and this movcment will probably continue. Each dot represents 5,000 cattle. Source: Voorhies and Koughan ${ }^{(133)}$.

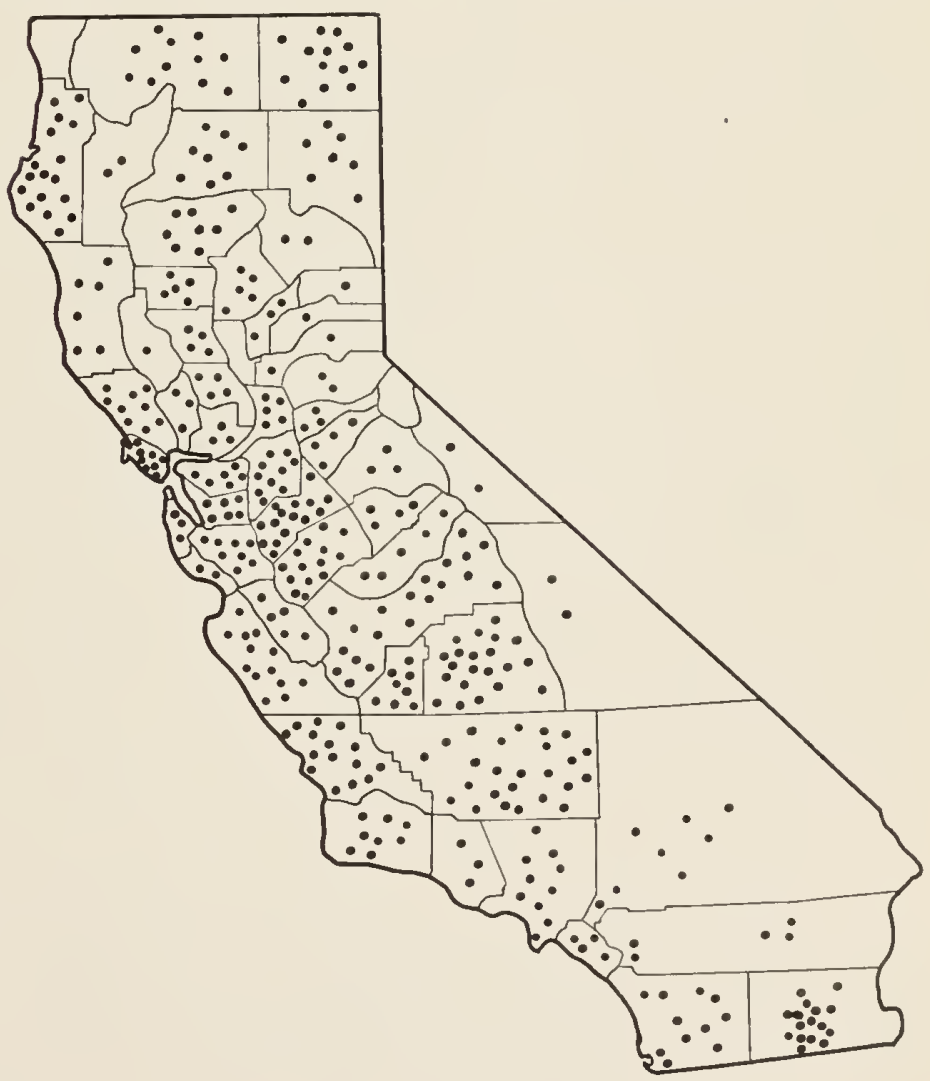




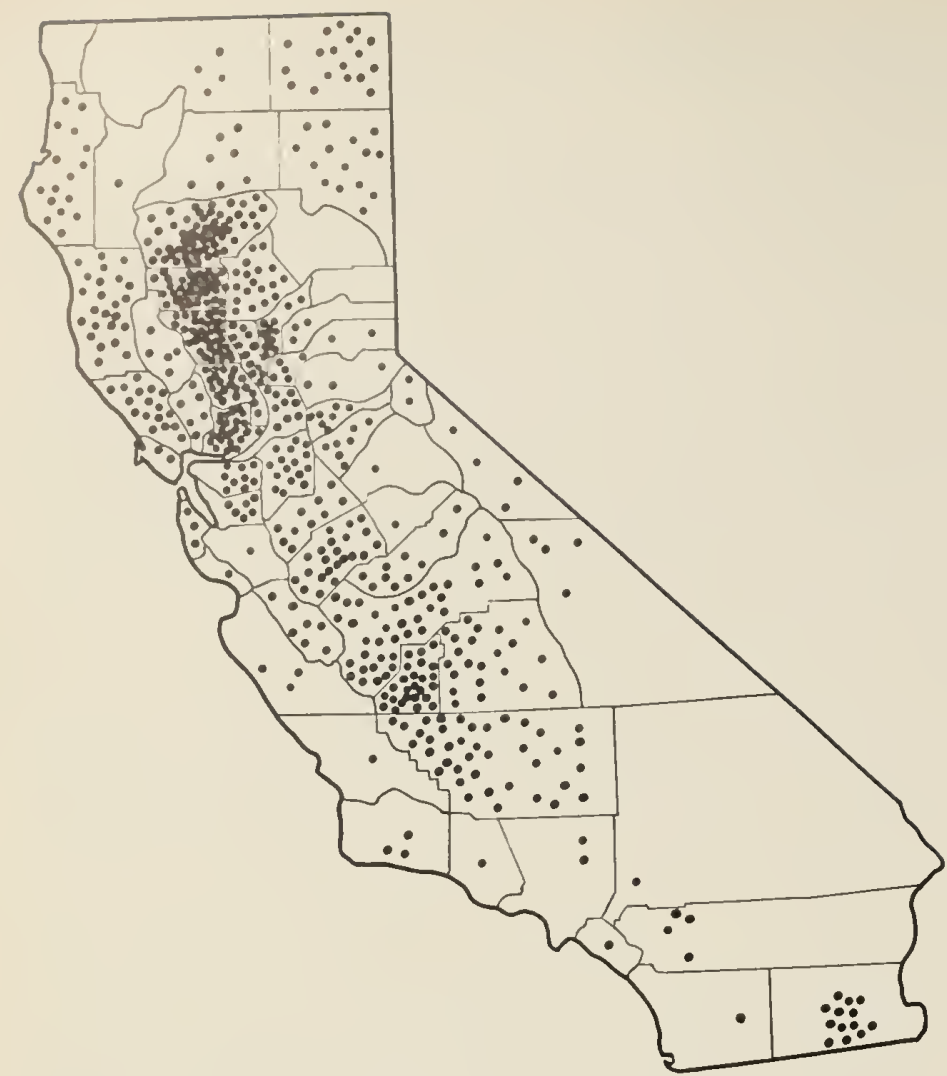

The largest number of sheep is found in the Saeramento Valley. There are also many sheep in the San Joaquin Valley and in the northern counties of Lassen and Modoc. Large movements of sheep occur within the State at different seasons of the year. Each dot represents 6,000 sheep. Source: Voorhies and Sehneider ${ }^{(154)}$.

University of California, on the San Joaquin Experimental Range in 1947-1948.

The vegetation on this range is essentially an open oak savannah, broken here and there by clumps of brush and a few arborescents. The percentage of area under canopy (trec cover) was 25.2 and the percentage of time spent browsing on the different woody species was 3.50 .

The more abundant woody species and the percentage of canopy that they produced were as follows: interior live oak (Quercus wislizenii), 7.58; blue oak ( $Q$. douglasii), 5.47; Digger pine (Pinus sabiniana), 4.19; chaparral whitcthorn (Ceanothus leucodermis), 3.15; wedgeleaf ccanothus (C. cuneatus), 2.10; hollylcaf redberry (Rhamnus crocea var. ilicifolia), 0.66 ; Mariposa manzanita (Arctostaphylos mariposa), 0.60; California buckeyc (Aesculus californica), 0.57; silver lupinc (Lupinus albifrons), 0.41; poison-oak (Rhus diversiloba), 0.28; bhe clderberry (Sambucus caerulea), 0.04; and California coffceberry (Rhamus californica), 0.0t. The seven remaining woody species accounted for only 0.06 per cent of tlic canopy,

\section{Experimental Results}

Cow hehavior was recorded for the pcriod from February 26,1947 , to February 17, 1948. Over the 12-month period, thirty-three 24-hom oloservations were made of individual cows. From February through June the cows observed were held in two pastures, one stocked for light grazing, the other for close grazing, with no supplemental feed for either group. From July to February the cows were held in two moderately stocked pastures, with one group receiving daily supplements of cottonseed cake and rolled barley, while the other group received no supplements. The total scasonal rainfall was slightly below normal. The combined size of the four pasturcs studied was 1,425 acres. The results were:

\begin{tabular}{|c|c|c|c|c|c|}
\hline & \multirow[b]{2}{*}{ OVER-ALL } & \multirow[b]{2}{*}{$\begin{array}{l}\text { PASTURES } \\
\text { LIGHTLY } \\
\text { GRAZED }\end{array}$} & \multirow[b]{2}{*}{$\begin{array}{l}\text { PASTURES } \\
\text { CLOSELY } \\
\text { GHAZED }\end{array}$} & \multicolumn{2}{|c|}{ PASTURES MODERATELY GRAZED } \\
\hline & & & & $\begin{array}{l}\text { SUPPLE- } \\
\text { MENTED } \\
\text { COWS }\end{array}$ & $\begin{array}{l}\text { NON-SUPPLE- } \\
\text { MENTED } \\
\text { COWS }\end{array}$ \\
\hline $\begin{array}{l}\text { Per cent of } \\
\text { time spent in } \\
\text { general } \\
\text { feeding }\end{array}$ & 42.7 & 44.8 & 41.2 & 38.4 & 46.3 \\
\hline $\begin{array}{l}\text { Per cent of } \\
\text { time spent } \\
\text { browsing }\end{array}$ & 3.5 & 1.5 & 2.4 & 7.7 & 3.8 \\
\hline $\begin{array}{l}\text { Per cent of } \\
\text { area eovered } \\
\text { by brush } \\
\text { canopy }\end{array}$ & 25.2 & 14.8 & 20.2 & 22.9 & 30.0 \\
\hline
\end{tabular}

The cows spent a yearly average of 42.7 per cent, year around, of the time feeding, yet only 3.5 per cent of the time was spent browsing. The graph below compares the important browse species relative to preference.

Cows in the lightly grazed pasture, with 14.8 per cent of the area beneath canopy, spent 44.8 per cent of the time feeding, of which 1.5 per cent was spent browsing. The cows in the closely grazed pasture, with 20.2 per cent of the area beneath canopies, spent an average of 42.2 per cent of the time feeding, but only 2.4 per cent was spent browsing.

On the moderately grazed pasture, with 30.0 per cent of the area under canopy, the cows without supplements spent 46.3 of the time feeding; but only 3.8 per cent of the time was spent browsing. The cows recciving supple-

Comparative preference by eattle of the more important browse species on the San Joaquin Experimental Range, 1947-1948. The unshaded columns indieate percentage of eanopy, the shaded eolumns percentage of browsing time.

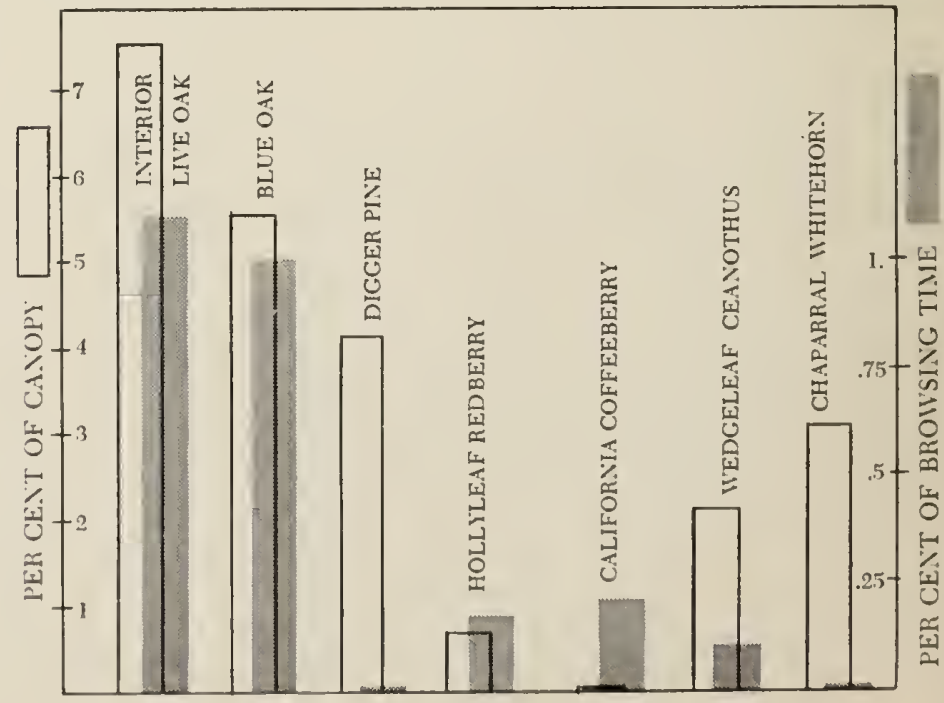


ments, in a field with 22.9 per cent of the area beneath canopies, spent 38.4 per cent of the time feeding, of which 7.7 per cent was spent browsing. Thus, supplementation of the range increased the browsing time from $1 / 12$ of the total feeding time to $1 / 5$, in spite of the fact that browse was $1 / 3$ more abundant on the unsupplemented pasture.

Because of the low palatability and the predominantly leathery character of the leafage, the amount of browse ingested was relatively small. Where the range was supplemented, the cows spent more time browsing than on non-supplemented ranges, possibly because of stimulation of their hunger for vitamin $A$, roughage, and certain minerals.

On certain more northerly forest ranges, where rainfall is heavier and the summers are less hot, and where more palatable browse species abound-such as Brewer oak (Quercus garryana var. breweri), bitterbrush (Purshia tridentata), western mountain-mahogany (Cercocarpus betuloides), and western serviceberry (Amelanchier alnifolia)-cattle apparently spend much more time browsing and ingest measurably more brushy leafage and current stems than reported for the San Joaquin Experimental Range. In many instances cattle, for example, will crop bitterbrush stands so closely that they dwarf the plants and frequently thin them out.

\section{DEER}

Various investigators ${ }^{\left(0,{ }^{21},{ }^{82)}\right.}$ have reported that, in recent years, the deer population in several localities of the State has been limited by an inadequate and often inferior supply of browse and other food plants as a result of range overutilization by livestock and deer. An attempt has been made to alleviate these conditions on many livestock-deer ranges by increasing forage production on public and private lands utilized by deer; apportioning the available forage for deer as well as for livestock on critical areas where the animals compete; and setting up within the framework of the laws and regulations established by the State Legislature and the Fish and Game Commission means by which a maximum crop of deer can be harvested annually from existing breeding populations. Without proper harvest of the annual increment large numbers of deer succumb periodically to major adjustments in carrying capacity due to inclement winters or short growing seasons. These climatic factors affect annual as well as browse forage production on winter and summer ranges.

Deer originally were abundant in the chaparral and oak-woodland zones bordering the Central Valley; scarce in the arid shrub-grassland of the Great Basin in the northeastern part of the State; and scarcer still in the desert $^{(02)}$. Persistent year-long hunting, and overgrazing by livestock, drastically depleted the deer and other big game. The low point of deer population for the State as a whole was reached in the period 1890-1910, when severe winters and other adverse factors combined to reduce their numbers drastically ${ }^{(102)}$.
An important factor responsible for the increase in deer numbers since 1910 is the growing number of wild fires which occurred on both public and private lands. How much of the deer increase could be attributed to improved land management practices is questionable. Generally overlooked is the fact that the destruction of the grazing capacities of most California ranges occurred before the turn of the century. More recently, better land management practices have been introduced as range conditions have improved for deer. Also, there has been an increase in resident deer numbers in the foothill regions of woodland-grass. This is due to the establishment of irrigated pasturage in the once summer arid intermountain valley lands. Many deer avail themselves of this summer supplementary green feed and carry themselves over a period of poor forage conditions ${ }^{(32)}$.

However, the concept is now generally accepted that deer populations are dynamic and that range condition on our California annual ranges-which now include Great Basin ranges-is equally dynamic. Especially is this true in annual forage production. It is possible to correlate reduction in deer numbers directly with abnormal environmental conditions brought about by climatic conditions. Winters can, if they are cold and dry, result in poor range response. Wet open winters can produce, on even the poorest overbrowsed deer ranges, forage conditions which materially increase the capacity of these ranges to support animals. Accordingly, carrying capac-

Estimates of numbers of bucks killed based upon hunter tag returns. This method of estimating was found to be particularly useful. Each dot represents 50 bucks killed (1955); $L$ represents lake. Sources: California Department of Fish and Game, Longhurst et al. ${ }^{(92)}$.

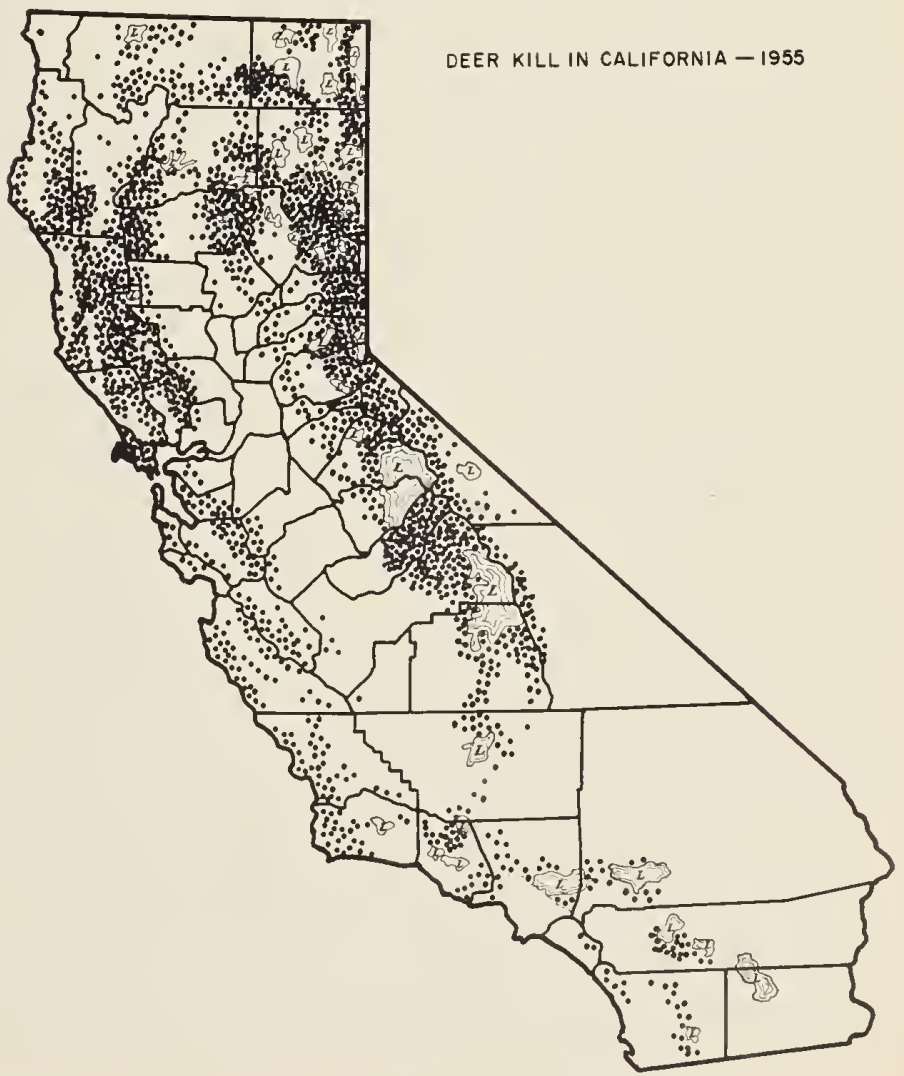


ity is not a set figure dctermined entircly by browse abundance and production.

In 1956 the California Department of Fish and Game cstimated the State's deer population at 1,300,000; this number mav fluctuate as much as 100,000 or so ${ }^{\text {(usa) }}$, as would be expected in a region where the ranges are as fully stoeked with deer as they are in California (map on page 11). At present many wild life biologists believe that there arc more than two million deer in the State.

Today the period of "restoration" of deer numbers is past. Game managers are working toward the adoption of regulations and management procedures which will result in harvesting a maximum annual crop of deer from existing breeding herd numbers, and toward improvement and maintenance of the ranges so they will support indcfinitcly, and in good condition, an optimum breeding herd.

An indieation of the improved forage conditions on the mountain range is the fact that approximately 43 per cent of the population, or 560,000 animals, inhabit government lands administered by the Forest Service during the period from spring into the autumn. The winter ranges are critical areas becausc of the heavy deer concentration on them. During the early winter many of the deer herds either partially or wholly migrate from national forest land into either private, state-owned, or public domain lands administered by the Bureau of Land Management. There are also, in some instances, movements of deer from the national parks into the national forest wintering grounds. The estimated number of deer on national forest winter range is 350,000 , as reported in correspondence with E. C. Hjersman of the California Department of Fish and Game.

The present population estimate of 1,300,000 deer in the State scems to represent about the maximum numbers that the deer ranges will support permanently ${ }^{(193)}$. This dcer population is producing an annual erop of some 250,000 animals. Hunters bagged more than 75,000 bucks, "forked horns" or better, in 1960 (see graph below); the rest of the crop succumbed through natural mortality, such as malnutrition, disease, and predators. In 1960 the harvest was 75,584 bucks and 7,360 antlerless deer, of a total of 82,944 deer legally taken during the regular hunting season. The harvest will vary from year to vear but stays within about 5.5 to 7.0 per cent of the total deer population. To effect an adjustment whereby the sportsman is allowed a much larger share in the annual increment of cleer, it was proposed that hunting regulations be broadened to allow a much larger annual harvest than is now permitted, including the taking of both sexes ${ }^{(2)}$. In 1956 such libcralized hunting regulations were initiated in a few localities.

Numbers of deer tags sold and numbers of bucks reported killed in California, 1927-1960. Source: California Department of Fish and Game.

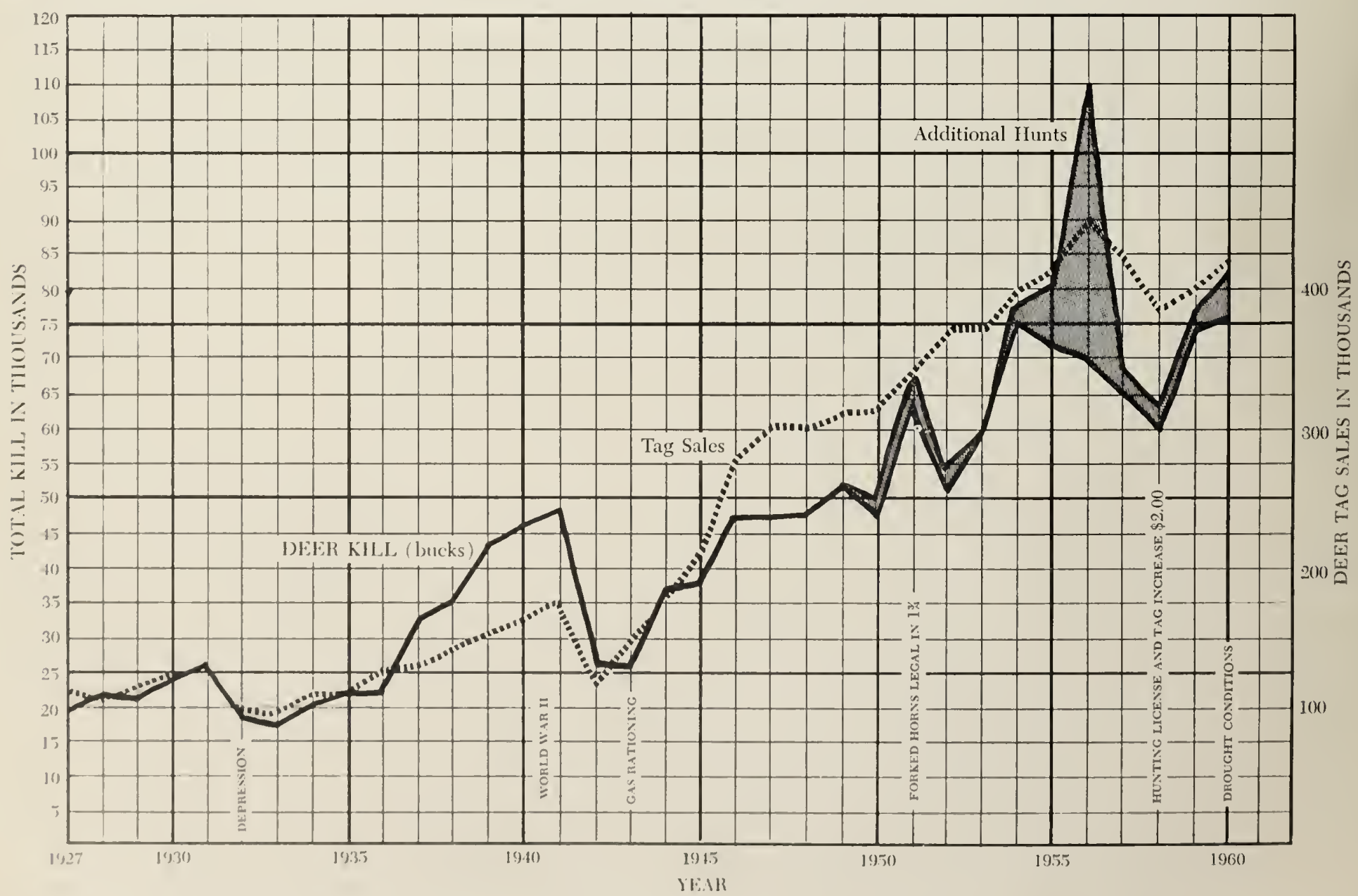


Deer inhabit over 20 million acres of privately owned range land. These lands often support 20 to 50 deer per square mile, and in some areas more than 100 deer per square mile ${ }^{(033)}$. Obviously the number of hunters is not increasing in proportion with California's population upsurge, mostly because the available hunting area has decreased as many private owners do not permit trespassing on their land in order to prevent damage by an irresponsible minority.

California Department of Fish and Game and Universiiy of California research workers have long recommended that either-sex hunting be incorporated in the management plans. They feel that only through such control of deer numbers can stocking rates be balanced with the grazing capacity and other uses of the lands. In this wav the remaining deer will have more and better forage available and therefore be healthier, attain better size, and be more productive ${ }^{(1+5)}$. To be fully effective, such hunting policy would have to be accompanied by certain management practices to improve the forage cover.

In addition to regulation of the deer herd numbers as an essential step in range management, various new techniques of range improvement have been investi- gated and are now being applied to a limited extent by the California Department of Fish and Game on certain public lands used by deer. Some of these improvement measures are: spot burning; broadcast-control burning; resecding; opening up the brush stand on small selected sites by bulldozing; regulated grazing of livestock on critical areas; selective and regulated logging in timber areas; water development; salting; and certain other procedures useful in promoting better range condition $5,21,23,60,20,145$. Such improvement is equally beneficial to livestock and deer, and may be expected to increase the returns from both. However, few California ranchers have resorted to such improvement measures (sce photo below).

\section{Prong-Horn Antelope}

The original range of the prong-horn antelope in California included most of the coastal area from San Francisco southward, Salinas Valley, Santa Clara Valley in Ventura County, and in the vicinity of San Diego. Brewer observed antelope in San Benito County as late as the $1860^{\prime}$ 's. They also occupied the Mojave Desert region and extended southward into Mexico ${ }^{(22,110)}$. Shecpmen are said to have killed antelope in large numbers

Range improvement techniques to increase deer forage inchude burning. This area, on a San Joaquin winter deer range, was burned several years ago. The dominant species are western mountain-mahogany, species of ceanothus and manzanita, hollyleaf redberry, yerba santa, fremontia, bitterbrush, and annual grasses and forbs. In open winters this area is browsed heavily; in heavy snowfall years the more protected lower slopes and flats of this range supply most of the forage.

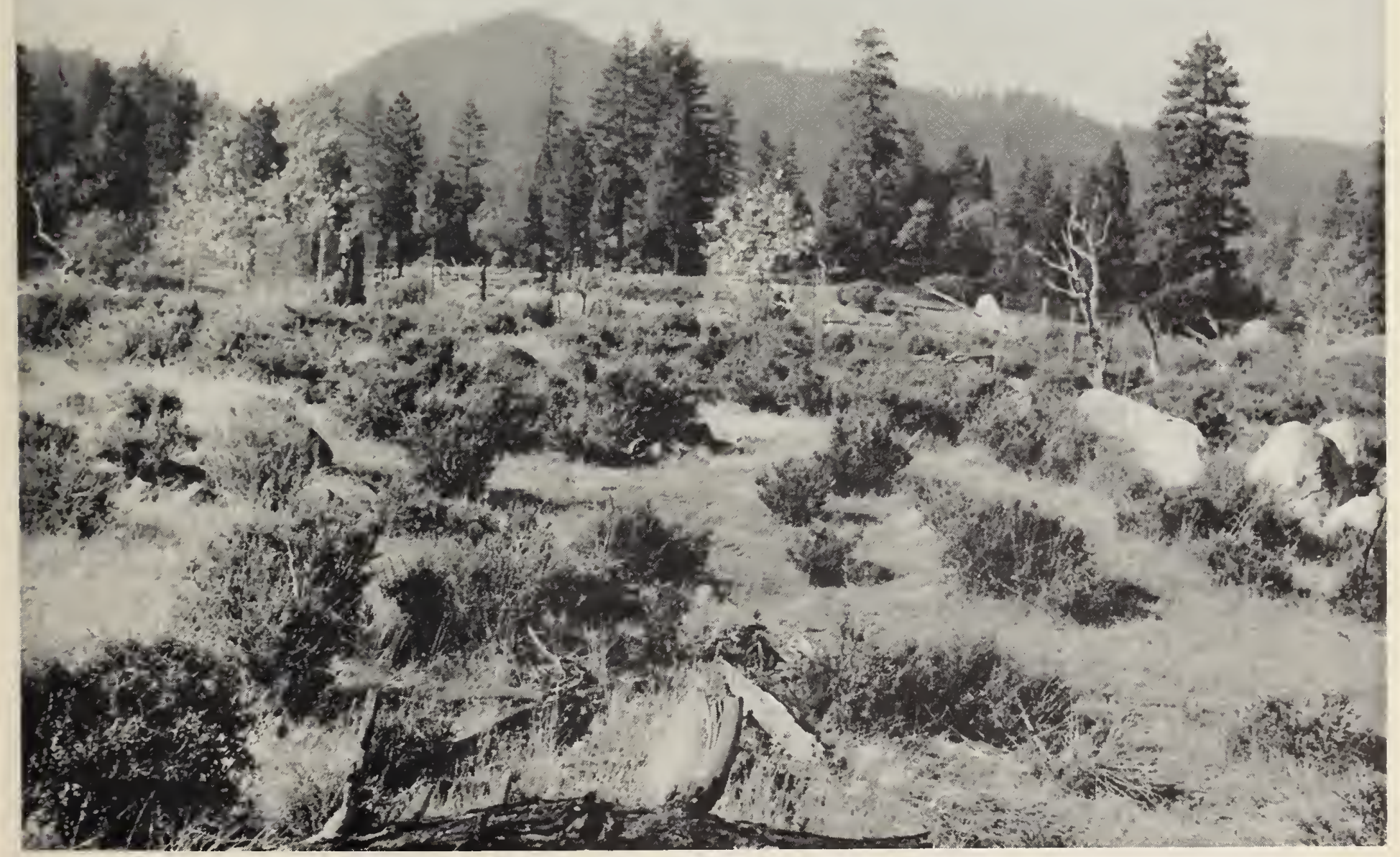




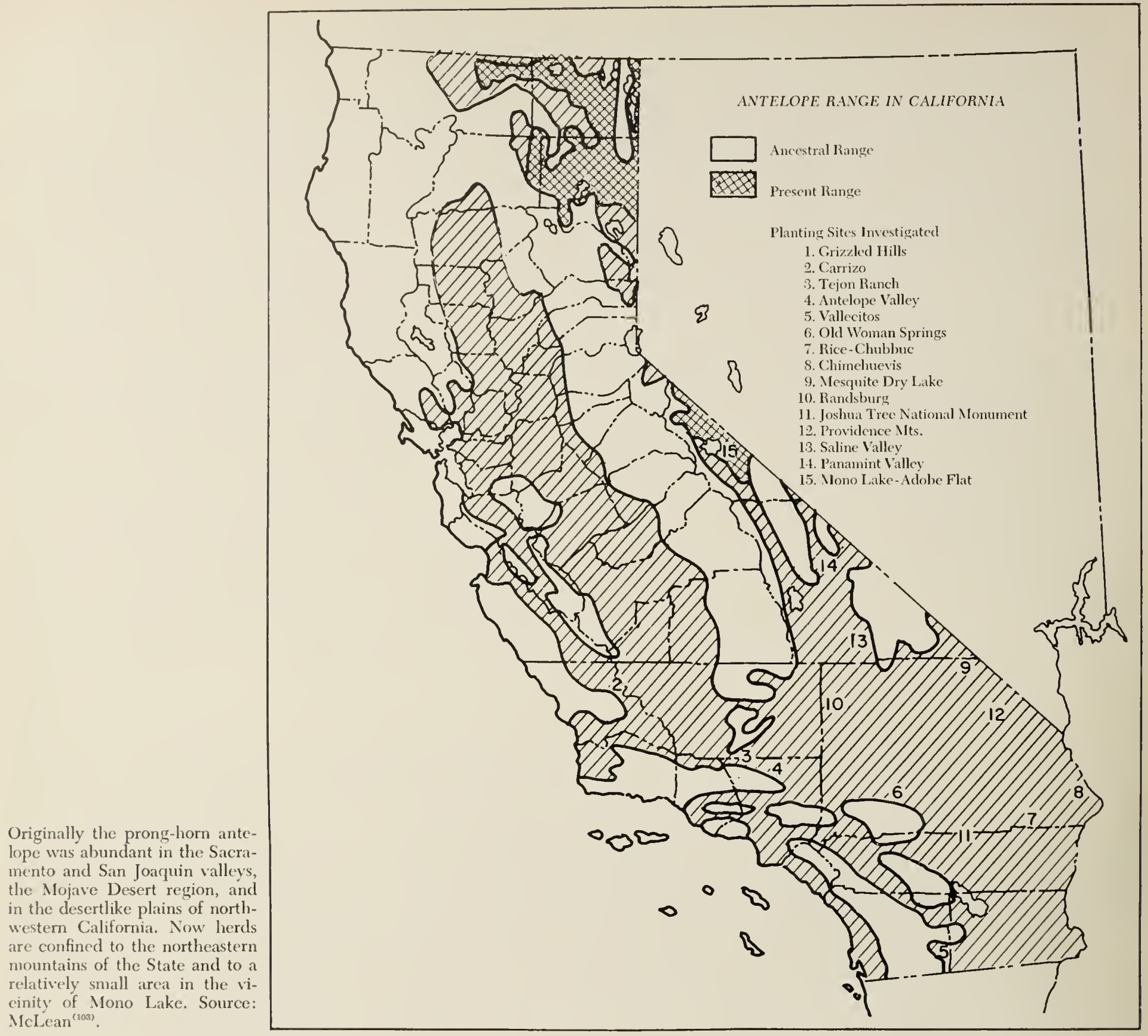

to eonserve the forage for their animals. As early as 1854 the California Board of Fish and Game eommissioners closed the lunting season of antelope; but sinee the Board was mable to enforce the law, market hunters continued their depredations. With extensive agrieultural development, including irrigation in the great valleys, antelope took to feeding on alfalfa and other erops $^{(33)}$. As a means of protection the farmers slaughtered these animals in great numbers. The results were so drastic that in 1922 the California Aeademy of Sciences annominced that the number of antelope in the entire State totaled only 4.34 head. Fearing that the antelope would become extinct, leading eonservationists set up an action program which authorized game wardens to protect the prong-horn. This measure undoubtedly acconints for the recovery and present status of the pronghorn antelope (niap) above).
Aeeording to the fairly aceurate airplane census method used in recent years to count the highly mobile antelope, population figures have flnetuated relatively little. These figures were as follows:

$\begin{array}{ll}1952 & 2,282 \text { antelopes } \\ 1953 & 2,247 \\ 1954 & 2,022 \\ 1955 & 2,155 \\ 1956 & 2,338 \\ 1957 & 2,080 \\ 1958 & 2,165 \\ 1959 & 1,917 \\ 1960 & 1,780 \\ 1961 & 1,906 \\ 1962 & 2,269\end{array}$

The range of the antelope is now essentially restrieted to northeastern California, with Modoe the leading an- 
telope county, followed by Lassen County; but there are small numbers of prong-horns in Siskiyou, Plumas, and Sierra counties. In December, 1949, 143 antelopes were transplanted to Mono County in the hope of extending their present range; by 1956 this band had increased to 200 animals. This number is not included in the census figures reported. No census has been taken since but it is believed that they have not reproduced extensively.

Great increase in population of the prong-horn antelope in California is not likely because of limited suitable open range, the pressure by predators, and the fact that the nature of these animals precludes them from occupying ranges that are interrupted by extensive areas of agricultural development.

\section{Other Big-Game Animals}

The other big-game animals in the State are elk and mountain sheep. The estimated number of elk was 2,600 in 1960 , and the number of mountain sheep was 2,000 to 2,500 in the same year.

\section{Competition for Forage Between Livestock and Big Game}

A factor which complicates the management of important tracts of grazing lands in California is the competition for food plants between domestic livestock and big-game animals.

Where large deer numbers utilize the same range as cattle or sheep, serious overgrazing may and often does result. Knowledge of the dietary habits of deer, and incidentally of antelope, is of special importance since they may be consuming more plant species desired by livestock than is generally realized. On range of exceptionally rugged terrain, on the other hand, big-game animals often utilize areas that are not accessible to domestic stock.

Most of the big-game grazing lands in California, and of the WVest generally, are also grazed by livestock. Large tracts of the California ranges are closely utilized by both deer and livestock. This has resulted in overgrazing of the forage on the most heavily stocked areas and has caused conflict for the feed between deer and livestock. This condition is referred to as "grazing-forage competition."

The degree of livestock-game competition for forage is determined by the extent to which game and livestock graze the same area; and the extent to which these animals prefer the same forage species. Various field techniques for measuring degree of competion have been $\operatorname{proposed}^{(47,83,84)}$.

\section{Competition Between Livestock and Deer}

In Califomia competition for forage between livestock and big-game animals takes place mainly among cattle, sheep, and deer, and, perhaps in a few localities, between sheep and antelope. The problem of livestock- game competition in California has been studied only limitedly on a few selected deer-livestock ranges. Competition is also regulated by the stocking rates of deer and livestock in relation to available shrubby browse and damage to young conifers in the timber belt, notably along the coast. When the deer have a sufficient supply of the more palatable browse species available, they do not browse heavily upon the less palatable Douglasfir and redwood seedlings. But when palatable browse is in short supply as a result of overstocking or growing out of reach, damage to young conifers is often severe.

Many stockmen using the public range, where game is abundant, have contended that reductions in their grazing permits have been made chiefly to provide forage for the deer. The deer population, they point out, has been permitted to increase enormously in the past two decades, thereby depriving domestic livestock of their fair share of herbage and browse. They recognize, however, that competition between cattle and sheep in opposition to deer is slight or nonexistent on properly stocked range in good condition. But proper stocking, they point out, has been achieved largely by reduction in cattle and sheep numbers.

Competition for range forage, especially between sheep and deer under certain conditions, is no longer questioned by those who have studied the problem. The specific degree of competition, however, is difficult to ascertain ${ }^{477}$. Variations exist on different types of range, on different plant compositions, in different regions, and according to topography and range conditions. Both deer and antelope tend to feed over a much larger range area than do cattle or sheep, and inhabit drier and more rugged terrain. On steep and partially timbered ranges in Utah, only about 50 per cent of the area used by deer would be grazed by cattle, and only some 75 per cent would be grazed by sheep ${ }^{(139)}$. Thus it is seen that a knowledge of total numbers of game alone would not necessarily indicate the degree of competition.

In California there are many large bleak areas of brushland so inferior for livestock grazing that they should be devoted exclusively to game production. Typically, these areas support on the western slopes stands of chamise, manzanita, Sierra mountain misery, coastal sagebrush, and deerweed; and in the Great Basin areas sagebrush, juniper, and other browse plants that are seasonably relished by deer but are little used by cattle and sheep. In contrast, there are open brushlands interspersed with grasslands where a scattering of palatable shrubs, such as bitterbrush, western mountain-mahogany, common snowberry, and certain other browse species are acceptable to both livestock and deer and are often utilized heavily. Dasmann ${ }^{(47)}$, working on the Interstate Deer Range in Modoc County, found that cattle, sheep, and deer cropped bitterbrush and certain other shrubs, as well as the bluegrasses, to the extent of depleting the stand.

In general, forbs and browse provide most of the sustenance of deer, but the proportion taken of these plant groups differs greatly with the march of the sea- 
son s: st w.1ws. During the winter the Great Basin deer herds California, populated by the Roeky Mountain and Invo mule deer, subsisted mostly on big sagebrush Artemisia tridentata), bitterbrush (Purshia tridentata), juniper (Juniperus spp.), and anmual grasses. Big sagebrush supplied the greater feed bulk during the late winter months, but a eombination of sagebrush and western juniper (Juniperns occidentolis) was eonsumed hearily in some loealities. Bitterbrush was eropped throughont the vear on all the deer ranges. It was taken heavily during the first three months of the winter, but lightly for the remainder of that season. On the lower edges of the summer range deer eonsumed large amounts of curlleaf momtain-mahogany (Cercocarpus ledifolius), greenleaf manzanita (Arctostapluylos potula), eommon snowberry (Symphoricarpos albus), and squaw earpet (Ceanothius prostratus) until snow drove the animals to the more open winter range. Grass was the most varied item. Open winters were eharaeterized by heavy usage of grass and a more diversified browse diet, whereas in severe winters, with abundant snow, deer were foreed to subsist largely upon browse. In early spring the northeastern deer herds fed extensively on anmual grasses and only limitedly on browse. However, as the tender sprouts or twigs of palatable shrubs began to appear, deer subsisted largely on the woody plants. During the summer months the interstate deer herds, while on mountain range, eonsumed from 50 to 75 per eent bitterbrush and snowberry while forbs contributed most of the remaining food requirement. The amount of grass taken was negligible ${ }^{(53)}$.

Based on intensive studies a similar pattern of seasonal browse-herbage utilization by Columbian blaek-tailed, California mule, and sonthern mule deer seems to hold true. These deer inhabit the brushlands, woodland-grass, and forest areas of the mountainous areas of California and in places ranging into the Central Vallev. Little is known aloout the deer inhabiting California desert ranges. During early spring a large part of their diet eonsists of anmul grasses and forls, but when the new growth of the browse appears the deer are strongly attracted to the twigs, sprouts, and seedlings of the shrubs. New growth of this kind may be provided by spot burning, to convert the brushland to shrubland, thereloy enhancing both the (fuantity and quality of deer feed ${ }^{(21)}$. The bulk of the feed of the blacktails is provided by varions species of ceanothus, particularly deerbrush ceanothns, and chamise, common snowherry, oaks, and western monntain-mahogany. Forbs make up the renainder of the diet whereas grass is ntilized but little.

The resillts of the sturlies here reported are remarkahly similar to those conducted in a winter-summer deer and cattle and sheep range of 49 senare miles in Utallas . There hrowse supplied most of the deor eliet on the winter range, whereas browse and forbs ac(omoled for the lonlk of the smmmer deer diet. Most of the choicer dere browse species such as bitterbrush,

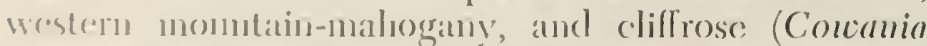
mrexirmm var. stomshmriono), were utilized to some extent by eattle, but grass-the primary eattle forage-while eropped by deer in early spring, was taken but little in the summer. It was reeommended that on the natural eattle mits the grazing be geared to proper use of the perennial grasses, and that on eombination deer-eattle range proper use of all the palatable vegetation should be kept in vigorous eondition. The sueeess of these recommendations would be predieated on establishment of proper numbers of both domestie stoek and deer.

On Colorado mountain range eompetition was found to be keener between deer and sheep than between deer and eattle ${ }^{(121)}$. Browse was the primary year-long diet for the deer, whereas browse and forbs were highest on the list of preferenee for sheep. Thus on range in good condition it seems unlikely that eompetition for forage will be serious between these animals, whereas on poor eondition range eompetition might beeome serious.

\section{Competition Between Livestock And Antelope}

The California prong-horn antelope are not formidable eompetitors with eattle, sheep, and goats for forage, nor are they seriously damaging on agrieultural land under present populations ${ }^{(53)}$. The spring diet, based on analyses of 83 antelope stomaehs, eonsisted of 63.6 per eent browse, 34.8 per eent forbs, and 1.6 per eent grass $^{(33)}$. The prineipal browse speeies were big sagebrush ( $A r$ temisia tridentata), bitterbrush (Purshia tridentata), and rabbitbrushes (Chrysothamnus spp.). Among the more important spring forbs were hog-fennel (Lomatim $\mathrm{spp}$.), balsam root (Balsamorhiza spp.), false caraway (Carum spp.), phlox (Phlox spp.), and speeies of the sunflower tribe (Heliantheae). The grasses eropped included several species.

The fall diet eonsisted of 46.9 per cent browse, 52.1 per eent forbs, and 1.0 per eent grass. The prineipal browse species were essentially the same speeies cropped in the spring. The forbs eaten differed considerably from those ehosen in the spring-evidently due to changes in stand composition. Speeies of the Compositae family were eropped most.

The winter diet eonsisted of 95.8 per cent browse, 2.3 per eent forbs, and 1.9 per cent grass. Big sagebrush aecounted for 95.2 per eent of the browse whereas bitterbrush and spiny saltbush (Atriplex confertifolia) composed the remaining 0.6 per cent of the browse. The forbs eaten were mostly dry seed heads and stems, whereas dry leaves eomposed the grass cliet.

Bucehner ${ }^{(20)}$, working in western Texas, also found that the antelope ate little grass, but that on overgrazed range sheep and antelope may compete severely for the palatable invading forbs. Where sheep graze closely upon a large variety of such sueeulent vegetation, eompeting antelope may die from starvation. On overgrazed spring and summer cattle range antelope eompete little if at all, sinee they mostly sulosist on forlos, few of whieh are grazed closely by eattle.

In Moutanat ${ }^{(3 \pi)}$ forage utilization studies of the prong- 
horn antelope revealed that 12 browse species accounted for 63 per cent by volume and 64.9 per cent by weight of the average vear-long food intake. Forty-seven forb species composed 33.9 per cent by volume and 31.2 per cent by weight. Grasses constituted only 3.1 per cent by volume and 3.9 per cent by weight. Throughout late fall, winter, and the first two months of spring big sagebrush (Artemisia tridentata), fringed sagebrush (A. frig$i d a$ ), and hoary sagebrush (A. cana) were the major food items. Forbs were grazed most extensively from May to October. Grasses were cropped but little at any time.

Improperly fenced or unfenced alfalfa fields were cropped by the antelope in varying degrees of intensity from about mid-August until in October. Hunting season of either sex, beginning early in September was recommended for reduction of these animals in problem areas. Fences properly constructed of woven wire and of suitable height around alfalfa fields was also recommended.

Considering the present low antelope population in California, there is but limited competition for range forage between livestock and the antelope. The most common complaints among stockmen are the invasions of antelope on alfalfa fields, pastures, and patches of grain. Fences are sometimes broken down and grain fields may show limited damage by trampling.

\section{Competition Between Livestock and Other Big-Game Animals}

Such competition occurs only in localized areas. In Owens Valley, for instance, the presence of some 300 tule elk has given rise to a controversy among stockmen, sportsmen, and conservationists. Another example is a small elk herd above Capay Valley in Yolo and Lake counties. The Roosevelt elk in the rain forest of Humboldt and Del Norte counties is damaging to certain lumber interests. Bighorn sheep, too, have a restricted distribution and localized problems in respect to range conditions.

Generally, there seems to be slightly more competition between elk and livestock than between livestock and the other big-game animals. The area of greatest competition between elk and livestock exists in Owens Valley and in Colusa County.

On the public lands it is usually the stockmen who must undergo reduction in their grazing permit to alleviate the over-utilized game-livestock ranges. Bccause these lands are mostly owned by the public, livestock reductions may be justified, for many persons derive enjoyment in one way or another from the game ${ }^{(139)}$. However, any decision to favor the game over livestock grazing must be based on the best land management principles available, and on sound economics. Better information is needed on the costs and income from game and livestock production. Administratively, adjustments of livestock and/or game numbers is not likely to please all the people involved, even when based on careful scientific study ${ }^{(140)}$.
On the private lands in game country, the livestock operator is likewise concerned with excessive numbers of deer. Since there is no means of remunerating landowncrs in California for furnishing feed to the Stateowned deer, their resentment towards excessive numbers of game is understandable. To help meet the everincreasing demand for hunting, quite a few land owners are selling hunting privilcges on an annual-fee basis. These sales partly or wholly compensate for the forage consumed by the game, and at the same time help prevent the deer population from building up excessively. If both sexes could be taken, the returns would be much greater and the range corespondingly improved.

Dual use of public lands by livestock and deer is generally desirable since both animal groups are in grcat demand $^{(140)}$. Such common use is possible if all concerned will regard the land as a heritage that must be used and managed in the interest of all the people. To accomplish such dual use effectivcly will require enlarged study of range condition, game populations and hunting demands, and the degree of reliance of local ranchers on the public lands in the interest of livestock-game production economy. A fair division of the herbage and browse between livestock and big game must takc into account future demands for livestock products by a rapidly increasing human population ${ }^{(83)}$, as well as increasing demands for big-game and recreation purposes.

\section{Economic and Social Aspects}

Game management is complicated and often difficult to apply on many ranges because of the peculiar status of the animals, the lands which they occupy, and the conflicting views of the sportsman and the livestock operator. Since the game animals are owned and managed by the State in which they occur-much as the Crown owned and managed the game under early English law-and occupy both privately and federally owned lands, conflict in their management is to be expected. The sportsmen, who generally favor increased game, clearly outnumber the stockmen and landowners, hence the latter are confronted with a difficult economic problem. Any land management program which calls for reduction in game numbers, as most of them do, is bitterly and boisterously opposed by many sportsmen.

\section{Nutritional Levels and Trends of Browse Plants}

Nutritional studies of range forage for livestock and big-game animals is so meager that it is difficult to translate the findings into practical use by the operator or wildlife manager. Stockmen are especially in need of information on what supplemental feeds, such as cottonseed cake, grains, or havs should be provided, if any, at specific periods, and what the cost and returns would be. They realize that the requirements for supplemental feeding are not the same for all ranges and localities.

Needs for supplementing the range primarily depend 
on the adequacy of the feed; and the condition or "health" of the range. In recent years the feeding of supplements on the predominantly ammual foothill ranges of the State has become morc popular ${ }^{(0,01)}$. On the other hand, on annual ranges that support an adequate combination of grass and good-quality evergreen browse, or even of bur clover, supplemental feeding is seldom practiced nor does it appcar necessary-except, possibly, to induce heavier utilization of browse. As demonstrated later, mature annual grass range is distinctly inadequate in protein, certain essential minerals, and carotene-the precursor of vitamin A-but is high in fiber and lignin. In contrast, the protein, mineral, and vitamin levels of evergreen browse speeies are moderately high at all seasons, and in much better balance than in mature grass.

The discussion which follows inchudes a summary of the changes in chemical constituents of some of the more important species and forms of browse plants, and how these values compare with those of annual grasses and certain other herbaceous species.

IVith deer, as with domestic livestock, the raw materials of cellulose and crude protein in the leaves and stems of plants are converted into energy and flesh. Obviously, a satisfactory balance of all essential plant constituents is required if seasonal die-offs, impaired reproduction, and poor condition of the deer are to be minimized ${ }^{(87,02)}$. Therefore a knowledge of the changes in the percentages of the raw plant materials is essential to an understanding of the nutritional shortages and needs of grazing animals, be it domestic livestock or big game.

\section{Seasonal Changes in Chemical Composition of Three Plant Groups}

Although many workers have studicd the chemical composition and nutritive valucs of browse and herbaceous forage and domesticated foclder plants, only a few broad principles have bcen established. In general therc is high protein content and low fiber and nitrogen-free cxtract in the early growth stages, followed by decline in the former and increase in the latter two. In some species the quantitative scasonal trend in the ash content, which includes the mincrals essential to growth of domestic livestock, has also been well established. In other species or plant groups these trends are less well known. Many of the fluctuating trends noted in the plant constitucnts may be accounted for by heavy browsing or grazing, by variations in soil moisture resulting from dronght, by the movement of clements from one plant organ to another and from the roots to the soil, and, particularly, by the stage of plant development ${ }^{20,80,85,88,}$ 100, 12a, 10:2). However, the biological or elimatic factors arc seldom, if ever, sufficiently powerful to overcome wholly the genctic influence of the plant in maintaining the characteristic compositional trend. This is also true for certatin unrelated groups of growth forms. Deciduous shrubs and trees, e.g., have consistently different compositional trends than nondeciduous or evergreen forms "ren thongh they commonly oecupy the same habitat.
The seasonal trends in composition of several deciduous and of evergreen shrubs, as well as of representative annual grasses, were determined from samples collected on the San Joaquin Experimental Range ${ }^{(00)}$. The data wcre averaged for each of the different growth stages, to show broad trends of the two shrub groups and of the annual grasses rather than the levels of individual species. Samples of the annual grasses were collected in the same general localities where the shrubs were sampled.

The deciduous species most extensively analyzed were blue elderberry (Sambucus caerulea), blue oak (Quercus douglasii), California buckeye (Aesculus californica), California coffeeberry (Rhamnus californica), and poison oak (Rhus diversiloba).

The evergreen species analyzed throughout the season were chaparral whitethorn (Ceanothus leucodermis), deerweed (Lotus scoparius), mountain whitethom (Ceanothus cordulatus), and wedgeleaf ceanothus Ceanothus cuneatus).

The annual grasses analyzed at all seasons were foxtail fescue (Festuca megalura), ripgut (Bromus rigidus), slender wild-oat (Avena barbata), and soft chess (Bromus mollis). The data, shown in the graphs on the next page, were adapted from California College of Agriculture Bulletin No. 627, "Composition of Common California Foothill Plants as a Factor in Range Management"

The seasonal changes in chemical levels and trends differ markedly in the three plant groups in many vital respects, notably as follows:

1. The crude protein content (graph, top left) in the deciduous shrubs and trees is by far the highest in percentage in the spring and early summer, compared to the other groups. However, the protein level in this group declines rapidly after midsummer and is lowest at leaf maturity early in the fall. The grass group is also high in protein in the spring, intermediate in the summer, and notably lower after the herbage has matured in the fall. This pattern has been verified by other workers $^{\text {(189) }}$. The evergreen shrubs maintain fairly constant levels of protein throughout the growth cycle, being the lowest of the groups early in the scason, but considerably the highest (14 per cent) in the fall.

2. In crude fiber levels (graph, top right), the deciduous shrubs and the evergreen shrubs and trees run essentially parallel and have ncarly the same valucs throughout the scason, ranging from about 10 to 12 per ccut. These values arc conspicuously lower than in the grass group. In the latter there is a sharp and continuous risc in fiber from spring to the end of the growing season, ranging from about 23 to 34 per cent.

3. The calcium content varies widely in the deciduous shrubs and trees, starting at about 0.9 per ecnt in carly spring, then rising rapidly and continuously until leaf maturity in the fall to abont 3.7 per cent (graph, bottom left). In contrast, in the evergrecn shrubs calcium content averages about 1.4 per cent in early spring and declines to $0.7 \mathrm{per}$ cent in the fall. Slightly higher levels occur between late summer and early fall. The grass 
group is mueh the lowest in calcium levels, ranging from 0.6 per cent in early spring and declining very gradually through the growth cyele to 0.2 per cent at full maturity in the fall.

4. In phosphorus the range in the early spring leaf stage is mueh wider than in the ealcium levels for the three plant groups, and is measurably narrower at leaf maturity in the fall (graph, bottom right). The deeiduous shrubs and trees are mueh the highest in phosphorus eontent from early spring to late summer; the evergreen shrubs are the lowest in this eonstituent throughout the season. In the grass the phosphorus levels are intermedi-

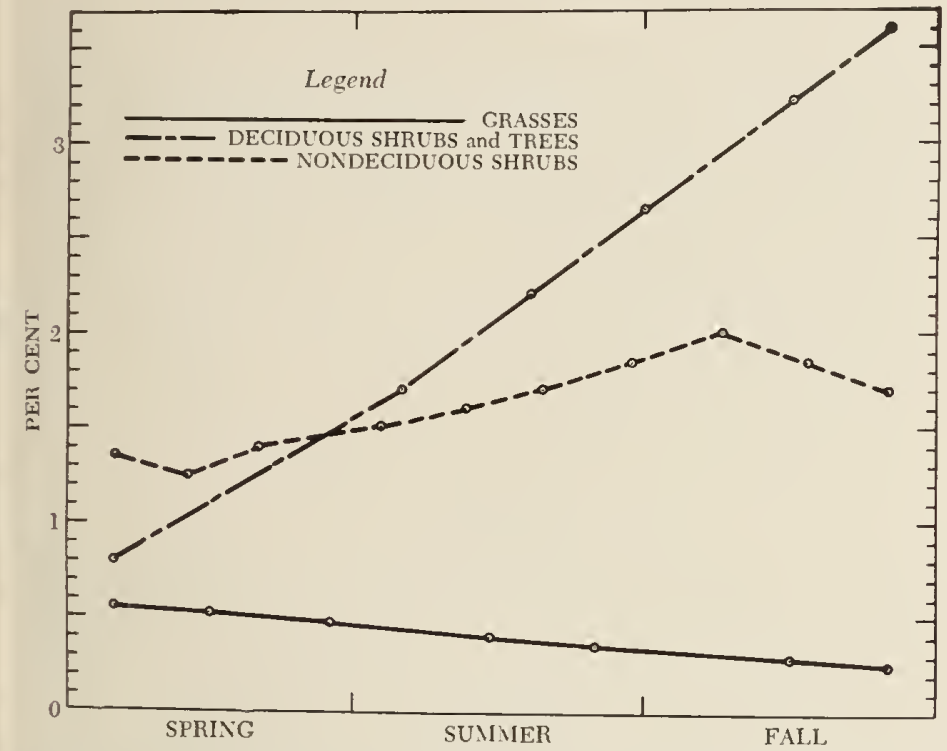

Crude protein in deciduous shrubs and trees is highest in spring and early summer, less high in grasses, and low for both in the fall. For evergreen shrubs the crude protein level remains fairly constant. ate between the two woody groups in the spring and then deeline gradually to reaeh the lowest levels in the fall ${ }^{(18)}$

5. The calcium-phosphorus ratio shows eharaeteristie behavior in the respeetive plant groups. In the grasses this ratio remains elose to 1 to 1 at all growth stages; in the evergreen shrubs the ratio is approximately 5 to 1 in the early leaf stage and in some speeies the ratio rcaehes 16 to 1 late in the autumn. In the deeiduous shrubs and trees the ratio varies most, averaging approximately 1 to 1 in the early leaf stage and as high as 28 to 1 at leaf maturity in some speeies.

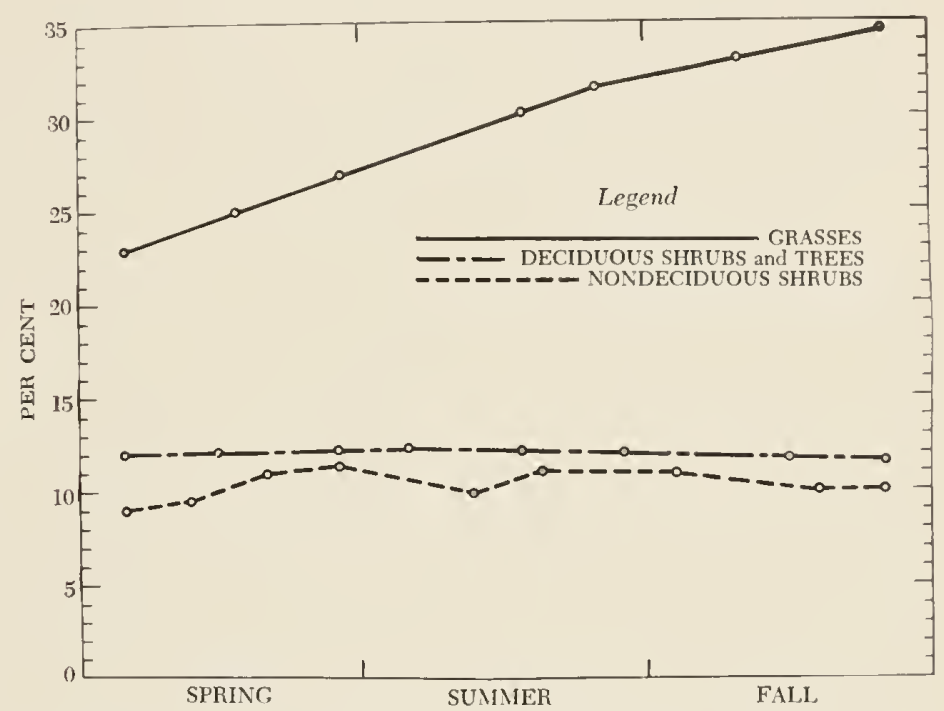

Crude fiber is high in grasses and rises as the season progresses. It is lower and constant in the shrubs and trees.

\section{Chemical changes in shrubs and grasses over the seasons.}

Calcium content rises rapidly in deciduous shrubs and trees, is more or less level in the evergreens, and very low in the grasses.

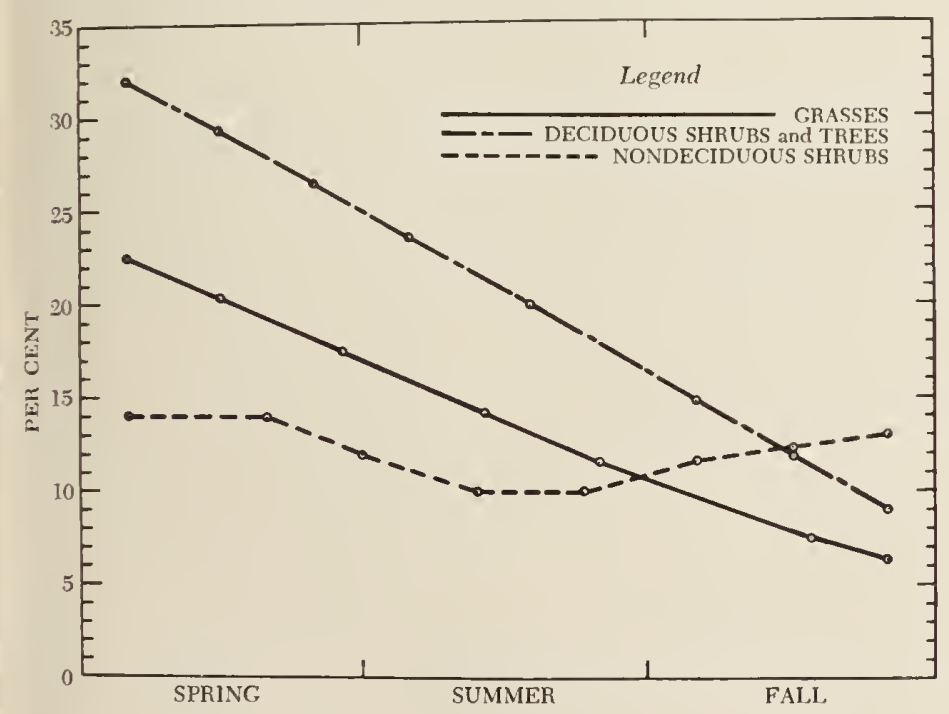

Phosphorus drops very steeply in the deciduous shrubs and trees, is intermediate in the grasses, and varies in the evergreen shrubs.

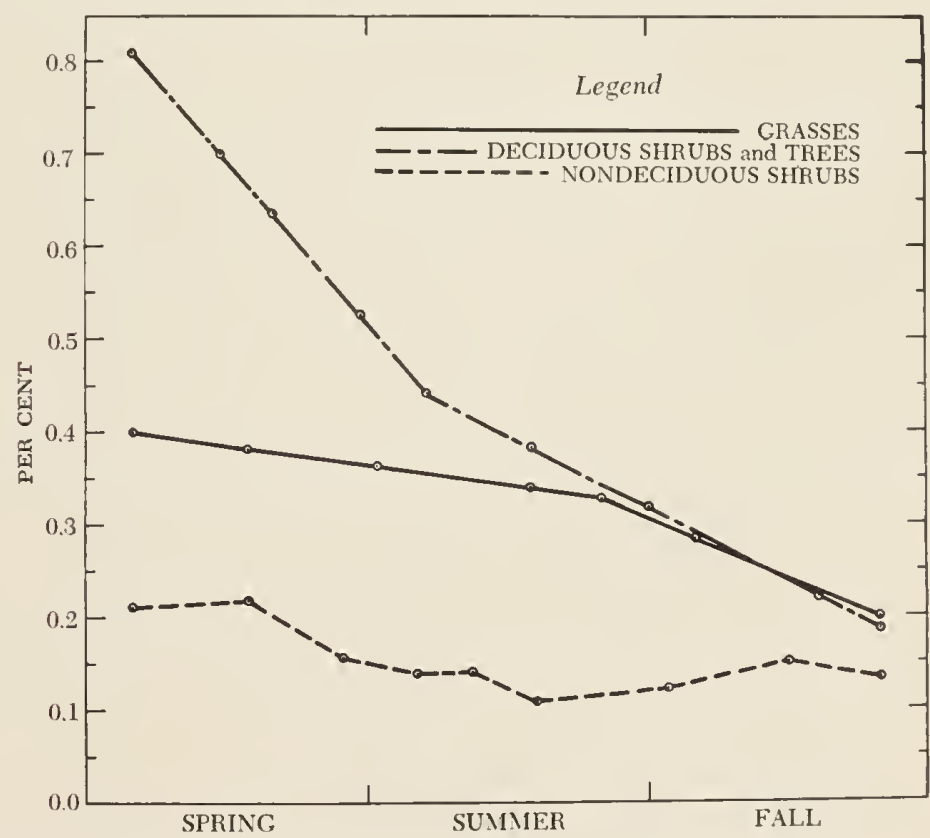


The changes in levels of the three plant groups from the early lcaf stage in the spring to leaf maturity in the fall are indieated below:

\begin{tabular}{|c|c|c|c|c|c|c|}
\hline PLANT CROT'S & ASH & ProteIN & FIBEH & CALCITM & $\begin{array}{l}\text { PHOS- } \\
\text { PHONUS }\end{array}$ & $\begin{array}{l}\text { CALCHOM- } \\
\text { pHOS- } \\
\text { PHORUS }\end{array}$ \\
\hline Grasses & Decrease & Decrease & Increase & Decrease & Decrease & Constant \\
\hline $\begin{array}{c}\text { Eicrogreen } \\
\text { shrubs }\end{array}$ & $\begin{array}{l}\text { Level } \\
\text { varies } \\
\text { slightly. }\end{array}$ & $\begin{array}{l}\text { Level } \\
\text { varies } \\
\text { slightly }\end{array}$ & $\begin{array}{l}\text { Level } \\
\text { varies } \\
\text { slightly. }\end{array}$ & $\begin{array}{l}\text { Level } \\
\text { varies } \\
\text { slightly }\end{array}$ & $\begin{array}{c}\text { Level } \\
\text { varies } \\
\text { slightly }\end{array}$ & $\begin{array}{l}\text { Moderate } \\
\text { increase }\end{array}$ \\
\hline $\begin{array}{c}\text { Deciduous } \\
\text { trees and } \\
\text { shrubs }\end{array}$ & Increase & Decrease & $\begin{array}{l}\text { Level } \\
\text { varies } \\
\text { slightly }\end{array}$ & Increase & Decrease & $\begin{array}{l}\text { Sharp in- } \\
\text { creasc }\end{array}$ \\
\hline
\end{tabular}

The relatively wide ealeium-phosphorus ratios in the deciduous plant group in late summer and autumm would indieate their inferiority as browse eompared to those of the evergreen shrubs in this respeet. One reason why California range grasses are well-liked as forage seems to be their farorable ealcium-phosphorus ratio.

It is important that range livestoek reeeive adequate amounts of ealcium and phosphorus, and also that these two minerals should have a suitable ratio. A disproportionate amount of either one of these eonstituents may have detrimental effects ${ }^{(100,14 t)}$. An ideal ealeimm-phosphorus ratio is 1 to 1 , or 2 to 1 although a ratio of 6.5 to 1 has been found satisfactory for raising dairy ealves where the supply of vitamin D was adequate. On browse range an adeqnate stand of grasses and forbs provides variety in the diet and helps equalize a high ealieumphosphorus ratio in the browse, espeeially in the fall.

Most investigators have coneluded that the protein levels of range forage speeies are the most reliable single faetor in judging their nutritive values. Hagen ${ }^{(62)}$, studying the ehemical composition and digestibility of several deeidnous and evergreen shrubs eonsumed by deer on the Jawbone winter range in central Tuolumne County, found marked differenees in the nutritive levels of the species analyzed. There were also great differenees in the composition of speeies utilized by the deer during the sumner as eompared with those eropped in the winter. The most significant contrast hetween "good" and "poor" browse species seemed to be in the levels of their erude protein content. The plants whieh the animals preferred were persistently high in crude protein, whereas the emergency or "filler" species-which were eaten less by choice thim by necessity beeause of the overgrazed eondition of the range-were low in erude protein eontent. Differences in the fat and mineral contents were also uroted, but seemed less important in affecting palatability and mutrition of the forage than the protein levels. Indeed, low protein values are known to adversely affect regencration by cansing lowered eonception, later calving, lambing, and dropping of fawns, and to adverselv affect the ranclere's profits. Whether game and livestock sclecet forage plants for their protein content is not kuewen. Some workers, however, have conchelded that rortain sugats mav influener palatability.

Ilagention noted that the range in levels of the crude protein and erude fiber were much greater in the deeiduous than in the evergreen speeies. He also observed that on overstocked deer range the volume of available browse was conspieuously low in the winter because mueh of the current twig growth had been eonsumed earlier in the season. This low nutritional ebb of browse appeared to aceount for the heavy losses in the decr herds during the winter months. During this season plants high in earbohydrates may perhaps better meet the food requirements of deer than those having high protein levels.

\section{Diets of Four Animal Groups}

\section{Beef Cattle}

Beeause of their large population, and because one mature eow is assumed to consume approximately as mueh range feed as five sheep, beef eattle are far heavier users of the range forage erop than sheep. Cattle are natural grass eaters and will usually utilize gently sloping or flat grass range more effieiently than sheep and goats; they will also feed extensively upon various browse plants, but not upon as many brush speeies as sheep and goats.

\section{Sheep}

Sheep, and to a lesser extent goats, also consume large amounts of grass and forbs-in faet, exeellent lambs are often reared on well-drained sueeulent grass-and-forb range; but after the herbage matures these animals turn to palatable browse, espeeially sueeulent sprouts sueh as eommonly oceur on newly burned brushlands. A combination of browse-grass-forb range is usually more fully utilized by sheep and goats than by cattle. Sheep, and especially goats, will work their way through fairly dense stands of brush, provided a fair proportion of the stand is palatable and the soil is not wet. Goats are heavy browse eaters ${ }^{(127)}$.

\section{Deer and Antelope}

Deer and antelope rely more upon browse than do any of the domestie animals, with the possible exeeption of goats. During late fall and winter these native animals depend largely for their snstenanee upon brush, some speeies of which are eaten little by domestie livestoek ${ }^{(1+5)}$. In many loealities the browse sought by livestoek must be shared by big-game mammals, mostly deer, thus eomplieating the maintenanee of the more palatable brush speeies because of overutilization.

Although deer show marked seasonal forage preferences, this may often be traced to stage of growth or to availability. In Lake County in the north coast range the shrubs that furnished mosi of the winter browse were: C! amise (Adenostoma fasciculatum), semb interior live oak (Quercus wislizenii var. frutescens), California scrub) oak (Quercus dumosa), bitterbmsh (Purshia tridentala), wedgeleaf ceanothus (Ceanothus cuneatus), toyon (Ileteromeles arbutifolia), California lanrel (Unibellularia 
californica), and California yerba santa (Eriodictyon californicum $)^{14+14.155}$. On areas where fire had removed the old top growth of the chaparral and converted it to "shrubland" because of extensive sprouting, deer kept the plants low and rounded so the forage remains within their reach, although some plants were killed by overgrazing. Deer also consumed a considerable amount of herbaceous vegetation in late winter and spring; but woody plants supply the greater amount of food during this period.

A study of choice of forage species by eattle, mule deer, and sheep on mountain range in Colorado revealed that competition was keener between deer and sheep than between deer and cattle ${ }^{(122)}$. In a list of 15 choice forage species, eomposed of browse, forbs, and grasses, cattle fed on more browse species than did sheep, but grasses, which topped the list for eattle, eomposed a mueh larger proportion of the food ingested. Browse was the staple yearlong diet for the deer, while browse and forbs were highest on the list of preferenee for sheep, and accounted for the greater part of their food supply.

These differences in forage preferences are interpreted to mean that on ranges in good condition with a balaneed variety of browse, forbs, and grasses, there is little likelihood that competition for forage will be serious between these animals. On poor-condition range, on the other hand, where one or more of the three kinds of animals are out of balance with the choicer forage plants, eompetition for forage is likely to become serious.

Another conelusion was that if one animal species is out of balance with its preferred forage plants, the range grazing eapacity for that animal will be redueed more than for the other animal species. Accordingly, the most rational use of the range would result from balaneed conservative use by all three kinds of animals.

A knowledge of the food habits of the California prong-horn antelope is largely restricted to the analyses of stomach samples obtained on their present range in Modoc and Lassen eounties. This means of sampling was necessary since both techniques based on visual obscrvation are diffieult because the antelope's affinity for the open range, and its inherent shyness ${ }^{(20)}$. The samples showed that although antelope are heavy browse eaters they seasonally consume a large amount of forbs, but take little grass at any time. Since antelope were numerous in the Central Valley prior to their extinction there, grasses at certain seasons might have contributed in varying degrees to their diet. It seems possible that the present antelope habitat is marginal at best and that these animals have become adapted to the food plants of that region.

On the summer range the antelope primarily requires an abundance of succulent forbs; on winter range big sagebrush is the desired food plant, though-probably because of present rather artificial range restrictions of the prong-horn-it is cropped extensively throughout the year. The prong-horn antelope apparently does not suffer from malnutrition while subsisting largely on big sagebrush during the winter months. Some of the winter browse species in the eastern Sierra Nevada are somewhat low in protein and certain other nutritional components. Big sagebrush, however, has much the same levels of nutrients as other commonly associated browse species of the "preferred" list. In general, big sagebrush is the staple food for antelope during the spring, fall, and winter periods, with bitterbrush and rabbitbrushes, in the order named, providing important feed at seasons other than winter. Forbs are cropped in appreciable variety and bulk in spring and fall. The eating of grass is negligible.

\section{Nutritional Requirements}

Range livestock have five eardinal nutritional requirements-sufficient feed, and adequate levels of protein, carbohydrates, minerals, and vitamin A.

Insufficient feed, commonly reflected in poor range condition, is greatly influenced by the amount and distribution of the season's rainfall. The annual volume of forage produced and the length of the green-feed period on the foothill ranges may vary tremendously $y^{(6)}$. Low rainfall years commonly result in loss of weight in the animals, decreased growth rate, and increased losses from poisonous plants, parasites, and diseases ${ }^{(61)}$.

Seasons of limited forage production are also associated with shortage of protein, whieh is the muselebuilding and tissue-repair substance, and even with shortage of carbohydrates. This results in depressed appetite, loss in weight, failure of milk seeretion, and lowered reproduction. On good-quality browse-annual grass range the animals tend to eonsume much more leafage and twigs of the green woody plants. The browse also provides the essential vitamin $\mathrm{A}$, which is laeking in mature herbage, and the much-needed minerals, notably phosphorus.

Adverse forage-growth years suggest that palatablc evergreen browse may be more important in supplying food requirements and vitamin A of grazing animals during the grass-dry season than is generally realized.

Technicians and livestock operators need more information on the nutritive values of range forage plants to develop and apply improved management practices. The operator is eager for such knowledge to correct nutrient defieiencies before his animals lose in weight and eondition. However, where stands of brush occupy productive sites they should be cleared or at least opened up for the growth of grass. Complete elearing of brush is not always the best practice even on highly productive sites.

\section{Brush Control}

Some investigators of brushland problems in California have stated or implied that 10 million so-called "wasted acres" of brushlands are suitable for conversion to range grasses for livestock grazing ${ }^{(152)}$. Rational estimates of the brush acreage that can be permanently converted to grass can obviously not be made without careful analysis of the soil- and vegetation-survey findings and the results of the range improvement experiments 
which have been made on these lands. The estimates of the brushland aereage presently feasible for brushland improrcment is based upon all the reliable facts available.

\section{Acreage IVhere Brush Control is Feasible}

A preliminary estimatc of the aereage of foothill range where brush control might be clesirable and feasible was published in $1954^{(12 x)}$. At that time detailed appraisals of the acreage dominated by brush, where effective range improvement work might he practieable, had been undertaken for only two areas-the Sierra Nevada footlills, and Mendoeino Countv. The study in the Sierra Nevada foothills eovered an area of 660,000 acres of the woodland-grass association, located in six counties and represented 8.8 per cent of the total area of this plant corer in the foothill ranges ${ }^{(158)}$. It revealed that thcre was no brush problem on 30 per eent of the land dominated by this plant association. In Mendocino County, soils and associated natural vegetation of all wildlands of the county, exclusive of those within national forests, were carefully survered and mapped. Data from this survey furnished an important basis for the preliminary estimate of lands suitable for range improvement.

Sinee publieation of the earlicr estimate, the State Cooperative Soil-Vegetation Survey has been extended to include the whole of Lake and Glemn counties except areas devoted to intensive agriculture. A more reliable approximation of the acreage where brush eontrol is feasible can now be made for the rest of the State, based on results of thic current soil-vegetation survey of Glenn, Lake, and Mendocino eounties.

In these thrce eounties the soils and vegetation have been mapped in detail on a total of 3,274,000 acres of upland areas, as part of the State Co-operative SoilVegetation Surver ${ }^{(23,50)}$. In this survey, soil serics and associated dominant plant cover are identified and mapped concurrently in the field, at a scale of two inches to onc mile. Rclationships between soils and plant cover arc ascertained; and soils are appraised as to their suitability under natural eonditions for production of timber, range forage, and other uses ${ }^{(5)}$. The mapping and related investigations in these counties have included 1,299,000 acres of land with plant cover typical of the brush problem areas of the foothills. Data from this surver as summarized bclow, constitıte a sample of conditions ranging from nearly 5 per cent on the chaparral and coastal sagebrush commonity to more than 19 per cent of the total acreage occupied by minor conifers:

\begin{tabular}{|c|c|c|c|}
\hline \multirow{2}{*}{ PIANT CONINUNITY } & \multirow{2}{*}{$\begin{array}{l}\text { TOTAL. AIREA } \\
\text { OF FOOTIILL } \\
\text { HANCE } \\
\text { (MULLIONS } \\
\text { OF ACRES) }\end{array}$} & \multicolumn{2}{|c|}{$\begin{array}{l}\text { AHEA MAPPED IN } \\
\text { THUIE COUNTILS }\end{array}$} \\
\hline & & ACHES & $\begin{array}{l}\text { PEH CINT } \\
\text { OF TOTAI. }\end{array}$ \\
\hline Wers)llaud-grass & 7.5 & $589,(0)(0)$ & 7.7 .4 \\
\hline W'oxulland & 1.5 & $13.3,000$ & 8.88 \\
\hline Chaparral anrl coastal sagrebrush & 10.5 & 181,000 & 1.58 \\
\hline Minor conifors & .5 & $96,() 00$ & 19.20 \\
\hline Tolals & 21.1 & $1,299,(0) 0$ & 6.18 \\
\hline
\end{tabular}

These studies seem to encompass areas of sufficient size and variety to afford a basis for a fairly reliable estimate of the aereage on which brush control for range improvement might be feasible and have economic possibilities.

As the above table shows, soils and vegetation have been mapped on 589,000 acres of woodland-grass, or 7.74 per eent of the total area dominated by this cover. Information from the soil-vegetation survey confirms the earlier conclusion that essentially no brush exists on 30 per cent of the land dominated generally by woodlandgrass since they are already grass covered ${ }^{(128)}$. Results of soil-vegetation survey mapping also show that the soils of 17 per cent of this area having a brush problem are of poor to very poor quality for forage produetion. Thus, brush control may be desirable and feasible on only about $83 \times 70=58.1$ per eent of the total area dominated by woodland-grass; this would amount to 4.36 million acres.

Approximately 133,000 acres, or 8.88 per cent, of the area occupied by woodland have been mapped. At least 32,000 acres, or 24 per cent, of this cover oecur on soils that are poor to very poor for forage production. Brush control measures for range improvement probably would be practicable, then, on only about 1.14 million aeres of this woodland. However, more than 45 per cent of this cover occurs on sites suitable for commercial timber production. Such production no doubt would be more advantageous for these lands in the long rum.

Chaparral and coastal sagebrush covers were mapped on 481,000 acres, or approximately 4.58 per cent, of these plant communities oecurring in the foothills. Only 44,000 acres-some 9.1 per cent-of the chaparral and coastal sagebrush were on soils of fair or better quality for forage production. Perhaps an additional 20 per eent oeeurs on topography not too steep for good range use. Therefore, brush control for range improvement may be practicable on a total of only about 29 per cent, or 3.04 million acres of the foothill ranges dominated by chaparral and coastal sagebrush.

About 96,000 acres dominated by minor conifers have becn mapped in Glenn, Lake, and Mendocino counties, or about 19.2 per cent of the area occupied by this kind of cover. Twenty per cent of the minor conifers occurred on soils that are fair to very good for forage produetion. As in the chaparral and coastal sagebrush, an additional 20 per cent of the area having soils that are poor to very poor for forage production, may be on topograply where range use is possible. Therefore brush eontrol for range improvement may be feasible on a total of not more than 40 per ecnt of the area dominated by minor eonifers, amounting to 200,000 aeres.

Acreages of the foothill range where brush control may be possible and eeonomically feasible are summarized on top of page 23 for the four plant communities.

From these data it appears that the maximmm area whore brush eontrol may be feasible extends over 8.6 million aeres. This estimate of gross acreage is based on the best current information, ineluding the results of a 


\begin{tabular}{|c|c|c|c|}
\hline \multirow{2}{*}{ PLANT COMMUNITY } & \multirow{2}{*}{$\begin{array}{l}\text { TOTAL } \\
\text { AHEA OF } \\
\text { FOOTHILI } \\
\text { RANGE } \\
\text { (MALLIONS } \\
\text { OF ACRES) }\end{array}$} & \multicolumn{2}{|c|}{$\begin{array}{l}\text { AREA WHERE BRUSH CON- } \\
\text { TROL MAY BE FEASIBLE }\end{array}$} \\
\hline & & $\begin{array}{l}\text { PER } \\
\text { CENT }\end{array}$ & $\begin{array}{l}\text { MILLIONS } \\
\text { OF ACRES }\end{array}$ \\
\hline Woodland-grass & 7.5 & 58.1 & 4.35 \\
\hline Woodland & 1.5 & 76 & 1.14 \\
\hline Chaparral and coastal sagebrush & 10.5 & 29 & 3.04 \\
\hline Minor conifers & .5 & 40 & .20 \\
\hline Totals & 20.1 & 43 & 8.64 \\
\hline
\end{tabular}

soil-vegetation survey, of the lands concerned. As more data become available, the estimate must be revised. The present estimate rests largely upon the assumption that the operator will receive a return on the investment required for range improvement; and that the lands included are suitable for forage and browse production and range use. A "break even" basis-return of the actual investment, but with no allowance for profit or interest on the outlay-is considered to be the upper limit of economic feasibility. However, in any given situation factors other than those taken into account here may be of greater importance to the individual rancher, making range improvement feasible in his particular case under conditions where this would not be true generally.

While the foregoing analysis indicates that brush control, but not necessarily elimination, for range improvement may be feasible on a maximum of about 8.6 million acres of foothill range, only a small proportion of this acreage could be classed as highly productive for forage growth. Out of the total area mapped to date, where brush is a significant element in the plant cover, only about 438,000 acres occur on soils normally associated with grassland or woodland-grass vegetation under natural conditions. These are the soils most productive of range forage. Such sites afford the most favorable opportunities for brush control, from the standpoint of obtaining either successful results biologically, or a return on the investment. As was pointed out above, no brush problem exists on about 30 per cent-or 110,000 acres-of the area occupied by woodland-grass. Accordingly, the net area of soils normally associated with grassland and woodland-grass, where brush control may be nécessary, is about 328,000 acres, or some 25.2 per cent of the total area mapped in Glenn, Lake, and Mendocino counties. On the foothill ranges as a whole, brush is an important element in the plant cover of some 20 million acres (see table on top of page 23). Subtracting 30 per cent, or 2.25 million acres, of the woodland-grass, where brush is no problem, leaves a net area of 17.75 million acres where brush does pose a problem. Applying the above figure of 25.2 per cent as the average for soils normally associated with grassland and woodland-grass, indicates that the most favorable opportunities for economic returns from brush control are limited to about 4.47 million acres of foothill range. Certainly, when sites are critically evaluated, not more than two-thirds of this area, or about 3 million acres, could be classed as highly productive for range forage. If as much as 3 million acres of brushy foothill lands of good quality for range forage production purposes could be found in California, the task of its effective conversion during the next quarter to half century would be colossal. The particular needs of an individual rancher, however, may at times be such as to warrant conversion to grass, at considerable cost, of some rclatively inferior sites in order to carry his animals through certain critical times when his other lands are not available for grazing.

\section{Estimate of Success in Range IMPROVEMENT}

In an effort to broadly estimatc the degrce of success of the brush range improvement program, range technicians of the California Division of Forestry in 1953 resampled 3.5 per cont of the areas and 4.2 per cent of the acreage that had been control-burned ${ }^{4500}$ from 1948 to 1952, inclusive. The Sierra Nevada foothills from Butte to Tuolumne counties and southem California were more intensively studied than the rest of the State. On each selected area forage composition, density, and other factors that would indicate present condition and grazing capacity of the land were recorded. Also, estimates were made of the grazing capacity before buming by sampling similar adjoining unburncd lands. The areas sampled were segrcgated into the following five production classes:

\begin{tabular}{ll}
\hline Class designation & $\begin{array}{c}\text { Estimated GRAZING CAPACITY } \\
\text { (ACRES PER A.U.M. }{ }^{*} \text { ) }\end{array}$ \\
\hline Very good & Less than 1.0 \\
Good & 1.0 to 1.4 \\
Fair & 1.5 to 2.4 \\
Poor & 2.5 to 4.0 \\
Very poor & More than 4.0
\end{tabular}

- Animal unit month: quantity of feed needed by a mature cow for one month.

In still another study ${ }^{(10)}$, limited to Madera County but probably applicable over much of the woodland-grass region of Tuolumne, Mariposa, Fresno, and Tulare counties-reseeding was found suitable on less than 15 per cent of the total area burned during the four years of study, from 1950 through 1953. Approximately 98 per cent of such areas were reseeded. Reseeding after burning proved suitable only where the original brush cover had been dense enough to crowd out stands of grass and where the resulting ash prepared a favorable seedbed. The results indicate that little of this area was improved by control-burning and reseeding so far as grass yield was concerned.

The sampling results tabulated above showed that grazing capacity ranged from "fair" to "very good" (2.4 acres or less per A.U.M.) on 46.7 per cent of the area sampled; it was "poor" to "very poor" ( 2.5 acres or more per A.U.M.) on 53.3 per cent of the area sampled.

Combining the results of this study with observations throughout the State leads to the conclusion that somewhat less than half of the area that has been controlburned to date has been put into morc or less permanent grazing land with a predominantly herbaceous cover. The figure probably would lie between about 40 and 45 
per cent of the area burned each year. Applying that ratio to the ammual acreage would give the figures presented below.

\begin{tabular}{crrr}
\hline YEAR & $\begin{array}{c}\text { ACREAGE BURNED } \\
\text { UNDER PERMIT }\end{array}$ & $\begin{array}{r}\text { ACREAGE PERMANENTLY MMPOVED } \\
(\text { AT } 40 \%)\end{array}$ & $\begin{array}{c}\text { (AT 45\%) } \\
1946\end{array}$ \\
\hline 1947 & 54,164 & 21,666 & 24,374 \\
1948 & 24,945 & 13,178 & 14,825 \\
1949 & 87,909 & 9,785 & 11,008 \\
1950 & 83,249 & 35,164 & 39,559 \\
1951 & 133,885 & 33,299 & 37,462 \\
1952 & 181,710 & 53,551 & 60,248 \\
1953 & 178,354 & 72,684 & 81,769 \\
1954 & 227,131 & 71,342 & 80,259 \\
1955 & 134,370 & 90,852 & 102,209 \\
1956 & 149,043 & 53,748 & 60,467 \\
1957 & 109,731 & 59,617 & 67,069 \\
1958 & 150,564 & 43,892 & 49,379 \\
1959 & 83,079 & 60,226 & 67,754 \\
1960 & 128,430 & 33,232 & 37,386 \\
1961 & 85,416 & 51,372 & 57,794 \\
& & 34,166 & 38,437 \\
Total & $1,844,442$ & 737,777 & 829,999
\end{tabular}

There are indications that a somewhat higher proportion of the area control-bumed each year is having follow-up work and management practices that effect more lasting improvement than was true in the earlier ycars of this program.

\section{Increased Grazing Capacity Based on Potential Brushland Conversion}

Based upon the results reported, the question may well be asked: What is the probable increase in grazing capacity when all potentially good brushlands have becn improved for grazing? When the unimproved areas were originally sampled, in 1946, they had an average requirement of abont 15 acres per animal unit month, whereas in 1953, at time of resampling, the monthly requircment had declined to 6.5 acres. This represents a substantial incrcase in grazing capacity.

It has been pointed out that some degree of range improvement might conceivably be economically sound on about 9 million acres of brushland. The data indicate that 3 million acres have fair to high potential for range improvement and represent the better portions of the foothill area for clearing. Furthermorc, grazing capacity is ligher during threc to four years after clearing than it is later on. If range improvement is economically sound on approximately one-third of the total foothill range area-as indicated by this analysis-and grazing capacity on this one-third of the arca can actually be increased liy 50 to 60 per cent, then the maximmm to be expected for the area as a whole is an increase in grazing capacity of 15 to 20 per cent. Now, since it appears that this maxi$1111 \mathrm{~m}$ forage yield may not be sustained for the long run, it may be conchuded that an increase in grazing capacity of from 10 to 15 per cent is the very loest that can be exprected aceording to present practices. This estimate of ()ver-all capaloilities for increasing forage supply is entirely eonsistent with the experiener on individual ranches where local conditions man permit consiglerably greater expense in conversion. Conceivably, the application of much more intensive land improvement techniques on some ranches than appear economically feasible at this time might somewhat enlarge the grazing capacity estimates here presented.

An increase in grazing capacity of cven 10 per cent of the brushland area would entail, among other things, greatly enlarged soil-vegetation surveys leading to land classification. This procedure would have to be accompanied or followed by intensive study of soil characteristics and the need of soil fertilization; study of forages especially adapted to the different soils and sites; grazing management which would maintain the introduced plant cover; bettcr knowledge of the use of fire; improved machinery and herbicidal sprays for brush removal or control; and, finally, intensive study of the economics involved in all the major steps of brush suppression and in establishment and maintenance of a desirable herbaceous forage cover.

To do an effcctive job of planning, improving, and operating his ranch, the stockman as well as the public land administrator must have detailed and accurate information about his lands. The physical factors with which he is largely concerned include weather and climate, soils, topography, vegetation and its productivity, water supply, and plant and animal pests. Each of these factors may profoundly affect his profits, annually or over a span of ycars.

The need is evident for drawing upon all available sources for information on these factors. For the past several years the State of California, in cooperation with the U. S. Forest Service and the University of California, has participated in making an inventory of the vegetation cover of wildlands and the underlying soils of the upland area of the State ${ }^{(23)}$.

The soil-vegctation survey aims to obtain basic information on the kind and distribution of soils and natural vegetation, and their characteristics and potential uses as a guide to their improved management. The data are placed on maps of convenient sizc for field use. Much of the information olstained can be directly applicd to wildland improvement problems including both livestock and game production. With appropriate interprctation of the principal soil charactcristics such as depth, texturc, water-holding capacity, permcability, erodability, and fertility, the information has dircet application in formulating many effective ranching decisions. The data are particularly uscful in selecting areas most suitable for clearing, resecding, fertilizing, or other improvement measures.

These surveys have revealed that some fairly decp and widely distributed soils, like the Laughlin series, are well suited for clcaring and resceding to grass. Others, like the Los Gatos soil, are relativcly shallow, and attempts to improve them should be confined to the most favoral,le sites. The Maymen soil, which commonly supports clapparral, is generally too thin and infertile for forage production and livestock grazing. The soil-vegetation survey, then, is an extremely effective means of conveying nseful 
information to the rancher and public land administrator. Frequently the rancher will obtain his information from the maps through the help of a range technician, soil technologist, extension specialist, or another person who is working either as a private consultant or as a public agent.

\section{Brush Planting of Depleted Areas}

The drastic thinning out of various choice browse species on many deer and livestock ranges has stimulated study of how and under what circumstances certain key woody plants might be reestablished. Since most brush species produce abundant viable seed, artificial planting is the most effective way of reestablishing the stand.

It has been demonstrated that California deer ranges can be improved by planting of palatable native brush species in suitable localities if followed by proper management ${ }^{\text {18, }}$ 1833). Planting experiments with bitterbrush (Purshia tridentata) and desert bitterbrush ( $P$. glandulosa) have given promising results in several localities. Although brush seeding is costly, it seems justified in maintaining present deer numbers partly to meet the demands of the continuous increase in deer hunters.

Studies have shown that reseeding with brush plants generally requires the seeds to be sown at a suitable depth and the seedbed to be well prepared as protection against serious competition with aggressive native vegetation. It also requires that the planted seeds germinate at the time when growing conditions become favorable in the spring. Failure of the seeds to germinate at a suitable season can largely be overcome by learning how seed dormancy can be broken for each species to be propagated.

Directions for treating seeds of California wild plants to hasten germination were presented as carly as $1936^{(105)}$. Seeds requiring a long time to germinate can be divided into two groups: those that have a hard seed coat, and those whose capacity to germinate comes from the internal qualities of the seed.

Hard-coated seeds can be prepared for planting by some means that will make the seed coat permeable to water. This may be done by scarification, hot water treatment, a sulphuric-acid bath, or thiourea ${ }^{(75,112)}$. The treatment chosen will depend largely on the thickness and density of the seed coat.

Seeds that do not germinate until changes have occurred within their internal substances-a class to which many important native browse plants belong-require the physiological treatment known as "after-ripening." The specific needs must be determined for each species requiring such treatment.

In Montana seed treatment of several browse plants was studied, including such species and varieties found in California as bitterbrush, western serviceberry, western chokecherry (Prunus virginiana var. demissa), creek dogwood, redstem ceanothus (Ceanothus sanguineus), and snowbrush ceanothus (C. velutinus) $)^{(119)}$. The following recommendations were made:
1. The seed of species having stony or thick and hard seed coats, such as wcstem chokecherry, should be soaked in watcr held near the boiling point for 5 to 10 minutes and then allowed to cool gradually before applying any other treatmont.

2. Stratify the seed in finc, moist sand at tempcratures of 35 to $41^{\circ} \mathrm{F}$ for a pcriod found suitable for a given species by first conducting stratification timc tests. The stratification time requirements diffcr greatly: for wcstern mountain-mahogany it is 50 to 75 days; for western chokecherry 150 to 180 days; for American dogwood (Cormus stolonifera) 90 days. Check the seeds tested for germination readiness towards the end of the recommended stratification time factor as the response of a species may vary somewhat according to source of sced.

3. Do not allow stratified seed to dry before field planting. Be sure that the seed is well covered. If ample seed is available, plant a portion of it without stratifying to compare results.

4. Regulate the planting time carefully to correspond with the stratification period found best for a given species. Spring seeding has given best results under the conditions studied.

Seeds of shrub species that characteristically have a prolonged period of dormancy may be induced to germinate promptly if properly treated before field planting ${ }^{\text {(14s) }}$.

Study of bitterbrush seed in northern California revealed that if either seeds or fruits are planted in fall or spring at the proper depth, even without special treatment, they will often germinate satisfactorily ${ }^{(71)}$. However, many of the young bitterbrush seedlings are destroyed by weather conditions, insects, game, and rodents before the livestock grazing season begins. Probably no more than 5 per cent of the planted seed will produce well-established plants. The number of seedlings to survive will depend on various environmental conditions such as soil type, spring and summer rains, and the amount of competing vegetation.

Bitterbrush seed for artificial planting should be collected in July and August and its purity and viability should be testcd bcfore planting as a guide to the amount of seed to distribute. A study aimed at developing a quick test for determining bitterbrush seed viability was undertaken by observing the growth of excised (husked) embryos $^{(111)}$. This procedure to determine viability precludes the time-consuming task of pretreatment to break seed dormancy but stratification or some other treatment for spring planting is still necessary.

Another California study verifies previous reports that seeding with bitterbrush, as with other brush species, is complicated because it entails many critical factors, among them depth of planting ${ }^{(7)}$. In northern California ihe best planting depth seems largely to depend on soil type and amount and distribution of precipitation during the germination and emergence period. Bitterbrush sced, whether broadcast seeded or row planted mechanically, failed to produce good stands if planted deeper than 2 inches. Depth of from 1 to 1.5 inches generally gave the best results. The lighter the soil the deeper 
the planting should be beeause light soil dries more rapidly: Although the time of seedling emergenee was regarded as important for judging suecess in planting, depth of planting proved of primary importance in obtaining a high percentage of emergenee.

Laboratory treatment of bitterbrush seed soaked for 3 to 5 minutes in a 3 per eent solution of thiourea meas11rably shortened the rest period ${ }^{(133)}$. This dry treated seed made the handling of wet stratified seed unneeessary and permitted planting when loeal weather conditions were favorable. However, before recommending thiourea-treated seed for large-seale spring planting, we must find out why seedling survival was relatively low and develop methods that will inerease survival rate.

A fundamental study of the morphologieal and physiologieal variability in bitterbrush and desert bitterbrush has been under way at the University of California sinee 19.57. This study, by R. F. Wagle, also tries to determine certain environmental factors which tend to eontrol or limit the geographical distribution of these species. Germination experiments with seed of different sourees have been conducted in the field, laboratory, and greenhouse under varions temperature eonditions and in different types of soil. Preliminary results indieate that this kind of study may point the way to better understanding of suecessful regeneration of both woody and herbaceous range plants.

In the study of game-range restoration in California, eonsideration of suitable browse speeies for planting included fourwing saltbush (Atriplex canescens) ${ }^{(12)}$. To enhance germination, samples of seeds were searified in varying degrees of intensity. Both moderate and heavy scarifieation hastened germination rate. Under eritical soil-moisture conditions, a higher germination rate is likely to improve the establishment of seedling stands.

Grading (or sorting) of nonsearified secds into size classes by hammer milling revealed that the smallest seeds-those with most husk removed-gave the highest germination, averaging $5+$ per cent, against 33 per eent for the larger seeds. The germination pereentage of intermediate seed sizes ranged between the two extremes.

Regeneration studies were also made in California of westem mountain-mahogany (Cercocarpus betuloides). Greater abundance of this species is desirable on most areas within its range of distribution, especially on clepleted deer ranges. It was noted that a few seedlings cmerge each year near the old plants under undisturbed conclitions but few become established because of severe plant competition "'"). There is some evidence that control burning miglut be used in some instances to increase the almulance of this plant, as large numbers of seedlings often appeared where the fire was properly geared (1) the time of seed maturity but before seed dissemination. The fire should be intense enough to kill the western monntain-mahogany trees and associated shrubs but not so) serere as to destroy the seeds of the mahogany.

A study was conducted in the Madera Connty foothills of central California to deternine the competitive reffects of a seceded graiss stand on a current brushland burn which supported seedlings of wedgeleaf eeanothus, chaparral whitethorn, Mariposa manzanita, and California yerba santa ${ }^{(132,133)}$. The first two named plants are important as deer and livestoek browse. Large numbers of brush seedlings emerged after burning off the brush. On the adjacent unburned areas few seedlings appeared. The stand of grass resulting from seeding was fairly heavy. On some plots all herbaceous vegetation was removed; on others the herbaceous vegetation was elipped baek to one-half inch each week; on still other plots the vegetation was left undisturbed. Both annual and perennial grasses were seeded but annual ryegrass formed most of the eover. Grass proved to be a severe competitor for moisture and eaused heavy mortality among the brush seedlings. Most of the brush seedlings on the ryegrass plots had clied by the time the grass had matured late in the summer. The few remaining seedlings averaged only 2 inches tall. On the plots where all vegetation had been removed the brush seedlings were vigorous and averaged 8 inches tall. Few, if any, died from drought. On the unseeded plots the brush seedling roots extended to a maximum of 43 inehes, whereas on the seeded plots maximum root penetration was only 11 inches. Competition was much more severe on the unelipped seeded plots than on the similar elipped plots.

This study demonstrates the importanee of holding eompeting vegetation in eheek on young brushland.

\section{Brushland Improvement}

Researeh workers have eome to reeognize six primary measures in brushland improvement: Selection of suitable sites; brush removal by control-burning; brush removal by mechanical means; brush removal by ehemieals; brush removal by biologieal means; and rational management of eleared brushlands.

Most important is appraisal of the quality of the brushland sites for range improvement. The skill with which this is done will determine, more than any other procedure, the suecess or failure of the undertaking.

\section{Selection of Suitable Sites}

Sinee brushlands vary in forage produetivity from extremely low to high, sites must be seleeted with a yield capaeity that will make improvement eosts and efforts worth while. Topography, nature of the vegetation, and soil eharaeteristies are most important in judging the suitability of brushland sites.

\section{Nalure of Terrain}

The nature of the terrain determines the general snitability of the land for range improvement and indieates how innch erosion may result from reducing the natural plant cover. Site elassifieation also indicates whether the area might be more useful for watershed protection than for any other purpose. Steepness of slope is the most important consideration of topography in brush eonversion work. The best possibilities of brushland improvement for livestock grazing are flats or gentle slopes, with rela- 
tively deep soil. On gentle sloping land machinery as well as fire can be used to remove the brush.

\section{Nature of Vegetation}

Luxuriant stands of brush, with the openings covered with dense grass, usually indicates a productive site for range forage. Areas of nonsprouting brush should be favored over those having sprouting species because they can be cleared with relative ease. Chamise and sprouting forms of manzanita generally occupy the most inferior sites.

soil Characteristics. For good grass yield the soil should be free from hardpan and should average 24 inches or more in depth, although fairly good grass production, mainly annuals, have been obtained on soils of 12 inches in depth and of clay-loam texture. Deep soils are most desirable for reseeding to grass because they can store more soil moisture and nutrients. Soils derived from serpentine rock should be avoided because of their low fertility. These soils are generally red in color and the outcroppings contain shiny green stony fragments. Sites having soils that erode readily, such as those with a profile of sandy topsoil and with clay subsoil, had best be left undisturbed unless it is certain that a better cover can be established before devastating erosion occurs.

When selecting brushy areas to be improved for grazing, it is not sufficient to consider one single factor alone; the composite effect of all the factors on yield and longevity of the converted forage crop must be weighed.

\section{Brush Removal by Control Burning}

Fire is the oldest, most common, and perhaps the cheapest method presently available for removing standing brush. Fire is also used to dispose of piled, lopped, and windrowed brush. The term "light burning" implies the use of fire in late fall, winter, or early spring. It reduces the danger of wild, destructive fires, and often improves the grazing. "Heavy burning" refers to firing during the dry, hot season to destroy the existing unwanted woody vegetation in order to increase and improve the quality of the forage for livestock and game.

Studies by the U.S. Forest Service ${ }^{(2,50,51)}$ have pointed out that before control-burning can be fully effective, more must be known about how fire spreads over the landscape. Two elements of particular concern are fire intensity and rate of spread. The factors that influence these two elements most are: Character and moisture content of the fuel, atmospheric humidity and temperatures, wind velocity and wind direction, and topography. All these factors determine how, when, and where burning is fairly safe and influence the decision as to how the fire may best be controlled.

Control-burning implies planned application and confinement of fire to preselected wildland areas. The actual firing is done in so many ways that no clean-cut description can be made of all of them. One control-burning technique is the "convenience" fire where the only elements predetermined are the time and place. Control- burning also presupposes a knowledge of the behavior of fire when used as a means in brushland improvement. This knowledge, however, would not necessarily prevent fires from escaping as judged by the acres burncd by escape fires shown. The figures listed below show that since 1945, of a total of about 2 million acres, some 160,000 acres, or 8 per cent, wcre caused by escape fires.

\begin{tabular}{|c|c|c|c|c|}
\hline YEAR & $\begin{array}{c}\text { NO. OF } \\
\text { PERMITS } \\
\text { USED }\end{array}$ & $\begin{array}{c}\text { ACRES } \\
\text { BUKNED } \\
\text { UNDER } \\
\text { PERMIT }\end{array}$ & $\begin{array}{c}\text { ACRES } \\
\text { BURNED } \\
\text { BY } \\
\text { ESCAPE }\end{array}$ & $\begin{array}{c}\text { TOTAL } \\
\text { ACRES } \\
\text { BURNED }\end{array}$ \\
\hline 1945 & 252 & 50,424 & 15,232 & 65,656 \\
\hline 1946 & 212 & 54,164 & 9,320 & 63,484 \\
\hline 1947 & 170 & 32,945 & 6,106 & 39,051 \\
\hline 1948 & 154 & 24,462 & 6,786 & 31,248 \\
\hline 1949 & 344 & 87,909 & 14,628 & 102,537 \\
\hline 1950 & 337 & 83,249 & 14,125 & 97,374 \\
\hline 1951 & 438 & 133,885 & 19,653 & 153,538 \\
\hline 1952 & 617 & 181,710 & 9,103 & 190,813 \\
\hline 1953 & 593 & 178,354 & 3,679 & 182,033 \\
\hline 1954 & 699 & 227,131 & 6,342 & 233,473 \\
\hline 1955 & 524 & 134,370 & 11,842 & 146,212 \\
\hline 1956 & 453 & 149,043 & 7,836 & 156,879 \\
\hline 1957 & 373 & 109,731 & 14,225 & 123,956 \\
\hline 1958 & 448 & 150,564 & 11,617 & 162,181 \\
\hline 1959 & 330 & 83,079 & 2,405 & 85,484 \\
\hline 1960 & 451 & 128,430 & 4,755 & 133,185 \\
\hline 1961 & 331 & 85,416 & 2,982 & 88,398 \\
\hline Totals & 6,726 & $1,894,866$ & 160,636 & $2,055,502$ \\
\hline
\end{tabular}

Neither the number of permits used nor the extent of burns or escapes changed significantly during these years. Damage to the adjoining lands, fences, and other property from the escape fires varied from nil to severe. Benefits to the control-burned brushlands varied from nil or poor to fair, good, and even exccllent on superior sites and under wise follow-up management.

Though objectionable because of its adverse effects on the site, reburning of "clearcd" brushlands every few years is usually neccssary to destory the reinvading brush seedlings ${ }^{(1,73,250,135)}$. Reburning, however, is usually not possible except wherc a fair to heavy cover of dry grass is present. It is therefore a rather common practice to artificially seed with grasses on freshly burned brushlands to protect the soil from destructive erosion and to provide fuel for reburning ${ }^{(133)}$.

For best results it is frequently desirable to use two or more techniques for clearing brush. The first step is to break down and level the brush for drying. Bulldozing with the blade held about a foot above the ground surface, or dragging a heavy rail or chain over the brush has given good results. Finally, when the leveled brush has dried out, the area is control-burned. This combination method insures a clean burn with minimum disturbance of the soil.

Control brush-burning is not necessarily inexpensive. It first requires state inspection of areas planned for burning, and consultation with the State Division of Forestry on plans for width and location of fire lines and of the burning. It also often requires stand-by fire suppression men and equipment of the State Division of Forestry during burning. 
A study conducted in northern California revealed that where effective fire lines must be constructed for safe control burning costs are considcrably higher for small areas than for large tracts ${ }^{(22)}$. For areas of 40 acres the total cost was $\$ 3.65$ per acre, whereas for burns of 410 acres the cost decreased to $\$ 0.60$. The cost was even lower on areas up to 640 acres. Operators of suitable adjoining brushlands have been instructed to pool their lands and buming operation since costs are lowered by increasing the acreagc.

\section{Brush Removal by Mechanical Means}

Where it is desircel to retain certain segments of a brushfield intact, suitable machinery is usually most satisfactory for clearing.

Mechanical clearing is gaining in popularity. It is used most in localities where firc cannot be used safely, to uproot the brush to hasten reseeding, or for growing farm crops. The cost pcr acre of mechanical clearing is high, ranging from $\$ 10$ to $\$ 50$ for bulldozing. Costs depend largely on the height and density of the brush and the rockiness of the area. The bulldozer is more extensively employed than any other kind of tractor-powered machinery. The root cutter, root rake, standard disk plow, offset disk harrow, the Wheatland-type plow, and similar devices are uscd in varying dcgrees according to the form of brush. The merits of the different kinds of cquipment have been fully discussed in UNASYLVA ${ }^{(120)}$. The brush acreage clearcd amnually by mechanical means in California is scveral times less than that burned. It has the advantage of complete removal of the topgrowth, and also of the roots, where desircd. Mechanical clearing also becomes more important as burning is rulcd ont from some areas because it produces smog.

IIcchanical removal must be restricted to fairly gentlc terrain. Machinery camnot be operated effieiently or eeonomically on steep slopes because of the difficulty and risk of handling the equipment and the fact that the lands is less productive than on gentle slopes or flats. Slopes of 5() per cent or more are too steep to clear with implements, and the barcd soil is subjeet to severe crosion. Where the steeper brushlands are to be cleared, burning, spraying, and the usc of hand methods are best. Usnally the bruslı cover of the stecper slopes should be left intact. Otherwise there may be loss of soil and fertility; the graring animals may trample and tear up the soil during the spring period; and the protective grass cover maly be sparse.

\section{Brush Control with Chenicals}

The use of chemicals for controlling brush ancl undesiralule trees dates back to the early history of agricultural development. Such common substinces as table salt, kerosene, and arsenic have long been nused to kill vegetation. Latrge-scale effort to control plants with chemincals, hewerer, hacl to await the derelopment of componnds which were specific in their action. Exten- sive control of woody plants developed east of the Rockies in the late 40's and has been studied in California since then ${ }^{(00)}$. Before 1945 ammonium sulfamate, diesel oil, ammonium thiocyanate, sodium chlorate, and a dry mixture of common salt and borax were the substances most commonly used for practical plant control. Discovery of the now popular hormone or growthregulating eompounds revolutionized the control of undesirable plants.

Extensive field trials have demonstrated that most woody plant species can be killed by treatment with suitable hormone sprays if the dosage, concentration, and methods of application are properly carried out. The most common selective herbicides are 2,4-D, and 2,4,5-T esters. The acid or salt or amine forms may also be used for special conditions. The low volatile esters-butoxyethanol and propylcneglycolbutyl ether-are now becoming more widely used than the highly volatile esters. 2,4,5 TP is usually more effective, when applied in ester form, for killing coast live oak, scrub intcrior live oak, and blue oak than either 2,4-D or 2,4,5-T, but on brush in general it is less effective than the other two compounds mentioned. For treating various species of freshly cut or frilled trees and stumps there is at present no better chemical than 2,4-D amine.

The advantages in using hormone sprays are that they are not poisonous to animals or man; cause no fire hazard; are noncorrosive to equipment; are effective in low dosage; are selective in thcir reaction on vegetation; and do not significantly poison the soil.

Ranchers are interested in chemical control for reducing brush encroaching on grassland; reclaiming brushlands for conversion to good pasture; and destroying trees and brush around springs to increase water for range livestock. Likewise the wildlife manager is interested in chemical control of unpalatable sprouts. He is also intercsted in chemical pruning of some brush stands to make browse more available to wildlife.

\section{How Selective Hormones Work}

Hormones of growth-rcgulating herbicides, singly or in combination, arc absorbed by tissues of the leaves or stems or even by the roots. Traces of these chemical compounds tend to eoncentrate in the growing tips and other vital tissues where sugars arc transported and stored. This results in cell elongation and causes twisting and other distortions of petioles and leaves, which interrupts or distorts certain basie physiologieal functions. Sinee these growth-regnlating chemicals act essentially. on the hormone systems within the growing tissue, they are selective in the killing of vegetation. This is becanse hormones are more or less specific in different plant genera or species, hence the spray may react specifically on the protoplasm of one plant gronp and not on that of another ${ }^{(12 y)}$. This kind of reaction is advantageous where the molesirable plants are susceptible. Since grasses are nusually not affected, these selective compounds are popular where brush has encroached on grassland. 
Certain nonselective herbicides, such as ammate (ammonium sulfamate), arsenicals (especially sodium arsenite), fortified petroleum products (particularly of kerosene and diesel oil), and TCA (trichloracetates), are also employed to kill brush or weed trees. Of these, ammate is most extensively used.

\section{Application}

Chemical sprays are applied in three different ways; foliar sprays, basal sprays, and cut surface treatment ${ }^{(80)}$. The objectives and the kind of vegetation determine which method to use. In brush control, foliar sprays are used almost exclusively. However, basal sprays on the bark of small-stemmed plants and cut surface treatment of single-stemmed trees are usually effective where the correct chemical concentrations are used.

Herbicidal sprays are more useful to destroy invading brush seedlings and sprouts after burning or mechanical removal than as the initial treatment. However, initial spray treatment, as with 2,4-D, is effective in killing such common brush plants as sagebrushes (Artemisia spp.) and chaparral broom (Baccharis pilularis var. consanguinea $)^{(40,41,112)}$. Occasionally spraying may be the first step to obtain a clean burn, but it is more costly and less effective than to crush the brush with a bulldozer blade.

Successful use of hormone-type sprays requires careful attention to the stage of plant development and the availability of soil moisture. Lush growth is essential. Also different esters and concentrations of the compounds affect the results. Since new materials and procedures in chemical control are rapidly being developed, consult your local farm advisor or other qualified agent for latest information on the subject. It may save you disappointment and financial loss.

\section{Brush Control by Biological Means}

The use of natural enemies to combat encroaching range weeds goes back somc 50 years, when eight species of insects were brought to Hawaii from Mexico to combat the aggressive shrub lantana (Lantana camara), also of Mexican origin. Insects have since been used successfully in many areas of the world. In Australia, for example, prickly pear (Opuntia spp.), introduced from South America as an emergency livestock food plant, within a few years invaded literally millions of acres of choice range lands to the virtual exclusion of good forage plants. Even more spectacular, however, was the control of this pest by the introduction of its native insect enemy, Cactoblastis cactorum. Koster's weed curse (Clidemia hirta) in the Fiji Islands, ragweed (Senecio jacobea) in New Zealand, and St. Johnswort (Iypericum perforatum), have all been controlled by insects introduced from countries where these plants are indigenous.

In California, Klamath weed, the local name for St. Johnswort, is a classical current example of biological weed control. Several years ago this perennial had infested about half a million acres of range lands in the State, in addition to large areas in Oregon, Washington,

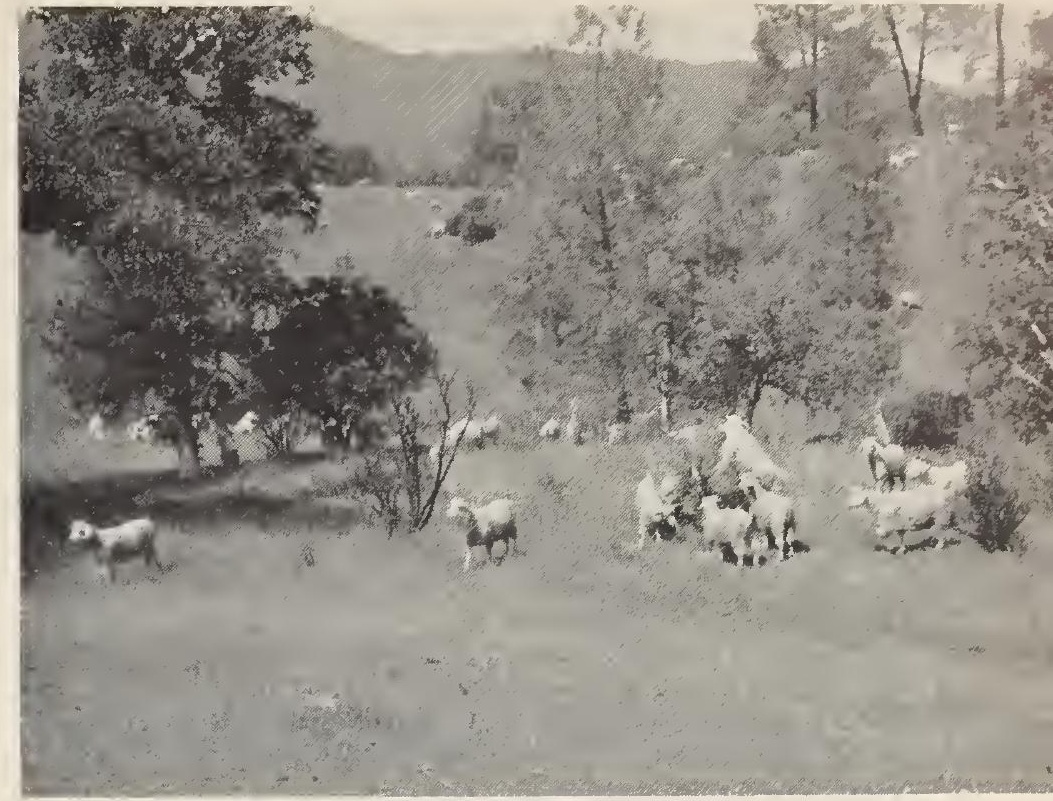

Angora goats on an Amador County range bcing used to control brush on woodland-grass-brush range by close cropping. The animals have opened up the brush and allowed the natural grass cover to extend over the area.

and parts of the Inland Empire. Today most of this vast infestation-for many years so serious that ranchers were unable to obtain improvement loans-has been controlled through introduction, from Australia, of species of beetles of the genus Chrysolina. The native home of these insects is wcstern Europe, where they are effective in controlling St. Johnswort.

The proof in California that Klamath weed can be effectively and safely controlled by biological means, has provided incentive to explore this method of control with other unwanted plants. Rcccntly, for example, a wcevil has been introduced that concentrates on and destroys the sced of gorse (Ulex europaeus), a vicious thorny pest on about 25,000 acres in California and Oregon. Explorations are under wav by fedcral and other workers in Europe and elsewhere to discover other insects to control introduced weed pests.

While many introduccd range weeds can undoubtedly be controlled by biological mcans, far less success cain be expected in thinning out or destroying exotic weedy species. This is largely so because of the natural balance that has developed between native plants and native insects and diseases. Large insect populations occasionally occur on native shrubs that tentatively slow down thcir growth ${ }^{(33,46)}$. The Great Basin tent caterpillar (Malacosoma fragilis), for example, has in some localities seriously reduced the vigor of bittcrbrush, or actually killed individual plants, by defoliation. Large outbrcaks of this insect, however, do not sccm to follow a well-defined pattern. Insect damagc has been most closely observed on native palatablc browse species to maintain these plants rather than on unpalatablc or otherwise undesirable woody spccics.

Control of brush by heavy browsing with cattlc, sheep, goats, and, on a smaller scalc, with deer, has been em- 
the released ash for a time enhances soil fertility and the heat temporarily increases the available soil nitrogen by killing the protozoa which feed on the beneficial nitrogen-fixing bacteria ${ }^{(i \theta)}$. The disadvantages are: fire may escape and cause severe clamage to adjoining property unless adequate precautions are taken; it may not only induce erosion, thus lowering soil productivity and impairing soil moisture and air relationships, but may set the stage for substantial off-site damages such as flooding and depositing of sediments on roads, on developed lands, and in water-storage and distribution facilities; and it usually requires much follow-up work to establish a satisfactory grass cover. Burning is most effective on areas of nonsprouting brush but stimulates seed germination of brush species on all sites.

\section{Advantages of Chemical Control}

Selective sprays may destroy unwanted woody vegetation without damage to the grass cover; sprouting may be greatly reduced or eliminated; and invading brush seedlings and small islands of remaining brush and weed trees may be destroyed at relatively low cost. The main d:sadvantages are: the cost is generally high; the dead vegetation must be crushed and burned or removed mechanically; and spraving must be done at a specific growth period.

\section{Advantages of Biological Control}

Destructive browsing by cattle, sheep, goats, or deer, usually after burning, mechanical thinning, or spraying provides forage for three to five years while the sprouts are being killed; and profits from the improved condition of the animals may offset the cost of necessary fencing and water development. The chief disadvantages are: Domestic livestock must be confined on the area by fencing which is often expensive; only the brush species of rather high palatability are killed; deer can be induced to browse closely on burns of only a few acres if the sprouts are to be killed; and stocking lands at rates sufficiently high to accomplish brush control by destroving sprouts and seedlings within a reasonable time may result in appreciable damage to the site through trampling, soil compaction, and erosion. At best, brush destruction by browsing is an indirect rather than an initial step in a clearance program.

Because of certain advantages of each of the four methods here mentioned, two or more techniques are often combined to obtain the cheapest and most efficient brush control. On superior sites, for example, mechanical clearing followed by spraying to destroy the sprouts and brush seedlings, is a good practice. On the poorer sites burning, followed by spraying or browsing to destroy the invading brush plants, usually affords some temporary increase in forage production.

\section{Revegetation and Management of Cleared Brushlands}

The importance of establishing a grass cover promptly after the brush has been removed cannot be overempha- sized. A measurc of cqual importance is to manage the area so as to insure a continued vigorous grass cover.

\section{Reseeding}

Bcfore you clear brush arcas, determine whether the area will regrass naturally or whether artificial reseeding will be necessary. If the site contains many grassy openings, artificial reseeding is usually not necessary. However, if productive units have no grassy spots, reseeding will usually enhance the grazing capacity and protect the soil.

Both annual and perennial species are used for reseeding. Guides for selecting suitable species for seeding in the different zones in which brush clearing is done have been prepared by the California Agricultural Experiment Station ${ }^{(93)}$. The seed bed should be well prepared and reasonably free from competing vegctation. Many successful seedings have been nbtained by broadcasting the seed directly on the ash of newly burned areas. If legumes are included in the seeding mixture they should be innoculated with the appropriate culture of nitrogen-fixing bactcria.

On critically eroded units, or on thin soils of cleared land that has been seeded to grass or, indeed, on annual grasslands, fertilization-usually with ammonium sulfate or ammonium phosphate, and occasionally gypsum, has in good growth years measurably increased the forage yield and has prolonged the green feed period ${ }^{(7,57,101)}$. Ask your Farm Advisor or other agricultural agents about suitable species for seeding and the kind and amount of fertilizer best suited for your site.

\section{Grazing Management}

After the brush has been removed, good management of the area requires careful consideration of proper grazing season, and proper forage utilization.

The most desirable season for grazing improved foothill brushlands is between March 15th and June 1st. Throughout this season the grass and browse feed is palatable and highly nutritive, whereas during the summer months the dry grass and fibrous brush sprouts provide poor feed. During the cool winter months when rainfall is heaviest the forage is short and often sparse. Too early grazing forces the livestock to travel extensively in search of feed, thereby destroying much vegetation by trampling it into the wet soil. Areas seeded to annual grasses may be pastured in April or May of the first year, but those seeded to perennial grasses must be protected from grazing at least throughout the first year. Thereafter grazing should be adjusted according to the vigor of the peremnial grass species and the seasonal growth conditions.

It is always important to regulate stocking so as to leave a proper residual of browsc and grass herbage at the end of the grazing season. This residual of litter will protect the soil from excessive crosion, and the shallowrooted grass seedlings from frost damage and drying out in early spring. Thus the grass stand will be kept more vigorous. 
Moderate grazing by eattle and/or sheep and deer is necessary where the objeetive is to maintain the more palatable brush speeies in balance with the grass eover on browse range. This is not casily done where deer utilize the range in winter and early spring after it has already been properly cropped by livestoek. Therefore it is sonctimes neeessary to recluee both livestock and decr numbers in order to build up grass and browse where the forage resouree is inadequate.

\section{Cost Analyses of Brishland Conversion}

Cost versus potential returns should be earefully eonsidered before entering into a planting or brush-elearing and reseeding program ${ }^{(7,19)}$. The land owner should attempt to analyzc sueh leading questions as these: Will the project pay its way on this partieular site? What will the land produee when the planting program has been completed or when the brush has been eleared? What will the eost be to obtain profitable returns? Is it necessary to remove all the brush or should only the better sites be cleared? Will an intensive treatment of planting or some other procedure eosting more money inerease the rate of return? What equipment, labor, time, and money are loeally available for the initial and the follow-up brush clearing operation? What is the final choiee of treatment, considering the character of the land and the objeetives?

Two levels of trcatment are frequently justified on a brushland area. If the unit is only moderately steep and the soil is equally produetive, all the brush may be removed and the land reseeded to grass and subjeeted to the same general management. But if some units contain steep slopes and have thin soils whereas other units are fairly level and have deep produetive soil, then different degrees of treatment are justified. The eost of removing brush and reseeding, or even of brush planting, may be justified on flats and gently sloping lands, followed by brush-control work, feneing, and other neeessary improvements. In many instances it is best to leave the brush intact on the steeper slopes, or merely open up small areas to cnhance their usefulness for game ${ }^{\text {(138) }}$. As a rule most ranches have eertain conditions that govern the amount of money justified for their individual brush elearing operation, sueh as proximity to their other grazing lands, shortage of forage at a particular season, and the like.

\section{Proper Browse Utilization}

In localities where brush species provide valuable browse it is of the greatest importance to maintain this cover in vigorous condition. Failure to do so often necessitates drastic change in a long-established management plan.

\section{Old (Established) Techniques}

The carliest and most complete studies of proper browse utilization in California was conducted by Hormay with bitterb)rush ${ }^{(7,72)}$. He recommended that not less than 20 plots, 20 inches wide and 130 to 200 feet ( 2 to 3 ehains) long, be employed to determine utilization for a given range unit. The pereentage browse utilization on the plot was determined by dividing the total estimated twigs browsed by the total estimated volume of twig growth produeed, multiplied by 100 . Thus if the crown area of a bitterbrush plant was 300 square inches and the ungrazed twig length average was 6 inehes, then the index of total available forage would be 1800. If 30 per eent of the twig growth on this plant had been grazed then the index of total forage grazed would be 540 . If there were 10 bushes on the plot with the following measurements:

\begin{tabular}{cc}
\hline $\begin{array}{c}\text { INDEX } \\
\text { EXPRESSION OF TOTAL } \\
\text { FORAGE AVAILABLE }\end{array}$ & $\begin{array}{c}\text { INDEX } \\
\text { EXPRESSION OF TOTAL } \\
\text { FORAGE BROWSED }\end{array}$ \\
\hline 1800 & 540 \\
1732 & 320 \\
1940 & 750 \\
1620 & 630 \\
1510 & 250 \\
1700 & 375 \\
1650 & 592 \\
1975 & 850 \\
1530 & 710 \\
1875 & 932 \\
\hline 17,332 & 5,949 \\
\hline
\end{tabular}

then $\frac{5,949}{17,332} \times 100=34.3$ per eent would be the utilization on the plots.

This study demonstrated that removal of 60 per eent of the current twig growth of bitterbrush is the maximum that this shrub ean endure. Heavier utilization would indieate need for reduetion in livestoek and/or game numbers. Although this method was specifically worked out for bitterbrush, it is presumably applicable to some other browse speeies with current twig growth that ean be readily measured.

The maximum amount of leafage that ean be removed from a well established browse plant undoubtedly varies largely with its age and eondition, its past history, and the site on whieh it grows ${ }^{(77)}$. More study of bruslı utilization standards is needed.

"Key areas" and "key species" are now rather commonly used as a guide to determining condition of browse and other range plants. A key area is an indieator or representative area, preferably located somewhat remote from water, driveways and the like, where the animals would graze frcely and normally. Key speeies are indieator plants that are the most important on that partieular rauge ${ }^{(127,241)}$. Selection of a few key areas and key speeies simplifies the study of determining the degree of range use for the range as a whole. "Key forage species" are defined as plants for which deer and/or livestock show a prefercnce and whieh are suffieiently abun(lant to be used as a praetical base for making grazing capacity estimates ${ }^{(13)}$.

Study of range eondition on the interstate deer winter 
range in northern California revealed that strong competition existed between livestock (cattle and sheep) and deer for two of the main key species, in this instance bitterbrush and bluegrasses (Poa spp. $)^{(47)}$. Nine per cent of the bitterbrush had been cropped in excess of 60 per cent contrary to recommendations by Hormay, when the livestock left the range in the fall. By the following spring, however, deer had taken an additional 15 per cent of all the remaining bitterbrush growth. On this area bitterbrush was declining rapidly in vigor and yield.

In a game range study in northern Arizona, Hunter ${ }^{178)}$ found that aspen (Populus tremuloides) was the key browse species on the summer range, and cliffrose $(\mathrm{Co}-$ wania mexicana var. stansburiana) on the adjoining winter range. Since the growth habits of these species were strikingly different, separate measurement methods had to be adopted for each. Annual utilization of the aspen was determined by measuring the length of all current shoot growth of branches within the reach of deer, sheep, and cattle before and after browsing. Takedown enclosures were used to determine different degrees of utilization on established plots. From these measurements it was determined that proper use of aspen by sheep and deer was 70 per cent and by cattle 5 to 10 per cent, depending on its degree of palatability to these animals. Utilization measurements for cliffrose were made on tagged twigs occurring within established plots, before and after browsing. It was concluded that proper use of cliffrose by deer and sheep was 75 per cent and by cattle 65 to 75 per cent.

In a game-browse management study in eastern Oregon and Washington ${ }^{(50)}$ maximum limits of utilization of current twig growth completely within reach of grazing animals that could safely be cropped on the best sites were as follows: bitterbrush-60 to 65 per cent, snowbrush ceanothus (Ceanothus velutinus) -35 to 40 per cent, and curlleaf mountain-mahogany (Cercocarpus ledifolius) 50 to 60 per cent. Not more than 50 per cent of the current growth of bitterbrush should be utilized on the poorer sites.

A study in Colorado ${ }^{(121)}$ showed great variability in growth characteristics of true mountain-mahogany (Cercocarpus inontonus) and Utah serviccberry (Amelanchier utahensis) as compared to such growth form as bluebunch wheatgrass (Agropyron inerme). Much greater numbers of replicated measurements were necessary to obtain a reliable estimate, both of volume of growth produced and of degree of utilization of the stems, of the shrubs. In spite of the variability exhibited in the twiglength growth of browse, the study showed that both browse and grass associations can be measured satisfactorily before and after grazing.
Use standards may need to be adjusted to meet local conditions. For example, on range in poor condition, or where erosion is serious, the maximum allowable usc should be lower than on range in good condition. Also, lower use standards should be applied on steep slopes or on unstable soils than on gently sloping or flat ground where severe soil erosion is less likcly to occur.

\section{New (Experimental) Technique}

A technique of browse utilization that might greatly enhance the value of the brushfields is in the early exploratory stage. Ranchers have long hoped thcy could merely chop up and grind the brush so it could be fed to their stock.

This hope has been realized, in part, by studies conducted by the California Division of Forestry ${ }^{(2+, 5)}$. Blueblossom ceanothus (Ceanothus thyrsiftorns), which grows abundantly in the northern coastal ranges, was selected in the first test. The size of the brush stems included was limited to about one-half inch in diameter, which probably was as large as the hay chopper avaitable could handle.

After chopping stems, twigs, and leaves, the mixture was ground up into meal in a hammer mill. The meal was made into pellets for convenience in feeding. A small amount of molasses was added during the pelleting process to increase palatability.

Analyses of the ground blueblossom meal and the pellets revealed that these feeds had nutritive valucs similar to oat hay or sudan grass hay, and to poorer grades of alfalfa. Cattle and sheep ate this pelleted fced readily and made satisfactory though not large gains while subsisting upon it.

It is conceivable that there might be a large reserve of livestock feed in the brushfields that has long been regarded as a menace rather than an asset. If further studies should support this conjecture, it would be necessary to determine to what extent the branches of brush species could be harvested without destroying the stand. This area of research appears worthy of further study.

In Texas a similar feed study was conducted with mesquite ${ }^{(88)}$. Cottonseed meal, sorghum grain, and molasses wcre mixed with the mesquite meal in the experimental ration. Steers fed generous portions of mesquite meal, complemented by other feeds, made satisfactory gains. The value of vitamin $A$ in the mesquite meal was demonstrated in an experiment with calves. After an 84-day feeding period on cottonseed hulls the calves developed night blindness, whereas thosc on mesquite meal showed no symptoms of vitamin A deficiency. It is hoped that this field of study will be pursued to its logical economical conclusion. 


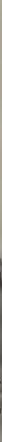




\section{PART II. APPRAISAL OF BROWSE SPECIES}

\section{Palatability and Utilization of Browse Plants}

$\mathrm{T}$ HE VALUE OF ANY BRowse PLANT is determined, first of all, by the extent to which it is cropped by grazing animals. Unless eaten to some extent, even a widely distributed and accessible species has little direct range value. In practical range management it is important to know which are the most palatable species and which ones supply some feed at one season or another. A widely distributed species eaten more or less avidly at all seasons is regarded a "primary" browse plant; a species cropped only lightly at any season, regardless of its distribution, is classed as a "secondary" browse species.

"Palatability," in this manual, is used synonymous with "preference" or "selectivity" of the plant by grazing animals; "utilization" implies degree of browsing. A shrub that is closely cropped where other desirable browse plants are abundant would be classed as highly palatable and well utilized. Such a plant would be given a strong preference rating for the particular animal that consumed the forage. The terms "proper" or "allowable" use refers to use standards in brushland management. Such standards have been developed through research by actual measurement of twigs cropped for key species representative of stands or associations of brush areas ${ }^{(72)}$.

There is no infallible way to judge the degree of palatability of an unfamiliar shrub by merely observing, feeling, tasting, or smelling the foliage, though each of these procedures may have some significance. In general, grazing animals prefer the larger, thinner, succulent-leaved species to those with linear or scale-like leaves or to species with thick leathery (sclerophyll) foliage. Dominance of shrubs or a particular leaf form is largely determined by the nature of the habitat. The larger succulentleaved occupy the moister and better protected sites, usually those with fairly deep productive soil; the small or scale-like leaved species are characteristic of desert sites where rainfall is low and transpiration and evaporation are high; and the leathery-leaved drought-enduring shrubs are characteristic of somewhat inferior chaparral sites where the summers are hot and dry and the winters cool and rainy. Fewer acres are required to support an animal unit on areas supporting large thin-leaved shrubs than on dry desert areas where the leaf area per plant is

Photo left, woodland grass area. small, or than on chaparral sites where thick-leaved species prevail.

Smell and/or taste of foliage or blossoms occasionally afford some clue as to whether a given shrub species is palatable or actually objectionable to grazing animals. Certain species of elderberry (Sambucus), for example, are browsed little or not at all until the first killing frost in the fall has blackened and killed the succulent foliage. Throughout the spring and summer months the plant has a disagreeable odor which largely disappears after a heavy frost. Mountain misery (Chamaebatia) is a shrub whose foliage has resinous oils of a distinctly penetrating and disagreeable odor that seems to repel all grazing animals throughout the growing season. In the winter, however, when rains have washed off the glutinous foliage the plant is cropped in varying degrees. Likewise shrubs with bland sap, like most species of the rose and maple families, are more likely to be relished by grazing animals than those with distinctly acrid, bitter, or astringent sap, such as, for example, species of the dogwood family. There are many exccptions to this generalization, however, such as in bitterbrush (Purshia) and cliffrose (Cowania $^{(45)}$. The foliage of these species has a decidedly bitter taste yet they are cropped with much relish. Aroma and taste of foliage are apparently bound up in delicate chemical distinctions which may seasonally or year-long repel grazing animals but which are not distinguishable to the sense of smell or taste of humans. Even so, both smell and taste by humans afford certain useful clues as to whether a given shrub is palatable or not. Plants with "salty" taste, such as the shadscales or saltbushes (Atriplex), which occupy alkaline or saline sites, arc generally palatable to livestock. In contrast, foliage with an acid taste or those with milky juice is seldom palatable to livestock.

Palatability and the degree of browsing are also affected by season of range use; composition of the plant cover; growth form of the woody plants; geographical location of a species; and differences in palatability among varietal forms. Not much reliable information is available on these aspects of palatability.

Most palatable shrubs are cropped closest early in the growing season. This is apparently because the leaves and twigs are succulent and tender in the early growth stages. Incidentally, the early seasonal growth is also more nutritious. Palatable species that sprout after burning or cutting are especially succulent and are closely utilized for a year or two after the burn.

(Continued on page 38) 


\section{Illustrated Glossary}

This glossary illustrates scientific terms which are used in the recognition key to the genera and species of browse plants.
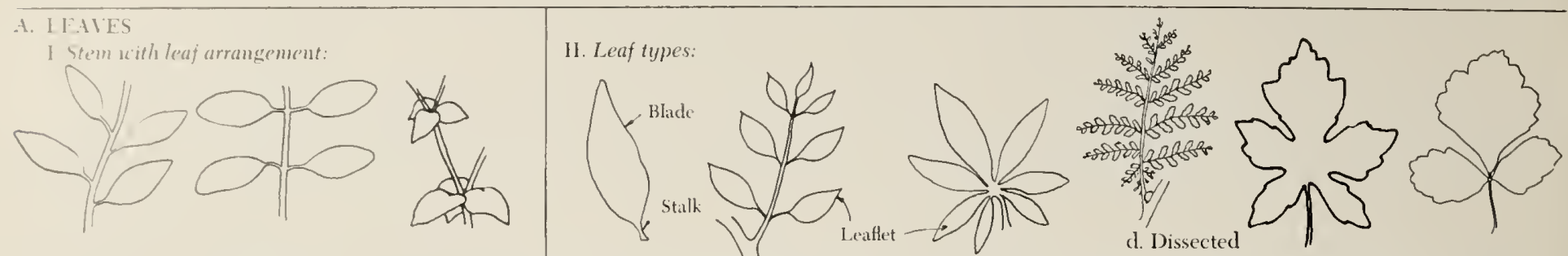

a. Alteriate leaves b. Opposite leaves c. Whorled leaves

a. Simple b. Pinnitely compound c. Palmately compound (fern-like) e. Maple-like f. Trifoliate
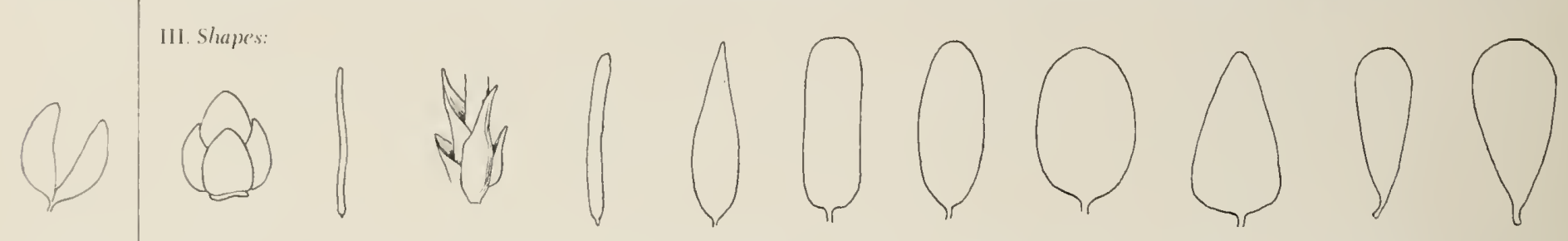

g Bilobed a. Scalle-like b. Needle-like c. Awl-shaped d. Linear e. Lanceolate f. Oblong g. Elliptic

h. Oval

i. Ovate

j. Olslanceolate $k$. Obovate

IV. Margins:
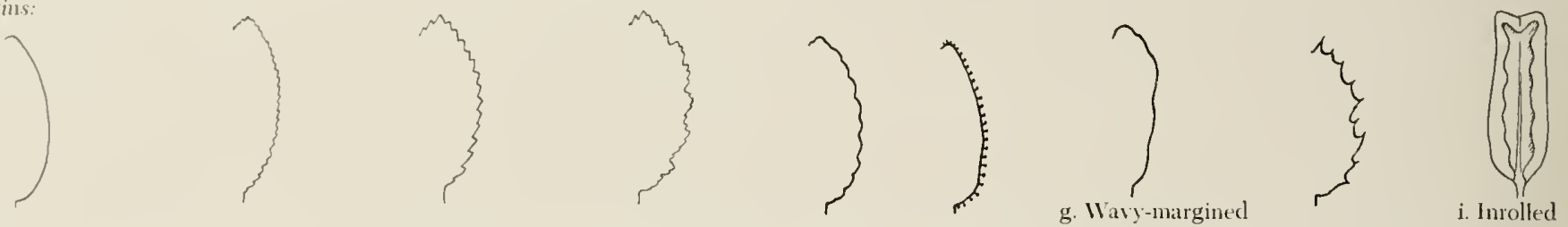

a. Entire

1. Finely tootled

c. Coarsely toothed d. Double-toothed

e. Crenate f. Gland-toothed (undulate)

h. Spiny-toothed

(revolute)

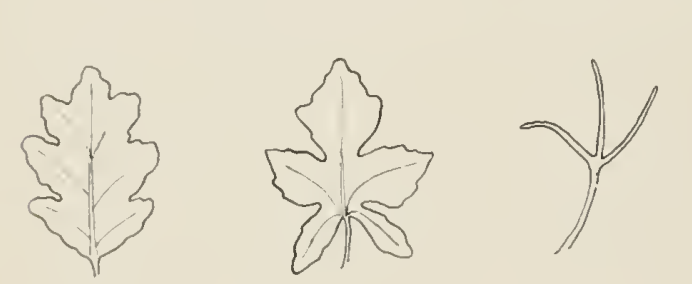

j. Pinnately loled k. Palmately lobed 1. Threadlike lobes

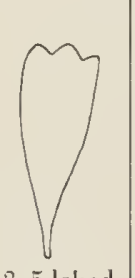

17. 3-5 lobed at apex

V. Tips:

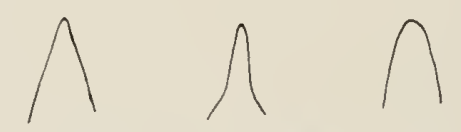

a. Pointed b. Lomg pointed c. Blunt

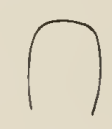

d.

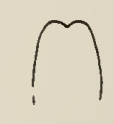

c. Notched f. Short pointed (emarginate) (mucronite)

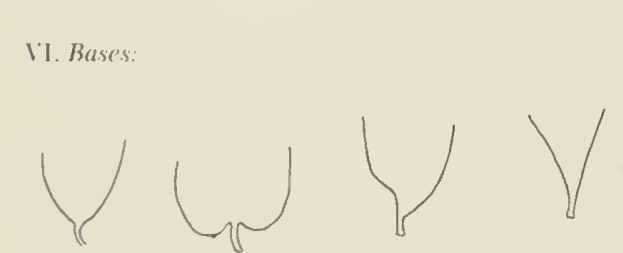

b. Ileart-shaped
Net-r

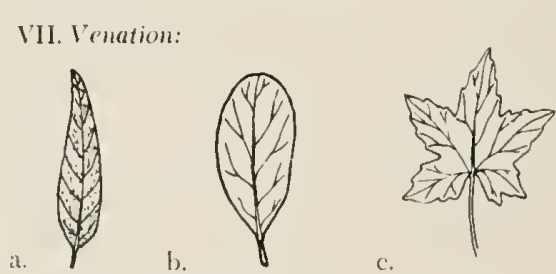

b. c.

(1.

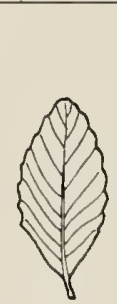

a. Rounded (ordate) co Lneogual d. Wedge-shaped

-voined Pinnatelyeined Palmately veined Feather veined B. SOMIE STEM AND LEAF

MODIFICATIONS
1. Types of hairs:

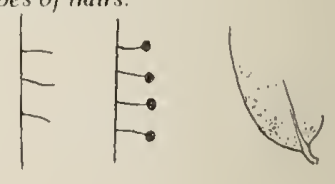

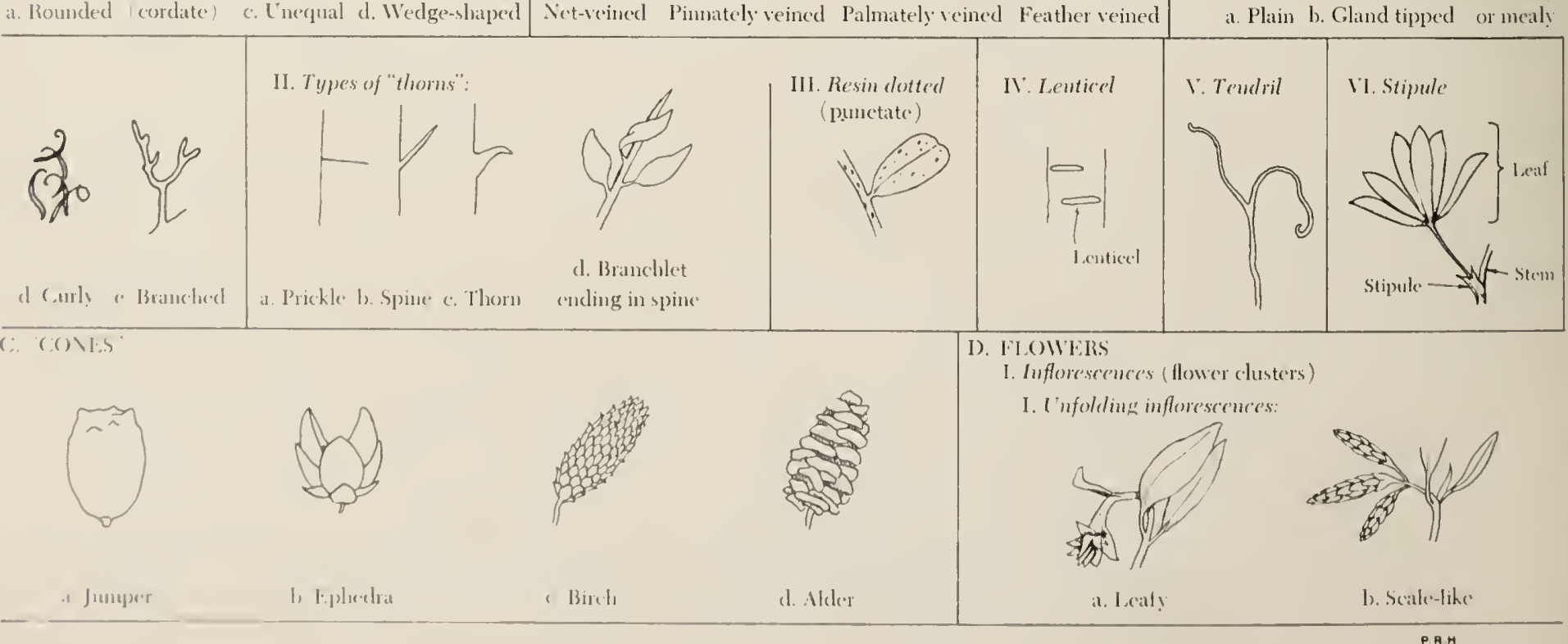


2. Types of flocer clusters:
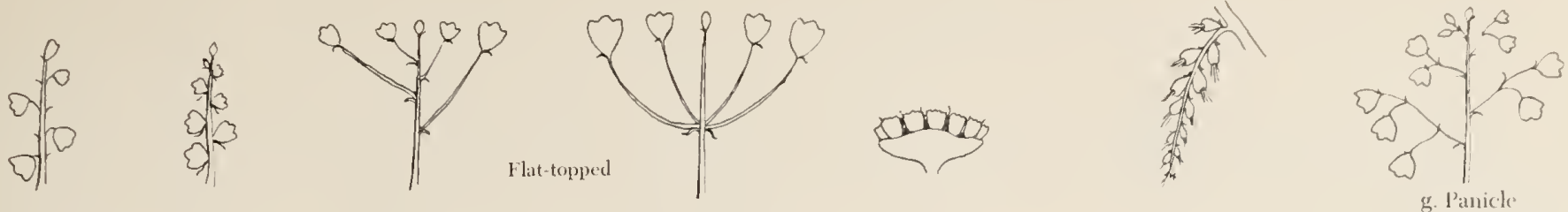

i1. Rilcente

b. Spike

e. Coryml,

d. Umbel

c. Ilead

f. Cathin

g. Panic

(ompouml)

II. Parts of the flower

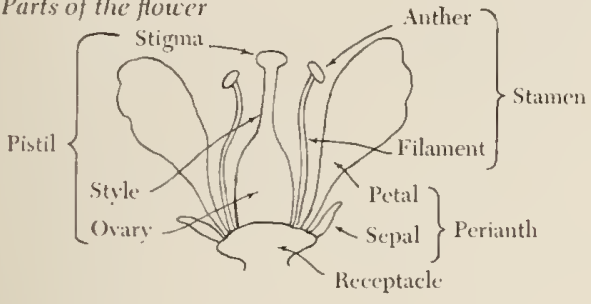

Note: The parts of the flower vary considerably in varions genera and species. The sepals may be joined together (calyx) or free. The petals may be joined together (corolla) to form bell-like, or long, tubular flowers with only the tips free, or the petals may be completely separate. The position and shape of the ovary, number of stamens and their position also vary with different genera and speeies. The flowers of some speeies may lack sepals, or petals, or both. If stamens are lacking in a flower this will be known as a female flower, and if the pistil is lacking. the flower will be referred to as a male. These are called unisexual flowers. Where both sexes are in same flower, it is bisexual. When male and female flowers are on separate plants, the species is dioecious; on sane plant-monoecious.

1. Flower types:
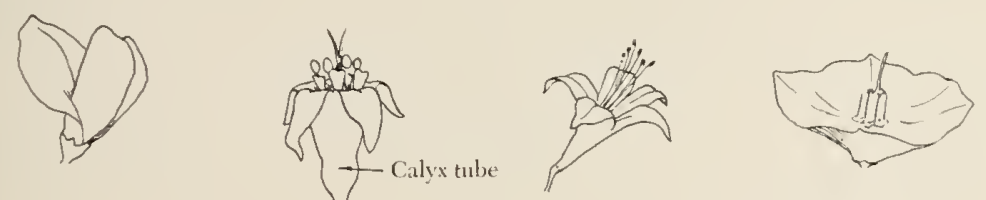

d. Saucer-like or wheel-shaped

a. Sweet-pea shaped b. Currant flower

c. Rhododendron
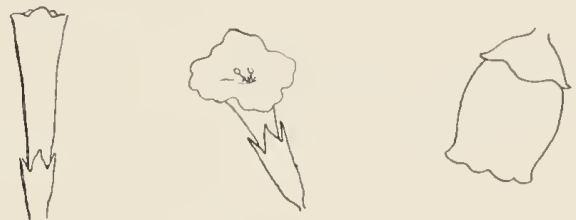

e. Tubular

f. Funnel-like g. Bell-shaped or um-shaped

\section{E. FRUITS}

2. Head with involucre:

1. Dry fruits:

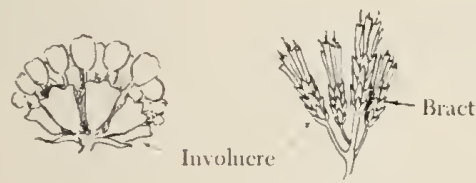

b. Sagebrush

a. Eriogonum and rabbitbrush

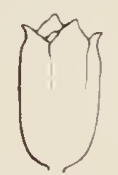

a. Capsule

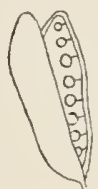

b. Pod c. Simple achente

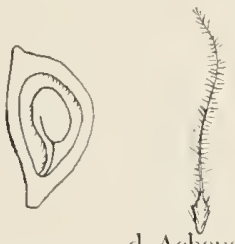

d. Achere with

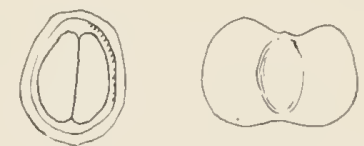

feathery tail e. Simple nut f. Winged nut
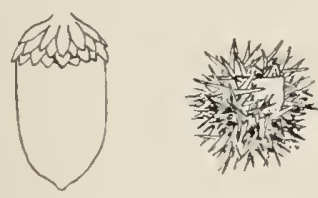

g. Acorn

h. Bur

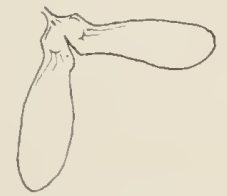

i. Double samara

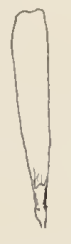

j. Single samara
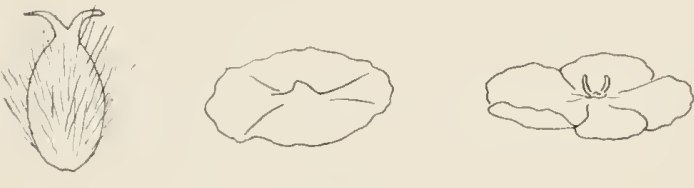

k. Eurotic

1. Siarcobatus

m. Kochia

11. Fleshy fruits:
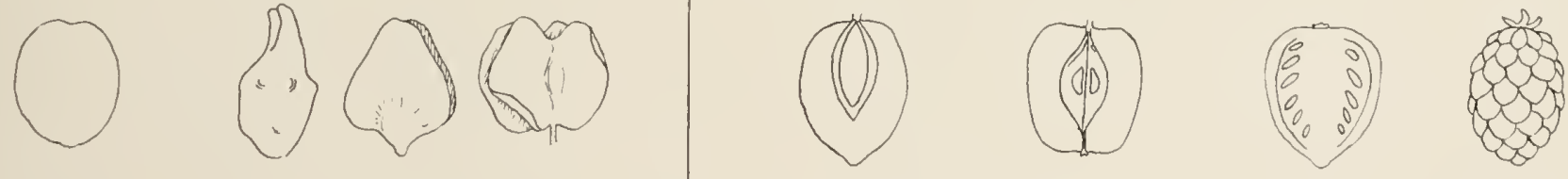

11. Crayia

(1). Atriplex

a. Drupe

b. Pome

c. Berry

d. Aggregate 
Certain shrubs tend to be cropped more closely where they compose only a relatively small part of the total plant cover than where they form a large part of the stand. A mixture of herbaceons species-grasses and other herbs-evidently provides the variety which browsing animals prefer.

The particular growth form of palatable woody plants is especially important to the degree they are utilized. Shrulos of relatively low and spreading growth, such as most saltbushes (Atriplex spp.), are accessible to all kinds of browsing animals, while the foliage of many palatable trees and the taller shrubs is largely wasted because it is berond the reach of the animals. High hedge lines are commonly seen in such plants as California jumiper (Juniperus californica) and western mountain-mahogany (Cercocarpus betuloides). Sprouting species of this kind may be made productive by cutting or burning.

Palatability and utilization according to geographical location varies strikingly in some brush species. In Mackera County, for example, California coffeeberry (Rhammus californica) is cropped with considerable relish by livestock and deer, whereas in Trinity County it is browsed only lightly. No explanation is at present available for such differences in palatability. Edaphic, climatic, genetic, or other factors may be responsible.

The varietics and ecotypes within a species differ appreciably in palatability. Some forms are utilized more closely than the specics, others are relatively low in palatability. Whether these differences are caused by slightly more hairiness, aroma, taste or other factors is not known. In a slurub-planting program careful selection of the species, their palatability, and sources of the seecl conld be of great economic importance.

\section{Over-all Ratings of Browse Species}

In cralnating the over-all browse value of a species one must realize that exceptions can probably be found for any hrowse rating made. The browse value of a given specics varies from one locality to another, from one season to another, and among cattle, sheep, goats, deer, and horses. Even so, it is helpful to sum up the ratings of browse plants to get a quick idea abont the value of a given species and to permit comparison with other specics.

Horses and goats are included in the ratings although their importance on California ranges is decreasing. Goats are still used in some localities to control brush stauds wlicll are reasonably palatable to them.

Many so-called secondary browse species were inclucked in the keys, distribution maps, and discussions, becanse econonic information on the less palatable species may be needed even more than that of the nore higlily rated and better known forns. Even so, no claim is mate to having included all of the less valuable speries.

The general ratings of all species discussed are given in the summativ tablo on patges 1 16-148.

\section{Principal Browse Families}

Of the large number of shrub species that compose the cover on the millions of acres of California brushlands, a surprisingly big proportion provides some browse for livestock and big-game animals. Most of this feed, however, is supplied by a relatively small percentage of the total number of plant families.

California's browse crop is produced by about 33 plant families and some 68 genera. Of these, the following seven families account for the choicest browse species and the largest volume of this feed: willow family (Salicaceae); oak or beech family (Fagaceae); goosefoot or saltbush family (Chenopodiaceae); rose family (Rosaceae); buckthorn family (Rhammaceae); honeysuckle family (Caprifoliaceae); and the sunflower family (Compositae).

The willow family contains the aspens, poplars, cottonwoods (Populus), and the willows (Salix). The species of this group inhabit moist deep soils and furnish a large volume of palatable browse.

The oak or beech family is important mainly because of the vast area which its species occupy rather than high palatability of the foliage. The ammual mast of acorns is eagerly sought by all grazing animals and by various birds and rodents.

The goosefoot or saltbush family, best known for the saltbushes (Atriplex) and winter fat (Eurotia), is more important than grasses (Gramineae) on some winter ranges.

The rose family, characterized by such choice genera as bitterbrush (Purshia) and mountain-mahogany (Cercocarpus), and the abundant but less palatable chamise (Adenostoma), contributes richly to the browse crop.

The buckthorn family is best known for its many species of ceanothus (Ceanothus) and the buckthorns and coffeeberries (Rlamnus). This family provides much browse of varied quality for both livestock and big gamc.

The honeysuckle family contains many shrub species which provide good quality browse. The most important genera are the snowberries (Symphoricarpos) and the elderberries (Sambucus).

The sumflower family, with it many genera and species, is probably best known to stockmen by the sagebrushes (Artemisia) and the rabbitbrushes (Chrysothamnus). Few species are cropped closcly, yet collectively they furnish a large amount of moderately nutritious browse. They are especially important for dcer and antelope during the winter months, notably whcre other forages are available to lend variety to the diet.

In addition to these seven outstanding plant families,

- The seruenee of plant families here listed, and the later listing of families under the discussion of species, is that used by Engler and P'rantl in their Natiorliche Pfanzenfamilien and in Engler's Syllabus. The sequence is essentially the same as in McMinn's Illustrated Mamual of Californiat Shrubses ${ }^{(1+1)}$, which has been consulted for various details. The seientifie nonenclature likewise corresponds for the most part with that in MeMinn's Mannal. There are a few execptions. The common bumes of families, genera, and species are those most used by botanists and ficlel workers of California, and have appeared more or less frecpuently in botanical and ecological literature. 
the following 24 families include shrubs of lesser browse value, either because of limited abundance or distribution or because of relatively low palatability:

\begin{tabular}{|c|c|}
\hline PLANT FAMILY & IMPORTANT GENERA \\
\hline Cipress (Cupressaceae) & Juniper (Juniperus) \\
\hline Ephedra (Ephedraceae) & Ephedra (Ephedra) \\
\hline Birch (Betulaceae) & $\begin{array}{l}\text { Alder (Alnus); birch (Betula); hazel- } \\
\text { nut (Corylus) }\end{array}$ \\
\hline Elm (Ulmaceae) & Hackberry (Celtis) \\
\hline Buckwhcat (Polygonaceae) & Woody buckwheat (Eriogonum) \\
\hline Lalurel (Lauraceae) & California laurel (Umbellularia) \\
\hline Poppy (Papaveraceae) & Bush poppy (Dendromecon) \\
\hline Saxifrage (Saxifragaceae) & Currant and gooseberry (Rihes) \\
\hline Pea (Leguminosae) & $\begin{array}{l}\text { Redbud (Cercis); chaparral pea } \\
\quad \text { (Pickeringia) }\end{array}$ \\
\hline Caltrops (Zygophyllaceae) & Creosote bush (Larrea) \\
\hline Box (Buxaceae) & Goatnut (Simmondsia) \\
\hline $\begin{array}{l}\text { Sumac or cashew } \\
\text { (Anacardiaceae) }\end{array}$ & Sumac; poison oak (Rluus) \\
\hline Maple (Aceraceae) & Maple (Acer) \\
\hline $\begin{array}{l}\text { Horse-chestnut } \\
\text { (Hippocastanaceae) }\end{array}$ & Buckeye (Aesculus) \\
\hline Grape (Vitaceae) & WVild grape (Vitis) \\
\hline Cacao or sterculia (Sterculiaceae) & Flannel bush (Fremontia) \\
\hline Oleaster (Elaeagnaceae) & Buffalo berry (Shepleerdia) \\
\hline Silktassel (Garryaceae) & Silktassel (Garrya) \\
\hline Dogwood (Cornaceae) & Dogwood (Cornus) \\
\hline Heather (Ericaceae) & $\begin{array}{l}\text { Manzanita (Arctostaphylos); huckle- } \\
\text { berry (Vaccinium) }\end{array}$ \\
\hline Ash or olive (Oleaceae) & Ash (Fraxinus) \\
\hline $\begin{array}{l}\text { Phacelia or waterleaf } \\
\text { (Hydrophyllaceae) }\end{array}$ & Yerba santa (Eriodictyon) \\
\hline Mint (Labiatae) & Sage (Salvia) \\
\hline Nightshade (Solanaceae) & Nightshade (Solanum) \\
\hline
\end{tabular}

\section{Recognition Key-An Aid to Identify California Browse Plants}

The recognition ker, presented on pages 39 to 44, will help you idcntify only those trees and shrubs discussed in this manual. It cannot be used for all California plants. Plants not considered in this manual can be identified with the assistance of the Botany Department, University of California at Berkeley or Los Angeles, or some other institution or agency; or with the help of the following standard botanical publications:

Abrams and Ferris: Illustrated Flora of the Pacific States-Washington, Oregon, and California ${ }^{(1)}$.

Jepson; Flowering Plants of California ${ }^{(8)}$.

Mc.Minn: An Illustrated Manual of California Shrubs ${ }^{(104)}$.

Munz and Keck: A California Flora ${ }^{(100)}$.

A glossary illustrating scientific plant terms is shown on pages $36-37$.

\section{The Recognition KeY*}

1. Leaves awl-like, or scale-like, or branches appearing leafless; fruits oblong or ovoid, seeds borne not wholly

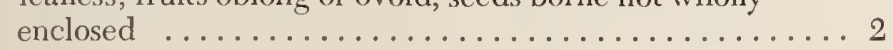

1. Leaves not awl-like or scale-like; fruits various but seeds borne wholly enclosed.
2. Stems fluted and jointcd, appcaring leafless; leaves 2 to 3 at a joint, papery and not green; fruit oblong, usually angled, lrownish .......... EPHEDRA (page 47) $\nmid$ (Ephedra)

2. Stems not fluted or jointed; thickly clothed with grcen or gray-green scale-like or awl-like leaves, in wliorls of 2 or 3 ; fruit ovoid, not angled but with a fcw small projections. Juxiper (page 44) (Juniperus)

3. Male flowers borne in separate erect or drooping catkins, female flowers in catkins, clustered or solitary; fruit berry-like and purplish (silktassels), a capsule containing seeds with silky tuft of hairs (willows and cottonwoods), a small woody or papery-scaled conc (alders and birches), an edible nut (hazelnut), a bur (chinquapin), or an acom (oaks).............. 4

3. Male and female flowers not borne in catkins; fruit va-

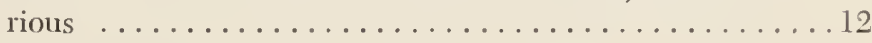

4. Leaves opposite; fruit berry-like, purplish FREMONT SILKTASSEL (page 118) (Garrya fremontii)

4. Leaves alternate; fruit not berry-like............5

5. Male and female flowers bome in catkins; fruit a capsule containing seeds with silky tuft of hairs, or a small

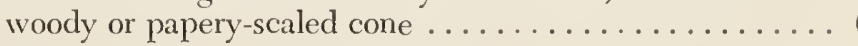

5. Male flowers in catkins; female flowers solitary or clustered; fruit an edible nut, a bur, or an acorn........9 9

*Where one geuus contains more than one species or variety of browse plants, their keys are presented under the genus.

t Page number after the common name of the genus and/or species (printed in boldface) indicates the page in this manual where the discussion of the genus, its species, and its economic value begins.

\section{How to Use THE KeY}

The key lists two altemative descriptions under each number on the left side of the page. Compare your specimen with the two alternatives, starting with number one. Selcet the alternative which best describes the specimen. Be certain to consider all possibilities in cach alternative. If the description is followed by a plant name, you have identified your specimen. If it is followed by a number on the right side of the page, proceed to the two alternative descriptions given under the same number on the left side of the page. Again compare the specimen with the alternatives, and follow the same procedure until you reach a plant name. If the unknown plant does not key out to a name, it is probably not onc of the important browse species and must be idcntified by other mcans listed on this page.

Note: Make identifications in the field rather than from collected specimcns. 
6. Male and femalc flower catkins borne on separate plants; fruit a capsule containing sceds with silky tuft of hairs

6. Male and fomale flower catkins borne on the same plant; fruit a small woody or papery-scaled cone containing flat, winged or margined nutlets . . . . . . . . . . 8

7. IVinter buds of several scales, usually resinous; leaves trianoular or roundish, usually with long stalks ASI'EN, POPLAR, COTTONWOOD (page 50) (Populus)

7. Vinter buds of 1 scale, not resinous; leaves not triangular or roundish, usually with short stalks

1L Low (page 48

(Salix)

8. Bark with prominent horizontal lenticels; scales of fruiting cone somewhat papery, these scales falling awav from the cones at maturity......... B1ncri (page 53) (Betula)

8. Bark without lenticels; scales of fruiting cones woody, these scales persistent at matruity......... ALder (page 52

(Alnus)

9. Leaves obovate, unecpual-sided or heart-shaped at base, margins with coarse teeth, these again toothed (double-toothed); fruit a rounded nut with hard shell, enclosed in bristly-hairy envelope which extends bevond nut $\frac{1}{2}$ inch to $1 \frac{1}{4}$ inches into fringed tube CALIFORNIA IIAZELNUT (page $\mathbf{5 5}$ (Corylus cornuta var. californica)

9. Lcaves usually not obovate, mostly even-sided at hase, margins with coarse teeth (not double-toothed), spinytoothed, lobed, or entire; fruit a bur or an acorn... .

10. Nale catkins ercet and often much branched; fruit a spiny bur completely enclosing 1 to 3 nutlets SIERIRA CIINQUAPIN (page 61) (Castanopsis sempervirens)

10. Male catkins crect or drooping, not branched; fruit an acorn

11. Lcives coarsely toothed, densely covered with whit ish or tan scurf-like or incaly hairs, upper surface smooth in agc; malc catkins erect; acorn cup of hooked

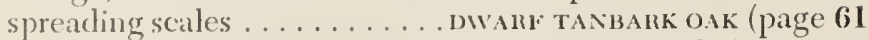

(Lithocarpus densiflora var. echinoides)

11. Leives cntire, toothed or lobed, smooth, or if hairs present then not densely scurfy or nncaly; male catkins drooping; acom cup of scales hut these not hooked or spreading

(Ouercus)

12. Woudy vine, climbing by branched tondrils; leaves hriat-shaped, sometimes shatlowly 3 or 5-lobed; flowcos grecouish, fragraut, profuse; fruit berry-like, purplish with a whitish bloom

(Vitis californica)

12. Trees or slmuls, sonnetines vine-like (poison-oak), witheret luancheed toudrils; leaves, flowers and fruts Varions
13. Leaves pinnately or palmatcly divided into leaflets, in one species the two leaflets resemble a bilobed leaf (creosote bush), or dissected into numerous segments, or merely palmately veined and deeply or shallowly lohed ............................. 14

13. Leaves not divided into leaflets, not dissected, nor palmately veined and lobed . . . . . . . . . . . . . 30

14. Leaves opposite ..................... 15

14. Lcaves alternate ... . . . . . . . . . . . . . . 19

15. Leaves appearing bilobed, palmately lobed, or (in one species) pinnately divided into 3 leaflets 1 inch or more long; fruit a densely white-hairy capsule which separates into 5 nutlets, or a double samara . . . . . . . . 16

15. Leaves pinnately or palmately divided into 5 to 9 leaflets, rarely only 3 leaflets, these toothed or lobed; fruit a 1-seeded capsule, or a single samara, or berry-like. . . . . 17

16. Evergreen desert shrubs with strongly scented resinous foliage; leaves appearing bilobed, leaflets (lobes) is inch or less long; flowers solitary and terminal on short branchlets, showy, bright yellow; fruit a small, densely white-hairy or rusty hairy capsule which separates into 5 nutlets . . . . . . . . . . CREOSOTE Bush (page 95)

(Larrea divaricata)

16. Deciduous trees or shrubs of streamsides or moist slopes; foliage not resinous or scented; leaves pinnately divided into 3 leaflets 1 inch or more long, or palmatcly lobed; flowers borne in drooping chusters, rather inconspicuous, not bright yellow; fruit a double samara ................ MA Ple, BoxElder (page 98)

(Acer)

17. Leaves palmately compound with 5 to 7 leaflets; flowers white or pinkish-white in dense cylindrical clusters; fruit a capsule containing one or two large shining brown seeds ......... CAL1FOnN1A BUCKEYE (page 101) (Aesculus californica)

17. Leaves pinnately compound with 5 to 9 leaflets, or sometimes 3 ; flowers creamy white or grecnishyellow, not in dense cylindrical clusters; fruit not a

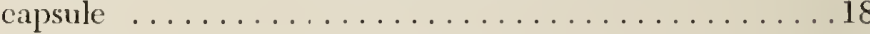

18. Branches not pithy; leaf margins entire, or toothed usually above the middle; Howers in small crowded panicles appearing before the lcaves, greenish-yellow; fruit at single samara . . . . . . . . . . . . . Ası (page 128

(Fraxinus)

18. Branches usually very pithy; leaflet margins sharply toothed; flowers in laige flat or dome-shaped clusters, appearing with the leaves, creamy white; fruit berry-

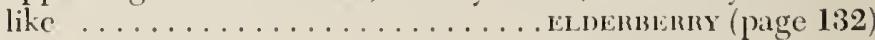
(Saulucus)

19. Leaves divided into leaflets, long throad-like lobes, or decply dissected into numerous segments. . . . . . . . . 20

19. Lcaves pathnately veined and usially loloed, not divided into leaflets or deeply dissected . . . . . . . . . . 27

20. Isaves pallnately divided into 2 loaflets, sometimes simple; flowers sweet-pea shatped; fruit a porl..........21

20. Isalves pinnately divieled into leaflets, thread-like lobes, or decply dissecterl into muncrous seguncuts. . . . . . 22 
21. Rigid, densely branched shrub with very thorny graygreen branches; flowers rose-purple, usually solitary in the leaf axils ...................

(Pickeringia montana)

21. Spreading subshrubs with wiry or somewhat rush-like green branches; flowers yellowish, sometimes tinged reddish, in 1 to 3 or 5 -flowered clusters, scattered profusely along the ultimate branchlets... . DEERwEED (page 94) (Lotus scoparius)

22. Gray-foliaged shrub with a sharp sage odor; leaves divided into thread-like lobes often with small leaves clustered in the axils; flowers in heads, the heads many, nodding, in racemose panicles

(Artemisia californica)

22. Green shrubs without sage odor; leaves pinnately divided into leaflets or dissected into numerous segments, the segments or lobes not long and thread-like;

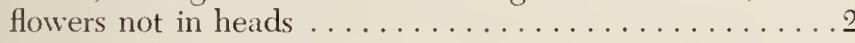

23. Deciduous or semi-deciduous shrubs; foliage not scented; leaves pinnately divided into definite leaflets, not dissected into numerous segments........24

23. Evergreen low shrub with heavily scented foliage; leaves dissected into numerous segments

SIERRA MOUNTAIN MISERY (page 87)

(Chamaebatia foliolosa)

24. Shrubs with an acrid or milky sap; leaves typically with 3 leaflets which are variously toothed or lobed; flowers greenish or pale yellow.......... sumac (page 97)

(Rhus)

24. Shrubs without acrid or milky sap; leaves with 3 to 15 leaflets, margins simply toothed, entire, not lobed; flowers rose, light pink, white, or bright yellow . . . . . . . . 2.

25. Leaflets usually 3 to 7 , smooth or hairy on the upper surface, usually hairy or glandular-hairy beneath; flowers rose colored, light pink, or bright yellow, $1 / 2$ inch or more broad, borne in large or small loose clusters, or solitary; fruit orange-red or brownish. . . . . . .26

25. Leaflets 7 to 15 , smooth on both surfaces; flowers white, $1 / 4$ inch broad, borne in flat-topped clusters 2 to 3 inches broad; fruit coral red

$$
\text { WESTERN MOUNTAIN ASH (page 93) }
$$

(Sorbus sitchensis)

26. Erect shrub 3 to 9 feet high; common at middle and lower elevations; branchlets with straight or curved thorns; leaflets not crowded, $\frac{1}{2}$ inch to $1 \frac{1}{2}$ inches long, light green, smooth or finely hairy on the upper surface, finely hairy or glandular-hairy beneath, margins toothed; flowers rose colored or light pink, few to 30 in a cluster, the petals ${ }_{/ 4}^{3}$ to 1 inch long; fruit orangered, $\frac{1}{2}$ to $\frac{3 / 4}{4}$ inch long, usually smooth

$$
\text { CALIFORN1A WILD ROSE (page 91) }
$$

\section{(Rosa californica)}

26. Low shrub 1 foot to $3 \frac{1}{2}$ feet high, occurring near timberline; branchlets without thorns; leaflets crowded, ${ }_{*}^{*}$ inch or less long, dark green and lightly hairy above, white with silky hairs beneath, margins entire and often inrolled; flowers bright vellow in small loose clusters, or solitary, the flower $1 / 2$ to 1 inch broad; fruit tan or brownish, very small, long hairy

$$
\text { SHRUBBY CINQUEFO1L (page 92) }
$$

27. Flowers with sepals joined so as to form a tubular base (calyx tube), petals joined to the throat of this tube, flowers usually not pure white or bright yellow; fruit berry-like, 1-celled and many seeded CURRANT, GOOSEBERRY (page 72)

(Ribes)

27. Flowers with sepals and petals separate, not forming a tubular basal portion; flowers white or bright yellow; fruit not as in currants and gooseberries. . .

28. Shrub or small tree 6 to 15 feet high; leaves normally $1 \frac{1}{4}$ inch to $1 \frac{1}{2}$ inches long, usually 3 -lobed, occasionally entire, dark green and roughish above, densely rustyhairy beneath; flowers lemon yellow; fruit a rustyhairy capsule .............. FLANNeL BUSH (page 116

(Fremontia californica)

28. Shrubs 3 to 6 or 8 feet high; leaves 1 inch to 7 inches long, 3 to 5-lobed, light green above, paler beneath, smooth or sparingly hairy above, usually hairy beneath but not densely rusty-hairy; flowers white,

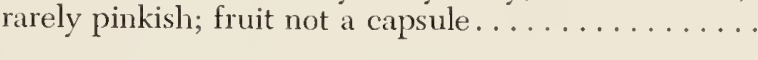

29. Leaves usually 1 inch to 3 inches long, $\frac{3}{4}$ inch to $1 \frac{1}{2}$ inches wide; flowers less than $\frac{1 / 2}{2}$ inch across, in flattish clusters 2 to 3 inches broad; fruit a reddish pod becoming brown in age........ Western NINEBARK (page 92)

(Physocarpus capitatus)

29. Leaves 2 to 7 inches long and as broad; flowers 1 inch to 2 inches across, 4 to 7 in a terminal cluster; fruit an aggregate of edible drupelets known popularly as berries, the cluster cap-like, red to deep scarlet

THIMBLEBERRY (page 92)

(Rulbus parviflorus)

30. Leaves opposite . . . . . . . . . . . . . . 31

30. Leaves alternate ... . . . . . . . . . . . . 38

31. Branchlets and foliage silvery, whitish, or grayish, or bark is ashy gray turning black in age. . . . . . . . . 32

31. Branchlets and foliage dark or light green ... 34

32. Branchlets not thorny; foliage aromatic when crushed; leaves usually obovate, whitish with fine soft hairs; flowers deep blue, arranged in interrupted spikes, subtended by oval rose or purple bracts; fruit separating into 4 small dry nutlets...DESERT SAGE (page 131)

(Salvia carnosa)

32. Branchlets thorny; foliage not aromatic; leaves usually oblong-lanceolate to linear, silvery scurfy or gray hairy; flowers not in spikes, not blue, nor with colorful bracts; fruit fleshy or a dry achene...........

33. Shrub or sinall tree 4 to 20 feet high; branches ending in stout thorns; bark shaggy, gray or brown; leaves usually oblong-lanceolate, ${ }^{3} 4$ inch to $1 \%$ inches, long, silvery scurfy, not clustered at the ends of the branches; male and female flowers borne on separate plants, usually occurring in clusters at the stem joints; flowers small, silvery; fruit fleshy, red SILVER BUFFALOBERRY (page 117)
(Shepherdia argentea)

33. Very spiny shrub 1 to 6 feet high; bark ashy-gray turning black; leaves linear or club-shaped, $\frac{1}{1 / 4}$ to $\frac{1 / 2}{1 / 2}$ inch long, gray, usually clustered at the ends of the branches; male and female flowers not on separate plants, solitary, yellowish or brownish, about $\frac{1}{4} \mathrm{inch}$ long; fruit a dry brownish achene.... . вLACK вUSH (page 86) (Coleogyne ramosissima) 
34. Flewers with petals united, thus appearing tubular or bell-like

34. Flowers with petals not united, or with petals lacking. . . . 36

Branches of the scason angled; leaves dark green, margins entire, often with thread-like hairs (ciliatc); flowers in pairs in the leaf axils on stalks $\frac{1}{2}$ to 1 inch long with 2 ovate or oblong bracts at the summit which become red in age, flowers $\frac{1 / 2}{2}$ inch long, yellow or reddish, glindular-hairy; fruit black

\section{(Lonicera incolncrata)}

35. Branches rounded; leaves dull green or somewhat gray-green, margins entire, irregularly toothed or occasionally lobed, not ciliate; flowers ${ }_{8}^{3}$ inch or less tong in small dense terminal or axillary clusters on short stalks, or sessile, without ovate or oblong bracts, white, yellowish, or pink; fruit white. .svowBerRy (page 135)

\section{(Symphoricarpos)}

36. Rigidly branched shrubs, or prostrate mats; leaves cvergrecn, thick and leathery; plants of usually dry situations

36. Shrubs with flexible branches, never prostrate mats; leaves deciduous, not thick and leathery; plants of

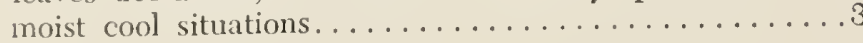

37. Leaves 1 inch to 2 inches long, 5 , to 1 inch wide; male and female flowers borne on separate plants, yellowish, male flowers in head-like clusters, female flowers solitary; fruit a short-pointed capsule ${ }^{3 / 4}$ inch long; limited to San Diego, Imperial, and Riverside counties, and southward and eastward....... GOATNuT (page 96) (Simmondsia chinensis)

37. Leaves $\frac{1 / 4}{4}$ to 1 inch long, $3 / 16$ to $\frac{1 / 2}{2}$, or rarely ${ }_{4}^{3}$ inch wide; flowers biscxual, white, or blue, conspicuous in small rounded or flattish clusters; fruit a capsule $\frac{1 / 8}{8}$ to ${ }_{1 / 4}^{1 / 4}$ inch wide, not sharp pointed.......... CEANotuus (page 102) (Ceanothus)

38. Lcaves 3 to 5 -veined from the base; flowers ${ }_{4}^{3}$ to 1 inch broad, numerous in clusters longer than broad; fruit a dry brownish or greenish capsule

WILD MOCKORANGE (page 74)

(Philadelphus lewisii var. californicus)

38. Leaves 1-veincd from the base; flowers less than 14 inch broad, in rounded or flattish elusters broader than long, the clusters sometimes surrounded by conspicuous petal-like bracts; fruit fleshy, berry-like, white or scarlet .............. (Cormus)

39. Plants with smooth, rich reddish-brown or purplish bark which flakes off in paper-thin rolls or curls........40

39. Plants without smooth reddish-brown or purplish bark which flakes off in paper-thin rolls or curls..........4

40. Tree with large leaves 3 to 6 inches long; berry-like fruit briglit red or yellowish-red, with a granular or warty' surface

. AIADHONL: (page 127)

(Arbulus monziesii)

40). Shrubs, with leaves gencrally less than 2 inches long; br.rry-like fruit reddish-lorown, smootl

MANKanita (page 122)

(Arclostophylos
41. Flowers not in heads, borne solitary or in clusters, or if appearing head-like, then composed of a number of clusters each surrounded by a small cup-like involuere of 4 or 5 united bracts (Eriogonum); foliage odorous in only 3 species; fruit various . . . . . . . . . 42

41. Flowers borne in heads, these heads in flattish or oblong elusters, each head surrounded by a cup-like involuere of several to many bracts, the bracts not united; foliage usually strongly odorous, or only slightly so; fruit a small dry achene (sagebrush, rabbitbrush, Baccharis, horsebrush). . . . . . . . . . . . . . . .67

42. Flowers tubular, bell-shaped, sweet-pea shaped, or wheel-shaped (saucer-like) . . . . . . . . . . . . . . . . 43

42. Flowers not tubular, bell-shaped, sweet-pea shaped, or wheel-shaped ...................... 48

43. Flowers sweet-pea shaped, red-purple, fruit a flat

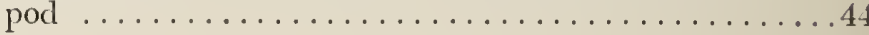

43. Flowers not siveet-pea shaped, nor red-purple; fruit berry-like or a capsule..................45

44. Deciduous tall shrub or small tree 7 to 20 feet high; branches without thorns; leaves simple, round, 2 to $3 \frac{1 / 2}{2}$ inches wide, heart-shaped at the base; flowers appearing before the leaves, in elusters along the branches; pods oblong, dull red when ripe. . WESTERN REDBud (page 93) (Cercis occidentalis)

44. Evergreen shrub 2 to 6 feet high; branchlets very thorny; leaves simple or palmately divided into 3 leaflets, these obovate, $1 / 2$ inch or less broad, tapered to the base; flowers appearing with the leaves, solitary in the leaf axils; pods linear, not red when ripe

CHAPARRAL PEA (page 94)

(Pickeringia montana)

45. Flowers tubular or wheel-shaped (saucer-like), pale blue or bluish-purple, rarely white............46

45. Flowers bell-shaped or urn-shaped, white, greenishwhite, or pinkish....................

46. Branchlets usually 5 -angled or ridged; leaves $1 / 2$ inch to 2 inches long, usually less than 2 inches, not gummy, or with prominent network of veins below, margins not toothed sometimes pinnatifid at the base; flowers wheel-like or saucer-shaped, purplish-blue or violet, rarely white, with 5 green glands at the base; fruit berry-like, whitish . . . . . . . . BLUE watcu (page 132) (Solonum umbellifermm)

46. Branchlets rounded; leaves 2 to 6 inches long, gummy above, with a prominent network of veins below betwcen which is a fine dense mat of hairs (the leaves frequently appear black because of spores from a fungus), leaf margins toothed; flowcrs short tubular, lavender, pale blue, or rarely whitish, ${ }^{\prime \prime} / 8$ to $/ 8$ inch long; fruit a capsule... CALmOHNIA YEnBA SANTA (page 129) (Eriodictyon californicum)

47. Evergreen shruls; branchlets glandular-hairy; leaves almost round, $1{ }^{\prime}$ to 4 inches long, $3_{4}$ inch to $1 \frac{1}{2}$ inches wide; flower clusters 3 to 6 inches long, glandularhairy, the flower stalks, bracts, and ealyx reddish SALAL (page 126)

(Goultheria shallon) 
47. Deciduous or evergreen (1 species) shrubs; branchlets not glandular-hairy; leaves usually less than $1^{1 / 2}$ inches long, rarely to 2 inches, usually less than ${ }_{4}^{31}$ inch wide; flower clusters short, 1 to 5 -flowered, smooth, bracts and calyx usually not reddish

HUCKLEBERRY, BLUEBERRY, BILLBERRY (page 124) (Vaccinium)

4S. Evergreen tree or sometimes shrub-like with bright green, laurel-like leaves that have the odor of bay rum when crushed (leaves used for seasoning in cooking) CALIFORNIA LAUREL (page 70) (Umbellularia californica)

48. Evergreen or deciduous shrubs or trees; foliage without any definite strong odor when crushed, or if slightly odorous not as above . . . . . . . . . . . . 49

49. Leaves needle-like or heather-like, very short and somewhat resinous; fruit an achene

CHAMISE, RED SHANKS (page 82)

(Adenostoma)

49. Leaves not needle-like nor heather-like, usually not resinous, or if so then leaves broader; fruit various . . . . . 50

50. Plants of very alkaline or subalkaline soils; branches often very rigid or spiny; fruit bladder-like, or with bracts or calyx expanding around fruit to form wings or bladder-like enclosure.....................51

50. Plants of non-alkaline soils or alkaline soils but fruit not as above; branches various............... 55

51. Leaves with margins strongly inrolled, the leaves densely white-hairy, becoming rusty in age; fruit surrounded by 2 persistent bracts about 11 inch long and covered by silvery-white hairs, beaked above with 2 short horns

Eurotia lanata)

51. Leaves with margins not inrolled or only shightly so, the leaves green, gray, or scurfy-hairy; fruit not

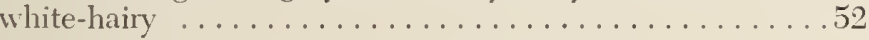

52. Leaves very fleshy, about 1/8 inch wide; fruit surrounded by a broad circular horizontal wing (halolike) about $1 / 2$ inch wide........... GREASEWOOD (page 68)

(Sarcobatus vermiculatus)

52. Leaves not fleshy or if fleshy then ${ }_{1}^{1}$ inch or more wide; fruit without broad circular wing . . . . . . . . 5

53. Erect perennial herb less than 1 foot high, woody only at base; leaves linear, green; fruit with a 5-lobed horizontal wing $\ldots \ldots \ldots \ldots \ldots \ldots$ GREEN MOLLY (page 69)

(Kochia americana)

53. Shrubs, or if woody, only at the base; leaves usually gray and not linear; fruit without a 5-lobed horizontal wing

54. Leaves usually almost smooth and green; fruiting bracts wholly united into a round sac which is often tinged reddish .............. SPINY HOP-SAGE (page 68) (Grayia spinosa)

54. Leaves more or less covered with mealy hairs giving the leaves a grayish appearance; fruiting bracts not united at the apex, tinged red only in one herbaceous species (Atriplex)
55. Leaves narrow, less than ${ }_{4}^{11}$ inch wille, not stalked; pinkish or white flower clusters borne at the ends of 4 to 9 unequal stalks which radiatc from a single stalk 3 to 10 inches long, each flower cluster surrounded by a small cup-like involucre; fruit a small dry achene

CALIFORNIA BUCK WHEAT (page 63) (Eriogonum fasciculatum)

55. Leaves broader, usually more than ${ }_{4}^{11}$ inch wide and stalked; flower clusters borne variously but not as above and without involucre; fruit various. . .

56. Deciduous shrub or small tree; leaves broad, coarsely veiny, unequal at the slightly heart-shaped base, sandpapery to the touch; flowers inconspicuous; mountain ranges bordering deserts of southern California . . . . . . . . . . WESTERN HACKBERRY (page 62)

(Celtis douglasii)

56. Deciduous or evergreen shrubs; leaves various but not coarsely veiny or sandpapery to touch; flowers usually conspicuous; range various.................. 57

57. Leaves 3 to 5 -divided or lobed at the apex, tapering to a wedge-shaped base...................... 58

57. Leaves coarsely or finely toothed, lobed or cntire, but not 3 to 5 -divided or lobed at the apex............

58. Flowers large, cream colored, or yellowish, rarely white, about ${ }^{\prime \prime}$ inch wide; fruit a leathery achene tipped with a long feathery tail; mountains of eastern Mohave Desert and Inyo County.... . . . CLIFFrose (page 85) (Couania mexicana var. stansburiana)

58. Flowers smaller, pale yellow, about $\%$ of an inch broad; fruit a leathery achene tipped with a short point .................. . 131ттеквиusn (page 75 (Purshia)

59. Flower large and showy, bright yeliow, inch to $1^{1 / 2}$ inches broad; fruit a large globose or long narrow capsule

59. Flowers not as large, nor bright yellow, $\frac{1}{2}$ inch or less broad; fruit various but if a capsulc then very small.

60. Branches with yellowish-gray or almost white shreddy bark, not hairy; leaves narrow to elliptical, gray or yellowish-green, smooth, apparently entire but actually finely toothed; flowers with 2 or 3 scpals, thesu falling early, and 4 or 6 separate petals; fruit a very narrow curved capsule 2 to 4 inches long, smooth Busil POPPY (page 71)

(Dendromecon rigida)

60. Branches dark colored, covered with stiff hairs; leaves round-ovate to clliptic-ovate, dark green, densely hairy beneath, entire to slightly lobed or sometimes maple-like; flowers with 5 sepals which are petal-like and united at the base, no petals; fruit a subglobosc capsule $\frac{5 \%}{8}$ to 1 inch long, denscly bristly-hairy

FLANNEL BUSII (page II

(Fremontia californica)

61. Fruit berry-like, a drupe or pome, fleshy, black, red,

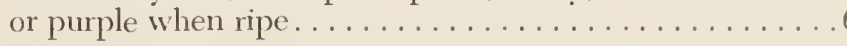

61. Fruit a leathery achene, a small pod, or a small dry capsule, $\tan$ or greenish ..................66 6 
62. Deciduous shrulss or small trees; leaves thin; flowers white or creamy-white, eonspicuous.

62. Evergreen slirulss; leaves thick and somewhat leathers, on if dcciduous, the bark very bitter, and flowers greenish and inconspicuous (cascara sagrada) . . . . 6. 65

63. Leares coarsely or fincly toothed above the middle, often lobed or occasionally entire or subcntire; fruit a pome

63. Lcaves finely toothed along the entire margin; fruit a drupe ................. PLum, Cherry (page 88)

(Prunus)

64. Branclies with coarse stout thoms; leaves 1 inch to 2 (or 4) inches long, coarsely double-toothed along the upper $\div$ of the margin, or often lobed WESTERN BLACKHAW (page 93) (Crataegus douglasii)

64. Branches without thoms; leaves ${ }_{/ 4}^{3 / 4}$ inch to $1 \frac{1}{4}$ inches long, sharply toothcd at the apex, or occasionally cntirc or subentire...... . IVESTERN SERviceberky (page 81) (Amelanchier alnifolia)

65. Leaf margins with bristle-pointed teeth; flowers white, in largc, terminal, flattish clusters; fruit bright or pale red, rarely yellowish........... Torow (page 92) (Heteromeles arbutifolia)

65. Leaf margins finely toothed to nearly entire; flowers grcenish or greenish-yellow, inconspicuous, several in small rounded clusters; fruit black or red

COFFEEBERRY (page 112) (Rhammus)

66. Shrubs or small trees with short spur-like leaf bearing branches; flowers solitary or several in a eluster, pale tan; fruit a hairy achene tipped with a long feathery tail .....................

(Cercocarpus)

66. Shrulss or sometimes small trees; usually without spur-like branches; flowers small, but usually showy because of their profusion, white, bluc, or pinkish, in small rounded clusters; fruit a three-lobed smooth or glutinous capsule .............. CEANothus (page 102)

(Ceanothus)

67. Silvery-gray shrubs; foliage with strong bitter sage odor; flower heads drooping or erect, in narrow leafy

spikes or panicles .............. sagebrusin (page 137)

67. Green or gray-green shrulss, or sometimes grayishwhite; foliage often oclorous or only slightly so, but not of litter sage; flower heads in flat-topped or rounded clusters, or if somcivhat olslong the cluster not leafy

68. Branchlets striate or angular; leaves coarsely toothed, remotely tootleed, to entire, not hairy; flowers white or dirty white to somewhat yellowish but not a clear briglt yellow; plants of low clevations (10 to 1500 ) feet) in the footliils and along water courses

BACCHAMS (page 142)

(Baccharis)

68. Branchlets rounderl, usually not striate; leares all contire, densely to lightly hairy, or smooth; plants of arid alkaline flats, dry mountitin slopes; mostly. descrts, somtlnern California momtanis and east sirle of the Sierra Nevardat ....................
69. Foliage with permanent gray or white soft felt-like hairs; leaves very gray; involucral bracts subtending heads 4 to $5 \ldots \ldots \ldots \ldots \ldots$. . . . . . . . HORSEBrush (page 144)

(Tetradymia eanescens)

69. Foliage often fincly hairy, but not felt-like, to smooth; leaves gray-green to bright green; involucral bracts subtending heads 10 to $25 \ldots \ldots$..... вавBitbrusir (page 140)

(Chrysothammus)

\section{Discussion of Individual Browse Species}

\section{Cypress Family (Cupressaceae)}

The cypress family, one of the families of cone-bearing plants, is characterized by having evergreen, small, scalelike leaves closely appressed to the branches forming fern-like sprays, or cord-like branchlets. The fruits are woody cones or rather soft and fleshy, almost berry-like.

Many members of this family are important ornamental plants. Some of them date back hundreds of years such as the columnar forms of the Italian cypress (Cupressus sempervirens var. 'Stricta'-important exclamation points in Italian formal gardens. The old-timers in the gold mining country of California's Sierra foothills generously decorated their cemeteries with them-some are still seen there. As far as browse is concerned, the only important members in the family are the junipers.

\section{JUNIPERS (Juniperus)}

Shrubs or small trees with usually aromatic foliage. Leaves in whorls of 2 or 3, of two kinds-almost needlelike with sharp, spreading tips, or seale-like and forming cord-like branchlets. Cones small, somewhat fleshy, and berrv-like.

Four junipers occur in California. One of them, a low, nearly prostrate shrub or ground cover (J. communis var. saxatilis) is so limited in the State, and usually at such high elevations, that it has no browse value. The other three are shrubby or tree-like.

Goats and deer, sheep to a lesser extent, are fond of the berries and to some extent the foliage. Some species have the reputation of being poisonous to goats. The oil (oil of cedar) from junipers is believed to eause abortion $^{(125)}$. None of the California species have been reported to be poisonous.

\section{Key to the Browse Species}

1. Mature fruit blue-black, pulp resinous; plants of usually high elevations, mountains of southern California, the Sierra Nevada, and the north Coast Ranges

WESTERN JUNIPLR (Jumiperus occidentalis)

1. Malure fruit reddish-brown, pulp dry; plants of lower elevations, or of desert monntain ranges........... 2 
2. Leaves usually in whorls of 2 , generally glandularpitted on the back, with blunt tip; Inner Coast Ranges, Sierra Nevada foothills, desert slopes of southern California mountains, and desert slopes, mostly below 5,000 feet elevation. . . . . CALIFOrNIA JUNiPER

(Juniperus californica)

2. Leaves usually in whorls of 3 , not glandular-pitted on the back, with pointed tip; desert mountain ranges of eastern San Bernardino County, and in Mono and Inyo counties, usually at elevations of 4,800 to 8,500 feet

(Juniperus osteosperma)

CALIFORNiA JUNIPER (Juniperus californica) (drawing on page 46). Shrub or tree 3 to 15 (occasionally up to 40 ) feet high with sturdy irregular stems and ashy gray bark. Leaves usually in whorls of 2 , glandular pitted on the back, bluntly pointed, dull green. Fruit oblong-oval, about 1/2-inch long; bluish with dense bloom when young, reddish-brown beneath the bloom when ripc; ncarly smooth; pulp firm, dry, sweet. Seeds 1 to 2.

Distribution (map on page 46). Dry hills in the lower mountains, usually below 5,000 feet elevation, from Tehama County in the Inner Coast Ranges to the Tehachapi Mountains, eastward to the base of the Sierra Nevada in Kern and Tulare counties, and thence north as far as the Merced River. In the south it is abundant on the desert slopes of the Sierra Liebre, Sierra Madre, and San Bernardino mountains. ${ }^{*}$ It is commonly associated

- The distribution maps in this manual were prepared solely from collections in the Herbarium of the University of California at Berkeley and will show the distribution of a species at a glance. The descriptive distributions are sometimes broader than those shown on the maps because the Herbarium collections are not in all instances as representative as would be desired.

\section{How Browse Plants Are Rated}

An over-all browse rating of "excellent," "good," "fair," "poor," or "useless" is given at the end of the discussion of each prominent species or variety for cattle, horses, sheep, goats, and deer. These ratings are based on the following facts: degree of cropping within easy reach, taking into account season of the vear; abundance and distribution of the species and its nutritional value; abundance of twigs and leafage and whether deciduons or evergreen; reproductive capacity, whethcr solely by seed or also vegetatively by sprouting as when cut or burned; objectionable anatomical structures such as spines or prickles which are annoying or actually injurious to grazing animals; and whether the plant is poisonous to grazing animals at any season of the year.

A summation of over-all browse ratings of species discussed is presented in the table on pages 146-148.

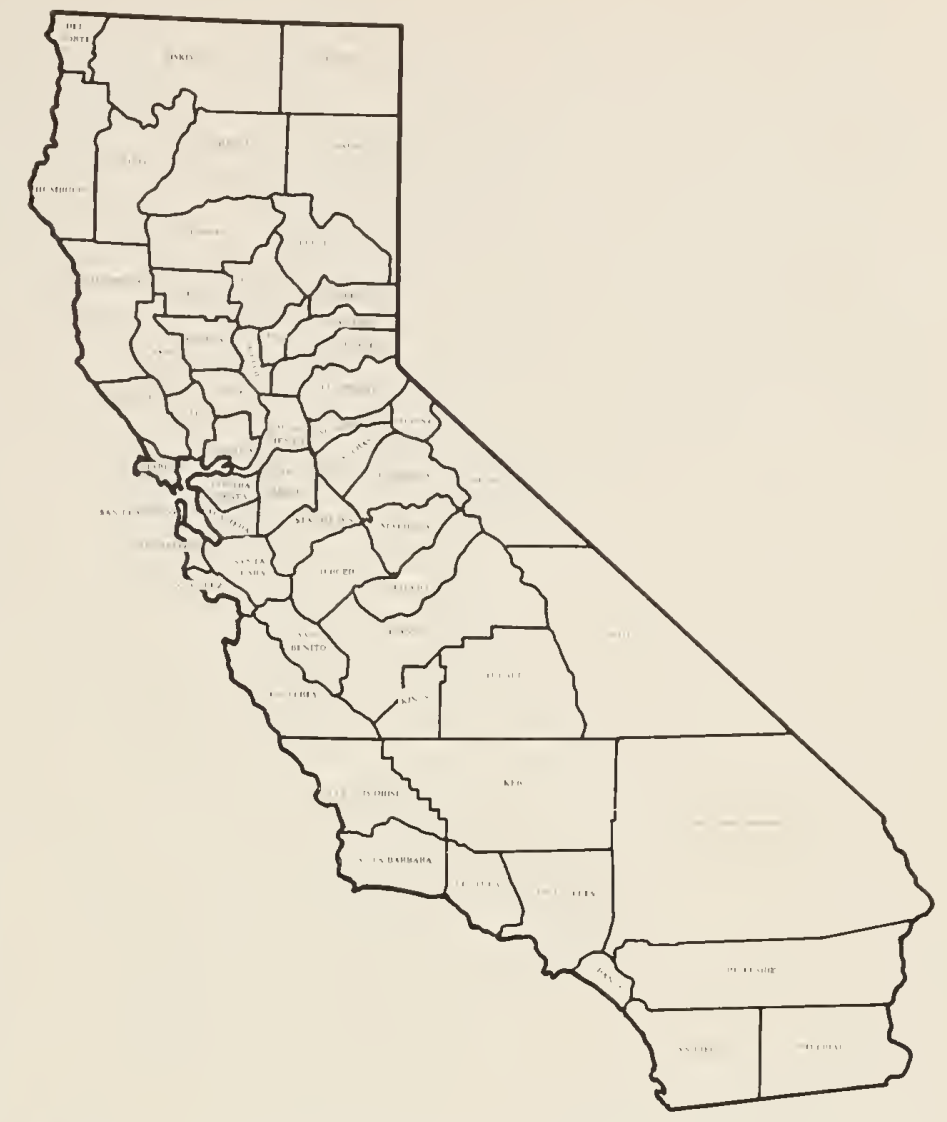

Map of California counties to identify their location on the distribution maps.

with cliffrose, Joshua trce, big sagebrush, and birchleaf mountain-mahogany in its southern range.

Economic value. California juniper is sometimes regarded as an emergency feed for sheep and goats on winter range, but is a staple winter browse for deer on many ranges. It was found in 5.2 per cent of the 96 stomachs of the black-tailed Tehama County deer herd in the winter of $1957^{(77)}$. In some localities, however, domestic livestock and big game scarcely utilize this plant if other more palatable feed is alumdantly available. On overstocked sheep and goat areas prominent browse lines on California juniper plants are common. Such heavy croppings occur frcquently on deer concentration areas and has sometimes resulted in destroying much of the juniper browse cover.

Browse rating. Fair to poor for goats and deer; poor to useless for shecp; and useless for cattle and horses.

ONESEED JUNIPER (Junipenis osteosperma), sometimes called Utah juniper. This plant, closely related to the California juniper, is usually more compact and tree-like. Its leaves are mostly in whorls of 3, usually not glandular pitted on the back, with pointed tip. Fruits are slightly smaller. Oneseed juniper is less abundant than the California juniper, occurring in the desert mountain ranges, 4,800 to 8,500 feet elevation, of eastern San Bernardino County and in Mono and Invo counties; more common eastward. Because of its sparse occurrence, its impor- 


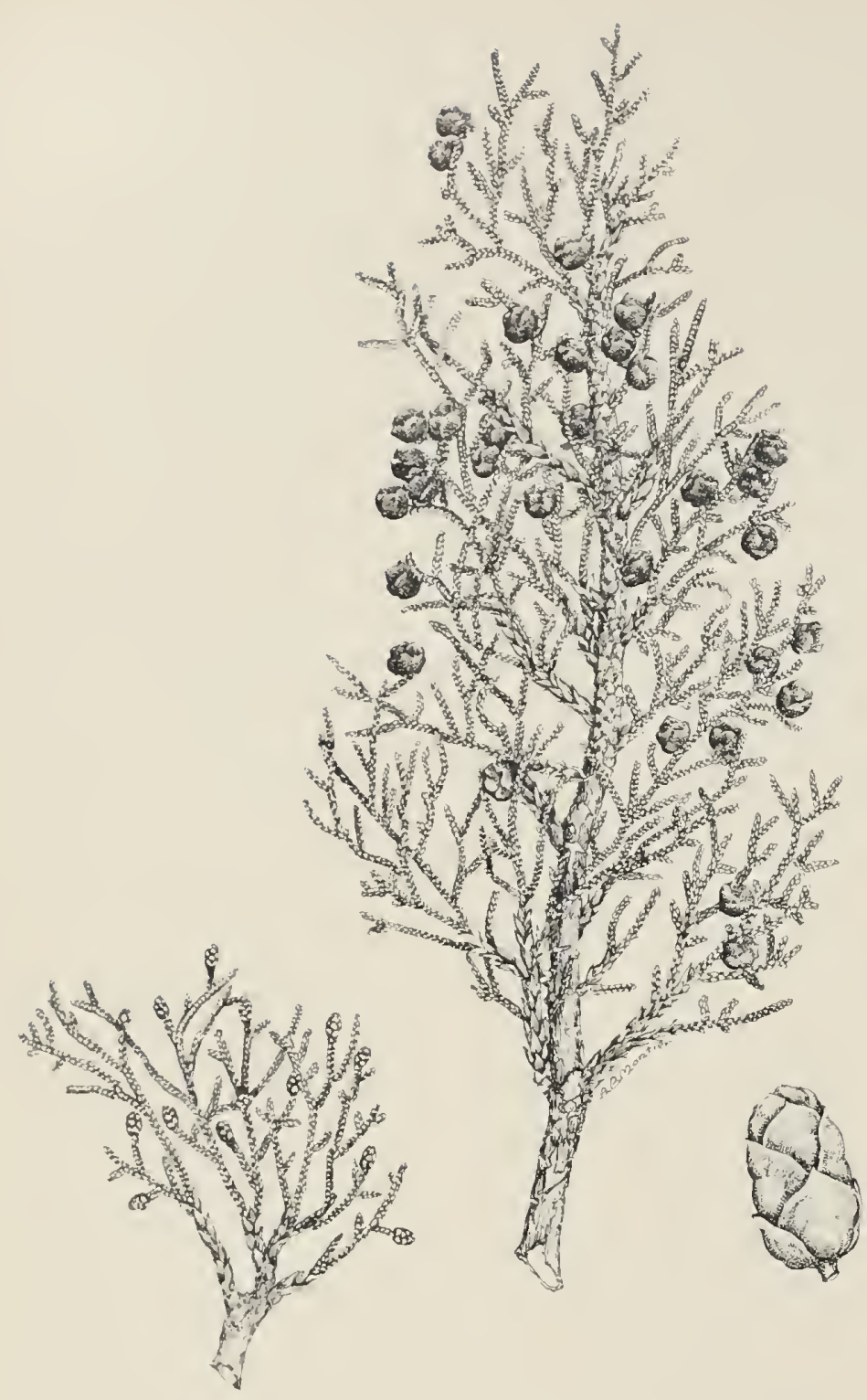

California juniper (Juniperus californica). Left, branchlet with male cones; center, branchlet in fruit; right, fruiting cone. This species is sometimes regarded as an emergency feed for sheep and goats, but is a staple winter browse for deer on many ranges.

tance as a browse plant in California is limited. Its browse ratings are given in the summary table on page 147.

WESTERN JUNJPER (Juniperus occidentalis). Subalpine tree, or somctimes a shrub, 10 to 25 , or even up to 65 feet higl. Trunk 1 to 5 feet in diameter, often picturesquely gnarled and twisted; bark dull red, shroddy. Scale-like l'aves in 2's or 3's, glandular pitted on the baek, gravgreen. Berries globose to ovoid, blue-l)lack witl whitish hloom, aloont yito ${ }^{33}$ inch long, pulp resinons. Secels 2 to 3.

Distribution (natp above). On granite ridges, dry slopes and flats between 3,000 to 10,500 fect elevation. It is (ommonen in the Sierra Nevada, scaree in the San BerIalrelino, Pananuint, ancl Yolla Bolly monntains. It extends monthwarl to Washington. Common associated plants are corlleaf momutain-1uahogany, manzanita, snowbrush, wild cherries, and conifers.

Eiconomic ealur. Western juniper is of low browse

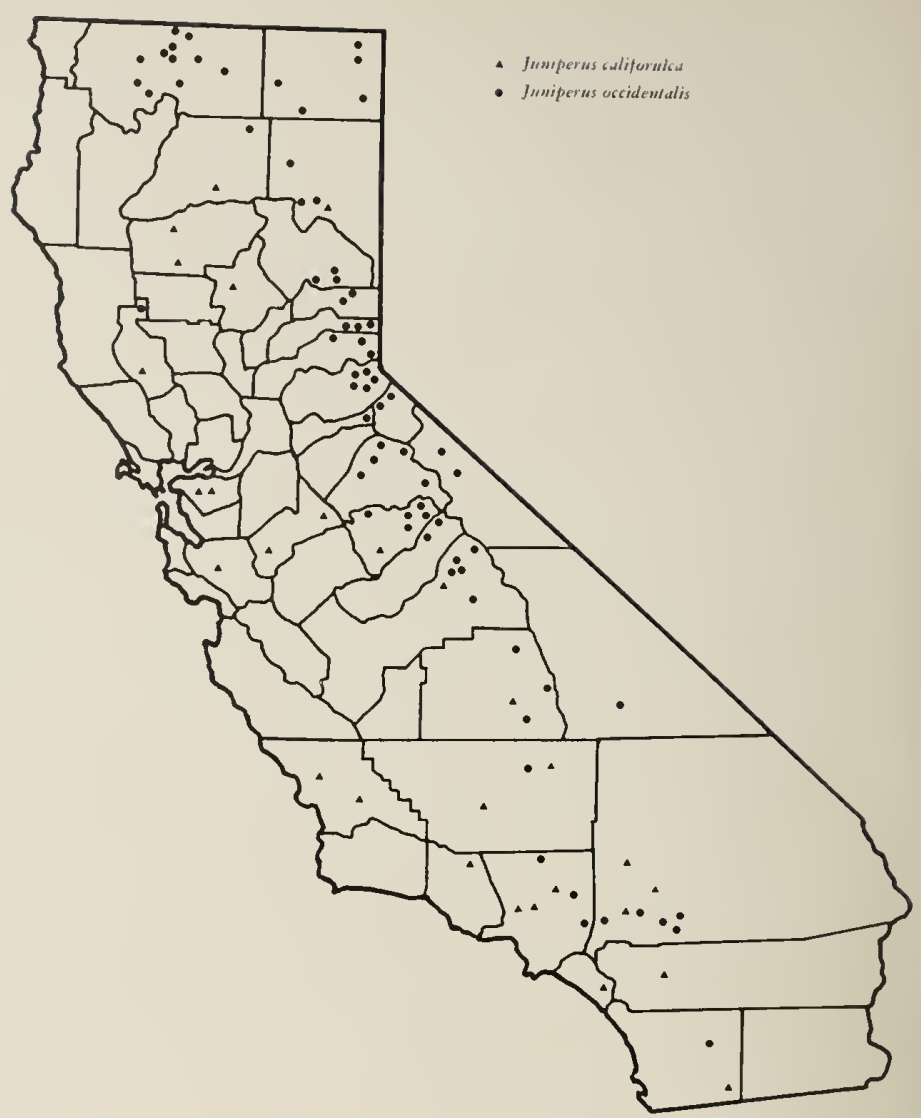

Distribution of California juniper (Juniperus californica) and western juniper (Juniperus occidentalis).

value for domestic livestoek, exeept oecasionally for goats; but in some loealities or at eertain seasons, it is a valuable food plant for deer. Reeords of foods ingested by the Interstate mule deer herds east of the Sierra Nevada and the Caseade Ranges of northeastern California and north into Oregon revealed that, during the eritieal winter of 1951-1952, utilization of western jumiper was extremely heavy ${ }^{(80)}$. It contributed 48.5 per cent of the diet in December, 53.6 per cent in January, 25.9 per eent in February, and 52.0 per eent in March. Heavy utilization of western jumiper during eritical winters has bcen verificd by several range utilization eheeks. The Devil's Garden mule deer herd, whieh oeeupies a portion of the Modoe Plateau in northeastern California, depended to a considerable degree upon western juniper during open favorable winter months, and deponded heavily on this speeies in severe winters. On the LassenWashoe winter range, the deer ate but little western juniper, the highest volmme taken was in Deecmber, amounting to $1.2 \mathrm{per}$ cent of the total volume of food ingested. It was found in 16.7 per eent of the 29 stomaelis analyzed. Why the mule decr of this region ntilized so little western jumiper has not been explained.

Browse rating. Fair to poor for deer; fair to uscless for shecp and goats; and uscless for cattle and horses.

\section{Gnetum Family (Ephedraceae)}

The representatives of this family in California are broom-like shrules that oceur in desert or semi-arid west- 
erm areas, eommonly in the sagebrush, piñon-juniper, and ponderosa pine zones. The genus Ephedra is the sole member of this family and shares the descriptive characters with this family, as discussed here.

\section{EPHEDRA (Ephedra)}

Ephedras are rather low shrubs with long fluted, jointed, opposite, or whorled, gray-green or yellow-green branches somewhat resembling the seouring rushes or horsetails (Equisetum) eommon along streams. Leaves are scale-like, small, paperlike, and ineonspicuous. Flowers are unisexual, appearing on separate plants, borne in catkins. The nut-like seeds are surrounded by a hardened perianth, partly enclosed or entirely enclosed by large papery fruiting braets, forming a eone-like structure.

Top, Nevada ephedra (Ephedra nevadensis). Branchlet in flower; fruit (left); male flower cluster (right).

This species inhabits the lower dry desert areas. It is modcrately palatable to both livestock and deer and is rather heavily utilized, especially in winter.

Bottom, Green ephedra (Ephedra viridis). Branchlet in flowers; female catkin showing young fruit (left); male catkin (right).

A common desert mountain shrub that is moderately palatable and highly rcgarded, especially as winter browse for livcstoek and deer.
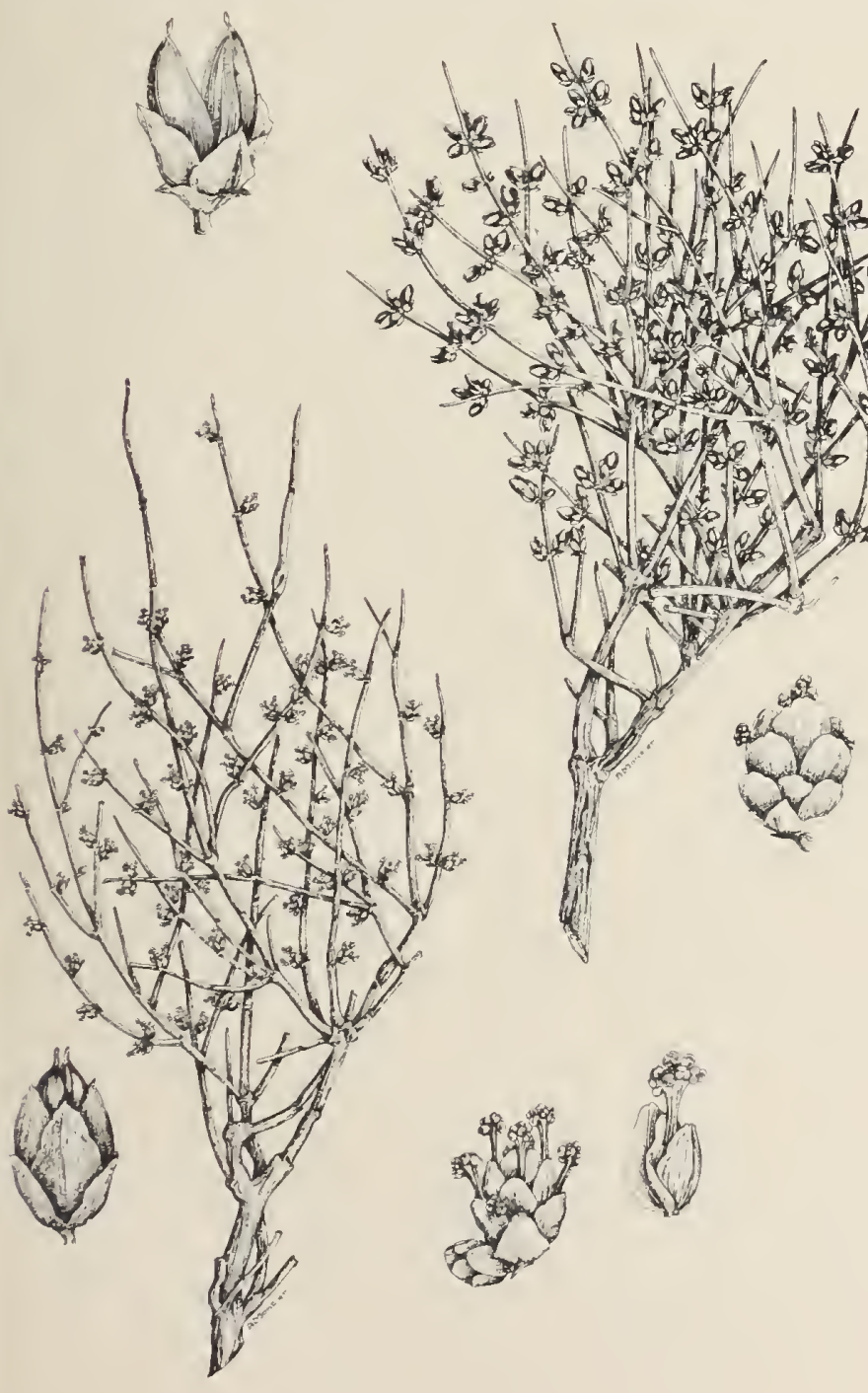

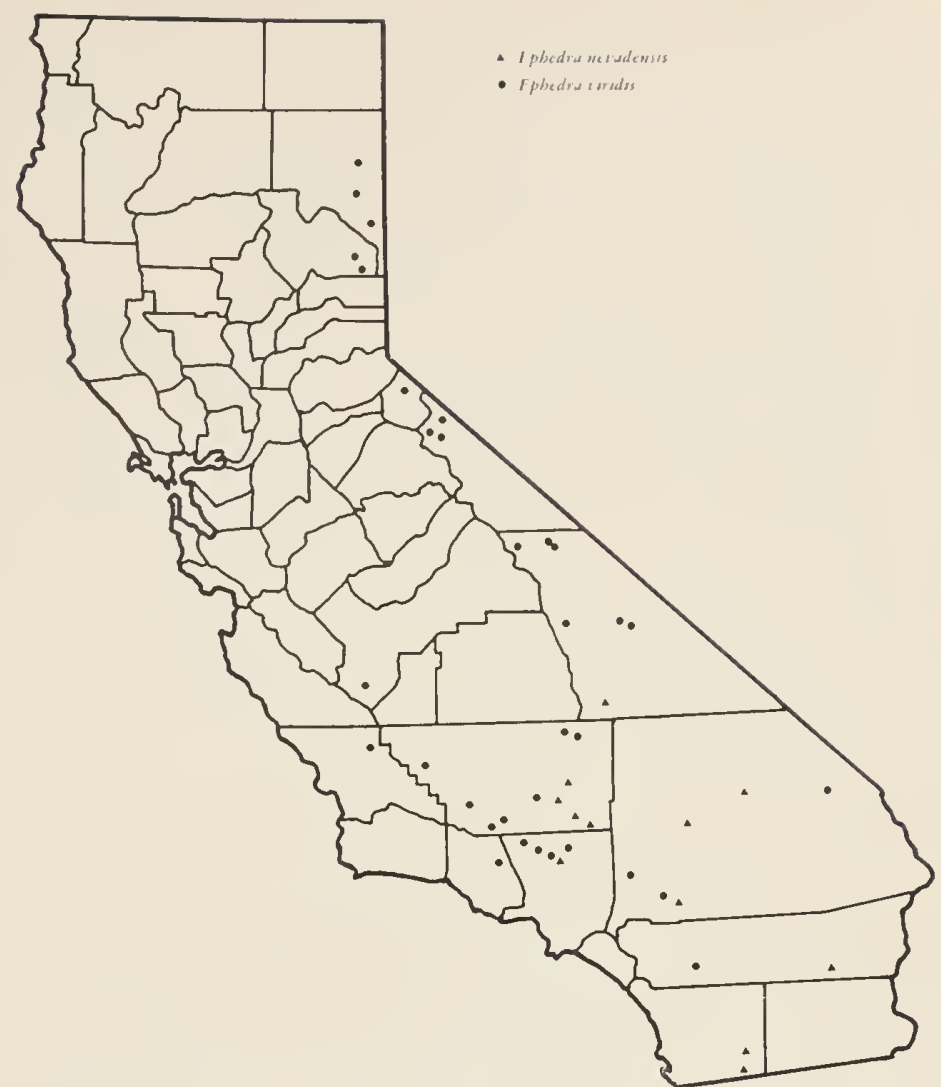

Distribution of Nevada ephedra (Ephedra nevadensis) and green ephedra (Ephedra viridis).

Ephedras are known by several common names. Their jointed, fluted stems have earned them the name of shrubby horsetails or jointfirs. The dried stems and flowers contain certain alkaloids such as pseudoephedrine and certain tannins, and some of the early settlers made a tonie beverage, hence the names Mormon tea or Brigham tea. The American species of Ephedra have long been of interest to pharmacologists as a possible source of the drug ephedrine used espeeially for colds, asthma, and hay fever, and used for that purpose by the Indians ${ }^{(17)}$. Actually the true drug ephedrine is obtained from a Chinese herbaccous species (Ephedra sinica).

The numcrous stems and rush-like twigs of these plants-nearly all within reach of grazing animals-are cropped with considerable relish by all livestock and big game on winter range, but to a lesser degree in other seasons. Since they are frequently abundant over a large area, they eompose a fairly important food element. Green ephedra and Nevada ephedra are the most important California browse species because of their wide distribution and relative abundance.

\section{Key to the Browse Species}

1. Bright green or yellowish-green broom-like shrubs, with numerous erect slender branches.... . GREEN EPHEDRA (Ephedia viridis)

1. Pale green or gray-green shrubs, with stout spreading branches . NEVADA EPHEDRA (Ephedra nevadensis) 
GREEN EPHEDra (Ephedra viridis) (drawing on page 47). Erect shrub 1 to 3 feet high, with numcrous, bright cllow-green, stender, parallel branches pointing uprard like the straws in an upturned broom. Leaves usually in 2's, their free tips falling away leaving thick brown bases. Cones ovatc, 4-angled, alont $\frac{1}{1 / 4}$ to $\frac{1}{2}$-inch long, surronucled by 4 to $S$ pairs of roundish bracts.

Distribution (map on page 47). This species occurs on desert mountain slopes and flats of the jumiper-piñon belt in the Upper Sonoran Life Zone from 3,000 to 7,500 feet elevation. It extends from the lava beds of eastern Lassen County southward into Mono and Inyo counties and to the mountain slopes bordering the Mojave Desert of Kem, V'entura, Los Angeles, and San Bcrnardino counties. It extends eastward in the desert region of Nevada and adjacent areas. Common associated speeies are creosote bush, Spanish bayonct, and the pinon-juniper community

Economic value. Although green ephedra is not as palatable as many superior forage plants, it is moderately relished by all kinds of livestock as well as deer. Gencrally it is only lightly browsed on summer and fall range where more sucenlent and palatable forage is abundant. On winter range, however, where extensive stands occur, it is often an important food clement. On the southern Invo County mule deer winter range green ephcdra accounted for 9 per cent of the plant cover. It was browsed most heavily during January and February but was also of some importance in the diet in Dccember and March ${ }^{(s)}$. The younger brush-like stems, in particular, arc eaten with considerable relish, utilization sometimes rumning as high as 40 per cent or occasionally higher.

Brouse raling. Good to fair for goats; fair to poor for cattle, sheep, and deer, and useless for horses.

NEVADA EPHEDRA (Ephedra nevadensis) (drawing on page 47). Ercct gray-grcen or olive-grcen shrub, $1 / 2$ to 2 feet high, with numerous, stiff, short, stout, spreading branches that typically grow in pairs. Leaves usually in 2 's, falling away leaving gray bases. Cones single, or in pairs, roundish, surrounded by 3 to 5 pairs of braets.

Distribution (map on parge 47). Nevada ephedra usually occurs at lower elcvations (below 4,500 fect) than green ephedra. It inhahits the lower dry sagcbrush, creosote bush, and lower jumiper belt of the Lower and Upper Sonoran Life Zone in Modoc, Inyo, San Bernardino, Riverside, San Diego, and Kern counties. It extends eastward to Nevada, Utah, and Arizona, and southward to Lower California. Common in the creosote bush serml) colmmmity.

Eiconomic value. The stems of Nevada ephecha often supply important hrowse for cattle, sheep, goats, and decron the winter range. In some localities cattle have utilized alonent 50 per ecut of the stems. Because of the nomerons twigs and the almulance of the plant it is at times a highly important eonstiturent of the winter range frecel. It is also croppred to a small extent at other scasons.

Browesp rating. Food to fatr for goats; fair to poor for cattle, shreep), and dere; and inseless for horses.

\section{Willow Family (Salicaceae)}

The willow family includes both deciduous trees and shrubs. Their leaves are simple, alternate, and usually bear stipules at the base of the stalk. The flowers are borne in catkins, before or with the leaves; the male and fcmale catkins on separate trees. The small capsules bear many tiny seeds that have tufts of white silky hairs.

Both willows (Salix) and cottonwoods, poplars, and aspen (Populus) are included in this family. Speeies of these two genera usually occur along streams and in moist places, and are easily recognized. As browse plants they are rated relatively high. However, home gardeners often considered them pests bccause of their voracious "appetities," their bad suckering habit, roots that penetrate plumbing and septic tanks, and the profusion of feathery seeds that cause a litter problem.

\section{IVILLOWS (Salix)}

Willows vary in size from low creeping plants to large shrubs, and small trees. Winter buds are covered by a single scale. Leaves are mostly narrow.

Several native willows are planted for erosion eontrol, notably in southern California. They are especially useful for this purpose bccause of their extensive root system, rapid growth, their vigorous vegetative reproduction by root shoots and suckers, and their ready establishment by stem cuttings. While most species endure fairly elose browsing, excessive utilization has sometimes defeatcd the purpose of planting them for erosion control. Although few of the native willows are used in landscaping, several exotie species have found their way into gardens. The most commonly planted, and familiar to many, is the graccful weeping willow (S. babylonica).

Willows provide wholcsome browse of satisfactory nutritional balance. Their crude protein content compares favorably with that of other deciduous shrubs. Unidentified samples of willow species collected on one deer range in northern California gave the following protein valucs: During January, February, March, and April the percentages were 7.3, 7.3, 12.1, and 18.6 respeetively. In December the naked branches, which are cropped extensively by big game where feed is limited, contained $4.6 \mathrm{per}$ cent protein. The volume of willow eaten by mule deer on the southem Inyo range in 1952 was 12.9 per cont in January, 15.2 per cent in February, and 12.5 per cent in Marchi(i).

Willows generally are good food plants for cattle, sheep, goats, and big-game animals. In California deer feed extensively in winter on the leafless twigs of last season's growth. In other westem states elk rely on willows for a large part of their winter and carly spring feed. Among (lomestic livestock, cattle, becanse of their greater reach, make the best use of willows; and unlike sheep and goats, cattle do not shy away from the wet soils where these plants ty pically ocenr. Since cattle tend to "shade up" for long periods in patches of willow during the warmer weather and more severe fly season, they often form a heelged browse line on the trees. 
While practically all willows are cropped to some extent by livestock and big game, some species rank higher than others because of greater palatability, more extensive distribution, and accessibility to browsing animals. The dwarf forms of willows, common at alpine elevation, are relatively unimportant as browse.

Nuttall willow and arroyo willow are among the most important species and will serve to typify the browse values of the genus.

\section{Key to the Browse Species}

1. Plants usually with a grayish appearance; leaves linear to linear-lanceolate or oblanceolate, usually much longer than broad..................

1. Plants usually green in appearance; leaves linearlanceolate, oblanceolate to obovate, rarely linear, usu-

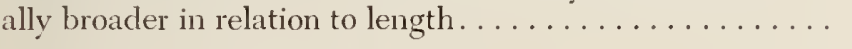

2. Capsules white hairv; style evident but short; stigmas 3 to 4 times longer than broad; willow of the Great Valley, Coast Ranges, Southern California, and Sierra foothills to 3,000 feet elevation.......... VALLEY wiLlow (Salix hindsiana)

2. Capsules smooth; style obsolete; stigmas less than 132 inch long; found east of the Sierra Nevada from Modoc County to southern California . NARrowleaf willow (Salix exigua)

3. Leaves usually less than $\frac{1}{2}$ inch wide. . . . . . . . . . . 4

3. Leaves usually $\frac{16}{2}$ inch or more wide. . . . . . . . 5

4. Low spreading shrub 1 foot to $2 \frac{1}{2}$ feet high; leaves dull green and finely hairy above, paler beneath, with gray hairs thickly covering the raised veins; catkin scales yellow; inner Coast Ranges, San Luis Obispo County, northward to Lake and Colusa counties

BHEWER WILLOW (Salix breweri)

4. Rounded shrub, 4 to 12 feet high; leaves deep green and shining above, smooth beneath and usually grayish; catkin scales black; Sierra Nevada Mountains, 5,000 to 10,000 feet elevation, to southern Siskiyou County .................. LEMMON WVILLOW

(Salix lemmonii)

5. Tree 20 to 45 feet high with roughly fissured brown bark; leaves tapering to a long slim point. . Y yelLow wiluow (Salix lasiandra)

5. Usually shrubs or small trees with smooth bark; leaves not taper pointed . . . . . . . . . . . . . .

6. Stamen filaments united at base; styles evident; ovary and capsule smooth or minutely hairy; one of the most common willows of valleys and foothills throughout California, from sea level to 5,000 feet elevation

ARROYO WILLOW

(Salix lasiolepis)

6. Stamen filaments not united; styles none or very short; ovary and capsule white-hairy; Sierra Nevada Mountains 4,000 to 10,000 feet elevation; Coast Ranges near the coast, Del Norte County, southward to Alameda and Monterey counties; San Antonio, San Jacinto, and San Bernardino mountains of southern California NUTTALL WHLLOW (Salix scouleriana)

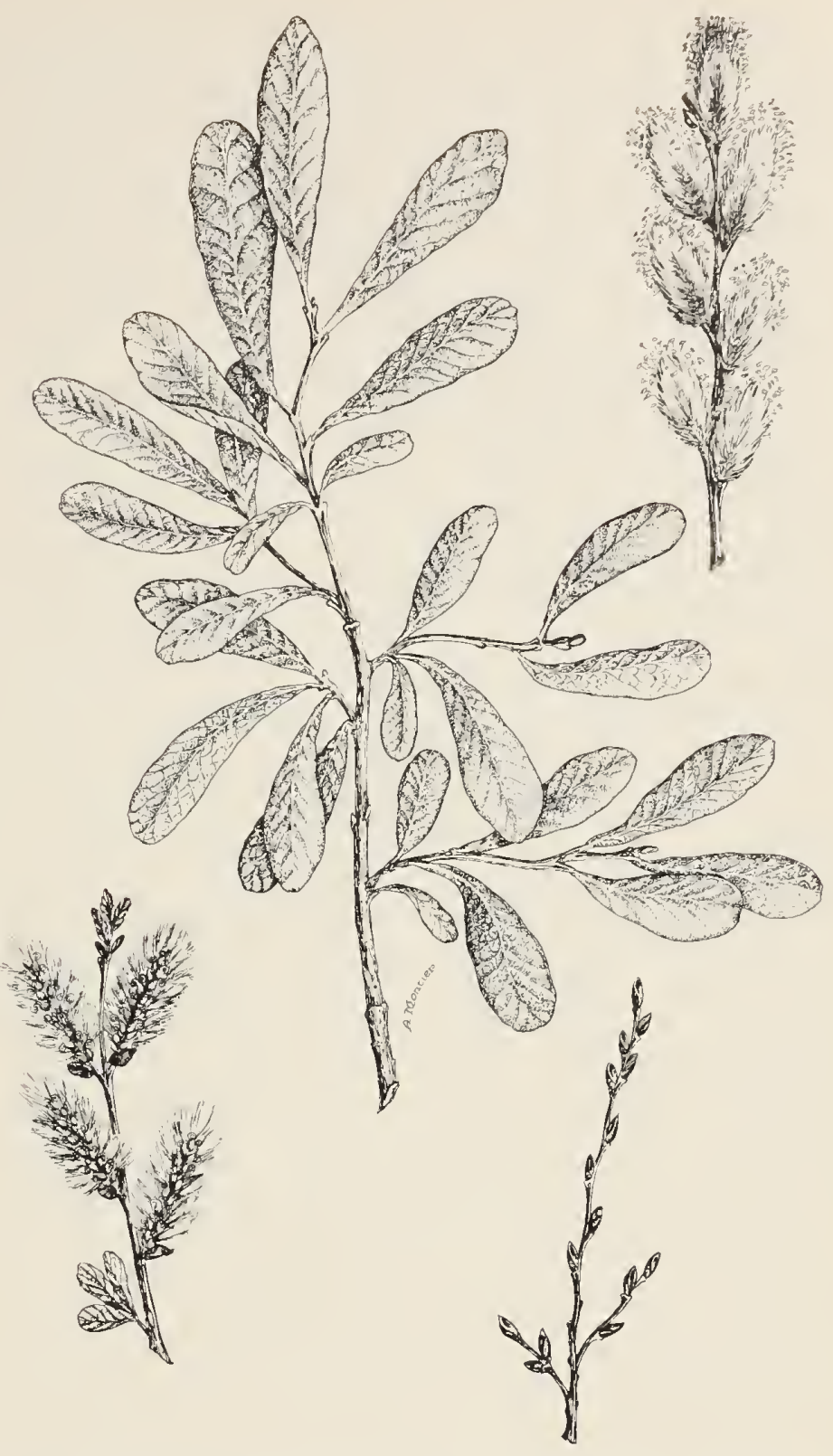

Nuttall willow (Salix scouleriana) provides much browse for livestockespecially cattle-and deer. Because of its favorable size for browsing and its palatability it is regarded as among the best of the willow for livestock.

\section{Primary Willow Species}

NutTall willow (Salix scouleriana) (drawing shown above), also known as fire willow, and black willow. Shrub or small tree 3 to 25 feet high, usually with multiple, whitish barked, leafy stems spreading from the base. Leaves obovate to oblong-obovate, usually acute at the tip, 1 to $1 \frac{1}{2}$ inches long (or sometimes to 4 inches), $1 / 2$ to 1 1/2 inches broad, margins entire; dull green above, smooth and glaucous or densely silvery short hairy beneath. Male and female catkins appearing before the leaves, $1 / 2$ to 1 inch long, nearly stalkless; catkin scales black, hairy. Stamen filaments not united; styles none or very short. Capsules white hairy.

Distribution (map on page 50). Nuttall willow grows best in moist to wet sites along mountain streams and about springs and seeps, but it also occupies coarse, dry 
soils, and warm southern slopes, wherc its growth is more stunted and bushy, and the leaves smaller. It commonly occurs from near sea level up to 10,000 feet elevationSierra Nevada Mountains from Modoc and Siskiyou counties southward to Tulare County, Coast Range from Del Norte Countr sonthward to Alameda and Montcrey comntics, and in the San Antonio, San Jacinto, and San Bemardino momtains. It also ranges north to Alaska and east to the Rocky. Mountains. It is associated with various moisturc-loving shrubs and small trees.

Economic value. Because of its wide distribution, albundance, moderate size, and palatability, it provides muclı feed of satisfactory quality for livestock and deer. Cattle fecd upon it in all habitats, and sheep and goats utilize it fairly well on the drier sites. Its adaptability to many types of soils and its rapid invasion into disturbed habitats make it an especially valuable plant. Considering its strong recuperative capacity after close cropping, its sprouting qualities after a fire or when cut, and abundant foliage, Nuttall willow is among the choicest of the native willows in California, and perhaps in the cntire West ${ }^{(4)}$. Although it occasionally grows in patches too clense for grazing animals to work their way through, it usually forms scattered stands of low stature.

Browse rating. Good to fair for shcep and goats; fair for cattle and deer; and poor for horses. These ratings take into account the long grazing season provided by this species for domestic livestock and its year-long usefulness for big game.

Distribution of Nuttall willow (Salix scouleriana) and arroyo willow (Salix lasiolepis).

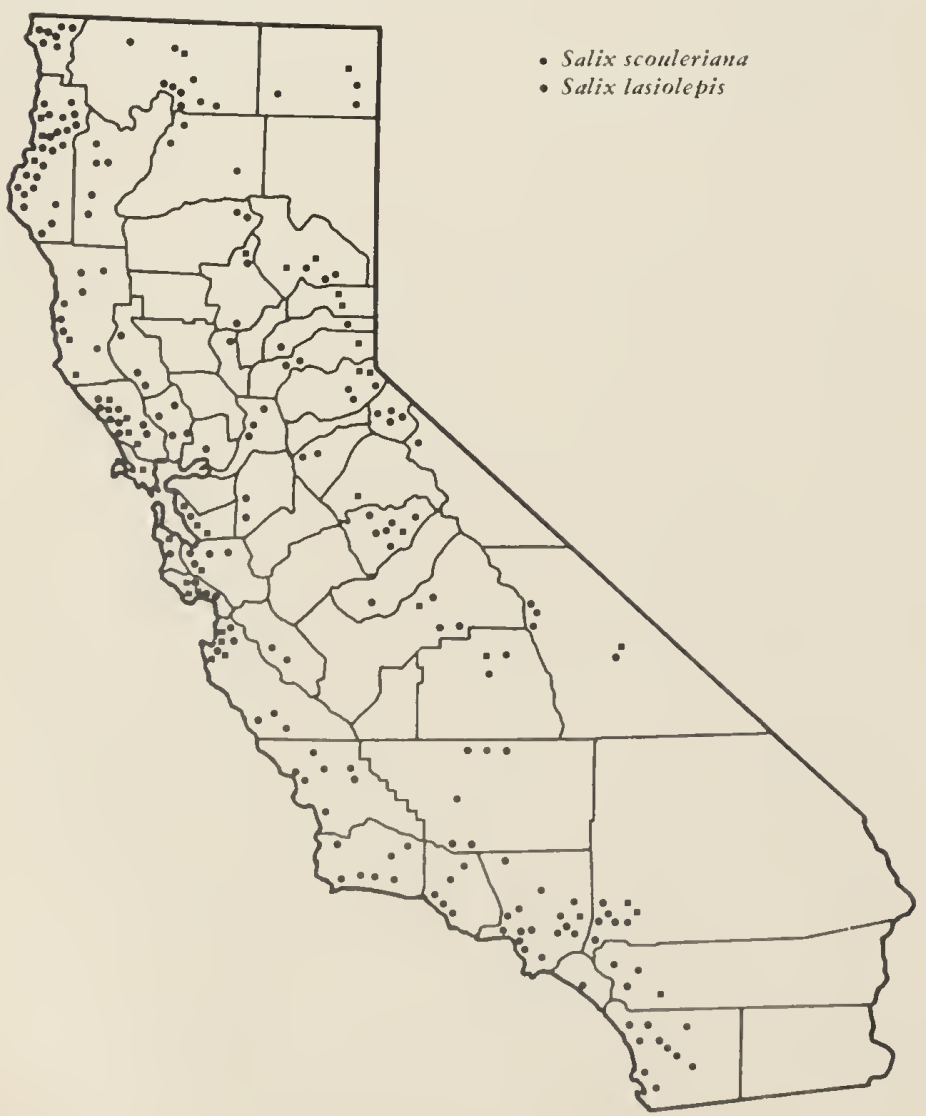

ARROYO WILlow (Salix lasiolepis). Ereet shrub or small tree, 6 to 20 feet high, rarely to 30 fect, with smooth bark and dark brown or ycllowish branchlets. Leaves 2 to 5 inches long, dark green and smooth above, paler and bluish, or hairy beneath, finely toothed or nearly entire. Catkins mostly appearing before the leaves, almost stalkless; male catkins $3_{4}^{\prime \prime}$ inch to $1 \frac{1}{2}$ inches long, the female catkins ${ }^{3}$ inch to $1_{1}^{1}$ inches long; scales dark brown to almost black, densely hairy. Stamen filaments united at base; styles evident. Capsules smooth, or minutely hairy.

Distribution (map on this page). This species occurs throughout California in beds of summer-dry arroyos, along stream banks, and on fairly moist soils in valleys and foothills, from sea level to 5,000 feet elevation. Outside of California it grows north to Washington and east to Idaho and New Mexico.

Economic value. Arroyo willow is browsed avidly by deer, and to some extcnt by sheep, goats, and cattle, in summer and early fall. Cattle will leave the willow patches when the foliage matures and dries, whcreas deer devour the current leafless stem throughout the winter.

Browse rating. Good to fair for sheep and goats; good to poor for cattle; fair for deer; and fair to useless for horses. Its palatability is much the same as the more widely distributed and abundant Nuttall willow.

\section{Other Willow Species}

Other willow species worthy of listing for the browse they contribute are: Brewer willow (S. breweri), Lemmon willow (S. lemmonii), narrowleaf willow (S. exigua), vellow willow (S. lasiandra), and valley willow ( $S$. hindsiana). Their browse ratings are given in the summary table on pagc 148.

\section{ASPENS, POPLARS, COTTONIVOODS (Populus)}

The species in this genus are deciduous trecs or treelike. Winter buds arc resinous and covered with several seales. The long stalked leaves are usually broad in comparison with the narrow-leafed willows.

Probably the best known in this genus is the cultivated Lombardy poplar (P. nigra var. 'Italica'). Rows of these spirelike trees are seen planted on many ranches and farms throughout California. Cottonwoods are sometimes grown to provide posts and rough lumber, mostly in the midwest, and aspen is used for matchwood, exeelsior, and minc props, notably in Utah.

\section{Key to the Browse Species}

1. Leaf stalks romeded; leaves usually longer than broad, dark glossy green above, silvery or minty beneath; capsules fincly hairy ............ BLACK COTTONWOOD

(Populus trichocarpa)

1. Leaf stalks flattened; leaves usually broader than long, yellowish-green, sometimes paler beneath but not silvery or misty, capsules smooth............ 2 
2. Large trees 40 to 100 feet high, usually found at elevations less than 6,500 feet; leaves 2 to 4 inches broad, margins coarsely toothed; capsule $5 / 16$ to $1 / 2$ inch long . . . . . . . . . . . . . FREMONT COTTONWOOD (Populus fremontii)

2. Small slender tree 10 to 60 feet high, usually found at elevations above 5,000 feet; leaves 1 inch to $2 \frac{1}{2}$ inches broad, margins finely toothed to almost entire;

capsules $\frac{118}{8}$ inch long. . . . . . . . . . . . . . ASPEN

(Populus tremuloides)

ASPEN (Populus tremuloides) (drawing on the right), also called quaking aspen. Slender tree 10 to 60 feet high with gracefully pendulous branchlets. Trunk 4 to 12 inches in diameter with greenish white, smooth bark, grav-black on old trunks. Leaves on flattened stalks, round-ovate, 1 to $2 \frac{1}{2}$ inches broad, the tip sharply pointed, margins finely toothed to almost entire; light green, paler beneath. Capsules 1/8 inch long, smooth. Many root and coppice sprouts are produced after the tree is felled.

Distribution (map below, right). Aspen occupies margins of streams, damp but well-drained meadows, or rocky fairly dry, but mostly fertile ground from 5,000 to 10,000 feet elevation. It occurs in the Sierra Nevada, Trinity Mountains, and on Mount San Gorgonio, south to Mexico, eastward to the Rocky Mountains, northward to British Columbia, and eastward to Labrador. It is more widely distributed than any other North American tree. Frequently the stand is sufficiently open to favor a fairly good understory of grasses, forbs, and such palatable shrubs as snowberry and red elderberry.

Economic value. Cattle browse more extensively, and in some instances more closely, upon the foliage and young stems of aspen than on most other western trees. However, the sprouts are far more closely cropped by sheep, goats, and deer which feed upon them in any season, but particularly in autumn. Since aspen typically occupy moist, deep, fertile soils, and the stands are open, there is usually an abundant understory of forbs, grasses, and palatable shrubs that supply much superior feed. Scrubby stands of aspen, such as occur on thin soils, are best utilized for grazing as their yield of wood is small and of inferior grade. Cattle browse aspen limitedly up to 60 or even 70 inches, but usually cause only slight injury to the reproduction except on overgrazed areas ${ }^{(22 t)}$. Sheep often browse young aspen sprouts so closely as to kill them, but sprouts at a height of 45 inches or more escape destruction. Where aspen is clear-cut and it is desired to maintain the stand, it is good practice to graze the area only with cattle for the first three years after cutting, or to exclude grazing entirely for that period. Afterwards the area may again be grazed by sheep as most terminal growth is then beyond their reach.

Goats, being particularly fond of aspen sprouts, should be excluded on recently cut-over areas unless it is desired to destroy the reproduction.

Aspen is also a favorite food for deer and elk during summer and autumn. After the leaves are shed big-game animals often devour the leafless stems rather closely.

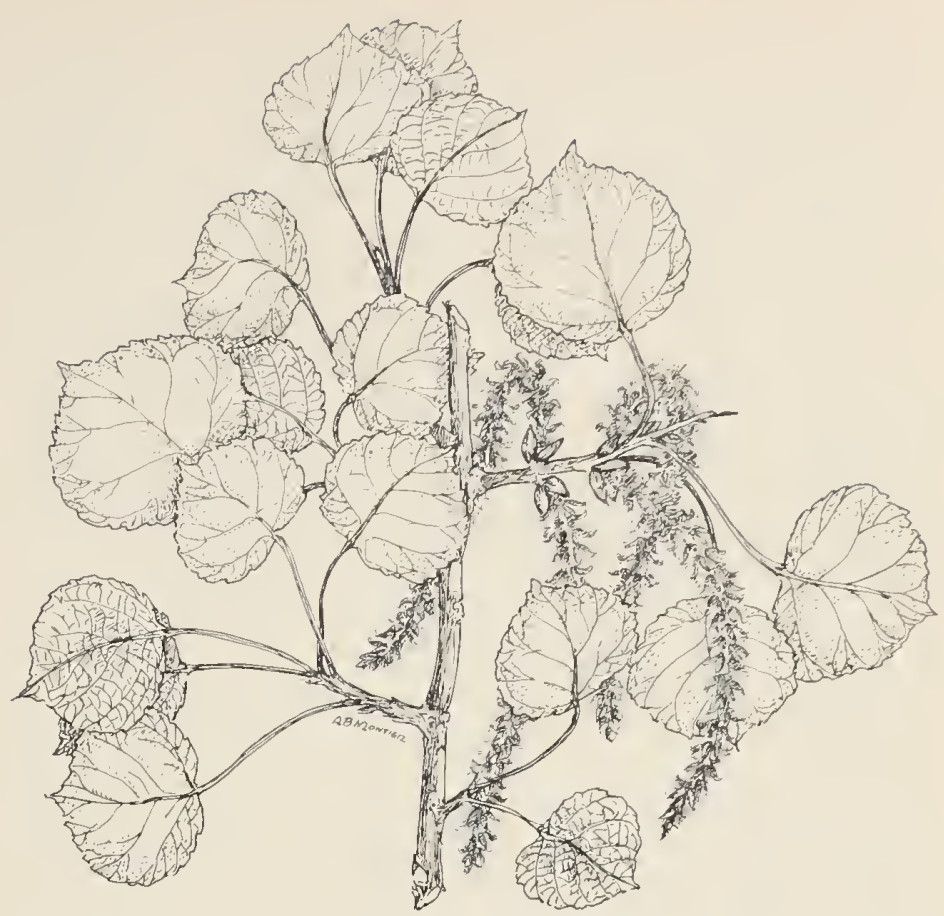

Aspen (Populus tremuloides). All domestic grazing animals, as well as deer, browse upon aspen throughout the summer and fall. The numerous sprouts which appear after clear cutting are cropped closely by sheep, goats, and deer. Even after the leaves have fallen deer often devour the naked stems rather closely.

Browse rating. Excellent for deer; good to fair for sheep and goats; and fair to poor for cattle and horses.

Distribution of Fremont cottonwood (Populus fremontii) and quaking aspen (Populus tremuloides).

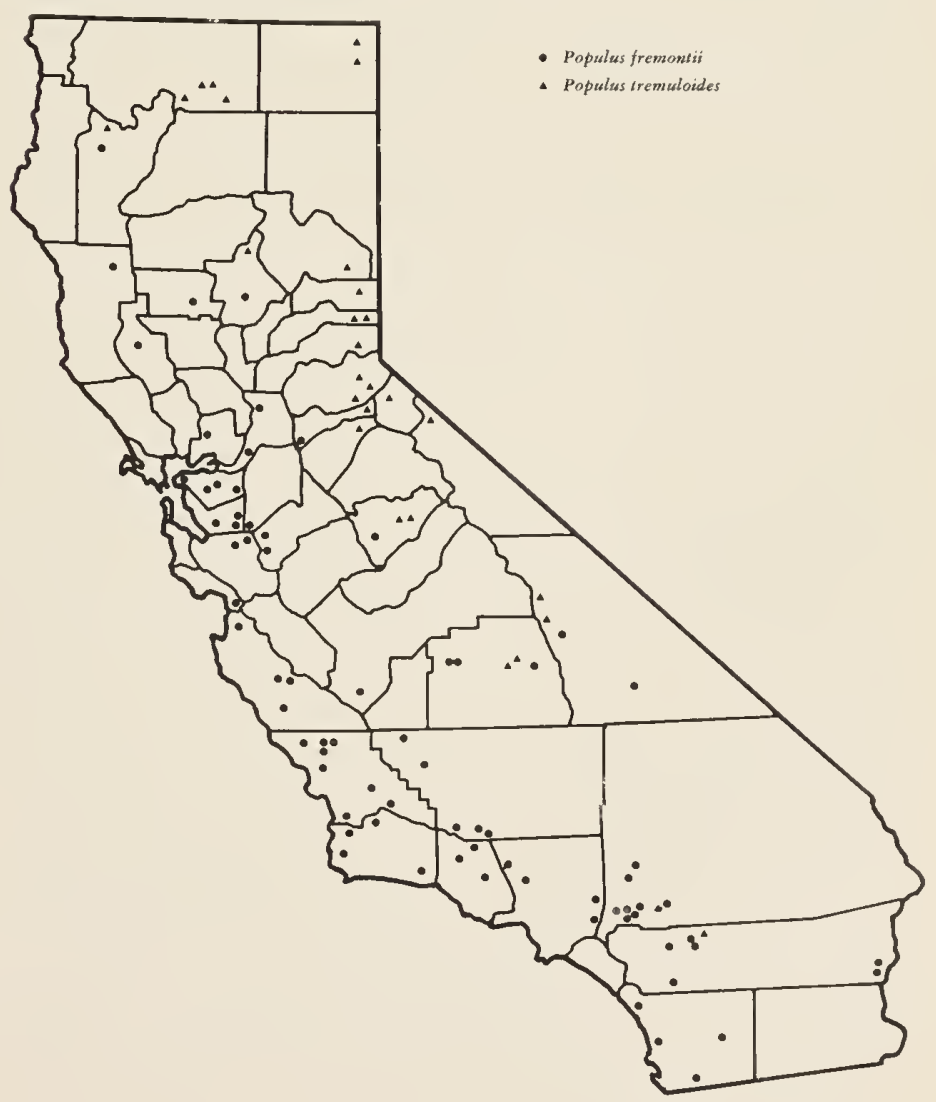


rineNONT (:OTTONWOOD (Populus fremontii) also called common cottonwood. Attractive tree, 40 to 100 feet high, with massive erown. Trumk 1 to 5 feet in diameter with furrowed, whitc or whitish bark. Leaves on flattened stalks, triangular or roundish in outline, 2 to 4 inehes broad, broader than long, the margins eoarsely toothed; bright green, shiny. Capsule ${ }^{5} 16$ to $1 / 2$ ineh long, smooth.

Distribution (map on page 51). Fremont eottonwood occupies vallers and foothills, below 6,500 feet elevation, commonly along living streams; the Great Valley, the Sierra Nevada foothills, the imner north Coast Ranges, south Coast Ranges, and southem California.

Economic value. At periods in the year when the soil is not too wet, the leafage, twigs, and shoots of Fremont eottonwood arc browsed by all domestie grazing animals and deer. The twigs are cropped especially elose by shecp, goats, and deer. However, early in the season when the soil is too $\operatorname{sogg} y$, eattle will utilize the leafage better than the smaller-hoofed animals.

Brouse rating. Good to fair for goats; fair to poor for shcep and deer; poor for cattle; and uselcss for horses.

BlaCk Cotronwood (Populus trichocarpa). Tree 30 to 125 feet high, with a broad erown of upright branehes. Trunk 1 to 3 feet in diameter; bark light or dark in color but commonly with a yellowish east, longitudinally fissurcd. Lcaves on romded stalks, broadly or narrowly

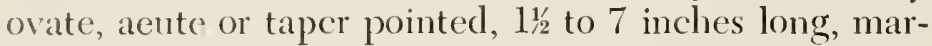
gins finely toothed, dark green above, silvery or rusty beneath. Capsules finely hairy.

Distribution. It oeeurs along living streams and rieh bottomlands in canyons and valleys between 500 and 9,000 feet elevation nearly throughout the State.

Economic value. Utilization of the leafage of blaek cottonwood by grazing animals is similar to that of Fremont cottonwood.

Brouse rating. Good to fair for goats; fair to poor for eattle, sheep, and decr; and poor to uscless for horses.

\section{Birch Family (Betulaceae)}

The birch family ineludes deciduous trees and shrubs. Leaves are alternate, simple, stalked, and the margins are usially toothed. Flowers are bome in eathins, both sexes on the same tree, and appearing before the leaves. Male catkins are isially long and pendulous; the female catkins shorter, upright, or drooping. Frnits are either one seeded winged nutlets in cone-like clusters, or larger and enclosed in an envelope of cularged bracts.

The alders (Almus), lirches (Betula), and California hazelnut (Corylus) are browsed to various extents by domestic livestock and big game, but no nember of this family is ontstanding as a browse plant. Henere this group is not discenssed under the leeadings of "primary" and "secoudiary" food plants.

\section{ALDERS (A/mus)}

Alders are trees or shornlos with scaly bark and fincly to coarsely toothed leates. Mate catkins are drooping

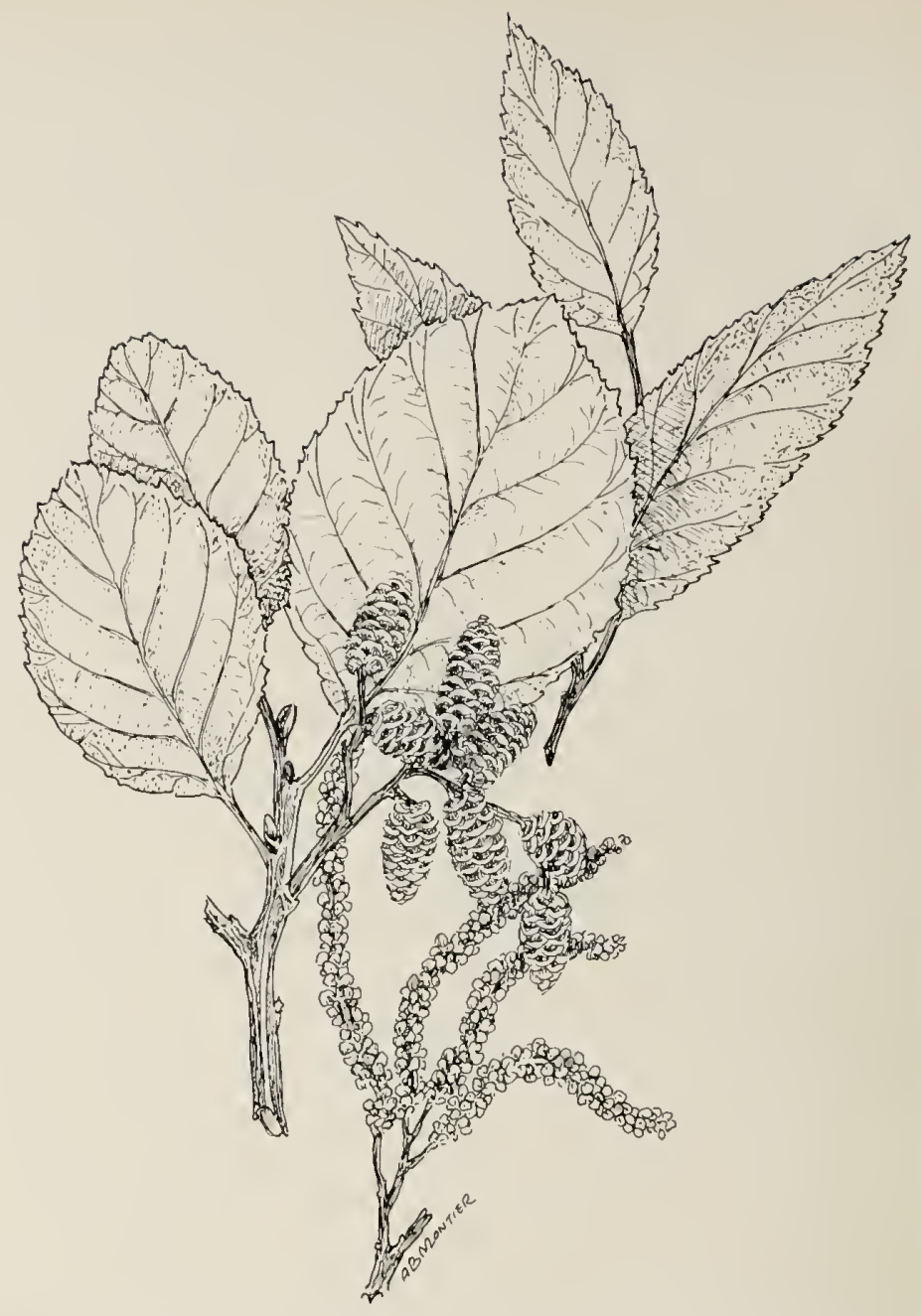

White alder (Almus rhombifolia). Although the leaves, young twigs, and shoots are browsed with moderate relish by livestock and deer, the restricted occurrence of white alder gives it secondary browse rating.

and elustered toward the ends of the branehlets. The scales of the female eatkin beeome woody in fruit and fall from the tree as miniature little eones.

Alders are eharacteristie of moist soils, and along stream banks. The native white alder (Alnus rhombifolia) is being welcomed into western gardens as a rapidly growing shade tree that will thrive under moist eonditions sueh as in a lawn. Beeause of the small size of most western alders they are not used in the limber trade. Various riparian species eompete for spaec with the alders.

\section{Key to the Browse Species}

1. Leaf margins inrolled between the teeth, leaves usually rusty-hairy bencath, at least on the veins; restricted to a narrow coistal strip. . . . . . . . . RED ALUEn

(Aluus oregona)

1. Leaf margins not inrolled between the teeth, leaves not rusty-hairy beneath; not in natrow coastal strip occupied by red alder . . . . . . . . . . . . . WhTE ALDER (Aluus thombifolia)

WhHTE Alonen (Aluus rhombifolia) (drawing shown above). Tree 30 to 115 feet high with whitish or graybrown bark. Leaves oblong-ovate, 2 to 4 inches long: 


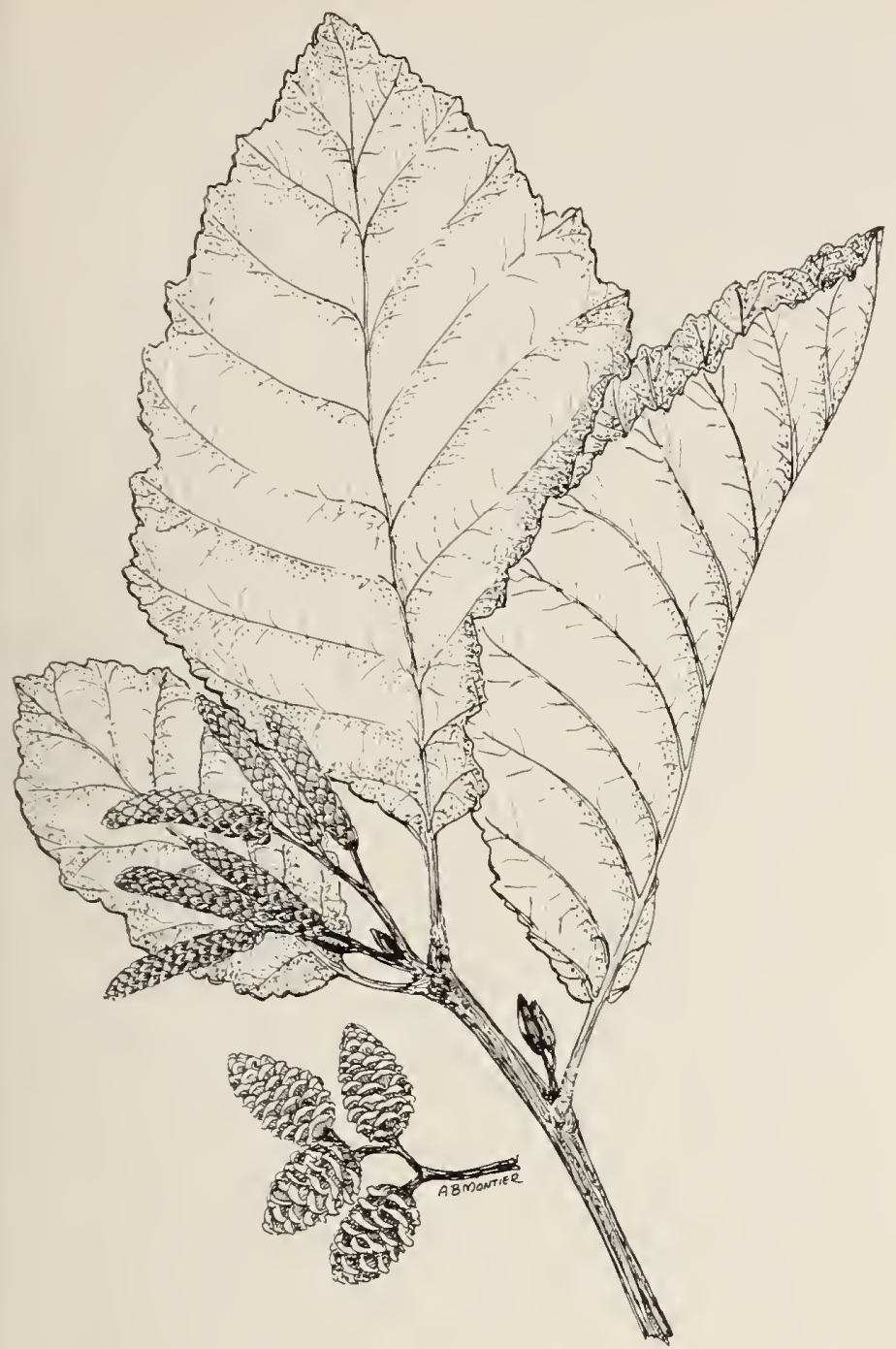

Red alder (Alnus oregona). The foliage and young twigs of red alder are cropped rather closely by cattle, sheep, and deer. Because of its rather restricted distribution, however, it is of secondary browse value

margins coarsely and doubly toothed, not inrolled; dark green above, lighter green beneath; nutlets with narrow margins. White alder propagates mostly by underground rhizomes, suckers, and basal sprouts.

Distribution (map on this page). This species occupies moist but well-drained soils along river banks and living streams, and margins of wet meadows below 5,000 feet elevation. It occurs in coastal southem California, Sierra Nevada canvons, the Great Valley, and the Coast Ranges except in the narrow coastal strip occupied by the red alder.

Economic value. The leaves, younger twigs, and shoots of white alder are browsed with moderate relish by domestic livestock and by deer. Because of its local abumdance in favored sites, it is sometimes a fairly important secondary constituent of the food supply.

Browse rating. Fair to poor for sheep and goats; fair to useless for deer; poor to useless for cattle; and useless for horses. On wet soils cattle tend to feed longer and utilize more of the leafage of white alder than other animals.

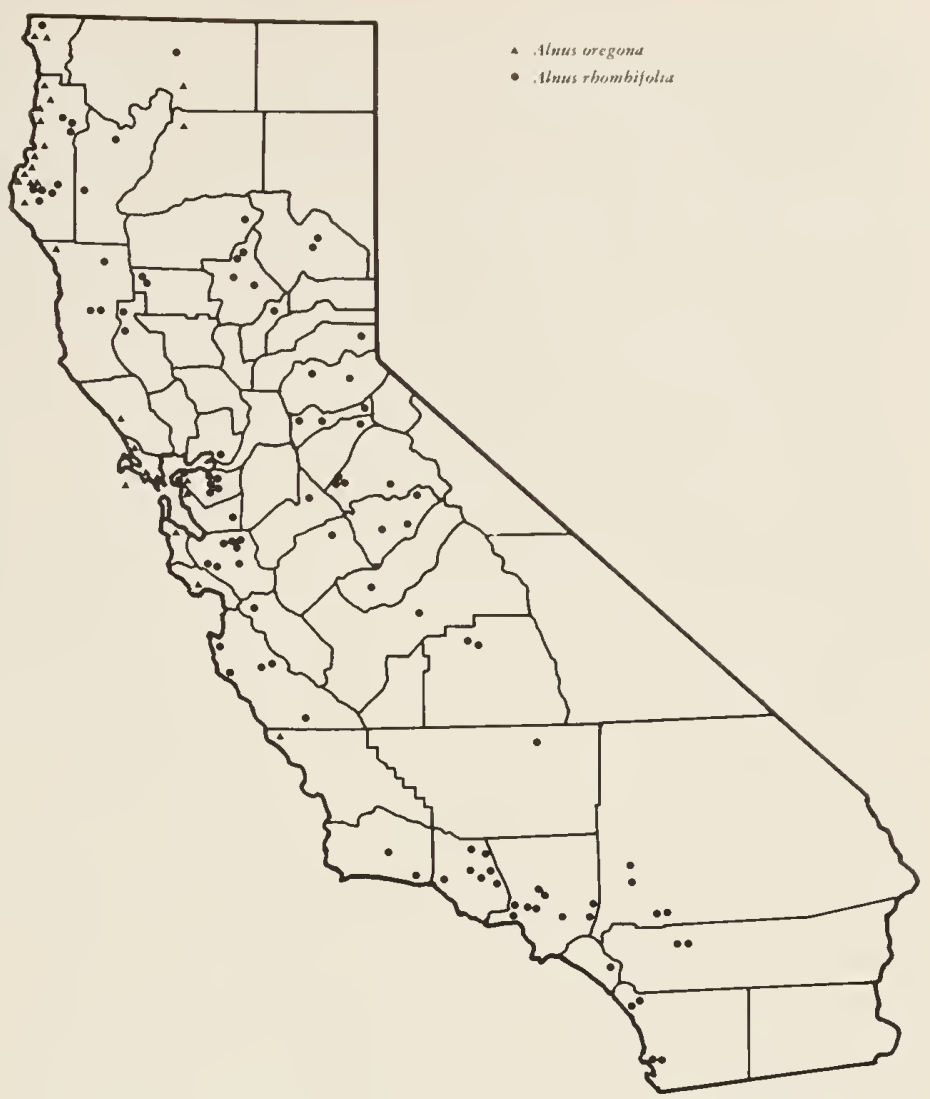

Distribution of red alder (Alnus oregona) and white alder (Alnus rhombifolia).

RED ALDER (Almus oregona) (drawing above), also callcd Oregon aldcr. Tree 30 to 90 feet high with very white or white-mottled bark. Lcaves 2 to 6 inches, broadly elliptic-ovate, margins bluntly or coarsely toothed, then finely glandular toothed, inrolled; dark green above, rusty hairy beneath. Nutlets narrowly winged.

Distribution (map above). This species occupies deep cool canyons or moist flats along the coast below 50 ? feet elevation. It occurs from the Santa Incz Mountains in Santa Barbara County, north to Del Norte County, thence northward into Alaska. From Marin to Humboldt counties it often forms groves of singular beauty.

Economic value. In many localitics the leaves and young twigs of red alder are sought by cattle, sheep, and deer in preference to other fairly good browse.

Browse rating. Fair to poor for cattle, sheep, and goats; fair to useless for deer; and useless for horses.

\section{B I RCHES (Betula)}

Birches are trces or shrub-like with smooth aromatic bark with long lenticels. The bark often separates in papery sheets. The elongate male catkins are borne singly or clustered. The scales of the female catkins are papery and deciduous with the nutlcts.

Actually birches are not as widely distributed natively in California as in other parts of the United States and Canada. Probably the one most commonly secn in Cahifornia is the cultivated European white birch (B. pen- 
dulat, and its weeping form, that is usually planted in gardens in groups of three on a lawn, or in multiplestemmed clumps. Elsewhere, as in the northeastern Lnited States and Canada, the pulp of ccrtain birches is valuable in the manufacture of paper, and they were highly prized by the Indians for making their birch bark canoes. Ther grow in association with various moistureloving plants.

\section{Key to the Browse Species}

1. Small shrub 1 foot to 6 feet high; leaves usually less than 1 ineh long, margins simply and regularly toothed with rounded teeth; wings mueh narrower than the nutlet

(Betula glandulosa)

1. Tall shrub or small tree 10 to 25 feet high; leaves usually more than 1 ineh long, margins irregularly toothed with sharp teeth; wings usually broader than

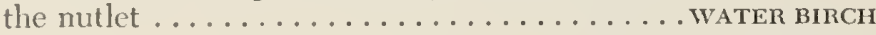
(Betula occidentalis)

WATER BiRCn (Betula occidentalis) (drawing shown below), also called red birch and mountain birch. Tall shrub or small trec, 10 to 25 fcet high, usually with many basal stems. Bark gray or dark bronze and shining. Twigs rough with big resinous glands. Leaves thin, broadly orate, ${ }_{4}^{3}$ to 2 inches long, $1 / 2$ ineh to $1 \frac{11}{4}$ inches wide, margins sharply and irrcgularly toothed except near the base, gland dotted when young. Nutlets broadly winged.

Distribution (map on this page). This species grows along canyon strcams and in moist flats between 2,000 and 8,000 feet elevation. It oeeurs in the Sierra Nevada

Water birch (Betula occidentalis). The foliage and twigs of water birch are cropped moderately to closely by all browsing animals. It is somewhat more palatable than the alders (Alnus spp.).

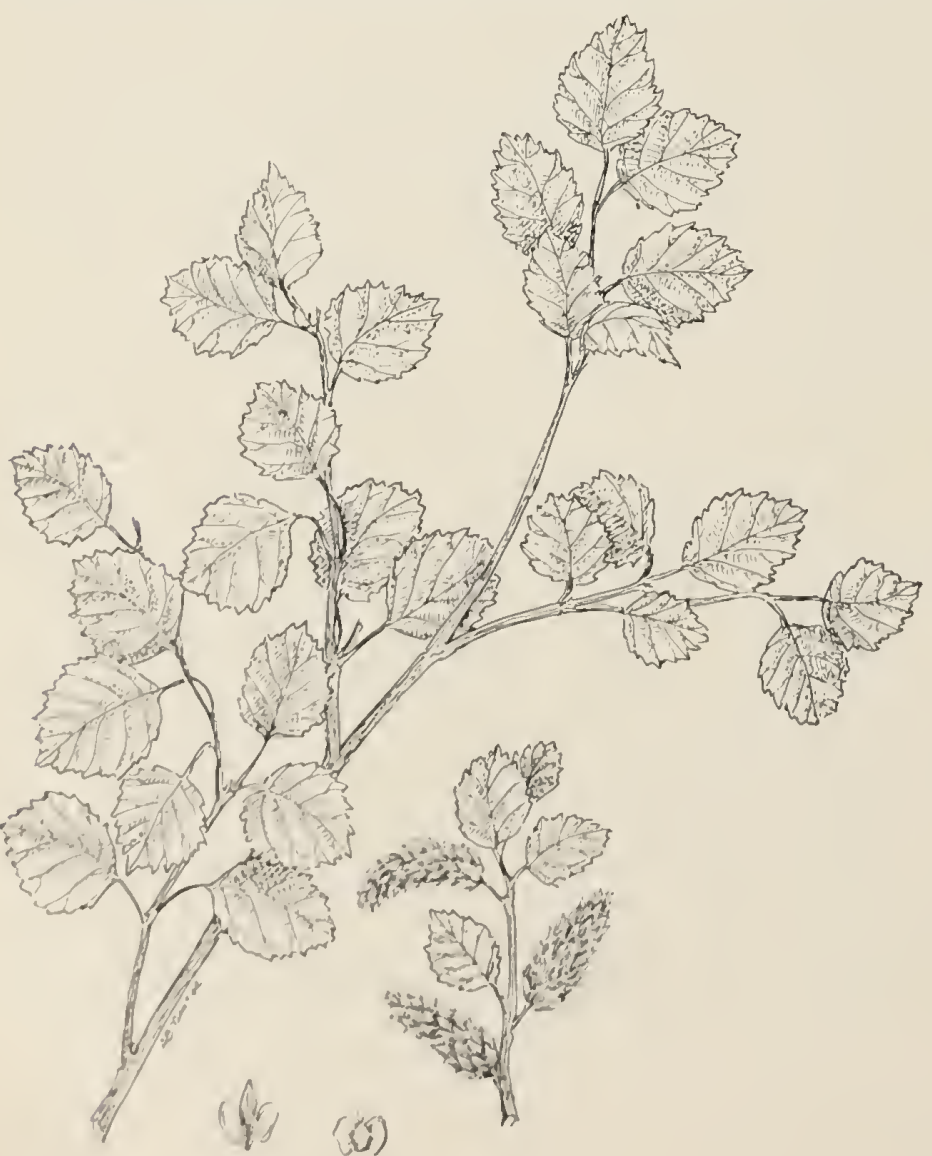

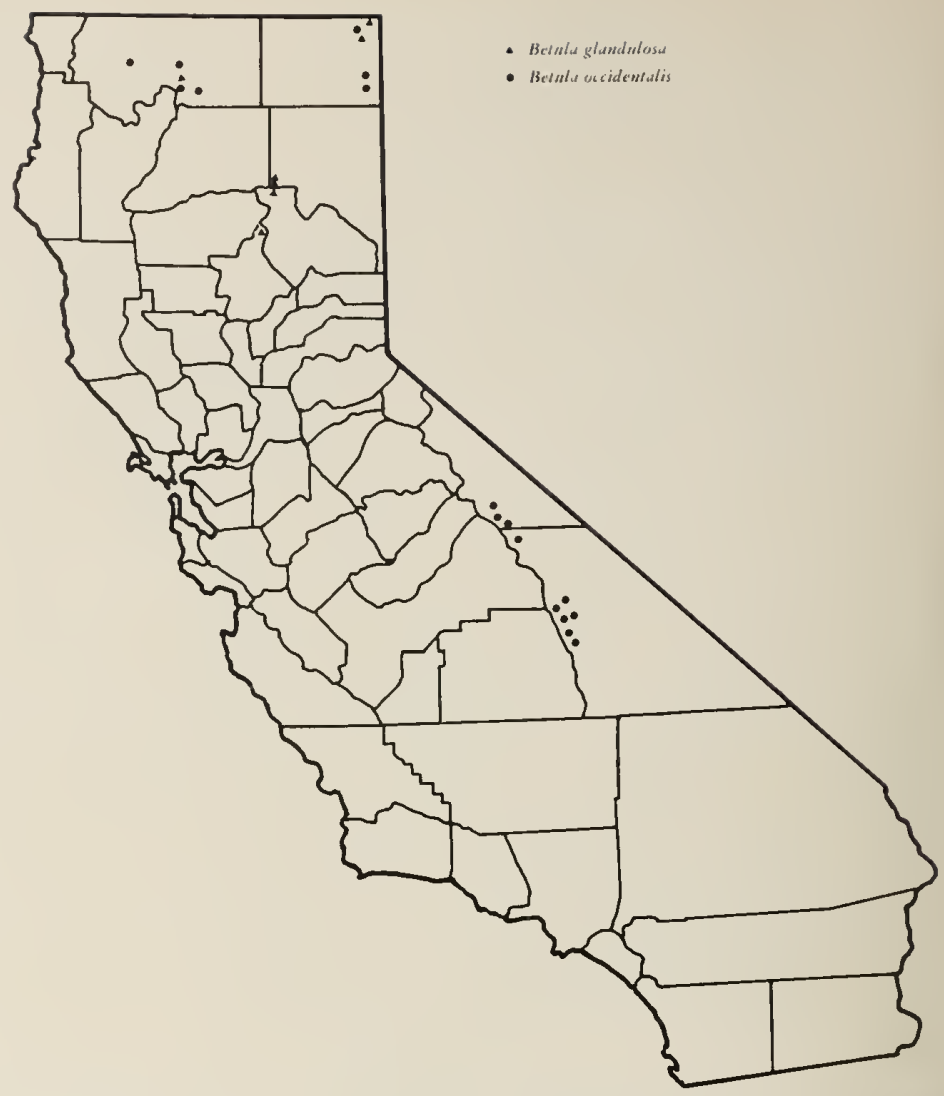

Distribution of resin birch (Betula glandulosa) and water birch (Betula oecidentalis).

from Tulare and Inyo counties to Fresno and Kings counties, northward to Butte and Modoc counties, and westward to Siskiyou and Iumboldt eounties. It extends eastward to the Rocky Mountains and northward to British Columbia.

Economic value. Water bireh is a fairly important browse species on some ranges. The leafage and twigs are eropped with moderate to good relish by all browsing animals, but it is sometimes inaeeessible because of the wet sites that it occupies. It is somewhat more palatable than the aldcrs, possibly beeause the sap is blander and the lcaves thinner and more delicatc.

Browse rating. Good to fair for deer; fair for goats; fair to poor for eattle and shecp; and poor to useles for horses.

RESIN BIRCu (Betula glandulosa), also called mountain bireh, is a shrub 1 to 6 fect high with smooth dark bark and glandular warty branchlets. Leaves thiek, broadly ovate or roundish, usually less than 1 ineh long, ${ }_{8}^{3}$ to I ineh wide, margins with rounded tecth. Nutlets obscurcly winged.

Distribution (map on this page). This is an exceedingly common species in the high momtains in its somewhat restrieted range in northern California, from 6,500 to 7,500 feet elevation. It oceurs in the IVarner Mountains, Modoe County; from near Lassen Peak and Big Mcadows, Plumas County; and in Buttc County. It extends northward to Oregon, Washington, and Alaska, castward to the Rocky Mountains, the Great Lakes region, and the New England states. 
Economic value. Resin birch is usually browsed more closely than red birch (B. occidentalis) but because of its narrower distribution and occupation of somewhat more boggy areas, it is of essentially the same value as the latter (see table on page 146).

Browse rating. Fair for deer; fair to poor for sheep and goats; poor for cattle; and useless for horses.

\section{HAZELNUTS, FILBERTS (Corylus)}

This genus is probably best known for the decorative small trees that produce the commercial filbert nut. There are several horticultural varieties cultivated in Europe and northwest United States. In the latter area it grows to perfection in the Portland-Willamette Valley area of Oregon, and will do well in the foothills of northem California. This genus also provides several species and varieties that are grown in gardens for their fallcolor display. Since the California hazelnut is the sole representative of the genus in this area, the description of the genus characteristics are included with the description of the California hazelnut below.

CALIFORNIA HAZELNUT (Corylus cornuta var. californica). Spreading shrub, 5 to 12 feet high, with smooth bark. Leaves thimnish, rounded to obovate, $1 \frac{1 / 2}{2}$ to 3 inches long, ${ }^{3} / 4$ inch to $2 \frac{1}{2}$ inches wide, margins doubly toothed; pale beneath, soft hairy, somewhat glandular, becoming smooth in age. Male catkins single or clustered, long and pendulous. Female catkins solitary and produced from small, rounded, scaly buds; stigmas bright red. Fruit a roundish smooth nut, $3 / 8$ to 58 inch long, with very hard shell; enclosed in a leafy envelope made up of 2 enlarged, bristly hairy bracts that are united and project beyond the nut like a beak, or fringed tube.

Distribution (map on the right). California hazelnut inhabits moist wooded canyons, slopes, and banks below 7,000 feet elevation, and is associated with many plant communities, including grasses and forbs. It occurs in the Coast Ranges from Santa Cruz County, northward along the coast to Del Norte County, eastward through Siskiyou County, and south in the Sierra Nevada to Tulare County. It extends northward and eastward outside of California.

Economic value. In some localities California hazelnut is extensively browsed by all kinds of grazing animals, in others it is scarcely nibbled, depending on the relative palatability and abundance of associated browse and other species within a given area. The numerous young shoots that spring up after a fire are usually cropped closely. In general, it rates low in palatability.

Browse rating. Fair to poor for goats and deer; poor for sheep; and poor to useless for cattle and horses.

\section{OAK OR BeEch Family (FAgaceae)}

This family includes both evergreen and deciduous trees or shrubs. The leaves are altemate, stalked, and may be simple or variously lobed. Male and female flowers are borne on the same tree. The male flowers are

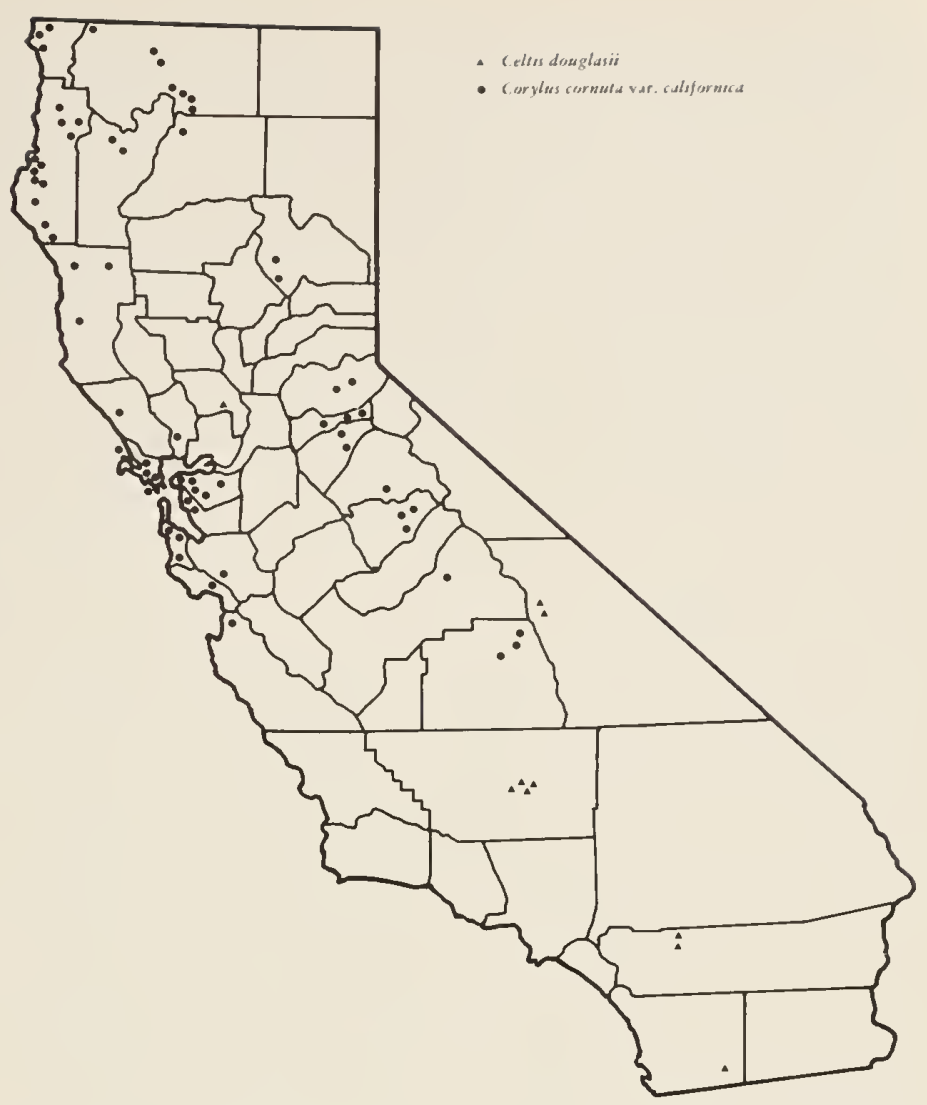

Distribution of western hackberry (Celtis douglasii) and California hazelnut (Corylus cornuta var. californica).

in catkins or head-like clusters. The female flowers are usually bome 1 to 2 in a cup-like involucre. This involncre eventually forms a hardened cup partially enclosing the 1-seeded nut (the acom of oaks and tanbark oak) or wholly enclosing the nut (the bur of the chinquapin).

Of the three genera native to California-oaks (Quercus), tanbark oak (Lithocarpus), and chinquapin (Castanopsis)-the true oaks, are by far the most important as browse plants and for watershed cover.

\section{OAKS (Quercus)}

Oaks are deciduous or evergreen shrubs or trees, usually with interesting branch pattern, and fairly slender twigs. Male catkins are slender, usually drooping or spreading, one or more borne in the lower axils of the current season's growth, the bracts deciduous. Female flowers single in involucres that have many small bracts, borne in the upper leaf axils. Fruit an acorn set in a cup.

Oaks are generally classified into two broad groups: 1) White oaks-commonly deciduous, with typically light colored bark, smooth, usually prickleless leaves that are often lobed; acoms maturing the first vear. 2 ) Red (or black) oaks-usually with more persistent or evergreen leaves and usually dark-colored bark. Veins of leaves often extend beyond the margin in prickle-like awns or teeth; acoms maturing the second year.

In the eastern states, oaks are used extensively for the manufacture of furniture and many other such uses, the wood being hard and strong. In California, the oaks are presently of little importance as lumber, but their use- 
fulness for such purposes is being developed. They are mainly used for cordwood, fence posts, and mine props. The acorns were of great value to the Indians as food.

Oaks in California are considered highly desirable in landscaping for their picturesque branching habit and wide spreading shade. As new housing developments morc into oak-grassland areas, efforts are usually made to save the existing oaks.

IIost California oaks are of value as browse; many are highly useful in checking soil erosion; and the larger trees provicle needed shade for livestock and cover for deer. The trce forms of oaks are usually spaced far enough apart to favor an understory of grasses, forbs, brush, and low-growing trees, whereas the shrubby species often form a dense cover.

Mast (acorns) of the oaks is an important source of food for many weeks in the autumn for domestic animals, inchuding hogs and turkers, and for such game animals as deer, bear, and several smaller mammals, well into the winter $^{(4)}$ The mature acorns arc essentially a fattening diet as they are conspicuously low in crude protein and high in fats and carbohydratcs. In the mature hulled (shclled) acoms of blue oak, for example, the crude protcin averaged less than 5 per cent, whereas the shells of the acorns averaged less than 3 per cent protein. The fat contcnt was high ${ }^{(0)}$.

So-called "acorn calves," assumed by many stockmen to result from the cows eating too many acorns during gestation, have becn commonly reported in the oak belt of the Sicrra Nevada foothills. The most common types of deformity are seen in the head which may be short, usually with undershot jaw, or it may be long and narrow. Also the typically long bones of the legs are usually conspicuously short. Other common abnormalities include lack of coordination, inability to stand alone, and arched back.

The presumed causc of this disease is not supported by investigation, but if acorns constitute most of the diet they may prevent the formation or utilization of some essential nutrients in the dict and thus aid in producing deformed calves ${ }^{(8)}$. Abnormal calves, however, may occur on virtually any range whcre the nutrition of the forage is poor. Acorns from different species have shown divergence in chemical composition but all are low in protein and minerals; if the ration is othcrwisc complete, they have considerable food value. Evidently, thereforc, a large crop of acoms should be regarded as fecd of good value if supplemented with aderiuate protein concentrate, such as cottonsecd cakc.

Chemical analyses of the foliage of several western species of oaks inclicate that these plants do not, in themselves, provide a well-balanced ration, and that an adequate supply of other forages should be available. On overgrated oak range, where the animals must subsist largely on oak for several weeks in the spring, sickness or even death has often resulted, evidently in part because of the high content of the astringent tamnic acid ${ }^{\text {sat. }}$

Sucl losses are usually preventalble through rational range managentent practices.
The young early-scason growth of leafage, twigs, and sprouts of oaks are the most palatable to sheep, goats, and deer. Since deer subsist yearlong on native vegetation, the evergreen oak species probably supply greater bulk than do the deciduous ones. In many localities deer feed more or less throughout the year on leafage, twigs, and acorns of oaks ${ }^{48,49}$. All California oak species sprout when cut or burned off ${ }^{(8)}$. In some localities oak sprouts may provide much feed for three years or so. Where it is desired to convert oak land to grass, close cropping for three to five years in succession by sheep or goats usually results in thinning out the oak, especially if the taller shoots that grow out of reach of the animals are cut back.

\section{Key to the Browse Species and Varieties}

1. Leaves generally lobed; deciduous species.......... 2

1. Leaves variously toothed to entire, not lobed, or if lobed, only slightly so and with short spiny teeth; evergreen species ..................

2. Leaf lobes ending in 1 to 3 or more coarse spine-

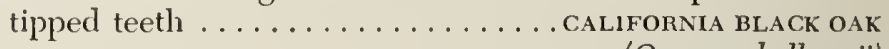
(Quercus kelloggii)

2. Leaf lobes without spine-tipped teeth........... 3

3. Branchlets drooping; acorn cups deep and thickly warty; acorn long and slender........ VALLEY WHITE OAK

(Quercus lobata)

3. Branchlets not drooping; acorn cups shallow, scales finely warty or flattish; acom short and fat......... 4

4. Leaves generally 1 inch to 3 inches long, shallowly lobed, bluntly toothed, or sometimes entire, bluegreen above, pale beneath, minutely hairy....... BLUE OAK

(Quercus douglasii)

4. Leaves generally 3 to 4 , or 6 inches long, deeply 5 to 7 or 9 -lobed, dark shiny green above, nearly smooth, rusty or whitish beneath with fine hairs. . OREGON IVHITE OAK

(Quercus garryana)

5. Leaves green above, lead color beneath, sometimes with a fine golden-yellow dust or finely hairy; acorn cup either with a thick golden fuzz which often obscures the scales, or scales covered with fine whitish

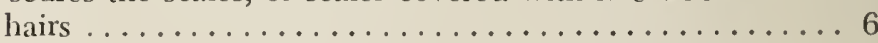

5. Leaves green on both surfaces, not hairy or with a fine golden-yellow dust beneath; acom cup not hairy or

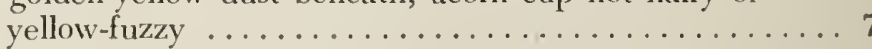

6. Large tree; lcaves toothed or entire, sometimes with fine golden-yellow dust beneath; acorn cup usually with a thick golden fuzz which often obscures the scales, acom 1 inch to $1 \frac{11}{4}$ inches long...... CANYON LIVE OAK

(Quercus chiysolepis)

6. Low, often prostrate slrub; leaves typically cntirc, fincly hairy bencath; acorn cup with fine whitish hairs covering the scales, acom about $\frac{1}{2}$ inch long

HUCKLEHERHY OAK (Qucrcus vaccinifolia)

7. Tree or shrubs with dark or black bark; lcaves gencrally over 1 inch long; acorn cup decp, scales flat and thin, acom somewhat clongate.............. $s$ 


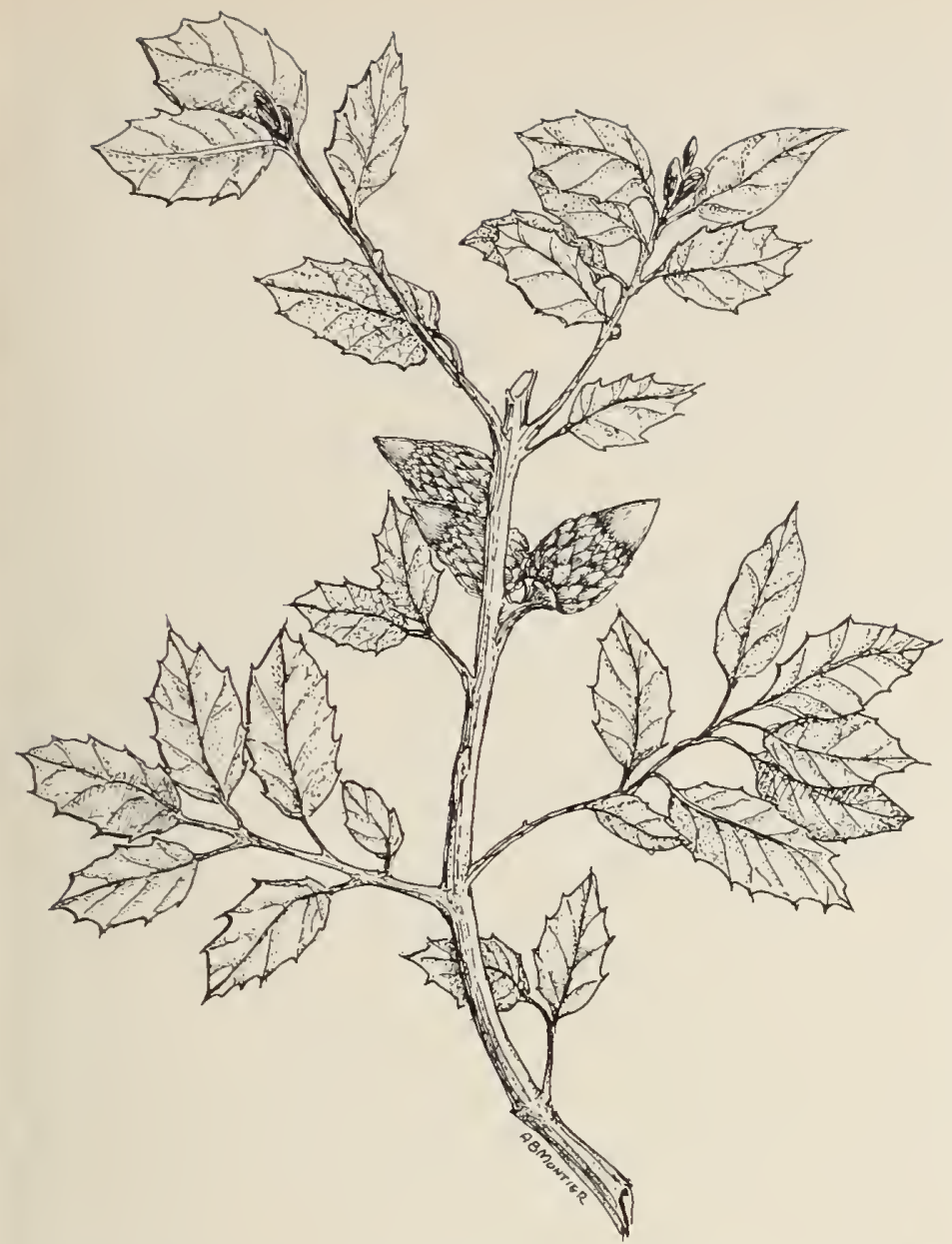

Scrub interior live oak (Quercus wislizenii var. frutescens). Important browse plant for deer at all seasons. Of little value for livestock except for the acorns which are highly palatable to all foraging animals.

7. Low shrubs with white or whitish bark; leaves generally less than 1 inch long; acorn cup saucer-like, scales warty, acorn shorter and thicker...... CALIFORNIA SCRUB OAK (Quercus dumosa)

8. Tree; leaves typically roundish, usually convex, pale green beneath and usually with small tufts of hair in the axils of the main veins; acorns maturing the first

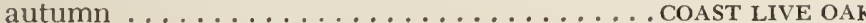

(Quercus agrifolia)

8. Shrub; leaves typically oblong, usually flat, bright yellow-green beneath and without tufts of hair in the vein axils; acorns maturing the second autumn

SCRUB INTERIOR LIVE OAK (Quercus wislizenii var. frutescens)

\section{Primary Oak Species}

The oak species of primary browse importance are difficult to select because grazing animals in different situations vary in their choice. The following species or varieties, however, seem to typify rather well the more palatable oaks over the range as a whole: Scrub interior live oak, California scrub oak, blue oak, and California black oak. Examples of species of secondary rank are: Oregon white oak, canyon live oak, and huckleberry oak.

SCRUB INTERIOR LIVE OAK (Quercus wislizenii var. frutescens) (drawing shown above). Evergreen shrubs 3 to 8 (up to 15) feet high, with stout stiff branches. Leaves ovate or oblong, $3 / 3$ inch to 2 inches long, $\frac{1}{2}$ to 1 inch wide, stiff, brittle, margins entire or irregularly to regularly spiny toothed; dark green, smooth and shiny above, ycllow-green and smooth below. Acom oblongovate, sharply pointed, ${ }^{3}$ inch to $1_{14}^{1 / 4}$ inches long, maturing the second year; cup with thin, brown hairy, ciliate scales.

Distribution (map shown below). This shrub form of the species occupies the dry chaparral regions of the inner Coast Ranges to Shasta County, the mountains of southern California, and sparingly in the foothills of the Sierra Nevada.

Economic value. Scrub interior live oak is of considerable importance as browse in many localities because of its abundance. The acorns are highly palatable, and the numerous sprouts that appear after a fire provide a large amount of feed which, when young, is cropped fairly well. Full-capacity grazing by goats for three to five years after a fire results in killing a large proportion of the plants, especially if the taller shoots are cut back in the third or fourth year to further facilitate browsing.

Study of the monthly crude protein levels in leaves and twigs of scrub interior live oak from samples collected on deer range in northern California, showed it to be "a plant of steady, although somewhat low protein content" ${ }^{\prime \prime 11}$. The highest protein levels-averaging about 17.5 per cent-were recorded in April and May. During June, July, and August the average was about 10.5 per cent, and from September to March about 8 per cent.

Distribution of scrub interior live oak (Quercus wislizenii var. frutescens).

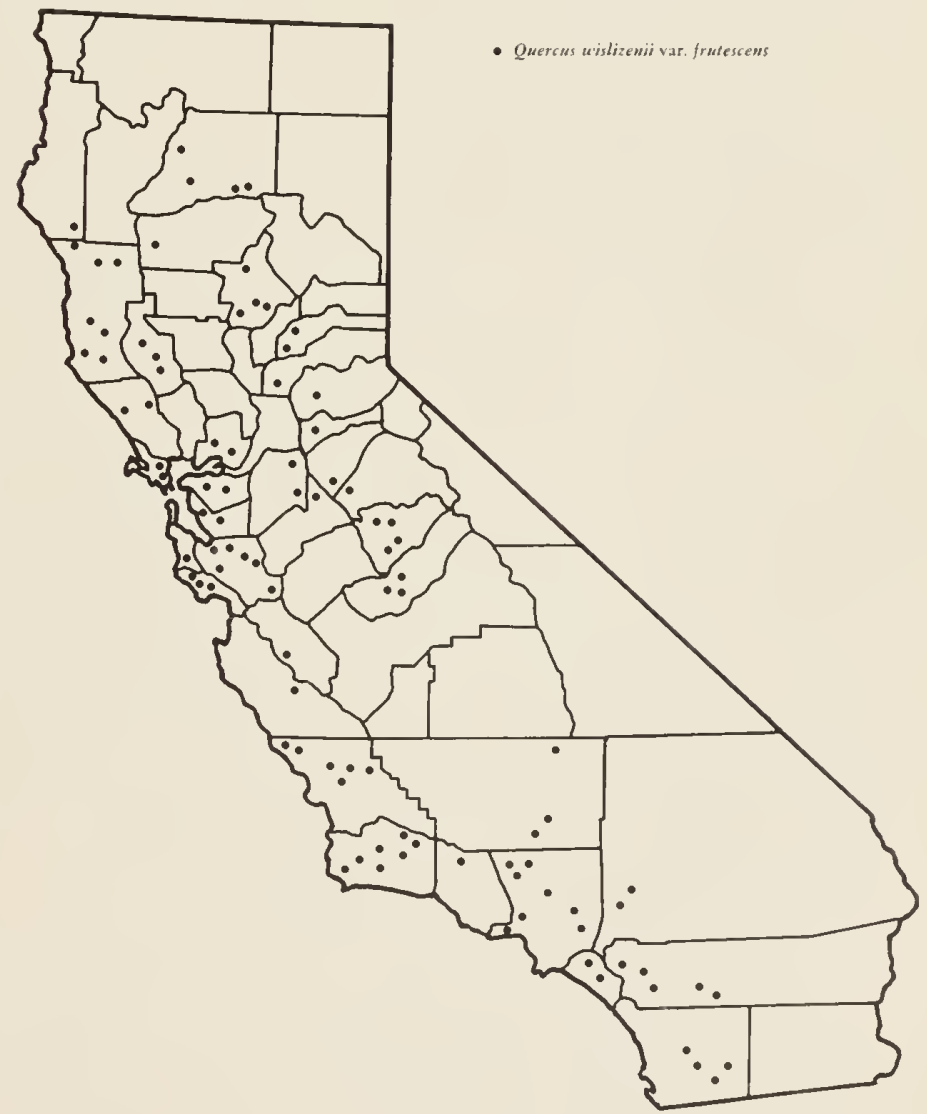


In a comparative study of digestibility of the new growtl of scrul) interior live oak and chamise with alfalfa hav, deer and sheep digested the protein of alfalfa hay distinctly better than that of either of the two native shrubs ${ }^{129}$. The percentage of total digestible nutrients $\left(T D N^{\top}\right)$ was high in alfalfa and measurably poorer in scrub interior live oak. The latter appeared to be of little or no valuc as a source of crude protein, but was a fair source of TDN. At the Hopland Field Station in southcastcm Mendocino County, where the digestion trials wcre made, scrub interior live oak and chamise are among the most important browse species for deer at all seasons of the vear. Hcaviest usc of this oak by deer, as well as by cattle and shecp, is in the late spring and summer months

Brouse rating. Excellent to good for decr; fair to poor for goats; fair to useless for shcep; poor for cattle; and uscless for horses. The sprouts up to two years old are taken by deer the year around.

California scrub oak (Quercus dumosa). An abundant species of the chaparral which supplies good browse for deer and is cropped to a limited extent by livestock. The acorns are highly relished by all foraging animals.

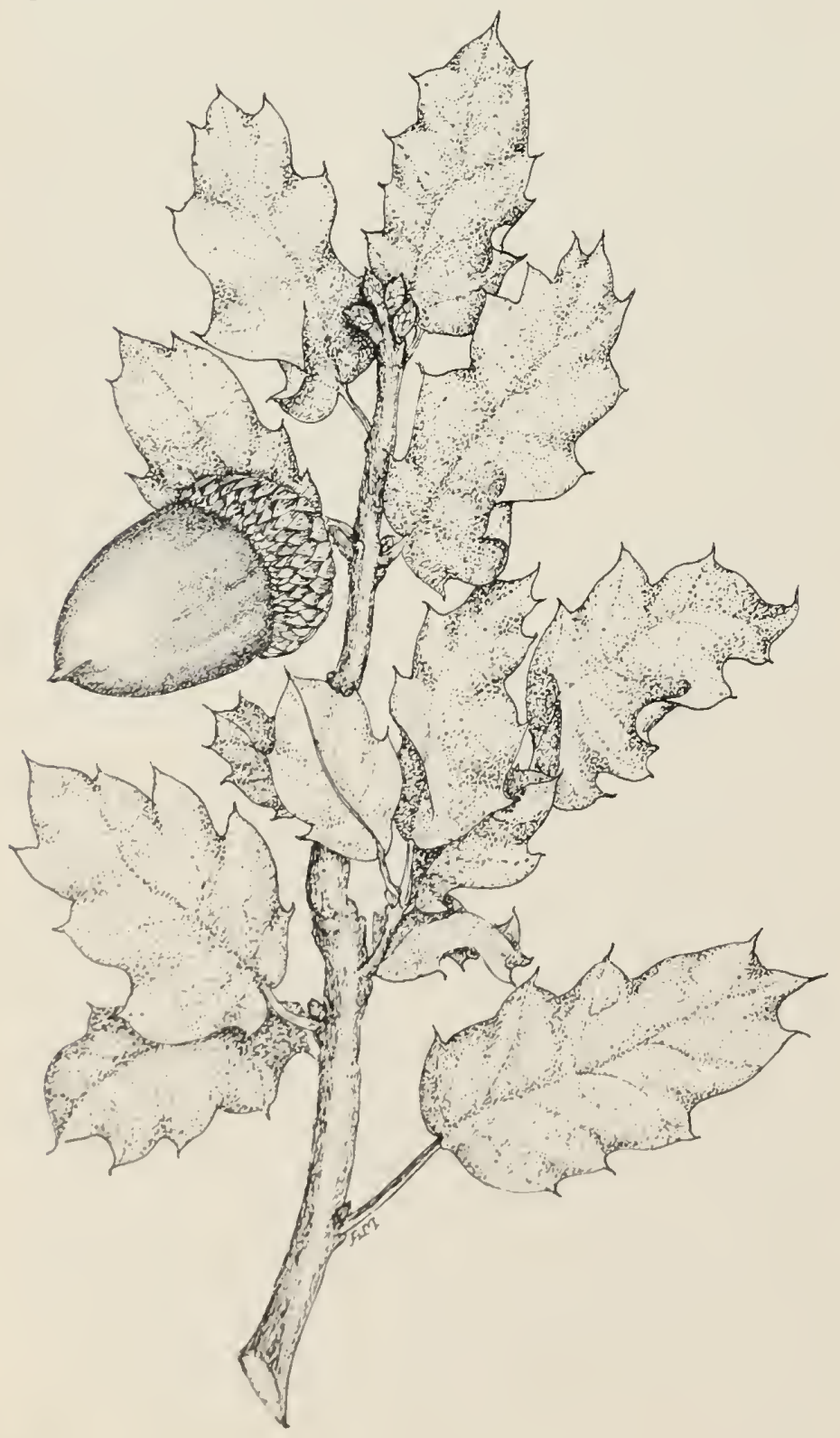

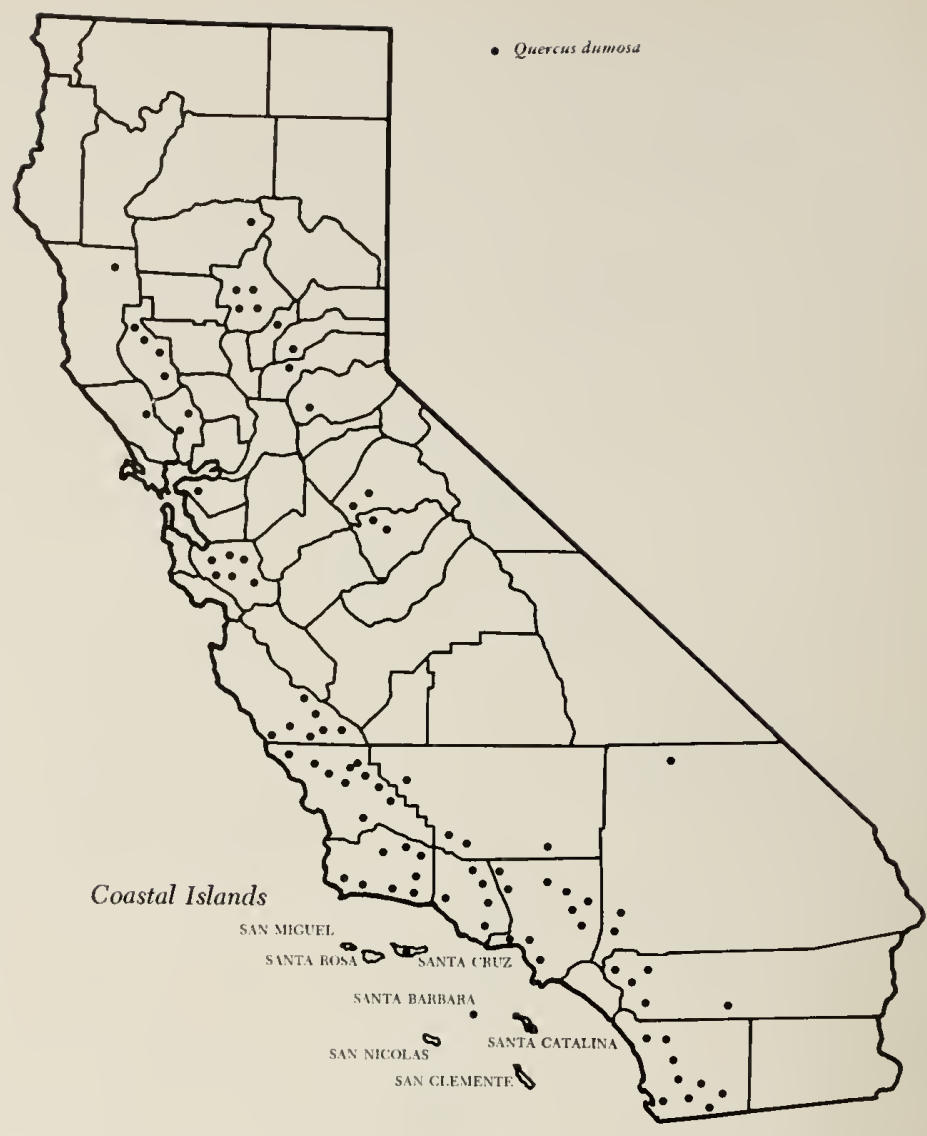

Distribution of California scrub oak (Quercus dumosa).

CALIFORNIA SCRUB OAK (Quercus dumosa) (drawing on the left) is an evergrecn shrub 2 to 6 feet high, or sometimes a small tree up to 30 feet high, with stout, rigid branches. Bark white or whitish. Leaves variable but typically roundish to oblong, $\frac{1}{2}$ inch to 1 inch long, $\frac{1 / 4}{4}$ to ${ }_{4}^{3 / 4}$ inch wide, leathery, margins spiny toothed to entire; green and shiny above, pale and hairy beneath. Acorns usually in clusters of 2 to 3 , maturing the first autumn, ovoid, rounded, or pointed at apex, $1 / 2$ to 1 inch long; cup with warty scales.

Distribution (map shown above). California scrub oak occupies dry, rocky or gravelly slopes of the chaparralcovcred slopes mostly below 5,000 fcet elevation. It occurs in southern California, extending northward in the Coast Ranges where it generally occurs on northwest slopes. It also occurs on the western middle slopes of the Sicrra Nevada to Tchama County, and is an important constituent of the chaparral association over most of its rangc.

Economic value. California scrub oak is valuable as protection against soil crosion. Becanse of its abundance on chaparal slopes and dry foothills, and its typically low halsit of growth, it is also of some importance to sheep and goats, and of good to high importance to (leer on many ranges. According to Mackie ${ }^{(05)}$, who analyzed the leaves of six species of California oaks, California scrul) oak contained the higliest content of tammin which, incidentally, induces constipation if excessive in the diet.

The cricle protein levels of the young sprouts were 


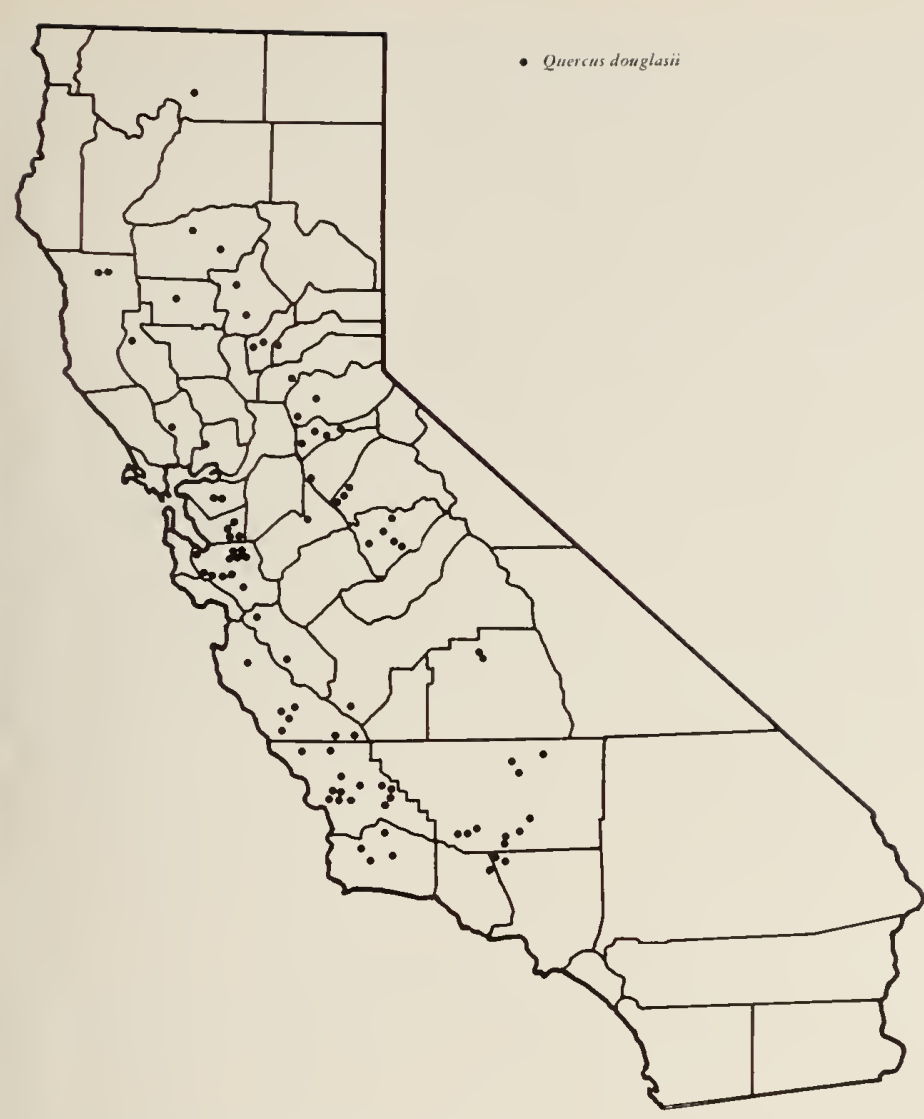

Distribution of blue oak (Quercus douglasii).

relatively high for oak speeies, ranging from 16 to 23 per cent from May to June, but deelined to an average of about 8 per eent from July to September, inelusive, when the foliage was fully developed ${ }^{(11)}$. On the Tehama County winter deer range, these animals fed lightly on California serub oak from Oetober to Deeember, inelusive, but from January to May it eomposed from 29.4 to 49.4 per eent of the volume of food eonsumed. This high preferenee ineluded the greater part of the season when the protein eontent was highest ${ }^{(8)}$.

Dixon $^{(10)}$ appraised California serub oak as follows: "This is another important deer food plant in winter. Aeorns are usually a heavy crop on California serub oak and these together with the leaves of this oak are... about the best and most dependable food supply of southern mule deer in winter."

The young sprouts, as on reeent burns, are browsed more elosely than the eurrent twig-and-leaf growth.

Browse rating. Exeellent to good for deer; good to poor for goats; poor for sheep; poor to useless for cattle; and useless for horses.

BLUE OAK (Quercus douglasii) (drawing on the right), also ealled iron oak and mountain oak. Deeiduous tree, 20 to 60 feet high, the white trunk bark shallowly cheeked into small thin seales. Leaves oblong, 1 to 3 inehes long, $1 / 2$ ineh to 3 inehes wide, shallowly lobed, bluntly toothed, or sometimes entire, oval, ${ }_{4}^{34}$ ineh to $1 \frac{1}{2}$ inches long; eups shallow with small warty seales.
Distribution (map on the left). This is a common speeies on dry roeky foothills, mostly below 3,500 feet elevation, where it usually forms open stands. It occurs mostly on slopes bordering the interior valleys from northern Los Angeles County to the head of the Sacramento Valley.

Economic value. Blue oak furnishes browse of some value to all grazing animals. Generally the eurrent growth of the lower branehes within reaeh of the animals are browsed baek to a limited degree. The numerous root erown and eoppiee sprouts that appear after eutting or burning blue oak stands are palatable to all kinds of grazing animals. The annual aeorn erop, which is usually large and mostly shed in September and October, is highly palatable to both domestic and native grazing animals. On the Tehama County winter range blue oak aeeounted for about 15 per eent of the volume of food eonsumed by the black-tailed deer during Oetober and November, and for lesser amounts at other periods ${ }^{(87)}$. It eomposed an average of 9.1 per eent of the volume of forage ingested for the entire period of eight months, from Oetober to May. On the mule deer winter range in Plumas County blue oak aeeounted for an average of 5.8 per eent of the volume of food consumed during Septem-

Bhe oak (Quercus douglasii). A common species at intermediate elevations which provides considerable feed for sheep but little for livestock except for the acoms.

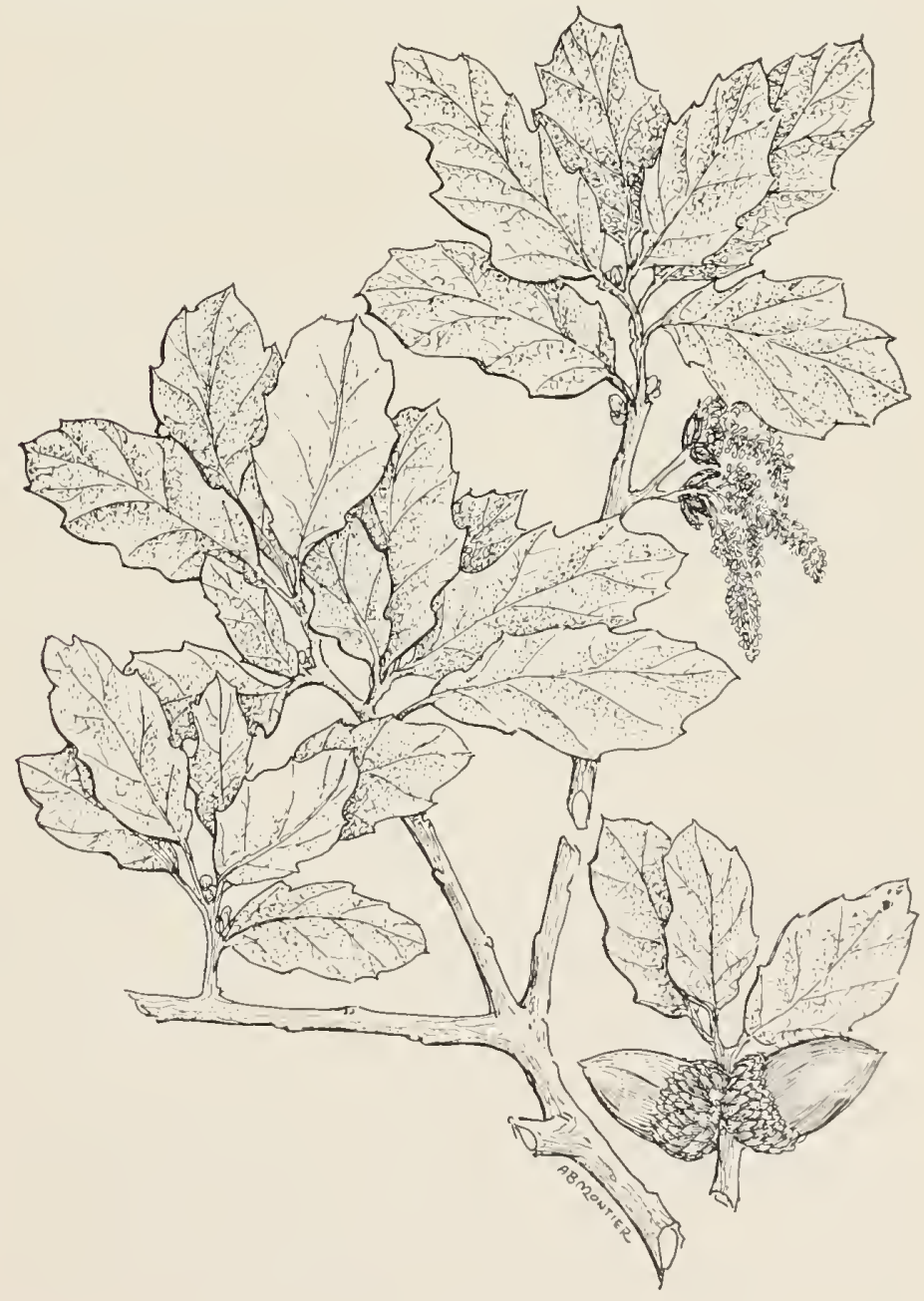




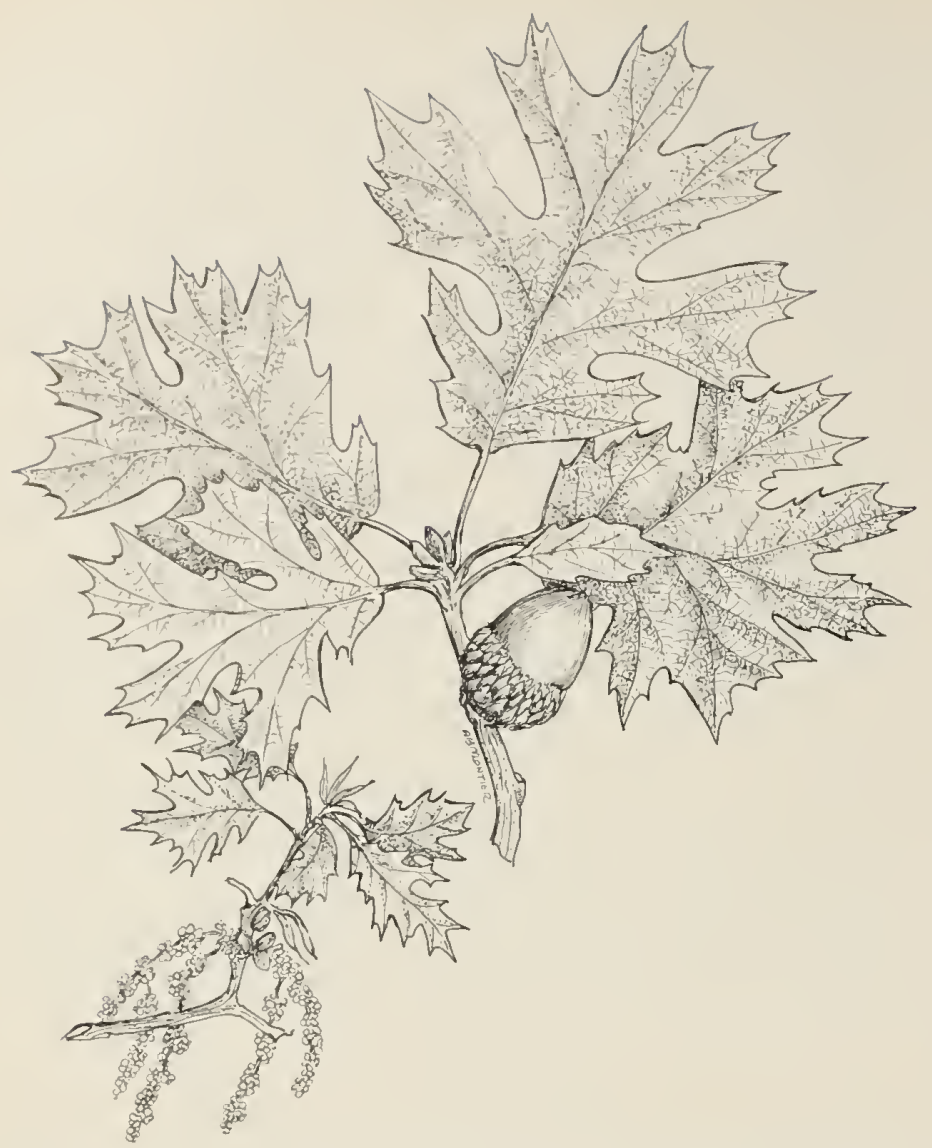

California black oak (Quercus kelloggii). A widely distributed species which supplies some browse for livestock but is highly relished by dcer. The acorns are relished by all livestock and deer.

ber, Octobcr, and November. Little was ingested during the other months ${ }^{(8 s)}$. During the autumn deer utilize the fallcn lcaves to some degree.

Studies on the San Joaquin Experimental Range showed that the crudc protein content of young, partially expanded leaves of blue oak averagcd about 30 per cent crudc protein; fully developed but still grcen leaves about 15 per cent; and mature leaves from 10 to 12 per cent. The ratio of calcium to phosphorus in young lcaves was nutritionally satisfactory, being 2.2 to 1 , but became disproportionate at leaf maturity, being about 15 to $1^{(60)}$. The mature acorns werc distinctly low in crude protein, the meats only avcraging about 4.0 per cent, but high in crude filser, fats, and oils. These facts explain the good fattening gralitics, but poor growth and bonebuilding balance of the acom mast, which is so eagerly eaten by hogs, eleer, and even by cattle and sheep in the autumn. These analyses appear to hold up fairly well for acoms of all oaks.

Browse raling. Excellent to good for decr; fair to poor for sheep and goats; poor for cattle; and poor to useless for horses.

(.ALERNA BHACK OAK (Quercus kelloggii) (drawing on this page) is a deciduones tree 30 to 80 feet high, with broad romeded crown. Tromk with dark smooth bark

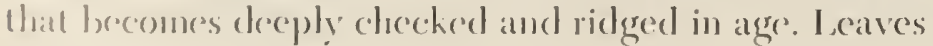

broadly elliptic to obovate, 4 to 10 inches long, $2^{\frac{1}{2}}$ to 6 inches wide, deeply lobed, usually with 3 lobes on each side ending in 1 to 4 coarse bristle-tipped teeth; lustrous green above, lighter beneath. Acorns, maturing in the second year, oblong, rounded at the apex, 1 to 1 $1 / 4^{1 /}$ inches long, deeply set in the cup; cup with thin membranous scales that are somewhat ragged on the edges.

Distribution (map shown below). California black oak occupies mountain slopes and gravelly valleys between 1,500 to 6,500 feet elevation, occasionally up to 8,000 feet or desccnding to 200 feet. It occurs in the Sierra Nevada, and in the Coast Ranges from Ventura to Shasta and Siskiyou counties, northward to southeast Oregon, but nowhere near the sea.

Economic value. The species is highly palatable to deer and is sometimes cropped rather closely by cattle. Deer feed especially heavily on the foliage and acorns (photo on page 61). On the Tehama County winter range California black oak contributed as much as 27 per cent of the volume of the stomach contents of the black-tailed deer in the autumn months, and from about 6 to 20 per cent during the spring months ${ }^{(87)}$. The average volume for all months observed was 13.6 per cent. Mule deer also utilize the leafage and twigs rather extensively and feed upon the acorns wherever available. Even in the spring does and fawns root about in the fallen leaves to find $\operatorname{acorns}^{(49)}$.

Browse rating. Excellent to good for deer; good to poor for cattle; fair to poor for sheep and goats; and poor to useless for horses.

Distribution of California black oak (Quercus kelloggii)

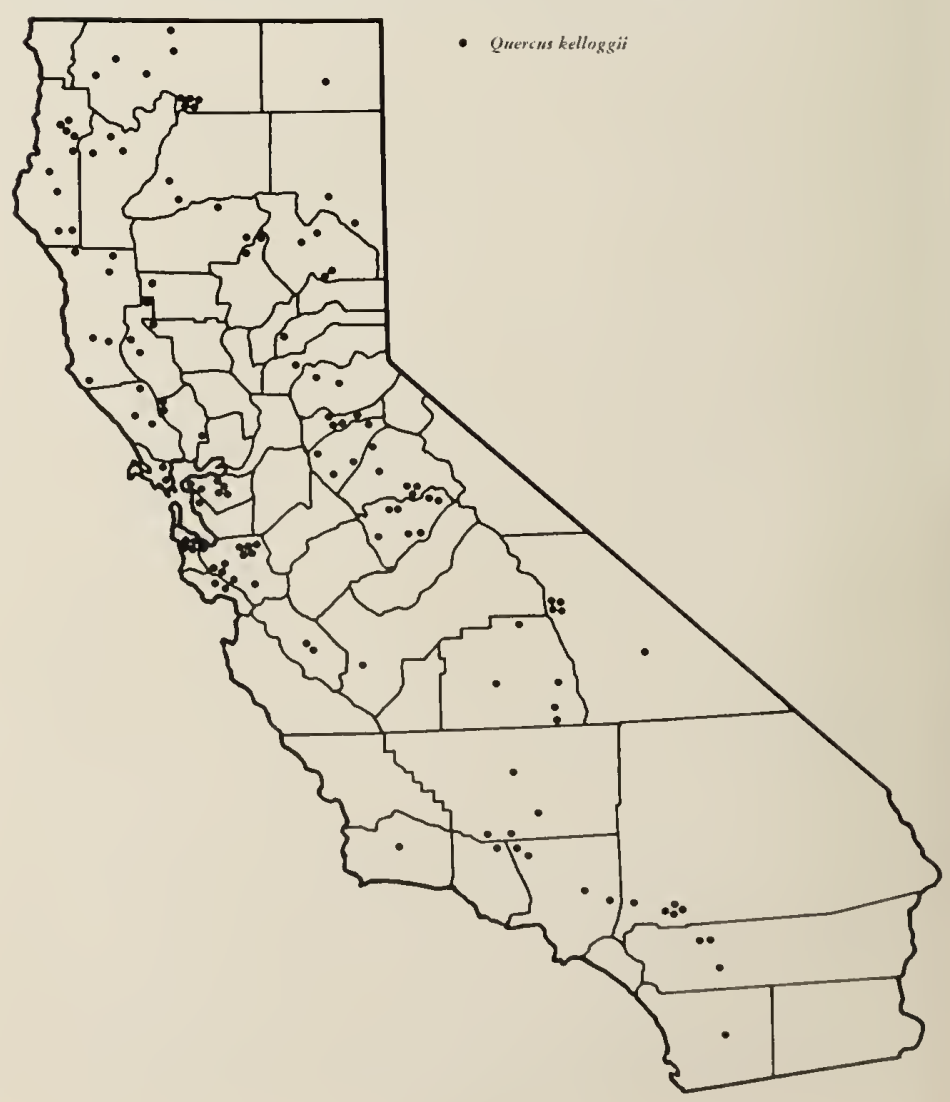


shrubs to some degree when other more desirable feed is not araiłable. In Yosemite National Park, mule deer browse the leafage of dwarf tanbark oak with fair relish and eat the acorns readily ${ }^{(4)}$. Sierra chinquapin, on the other hand, is utilized little by big game animals. These shrulss have becn considered as indicators of overgrazing, for generally animals browse upon them only in the absence of more palatable feed. Their browse ratings are given in the summary table on pages 147, 148.

\section{Elm Family (Ulmaceae)}

The elm family includes dcciduous, or sometimes evergrcen, trees and shrubs with alternate, simple, toothed leaves. Fruits may be a samara, nut, or drupe.

The well known, stately American elm (Ulmus annericana) of the New England states was formerly planted in California gardens. Beeause of its height, susceptibility to insects and diseases, its ruthless suckering habit, and brittle branches, it has fallen into disfavor. Its place has been taken by the lower growing, more graceful, well behaved Chinese elm (U. parvifolio) - usually the evergrcen form. This elm is seen throughout California in home gardens, parks, and as street trees. Although no elms are native to California the English elm (U. procera) is reported as a wecd tree in central California, and the smooth-lcaved elm (U. carpinifolia), native to Eurasia, is an occasional escape $\mathrm{e}^{(109)}$.

The only genus of the elm family represented in California is the hackluerry (Celtis). Several non-native tree species are planted in California, the most common being the castem native-eommon hackberry (C. occidentalis). It makes an excellent shade or street tree in the Sacramento and San Joaquin valleys, and is adaptable to the most adverse conditions. Only one species of hackberry is native to California and rather limited in distribution. The description of this species below includes the generic characteristies.

WESTERN HACKвERRY (Celtis douglasii) (drawing on this page). Deciduous, sometimes evergreen, low, densely branched shrub or small spreading tree, 10 to 30 feet high with smooth gray bark. Leaves thick, leathery, lanceovate, acute or aciminate at the tip, uncqual at base, and 3-nerved from the base, 1 to $3 \frac{1 \%}{2}$ inches long, ${ }_{4}^{3}$ inch to $1 \frac{1}{2}$ inches wide; margins toothed or entire; decp green and rough to the touch above, paler and fincly hairy on the strongly netted veins beneath. Flowers greenish, inconspicuons, monoecions, appearing with the leaves on current branches of the scason; male flowers in clusters at base of the season's shoot; female flowers solitary, or few in clusters, in the axils of the upper leaves. Fruit a glolose drupe, alont 16 inch in dianeter, orange-brown when mature.

Distribution (map on page 5.5). Westem hackberry is found in widcly scattered moist places from 2,800 to 5, () ()e feet elevation in momtain areas bordering the deserts. It occurs in local areas such as the Lagma Ifomtains, San D)iego County; Banning, Clark Moun-

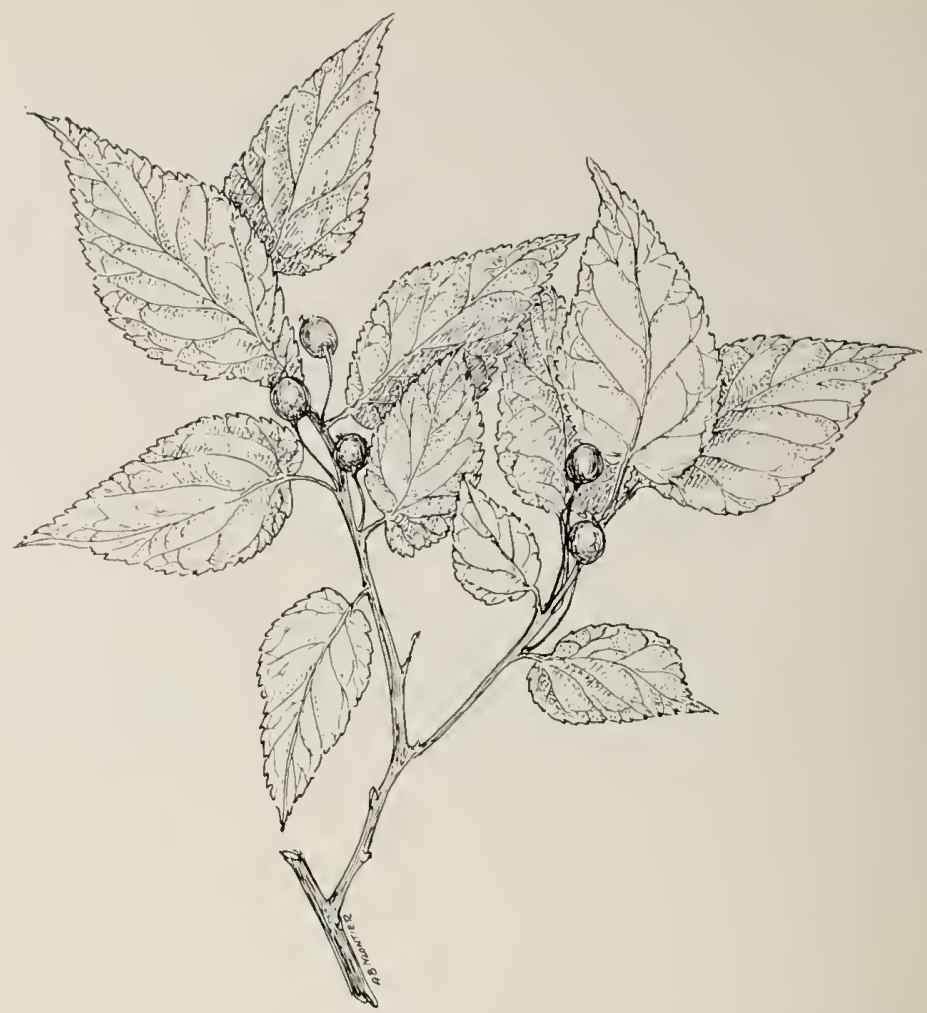

Western hackberry (Celtis douglasii). An important secondary browse plant in some localities of its rather restricted range. Its browse value is not paticularly high for any kind of browsing animal.

tain, Providence Mountains, etc.; Independence, Inyo County; Caliente Creek, and in Kern County; thence to eastern Washington, Utah, and Arizona.

Economic value. Western hackberry is an important secondary browse constituent in some localities in its rather restricted area and proxides considerable wholesome feed for domestic livestock and big game on winter, spring, and summer ranges.

Browse rating. Fair to poor for goats and deer; poor for cattle and sheep; useless for horses. This seemingly low rating is partly accounted for by its restricted distribution. Certain birds and other wild animals feed on the swcet pulpy berries.

\section{Buckwheat Family (Polygonaceae)}

This family includes a large number of ammual and perennial herbs, and evergreen shrubs and is well represented in California. It is probably best known for the domesticated grain plant, an annual originally from Eurasia-buckwheat (Fagopyrmm sagittotume)-which is reported as an escape at La Verne, Los Angeles County ${ }^{(10 x)}$. Several noxious weeds are inchuded in this fanily such as sheep sorrel (Rumex acetosella), knotgrass (Polygommm aviculare) and the docks (Rumex spp.). However, the genus Rumex also supplies an edible plant-rhubarl).

The most important genus in this family as far as browse is eoncerned is Eriogonmm which contains both amuals, lierbaceous peremnials, and shrubby species. These are relished in varying degrees by domestic livestock and big-game animals. This genus also inchudes 
two shrubby species that have become popular ornamentals in home gardens-Santa Cruz Island buckwheat (E. arborescens) and Saint Catherine's lace (E. giganteum). Both are native to the islands off the coast of southern California.

Of the distinctly shrubby or semi-shrubby species found in California the following will serve to represent the range values of this genus.

CALIFORNIA BUCKWHEAT (Eriogonum fasciculatum) (drawing shown below), also called flat top. Low, spreading evergreen shrubs, 1 to 3 feet high, and often 2 to 4 feet broad, with numerous slender, flexible, leafy branches. Bark thin, reddish, peeling off in narrow strips. Leaves alternate, simple, in clusters, oblong-linear to linear-oblanceolate, $\frac{1 / 2}{2}$ to ${ }_{4}^{3}$ inch long, barely ${ }_{1 / 4}^{1}$ inch wide, margins entire, usually strongly inrolled; dark green and almost smooth above, densely white woolly beneath. Small pinkish or whitish flowers borne in head-like clusters at the tips of long, branched, leafless stalks; inflorescence open; flowering from May to October.

Three varieties are recognized: var. foliolosum-

California buckwheat (Eriogonum fasciculatum). Since this species is an evergreen it is cropped to some extent throughout the summer and autumn by all domestic livestock, and by deer throughout the winter. However, it does not contribute a large volume of browse.

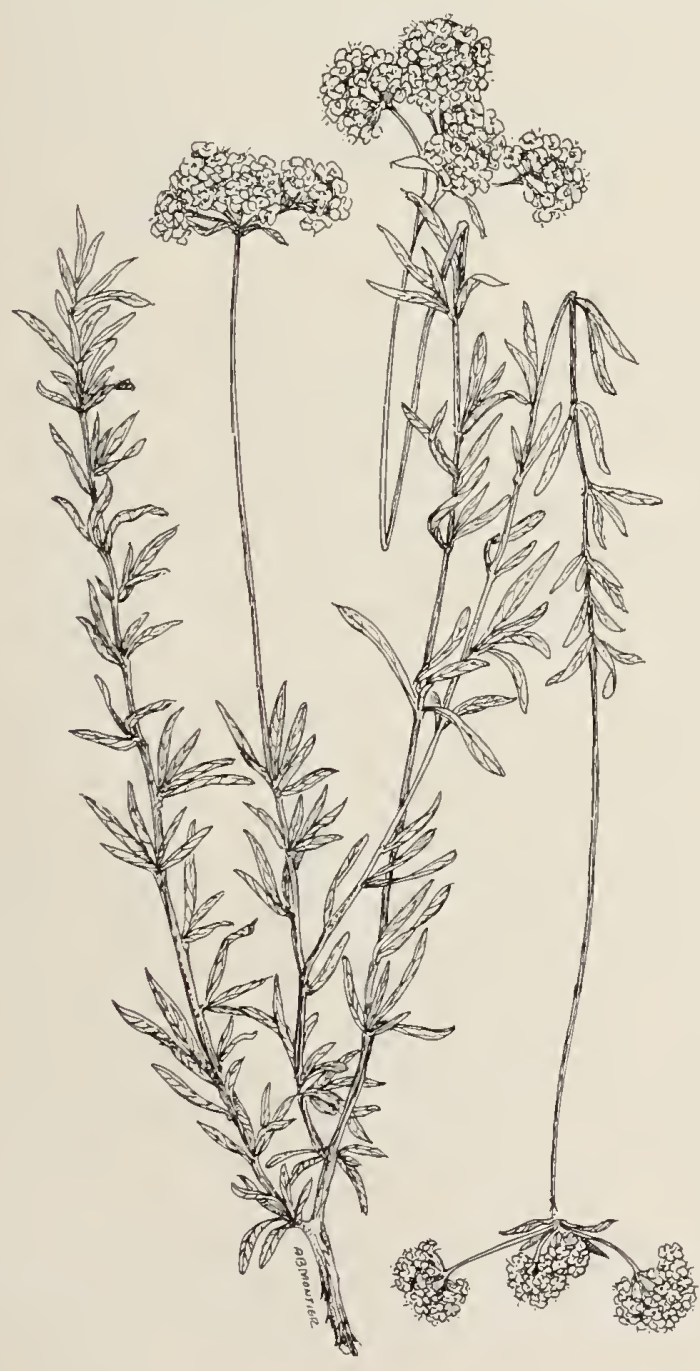

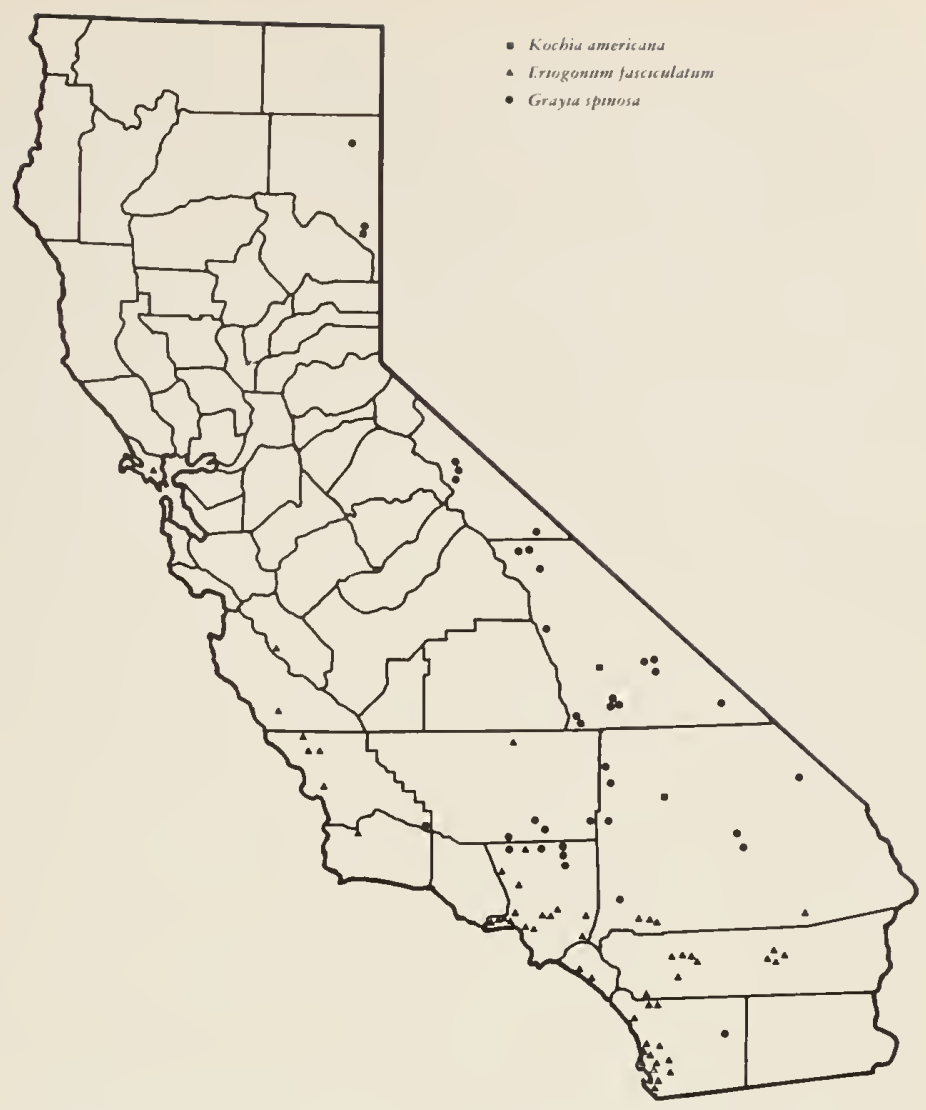

Distribution of green molly (Kochia americana), California buckwheat (Eriogonum fasciculatum), and hop-sage (Grayia spinosa).

upper surface of leaves hairy; var. polifolium-leaves densely gray hoary above, not as inrolled as the species; var. flavoviride-leaves yellow-green, almost smooth above.

Distribution (map on this page). The species occurs on dry slopes and canyons near the immediatc coast from Santa Barbara to northern Lower California. Var. foliolosum is common on interior slopes and mesas below 3,000 feet elevation from Monterey and San Benito counties to northem Lower California. Common associated plants are coastal sagebrush, sages, coyote bush, and various grasses and forbs. Var. polifolium ocurs commonly on dry slopes below 7,000 feet elevation on both deserts to the San Joaquin Valley and Inyo County, as well as in the interior foothills of southern California. Var. flavoviride grows in rocky places below 4,000 feet elevation in the Eagle Mountains of eastem Riverside County, to Little San Bernardino and Sheephole mountains.

Economic value. California buckwheat is browsed in varying degrees by all domestic livestock and big-game animals. Being an cvergreen, the lcafagc is cropped by domestic stock with fair relish throughout the summer and autumn, and by deer throughout the winter. Goats and deer utilize the current growth more closely than the other animals.

Browse rating. Good to fair for deer; fair for goats; fair to poor for cattle and shcep; poor to useless for horses which feed sparingly upon the leafage and current stems. 


\section{Goosefoot or Saltbush Family (Chenopodiaceae)}

The goosefoot family includes annual and perennial herbs or shrubs that are succulent or woody stemmed, or have a scurfy or mealy texture to the leaves. Many are weeds, such as the Russian thistle (Salsola kali var. tennifolia), and pigweed (Chenopodium album); some, like the beet and spinach are cultivated as vegetables. They frequently grow in saline or subsaline places. The leaves are simple, usually alternate, but sometimes opposite, or occasionally reduced to scales. Flowers are usually greenish, small and inconspicuous, but the arrangement of many compact flower clusters may be quite conspicuous.

Few species in this family are considered ornamental. However, the California Coastal native Brewer saltbush (Atriplex lentiformis var. breweri) is recommended for screens and hedges in gardens along the coast because of its capacity to thrive in pure sand, endure strong winds, and salt spray. Occasionally the attractive native desert holly (Atriplex hymenelytra) is also seen in southern California gardens.

In spite of the weedy nature of this family, and their little ornamental or commercial value, several genera contain important browse plants. The primary goosefoot genera include the saltbushes or shadscales (Atriplex), winter fat (Eurotia), and hop sage (Grayia). Secondary goosefoot genera are the greasewoods (Sarcolbatus) and green molly (Kochia).

Distribution of fourwing saltbush (Atriplex canescens), spiny saltbush (Atriplex confertifolia), and winter fat (Eurotia lanata).

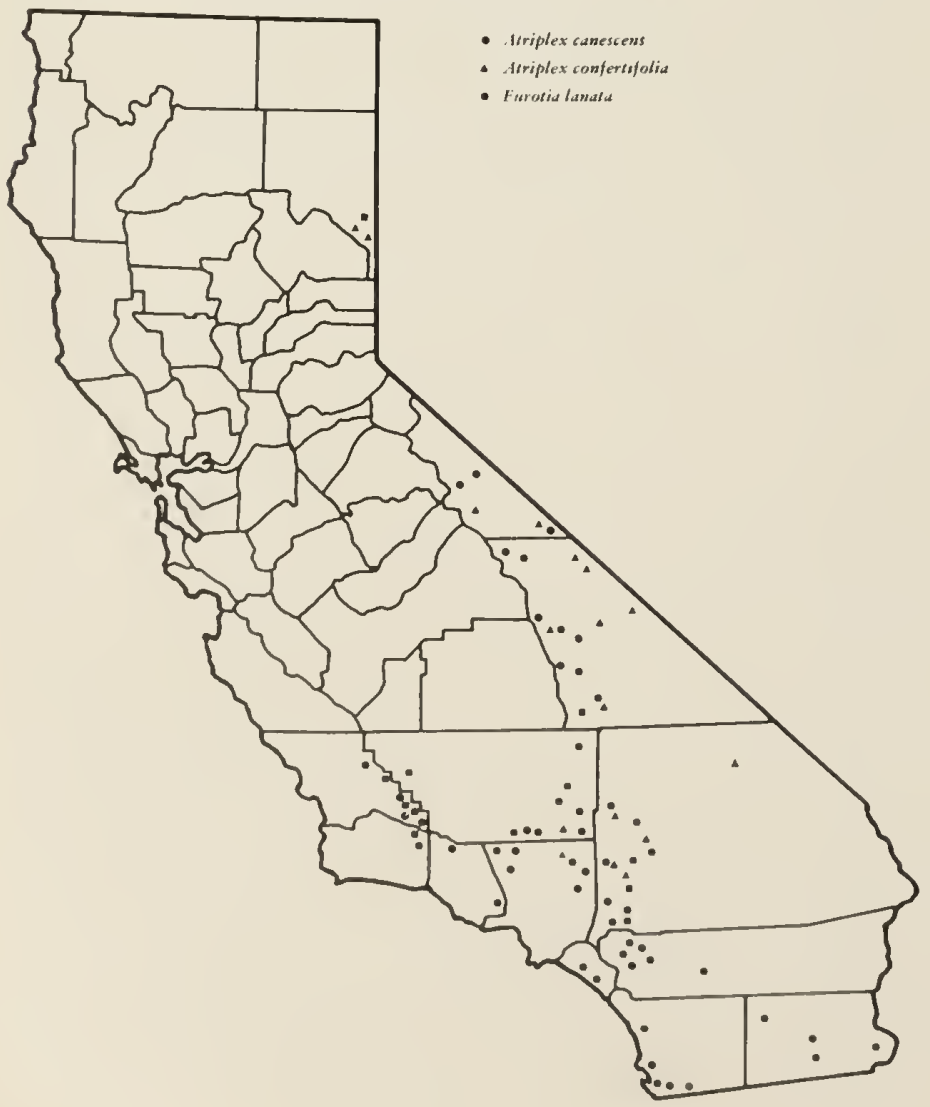

Primary Goosefoot Genera

\section{SALTBUSHES OR SHADSCALES (Atriplex)}

These are usually grayish or whitish, scurfy herbs or shrubs. Leaves may be alternate or opposite. Male and female flowers are borne on the same or on separate plants. Small green flowers are borne in axillary clusters, compact, head-like clusters, or in panicled spikes.

Fourwing saltbush, spiny saltbush, and allscale are the most important browse species of this genus. They provide a large part of the winter feed over extensive areas in the Great Basin region and adjoining areas. Some of the species of Atriplex are important as forage in the great interior mesas of Australia, where they are reputed to impart desirable properties to the wool of sheep ${ }^{(4 s)}$. Two secondary browse species of Atriplex-Nuttall saltbush and Australian saltbush-are also included.

\section{Key to the Browse Species and Varieties}

1. Plants perennial or woody only at the base, prostrate

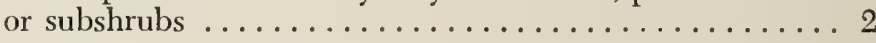

1. Plants woody throughout, never prostrate, usually erect shrubs ....................... 3

2. Diffusely spreading perennial, woody at base, often prostrate, the stems 2 to 3 feet long; leaves irregularly toothed to nearly entire; fruiting bracts shield-like, 3nerved on the sides and toothed at the apex, tinged red; escape from cultivation as forage plant, foothills of California from San Luis Obispo County to Lower California, San Joaquin and Imperial valleys

AUSTRALIAN SALTBUSH (Atriplex semibaccata)

2. Low leafy subshrub, woody only at the base, the rigid branches 1 to 2 feet high; leaves entire; fruiting bracts lanceolate to lance-ovate, warty, entire or toothed at the apex; not 3-nerved or tinged with red; native to Lassen County ................ nuttall SAltbush

(Atriplex nuttallii var. falcata)

3. Evergreen shrub; leaves $1 / 2$ to 2 inches long, margins somewhat inrolled; fruiting bracts with 4 free, flat, entire or fringed wings........... FOURIVING SALTBUSH

(Atriplex canescens)

3. Deciduous shrubs; leaves to $\frac{1 / 2}{2}$ or $3 / 4$ inch long, longer only on sterile shoots, margins not inrolled; fruiting

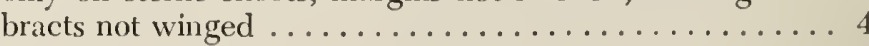

4. Rigidly branched shrub, without rigid spines; leaves crowded at the cuds of the young twigs; fruiting bracts with margins decply or shallowly toothed, the

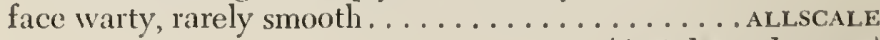

(Atriplex polycarpa)

4. Very spiny shrub; lcaves not crowded at the cnds of the branches; fruiting bracts with entire margins, the facc smooth ..................... SPINY SALTiuUsi (Atriplex confertifolia)

\section{Primary Saltbush Species}

Foumwang saltibusi (Atriplex camescens) (drawing on page 65). Evergreen, much branched, gray shrub 1/2/2 to 


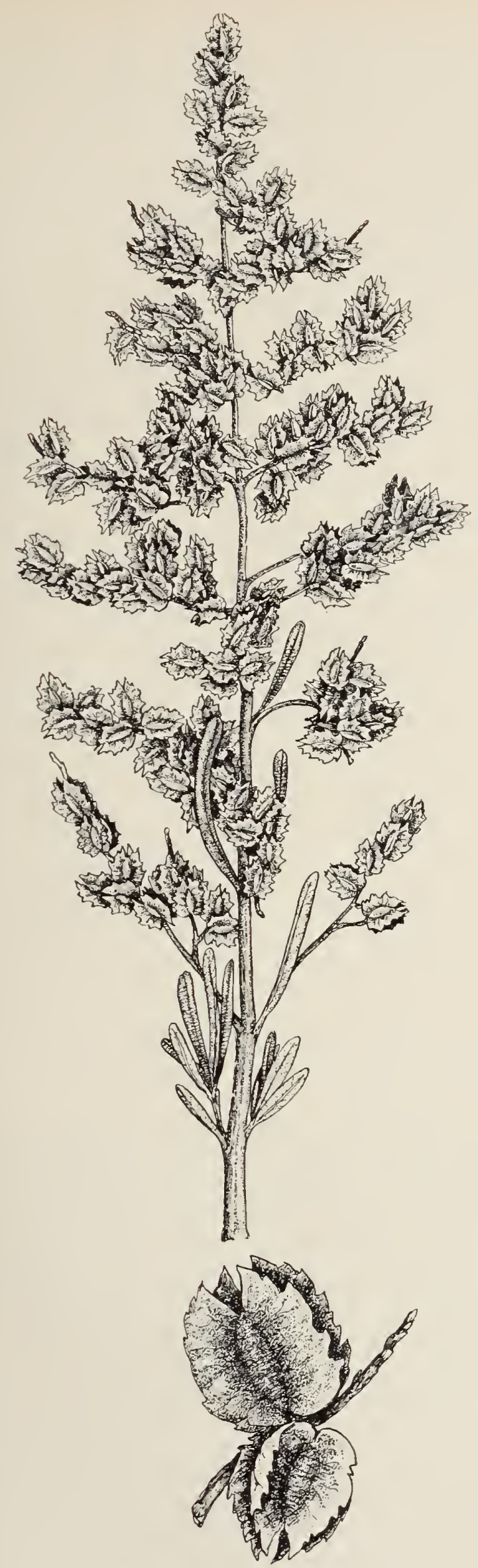

Fourwing saltbush (Atriplex canescens). A common species on many dry alkaline areas. It is a nutritious and palatable plant that is browsed by all grazing animals, especially during late fall and winter. The fruits are highly relished.
5 feet high, with stout, gray-scurfy branches. Leaves alternatc, lincar-spatulate to narrowly oblong, $\frac{1}{2}$ inch to 2 inches long, stalkless, margins somewhat inrolled; gray with dense permanent scurf on both sides. Nale and female flowers borne on separate plants, the male flowers in spikes forming large panicles, female flowers in dense leafy spike-like panicles. Fruiting bracts have 4 free, flat, entire, or fringed wings.

Distribution (map on page 64). This species is characteristic of and of ten abundant on saline desert flats or washes at elevations below 7,000 fcet in Mono, Inyo, Kern, San Benito, San Luis Obispo, Santa Barbara, Ventura, Los Angeles, San Bernardino, Riverside, and Imperial counties, and along the coast in Orange and San Dicgo counties. It often grows on lands heavily impregnated with white alkali but also cndures soils containing considerable black alkali. Common associated plants are sagebrushes, the creosote scrub, and various desert grass and forbs ${ }^{(1)}$.

Economic value. Fourwing saltbush is a highly palatable and nutritious forage plant. It is eaten by all kinds of domestic livestock, and by deer, particularly during the winter months. Numerous chemical analyses and fecding tests have shown that this species has fairly good nutritional balance. The percentage of crude protein and the carbohydrate contents of the young leaves are fairly high, and the percentage of crude fiber is about average for this group of plants ${ }^{(48)}$. The seeds are fully as palatablc as other parts of the plant and are eagerly devoured by livestock and big game. Because of its high palatability and the fact that the stems are brittle, the stand is subject to injury from overgrazing. However, where ample seed plants remain, its perpetuation is usually assured by proper grazing practices. In general, stands of fourwing saltbush have held up fairly well under grazing pressure. Studies to cnhance the rate of seed germination are under way ${ }^{(112)}$.

Browse rating: Good to fair for sheep, goats, and deer; and fair to poor for cattle and horses.

SPINY SALTBUSH (Atriplex confertifolia) (drawing on page 66), also called shadscale, saltsage, and saltbush. Deciduous, erect, rigidly branched, spiny shrub, 1 to 3 feet high, usually compact and rounded, branches straw colored. Leaves alternate, round-ovate or obovate to elliptic, ${ }_{4}^{1}$ to ${ }_{4}^{3}$ inch long, margins entire; gray-scurfy on both sides, falling early. Male and female flowers borne on separate plants; male flowers in axillary clusters, female solitary or several in cach of the leaf axils. Fruiting bracts broad, $1 / 3$ to $3 / 8$ inch long, entire, smooth, and joined over the seed.

Distribution (map on page 64). This species is common on dry, alkaline plains, mesas, and hills, mostly below 7,000 feet. It occurs on the east slope of the Sierra Nevada in Lassen, Mono, and Inyo counties and in desert areas of Kern, Los Angeles, and San Bernardino counties. Associated plants are drought-enduring desert and semi-desert plants, including various grasses.

Economic value. Spiny saltbush is a valuable food con- 
grassland with Atriplex the dominant shrub. This plant feeds from a deep taproot in the sub-surface strata and puts out succulent, nutritious foliage in the fall months when other forage is dry. It blooms and seeds in late fall. This fall growing habit and the ability to put out new growth in dry years when annual plants fail, makes this plant a 'sitting duck' for intensive year-round grazing practices. On the other hand, when browsed only to the extent of amnual increment, the plants thrive, and I know of stands that have been pastured on this basis as long as I can remember.... If I were running things in the interests of long term human welfare the Atriplex would be given back a big portion of its former domain."

Browse rating. Good for deer; good to fair for eattle, sheep, and goats; and fair for horses. The browse ratings would be higher than those given if this valuable plant were more widely distributed.

\section{Secondary Saltbush Species}

nutTall Saltbush (Atriplex nuttallii var. falcata). Low leafy subshrub, 1 to 2 feet high, woody only at the base, with rigid gray or whitish branches. Leaves linear or oblong-spatulate, 1 to 2 inches long, with or without short stalks, margins entire; grav scurfy. Male and female flowers on different plants in leafless panicled spikes. Fruiting bracts lanceolate to lanee-ovate, $1 / 6$ to 1,2 inch long, united around the seed to near the tip, entire, or toothed and warty.

Distribution. This variety has been reported only on dry alkaline flats in Lassen County, California. It is common, however, north to eastern Washington, and in the Intermountain and Rocky Mountain regions to the east.

Economic value. Nuttall saltbush is so highly relished by sheep that unless the stand is grazed eonservatively it is soon thimned out. It has strong seed habits, however, and depleted ranges usually respond well to a period of rest, or to deferred and rotation grazing. Because of its limited distribution over the State, this species does not contribute a large volume of feed to livestock.

Browse rating. Good to fair for sheep; fair to poor for eattle, goats, and deer; and poor to useless for horses.

australian saltbush (Atriplex semibaccata). Diffusely spreading prostrate perennial. Stems 2 to 3 feet long, woody below. Leaves altemate, elliptic-oblong, $1 / 2$ inch to 2 inches long, margins irregularly toothed to nearly entire; gray-green and scurfy. Fruiting bracts fleshy, shield-like, and nerved, united at the base, entire or toothed, becoming red at maturity.

Distribution. Abundant in saline waste places, along roads, marshes, etc. Foothills of California from San Luis Obispo County to Lower California, and in the San Joaquin and Imperial valleys.

Economic value. Australian saltbush was introduced experimentally in the IVest many years ago as a desirable forage plant, and has been tested for adaptability under varied conditions. It has done best on fairly dry warm sites, as evidenced by its present distribution. It is fairly palatable to all kinds of domestic livestock. Under favorable growth conditions it produced a large volume of forage or hay.
Browse rating. Good to fair for goats; fair for sheep and decr; and poor to useless for cattlc and horses.

\section{Other Primary Goosefoot Genera}

\section{WINTER FAT (Eurotia)}

Only one species represents this genus in California and both the deseriptive eharacters of the genus and species are deseribed under the species below.

W1NTER FAT (Eurotia lanata) (drawing shown below), also ealled winter sage, white sage, and fcathcr sage. Erect or spreading shrub, 1 to 3 feet high, the whole plant being covered with densc white, or rusty hairs. Leaves linear to lanceolate, $\frac{1 / 2}{2}$ inch to $1 \frac{13}{4}$ inches long, the margin inrolled. Male flowers in axillary clusters ar-

Winter fat (Eurotia lanata). A superior winter browse that occupies alkaline flats. It produces a large and strong seed crop on areas not excessively grazed. Some consideration has been given to planting of this valuable species where the stand has been destroyed by excessive cropping.

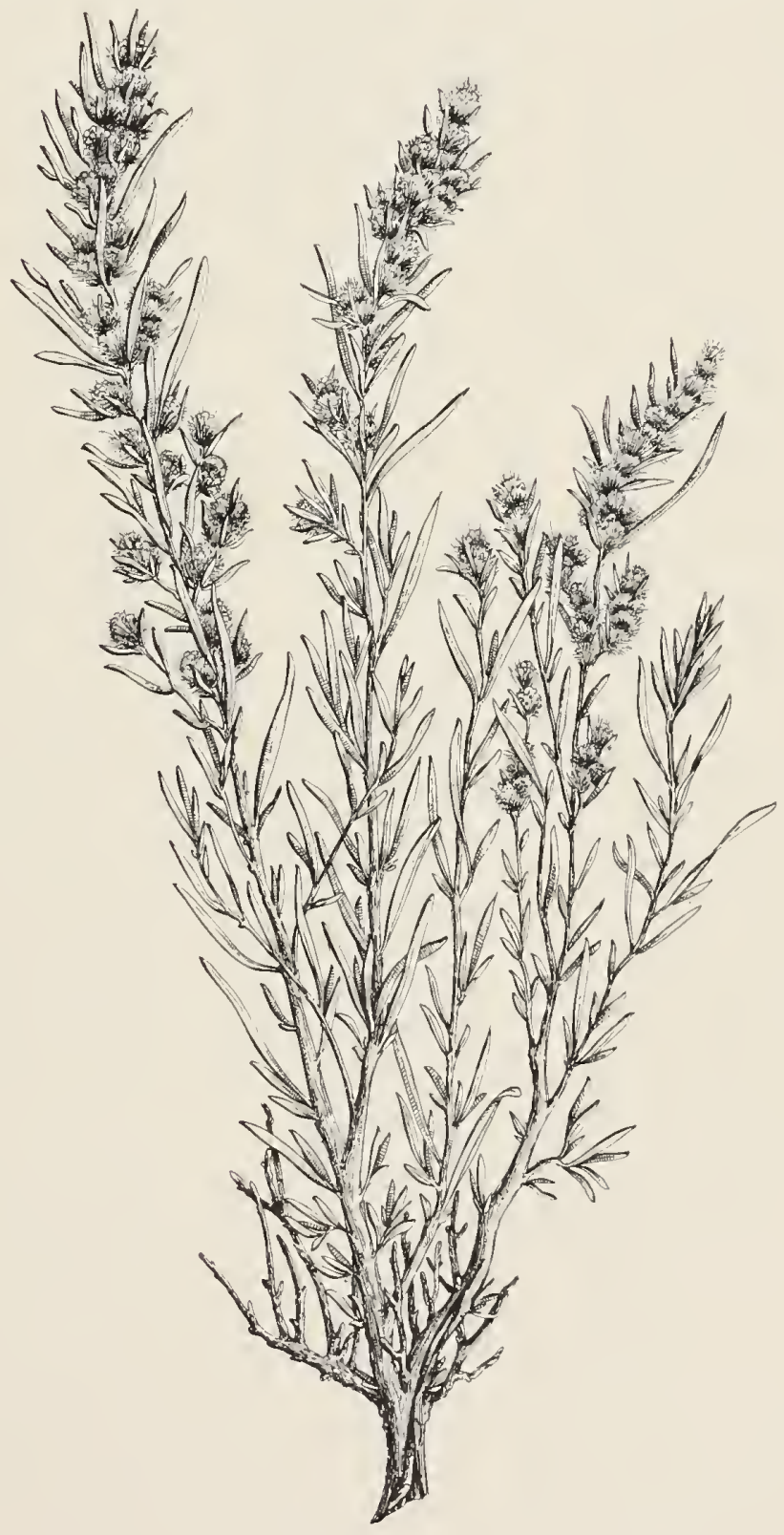


ranged in spikes at the ends of the branches. Female flowers borne in a pair of bracts which form a silky envalope that enlarges in fruit. Fruit 4-angled, beaked with 2 short horns, covered with silkv white hairs.

Distribution (map on page 64). This species is found on mesas and lower flats, on subalkaline soils in castern Lassen and Invo comties, Mojave Desert region of Kern County, Los Angeles, and San Bernardino countics, upper San Joaquin Valley, and the eastern foothills of the inner Coast Range in San Luis Obispo and Santa Barbara counties. It is commonly associated with greasewood and saltbushes.

Economic value. Winter fat is regarded as superior winter forage, hence its common name. It is highly relished by all domestic livestock, and by deer. Livestock are said to "be remarkably free from disease because of the tonic properties of the plant"(137). Moderately browsed plants make rapid spring and summer growth. It seeds prolifically and seeds are eaten eagerly by livestock. Goats crop winter fat in preference to most associated species, the leaves, seeds, and branches being taken closelv. Studies in Utah showed that the crude protein levels were fairly good, ranging from 9.1, 12.7, 10.5 per cent for early season, midseason, and late season, respectively $y^{(38)}$. The digestion coefficients were satisfactory except for cellulose and ether extract. It provided a good source of digestible protein and vitamin $\mathrm{A}$ but was slightly deficient in phosphorus ${ }^{(37)}$.

Browse rating. Excellent to good for cattle and sheep; cxccllent to fair for goats; good to fair for decr; and fair for horses.

\section{HOP-SAGE (Grayia)}

Here again, only one specics is representative of the genus in California. Both the descriptive characters of the genus and species are described under the species below.

SPINY HOP-SAGE (Grayia spinosa) (drawing on this page), also known as grayia, Gray's saltbush, spiny sagc, and horsebush. Evergreen erect bushy shrub, I to 3 feet high, the branches frequently spiny, the young parts somewhat mealy. Leaves alternate, small but rather fleshy, oblanceolate to oblong-lanccolate, $1 / 3$ inch to $1 \frac{1}{4}$ inches long, mostly stalkless. Male and female flowers borne on separate plants, small; male flowers clustered in the axils of the leaves forming dense terminal spikes; female flowers in dense, crowded, terminal spikes. Fruiting bracts united into a round papery sac $\frac{1 / 4}{4}$ to $\frac{1 / 2}{2}$ inch in diancter, often tinged reddish.

Distribution (map) on page 6.3). Although spiny hopsage of ten grows in moist areas, it is common in alkaline sites from $2,5()()$ to 7,500 feet elcvation. It occurs on the Mojave Desert of Kern, San Bernardino, and Los Angeles conntices, in the low momitains of Inyo County, in ('astern San Diego County, in Ioney Lake Valley of Lassen Comity, and in Siskivon Cominty; north to easten Washington, rast to Wroming and Arizona. Common associaterl plants ane those of the creosote bush scrub),

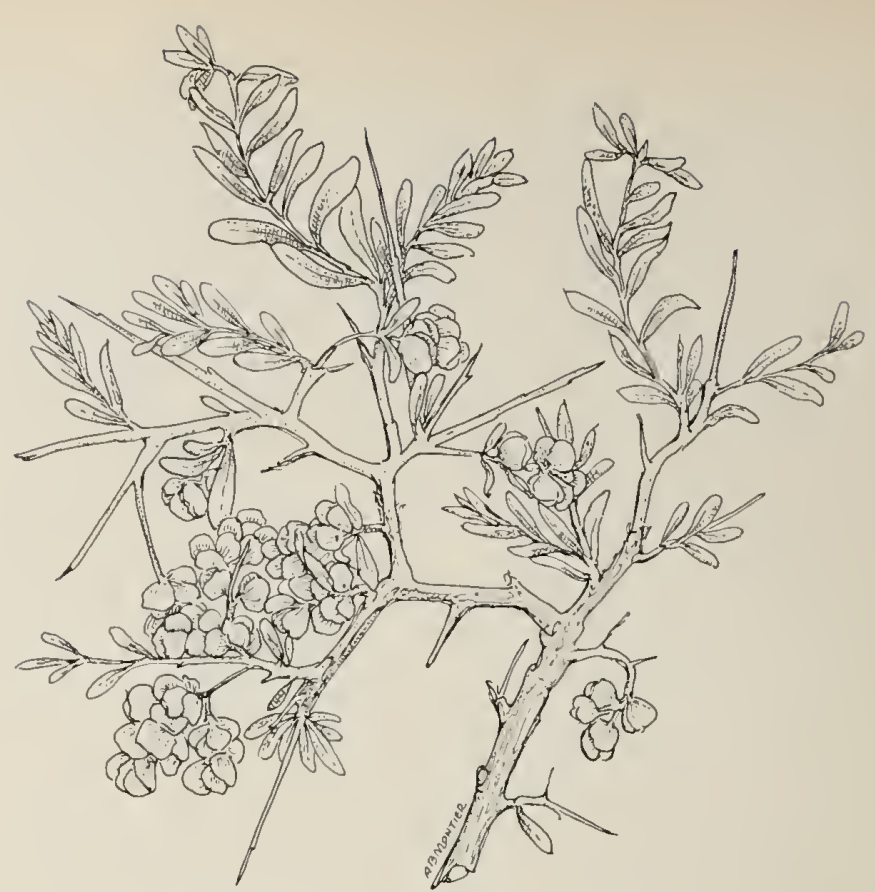

Spiny hop-sage (Grayia spinosa). Although this spccies occurs on alkaline as well as on neutral soils, it seasonally provides fairly abundant and palatable browse for all livestock and big game. It is uscful and wholesome feed throughout its distributional range.

the piñon-juniper complex, and various herbaceous desert species.

Economic value. This species provides fairly palatable browse for all livestock and big-game animals in fall, winter, and spring and, where abundant, is a real asset to the range feed. The buds and leafy twigs are cropped closely and the animals are said to fatten on the abundant sac-like fruits. It is regarded as a nutritious, wholesome feed that produces a solid fat. Modest browsing of the branches appears to stimulate production of twigs and leaves.

Browse rating. Good to fair for sheep, goats, and deer; fair to poor for cattle; and poor to useless for horses.

\section{Secondary Goosefoot Genera}

\section{GREASEWOOD (Sarcobatus)}

The following species is the only one known in the genus, hence the description of the species below includes both genus and species characteristics.

GREASEWOOD (Sarcobatus vermiculatus) (drawing on page 69) is an evergreen, thorny, much branched shrub, 3 to 6 feet high. Bark whitish in young plants, grayish to black in older ones. Leaves alternate or opposite, simple, stalkless, fleshy, linear, $1 / 2$ to $1 \frac{1}{1}$ inches long. Male and femalc flowers borne on the same or different plants; malc flowers in a terminal catkin-like spike; female flowers usually solitary in the axils of the upper leaves. Fruiting calyx cnlarges into a broad, round, membranous wing about $\frac{1}{12}$ inch wide.

Distrilution. This species inhabits alkaline flats along the borders of Mono Lake, Mono County, cast to Middle Lake, and near Momt Bidwell in northeastern Modoc County, near Iloney Lake in Lassen County, and about Owens Iake in Inyo Comnty, in the Upper and Lower 
Sonoran zones. It extends northward to eastern Orcgon and Washington and east and south through the Great Basin region to Arizona and Texas. The assoeiated plants range from those of the piñon-juniper complex, to saltgrasses, and other alkali-enduring plants.

Economic value. Greasewood is a plant of some browse importance on many extensive alkali flats. In some localities it furnishes a fair supply of the feed on winter range for cattle and sheep, although not equal in value to winter fat or spiny saltbush ${ }^{(137)}$. Over parts of its California range it is less palatable than elsewhere in the West. Because of the high alkaline content of the leafage, it gives best results on ranges containing a variety of forage plants. Animals that ingest large quantitics of greasewood may develop symptoms of poisoning ${ }^{(90)}$.

Browse rating. Fair to poor for sheep and goats; poor for deer; fair to useless for cattle; and useless for horses.

Greasewood (Sarcobatus vermiculatus). Branchlet showing leaves and numerous thorns; fruit; and male flower clusters on young twig.

A moderately palatable plant to livestock and deer in winter on alkali flats. Animals that consume large quantities of the herbage may show symptoms of poisoning.

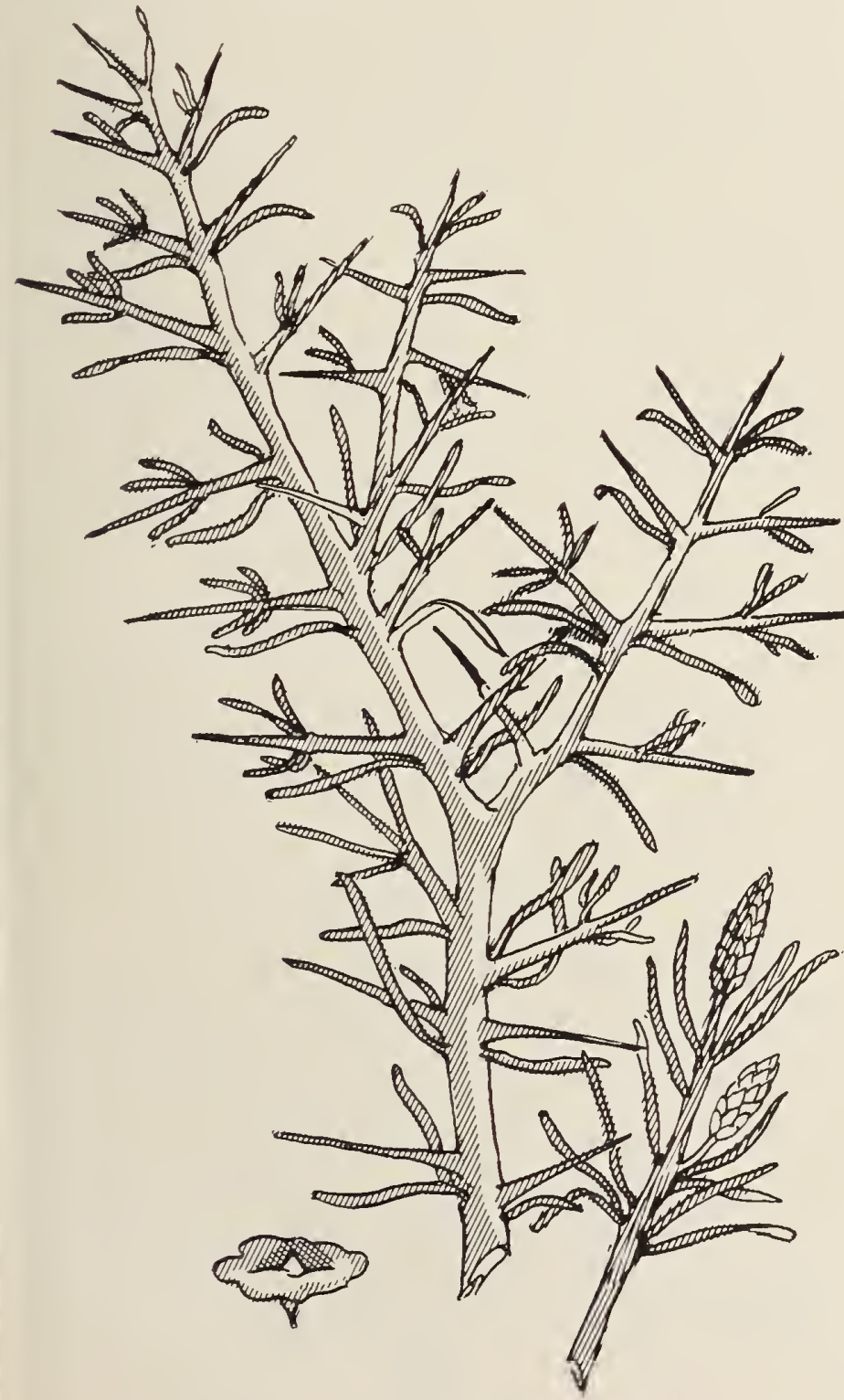

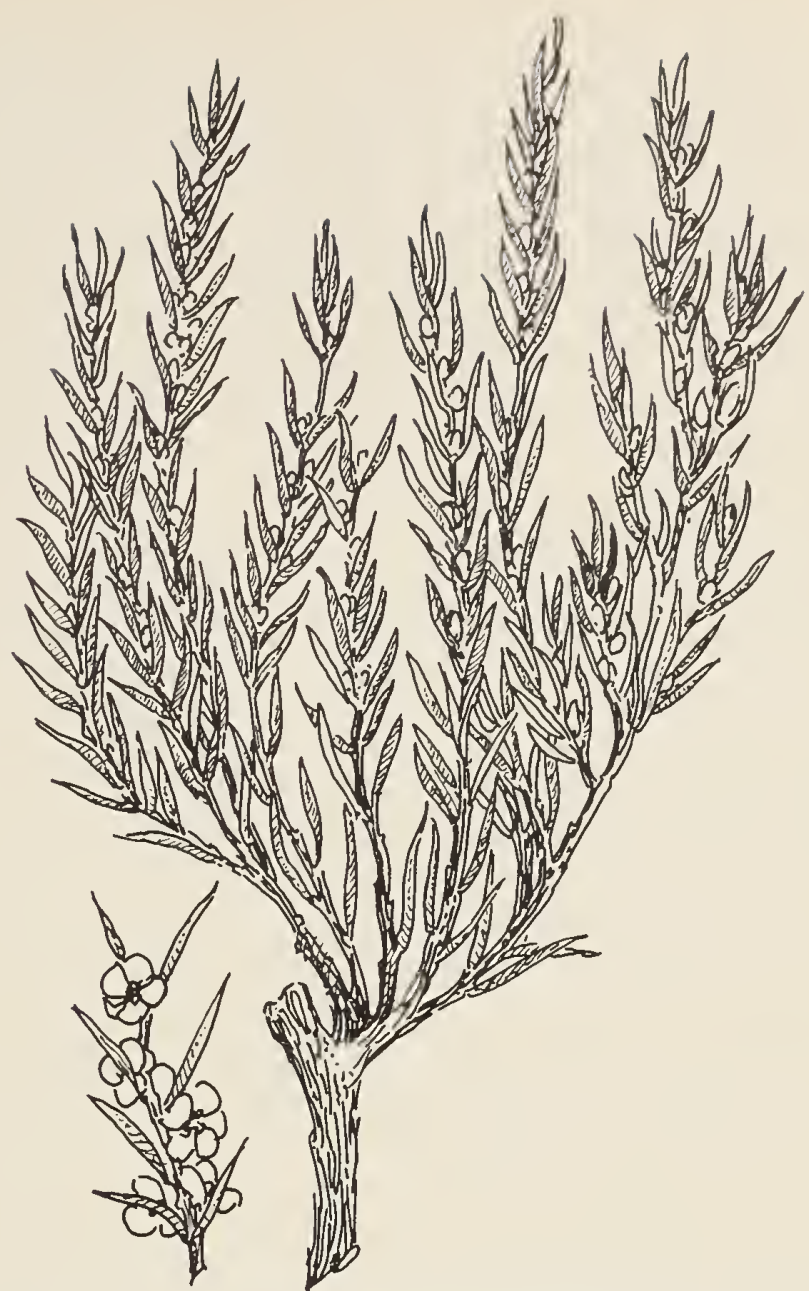

Green molly (Kochia americana). A desert plant of restricted distribution. It has only limited browse value for domestic livestock and deer but serves as a filler and useful variant.

\section{MOLLY (Kochia)}

Three spceies of this genus occur in California. Two are perennial natives-green molly ( $K$. americana) and rusty molly (K. californica) —of rather limited distribution. The third, summer-eypress (K. scoparia), native to Eurasia, is an annual garden plant that has escaped from cultivation, and has beeome a weed in certain areas of Los Angeles, Santa Barbara, and Contra Costa counties, and eastem United States ${ }^{(108)}$.

In this discussion green molly (Kochia americana) will serve to represent the browsc values of this genus in California. The generic characters are described with those of the species below. Rusty molly ( $K$. californica) is similar to green molly except that it is a more spreading plant, branched above, rather than from the base, and with shorter, flat leaves that are densely and permanently rusty hairy. It occurs in the Mojave Desert at Victorville, Rabbit Springs, and Lancaster, and in the San Joaquin Valley from Kern County to Madera County, to southeastern Inyo County, and Nevada.

GREEN MOLLY (Kochia americana) (drawing shown above) is also called red sage and desert molly. Evcrgreen low subshrub, 4 to 12 inches high, with many up- 
right stems branching from a woody base. Leaves linear, 1: to $3 / 2$ inch long, crlindrical, fleshy, sparsely silky hairy when voung, smooth in age. Flowers solitary or in 2's and 3 's in the leaf axils, white hairy. Calyx enlarged in fruit and persistent, with 5 fan-like papery wings that are bluntli toothed.

Distribution (map on page 63). This plant is relatively rare in Califomia. It oceurs on drv alkaline flats and saline soils in Invo, San Bemardino, and Lassen counties. It extends eastward to Colorado, Wyoming, and New Ilexieo. Common plant associates are those of the ereosote bush serub, Joshua tree, and annual and perennial grasses and forlos.

Economic value. During the fall months-before frosts-green molly is fairly high in crude protein (about 1.3 per cent) but during the winter periods, studies in Utah showed that this constituent was low ${ }^{(37)}$. At that season the digestible protein was distinctly deficient. The phosphorus levels were deficient at all seasons.

Browse rating. Fair to poor for sheep and goats; poor to useless for deer; and useless for cattle and horses.

\section{Laurel Family (Lauraceae)}

The laurel family eonsists of aromatic, mostly evergreen trees and shrubs of tropical and subtropical regions. The family contains a number of plants that are important both ornamentally and economically. Perhaps the one with the most romantic history is the sweet bay or Grecian laurel (Laurus nobilis), native to southern Europe. Wreaths of the leaves of this tree erowned the victors of Grecian and Roman sports events.

The roots, stems, and bark of the camphor tree ( $\mathrm{Cin}$ namomum camphora) provided camphor used for relief in nasal and head congestion, and was formerly a constituent of moth balls. In California it is one of the most popular street and garden trees. Another species of this genus (C. zeylanicum) from Ceylon, but now cultivated in many areas of the tropics provides the spice einnamon, obtained from the tree's bark. The sassafras ( $S$. variifolium), native to the eastern United States, also belongs to this family. A medicine and stimulant was extractech from the bark of its roots. Volatile oils from the trunk bark have been used in making perfumes, bitters, and flavoring agents for beverages.

Ilowever, the most important money-making member of the family to Californians, is the avocado (Persea americana). Several varieties are grown in southern California-both summer and winter fruiting. Along with citrus fruits, they comprise the predominant orchards of that area.

In spite of the fact that several members of this fanily are well adapted to growing in California, only one gemus with one species is native to this area.

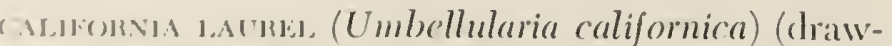
ing on this page), also called California bav, Oregon mintle, and pepperwood. Commonly an evergeren tree
20 to 60 feet high, but sometimes shrub-like on dry sites. Leaves simple, alternate, oblong-elliptic, 3 to 5 inches long, ${ }^{3}$ inch to 1 inch wide, smooth, entire, with a pungent odor when rubbed or crushed; glossy yellow-green to dark green. Flowers small, yellowish, bisexual, 4 to 6 in stalked umbels; sepals petal-like, petals none; appear in February to April. Fruit a plum-like drupe, about 1 ineh long, greenish turning purplish.

The wood of California laurel is used for various purposes. To the tourist, shops along the Redwood Highway offer a variety of vases, bowls, ash trays, lamp bases, and other trinkets made from this wood and sold under the name of myrtlewood. The wood has also been used in boat building, for furniture, and stave timber. The dried or fresh leaves can be used like those of Grecian laurel in flavoring meats, soups, and sauces.

Distribution (map on page 71). California laurel is found in canyons, on shaded moderately moist slopes, or along streams, but sometimes in dry sites, from sea level to about 4,000 feet elevation. It occurs from western Oregon, southward in the Coast Ranges and on the western slopes of the Sierra Nevada in California to San Diego County. The shrub form inhabits draws and dry slopes in the chaparral.

Economic value. California laurel is little utilized when growing as a tree, usually on shaded slopes. It sprouts abundantly when burned, however, and this young growth is choice browse in spring and summer for deer and goats, and also cropped by sheep and cattle. Utilization of 60 to 80 per cent, by weight, of the leaf-

California laurel (Umbellularia californica). As a tree, this plant is little utilized by livestock and deer. However, it sprouts vigorously when cut or burned. The sprouts are eropped with much relish by deer and moderately by eattle, sheep, and goats. Although not an abundant plant it should be protected from overutilization

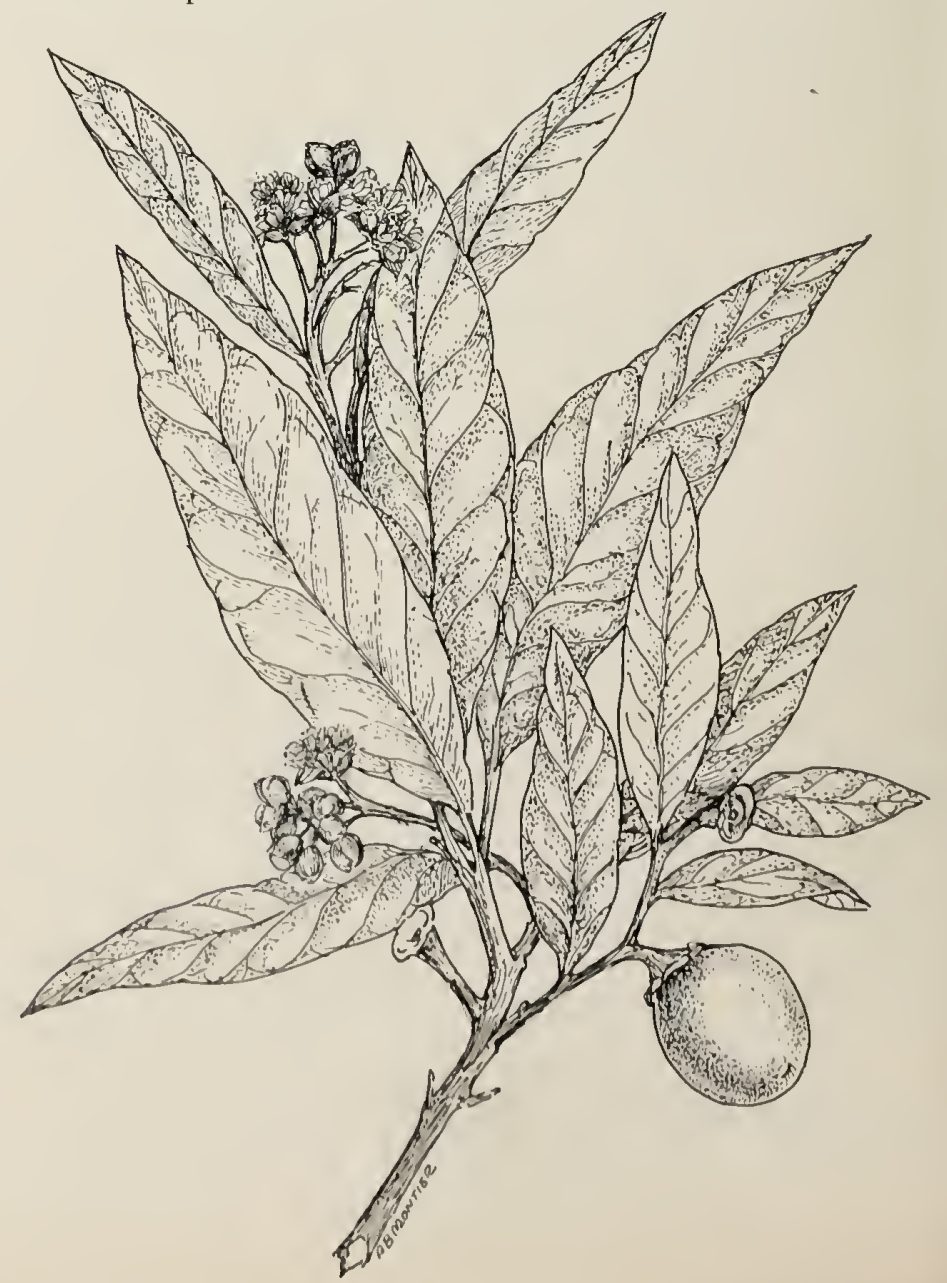




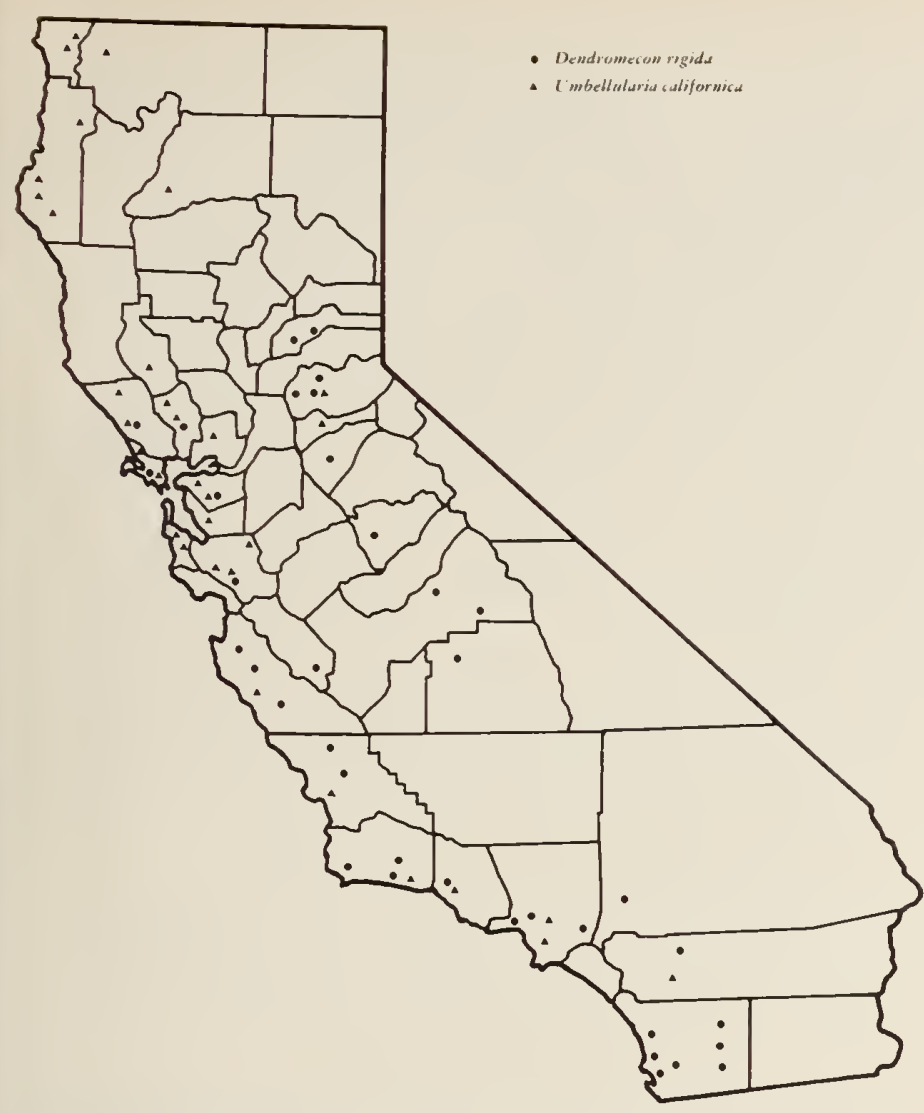

Distribution of bush poppy (Dendromecon rigida) and California laurel (U'mbellularia californica).

age and tender shoots was recorded on chaparral deer ranges in Madera and Lake counties. Not uncommonly the sprouts are cropped so closely as to kill individual plants. However, the total annual production of browse is not especially large as it is not an abundant plant ${ }^{(145)}$. On deer range the young shoots are cropped with gusto throughout the year. In some localities, however, the sprouts are not browsed by deer if they are not cropped back during the spring and summer months of the first year after a burn. This fact was observed on the Tehama winter deer range where the bulk of the deer herd moves into the area in early fall. Normally this occurs during the last few weeks of the deer season. In the summer months few if any deer inhabit the winter range.

Browse rating. Good to fair for deer; fair to poor for cattle, sheep, and goats; and useless for horses.

\section{Poppy Family (Papaveraceae)}

The poppy family includes both annual and perennial herbs, and some shrubs. To Californians the best known armual in this family is the California poppy (Eschschol zia californica). It is so abundant throughout Cahifornia and offers such brilliant swathes of orange color that it was declared the State of California's official flower. To many the name poppy family identifies itself with the source of opium-the opium poppy (Papaver somniferum).

Only one shrubby species in this family is significant as far as browse is concerned.
BUSII POPPY (Dendromecon rigida). Evergreen, freek branching shrub, 3 to $8 \mathrm{fcet}$ high, with colorless bitter juiee, and yellowish gray or almost white shreddy-barked stems from a woody basc. Leaves simple, alternate, linear-lanccolatc to elliptical, 1 to 4 inches long, 倠 incl to 1 ineh wide, margins fincly toothed; yellowish-green to gray-green. Flowers are bisexual, yellow, showy, solitary on stalks 1 to 3 inches long; sepals 2 or 3 , early deciduous, petals 4 to 6 (twicc as many petals as sepals), roundish, ${ }^{3 \prime}$ inch to $1 \frac{1}{11}$ inehes long; flowers April and May. The fruit are curved linear capsules, 2 to 4 inehes long.

Distribution (map on this pagc). Bush poppy occupies dry chaparral slopes and ridges of the Coast Ranges, the lower western slopes of the Sierra Nevada, and the chaparral mountain areas in southern California, from about 1,000 to 3,000 feet above sea level.

Economic value. The current growth of bush poppy is cropped in varying degrees by most grazing animals. Goats are particularly fond of the leafage and young twigs. On recent burns, sheep and deer utilize the sprouts closely and they also feed upon the young twigs and leafage of adult plants. Although the volume of leafage is seldom large, bush poppy locally often provides good secondary feed.

Browse rating. Fair to poor for sheep, goats, and deer; poor to useless for cattle, and useless for horses.

\section{Saxifrage Family (Saxifragaceae)}

This large and important family includes both herbs and shrubs. Leaves may be alternate or opposite. Flowers are perfect, variously borne in clusters or solitary. Sepals and petals are usually 4 or 5 , and stamens generally 5 or 10 . Fruits may be a capsule, follicle, or berry form.

To anyone who strolls through California gardens, the landscape value of this genus is evident. One might see a mass of hydrangeas, gay red coral bells, tufted saxifrages, pink flowered bergenia, shrubs of mockorange, and many others.

However, the best known representatives of this family are the gooseberries and currants. In gardens, horticultural varieties are raised for such culinary delights as gooseberry pie or currant jelly. In California therc are approximately 31 species that are native. The gooseberries, because of their thorny stems and berries are sometimes recognized as a separate genus-Grossularia, and only the thornless currants are included in the genus Ribes. In this discussion both currants and gooseberries are described under the genus Ribes.

Aside from their value as browse plants, the eurrants and gooseberries are of importance in all parts of the United States where white (5-needle) pines occur. Since these shrubs are the alternate hosts of the white pine blister rust fungus (Cronartium ribicola), they must be eradicated in the vicinity of stands of all white pine species. Such control measurcs have been under way for many years. Eradication has mostly been done by 
hand pulling and grubbing; but more reeently sueeessful chemical methods have been devised for killing Ribes speeies

The emrants and gooseberries are widely distributed and alundant on the western range. They are often an important factor in the grazing eapaeity of the range even though their palatability is relatively low. The berries of some species are pleasing to the human palate. They are an important source of food for many birds and mammals.

The browse values of the genus Ribes are well represented by sticky flowering currant and wax eurrant. A few are also listed that are of seeondary importanee.

\section{CURRANTS AND GOOSEBERRIES (Ribes)}

These are shrubs with or without spiny or bristly stems. Leaves are simple, alternate, usually lobed and somewhat maple-like. The flowers are borne in raeemes, oeeasionally solitary. Five (or 4) sepals are usually joined at the base to form a tube; the petals 5 (or 4 ) are separate but attached to the throat of the ealyx. The fruit is a one-eelled, many seeded berry.

They oceur in a variety of habitats ranging from open woodlands and forests to open or semi-shaded grasslands.

\section{Key to the Browse Species and Varieties}

1. Stems without spines or prickles............ 2

1. Stems with spines or prickles. 5

2. Rigid intricately branched shrub; leaves $\frac{1 / 2}{12}$ to 1 inch broad, usually clustered on short spurlike branches, obscurely 3 to 5 -lobed; flowers whitish, cream-colored or rarely pinkish; fruit bright red.......... WAX CuRRANT

(Ribes cereum)

2. Erect or spreading shrubs with straighter, less rigid branches; leaves $\frac{3}{4}$ inch to 3 or 5 inches broad, not clustered on spurlike branches, definitcly 3 to 5 -lobed; flowers pink, reddish, or greenish-white; fruit black

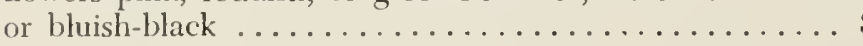

3. Flowers ${ }^{3}$ to $: *$ inch long, 3 to 12 in a cluster, greenishwhite, rarely somewhat pinkish; fruit more or less glandular-bristly ........... STICKY FLOWERING CURIRANT

(Ribes viscosissimum)

3. Flowers $1 \frac{1}{2}$ inch or less long, usually 10 to 30 in a cluster, pink, deep pink, to reddish; fruit covered with a whitish bloom, not glandular-bristly . . . . . . . . . .

4. Leaves finely hairy or sinooth on both surfaces; bracts at base of flower pale pink or greenish; flowers usually less than ${ }^{3}$ inch long; moist places and along streams, 4,000 to 8,000 feet elevation; Sierra Nevada; higher peaks, north Coast Ranges, momintains of sonthem

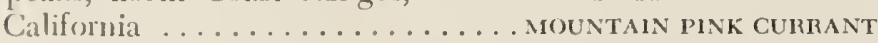
(Ribes nevadense)

4. Laves usually glandular on both surfaces as well as fincly or densely lairy, hairs often lacking in age; bracts at the hase of the flower reddisli; fowvers isnally ze inch or morr long; semi-moist stopes anrl eanyous along the coast from San Luis (Obispo Comnty

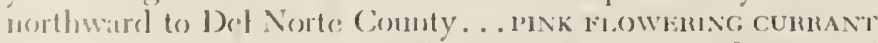
(Ribes songnine'nu var. glntinosum)
5. Flower parts in 4's, bright crimson-red, fuchsia-like; coastal, Santa Clara County south to San Diego County ............. FuCHSIA FLOTVERING GOOSEBERHY

(Ribes speciosum)

5. Flower parts in 5 's, not crimson-red..........6 6

6. Stems with 3 stout spreading spines at the nodes and numerous prickles on the internodes; leaves usually rough above with glandular hairs, velvety-hairy and glandular beneath; outer Coast Ranges, Del Norte County, south to San Luis Obispo County

CANYON GOOSEBERRY

(Ribes menziesii)

6. Stems with 1 to 3 spines at the nodes, usually lacking prickles on the internodes, except occasionally on young growth; leaves finely hairy or smooth, not glandular ........................

7. Fruit about $\frac{16}{4}$ inch in diameter, smooth

WHITE-STEMMED GOOSEBERRY (Ribes divaricatum var. inerme)

7. Fruit ${ }_{8}^{3 /}$ to $\frac{1 / 2}{2}$ inch in diameter, spiny or prickly........ 8

8. Flowers dull red, calyx tube longer than broad; fruit $\frac{1}{2}$ inch in diameter, with stout spines and usually some gland-tipped bristles; mostly Sierra Nevada

SIERRA GOOSEBERRY

(Ribes roezlii)

8. Flowers greenish or purplish, calyx tube broader than long; fruit ${ }^{3 /}$ inch in diameter, densely bristly or sparingly prickly and with glandular bristles; mostly Coast Ranges .......................LLSIDE GOOSEBERIXY (Ribes californicum)

\section{Primary Ribes Species}

STICKY Flowering CURRANT (Ribes viscosissimum) (drawing on page 73), known also as hairy eurrant and sandbox currant. Ereet, loosaly branched, deeiduous shrub, 1 to 4 feet high, the branehes spineless, with reddish shreddy bark, and fragrant glandular foliage. Leaves round in outline, heart-shaped at base, ${ }_{4}^{3}$ inch to 3 inches wide, 3-lobed or sometimes 5-lobed, the margins with rounded teeth; hairy or glandular on both surfaces. Flowers greenish, white, or pinkish, $5_{4}^{5}$ inch to ${ }_{4}^{3 /}$ ineh long, 3 to 12 in a cluster; April to June. Berry globular or ovoid, about $1 / 2$ inel wide, black, usually glandularbristly.

The seedy berries, which ripen in August and September, are readily eaten by birds, bears, and rodents. Although the berries are not partieularly juiey and have little pulp, they are used to some extent for preserves and in pies.

Distribution (map on page 74). Sticky flowering currant grows in shady woods and roeky places and occurs in the Sierra Nevada between 6,000 to 9,000 feet elevation, from Tulare County north to Mariposa County. Northward it gives waly to variety hallii and some intermediate forms, all of essentially the same browse values as the species. It extends eastward to the Rocky Mountains and northward in eastern Modoc County, California, to Washington and British Colmmbia.

Economic value. Sticky flowering eurrant is chicfly im- 


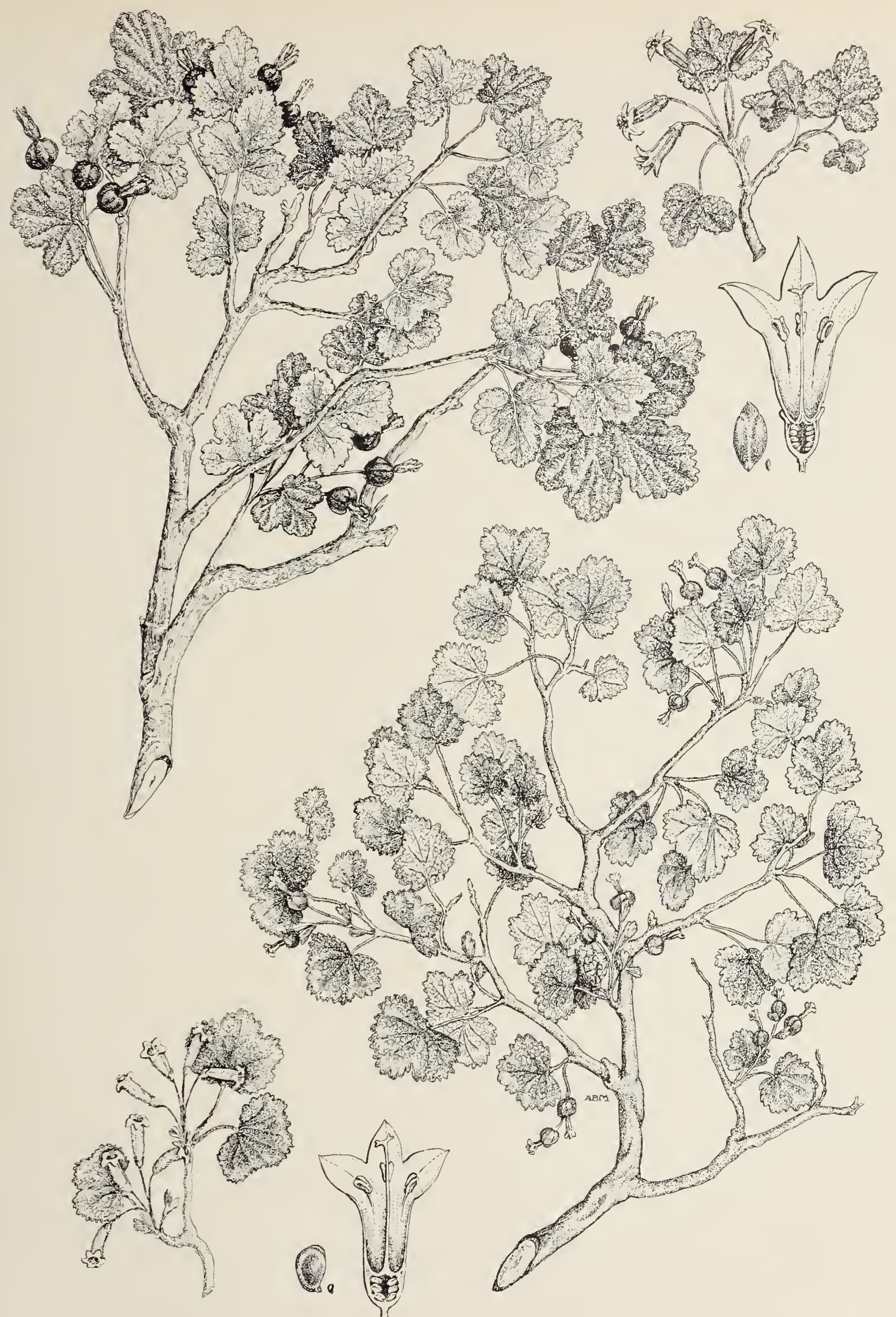

Top. Sticky flowering currant (Ribes viscosissimum). Fruit and section of flower, branchlet with flowers. A locally important browse plant at medium to high elevations. It is cropped most avidly by sheep, goats, and deer, notably in the autumn.

Bottom. Wax currant (Ribes cereum). Branchlet in flowering stage; twig in flower; seed and section of flower.

A more widely distributed species than sticky flowered currant. The two species have essentially the same browse values. 


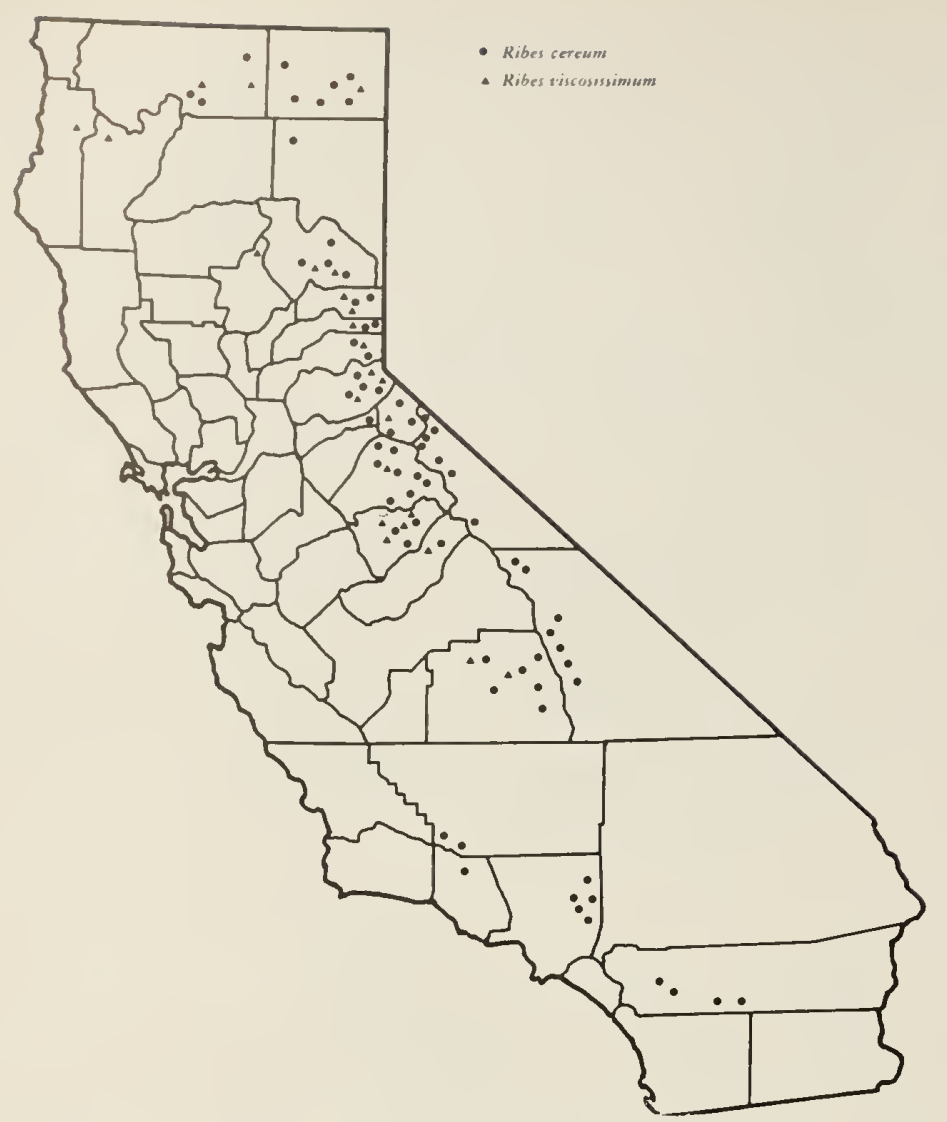

Distribution of wax currant (Ribes cereum) and sticky flowering currant (Ribes viscosissimum).

portant bccausc of its local abundance and its rather large amount of leafage. It is readily cropped by sheep, goats, and dcer, particularly in the fall before the first killing frost, after which the foilage turns dark. It also serves as a forage variant of some importance on summer cattle range.

Browse rating. Fair to poor for sheep and goats; fair to uscless for deer; poor for cattle; and poor to useless for horses.

WaX CURRANT (Ribes cereum) (drawing on page 73 ). Low, rigidly and intricately branched, deciduous shrub, 2 to 8 fcet high, with smooth gray or brown bark on old branches, fincly hairy on young shoots; spineless. Leaves fragrant, clustcred on short spur-like branches, or scattcred on youngcr twigs, roundish, obscurely 3 to 5-lolsed, 1/2 inch to 1 inch broad, glossy above, hairy and glandular bencath, margins finely toothed. Flowers whitc, cream-colored, or pinkish, 2 to 8 in short drooping clusters; Junc to July. Berries bright red, $1 / 2$ inch wide, slightly glandular hairy when young, bccoming smooth in age; maturing from August to Octobcr.

1)istribution (map on this pagc). Wax currant is morc widely distributed in California than sticky flowcring currant. The range of these species overlaps in the Sierra Nevada but wax currant cxtends into southern California. Also, where the ranges overlap, wax currant is usually more abundant. It occurs on lower momtain slopes and upwards to the Arctic Alpine I,ife Zone in the Sirrra Nevada from Tulare to Plumas counties; in the
Warner Mountains in Modoc County, Mount Shasta, Siskivou County; the higher mountains of Mono and Inyo counties; Mount Pinos in Ventura County; and in the San Gabriel, San Bernardino, San Jacinto, and Santa Rosa mountains. It extends eastward to the Rocky Mountains and northward to British Columbia.

Economic value. The palatability of wax currant is not quite as high as that of sticky flowering currant, but because of its wider distribution and greater abundance is a more valuable food plant. Its rounded growth habit, leafy twigs and branches, and tendency to form open stands give it fairly high local importance.

Browse rating. Good to fair for goats; fair for sheep; fair to poor for cattle and deer; and poor to useless for horses.

\section{Secondary Ribes Species}

Other species or varieties of currants and gooseberries that furnish some browse, particularly for deer and a somewhat lesser amount for domestic livestock, are: hillside gooseberry (R. californicum), white-stemmed gooseberry ( $R$. divaricatum var. inerme), canyon gooseberry (R. menziesii), mountain pink currant ( $R$. nevadense), Sierra gooseberry $(R$, roezlii), pink flowering currant $(R$. sanguineum var. glutinosum), and fuchsia flowering gooseberry (R. speciosum). The over-all browse ratings of these species are given on page 148.

\section{MOCKORANGE (Philadelphus)}

These are large deciduous shrubs with simple opposite leaves, entire or toothed. The large white flowers may be solitary or in clusters. The fruit is a many-seeded capsule.

Although this genus includes a number of attractive garden shrubs, popular especially in cold climate areas, there are only 2 members of this group native to California. Aside from the currants and gooseberries, they are the only other Saxifragaceae of sufficient browse value to warrant discussion. They are relatively low in palatability and usually form too scattered a stand to contribute a large amount of browse. The one form described below represents the browse value of this genus.

Wild Mockorange (Philadelphus lewisii var. californicus), also known as wild syringa. Attractive, looselybranched shrub, 4 to 10 feet high with smooth reddish bark on young branches and brown shrcddy bark on stems of thc previous ycar, old stems gray; leavcs ovatc, $1 \frac{1}{4}$ to $3^{\frac{1}{4}}$ inches long, $3_{4}^{\prime \prime}$ inch to $1 \frac{1}{2}$ inches wide, 3 to 5 veined from the base, margins cntire or finely toothed; smooth or nearly so. Flowers whitc, showy, ${ }_{4}^{3}$ inch to 1 inch broad, usually numcrous, in panicles; May to July.

Distribution. This varicty occurs on rocky slopes and in canyons in the Sierra Nevada from Siskiyou to Trinity countics south to Tularc County, betwecn elevations of 1,000 to 5,000 feet. It is perluaps most frequently cncountered in the ponderosa pine forest. It is nowhere abundant but its profusion of large white flowers make it appear so. A closely related varicty, gordonianus, witl more toothed and hairier leaves, and fewer flowers, oc- 
curs in Siskiyou, Del Norte, Humboldt, Mendocino, and Lake counties.

Economic value. Wild mockorange is browsed limitedly by all domestic livestock and by deer. On recent burns, however, the young sprouts are often eaten closely by sheep, goats, and deer.

Browse rating. Fair to poor for sheep, goats, and deer; poor to useless for cattle; and useless to horses.

\section{Rose Family (Rosaceae)}

The rose family includes herbs, shrubs, and trees both evergreen and deciduous. The leaves are usually alternate, with stipules at the base of the stalk, simple or divided into leaflets. The bisexual flowers are borne either solitary or in clusters. Sepals are 5 or 4 , petals 5 , 4 , or none. Fruit may be a follicle, achene, drupe, pome, or cluster of drupelets.

This large family supplies many genera important in both edible fruit production and plants that are highly valued in landscape design. In the small-fruit class, it offers blackberries, boysenberries, youngberries, raspberries, loganberries, and strawberries. Almonds, apples, apricots, cherries, crabapples, nectarines, peaches, pears, plums, prunes, and quinces-all are contributions of the rose family.

Few gardens in California are complete without at least one or several members of this family-hawthorns (Crataegus spp.); firethorns (Pyracantha); Cotoneaster, ground cover types to tall shrubs; Spiraea; European mountain ash (Sorbus aucuparia); flowering trees such as the crabapples (Malus), cherries, peaches, purpleleaf plums (Prunus spp.); flowering quince (Chaenomeles); Photinia; English laurel (Prunus laurocerasus), and Portugal laurel $(P$. lusitanica). And of course, the traditional rose, for which the family is named, is represented in most gardens.

It is not surprising, therefore, that this family collectively produces a larger volume of browse in California than any other single family. Many species are widely distributed and are highly palatable to livestock and biggame mammals; others, even though of only fair to low palatability, are useful because of the large volume of feed that they produce.

Not all botanists are in agreement as to the identity of certain common variants among the rosaceous species because of the apparent extensive hybridization that takes place among species where genetic constituents are compatible. As pointed out earlier, cliffrose (Cowania mexicana var. stansburiana), desert bitterbrush (Purshia glandulosa), and bitterbrush (Purshia tridentata) are known to have hybridized where their distributions join or overlap in southern California ${ }^{(113,119)}$. Intermediate characters in flowers, fruits, leaf shapes, leaf glands, and occasionally even in sprouting characteristics have been observed. It has been contended by some botanists that desert bitterbrush is but a stabilized hybrid of cliffrose and bitterbrush. Regardless of genetic status, these species appear to have found new ecological niches of economic importance in browse production.
The primary rosaceous browse species are: bitterbrush, western mountain-mahogany, western serviceberry, and chamise; those of secondary rank, but often of high local importance, are cliffrose, desert bitterbrush, curlleaf mountain-mahogany, Sierra mountain misery, blackbush, wild cherries and plums, wild roses, and toyon. Of the secondary browsc species descrt bitterbrush and curlleaf mountain-mahogany will be described and discussed along with the genus to which they belong under primary species.

\section{Primary Rosaceous Species}

\section{BITTERBRUSH (Purshia)}

Purshia is a western North American genus of two shrubby species, both native to California. They are deciduous or evergreen with diffusely branched stems. The leaves are simple, alternate, crowded, deeply 3-toothed or lobed, the margins inrolled. Flowers are pale yellow or white, single at the ends of the branches, or a few in the axils of the leaves. The fruit is a leathery, oblong, hairy achene, about $\frac{1 \%}{4}$ to $\frac{1}{2}$ inch long, that tapers to a persistent style.

\section{Key to the Browse Species}

1. Leaves without depressed glands on the upper surface, inrolled only on the upper margins; arid flats and slopes, eastern and higher western slopes of the Sierra Nevada from Tulare and Inyo counties, northward to the Warner Mountains, Modoc County, thence westward to Shasta, Siskiyou, Lassen counties and northern Trinity Mountains.

. BITTERBRUSH

(Purshia tridentata)

1. Leaves with depressed glands on the upper surface; leaves (not margins only) inrolled; western Colorado Desert, northward to the mountains of the Mohave Desert; Mount Pinos, Ventura County; and desert mountains of Inyo and Mono counties... DESERT BITTERBRush

(Purshia glandulosa)

BITTERBRush (Purshia tridentata) (drawing on page 76). Widely branched silvery shrub, 2 to 8 feet tall. Leaves wedge-shaped $\frac{1}{4}$ to $\frac{1}{2}$ inch long or sometimes to 1 inch long, 3-lobed or toothed at the apex; green and hairy above, densely white hairy beneath, inrolled only on the margins. Flowers white or yellowish, solitary, or few borne at the ends of short branches; April to July. Achenes reach maturity in August and September.

Distribution (map on page 77). Bitterbrush occupies about 7.5 million acres in California, with its principal range lying east of the Sierra Nevada and Cascade Mountains between elevations of 3,500 to 11,000 feet ${ }^{(71,113)}$. It occurs from Tulare and Inyo counties northward to the Wamer Mountains of Modoc County, westward to Shasta, Siskiyou, Lassen, and northern Trinity counties. It extends northward to eastern Oregon and eastward throughout the Rocky Mountains. Typical habitats are open well-drained flats, slopes, and valleys of fairly deep gravelly or rocky soils originating from various parent materials. Common associated plants are 


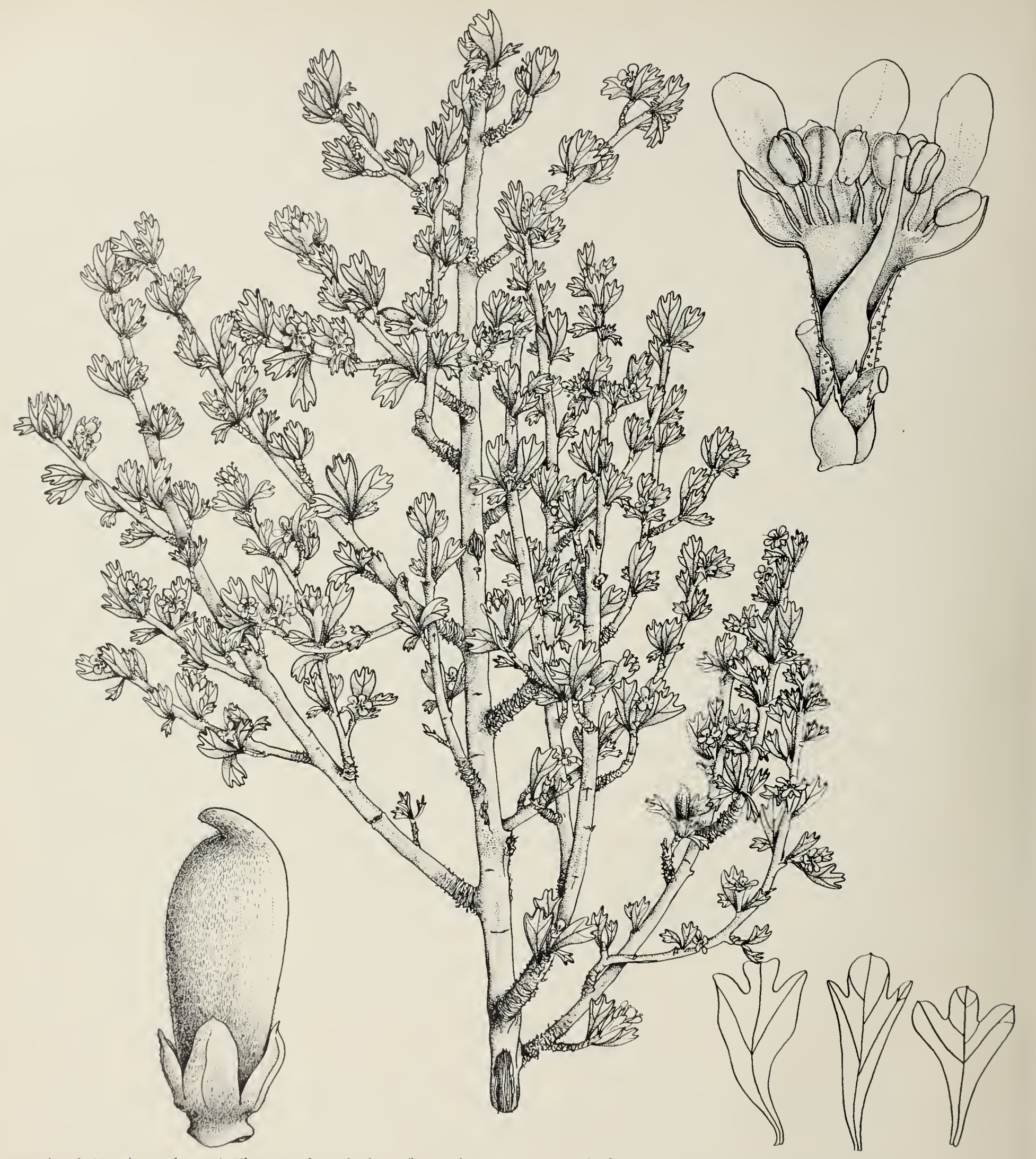

Bitterhorush (Purshia tridentata). Flowering branch; fruit; flower showing structure; leaf variations

This is one of the most important browse species in California-and in much of the WVest-for domestic livestock and big game. In many habi-

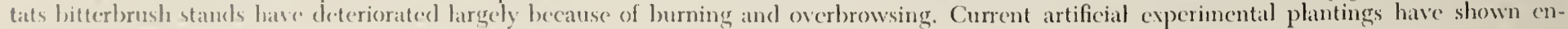
couratging results.

Sagebrusl, corllenf momutain-malogany, ponderosa, Jeffrey, and piñon pines, western juniper, and varions perennial grasses and fortss.

Economic value. In many habitats bitterbrush stands have long been deterionating, largely becanse of burning and/or excessive browsing. Natural reproduction is slow or nsually lacking even where abundant adult stands oceur. This weakness is a significant fact becanse of the great browse value of this species ${ }^{(15)}$.

Bitterbrush is one of the most important browse 
species in California-indeed in much of the West-for cattle, sheep, and big-game animals. East of the Sierra Nevada-Cascade Divide in California it ranks among the highest in browse value. The young leaves and twigs are eaten with much relish by livestock, deer, and antelope, especially in spring, late fall, and early winter.

"Wherever found (on Lake Almanor summer range of the Sierra Nevada) bitterbrush showed evidence of heary dcer use and appeared to be a highly preferred food"(a). The crude protein content is fairly high for native browse plants, ranging from 14 per cent in early summer to 9 per cent in early fall, and from 5 to 7 per cent in mid-winter ${ }^{(\theta)}$. The browse is most sought a short time before the leaves are shed in late fall. It is cropped least by deer in mid-winter when these animals consume some of the naked current twigs, probably in search of variety in the diet. Stomach analyses of the Great Basin deer herd in northeastern California showed that bitterbrush accounted for about 60 per cent of the total volume of food ingested in October, 19 per cent in November, and an average of only about 5 per cent from December to $\mathrm{May}^{(88)}$.

In some areas this shrub is browsed to the full extent of its endurance by domestic livestock in summer and early fall; then in the winter the remaining young twigs are closely cropped by deer, thus seriously lowering its vitality. Where such over-utilization is continued for a few seasons the stand is measurably thinned out ${ }^{(s)}$. Little or no seed is then produced and is limited to the branches that are out of reach of the animals. Safe utilization should provide for not more than about 60 per cent of the current twig length to be cropped each season. Excessive utilization on combination livestock and deer range may necessitate reduction in numbers of both kinds of animals.

Another factor accounting for the decline in bitterbrush in some locations is periodic clefoliation and occasionally killing of bitterbrush by the Great Basin tent caterpillar ${ }^{(33)}$. Attacks are most severe on the east-side area of California. Heavily infested plants may be completed defoliated usually during the period of maximum physiological activity of the plant. One recorded infestation in Modoc County spread over 70,000 acres and completely defoliated the bitterbrush stand, thus reducing the grazing capacity by about 25 per cent. If new foliage is produced the plants are subject to further weakening by livestock and decr browsing. Severe outbreaks do not seem to follow a well-defined pattern. Satisfactory control measures have not yet been developed.

Bitterbrush propagates mostly from seed, but in a few localities it sprouts after a fire, and occasionally it reproduces vegetatively by layering ${ }^{(113)}$. Both sprouting and layering may be influenced by genetic and/or environmental factors. Studies of re-establishing bittcrbrush on critical areas by broadcast seeding or row planting have demonstrated that this can be done successfully on suitable sites if the resulting stand is protected from grazing until the young plants are well established ${ }^{(74,111,113,118,118,1189}$. Re-establishment of bitterbrush in this way is expensive

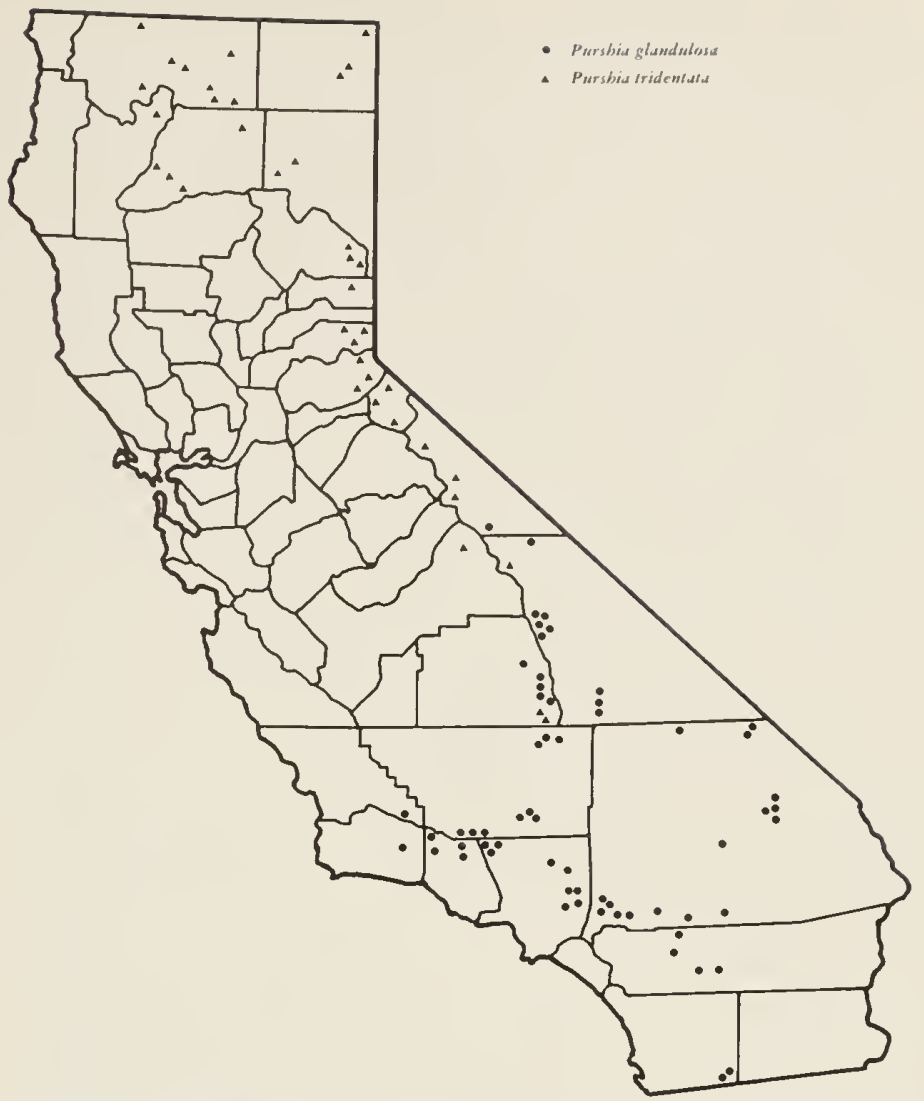

Distribution of desert bitterbrush (Purshia glandulosa) and bitterbrush (Purshia tridentata).

and could only be justified where proper utilization of the stand would be meticulously carried out (pages 2526). Bitterbrush planting programs arc now under investigation in several western states ${ }^{(71,119,103)}$.

Once a depleted bitterbrush stand has been re-established, it may be expected to thrive, under conservative use, over a long span of years. Some bitterbrush plants have attained an age of 160 years or more, and extensive stands are known to be vigorous at ages ranging from 35 to 50 ycars.

Browse rating. Excellent for sheep and dcer; excellent to good for goats; and good to fair for cattle and horses.

desert bitterbrush (Purshia glandulosa) (photo on page 78), also callcd waxy bitterbrush. Erect shrub, 2 to 8 feet high, with grecnish or dark brown bark. Leaves to $\stackrel{3 \%}{3}$ inch long, divided into 3 to 5 linear lobes, or sometimes mcrely toothed, with conspicuous glandular dots or pustules on the upper surfacc and along the margins, slightly hairy above when young or ncarly smooth in age, the leaf blacles rolled inward. Flowers pale yellow or white, $\frac{12}{2}$ inch or less wide, solitary and tcrminal on short leafy side branchlets; April to July. Fruit silvery hairy.

Distribution (map shown above). Desert bitterbrush occupies about 1 million acres and occurs in descrt canyons, slopes, and the mountains bordering the westcrn part of the Colorado Desert and extends northward in the mountains of the Mojave Desert and westward to Mount Pinos, Ventura County, and northward to the basin deserts of Inyo and Mono counties. It extends east- 


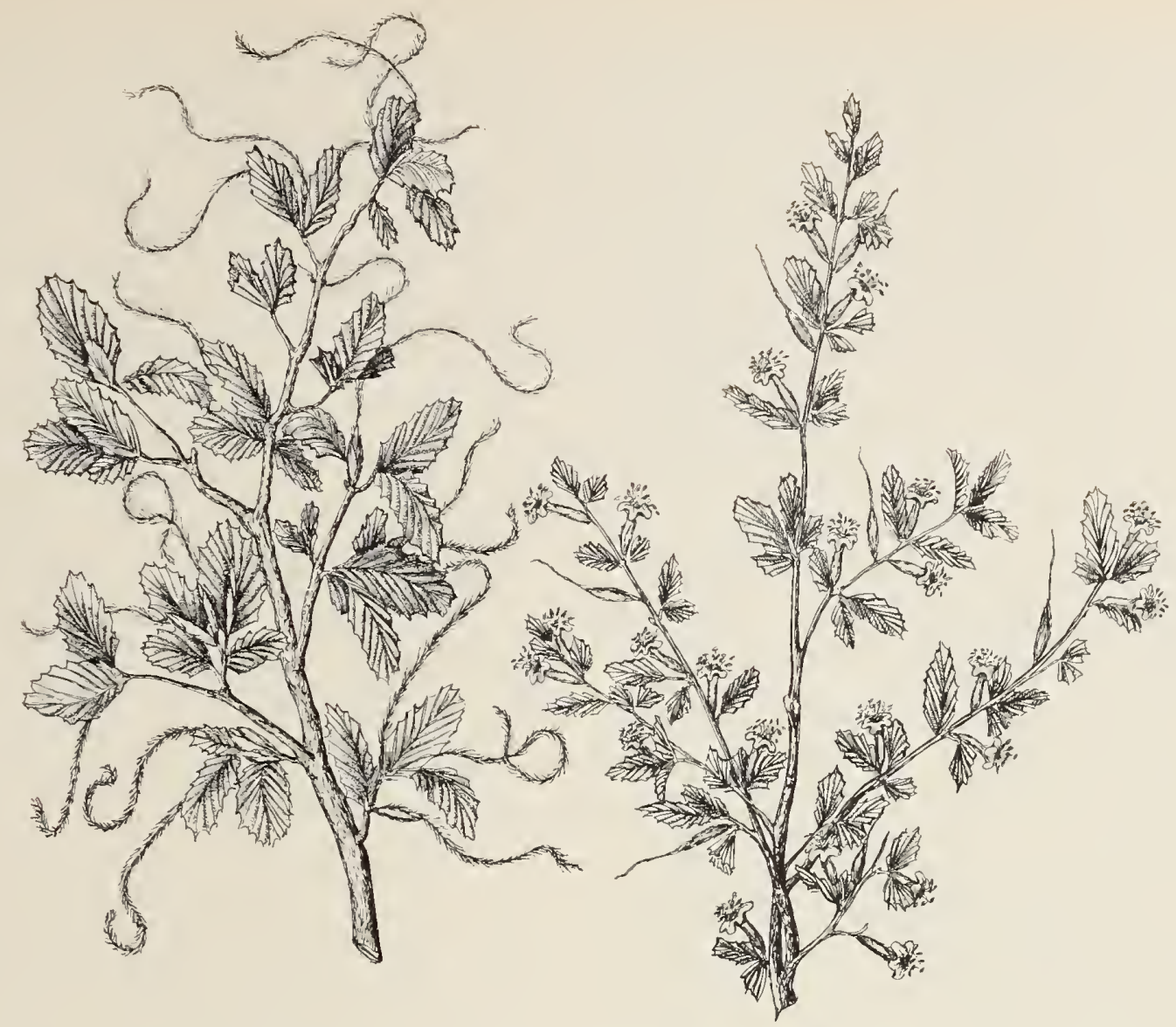

Western mountain-mahogany (Cercocarpus betuloides). Left, branchlet showing plumose twisted styles; right, young branchlet in flower.

This species provides excellent browse for all kinds of livestock and for deer. The numerous sprouts that appear after burning are cropped so closely as often to destroy the plants. It reproduces well by seed. Where possible this species should be increased.

Economic value. This species ranks among the highest as all-around browse (photo on page 80). It is similar in palatability and browse value to true mountainmahogany (Cercocarpus montanus), which is highly esteemed by stockmen and game managers alike throughout much of the Far West outside of California. Chemical analysis of western mountain-mahogany on the Jawbone mule deer range in central Tuolumne County showed that the crude protein content of leaves and twigs was fairly high, averaging 15 per cent in October and 11 per cent in December ${ }^{(2)}$. In another California study, where samples were collected monthly throughout the year, the crude protein content averaged about 7 per cent in January and February, when the stems were bare of leaves, 14 per cent in March, 15 per cent in April, May, and June, 12 per cent in July, August, and September, and about 9 per cent in October, November, and December ${ }^{(11)}$. The data show that the protein levels of the species are somewhat higher, on the average, than in most native browse species ${ }^{(14)}$. After the leaves are shed in late fall the twigs remain palatable and are cropped, notably by deer, throughout the winter.

Western mountain-mahogany endures close browsing fairly well. When cropped back repeatedly it tends to assume the desirable bushy and spreading form, which enhances its yield of browse, rather than allow it to attain the tree habit.

Studies reveal that this species might be increased in
Distribution of western mountain-mahogany (Cercocarpus betuloides) and curlleaf mountain-mahogany (Cercocarpus ledifolius).

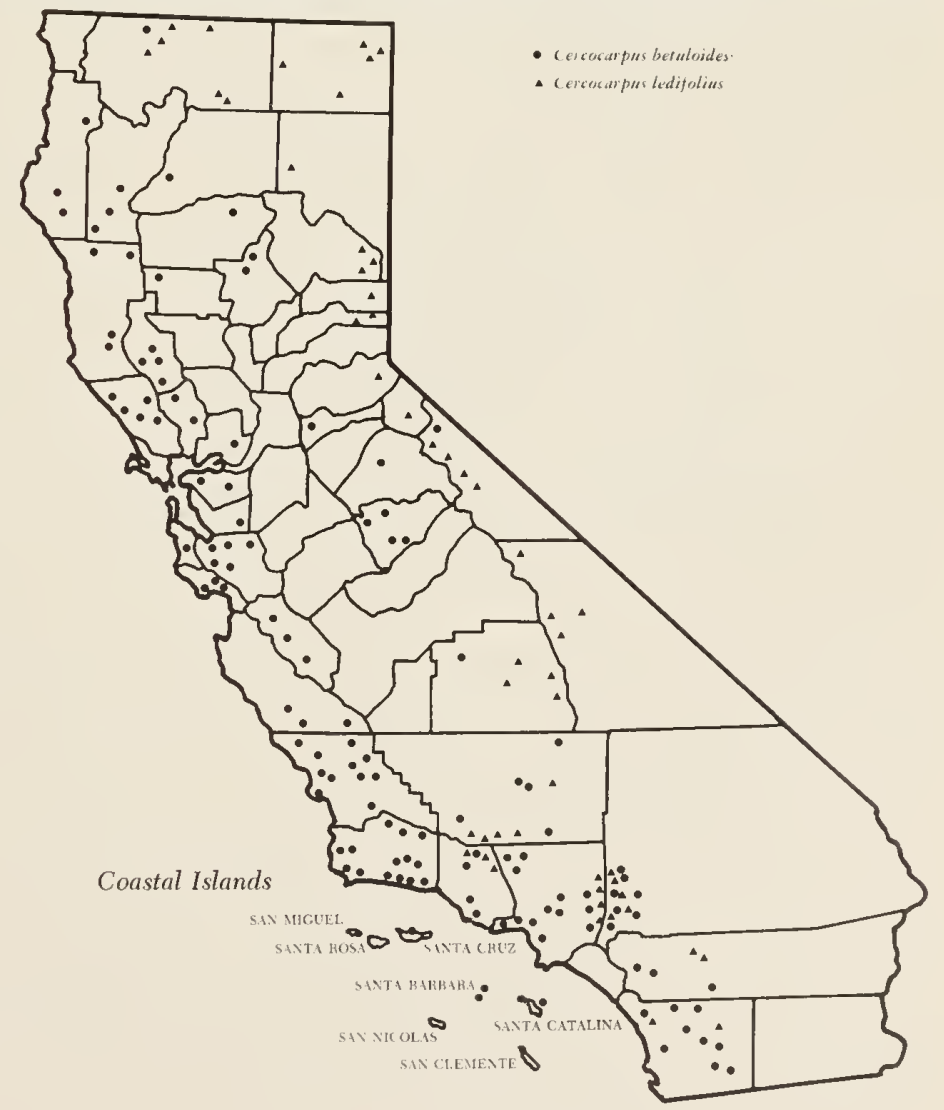




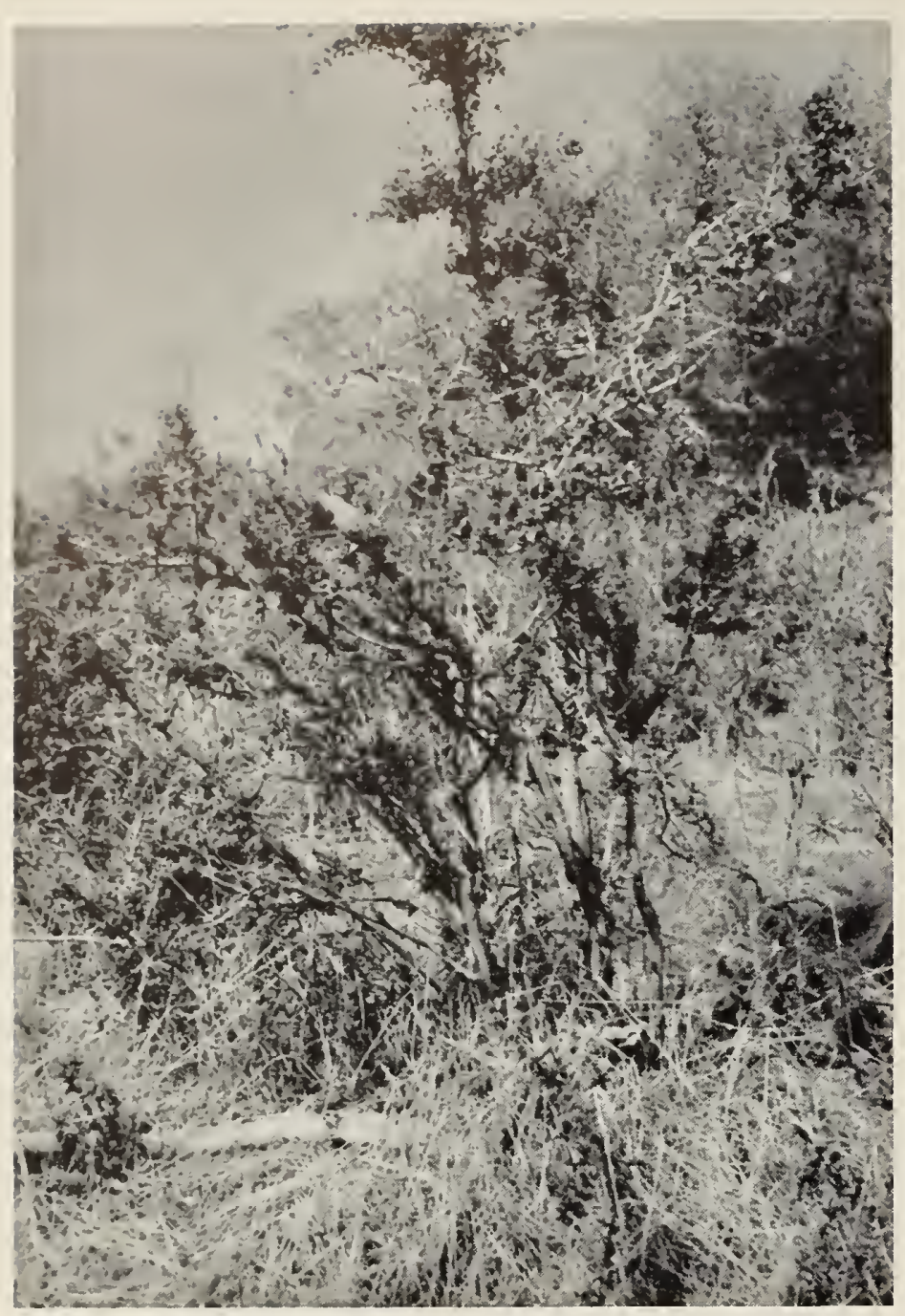

W'estern mountain-mahouany (Cercocarpus betuloides) showing heavy utilization by decr. Note the numerous naked lower stems caused by close cropping. Madera County.

abundince by timely control burning ${ }^{(1)}$. The fire should be restricted to years of heavy seed erop, and the burning delayed mitil the seeds are nearly ripe but before they are shed. "The ideal fire scems to be one intense enough to kill the mountain-mahogany trees and other shrubs but not so severe as to injure the seeds on the trees"

Although a few western mountain-mahogany seedlings become established in good growth years withont prescribed buming, the majority die as a result of severe competition witl associated vegetation. The abundant tender spronts that appear after a severe fire are so palatable to livestock and big game as to be killed unless grazing is carefully controlled. Deer tend to crop the twigs so closely throughout the winter that they inflict serere damage. In future browse range rejuvenation in (Californial by planting, it seems probable that westem momatin-mahogany will be included among the few speciess sedecterl for this purpose.

Brouse rating. Excellent for deer; excellent to good for sheep and groats; good for cattle; and good to poor for horses.
CURlleaf Mountain-Mahogany (Cercocarpus ledifolius) (drawing on this page), also ealled desert mountain-mahogany and desert mahogany. Evergreen shrub 6 to 12 feet high, or oceasionally a tree up to 30 feet high, with a trunk $1 \frac{1}{2}$ to 2 feet in diameter, with gray, rough bark, furrowed on old stems, smooth on young branches. Leaves leathery, resinous, elliptic or lanecolate, pointed at both ends, $\frac{1}{2}$ to 1 inch long about $\frac{1 / 4}{4}$ inch wide, dark green and smooth above, white hairy beneath, the margin entire and inrolled towards the lower surface. Flowers commonly solitary, or sometimes 2 to 8 in a eluster; April and June. Fruit with twisted plumose style 2 to 3 inches long; the seeds, usually numerous, mature late in the autumn.

Distribution (map on page 79). Curlleaf mountainmahogany typically grows on warm rocky and arid slopes, flats, and eanyon walls, from 4,000 to 8,500 feet elevation, in the mountains bordering the Colorado and Mojave deserts, San Jacinto, San Bernardino, and San Gabriel Mountains, westward through the Tehachapi Mountains to Mount Pinos in Ventura County. It also oceurs on easterly summits and slopes of the Sierra Nevada from Kern to Modoc counties, thence westward to Siskiyou County. Elsewhere it oceurs northward to Washington, eastward to Nevada, Utah, Colorado, Idaho, and Montana. It grows with a great variety of plants, ranging from sagebrushes and piñon-juniper to subalpine forest.

Economic value. The nutritive value of curlleaf mountain-mahogany compares rather favorably with that of

Curlleaf mountain-mahogany (Cercocarpus ledifolius). A good to excellent winter deer browse, but of moderate to low value for domestic livestock.

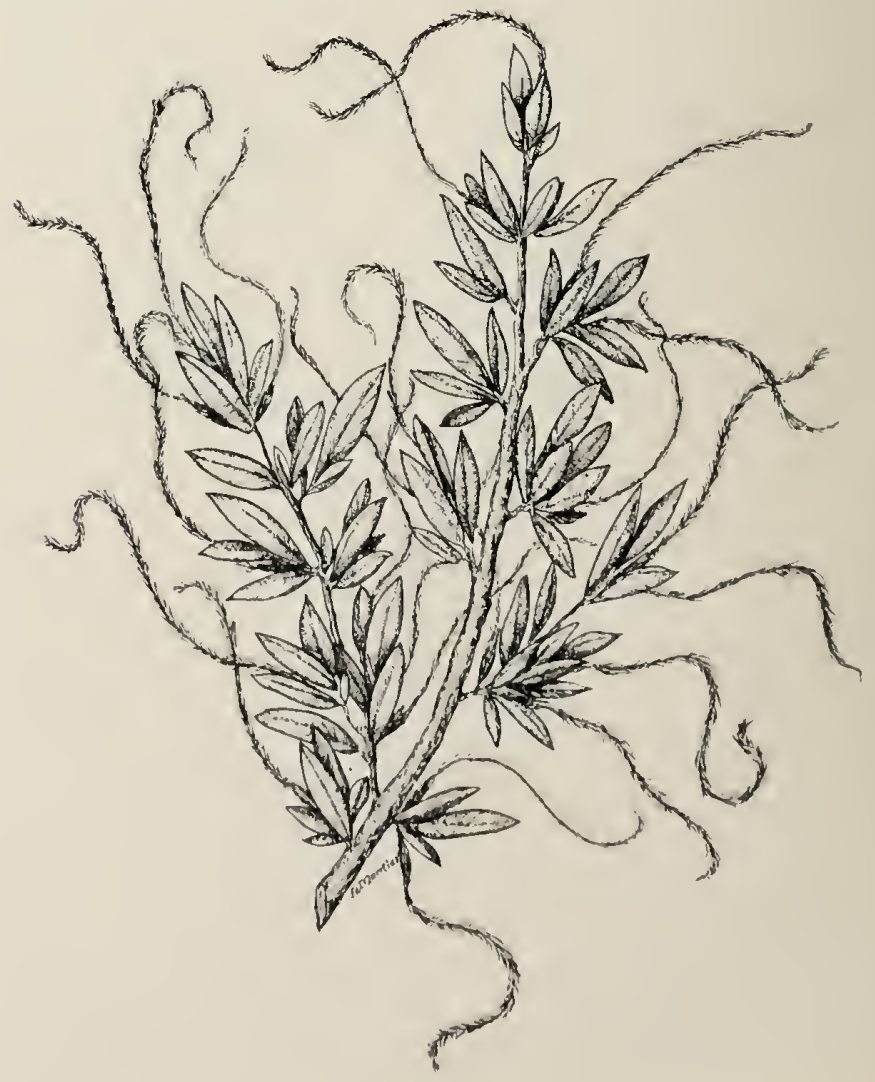


other highly regarded evergreen browse species. The crude protein content, for example, averaged about 15 per cent in April, May, and June, and between 7 and 9 per cent in the other months of the year ${ }^{(11)}$.

During summer months curlleaf mountain-mahogany is cropped little or not at all by domestic livestock or deer, but is utilized by all these animals in varying degree during the fall, winter, and spring months. Since the old leaves are not shed until the end of the second year, both foliage and young twigs are eaten. It is superior winter feed for big-game animals, and is cropped moderately to closely by them in late fall and early spring. Where these animals yard up in patches of "curlleaf" they take virtually all twigs within reach. Such close cropping has resulted in producing mature tree-like stands with conspicuous browse line beneath.

In Utah a study of the suitability of browse species for re-vegetation of depleted deer ranges indicated that curlleaf mountain-mahogany grows too slowly for reseeding purposes ${ }^{(119)}$.

Browse rating. Excellent for deer; good for goats; fair to poor for sheep; and poor to useless for cattle and horses.

\section{SERVICEBERRY (Amelanchier)}

The California plants of this genus show considerable variation, especially in the amount of hairiness of the leaves, and there is much intergradation throughout their range. Because of this intergradation some botanists prefer to consider the California plants as one speciesAmelanchier alnifolia. A more recent manual ${ }^{(108)}$ separates the California representatives into four species and one variety. However, since there is so much intergradation, and the differences are not definitely definable, the California plants are considered as one species in this discussion.

WESTERN SERVICEBERRY (Amelanchier alnifolia) (drawing on this page), also called sarvisberry, alderleaf sarvisberry, western Juneberry, and pigeon berry. Rigid, erect, deciduous shrub 3 to 10 feet high, or occasionally to 15 feet high, with spreading branches. Bark gray or reddish brown on younger branches. Leaves simple, alternate, usually borne on short side branches, broadly oval, to elliptic, or roundish, rather thick, ${ }^{3}+4$ inch to $1 \frac{13}{4}$ inches long, $\frac{1}{2}$ to 1 inch wide, dark or pale green, smooth or hairy above, paler and slightly hairy beneath, margins entire or toothed to below the middle. Flowers bisexual, white, in clusters 1 to 2 inches long, rarely solitary, at the ends of the season's leafy branches; sepals 5 , petals 5 , white, roundish to oval, stamens 10 to 20 , pistils 2 to 5 more or less united (ovary below sepals and petals); blooms from April to June. Fruit a bluish or purplish berry-like pome, ${ }_{1 / 4}^{\prime}$ inch wide, juicy and edible.

Distribution (map on page 82). It occurs on all slopes and flats, growing in canyons and gulches and on ridge tops, on both moist and rich soils, and in dry rocky and rather sterile soils, in the ponderosa pine and Douglasfir zones. In the mountains of southern California and in

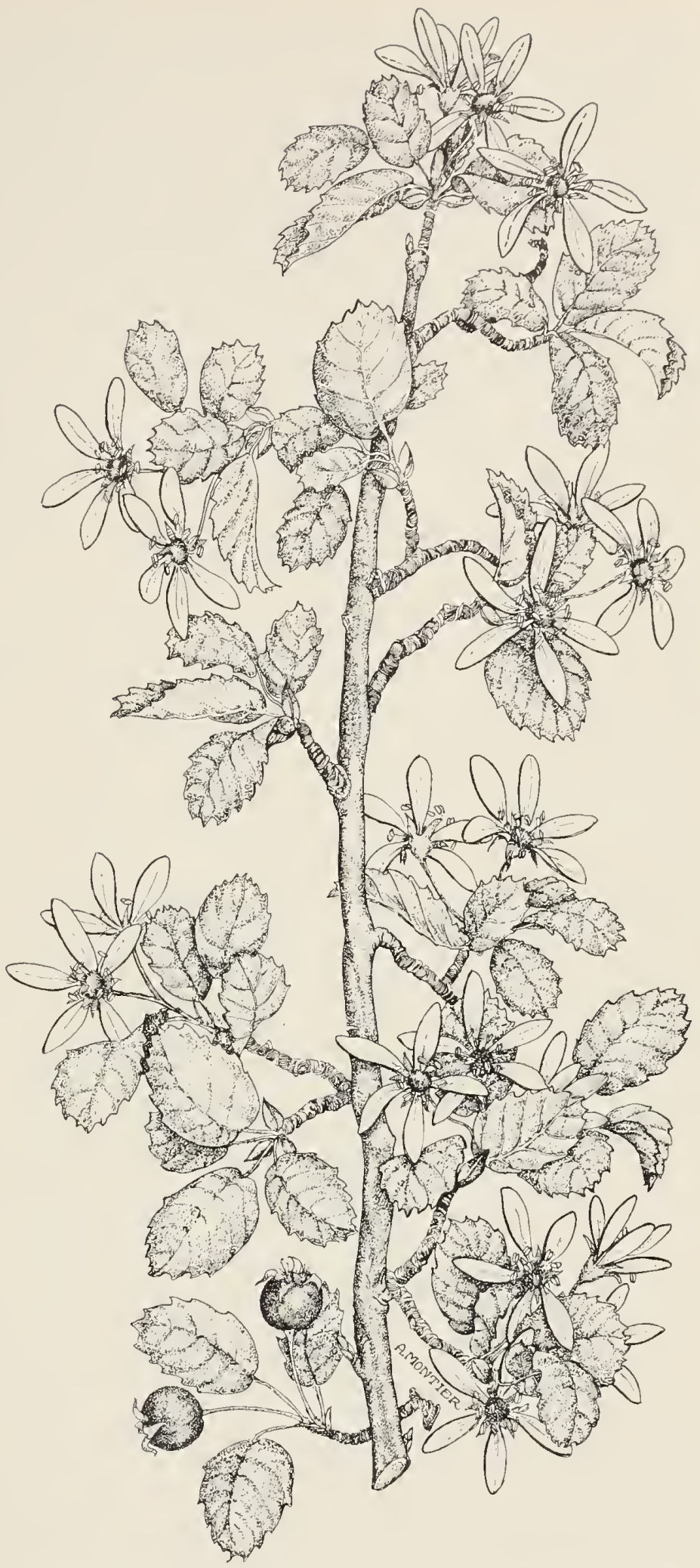

Western serviceberry (Amelanchier alnifolia). This plant is an esteemed browse plant, being cropped rather closely both by domestic livestock and deer. The young sprouts, as after a fire, are cropped closely.

the Sierra Nevada it occurs between 2,500 to 9,000 feet elevation, and in the Coast Ranges between 100 and 6,000 feet in altitude. It is found in several forest communities where rainfall is fairly high.

Economic value. Westem serviceberry is sought by grazing animals over its entire range. Its high rank as 


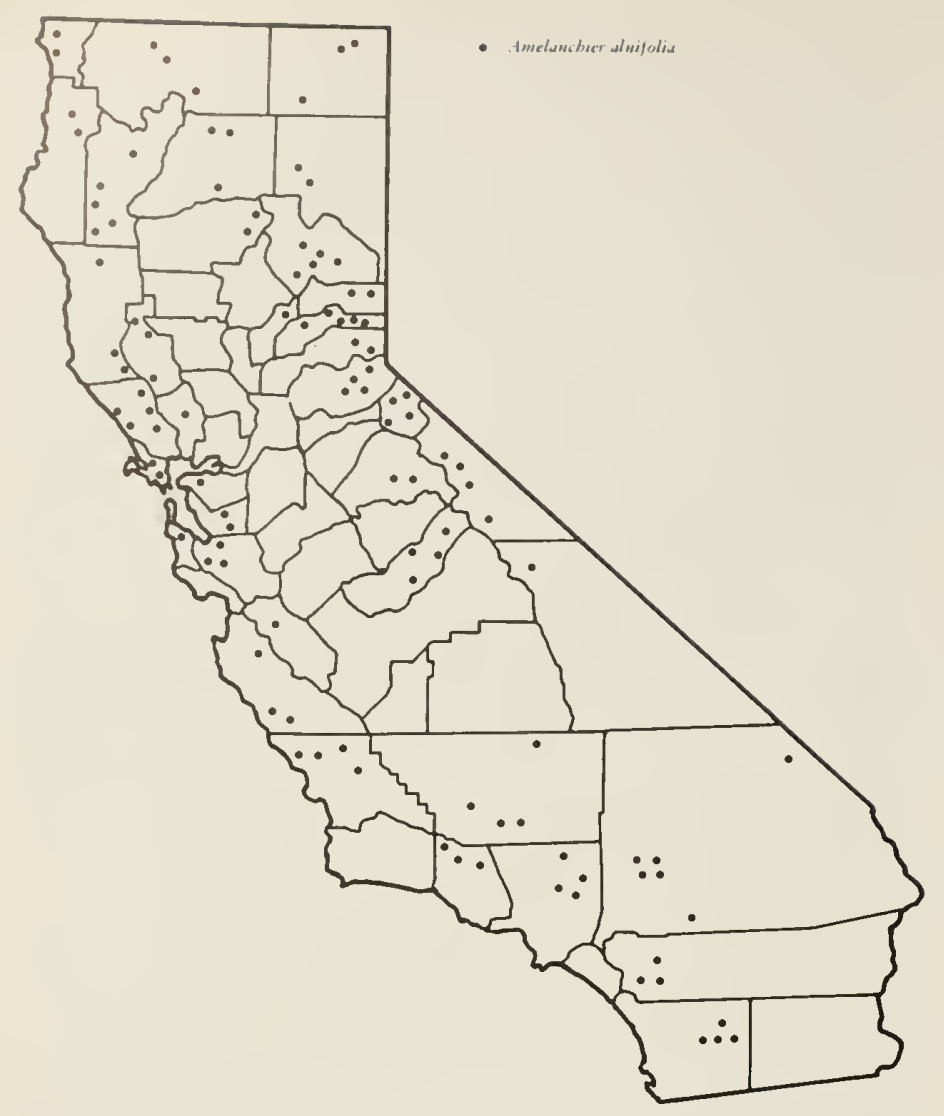

Distribution of western serviceberry (Amelanchier alnifolia).

browse is accounted for by its palatability, wide distribution, its abundance in many localities, and its apparently high nutritional values. Analyses of samples collected on dcer range in northern California showed that the crude protcin contents of leaves and current stems was 13.3 per cent in June, 11.3 per cent in August, 6.8 per cent in Octoher, and 4.3 per cent in November ${ }^{(11)}$. Similar studies in Utall ${ }^{(39)}$ gave crudc protein values of the leaves alone of abont 12 per cent in the early season, 11 per cent in mid-scason, and 12 per cent in the late scason. The levels of lignin-largcly indigestible material-fluctuated but little throughout the season and avcraged much the same as in other good deciduous browse species. It was measurably ligher in the stems (20.5 per cent) than in the leaves alone ( 15 per cent).

Since westem servicelserry is a spronter it survives and grows rapidly after a fire. The young leaves and twigs are especially palatable, and the mature foliage is also browsed, particularly by goats.

Browse ruting. Good for goats; good to fair for cattle, sliecp, and deer; and fair to poor for horses.

\section{CHA.MISE (Adenostoma)}

Two species represent this genus in California. Adcnostoma sparsifolium, alled red shanks or ribbonwood (drawing riglit), occurs in the chaparral from Santa Barhara Cominty sonth to Sam Diego and westem Imperial combities, extending into Lower Callifornia. It hats virtually no browse value (see page 146). However, the second species, $A$. fasriculatum (page 83), is one of the most (onmon shmos of Califomia's chaparral atreats.

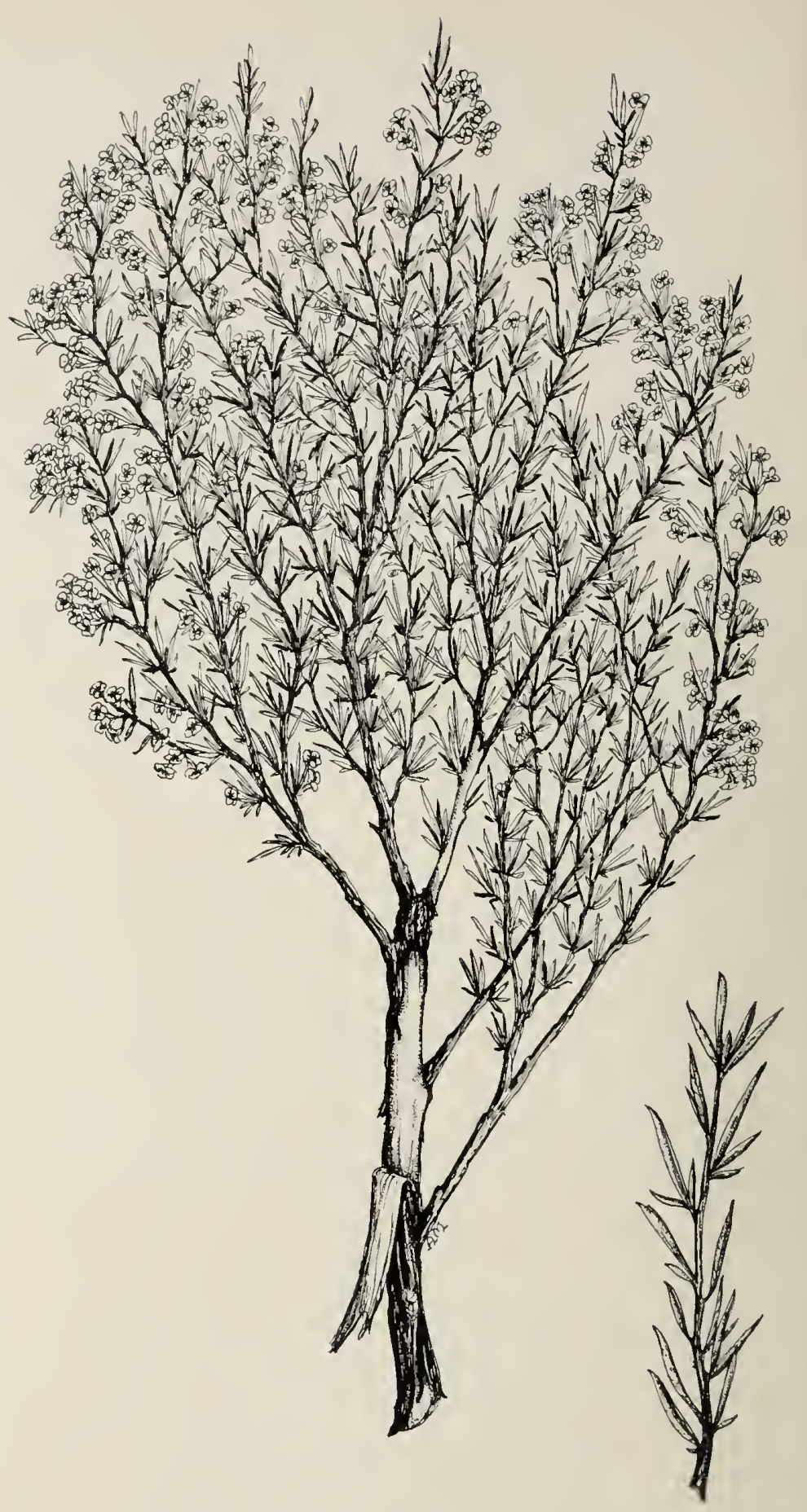

Red shanks (Adenostoma sparsifolium). A speeies of restrieted distribution and abundanee in the ehaparral. Its browse value is low to nil.

\section{Key to the Browse Species}

1. Bark gray or very dark on old stems; leaves usually clustered, occasionally single; flowers white, without stalks, in compact clusters $1 \frac{1}{2}$ to 4 inches long; common shrub of California chaparral . . . . . . . . Cinamise

(Adenostoma fasciculatum)

1. Bark somewhat reddlish on old stems; leaves not clustered; flowers white or rarely pinkish, stalked, in loose clusters $\%$ inch to $2 \frac{1}{2}$ inches long; chaparral, 2,000 to 6,000 fect elevation, Santa Barbara County, southward to San Dicgo and western Imperial County . . nuly suanks (Adenostomin sparsifolium) 


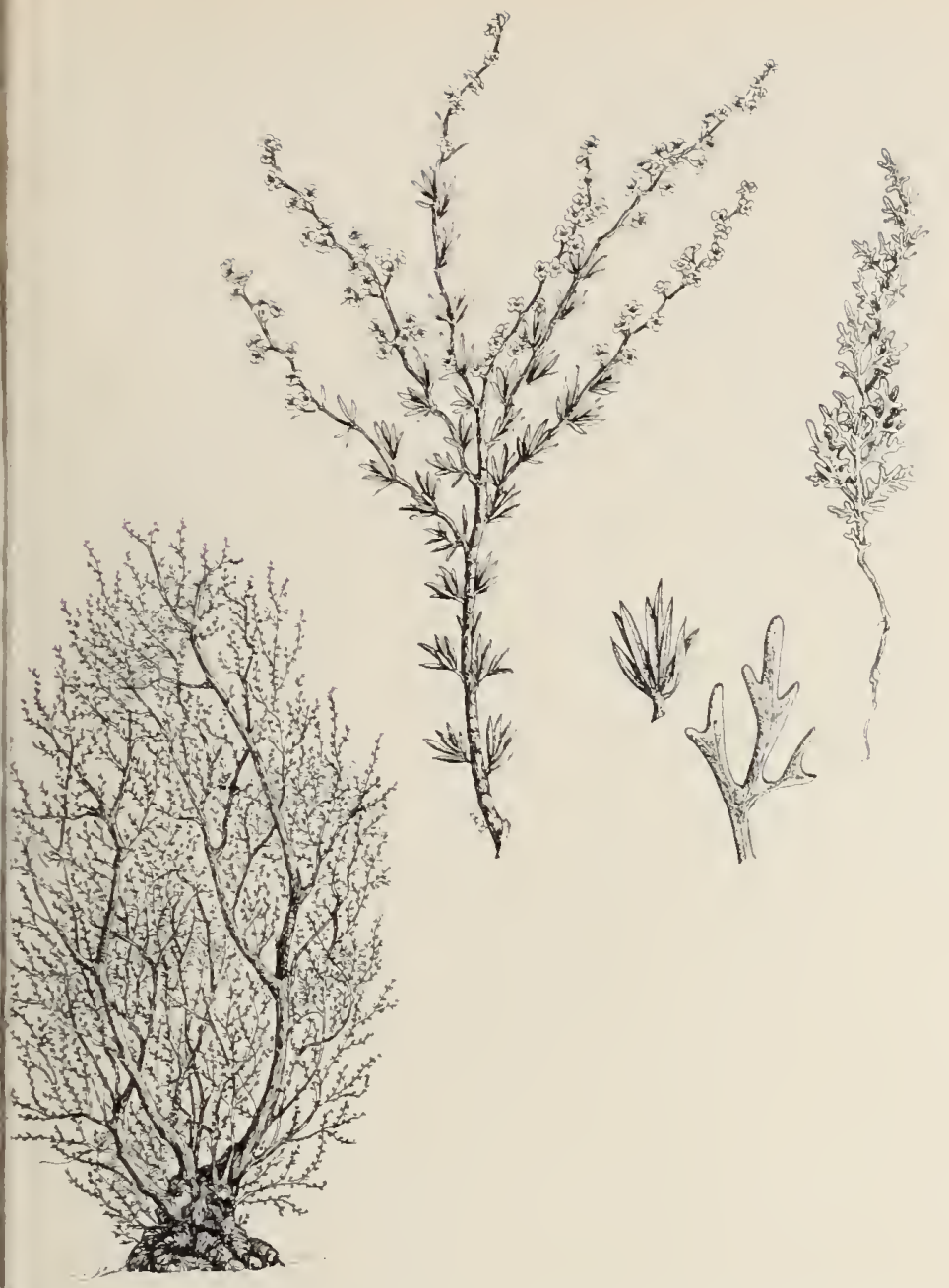

Chamise (Adenostoma fasciculatum). Left, showing growth habit of adult bush; right, details of the numerous clusters of linear leaves. Although the palatability of this species is not high for any kind of animal, it furnishes a large volume of medium quality browse on reeently burned areas. It is regarded as the "bread and butter" plant of forage for deer over extensive areas ${ }^{(145)}$.

CHAגISE (Adenostoma fasciculatum) (drawing above), known also as greasewood. Evergreen, diffusely branched, somewhat resinous shrub, 2 to 12 feet high, or occasionally higher. Bark gray or very dark on old stems. Slender branches densely clothed with alternate clusters (fascicles) of linear needle-like leaves, $\frac{11}{4}$ to barely $\frac{11}{2}$ inch long, sharp-pointed, the leaves of seedlings and sprouts divided into 2 to several linear lobes. Flowers small, white, in terminal feathery clusters, $1 \frac{11}{2}$ to 4 inches long; February to July. Fruit a small achene; seeds maturing from mid-summer to late fall.

Distribution (map on this page). Chamise probably has the widest range and produces more volume of growth than any shrub in California ${ }^{(128)}$. It is usually the dominant and often the most aggressive woody species on the lower mountains, ridges, and mesas of the chaparral association. It extends throughout the Coast Ranges, the mountains of southern California, and the lower Sierra Nevada foothills. Stands vary from nearly a pure cover to mixtures of manzanitas, ceanothus, and various other chaparral species.

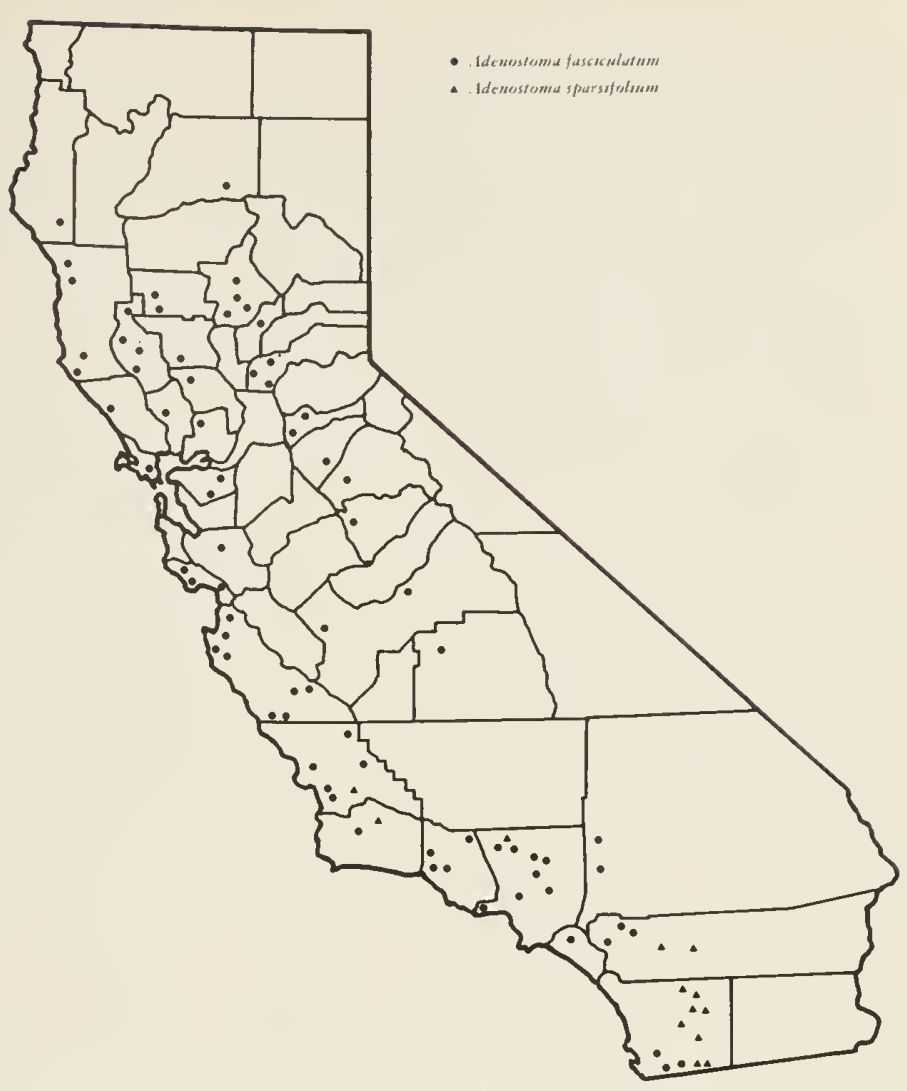

Distribution of chamise (Adenostoma fasciculatum) and red shanks (Adenostoma sparsifolium).

Economic value. Chamise is not highly palatable to either livestock or big game. Because of its wide distribution and abundance, however, it furnishes so large a volume of medium to low quality browse as to be classed among the primary brush species. The sprouts, which appear in great abundance after a fire, account for the main volume of browse (photo on page 84). In most localities the sprouts lose most of their attractiveness to grazing animals the third year after a fire ${ }^{(43,155)}$. This fact has induced some stockmen to burn their chamise lands on a three-year rotation basis ${ }^{(120)}$. Most old stands are too dense and high for grazing animals to work through them or reach much of the current growth. By periodic burning the old stand is largely replaced by young sprouts. This feed is best utilized from spring to carly summer by sheep and goats, and for a longer period by deer.

The abundance and wide distribution of chamise is partly accounted for by its capacity to occupy a great variety of habitats, including severe sites and shallow soils, such as the Maymen series, which are less than 12 inches deep, as well as some of the more productive lands. Its stability is enhanced by its strong vegetative reproduction and the vast numbers of seedlings that spring forth from accumulated seed crops which germinate readily after a fire ${ }^{(133)}$. These characteristics account for the terin "fire type" for the chaparral of which chamise is a prominent component.

The nutritive value of chamise is not high. During the winter months, from December to February inclusive, the crude protein content averaged about 7 per cent; 
during the spring months-Mareh, April, and May-it averaged about It per eent; in the summer-June, July, and August - the arerage was approximately 8.5 per eent; and in the fall months-Septcmber, Oetober, and November-it deelined to about 6 per cent ${ }^{(10 .}{ }^{11)}$. Young chamise leaves are measurably higher in crude protein than at later growth stages. These levels are lower than in certain superior browse spccies at the same growth stage ${ }^{(320)}$. In deer feeding trials with chamisc the protein digestion coeffieient was virtually negative, whereas for alfalfa hav, bitterbrush, and big sagebrush the coefficients were 71.4 per cent; 56.8 per cent, and 41.6 per cont, respectively. On the other hand, chamise, as well as many other browse specics studied, contained a potentially adequate source of digestible energy. Digestion trials with sheep and decr of the new chamise growth collected in May on the Hopland Field Station in southeastem Mcnclocino County, showed these animals digestcd alfalfa hay protein much better than that of chamise ${ }^{(12)}$. This study further substantiated the conclusions, that chamise is a satisfactory feed for supplying total digestable energy but is a poor sourcc for meeting protein requirements.

Although relatively low in palatability, except when the shoots are young, the plant is eropped by deer to a consiclerable cxtent throughout the year in the northem Coast Ranges. In Lakc County it has been referred to as the "bread and butter" plant for deer ${ }^{(1.5)}$. During the summer, when nutritive values of most food plants are low, deer-and goats to some extent-strip the leaves of ehamise from the straight root-erown sprouts from between thcir incisors, lcaving the stems almost naked ${ }^{1206}$.
Such browsing induces fresh leaf growth and extends the season of cropping upon this plant. Moderate browsing stimulates regrowth of suceulent sprouts, whereas close continuous browsing will eventually kill the stand.

In 1956, a study was made to determine twig elongation and the pattem of ehamisc growth ${ }^{(5)}$. Three chamise growth forms were studied: mature plants 6 to 8 feet high; plants that were hedged by deer browsing up to 3 fcet in height; and root crown sprouts which came up after the tops had been killed by fire. The crown sprouts grew faster and for a longer period than did those on the hedged or the ungrazed mature plants. The time when the twigs hegan to elongate was approximately March 24 for the mature and hedged plants and slightly later for the crown sprouts. Twig elongation ceased by June 23 on mature plants, July 24 on hedged plants, and not until late autumn on the crown sprouts. The patterns of twig branching between the growth forms showed littlc difference except in the amount of branching. Most of the twigs on the hedged and the mature plants did not branch. Removal of the terminal bud or of axillary or vegetative growth resulted in leaf enlargement. This implies that additional plant material would be produeed if twigs were cropped back during the growing season.

Management studies in Lake County, which were primarily concemed with methods and effects of opening up selected arcas of a few to several acres per section of land by mechanical mcans, burning or spraying, revealed that more and better fced resulted from this practice ${ }^{(13.3}$ (43). Spraying with 2,4-D is effective in the spring, followed by fall burning ${ }^{(\mathrm{ss})}$. The plan should provide that not more than 70 per cent of the brush area be so treated

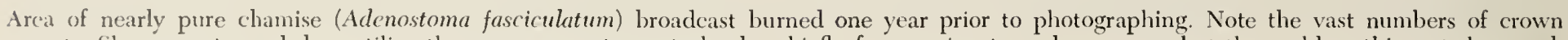

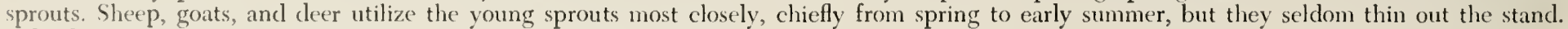
Palatability is low after the third year of burning. Shasta County.

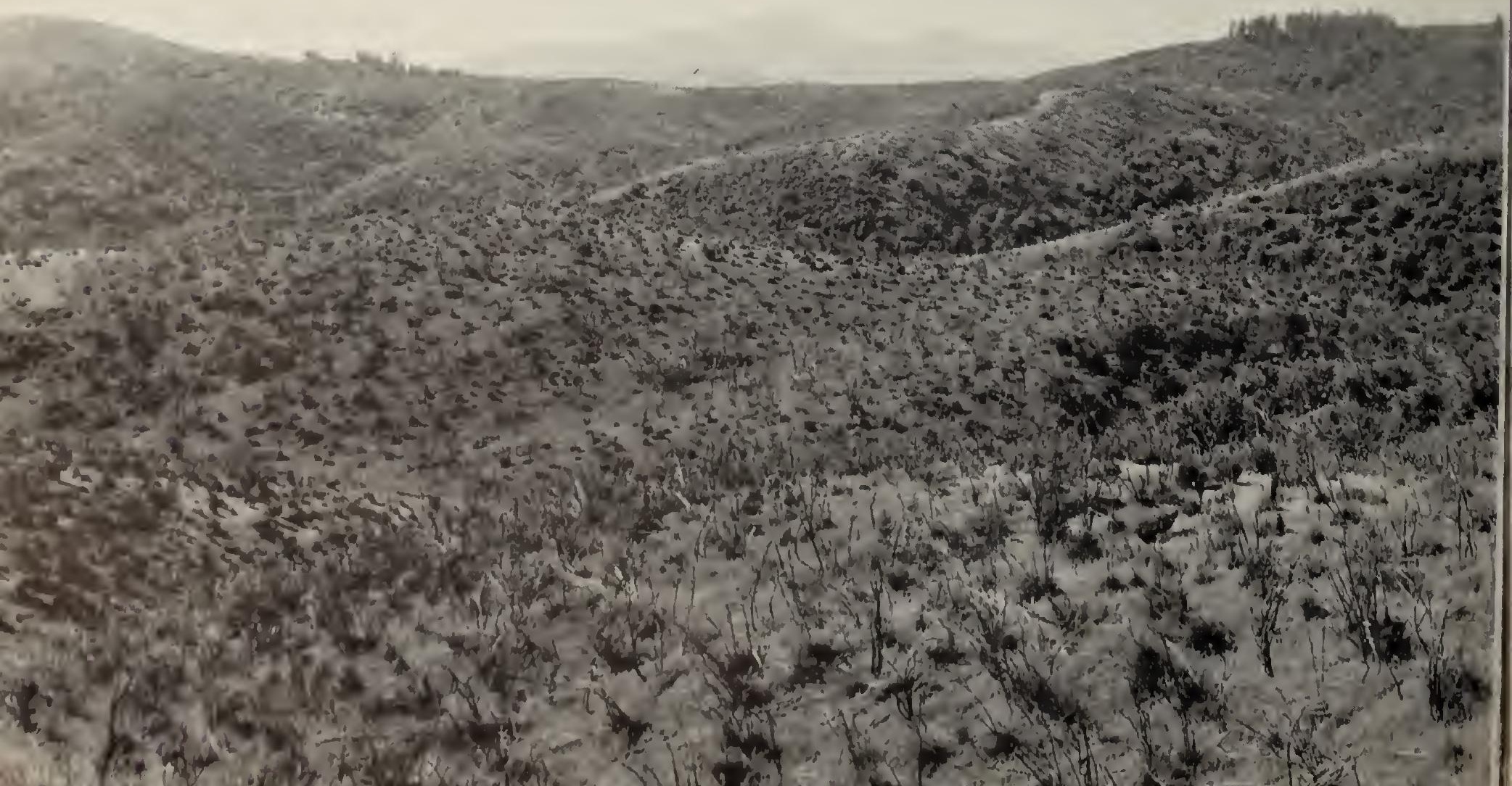




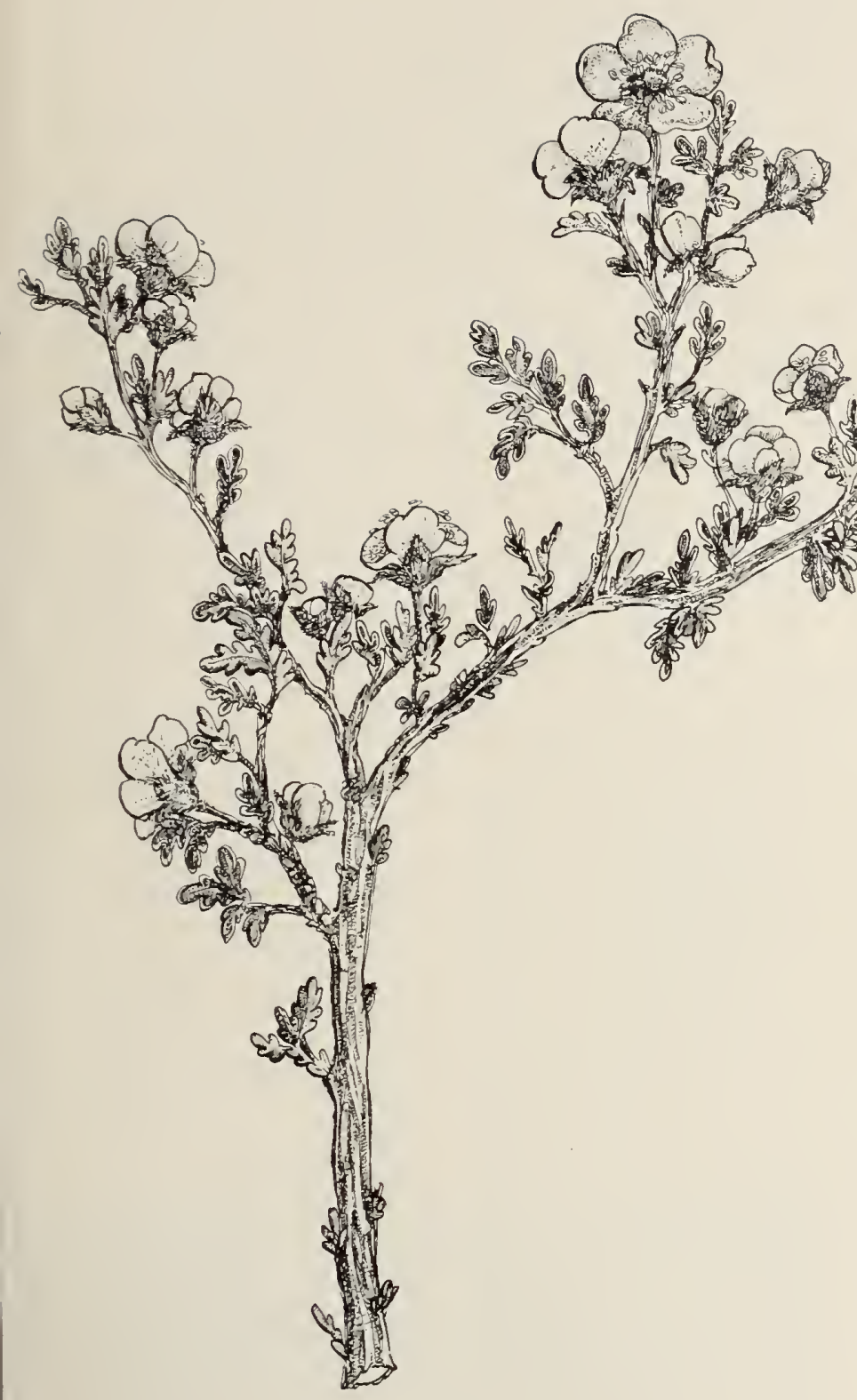

to insure adequate brush cover for needed shelter. To supplement the brush sprouts and other feed, the opened-up units should be seeded to suitable grasses and legumes to maintain a diet for grazing animals.

Because of its relatively low browse value no serious attention has been given to extending the range or of reestablishing chamise where the stand has been killed out. Nevertheless, this shrub is useful for watershed protection on the vast acreage of soils that tend to be so shallow and low in nutrients that herbaceous or other more desirable vegetation is poorly adapted to occupy such areas.

Browse rating. Good to fair for sheep, goats, and deer, notably on newly burncd areas; poor to useless for cattle; and useless for horses.

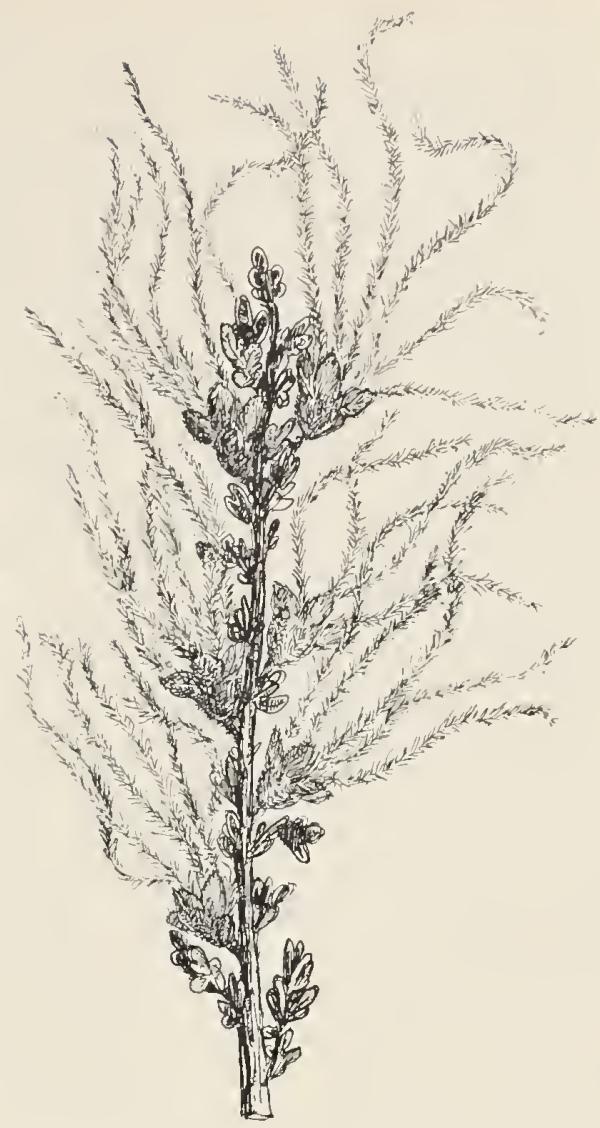

Cliffrose (Cowania mexicana var. stansburiana). Although this species is restricted to dry mesas, it is an excellent deer browse and is much relished by sheep and goats. Cattle also crop it with considerable relish. Physical injury to individual adult plants occurs frequently where hungry animals break the brittle branches. It frequently hybridizes with both species of bitterbrush.

\section{Secondary Rosaceous Species}

\section{CLIFFROSE (Cowania)}

This genus is represented by two varietics of the species in California. However, only the variety described below is important as browse. The pertinent characters of both the genus and the species are included in the varietal description.

Cliffrose (Cowania mexicana var. stansburiana) (drawing on this page), also known as quinine-bush, bitterbrush, and bitter aloes. Much-branched, spreading, evergreen shrub, 3 to 12 feet high, or a small tree 20 to 25 feet high in favorable habitats, with gray shaggy bark. Leaves simple, alternate, roundish in outline, $\frac{1}{4}$ to $\frac{1 / 2}{2}$ inch long, 3 to 5-divided or lobed, the lobes inrolled, glandular dotted and green above, white hairy beneath. Flowers solitary, cream colored, yellowish, or rarely white, $1 / 2$ to 33 inch broad; April to June. Fruit an oblong achene, about $1 / \otimes$ inch long, with an elongated feathery style 1 to 2 inches long; seeds mature in September and October.

Distribution (map on page 86). Cliffrose occupies arid mesas and canyon slopes from about 4,000 to 8,500 feet elevation in the castern Mojave Desert from the White 


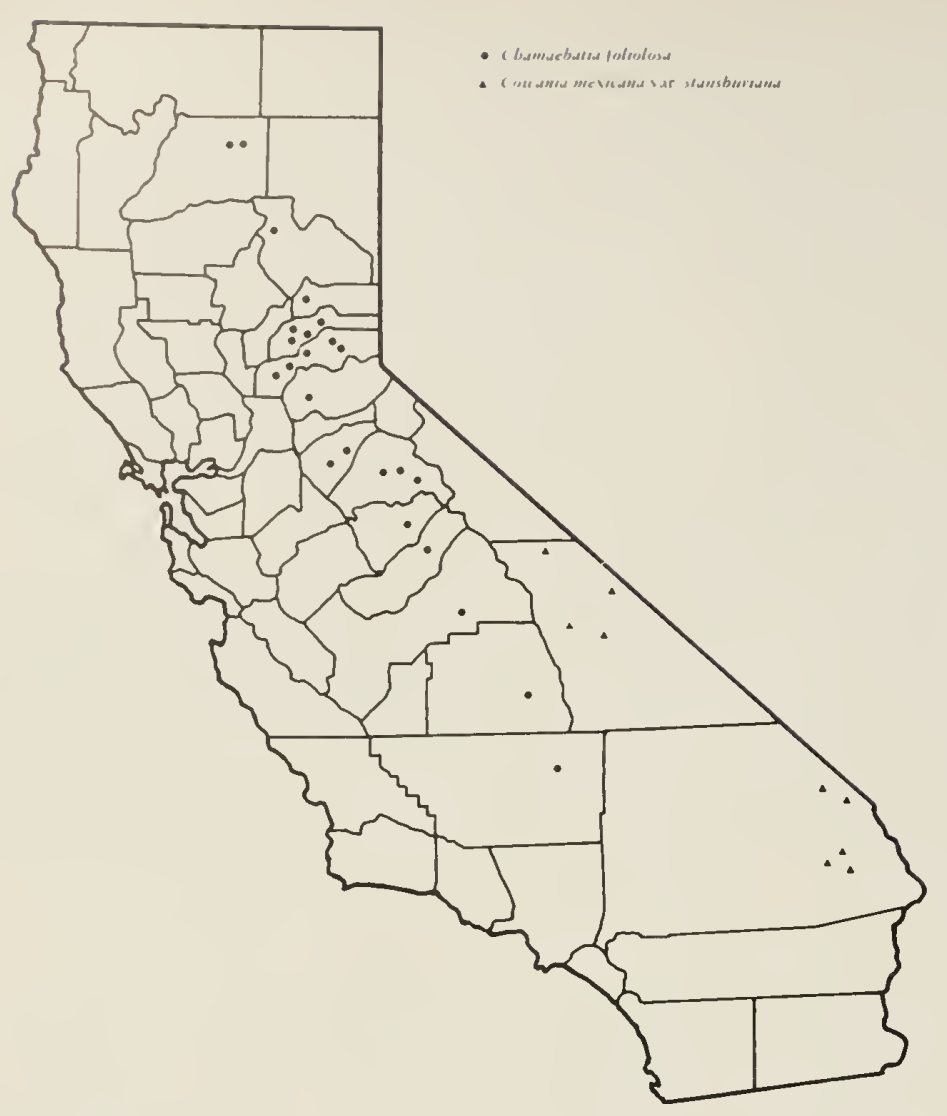

Distribution of Sierra mountain misery (Chamacbatia foliolosa) and cliffrose (Couania mexicana var. stansburiana).

Monntains to the Providence Mountains of San Bernardino and Inyo counties. It occurs rather commonly in the Joshua trec and piñon-juniper associations. It extends eastwards to New Mexico and southward to Mexico; usially occurring in scattered stands. Cliffrose freely hybridizes with both species of bitterbrush.

Economic value. Onc adverse factor as a browse plant is that the older branches are so brittle that hungry animals often break them, thus somctimes decreasing its yicld and vigor pcrceptibly. On cattle or shcep range overutilization of cliffrose is likely to be browsed to the cxtcnt of its cxtermination if the animals are not properly distributcd or if the grazing season is overly long (photo on the right). Another unfavorable factor is its rather restricted distribution. The high sclectivity of cliffrose by grazing animals places it in the category of a fairly important food plant. It is also utilized closcly by deer and desert bighorn sheep.

Browse raling. Excellent to good for deer; good for goats; good to fair for shecp; fair to poor for cattlc; and poor to inseless for horses.

\section{B L A CK BUSH (Coleogyne)}

The single species described below is the only representative of this genus. It is native to sonthern California, Arizona, Utalı, sonthwest Coloraclo, and Nevada.

131.ACK BESH (Coleogyne ramosissima) (clrawing on page 87), also called black hrush. Deciduons, crect, densely branched, spiny shrub, 1 to 6 feet high, with divergent opposite branches and ashy gray bark which becomes black with age. Leaves simple, opposite, linear, or club-shaped, $\frac{1 / 4}{14}$ to $\frac{1}{2}$ inch long, usually clustered at the ends of the branchlets, gray, flat above, 2 to 4 -grooved beneath; margins entire. Flowers solitary, $\frac{1 / 4}{4}$ to $\frac{1 / 2}{12} \mathrm{inch}$ broad, at the ends of short branches, subtcnded by 2 to 4 small 3-lobed bracts; scpals 4, united at the base, yellowish or brownish, petals none; March to July. Fruit a dry, brownish lcathery achene.

Distribution (map on page 87 ). This species inhalbits gravelly slopes, desert mesas, and foothills, below 5,000 fcet elevation, of the westem Colorado Desert and the eastern Mojave Desert, north to Mono County. Associated plants are those of the creosote bush scrub and the piñon pine-juniper communities.

Economic value. Where abundant, black bush is a moderately important winter deer and goat browse, and is cropped to a considerable extent during winter and early spring months by sheep and goats. Cattle feed upon it limitedly. Where it forms an appreciable proportion of the brush cover, it provides a fairly large part of the feed ingested by sheep, goats, and deer despite its small leaves and spinescent branches.

On the northern Inyo winter ranges, in 1951-52, black bush accounted for some 8.2 per cent of the total volume of the diet of the mule deer in December, 15.3 per cent in January, 26.8 per cent in February, 15.3 per cent in March, and 10.1 per cent in April ${ }^{(86)}$. Big sagebrush composed the greatest volume of the feed, black bush being second, and bitterbrush was third during the winter months mentioned. Although the crude protein content of black bush is not high, ranging from about 6.5 per cent from January into March to 8.5 per cent in April,

Old bush of cliffrose (Cowania mexicana var. stansburiana) showing typical close utilization on cattle range in Utah.

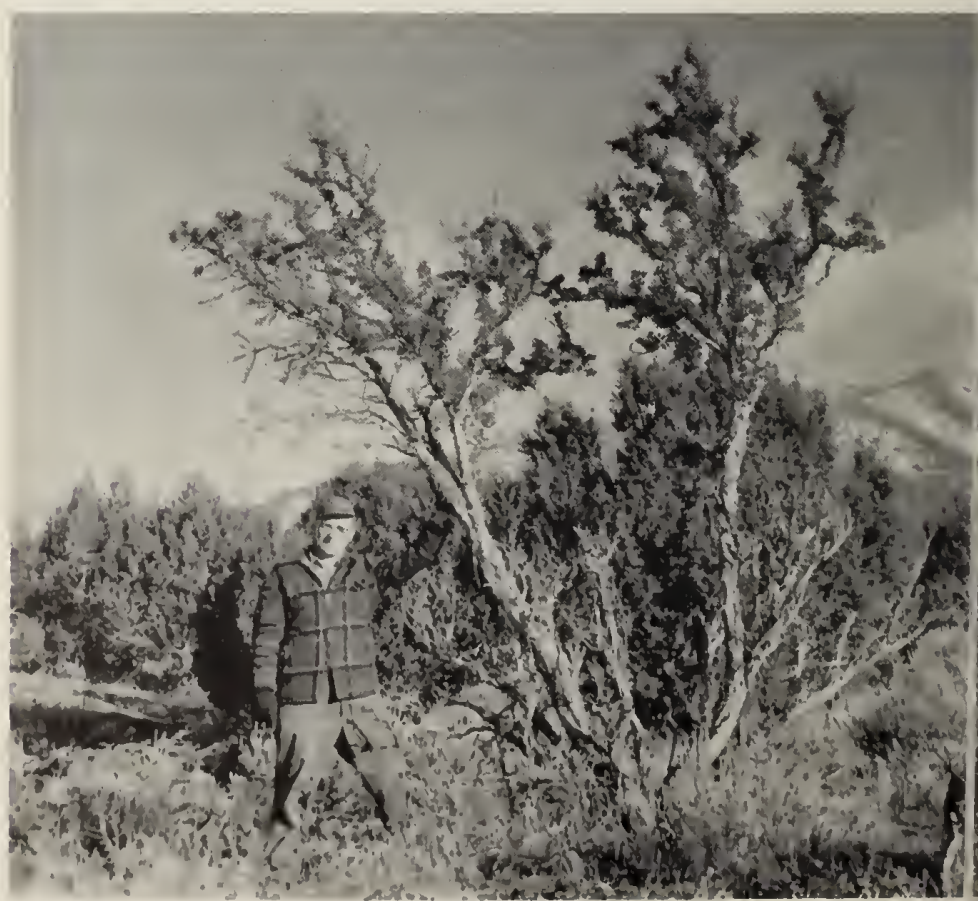




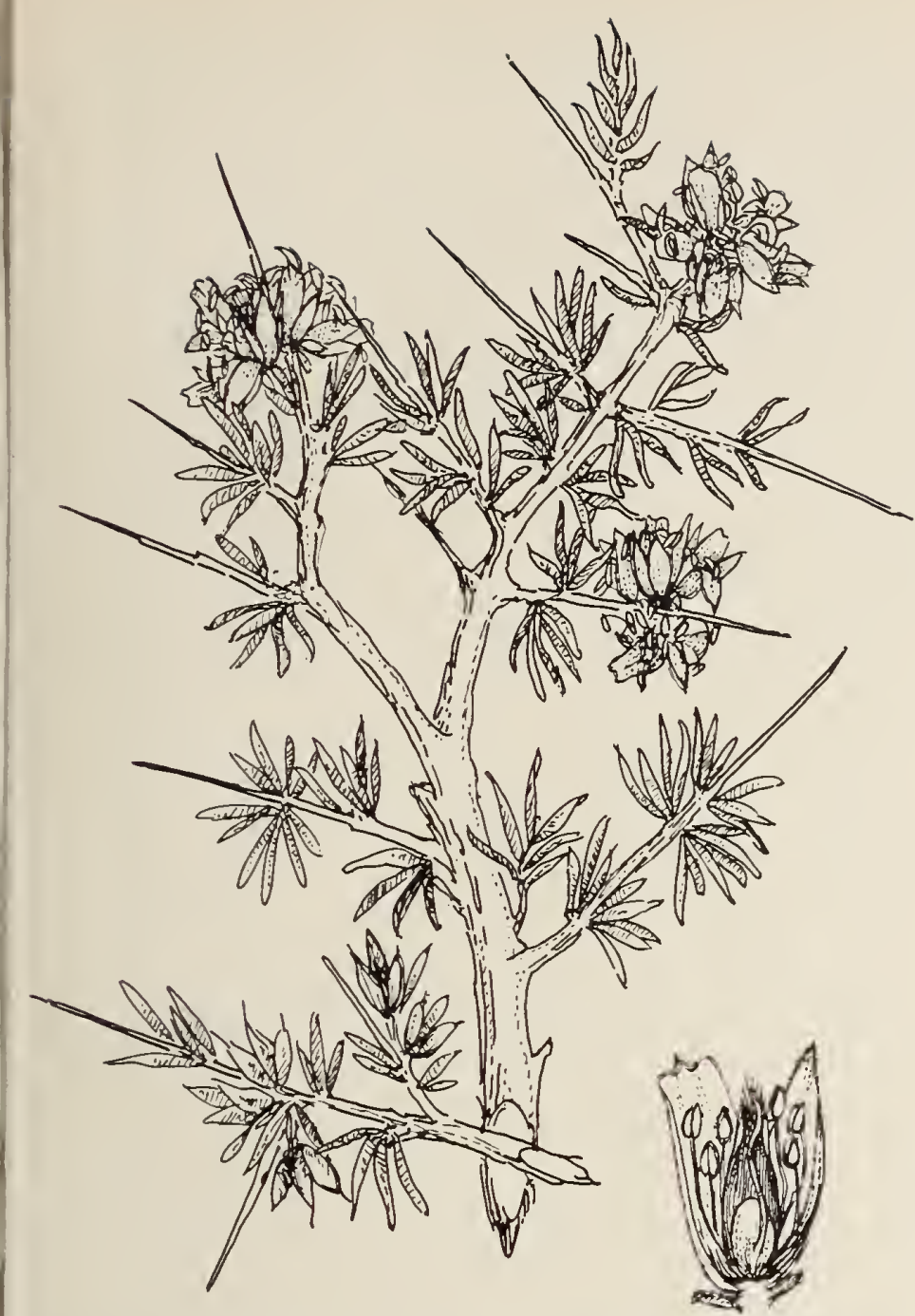

Black bush (Coleogyne ramosissima). This desert mesa plant is of moderate browse value for sheep, goats, and deer in winter and spring. Its volume of production, however, is not especially large.

animals seem to thrive upon this shrub in localities where certain other common feeds are not abundant or are relatively low in palatability ${ }^{(11)}$.

Browse rating. Good to poor for goats and deer; fair to poor for sheep; poor for cattle; and useless for horses.

\section{SIERRA MOUNTAIN MISERY (Chamaebatia)}

A single species and one variety represent this genus in California and Lower California. Probably the most unforgettable character of the plant is the unusual odor. Gregarious by nature, it forms extensive ground cover in open stands of ponderosa pines or mixed conifer forests. Because of the extent of coverage, the medicine-like odor of the glutinous foliage is very noticeable, especially on warm days. It is said that early day settlers found the odor so disagreeable that they developed headaches from it and thus labeled the plant mountain misery.

SIERRA MOUNTAIN MISERY (Chamaebatia foliolosa) (drawing on page 88), also called bear-mat, bear-clover, ket-ket-dizze, running oak, fern-bush, and tobacco plant.
Low, many-branched, heavily scented shrub, 1 to 2 feet high, with evergreen fern-like foliage. Leaves alternate, $\frac{1 / 2}{2}$ inch to 3 inches long, several times pinnately dissected into tiny crowded segments, each usually tipped with a somewhat ycllowish rcsin gland. Flowers white, $\frac{1 / 2}{2}$ inch wide, in loose terminal clusters; May to June. Fruit an achene included in a persistent calvx.

Distribution (map on page 86). This species inhabits mountain slopes on the west side of the Sierra Nevada from about 3,000 to 5,000 feet elevation, and from Kern County northward to Shasta County. It is a vigorous sprouter when cut or burned.

Economic value. Although Sierra mountain misery is generally of low palatability for livestoek, it is used considerably by deer. In some localities it composes a goodly portion of the summer and winter diet of deer. It contributes substantially to their diet during their movement to and from both ranges. On the Jawbone deer range in Tuolumne County, where Sierra mountain misery had a frequency oecurrence of 75 per cent, the mule deer herd browsed to a considerable extent upon this shrub in late fall and winter. Stomach analyses showed that this shrub composed 37 per cent by volume of the winter feed, and 7 per cent of the summer fecd ${ }^{(22)}$. This degree of ingestion is the more striking when compared with the volume percentage consumed of the better-known browse species. In the winter diet wedgeleaf ceanothus, for example, made up 12 per cent by volume of the diet as compared to the 37 per cent for Sierra

Distribution of Sierra plum (Prunus subcordata), black bush (Coleogyne ramosissima), and poison-oak (Rhus diversiloba).

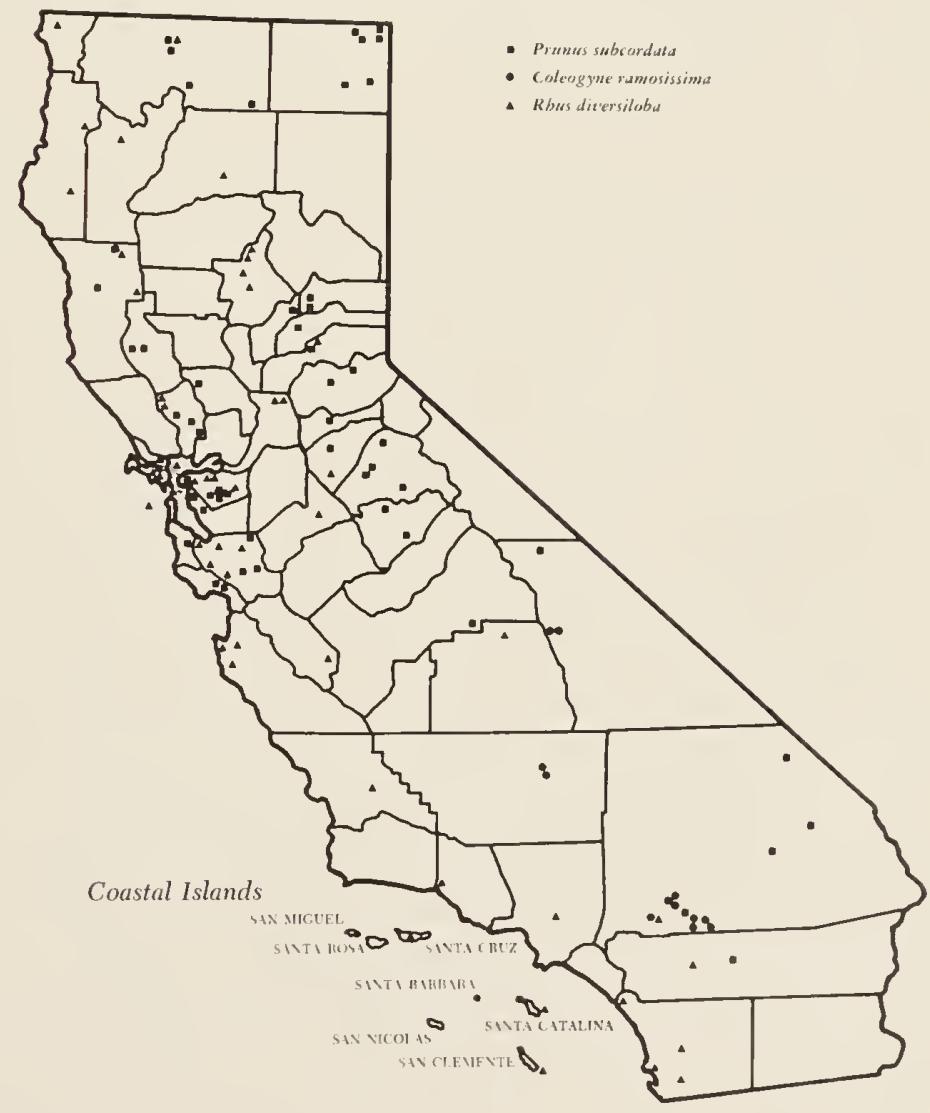




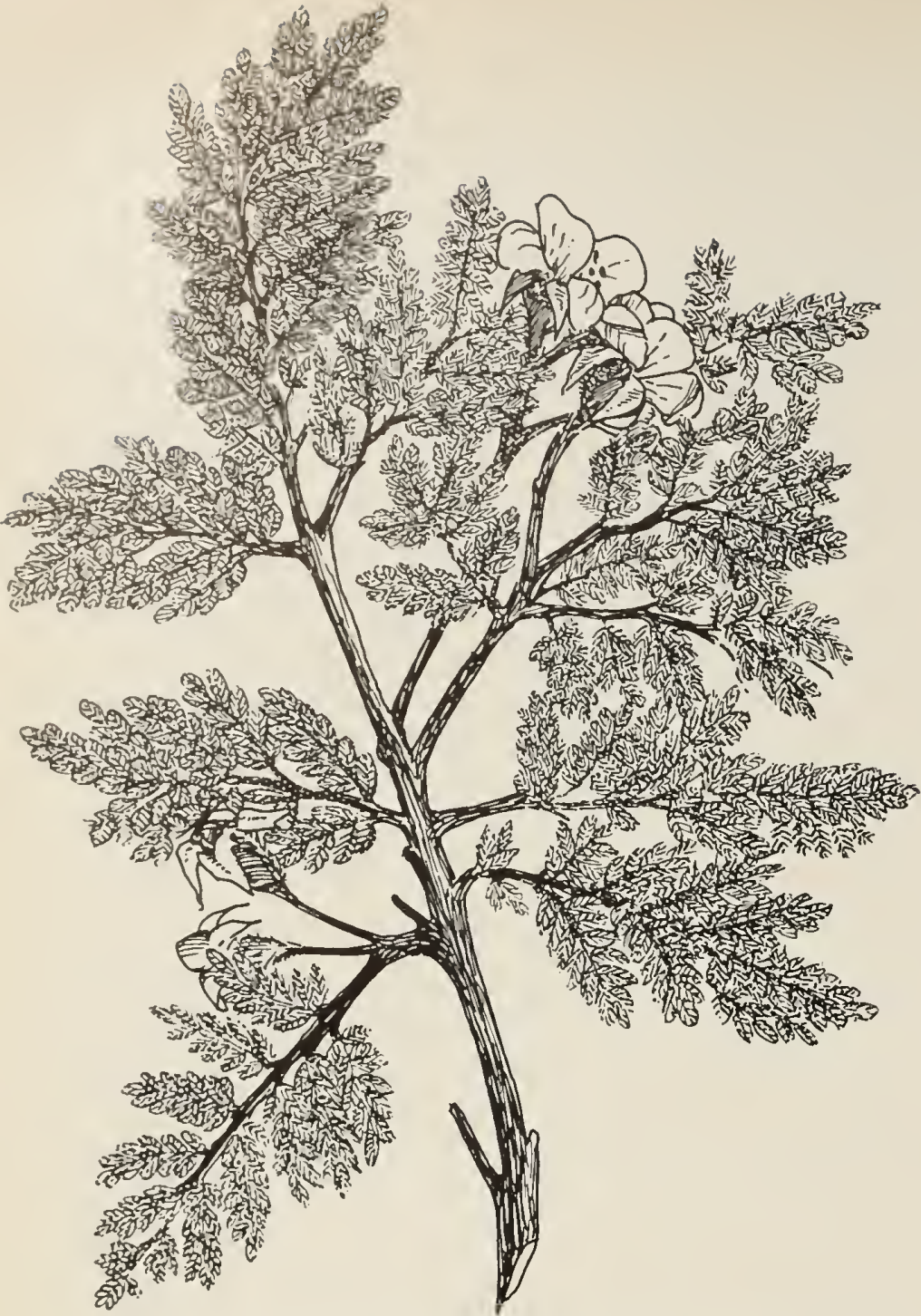

CHERRIES AND PLUMS (Prunus)

This genus includes deciduous or evergreen trees or shrubs, usually with bitter bark, leaves, and seeds. Leaves are simple, alternate. Flowers are borne in clusters, or rarely solitary, and the fruit is a drupe.

Probably no genus in the rose family contributes as much to our table or to our landscape design as does this genus. No one can deny the delights of almonds, apricots, cherries, peaches, plums, and prunes. Nor in the spring, can one fail to see the magnificent blossom displays of not only the edible fruits, but the purpleleaf flowering plums; the double flowering peaches in pink, white, red, or peppermint striped; the flowering cherries-traditional trees of Japan, but equally beautiful in many parts of California and elsewhere in the United States. Many members of this genus are also evergreen plants that supply lush foliage backgrounds, screens, or hedges, or even small shade trees.

All of the native cherries are browsed to a considerable extent by domestic livestock and big game animals. The leaves of some species form concentrations of deadly hydrocyanic or prussic acid during the aut:mm to cause livestock losses if sufficient amounts of the leafage are consumed $^{(120)}$. On properly managed range, however, relatively few losses occur from consuming these plants. Big-game animals apparently browse upon members of this genus without ill effects, possibly because they avoid them when most poisonous. The pattern of the crude protein content of the leaves and current stems is typical of deciduous species generally, the levels being highest early in the growth season and declining measurably in autumn. The protein content averaged about 20 per cent in April and May and then gradually declined to approximately 11 per cent in September and October ${ }^{(11)}$. There is no strong evidence of a correlation between protein levels and palatability as these shrubs seem to be cropped throughout the year by deer, although the animals do feed upon them mostly in summer and fall when the protein levels are high. The shrubs grow under a wide range of conditions from rocky ridges and damp slopes to the chaparral and the creosote bush scrub.

Representative and important species are bitter cherry, Sierra plum, and western chokecherry. All of these species sprout when cut or burned.

\section{Key to the Browse Species and Varieties}

1. Branehes stiff and erooked, with short thorn-like branchlets; leaves usually heart-shaped at base; flowers 装 ineh across, 2 to 4 in a chuster; fruit oblong. . SIERIA PLUM (Prunus subcordato)

decline in mineral content mav, in part, be causcd by rain washing off the dust allhering to the oily leaf surface.

All factors considered, Sicrra mountain inisery must be given consideration in the management of decr ranges where fair sized communities of this plant occur. Whether a planting program of this shrub shonld anywhere be considered is problematic.

Brouse rating. Good to fair for decr; fair to poor for genats; poor to useless for sheep); and useless for cattle and liorsios.

1. Branehes more flexible, straighter, and branchlets not thom-like; leaves usually rounded or wedge-shaped at the base, or sometimes slightly heart-shaped; flowers usually less than 12 ineh across, 3 to many in a cluster; fruit round.

2. Leaves wedge-shaped at the base; flowers 3 to $10 \mathrm{in}$

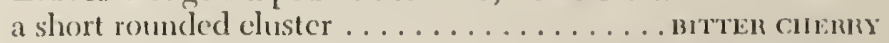

(Prunus emorginata) 
2. Leaves rounded at the base or slightly heart-shaped; flowers numerous in elongated cylindrical clusters 2 to

5 inches long . . . . . . . . . . WESTERN CHOKECHERRY

(Prunus virginiana var. demissa)

BITTER CHERRY (Prunus emarginata) (drawing on this page), known also as bird cherry, narrowleaf cherry, pin cherry, and quinine cherry. Deciduous shrub 4 to 12 feet high, occasionally becoming a small tree to 30 feet, with slim gray or reddish brown branches. Leaves ovate, oblong, or oblong-obovate, ${ }_{4}^{3 / 4}$ to 2 inches long, ${ }_{8}^{3 /}$ inch to 1 inch wide, wedge-shaped at base, margins finely toothed; smooth dark green above, smooth or hairy beneath. Flowers white, about $1 / 2$ inch wide, 3 to 10 in short rounded clusters; petals roundish or notched at the tip. Fruit oval, about $1 / 2$ inch long, red, turning black when ripe, smooth, very bitter. In southern California and the coast ranges blooms in April and May; in the Sierra Nevada June and July.

Distribution (map on page 90, left). Bitter cherry inhabits mountain ridges, moist slopes, and stream banks from about 500 to 9,000 feet elevation in the southern California mountains, Coast Ranges, and Sierra Nevada. It often forms extensive thickets on damp slopes and in canvons.

Economic value. This plant is commonly browsed by cattle, sheep, goats, and deer. Poisoning of sheep in the fall is not uncommon along trails. Deer feed extensively upon the leaves and twigs and utilize the plant rather closely in some seasons. Analytical study indicates that the levels of crude protein and other nutrients are similar to those of other desirable deciduous browse plants, ranging from about 15 per cent in early summer to 9 per cent in late fall ${ }^{(1)}$.

Birds, various rodents, and some other mammals avidly devour the fruits of the native cherries and largely account for their seed dissemination and reproduction.

Browse rating. Excellent to good for deer; fair for cattle and goats; fair to poor for sheep; and useless for horses.

SIERra Plum (Prunus subcordata), also known as Pacific plum and Klamath plum. Deciduous shrub or small tree, 6 to 20 feet high, with stiff, short, thorn-like crooked branchlets. Leaves ovate to almost round, usually heartshaped at the base, ${ }^{3} / 4$ inch to 2 inches long, $1 / 2$ inch to $1 \frac{1}{2}$ inches wide, the margins finely toothed. Flowers white, aging to pink, about $1 / 2$ inch wide, lightly fragrant, 2 to 4 in a loose cluster; March and April. Fruit oblong, ${ }_{4}^{\prime \prime}$ inch to 1 inch long, hairy or smooth, usually bright red or sometimes yellow; mature in September and October.

Distribution (map on page 87). Sierra plum inhabits moist or dry rocky slopes and flats of the Coast Range from Santa Cruz County north to Siskiyou and Del Norte counties, and in the foothills and at middle elevations of the Sierra Nevada from Kern and Tulare counties, northward to Modoc County and into southern Oregon. It often occurs in association with manzanitas, wedgeleaf ceanothus, and western chokecherry.

Economic value. This species is often heavily browsed

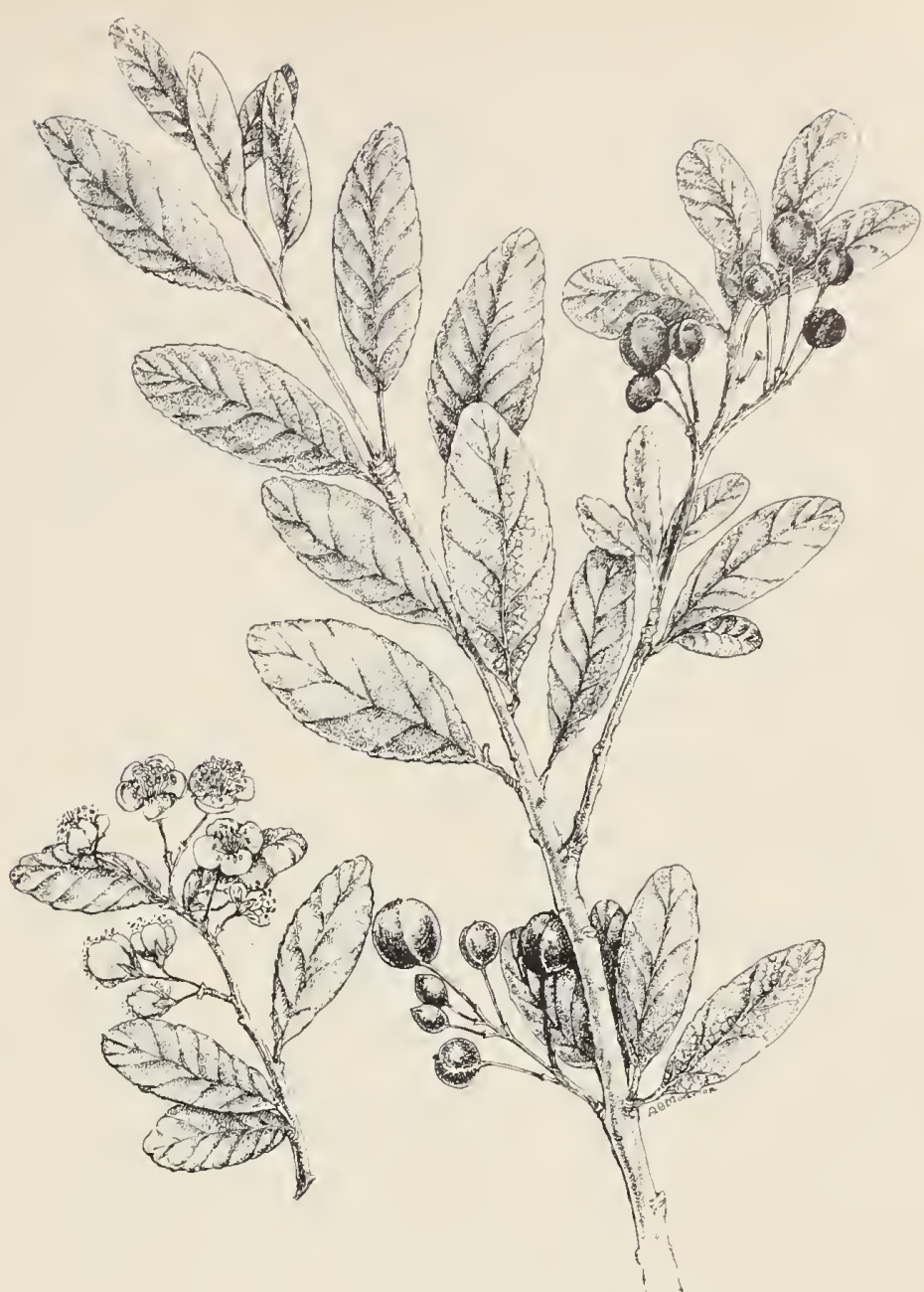

Bitter cherry (Prunus emarginata). This plant is commonly browsed closely by sheep, goats, and deer, but only limitedly by cattle. Poisoning of sheep in the fall occurs occasionally. Birds and rodents are fond of the mature fruits.

by goats and deer, occasionally by sheep, and only little by cattle. Where frequent overgrazing has occurred, as on some deer or goat ranges, the plants are sometimes killed out in spite of their thonn, thicket-like growth ${ }^{(48)}$. Its crude protein levels are similar to those of bitter cherry $^{(11)}$.

Browse rating. Excellent to good for deer; good to fair for cattle, sheep, and goats; and useless for horses.

WESTERN CHOKECHERRY (Prunus virginiana var. demissa) (drawing on page 90), also called bitter cherry. Deciduous shrub 3 to 8 feet high, but occasionally a small tree up to 20 feet high; the bark smooth or scaly and dull red. Leaves ovate or broadly elliptic, rounded at the base or slightly heart shaped, $1 \frac{1}{2}$ to $3 \frac{1}{2}$ inches long, ${ }_{4}^{3}$ inch to 2 inches wide, smooth or slightly hairy, margins finely toothed. Flowers white, $1 / 3$ to $1 / 2$ inch broad, numerous, in racemes 2 to 5 inches long at the ends of leafy shoots; April and May. Fruit round, $\frac{1}{4}$ to $\frac{1}{2}$ inch in diameter, red or dark purple; maturing in September and October.

Distribution (map on page 90, right). Western chokecherry occupies moist sites in the lower mountains throughout California. It extends from San Diego County 


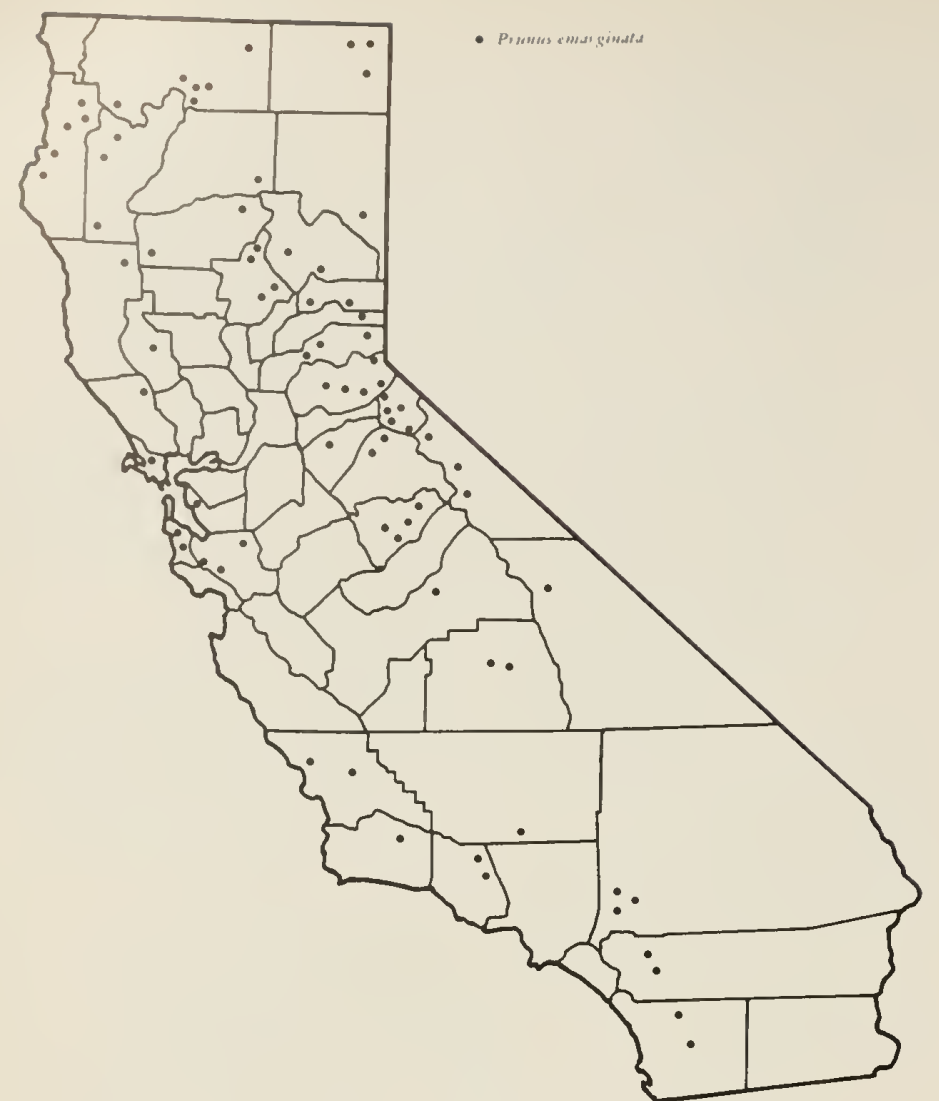

Distribution of bitter cherry (Prunus emarginata).

northward in the Coast Ranges; in the Sierra Nevada to the mountains of northern California; and northward to British Columbia; eatsward to Nevada and Arizona.

Economic value. Westem chokecherry is probably the best known member of the genus Prunus in California. The fruit is edible but astringent; more palatable to browsing animals than some other Prunus species; and apparently accounts for more sheep losses from poisoning than any other species of the rose family ${ }^{(100,120)}$.

This variety is elosely browsed by deer but is also sought by sheep and goats. Cattle feed upon it little except where the range is overgrazed. Analyses indicate that the crude protein levels are similar to those of associated deciduous shrubs, ranging from about 16 per cent carly in the season, 15.0 per eent in mid-summer, and 12.5 per cent in early fall ${ }^{(1(x))}$. The protein content of the current stems for the same periods are 7.5 per cent, 8.5 per cent, and 8.0 per cent respectively. The lignin content is higher than average for most shrubs, whereas the calcium to phosphorus ratios are not strikingly disproportionate for the three periods mentioned.

Although westem chokecherry is very poisonous at certain growth stages, whole bands of sheep are seldom affected; rather only individual sheep become ill or clic. The guantity of leaves required to poison one sheep laries with season, size of animal, amount of moisture contanined in the leaves, amount of forage in the stomach, and rapidity with which the leaves are eaten.

Browse rating. Excellent to good for deer; good to fair for cattle; fair to poor for slicep and goats; and useless for horses.

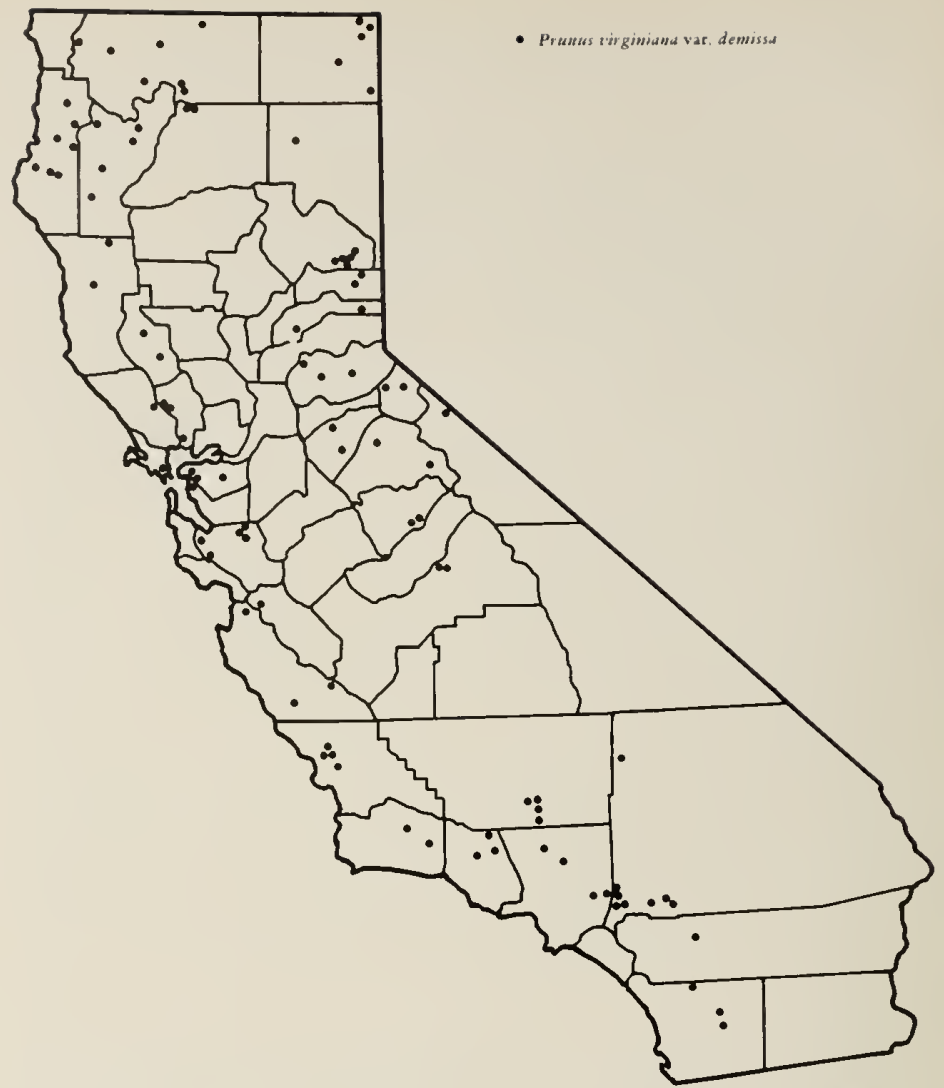

Distribution of western chokecherry (Prunus virginiana var. demissa).

Western chokecherry (Prunus virginiana var. demissa) is browsed with relish by livestock and deer. Poisoning of hungry sheep occasionally occurs along trails during long drives. The nutrient levels of this plant appcar to be typical of deciduous shrubs.

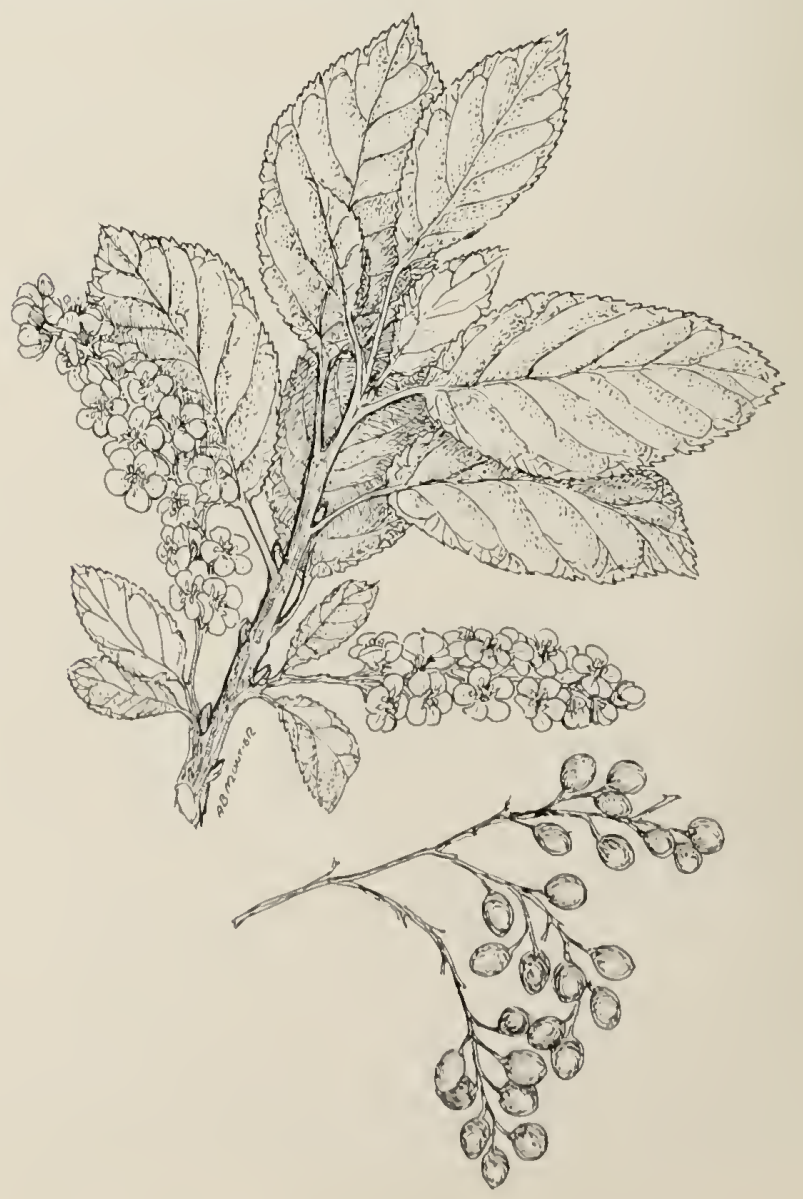




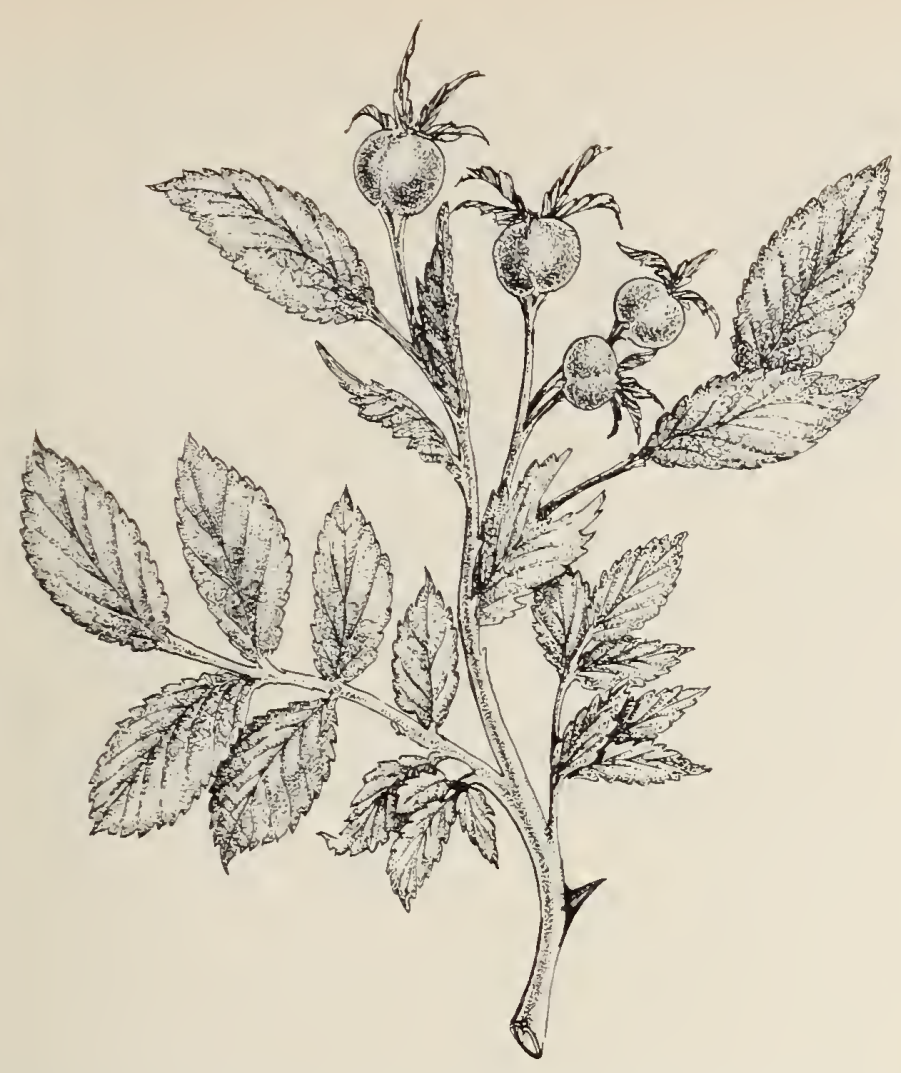

California wild rose (Rosa californica). This attractive widely distributed species in some localities furnishes abundant browse that is especially relished by sheep, goats, and deer. Cattle also feed upon it. Most of the foliage is within reach of grazing animals.

\section{ROSES (Rosa)}

The rose, whether a wild species or a garden hybrid, is probably the most popular and best known flower throughout the world. Mentioned in ancient writings, praised in poetry and literature throughout the years, growing in gardens past and present, the rose has become a romantic symbol of the ultimate in perfection, color, and fragrance. There are countless varieties to choose from-Hybrid Teas, the popular rose for cut Howers; climbing roses; Grandifloras; and Floribundas, the latter becoming very popular because they produce masses of color over a long season.

Few countries are without a native rose. They occur in all north temperate regions of all continents and in the high mountains of the tropics. In the United States, four states have adopted a wild rose species for their floral emblem.

Because wild roses arc relatively low in stature and frequently sprawling in growth habit, much of the delicate leafage and twigs is within reach of most browsing animals. Although the branches are usually prickly, the foliage of most species is cropped somewhat closely, especially by sheep, goats, and deer. California wild rose is among the commonest and most widely distributed species in the State, and is selected to represent the browse characteristics of this group.

CALIFORNIA WILD ROSE (Rosa californica) (drawing on this page). Much-branched stout shrub, 3 to 9 feet tall,

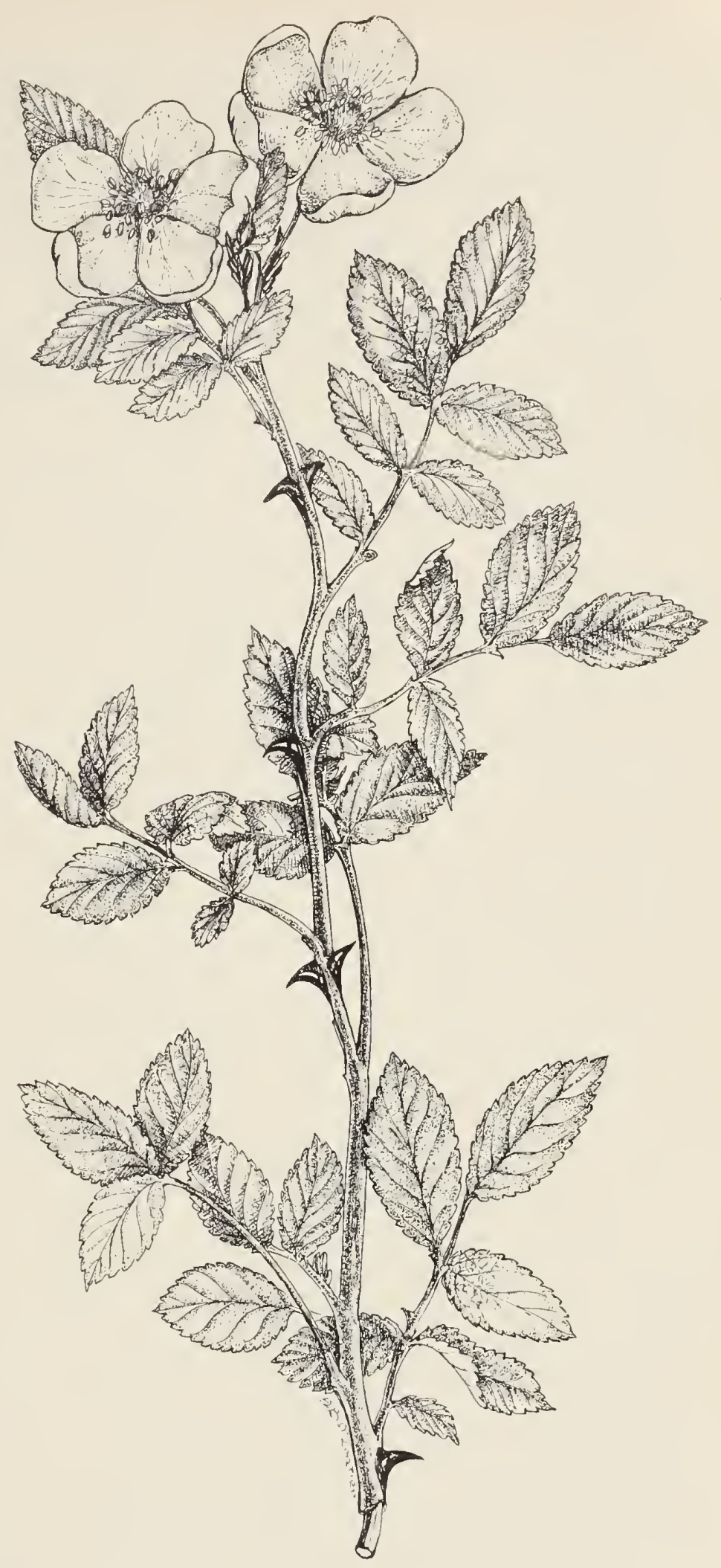

with usually straight or curved stout prickles on the branches. Leaflets 5 to 7 , ovatc to oblong, $\frac{1}{2}$ to $1 \frac{1}{1}$ inches long, smooth or hairy above, paler and slightly hairy or glandular beneath, margins toothed. Flowers rose colored or light pink, few to many in much branched clusters; March to July. Fruit composed of several bony achenes enclosed in a fleshy roundish calyx tube or "hip," orange colored, smooth. This species is extremely variable. 
Distribution. California wild rose is abundant along strcam banks and in moist places along roadsides, near streams, and in canvons from sea level to about 4,000 feet elevation throughout California. It occurs in many plant communities.

Economic value. In some localities California wild rose furnishes abundant browsc. Bccause of its moderate size much of the foliage is within reach of the animals. The prickly branches, however, tend to preclude close utilization either of the foliagc or current twigs by cattle and shcep, lut not by dcer. Various birds and mammals feed on the fleshy fruits.

Browse rating. Fair for goats; fair to poor for sheep and decr; poor for cattle; and poor to useless for horses.

\section{TOYON (Heteromeles)}

Toyon is the festive holiday berry of California. From Thanksgiving and to after Christmas the clusters of red berries on this shrub give wonderful color to the foothill areas of California. Florists carry it for holiday decoration, and although not as traditional as the English holly (Ilex aquifolium), it supplies much more color. In California it is widely used as Christmas berry. Gardeners, too, recognize its omamental value, and it finds a place in many a home garden.

Toyox (Heteromeles [Photinia] arbutifolia) (drawing on this pagc), also called Christmas berry and California holly. Evergrecn, large, erect shrub or small tree, 6 to 10

Toyon (IIeteromeles [Photinia] arbutifolia). This plant grows in scattered stands on all slopes. In dense chaparral it grows beyond the reach of grazing animals. It sprouts vigorously after a fire and is then utilized in varying degrees. Because of the leathery nature of the leaves it is not a highly important browse plant.

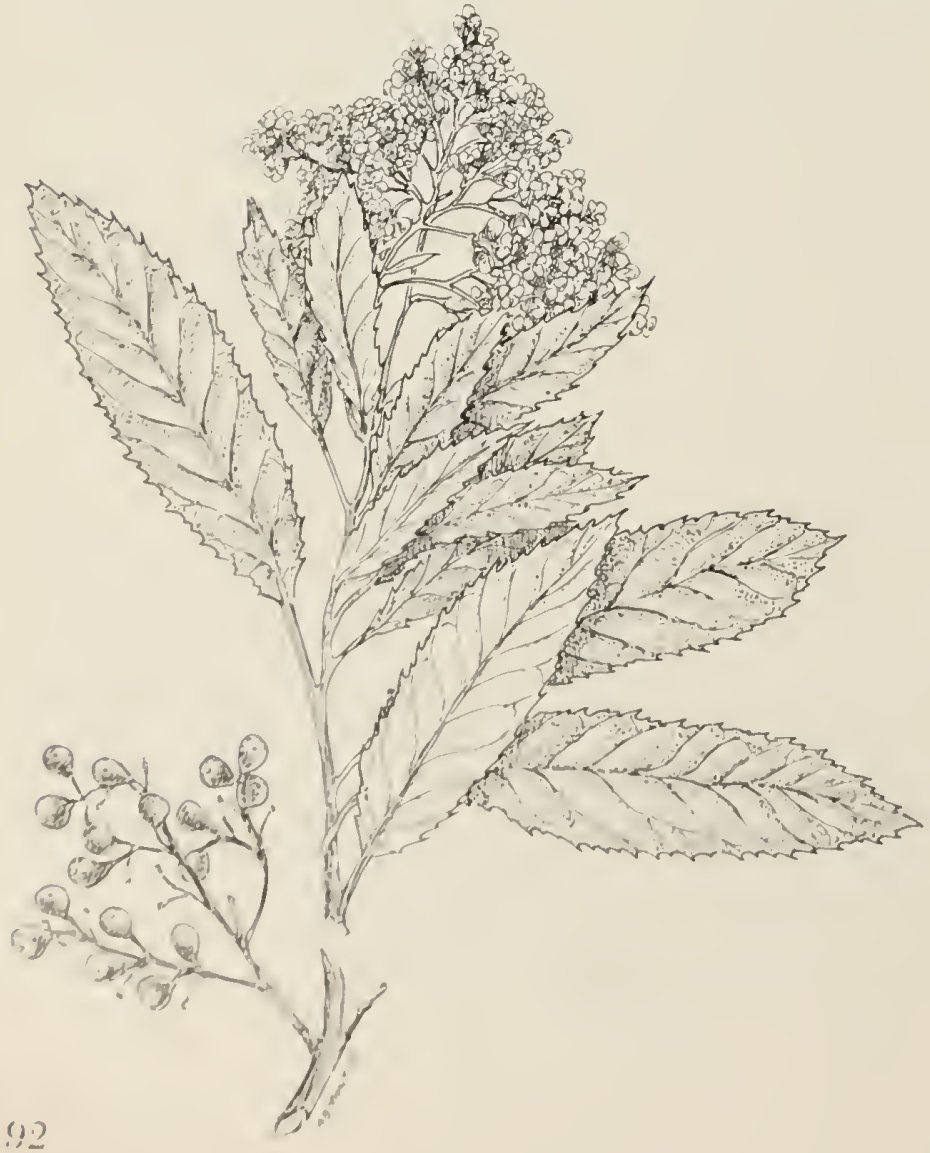

feet high. Leaves simple, alternate, oblong or elliptical, 2 to 4 inches long, ${ }_{4}^{3 /}$ inch to $1 \frac{11}{2}$ inches wide, thick and leathery, dark glossy green above, lighter beneath, margins regularly toothed and bristly pointed. Flowers small, white, in large, flattish, terminal clusters; June and July. Fruit bright or pale red, rarcly yellowish, berry-like, about $1 *$ inch in diameter; November to January.

Distribution (map on this page). Toyon inhabits rocky lower mountain slopes, canyon bottoms, and foothills in the lower Sierra Nevada from Shasta and Tehama counties southward to Tulare County, and in the Coast Ranges from Humboldt County southward into southern California, and Santa Catalina and San Clemente islands. It is a constituent of the chaparral community.

Economic value. In dense chaparral, toyon grows tall and provides little forage, but it sprouts vigorously after a fire and is then cropped rather closely. In a north coast range up to 21 per cent of the plant was utilized in a chaparral cover ${ }^{\text {(at5) }}$. Evidently because of the leathery nature of the leaves the plant is not browsed closely nor to the same degree over its range by any grazing animal. Birds feed extensively on the mature fruits.

Browse rating. Good to fair for goats and deer; poor to useless for sheep; and useless for cattle and horses.

\section{OTHER ROSACEOUS SPECIES}

Other genera and species of the rose family that provide some browse for livestock and big game are: Western ninebark (Physocarpus capitatus), thimbleberry (Rubus parviflorus), shrubby cinquefoil (Potentilla fruticosa), western mountain-ash (Sorbus sitchensis), and western blackhaw (Crataegus douglasii). These and related species contribute a small amount of low-quality

Distribution of toyon (Heteromeles arbutifolia).

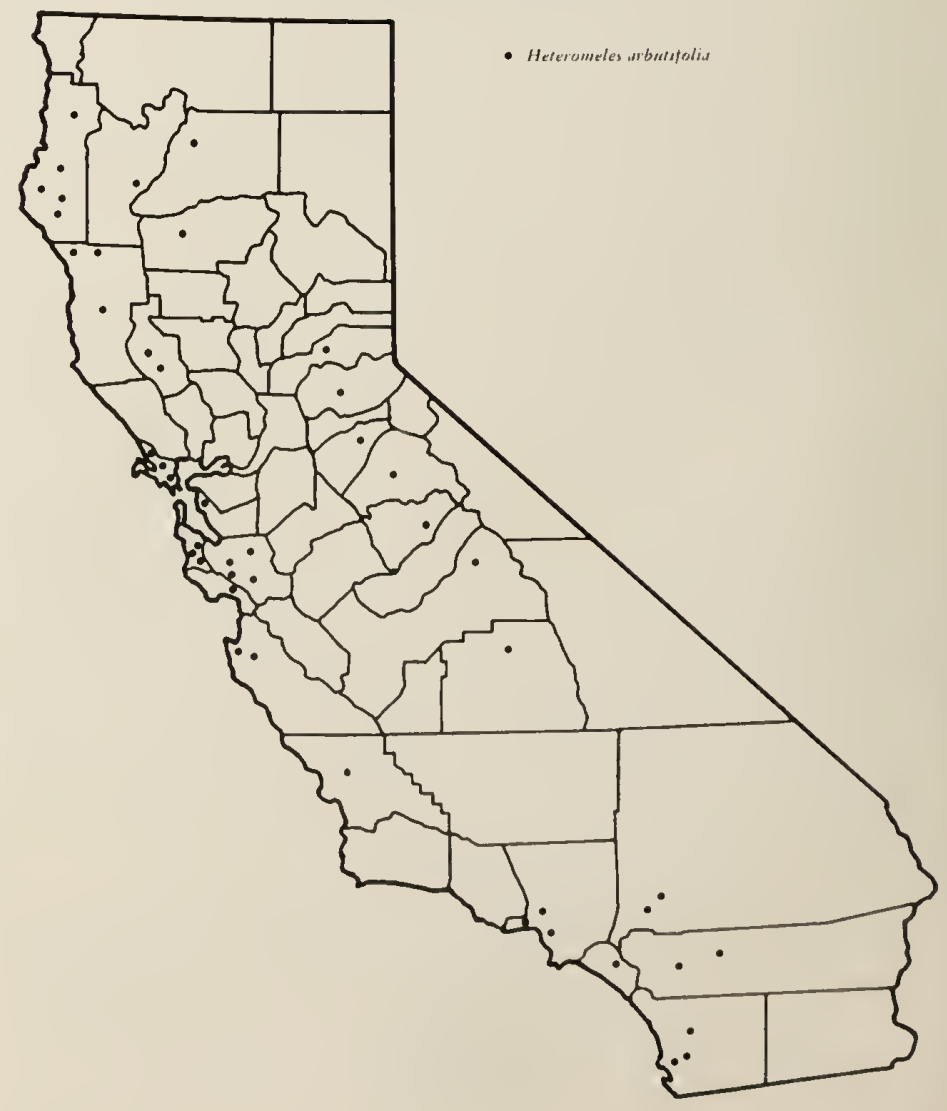


browse. Their over-all ratings are listed in the summary table on pages 146-148.

\section{Pea or Legume Family (Leguminosae)}

The pea or legume family is one of the largest families of flowering plants. Some of our most exciting ornamental flowering trees are members of this family. Striking is the golden brilliance of Bailey acacia (Acacia baileyana) in January, and that of the later blooming acacias. The silk tree (Albizia julibrissin), with its wide spreading canopy of fern-like leaves, and pink puffs of flowers, makes a handsome early summer show. The eastern redbud (Cercis canadensis), with magenta flowers on bare stems, is seen in a number of California gardens. The lovely wisteria vine also contributes an abundance of fragrant spring flowers. In the shrub class, the many species of brooms (Cytisus, Genista) provide generous flower displays. And lastly, no annual supplies such delightfully fragrant flowers in pastel shades as the sweet pea (Lathyrus odoratus).

On the more practical level, this family is responsible for the string beans, lima beans, and other beans, as well as the peas one buys in markets or grows in one's own vegetable garden.

The pea family is best known to California stockmen for such outstanding herbaceous species as alfalfa (Medicago sativa), the true clovers (Trifolium), bur clover (Medicago hispida), vetches (Vicia), and the like. Less well known and of much lower grazing values are the native browse species. Only three genera have appreciable value as browse on California ranges. No species is of high rank.

Some of the members of this family are poisonous or serious pests. Several herbaceous species such as locoweed (Astragalus) and lupines (Lupinus) are poisonous to livestock. In the Southwest species of mesquite (Prosopis) and catclaw acacia (Acacia greggii) are often serious invaders of overgrazed or otherwise badly managed range lands, and although they contribute but little palatable browse for livestock, they do contribute to the diet of deer and antelope. Gorse (Ulex europaeus), a densely spiny pest, and Scotch broom (Cytisus scoparius), both naturalized from Mediterranean Europe, have little or no browse value, are aggressive invaders, and have become established in several localities of California.

The only California genera worthy of discussion are: Cercis, Lotus, and Pickeringia.

\section{REDBUD (Cercis)}

The sole member of this genus is one of the most bcautiful of our native species, especially when in flower. The large clusters of reddish brown seed pods are an added attraction to the plant until the following spring.

WESTERN REDBUD (Cercis occidentalis) (drawing on this page), sometimes called Judas tree. Deciduous tall shrub

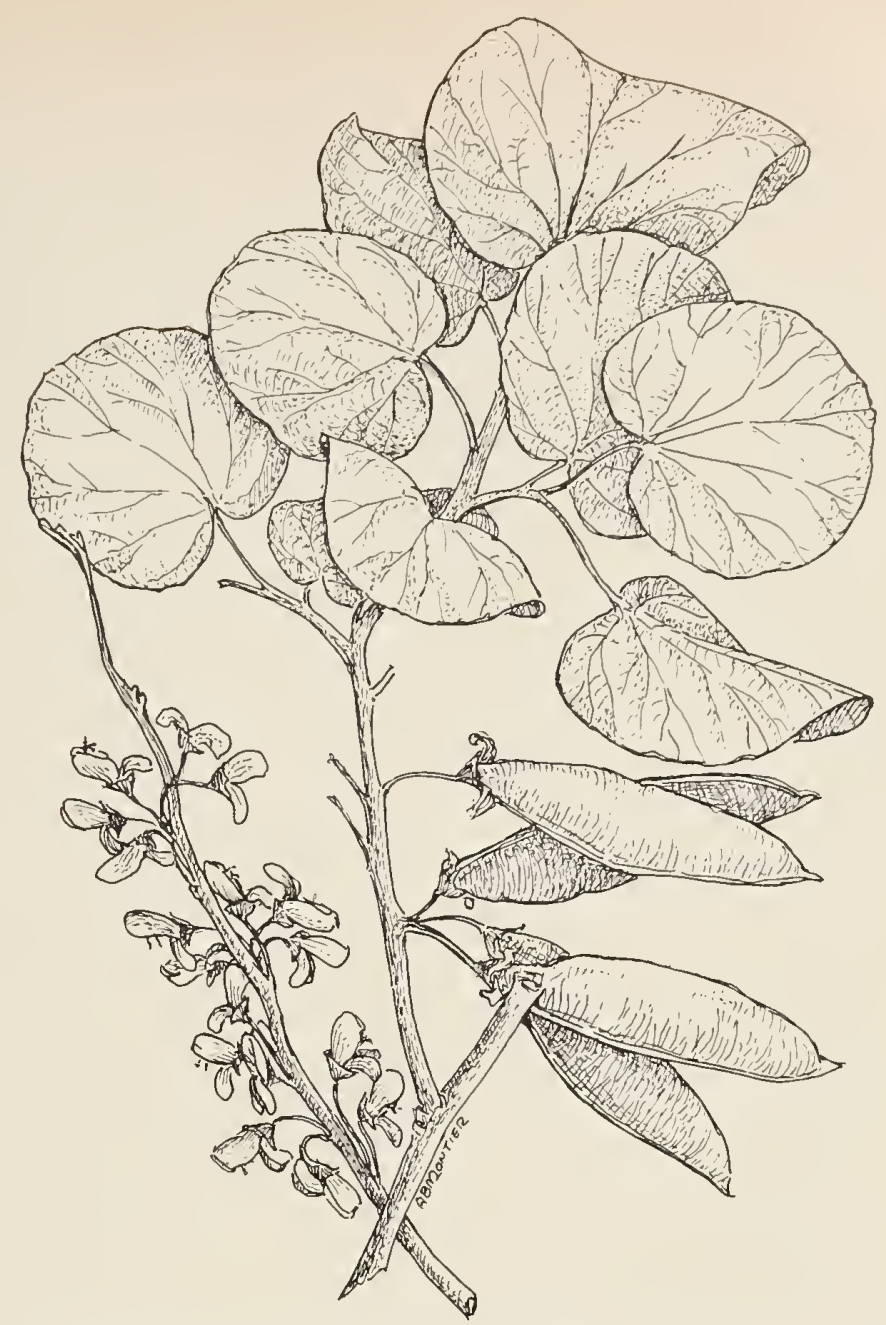

Western redbud (Cercis occidentalis). This is a moderately palatable browse plant for sheep, goats, and deer. The leafage, twigs, and seed pods are utilized most in fall and spring.

Distribution of western redbud (Cercis occidentalis) and goatnut (Simmondsia chinensis).

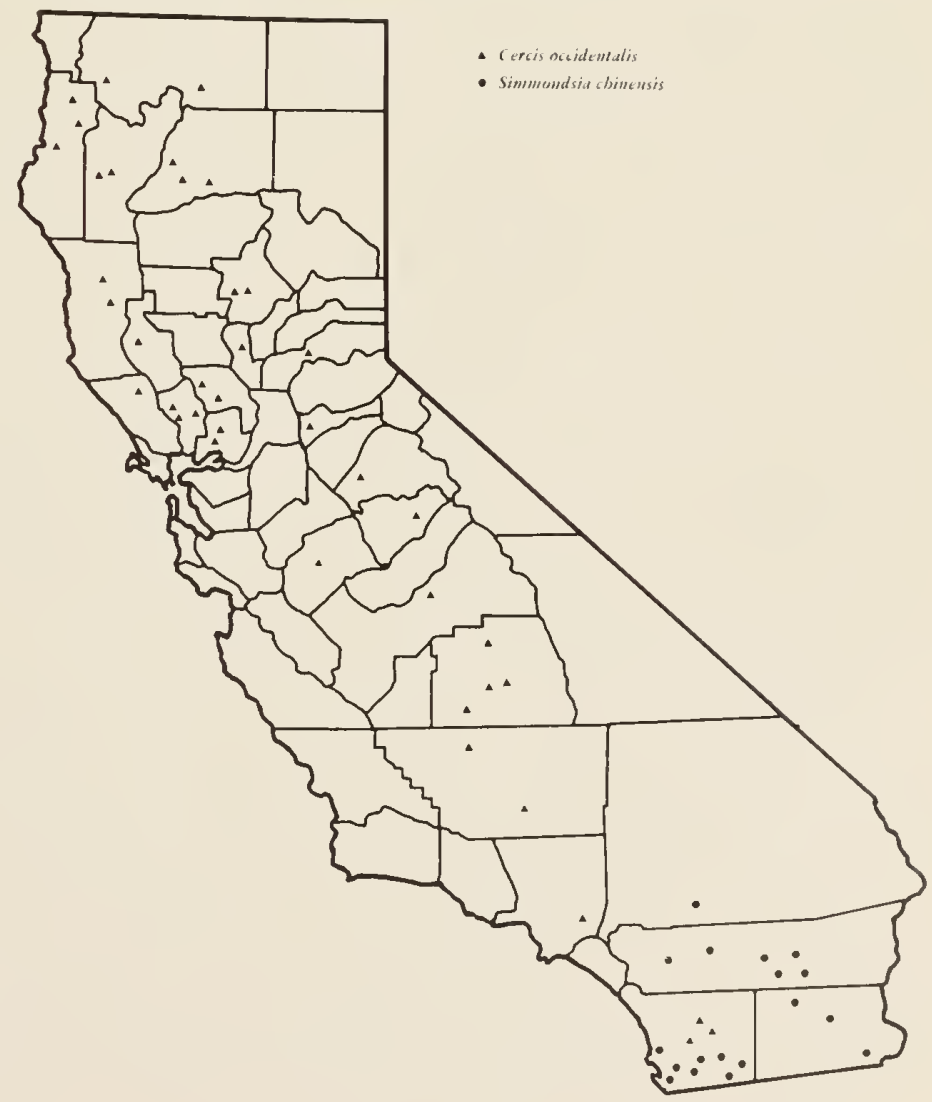


or small tree, 7 to 20 feet high, usually with many long basal stems. Leaves alternate, simple, roundish with heart-shaped base, 2 to $3 \%$ inches broad, somewhat palmately reined, smooth on both sides. Flowers small but so abundant that they are showy, red-purple, appearing before the leaves, in simple umbel-like elusters; February to April. Pods oblong, $1 \frac{1}{2}$ to 3 inches long, $1 / 2$ to ${ }_{8}^{5}$ ineh wide, clull red when mature.

Distribution (map on page 9.3). This species oceupies well drained foothills and flats between elevations of 1,000 to 4,000 feet. It is eommon in the Sierra Nevada from Tulare County northward to Shasta County, westward to Siskiyou, Trinity, and Humboldt counties, thenee southward in the inner Coast Range to Lake, Napa, and Solano counties. It also oceurs in Kern and San Diego counties. Common habitats are open woodland and chaparral.

Economic calue. Westem redbud is browsed in varying degrees by sheep, goats, and deer, and more limitedly by eattle. The young leaves, twigs, sprouts, and pods are eaten to some extent. Among the food items eaten by black-tailed deer on the Tehama winter range, Tehama County, westem redbud was most heavily utilized in the autumn months before the leaves had fallen, and again in April and May, when the young growth had beeome available ${ }^{(5)}$. Although utilization is not partieularly heary, westem redbud is a moderately important fall and spring deer food.

Browse rating. Fair to poor for goats; poor for sheep; and poor to useless for eattle, deer, and horses.

\section{DEERWEED (Lotus)}

The genus Lotus is popularly called bird's-foot trefoil, although aetually this conmon name belongs to the herbaceous species, Lotus corniculatus. It is a genus of lierbs or semi-shrubloy plants. Of the thirty speeies oecurring in California, several are sub-shrubby or more or less woody at the base. Among the latter only deerweed provides enough browse to be of any appreciable value on the range.

DEERwLE) (Lotus scoparius) (drawing on this page).

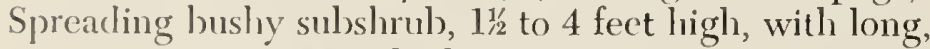
wiry, virgate, grcenish branches. Leaves alternate, pinnately componnd; leaflets oblong or oblanceolate, smooth or lightly hairy. Flowers yellow, tinged with red, $3 \times$ to 1 inch fong, usnally 3 to 8 (rarely one) in stalkless umbels that are erowded along the branehes; Febrinary to Octolyer. Pods, 1 to 2 seeded, $\frac{12}{12}$ inch long.

Distribution. Deerweed is common in the lilly brush comtry from nearly sea level to about 2,500 fect clevation. It oceurs in the Sierra Nevada foothills from Amador County to Kern Connty, and in the Coast Ranges from Ilumboldt Cominty to Sinn Luis Obispo Connty, sonthward to sonthem California. It often grows in open stands of clamise, manzanita, and in grass eover.

Eronomic ealue. Early in the season when new growth appears, deerwered is ittized rather closely by sheep, gerats, and derer. Early in the season the leafage and

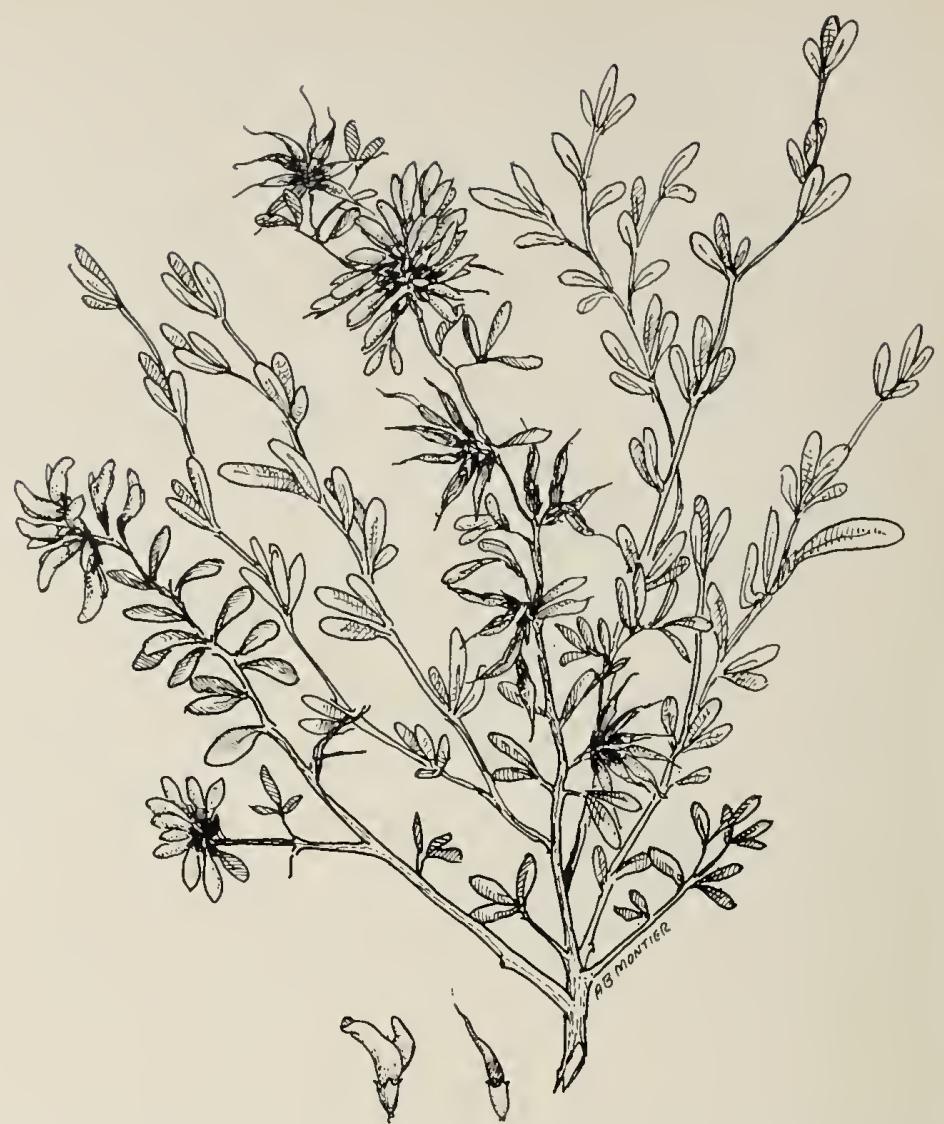

Deerweed (Lotus scoparius). Branehlet showing foliage, flowers, and fruit pods; flower; and pod.

This plant is browsed mostly by deer, but seldom closely if other good forage is available. Sheep and goats browse upon it lightly. Early in the season the foliage and young twigs become harsh and unattraetive to grazing animals.

young twigs beeome harsh and relatively unattractive to all grazing animals.

Browse rating. Fair to poor for deer; poor for sheep and goats; poor to useless for cattle; and useless for horses.

\section{PICKERINGIA (Pickeringia)}

This genus contains only one species, deseribed below, and one varicty native to Califomia. The variety $-P$. montana var. tomentosa-has hairy leaves and branchlets, and oceurs in the mountains of eastem San Diego County, and limitedly in the San Bernardino Mountains.

Chaparmal pea (Pickeringia montana) (drawing on page 95). Erect evergreen shrubs, 2 to 7 feet high, with many spinose branchlets that are sparingly leafy. Leaves alternate, simple, or palmately 3 -foliate, ovate, ${ }_{4}^{1}$ to ${ }^{1 / 2}$ inch long, smooth, entire. Flowers solitary, rose-purple, ${ }_{4}^{3}$ inch, sweet pea-shaped, the banner with long ycllowish spot near the base; May to Jme. Pod linear, flat, straight, several seeded, 1\%2 to 2 inches long, on a short stalk. Chaparral pea produees seed sparingly but is a vigorous root and crowu sprouter.

Distribution (map on page 95). This speeies oceurs in the dry chaparral association from Lake and Mendoeino comnties sonthward in the Coast Range to Santa Monica 


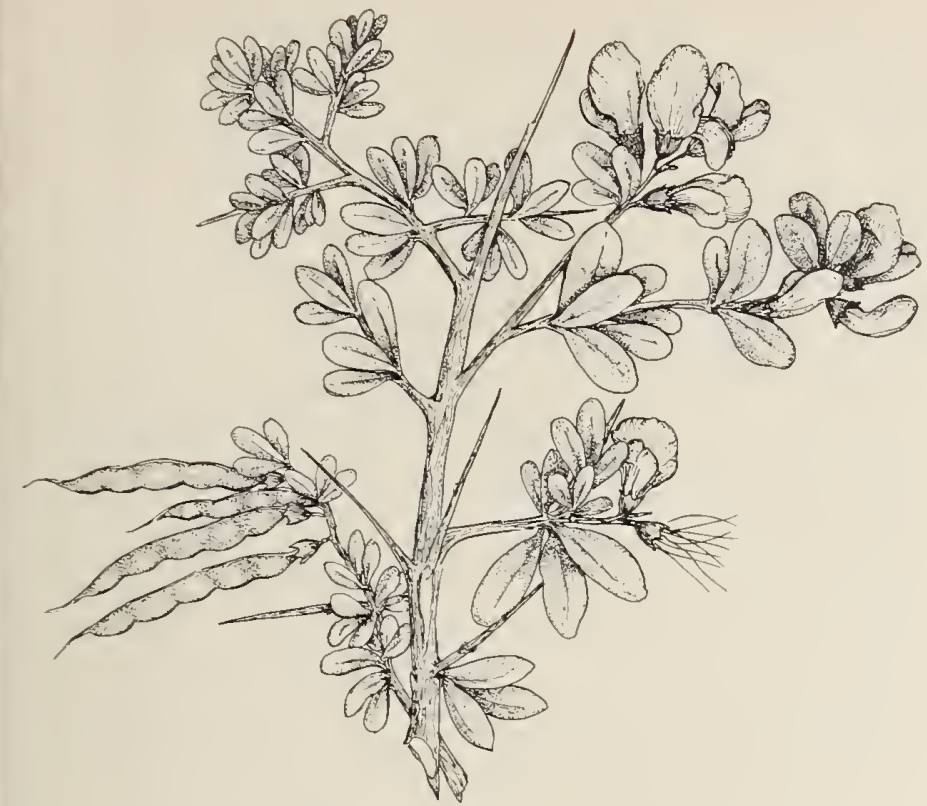

Chaparral pea (Pickeringia montana). This species provides a fair amount of browse, notably for deer, on recently burned or on mechanically treated brushland areas, and is a vigorous sprouter. It serves more or less as a variant or filler for livestock.

and San Bernardino mountains of southern California. It also occurs sparingly in the chaparral in the Sierra Nevada from Butte County south to Mariposa County and on Santa Cruz Island.

Economic value. Chaparral pea provides little browse in heavy stands of chaparral but is fairly important deer feed on recently burned or on mechanically treated brushland areas, where the sprouts are cropped with considerable relish. It sprouts wherever the roots are exposed, hence light disking favors its spread ${ }^{(145)}$. Analyses of the crude protein content as an indicator of its nutritive value for grazing animals gave the following results $^{(11)}: 19.2$ and 18.1 per cent for April and May; 14.3, 11.5, and 11.4 per cent for June, July, and August; and a range of from 6.1 to 8.1 per cent from September to March. The protein levels were notably higher in the early growth stages than in most evergreen shrubs, and also somewhat higher than average of most shrubby species during the winter period. Based upon these facts it would appear that chaparral pea is one of the more nutritious evergreen shrubs. Sheep and cattle utilize this plant more or less as a variant or filler. Deer carefully pick out the leaves from among the thorny stems and often utilize the foliage rather closely; and they are especially fond of the flowers.

Browse rating. Excellent to good for deer, depending on the season and the number of sprouts available; fair to poor for sheep and goats; poor for cattle; and useless for horses.

\section{Caltrops Family (Zygophyllaceae)}

Five genera represent this family in California. Three are woody and two are herbaceous annuals. Of the five genera, two are introduced from the Old World becom- ing naturalized. The most common of these Old World introductions and the best known because it is a serious pest, is the puncture vinc (Tribulus terrestris). It is a prostrate annual that has naturalized in waste places throughout much of California below 5,000 feet elevation. Puncture vine produces fruits with 2 to 4 sharp spines that will puncture tires, bare feet, dogs' and cats' paws, and the like. All species of this family are of low browse value. Only one species is discussed here.

CREOSOTE BUSh (Larrea divaricata) (photo on page 7), also called greasewood and various local names. Erect, diffusely branched, evergreen shrub, 2 to 9 feet high, with strong-scented resinous foliage, and brittle branches with glutinous or corky rings at the nodes. Leaves opposite, consisting of a pair of stalkless, lanceolate or oblong leaflets about ${ }_{8}^{3 /}$ inch long, indistinctly 3-veined from the base, finely silky hairy becoming smooth. Flowers yellow, terminal and solitary on short side branchlets; November to May. Fruit a globose capsule, 11 inch or less long, composed of 5 carpels that eventually separate into 1-seeded, denscly white or rusty hairy nutlets.

Distribution. Creosote bush is the most common and widely distributed shrub of the desert region of southern California where it often forms a distinct vegetation belt. It is most abundant in the Mojave and Colorado deserts. It extends north to Inyo County and east to Texas and Mexico. Common associated plants are ephedras (Ephedra), cacti (Opuntia), hedgehog cacti (Echinocactus), spanish bayonet (Yucca), Joshua tree (Yucca brevifolia), and various perennial and annual grasses and forbs.

Distribution of chaparral pea (Pickeringia montana).

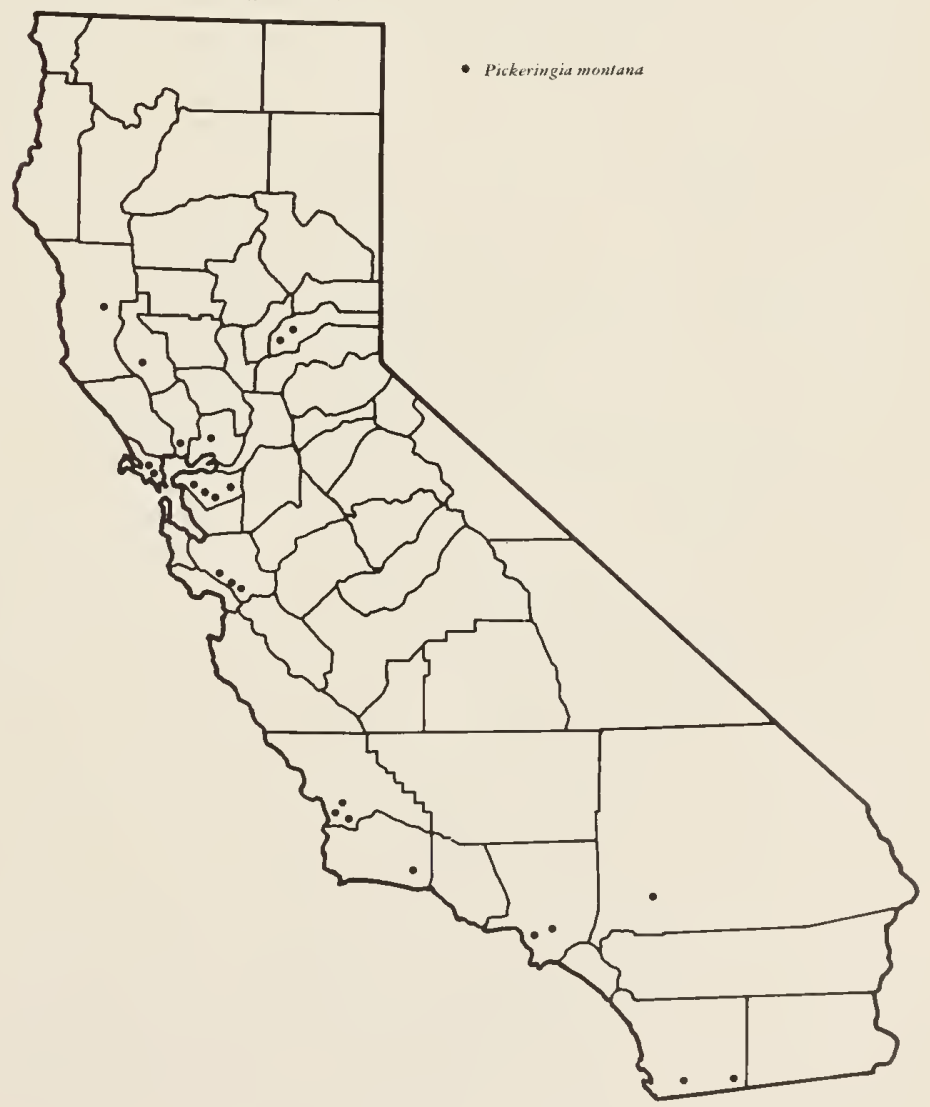


Economic talue. Ecologically, creosote bush is an unusually interesting plant because of its high inflammability, execedingly decp root system, capacity to reprodice and grow on severe sites, reduced leaf area, its active chemical properties, and its use as domestic medicines and concoctions of the aborigines.

Stanley ${ }^{\text {(135) }}$ gives the following account of the economic importance of creosote bush. "The flower buds, pickled in vinegar, are said to be eaten like capers. The plant is much nsed in domestic mcdicine, especially for rheumatism, a decoction of the leaves being employed for baths or fomentations. The decoction is said, also, to have rcmarkable antiscptic properties, and is applied to bruises and sores. It is taken internally for gastric disturbances and for venereal diseases. A reddish brown lac is often deposited upon the branches by a small scale insect. This lac is used in somc parts of Mexico for dyeing leather red, and the Coahuilla Indians of California employ it as a cement. The same Indians use a decoction of the plant for intestinal complaints and for tuberculosis. The Pima Indians of Arizona drink a decoction of the leaves as an emetic, and apply the boiled leaves as poultices to wounds and sores.

The palatability of crcosote bush is low to nil for all grazing animals. It is included in the discussion because of its abundance in the California deserts and the many inquirics about its food value. The current leafage is nibbled slightly in the winter and early spring by some animals but is not cropped at all by others. Some authors lrave reported it to bc poisonous to livestock ${ }^{(115)}$.

Goatnut (Simmondsia chinensis). Flowering branchlet; flower; and fruit. This is a palatable and nutritious plant for all kinds of livestock and big game, especially sheep and deer. It reproduces readily from sprouts after a fire, and from seeds deposited in squirrel caches. Limited planting trials have been made in southern California of this useful and interesting plant.

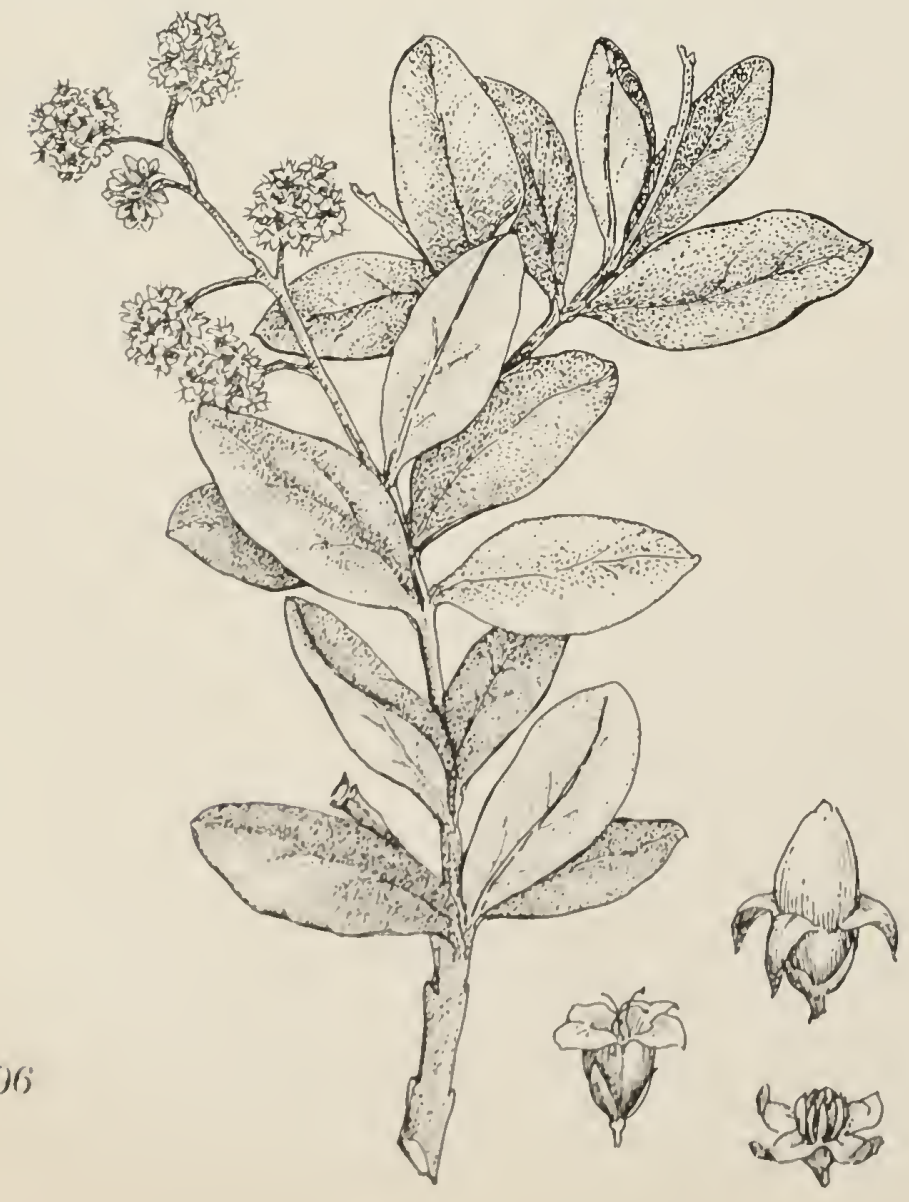

Browse rating. Poor to useless for sheep, goats, and deer; and useless for cattle and horses.

\section{Box FAMILY (BUXACEAE)}

This family is best known for the boxwoods (Buxus). Several kinds are used primarily for either low or tall hedges in California gardens. All have lustrous dense foliage and can be pruned to any shape or form. Many of the very formal gardens of Europe rely heavily on the English boxwood for a elipped geometric design pattern. And they use these plants for their topiary work, trimming them into birds, urns, and the like.

Only one genus including one species is native to California.

GOATNuT (Simmondsia chinensis) (drawing on this page), also known as jojoba, pignut, sheepnut, quinine plant, wild-hazel, and deernut. Rigid, spreading, evergreen shrub 3 to 10 feet high, with yellowish green hairy twigs branching by 2's. Leaves simple, opposite, thick and leathery, oblong-ovate, rounded at both ends, 1 to 2 inches long, 5 inch to 1 inch wide, pale green or yellowish green, margins entire. Male and female flowers bornc on separate plants, yellowish, the male flowers about 1/; inch long, in clusters; female flowers, solitary, about $\frac{1}{2}$ inch long; March to May. Fruit a short pointed, smooth, cylindrical capsule, about ${ }^{3} / 4$ inch long, somewhat resembling an acorn; sceds smooth, brown or black.

Distribution (map on page 93, bottom). Goatnut is limited in California to the arid rocky hills and mountains below 5,000 feet elevation in San Diego, Imperial, and Riverside counties. It extends eastward to Arizona and southward to Lower California, and Sonora, Mexico, and occurs in some nearby islands. It is locally abundant in restricted areas of the creosote bush scrub and Joshua tree communities.

Economic value. Goatnut is a highly palatable and wholesome browse plant for all kinds of livestock and big-game animals, including descrt bighorn shecp. The size, abundancc, and cvergreen character of the lcaves, and the fact that it is occasionally abundant in dry sites where few other palatable species occur, enhances its value as a food plant on desert range. Bccause of its restricted distribution, however, goatnut does not rank as high in general browse valuc as more widcly distributed and cqually palatable specics.

The seeds of goatnut have a nutty flavor with a slight bitterness similar to that of chestnuts and hazelnuts, and are a source of food among certain Indians in southern California and Mcxico. A substitute beverage for chocolate and coffec is prepared by grinding and roasting the seeds and adding certain suitable ingredients. The seeds are rich in oil or wax which has been used in the mannfacture of hair tonic, and which may come into much wider usage. This plant is being cultivated limitedly in sonthem California with the view of increasing yield of the mit crop) and further to explore the properties of the seed was ${ }^{\text {inem }}$. 
Although goatnut reproduces readily from sprouts, as after a fire, new plants commonly develop from squirrels' caches. Because of its slow growth it appears unsuitable for planting on depleted browse range.

Browse rating. Good for goats and deer; good to fair for sheep; fair to poor for cattle; and poor to useless for horses.

\section{Sumiac or Cashew Family (Anacardiaceae)}

The sumac or cashew family inchudes two trees that supply edible nuts-the cashew (Anacardium occidentale) and the pistache (Pistacia vera), as well as a fruit tree-the mango (Mangifera indicum) - all tropical trees. The pepper tree (Schinus molle) is probably the best known to Californians, and its history is romantically linked with that of the missions and old Spanish California. Its lacy foliaged crown, gnarled trunks, and rosy-red berries are such a familiar sight in southern California that it is almost considered a native even though it comes from Peru.

In California the family is represented by one genus (Rhus) which includes five woody species.

\section{SUMACS (Rhus)}

These are evergreen or deciduous trees or shrubs with resinous, acrid, or milky sap. Leaves are alternate, simple, or compound. The small flowers are borne in axillary or terminal panicles, or in spikes. The fruit is a small dry or semi-fleshy drupc.

Two evergeen natives with simple leaves-lemonade berry (Rhus integrifolia) and sugar bush (Rhus ovata) have found their way into many California gardens. Their clean, dense foliage is attractive throughout the year. They are excellent when planted as individuals or as tall background shrubs, or even as a bank cover when kept to 3 or 4 feet. The equally handsome evergreen laurel sumac (Rhus laurina), although less hardy, is planted to some extent in southern California.

Two well-known, and closely related, culprits also belong to this genus-poison-ivy (Rhus toxicodendron) and poison-oak (Rhus diversiloba). Poison-ivy does not occur in California but it has the same allergic affect on humans as described for poison-oak.

The two species described below are the only ones that have appreciable browse value.

\section{Key to the Browse Species}

1. Shrub, or sometimes vine-like; leaves usually 3 to 6 inches long; flowers greenish-white in drooping loose panicles appearing with the leaves; fruit a tan or whitish dry berry-like drupe................ POISON-OAK

(Rhus diversiloba)

1. Spreading shrub, never vine-like; leaves usually 3 inches or less long; flowers pale yellow in terminal erect densely clustered spikes, appearing before the leaves; fruit a reddish fleshy berry-like drupe which is covered with a gummy secretion .

. SQUAW BUSH

(Rhus trilobata)

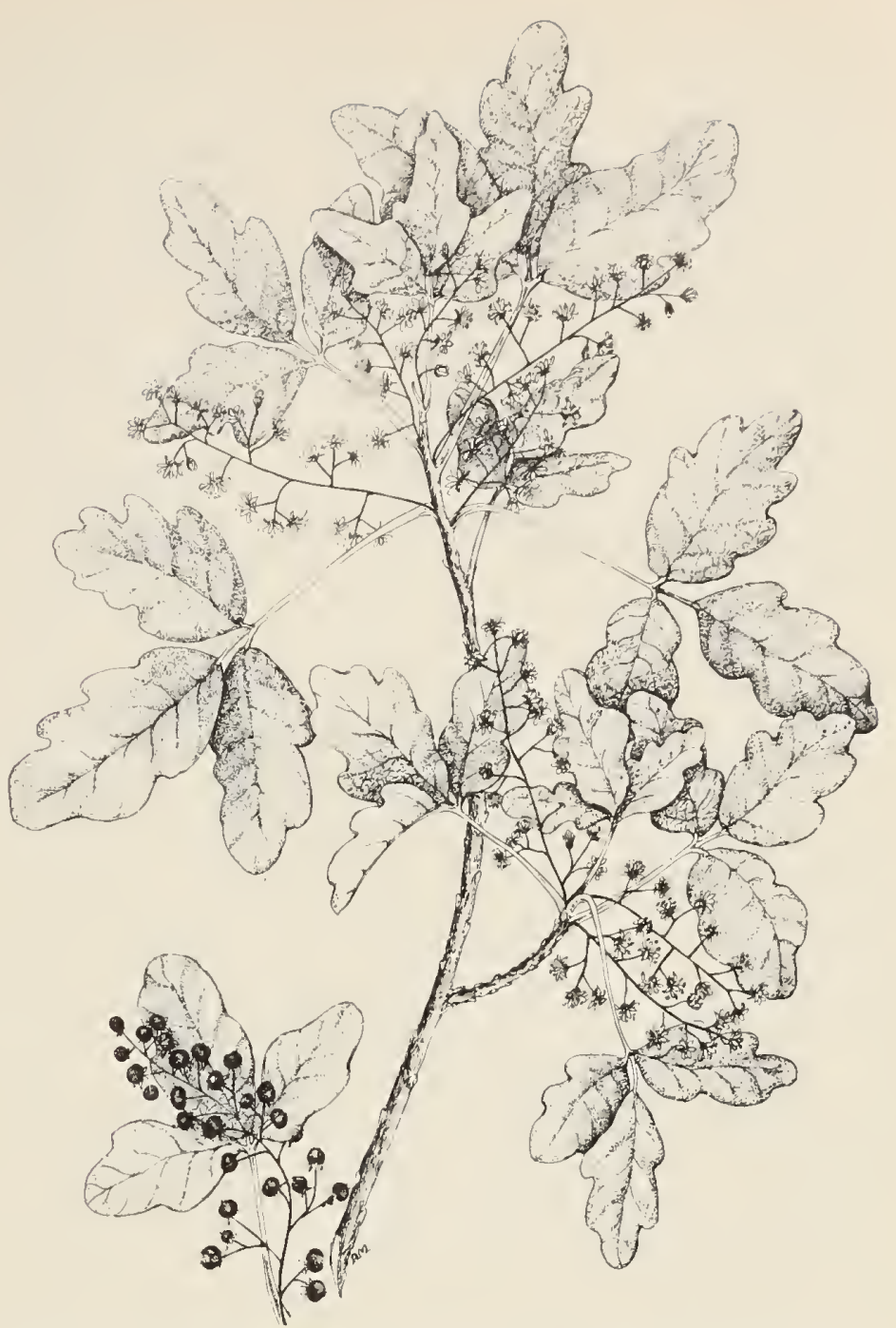

Poison-oak (Rhus diversiloba). This is neither a poisonous plant nor a true oak. 'The oils, however, are irritating to the skin of most persons On burns it sprouts heavily, and in open stands it never grows beyond the reach of sheep or deer. It is moderately palatable to all grazing animals except cattle. Even horses browse upon this plant to a considerable extent.

POISON-OAK (Rhus diversiloba) (drawing shown above) Erect or spreading, deciduous shrub, 1 to 6 feet high, or sometimes growing as a woody vine. Leaves typically trifoliate, rarely simple, 3 to $\dot{6}$ inches long; leaflets variously toothed, lobed, or rarely cntire, 1 to 4 inches long, distinctly stalked; foliage turns a beautiful red in autumn. Flowers small, greenish white, in axillary, drooping, loose panicles, appearing with the leaves; April to May. Fruit tan or whitish, smooth, dry drupe, about $\frac{11}{1}$ inch wide, falling soon after maturity.

Poison-oak is ncither a poisonous livestock range plant nor it is a true oak. The common name has evolved from the fact that its juices or oils are highly irritating to the skin of most persons, and because the leaves strongly resemble those of somc deciduous oaks. One must cone in contact with the oil particles, cither directly from the plant or brush against clothes, or other articles, that have touched the foliage. Some of the worst infections are likely to occur cluring a fire, when the irritating oils are released into the atmosphere. 
Distribulion (map on page 87). This is one of the most widely distributed shrubs in California. It oceurs from sea level up to about 5,000 feet elevation and grows in open woodland, on grassy hillsides, and in open stands of chaparral. It occurs in the Great Valley, the foothills and mountain slopes of the Coast Ranges and Sierra Nevada, and the foothills and mountains of southem California. It commonly forms scattered stands in the open woodland-grass community

Economic value. Poison-oak causes no apparent ill effects to browsing animals. Dogs and cats, on the other hand, often have infected eves from nosing around the bushes ${ }^{(45)}$. This species is a prolific sprouter and is difficult to eradicate.

Chemical studies indicate that poison-oak is a fairly nutritious plant ${ }^{(11,60)}$. The crude protein content in the voung early growth-stage foliage is around 35 per cent, 19 per cent when the plant is in late bloom, and 8 per cent when the leaves are fully developed and have changed color. These data show higher protein levels than in grasses at corresponding growth stages. Also the crude fiber content appears to be more favorable to grazing animals in that it does not reach as high levels as in certain other shrubs and in the grasses. The calcium to phosphorus ratios, however, are much higher than in associated grasses in corresponding growth stages.

Whether the chemical values are associated with the palatability of this species is not known. Horses feed upon poison-oak at the different growth stages much more extensively than on most other woody plants. Sheep, goats, and deer likewise browse upon the leaves and young stems throughout the growing season in preference to those of many other woody species, whereas cattle utilize it to a lesser extent. On the Tehama winter range black-tailed deer utilized poison-oak fairly heavily in the fall months and again in April and May, according to actual stomach analyses ${ }^{(57)}$. In Lake County on shrubland-a managed shrubland range where the tall chaparral has been reduced by burning or by meehanical means-abont 20 per cent of the annual poison-oak growtl, was eaten by deer ${ }^{(15)}$.

This plant sprouts abundantly after burning. Although difficult to eradicate, certain weed killers are now availal)le that are effective. When applied thoroughly, 2,4-D plus 2,4-5-T will knock it out completely. Amino triazole is effective up to the time poison-oak foliage turns color. But it may be necessary to spray regrowth again. Ammate will quickly destroy the top growth but sprouts are soon likely to appear.

Browse raling. Good to fair for horses and deer; and fair to poor for cattle, sheep, and goats.

sovaw ве'sn (R/mus trilobala), also called skunk bush. Somewhat similar in appearance to poison-oak but does not cause skin irritation in lumnans. More diffusely branched and spreading, deciduous, 3 to 5 feet high, and sometimes 8 feet across. Leaves typically smooth, trifoliate, or sometimes 3 to 5 parted, 3 inches or less long; leaflets distinctly 3 -loberd, the lobes toothed, terminal leaflet ${ }_{4}^{3}$ inch to 2 inches long. Flowers pale yellow, appearing before the leaves, in terminal clustered spikes, $1 / 2$ inch to 1 inch long; March and April. Drupe fleshy, berry-like, reddish, about ${ }_{14}^{1 /}$ inch wide, covered with a viscid substance.

Distribution. This species inhabits canyon bottoms and dry flats in the middle and inner Coast Ranges, in the Sierra Nevada foothills, and in southern California. It extends northward to Oregon, southward into Lower California, and eastward to the Rocky Mountains and Texas. It oceurs in many plant communities.

Economic value. Squaw bush is not nearly as abundant as poison-oak, nor is it as palatable to browsing animals. It is somewhat closely cropped only where more desirable feed is limited. In open woodland-grass cover it endures moderate shade.

Browse rating. Fair to poor for deer; poor for sheep and goats; poor to useless for cattle; and useless for horses.

\section{Maple Family (Aceraceae)}

The maple family includes deciduous trees or shrubs with simple or compound leaves. The small flowers are borne in drooping elusters. Fruits are single winged samaras.

Perhaps no plant family emphasizes the word shade as well as the maple family. In summer when traveling

Vine maple (Acer circinatum). In open stands this plant furnishes fairly important browse for all grazing animals. In dense stands, on the other hand, it often forms such a tangled cover as to virtually exclude livestock.

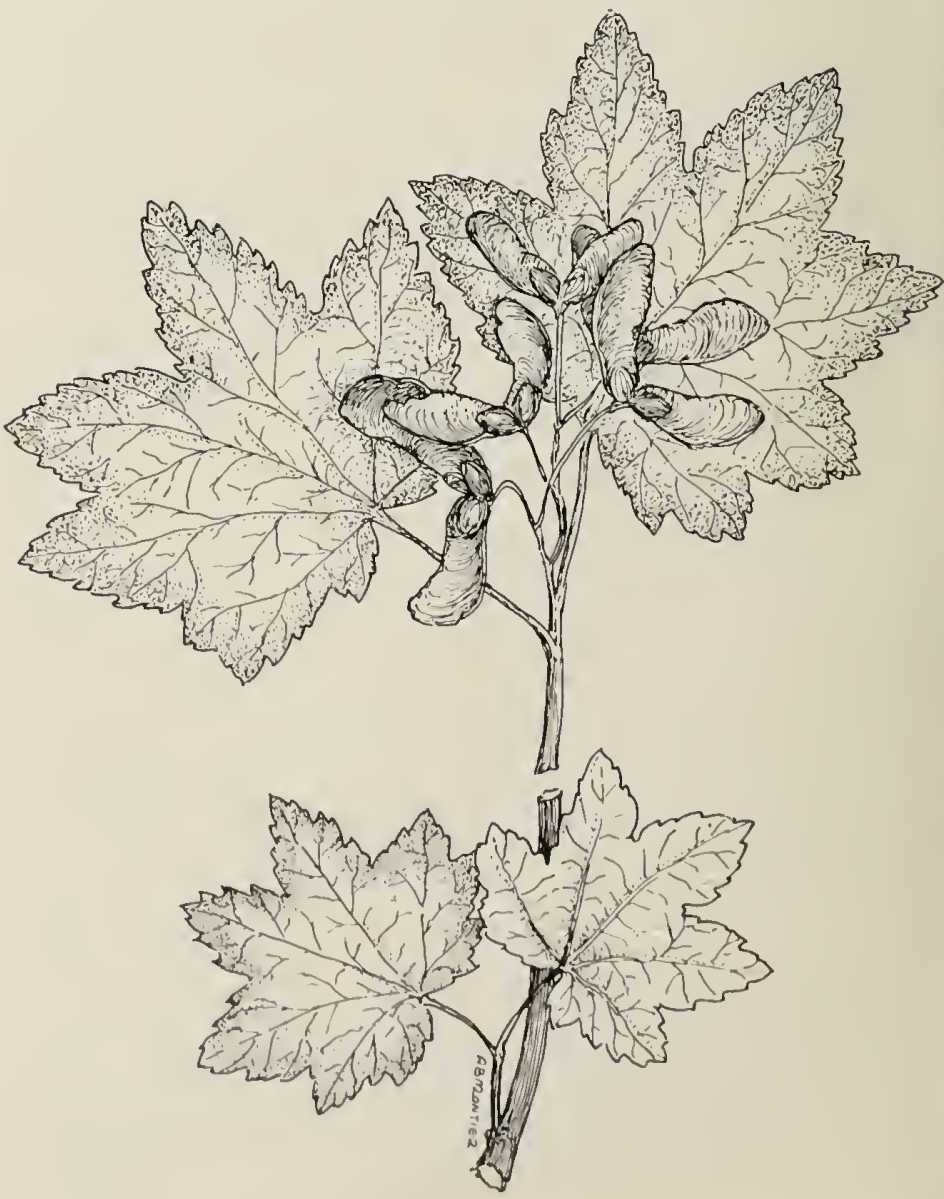


throughout the Midwest or the East, or even the hotter parts of the West, one cannot help but notice the maplelined streets of most towns and cities because their shade on a hot day is so welcome. And many of the maples provide an outstanding fall color display.

One also thinks of maples, actually only one-the sugar maple (Acer saccharum) of the Northeast-as synonymous with maple sugar, maple syrup, and maple candy. Maples are especially well represented in eastern United States where they are of great importance in the lumber trade. In contrast, most western species are small trees or shrubs and have little or no significance in the lumber trade.

Several western species furnish a large volume of fairly palatable browse, and needed shade for grazing animals during hot days. Four species are native to California. The two shrubby species are the most important as browse plants.

\section{Key to Browse Species and Varieties}

1. Leaves pinnately divided into 3 leaflets, these toothed

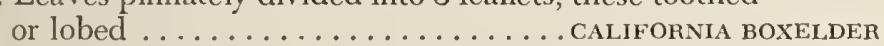
(Acer negundo var. californicum)

1. Leaves palmately lobed, not divided into leaflets....... 2

2. Large tree to 80 or 100 feet high; leaves 4 to 10 inches wide; samaras hairy . . . . . . . . . . BIGLEAF MAPLE (Acer macrophyllum)

2. Shrubs or small trees, sometimes reclining and vinelike; leaves usually less than 4 inches broad; samaras not hairy $\ldots \ldots \ldots \ldots \ldots \ldots \ldots \ldots \ldots \ldots \ldots \ldots \ldots \ldots \ldots$

3. Leaves 2 to 4 inches long and as broad, 5 to 11 -lobed; flowers reddish-purple; wings of fruit spreading in a nearly straight line; coastal northern California eastward to Siskiyou, Shasta, and Trinity counties, southward in the Sierra Nevada to Butte and Yuba counties, below 5,000 feet elevation........... vine MrApLE

(Acer circinatum)

3. Leaves 1 inch to 3 inches long and as broad, mostly 3-lobed; flowers greenish-yellow; wings of fruit spreading at an oblique angle; high mountains of southern California, the Sierra Nevada, and northern California, above 5,000 feet elevation...... . DWARF MAPLE

(Acer glabrum)

\section{Primary Maple Species}

IINE MAPLE (Acer circinatum) (drawing on page 98). Reclining or vine-like shrub, rarely a small tree, 5 to 20 feet high. Leaves simple, 2 to 6 inches long and as broad, 5 to 11 -lobed, the lobes triangular, acute, and with toothed margins; petioles 1 to 2 inches long, grooved. Flowers reddish-purple, 2 to 10 , or sometimes more, in umbel-like clustcrs; April to May. Samaras reddish, the $\frac{1}{12}-$ inch to 1 -inch wings spreading in a nearly straight line. Vine maple is unusually ornamental in the fall when its foliage turns a rich scarlet. It is cultivated in eastern, northwestern states, in northern California, and in Europe because of its attractive foliage, purplish twigs, and reddish flowers with yellow stamens. When grown in the sun it is less vine-like, and becomes a beautiful small tree.
Distribution (map shown below). This species grows along stream banks and in well-draincd shaded areas from the coastal mountains of British Columbia southward to western Washington, in the mountains of northern California in Del Norte, Humboldt, Mendocino, Siskiyou, Shasta, Trinity, Butte, and Yuba countics, from near sea level to 5,000 feet elevation. It is very tolerant and often forms an understory in pine, fir, and coast hemlock woods, and is commonly associated with western serviceberry.

Economic value. In open stands vine maple is a fairly important browse for all grazing animals. Because of its low stature much of the leafage is available to livestock. However, it sometimes forms such a dense and tangled cover as to prevent animals from feeding extensively on it.

Browse rating. Good to poor for deer; fair to poor for cattle, sheep, and goats; and poor to useless for horses.

DWARF MAPLE (Acer glabrum) (drawing on page 100), also called mountain maple. Shrub or small tree 5 to 15 feet high, with smooth gray bark on the main stems and branches. Leaves simple, or rarely compound, 1 to 3 inches long, and about as broad, palmately 3-lobed, often with 2 supplementary lobes at the base; petioles 1 to 5 inches long. Flowers greenish-yellow, borne in branching clusters about 1 inch long, appearing with the leaves; May to July. Samaras straw-colored, or reddish, wings $\frac{1}{12}$ inch to 1 inch long, diverging at an oblique angle.

Distribution of vine maple (Accr circinatum) and California buckeye (Aesculus californica).

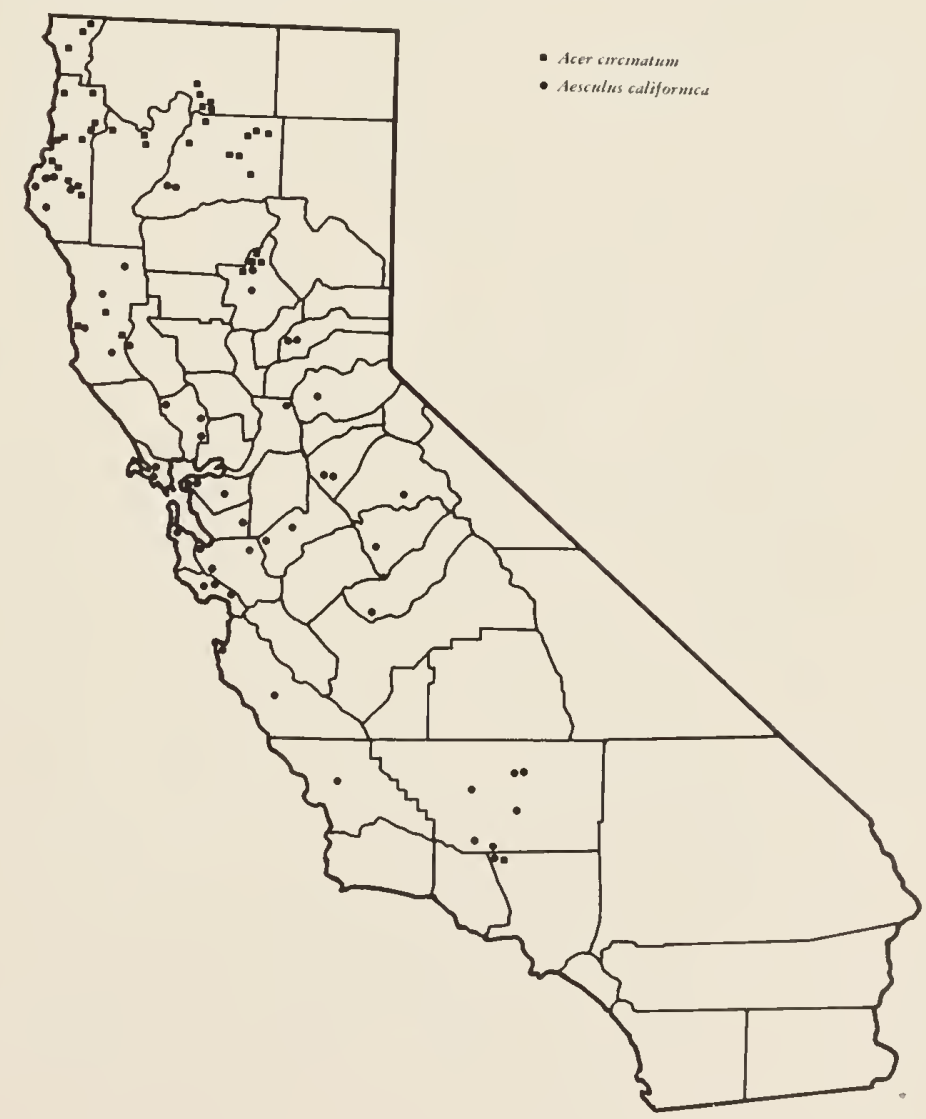




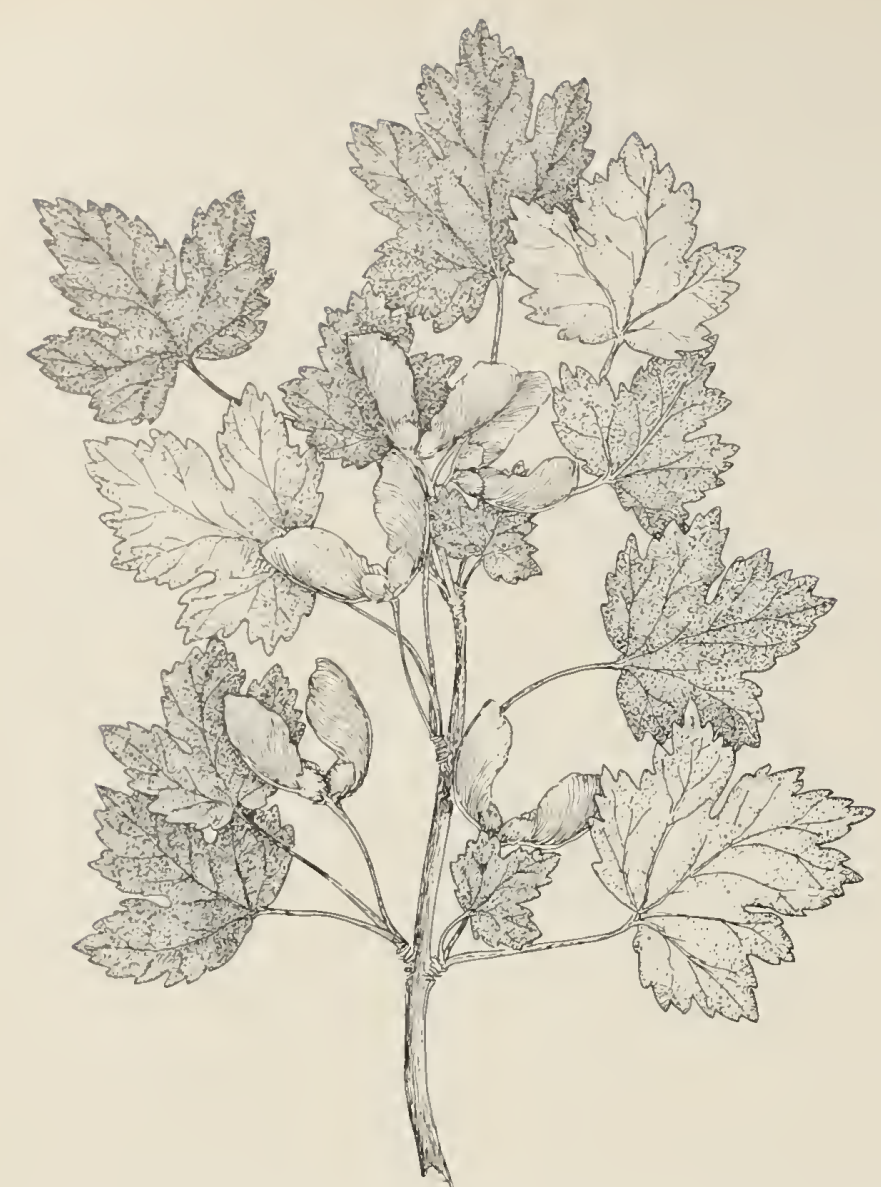

Dwarf maple (Acer glabrum). The browse value of this species varies from good to useless. It is utilized most by deer.

Distribution of dwarf maple (Acer glabrum).

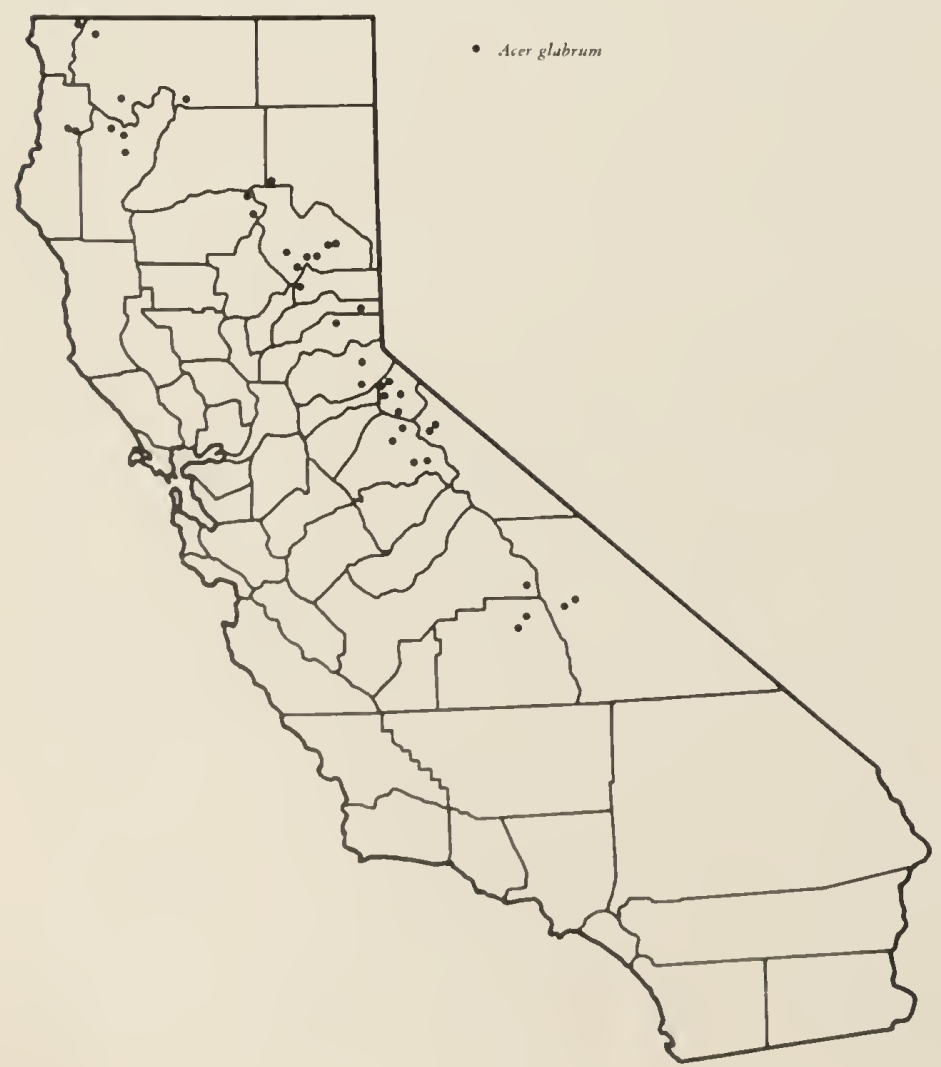

Distribution (map shown below). Dwarf maple oceupies gravelly or rocky soils along streams and moist to moderately dry flats and slopes, frequently in assoeiation with mountain snowberry, bireh, and western serviceberry. It oceurs in the San Jacinto and San Bernardino mountains of southern California, the Sierra Nevada, and the higher mountains of northern California at elevations from 5,000 to 9,000 feet. It extends northward through Oregon, Washington, and British Columbia to Alaska, and eastward to the Roeky Mountains.

Economic value. The browse value of dwarf maple varies from fairly good to useless. The young foliage and sprouts are browsed eagerly by sheep, goats, and deer, and moderately by eattle. Because of its wide distribution it is a valued browse, but is seldom abundant enough to supply a large volume of forage.

Browse rating. Good to poor for deer; fair to poor for goats; poor for sheep; poor to useless for eattle; and useless for horses.

\section{Secondary Maple Species}

BIG-LEAF MAPLE (Acer macrophyllum). Broad-erowned tree, 30 to 100 feet high. Leaves, among the largest of the maples, roundish in outline, 4 to 10 inehes broad, palmately divided into 3 , or usually 5 broad eoarscly toothed lobes. Flowers greenish in racemes; April and May. Body of samara short bristly-hairy, the tawny wings diverging at an aeute angle.

Distribution. It oceurs along living streams and on north and east slopes throughout the foothill area of California (west of the main Sierra Nevada crests) in the zone of 25 to 50 inches of rainfall. It extends northward to Alaska.

Economic value. Since a large part of the leafage grows beyond the reach of grazing animals, the volume of forage eonsumed is rather small. The foliage available is eropped with fairly good relish.

Browse rating. Fair to poor for deer; poor for sheep and goats; poor to useless for eattle; and useless for horses.

CALIFORNIA BOXELDER (Acer negundo var. califormi$\mathrm{cum}$ ). Round headed trce 29 to 60 feet high. Leaves pinnately 3 -foliolate, the leaflets $1 \frac{1}{1}$ to 5 inehes long, toothed, incised, or decply 2, 3 or 5-lobed, densely hairy especially when young. Male flowers elustered on threadlike hairy stalklets; female flowers borne in slender racemes. Samaras straw-white, erimson when young, fincly hairy.

Distribuliom. It occurs along streams and in low moist valley bottoms below 6,000 feet elevation, in the Great Valley, in the Coast Ranges, and sonth to the momntains of Santa Barbara County; also oeeasionally in the San Jacinto and San Bernardino mountains.

Economic value. The browse value of Califomia boxelder is essentially the same as that of the three species discussed above.

Brouese ratiug. Fair to poor for deer; poor for sheep, goats; poor to useless for cattle; nseless for horses. 


\section{Horse-Chestnut Family (Hippocastanaceae)}

This family includes two genera. The better known is the genus Áesculus, comprising a number of deciduous trees and shrubs, two of which are highly valued as ornamentals. The densely foliaged, wide spreading, round headed, common horse-chestnut (Aesculus hippocastanum) is widely planted as a street tree in many sections of the East, Midwest, and Northwest, as well as in Europe. The state flower of Ohio is their native buckeye (Aesculus glabra), and one frequently hears Ohio referred to as the Buckeve State.

The horse-chestnuts are not related to the chestnut. The only resemblance is the big round fruits, especially those species which bear spiny fruits. One species of the genus is represented in California and the characters of the genus are included with those of the species.

CALIFORNIA BUCKEYE (Aesculus californica) (drawing below). Deciduous tree 15 to 40 feet high, but sometimes shrub-like, with smooth gray bark and broad open crown. Leaves opposite, palmately compound, with 5 to 7 oblong-lanceolate, toothed leaflets, 3 to 6 inches long, nearly smooth; lcaves early deciduous. Flowers large, pinkish white, fragrant, in showy, erect, cylindrical, or rarely drooping clusters, 6 to 10 inches long; May to July. Fruit a large, pear-shaped, 3-valved capsule, 1\%/2 to 2 inches long, with one or two large, shiny, brown seeds.

California buckeye (Aesculus californica). This is not a high-quality browse plant yet it supplies a considerable amount of feed. The newly fallen leaves are sought by most grazing animals, and the green foliage is cropped rather closely in some localities. The mature leaves are high in calcium content but are low in phosphorus.

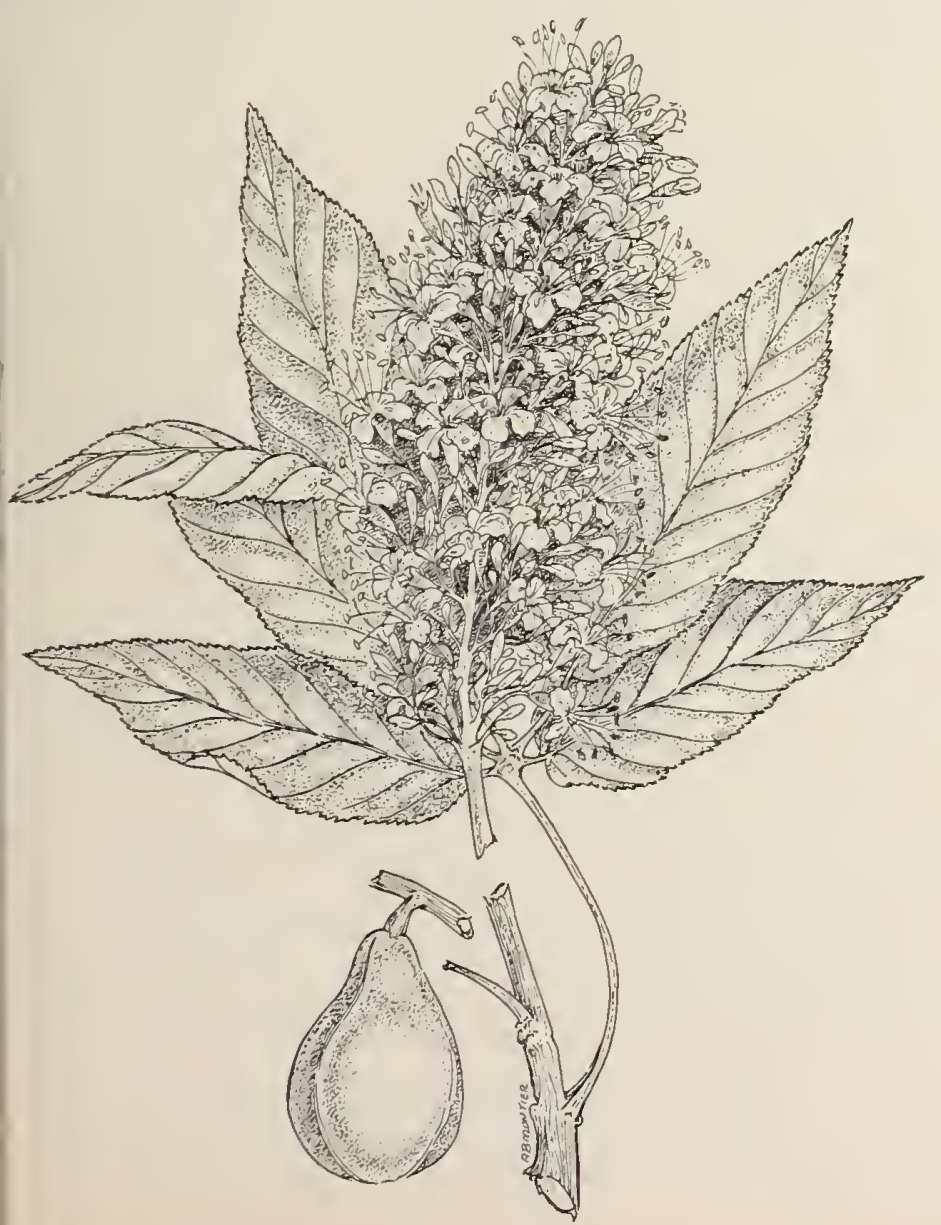

Distribution (map on page 99). California buckeye inhabits dry canyon slopes and low hills of the Coast Ranges and the Sierra Ncvada from Siskiyou and Shasta counties southward to the Tehachapi and Liebre mountains in Kern and Los Angeles countics up to about 4,000 feet elevation. It commonly grows in scattered stands in association with blue oak, wedgeleaf ceanothus, blue elderbcrry, and various grasses and forbs.

Economic value. The palatability of California buckeye varies considcrably through the grazing season. It is cropped most in early winter when the first leaves appear. Deer tend to feed extensively upon the newly fallen leaves, which are mostly cast in August, or sometimes earlier. Sheep and goats browse rather freely upon both the green foliage and the newly fallen leaves, whereas cattle crop the leaves and twigs limitedly or not at all.

A nutritional study ${ }^{(00)}$ showed that the crude protein content of the young expanding leafage was exceptionally high, reaching some 39 per cent. Just beforc flowering the protein content of the leaves had declined to about 24 per cent, and when the plant was in late bloom the levels had declined to about 17 per cent. When the leaves had changed color and were bcing cast the protein content had declined to approximately 13 per cent. At full leaf maturity the protein content was about twice as high as that in fully mature grass leafage.

In contrast to the protein content, the crude fiber in the leafage changed little with advancement in growth. The levels ranged from about 9 per cent in early spring to 12 per cent when the leaves were mature and cast. The most striking contrast took place in the calcium levels, which ranged from 0.16 per cent in the early stage to 5 per cent when the leaves were mature and shed. The revcrse took place in the phosphorus levels, which were highest in the young leafage and lowest in the newly fallen fully mature leaves. The levels ranged from 0.9 per cent in the early-stage leafage to 0.18 per cent in newly fallen leaves. The wide differences in the calcium and phosphorus levels, notably when the foliage had fully matured, accounted for the exceptionally wide calcium to phosphorus ratio (about 1 to 23) at that stage. Some investigators have speculated that pregnant does eagerly seek the mature leafage because of their craving for calcium induced by physiological requirements for that mineral. On the other hand, a fairly close ratio of calcium to phosphorus is recognized as desirable ${ }^{(107)}$.

Both the fruits and leafage of California buckeve are reported to be poisonous to domestic livestock during certain seasons of the ycar if large amounts are ingested. It has also been reported that the unhulled fruit causes cows to abort ${ }^{(13)}$. No authenticated cases of livcstock poisoning from this source have been reported in California ${ }^{(125)}$. Losses from poisoning among California honey bees and their larvae have also been reported to occur from the toxic effccts of the nectar in the flowers ${ }^{(150)}$.

Browse rating. Exccllent to good for deer; fair to poor for shcep and goats; poor for cattle; and useless for horses. 


\section{Buckthori Family (Rhamnaceae)}

This family includes both shrubs and small trees, and cren some climbing spccics. Many of the species are thomy: The learcs are alternatc or somctimes opposite. Flowers are small, regular, perfect, or imperfect, usually bome in terminal or axillary cymes, corymbs, or panicles madc up of small umbels. The fruit is a capsule or a drime.

This is a large family of some 45 genera and 600 species of both temperatc and tropical regions. One interesting ornamental, occasionally grown in California gardens, is the Chinese jujulse (Zizuphus jujuba), a most attractive small tree with glossy bright green foliage. The small, 2-inch dark brown fruits are sweet and considered a delicacy when candied.

Five genera are native to California, three of which (Colubrina, Adolphia, and Condalia) are of such limited distribution that they are of no browse value. They are very spiny plants of descrt areas. Only Ceanothus and Rhamnus contain species of significant browse value. These gencra accomt for a large and important segment of both the thin-leaved and the thick sclcrophyll leaved brush species that make up the woodland-grass, and the understory of the open forest associations. Both genera include highly ornamental species.

Only a few species of thesc genera are highly palatable to grazing animals, but several contribute browse of considerable local valuc at different seasons of the year. The current twigs of the deciduous species are browsed avidly when young. Ceanothus is by far the more important browse genus.

\section{CEANOTHUS (Ceanothus)}

This genus includes mostly deciduous or evergreen shrubs, but sometimes small trecs. Leaves are simple, altcrnate, or oppositc. Flowers are small, borne in raccmes, panicles, or umbels. Sepals, hood-shaped petals, and stamcns are five in number. The fruit is a 3-lobed capsule which splits into threc parts when ripe; seeds are smootl, convex on one side.

Until recently only one or two ccanothus werc seen in gardens. The most popular, and still available at the prescut time, is the tall-growing Europcan hybrid 'Gloire de Versailles.' Within the past 10 to 15 vears the native California ceanothi have become so much a part of California gardens that many gardeners hardly realize that they are natives. Especially well liked are the ground cover forms that take to dry bank planting so naturally. Thery offer clense attractive foliage, a profusion of flowers, and so litte maintenance. Growers are continually selecting better forms, cither for flower color, more prostrate habit, lusher foliage, or for other reasons.

In many localities Ceonothus is popularly known as wild lilac, but it has no relation to the lilac of cultivation which is Syringa vulgaris.

The prinatry browse species of Ceanothus, essentially in the order named, are: Decrhmush ceamothus, wedgeleaf coanothens, chaparral whitethom, and mountain whitethorn. Those of secondary browse rank are: Squaw carpet, Lemmon ceanothus, blueblossom ceanothus, trailing ceanothus, snowbrush ceanothus, coast whitethorn, and littleleaf ceanothus.

\section{Key to the Browse Species and Varieties}

1. Leaves opposite $\ldots \ldots \ldots \ldots \ldots \ldots \ldots \ldots \ldots$

1. Leaves alternate $\ldots \ldots \ldots \ldots \ldots \ldots \ldots \ldots \ldots \ldots$

2. Shrub 3 to 8 feet high; leaf margins entire, rarely toothed; flowers white, lavender, or sometimes blue; widespread shrub often forming extensive thickets in dry chaparral areas ............ WEDGELEAF CEANOTHUS

(Ceanothus cuneatus)

2. Prostrate shrub usually 2 to 6 inches high; leaf margins coarsely toothed; flowers blue; forms carpets under pines in the higher mountains of the North Coast Ranges, the Siskiyou Mountains, and the Sierra Nevada Mountains ................ sQuAw CARPET

(Ceanothus prostratus)

3. Spiny or thorny plants with grayish leaves thus giving the plant a grayish appearance............... 4

3. Plants without spines or thorns; leaves green thus giving the plant a green appearance..................

4. Low rounded shrubs, 2 to 5 feet high; rocky ridges in pine forests, 3,500 to 9,000 feet elevation

MOUNTAIN WHITETHORN (Ceanothus cordulatus)

4. Tall stout shrubs 5 to 12 feet high; plants of lower elevations usually less than 5,000 feet elevation. . . . . . . 5

5. Leaves $\frac{1}{2}$ inch to $1 \frac{1}{2}$ inches long, $\frac{1}{4}$ to $\frac{11}{2}$ inch wide; flowers pale blue varying to white; fruit not crested; dry chaparral, mostly low elevations in the mountains of southern California, inner Coast Range to Alameda County, and Sierra Nevada to Mariposa County

CHAPARRAL IVHITETHORN (Ceanothus leucodermis)

5. Leaves 1 inch to $2 \frac{1}{2}$ inches long, $\frac{1 / 2}{2}$ to 1 inch wide; flowers creamy-white; fruit crested; valley flats, moist slopes in the redwood belt, Santa Cruz Mountains, northward to Humboldt County, and southwestern

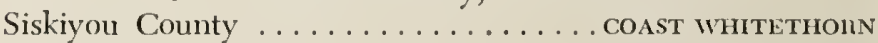

(Ceanothus incanus)

6. Branchlets gray or whitc hairy, occasionally somewhat glandular; leaves 1-veined from the base or indistinctly 3-veined, very densely hairy, or gray or whitish on the under surface of the leaves; Hower clusters simple, 1 inch long, flowers blue, rarely whitc......... 7

6. Branchlets not gray or white-hairy; leaves usually distinctly 3 -veined from the base, or sometimes 1-veined, smooth or hairy only along the veins on the under surface, or densely hairy or whitish, the leaves highly varnished on the upper surface (Ceanothus velutinus); flower clusters simple or compound, 1 inch to 4 or 6 inches long; flowers bluc, white or occasionally pink...... 9

7. Low trailing shrul, 1 foot or less high, 2 to 4 feet wide, often forming carpets under oaks and pines; leaves soft, rather thin, hairy, the upper surfaces not Waxy .................. THAHLING Clanothus (Ceanothus diversifolius) 
7. Erect spreading shrubs 1 foot to 3 feet high, or occasionally higher, not forming carpets; leaves thicker, not soft, and usually the upper surface is waxy.........

8 . Leaves often with smaller leaves clustered in their axils, commonly wavy-margined, dark green above, whitish beneath, smooth or hairy along the veins; dry ridges and brushy slopes, Coast Ranges from Mendocino County southward to the Santa Cruz Mountains, Monterey and Santa Clara counties, southward in the Coast Ranges away from the coast to San Luis Obispo County, also in the Cuyamaca Mountains, San Diego Counti ................... WAvyleaf CEANothus (Ceanothus foliosus)

8. Leaves without clustered leaves in their axils, not wavy-margined, bright green above, very densely hairy on the under surface; open wooded hill slopes or burned over areas in the Sierra Nevada foothills from El Dorado County, northward to Shasta County, and in the inner north Coast Range in Trinity and northern Lake counties ............ LEMMON CEANOTHUS

(Ceanothus lemmonii

9. Foliage with a balsam-like odor; leaves very broad, 3/4 inch to $1^{1 / 4}$ inches wide, dark green with highly varnished upper surface; flowers white.............. I

9. Foliage without balsam-like odor; leaves narrow, $1 / 2$ to $x_{4}^{*}$ inch wide, upper surface not highly varnished; flowers blue or white, occasionally pink........... 1

10. Shrubs usually 2 to 5 feet high; leaves pale and finely hairy beneath; Sierra Nevada from Tulare to Modoc counties, westward to Shasta, Trinity, Siskiyou, and Del Norte counties, 3,500 to 10,000 feet elevation

SNOIVBRUSH CEANOTHUS

(Ceanothus velutinus)

10. Shrubs 6 to 20 feet high; leaves paler beneath but not hairy; north Coast Ranges near the coast

VARNISHLEAF CEANOTHUS

(Ceanothus velutinus var. laevigatus)

11. Evergreen shrub; branchlets angled; leaves dark green and smooth above, pale beneath except for a few coarse hairs on the prominently raised veins, margins finely toothed, occasionally inrolled, thus appearing entire; flowers light or deep blue

BLUEBLOSSOM CEANOTHUS (Ceanothus thyrsiflorus)

11. Deciduous or semi-deciduous shrubs; branchlets not angled; leaves light green, finely hairy or almost smooth above, smooth or finely hairy on the veins beneath, margins entire or sometimes finely toothed near the apex; flowers white or pale to dark blue,

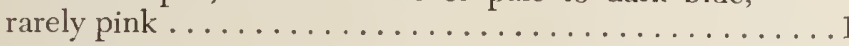

12. Low spreading shrub, 1 to rarely $3 \frac{1}{2}$ feet high; leaves $\frac{1}{14}$ to 1 inch long; flowers blue in nearly simple clusters to 3 inches long ............. LITtLELEAF CEANothus

(Ceanothus parvifolius)

12. Taller, more upright shrubs, 3 to 12 feet high; leaves usually 1 to 3 inches long, sometimes smaller; flowers usually white but may be blue or sometimes pink, in large branched clusters 2 to 6 inches long

DEERBRUSH CEANOTHUS

(Ceanothus integerrimus)

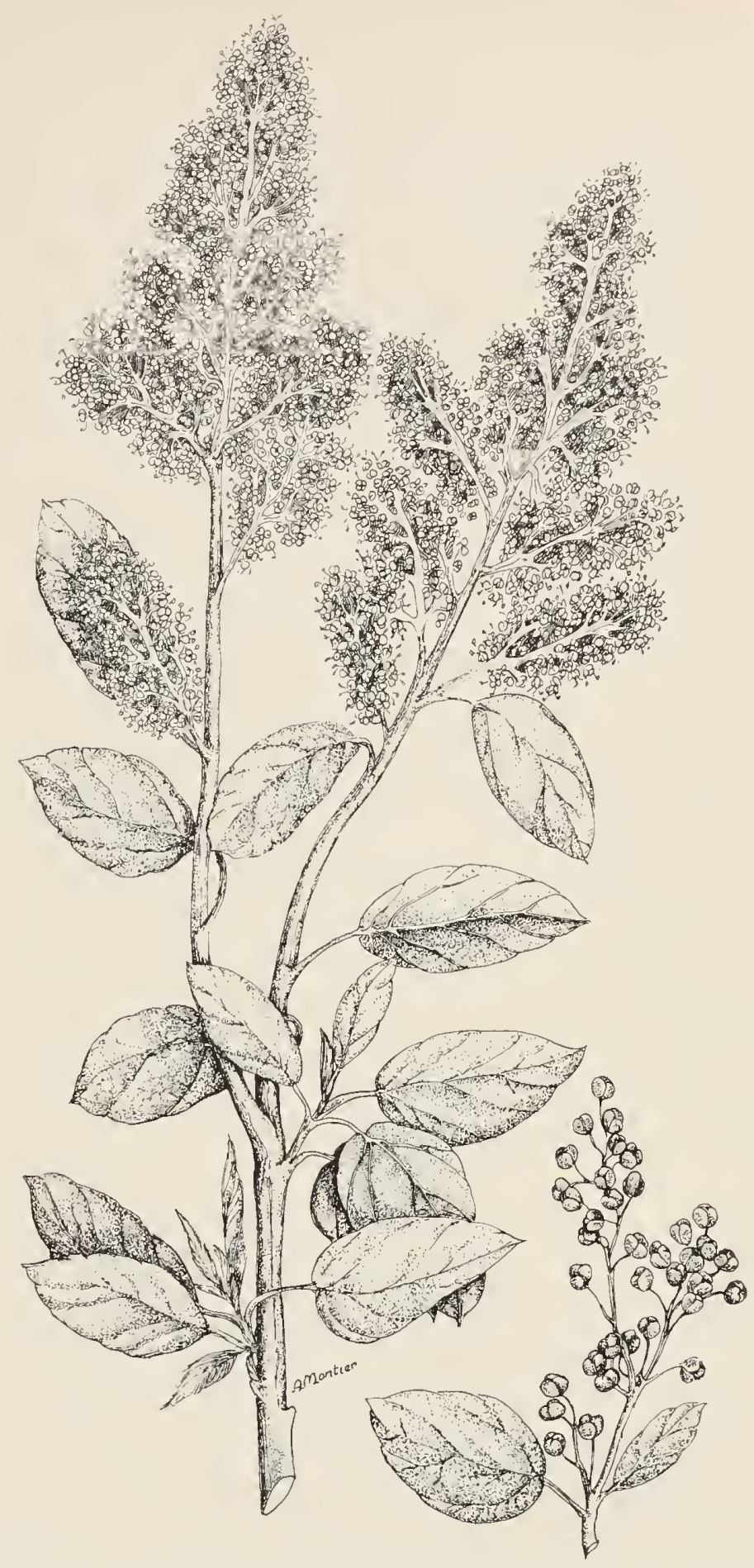

Deerbrush ceanothus (Ceanothus integerrimus). Right, branch in foliage and blossoms; left, fruiting spray. This is one of the most important browse species in the ponderosa pine forests of California.

\section{Primary Ceanothus Species}

DEERBRUSH CEANOTHUS (Ceanothus integerrimus) (drawing shown above), also called sweet birch, blue brush, wild lilac, and certain other names locally. Widely branched, deciduous or semi-deciduous shrub, 3 to 12 feet high, with green or yellowish, often drooping branchlets. Leaves alternate, broadly elliptical to ovate, or oblong, 1 to 3 inches long, ${ }_{8}^{3}$ inch to $1 \frac{1}{2}$ inches wide, usually 3 -veined from the base, light green, lightly hairy 


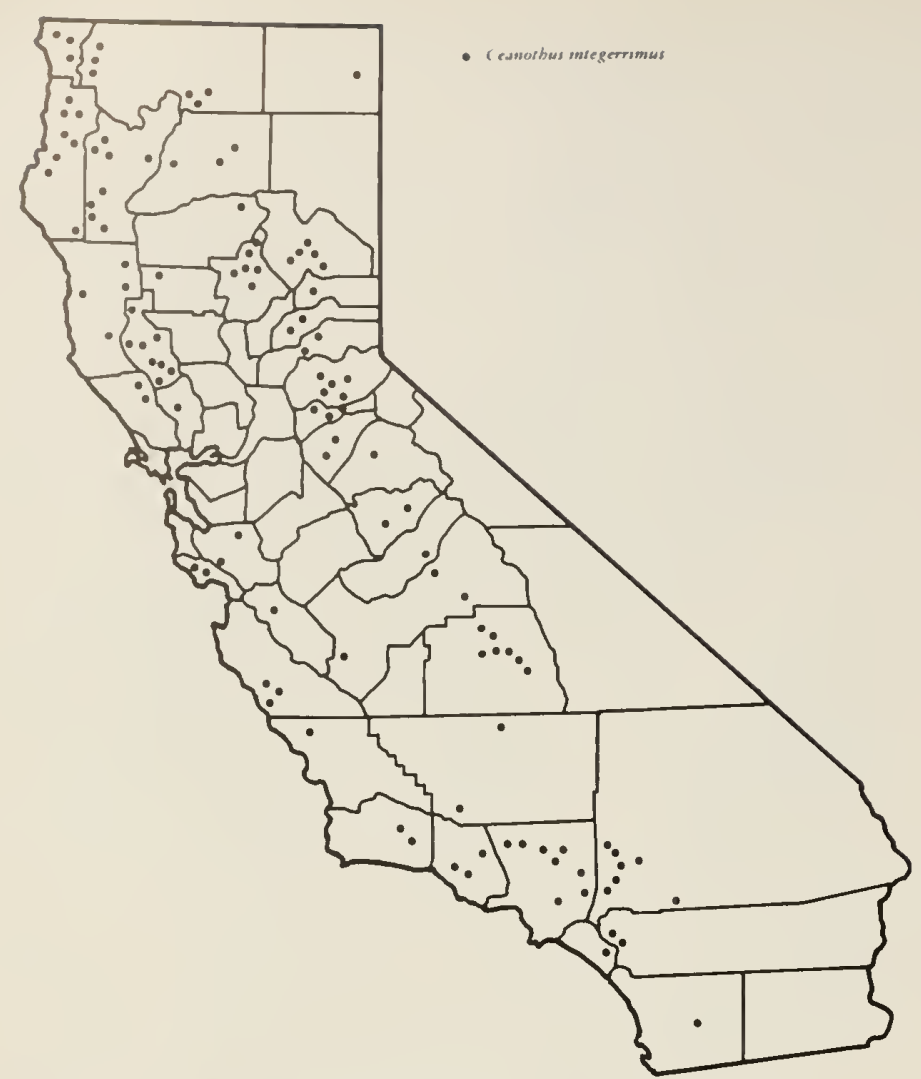

Distribution of deerbrush ceanothus (Ceanothus integerrimus).

to smooth above, paler and hairy along the veins beneath, margins entire, or occasionally toothed near the tip. Flowers white, pale to dark blue, sometimes pinkish, in compound clusters, 2 to 4 , or even 6 inches long; May to July. Capsule roundish or triangular, 将 inch or less widc, viscid, often with small lateral crests.

An eleven-year-old bush of deerbrush ceanothus (Ceanothus integerrimus) growing in a sugar pine stand on the Stanislaus National Forest. A large part of the branches are beyond reach of grazing animals.

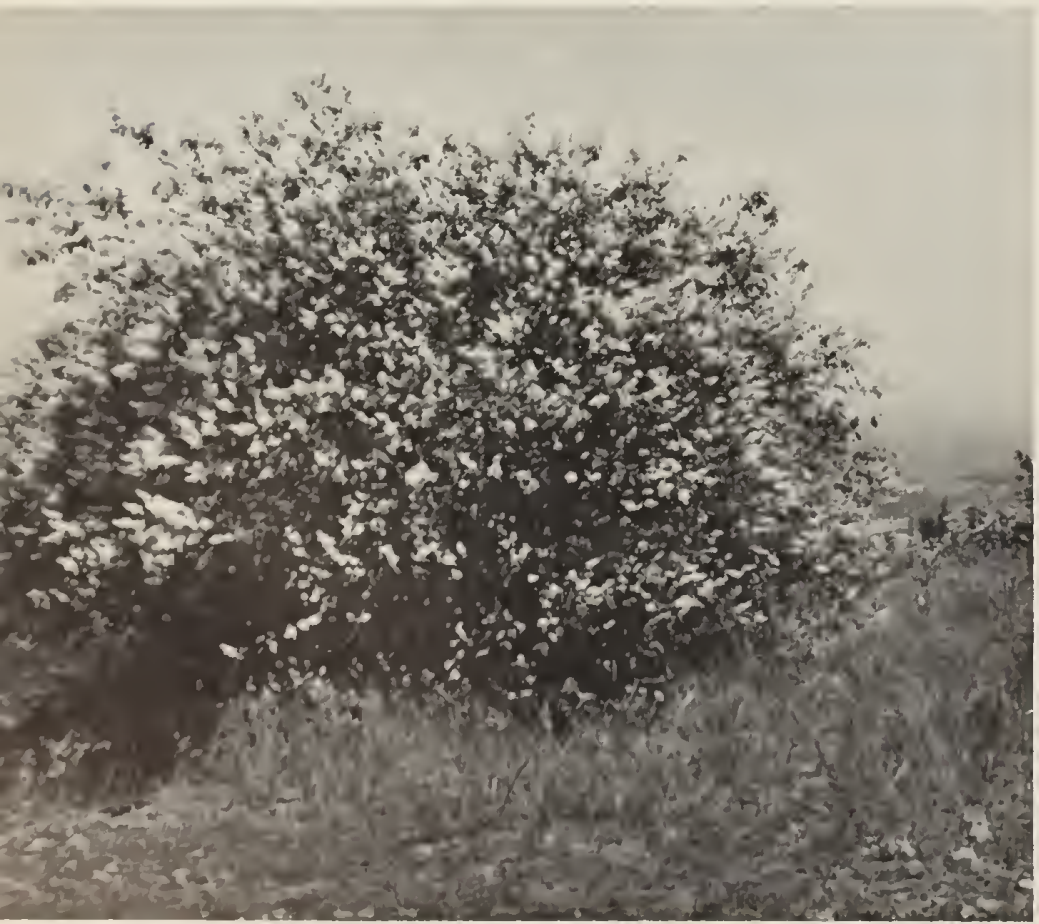

Distribution (map on the left). Deerbrush ceanothus inhabits mountain slopes, ridges, and flats from 1,000 to 7,000 feet elevation, being most abundant and luxuriant on fairly deep but often rocky well-drained soil in the ponderosa pine belt. It occurs in southern California in the Cuyamaca, San Jacinto, and San Bernardino mountains, northward in the Sierra Nevada from Kern to Modoc counties, thence westward through Siskiyou, Trinity, and Shasta counties to the Coast Ranges, away from the coast, southward to Santa Barbara and adjoining counties. It commonly grows in association with ponderosa pine, manzanita, Sierra mountain misery, mountain whitethorn, gooseberries, grasses, and various species of ferns.

Economic value. Deerbrush ceanothus is one of the most important summer browse species in California, in some localities supplying most of the feed. Its high palatability, abundance, and wide distribution combine to enhance its usefulness. Livestock thrive well upon this shrub in spring and summer, and grazing capacity is often based largely on its abundance and the age of the stand. Numerous vigorous sprouts spring up after a fire in most locations, and this growth, while it is still young, provides highly palatable browse for the first two seasons.

Analysis of the leaves of deerbrush ceanothus collected on winter deer range in October in the mountains of central Tuolumne County showed well-balanced amounts of crude protein, fat, mineral matter, crude fiber, and nitrogen-free extract ${ }^{(62)}$. It had been presumed that the preference deer had for this plant might be accounted for by its relatively high protein and mineral contents. This assumption seemed to be supported by the analytical data. Samples collected in April, in Madera County, showed that the crude protein content of succulent growing sprouts and seedlings averaged about 27 per cent, and the leaves alone about 20 per cent. In August the crudc protein content of mature spronts and leaves ranged from 12.5 to 14 per cent ${ }^{(i)}$. These data would seem to indicate higher nutrient values for deerbrush ceanothus than for most grasses at corresponding growth stages.

Cronemiller ${ }^{(41,4)}$, who for several years studied the feed value and management of deerbrush ceanothus on national forest ranges in California, states:

"Deerbrush is an important and frequently the principal forage species on summer ranges in forested areas in California within its range. It is mainly on ranges occupied by cattle, to a lesser degree by sheep. Deer are consistent users of the browse wherever it exists. It supports a large number of cattle on the Stanislaus, Eldorado, and Tahoe forests, where it apparently finds its optimum site (photo on the left). It is an important summer forage plant in some localities on the Shasta, Lassen, Plumas, and Sequoia forests."

Deerbrush ceanothus is poor winter feed because it is largely decidnous. However, when new growth appears deer seek it out and leave most other forages. It appears that the altitudinal movement of deer to the smmmer 


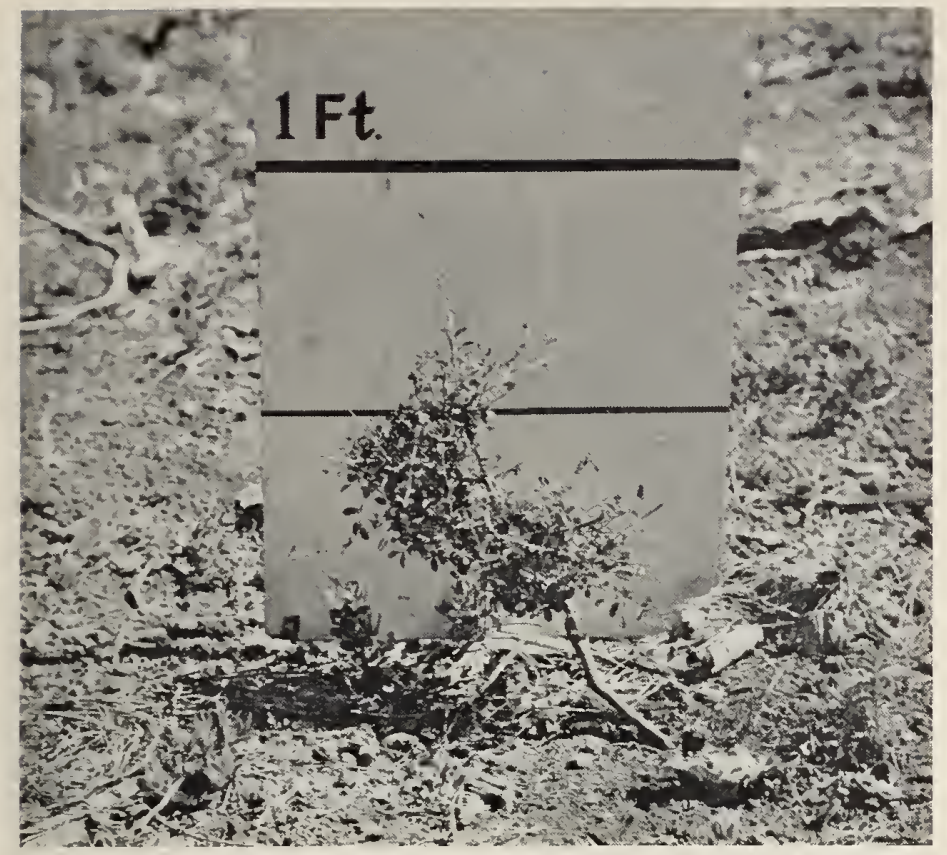

Deerbrush ceanothus (Ceanothus integerrimus). On heary stands, as frequently in ponderosa pine areas, the volume of growth is usually so large that browsing seldom depresses the plants. Where the stand is scattered and browsing is severe, on the other hand, individual plants may become badly distorted, as shown above, or actually destroyed. Lake County.

range is mostly determined by the leafing out of deerbrush ceanothus and other desirable browse plants. Since the beginning of growth varies with elevation, deer distribute themselves accordingly.

Excessive browsing of sprouts and seedlings must be avoided if the stand is to be fully maintained (photo above). Not more than about 50 per cent of the current growth should be removed during this reestablishment period. During the third to fifth years measurably closer utilization is possible and even desirable to keep a maximum number of branches within reach of the animals. After the tenth year grazing capacity declines sharply because of competition with associated vegetation and the height attained by deerbrush ceanothus. It is well, therefore, to lower the grazing capacity estimates from the time of maximum yield of deerbrush ceanothus every three years or so up to and beyond the fifteenth year.

To date only limited studies have been made to extend the range or to reestablish deerbrush ceanothus. Although control burning of decadent stands is known to induce abundant seedling and vegetative reproduction, this means of regeneration has not been employed because of the danger of fire damage to the forest and watersheds.

Browse rating. Excellent to good for sheep, goats, and deer; good to fair for cattle, and fair for horses.

WEDGELEAF CEANOTHus (Ceanothus cuneatus) (drawing on the right), also called buck brush, hornbrush, and greasebush. Erect, medium size to tall, evergreen shrub, 3 to 8 feet high, with rigid divaricate branches and stout, short, usually opposite branchlets. Leaves opposite, thick, borne on spur-like branchlets, spatulate to obovate-cuneate, wedge-shaped at the base, usually rounded at the tip, ${ }_{14}^{1 / 4}$ inch to 1 inch long, dull green, paler and white felted beneath, the margins mostly entire. Flowers white, lavender, or bluish, in short dense roundish clusters; March to April. Capsule nearly round, $\frac{1 / 8}{18}$ to $\frac{16}{14}$ inch wide, with conspicuous horns on the back; matures in September and October.

Distribution (map on page 106). This is a prominent component of the California chaparral and is widespread on dry exposed mountain slopes, ridges, and semi-arid valleys of well-drained soils between elevations of 300 to 4,000 feet, often forming pure dense stands. It occurs in the Coast Ranges, the Sierra Nevada, and in the mountains of southern California.

Economic value. Wedgeleaf ceanothus is a nonsprouter; yet stands in general have held up well against browsing pressure. Deer, goats, and sheep have high preferencc for the leafage, deer crop it several months in the year. Cattle take it somewhat sparingly (photo on page 106).

The crude protein content of the leaves of this shrub is similar in pattern to that of other evergreen shrubs but the average is somewhat higher than in some species. It ranges from about 15 per cent in the young leafage to about 8 per cent in the fully developed leaves in early $\mathrm{fall}^{(60,02)}$. It is significant that the protein content of the

Wedgeleaf ceanothus (Ceanothus cuneatus). Flowering branchlet; flower showing structure; leaf variations.

This is a widespread and common component of the California chaparral.

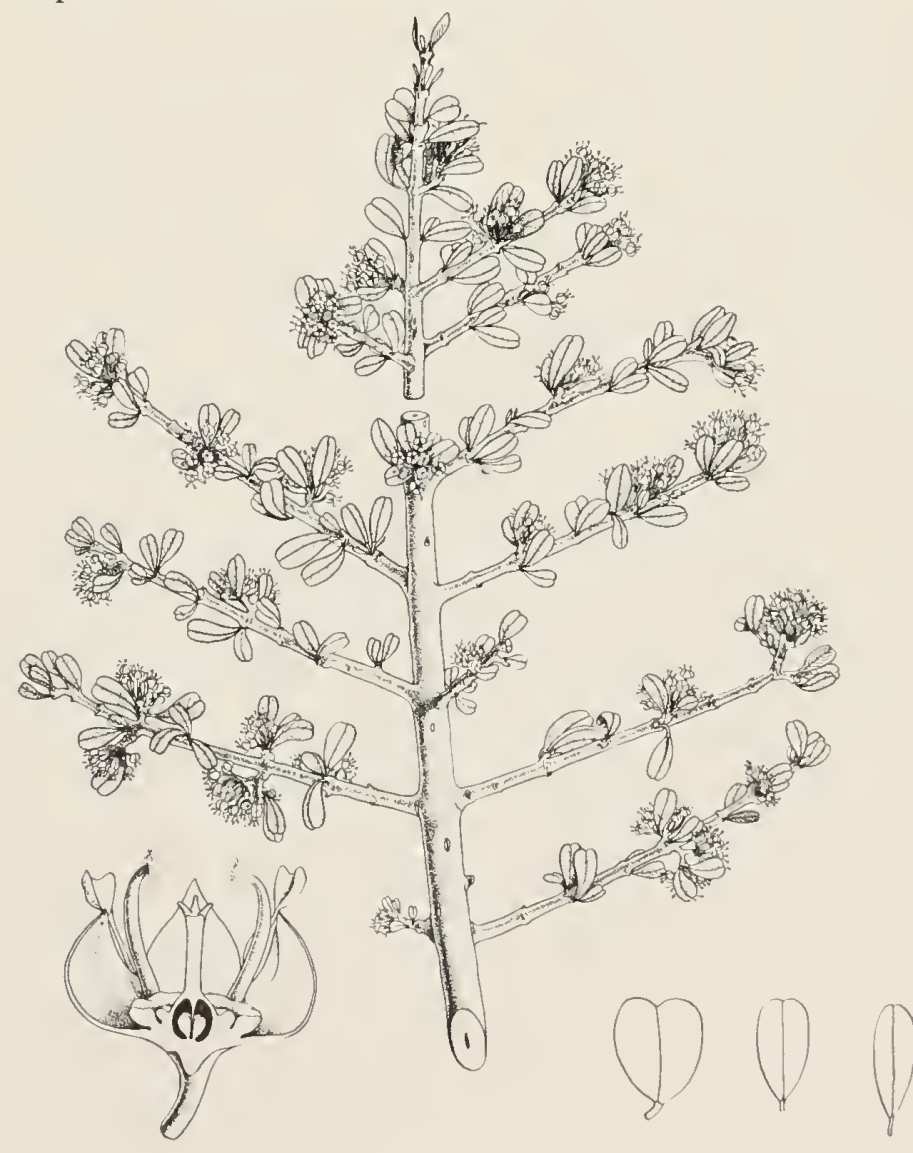




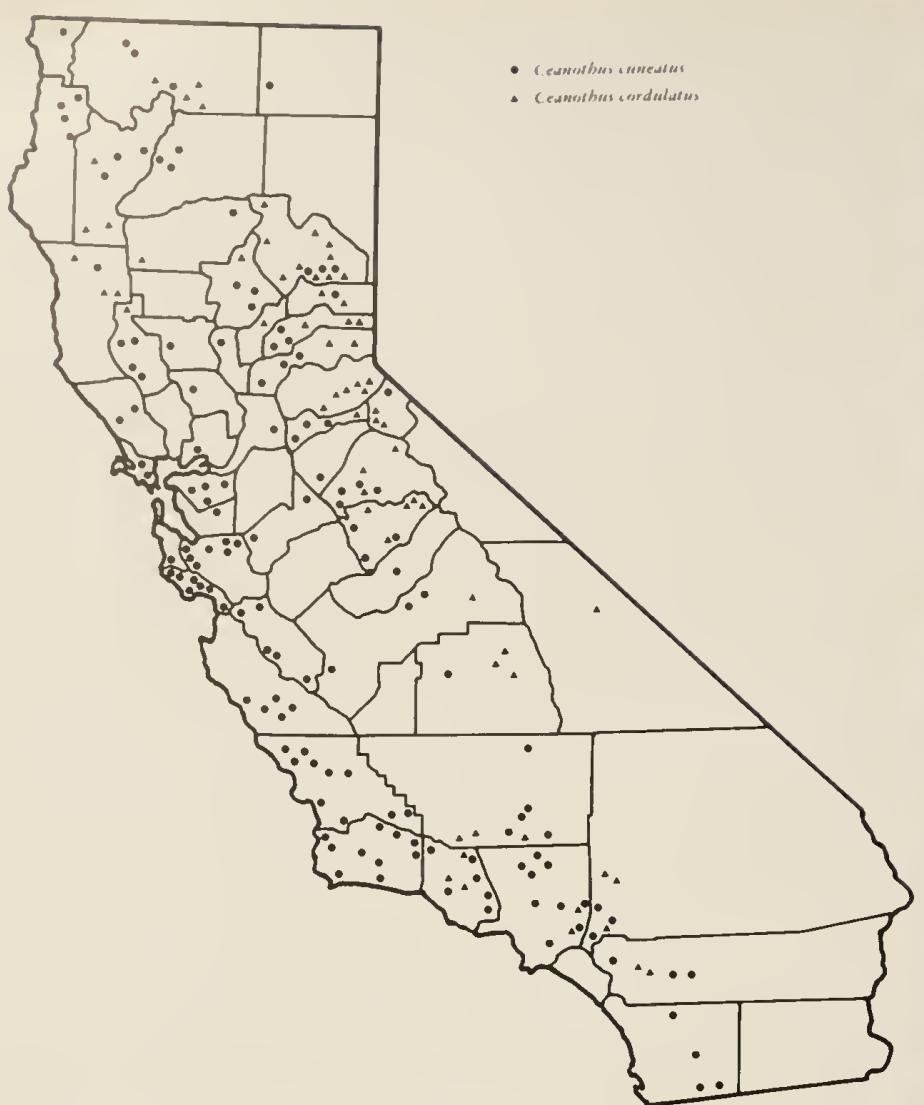

Distribution of wedgeleaf ceanothus (Ceanothus cuncatus) and mountain whitethorn (Ceanothus cordulatus.).

foliage is considerably higher than that of mature deciduous shrubs and amnual grasses from mid-summer on through the remainder of the grazing season. The crude fiber content, on the other hand, is distinctly low, ranging from about 5.5 per cent early in the season to 12.5 per cent in late fall. The calcium to phosphorus ratios vary widely through the year, ranging from about 6 to 1 in early spring to about 19 to 1 just after the seeds are shed. The succulence of the foliage and its moderately high protein content through the year may account, in part, for the relatively high palatability of this shrub.

In experimental digestion trials with deer it was indicated that wedgelcaf ccanothus has nearly as grcat a percentage of total digcstible nutrients as good hay ${ }^{(62)}$. Thus it may be concluded that "wedgeleaf" is a bctter food for decr than is gencrally realized. The most striking point about the digestion trials with winter leaf samples, however, was the low digestibility of the protein. It is possible that the low protein digestion of this slumb may angment the protcin deficiency commonly encountered by deer in their late winter dict.

Wodgoleaf ceanothus has strong seed habits and the seed crops remain viable in the soil for long periods. Undre favorable germination conditions, as after a fire, great numbers of secellings appear the first vear. Al(homgl many secollings succuml on burns the first two vears from clrought and competition with grasse's and other plauts, enomgl usually survive to produce a copjous stand if lofe mudistmrled. Stockmen profer grass to this

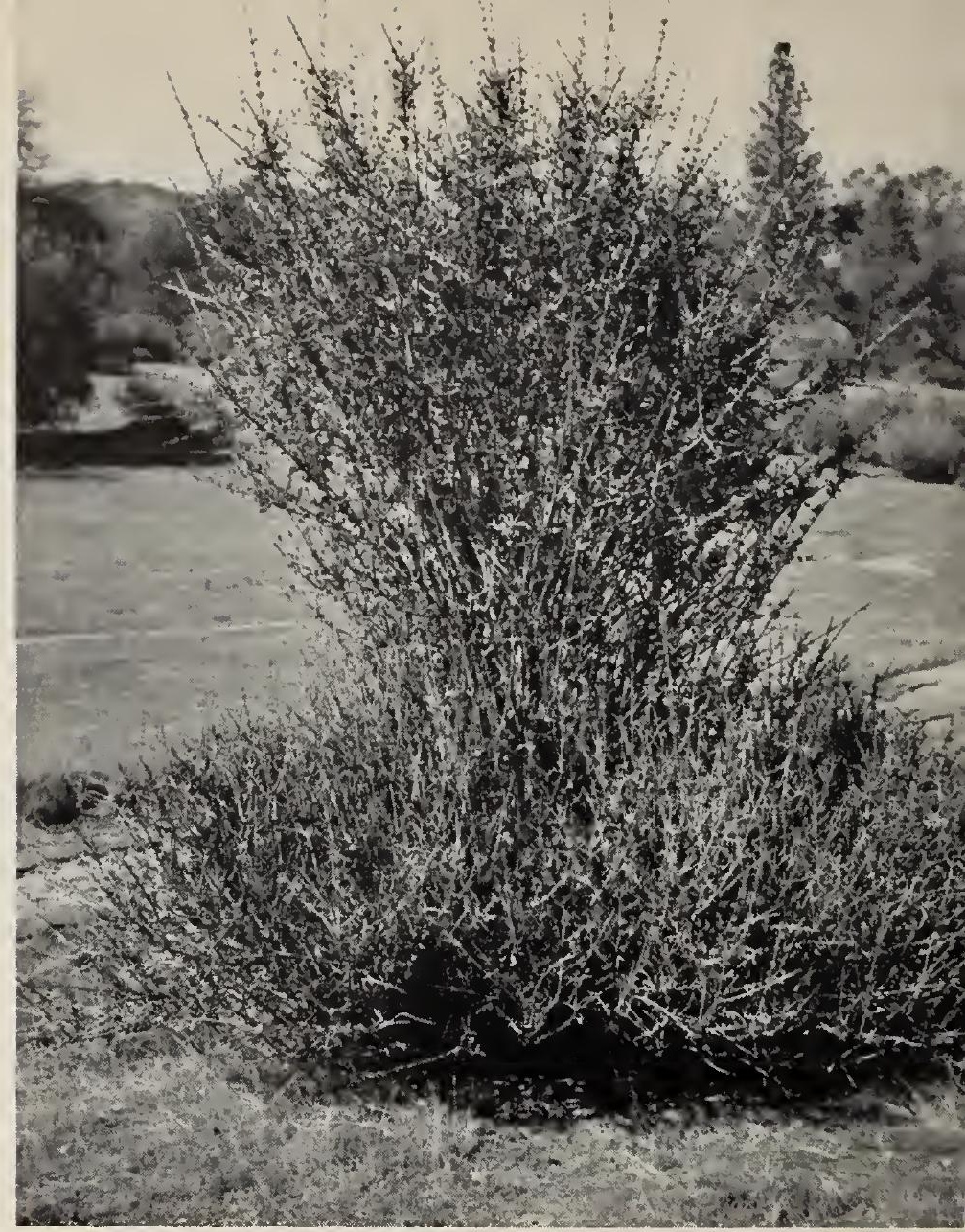

Utilization of wedgeleaf ceanothus (Ceanothus cuneatus), mostly by deer and more limitedly by cattle. Note removal of most of the foliage as high as the animals could reach. The brushy lower growth has resulted from close cropping over a period of many years. Near San Joaquin Experimental Range.

brush. Following the recommendations of several workers $^{(139,132,133)}$, quite a few stockmen broadcast seed of aggressive annual grasses soon after the fire to provide grass competition for the brush seedlings. The operator may also reburn the second year or so after the fire to destroy the remaining seedling stand. Care must be taken to permit adequate grass to accumulate to carry a fairly hot fire through the area in late summer or fall before the brush seedlings get overly large. The somewhat common practice of destroying all the wedgeleaf ceanothus on burns should usually be avoided, especially where early-matming annual grasses predominate. By protecting a few arcas of small acreage herc and there from rebuming during the clean-up operation adequate wedgeleaf ceanothus can be prescrved.

Its greatest usefulness secms to be on amnual grassland ranges where it supplies succulent green leafage and needed vitamin A in the summer and fall when the grass forage is dry and bleached.

Browse rating. Good to fair for sheep and goats; fair for deer; poor for cattle; and nseless for horses.

(IIAPABRAL, WHTETHORN (Ceanothus lencodermis) (drawing on page 107). Tall evergreen shrub, 5 to 12 feet ligh, with rigid, divaricate, spiny lonelses, nsmally gray or white in color. Icaves altemate, elliptical-oblong to ovate, $\frac{1}{2}$ incle to $1 \frac{1}{2}$ inches long, $\frac{1}{4}$ inch to $\frac{1}{2}$ incl w wide, 
3-veined, gray-green. Flowers in mostly short, dense, simple clusters 1 to 3 inches long, usually pale blue or white; May to June. Fruit roundish, about $\frac{1 / 4}{4}$ inch wide, viscid, not crested; seeds mature in September and October.

In some localities abundant sprouts appear after cutting or burning, whereas in other areas no sprouting takes place.

Distribution (map on the right). Chaparral whitethorn inhabits dry (but not desert-like) rocky chaparral slopes at medium to low elevations, usually below 5,500 feet. It occurs in the mountains of southern Califomia, exclusive of the desert, northward in the inner Coast Range to Alameda County, and in the Sierra Nevada foothills from Kern County to Mariposa County, and in a few localities northward to Shasta County.

Chaparral whitethorn (Ceanothus leucodermis). Flowering branchlet; flower; and fruit.

This evergreen shrub is of medium palatability to sheep, goats, and deer. It is seldom eaten closely by cattle. In localities where it sprouts, as after a fire, it is browsed much more closely than are the current twigs of adult bushes. It does not sprout over all localities of its range.

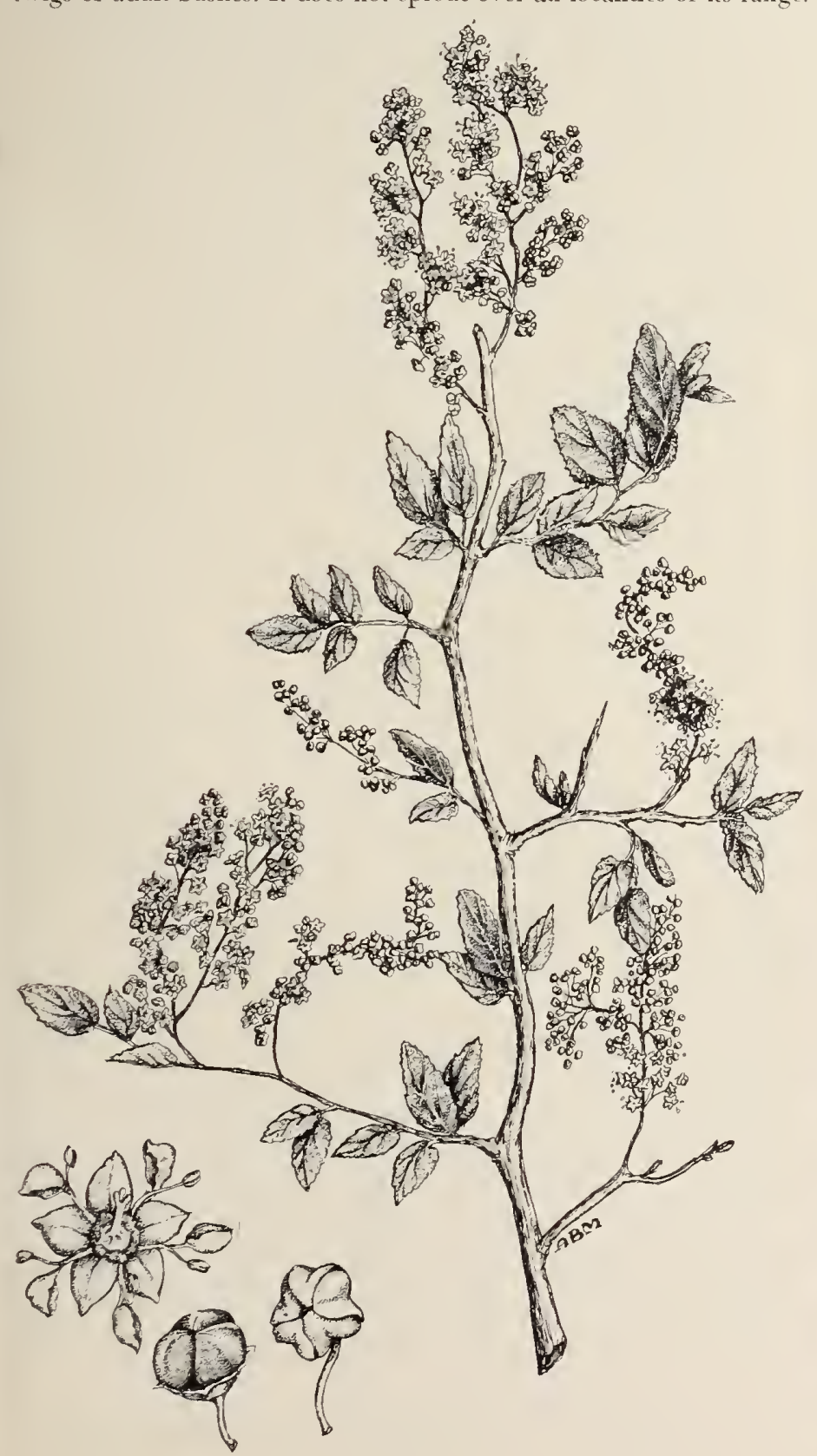

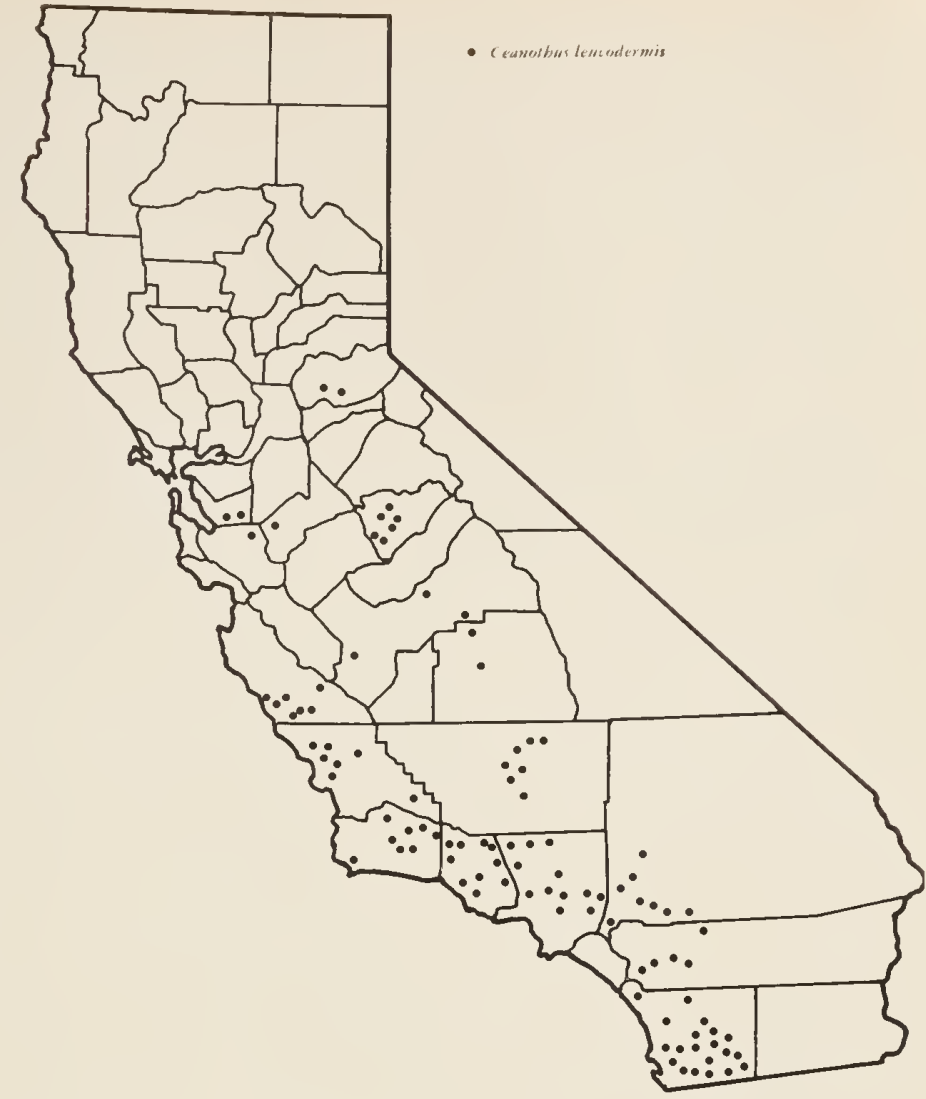

Distribution of chaparral whitethorn (Ceanothus leucodermis).

Chaparral whitethorn (Ceanothus leucodermis) is occasionally cropped closely by deer, as shown, but less often by domestic livestock. On this San Joaquin winter deer range the deer population was fairly heavy although little of the range was overbrowsed.

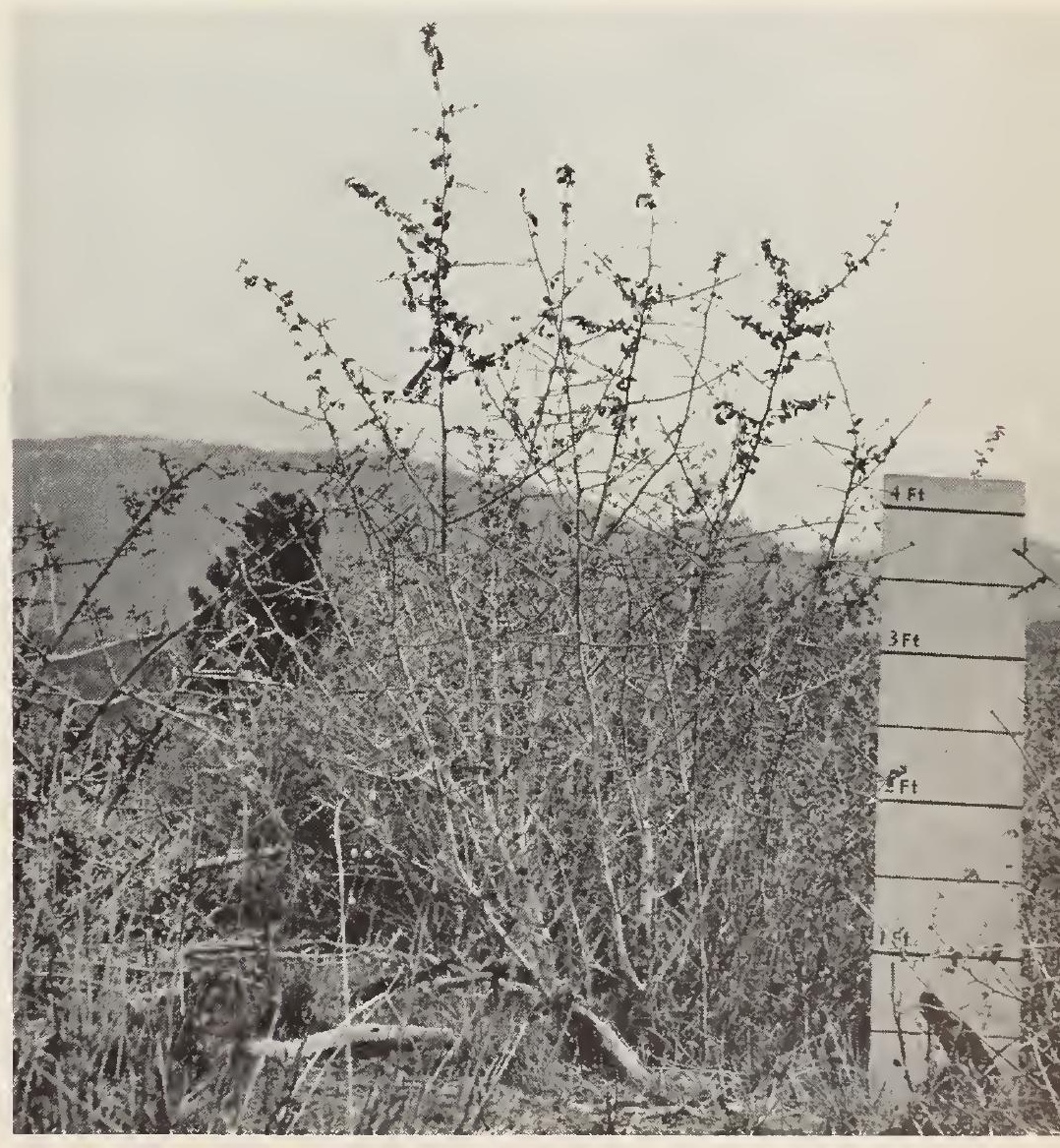


Economic value. In southern California this species sprouts readily after a fire, whereas from Tulare County northward, no sprouting occurs.

Chaparral whitethorn is of medium to low rank as browsc. Seldom are all the leares or sprouts taken, yet it is valuable in adding variety to the feed. In some localities decr, and less frequently sheep and goats, erop a large proportion of the current growth (photo on page 107). Its nutritive value, as indicated by the crude protein levels from samples collected on the San Joaquin Experimental Range, is much the same as for its common associate, wedgeleaf ceanothus. It ranges from about 16 per cent in the young leaves to 11 per cent at full leaf development ${ }^{(i n)}$. Samples collected and analyzed by the California Department of Fish and Game gave similar protcin values ${ }^{(11)}$. The crude fiber content is low at all stages, ranging from 6.5 to 9.5 per cent throughout the year. The widest calcium to phosphorus ratio, about 11 to 1 , occurred in the fall in the fully developed leaves.

The sprouts, such as appear after a fire in some localities, produce more volume of browse and are more palatable than the current twig growth of adult bushes. Non-sprouting stands, on the other hand, are less difficult to eradicate or to open up where desired. It is important to know in advance whether this species sprouts or not in a locality where range improvement measures are to be undertaken, for this largely determines the management plan to be used. Cutting off a few bushes with an ax will reveal this characteristic in a few weeks.

Decr feed more closely on this shrub than livestock. On the San Joaquin Experimental Range eattle crop it less closely in early spring than wedgelcaf ceanothus.

Browse rating. Excellent to good for deer; good to fair for sheep and goats; poor to useless for cattle; and useless for horses.

MOUNTAIN WHTETHORN (Ceanothus cordulatus) (drawing on this page). Much branched, spinv, evergreen shrub, 2 to 5 feet high, with smooth bluish green leaves and branchlets. Leaves alternate, ovate to elliptic, smooth, $\frac{12}{2}$ inch to 1 inch long, pointed at the apex, ronnded at the base, 3-veincel, margins entire or rarely toothed. Flowers white, in short dense chusters, $1 / 2$ inch to $1 \frac{1}{2}$ inches long; May to July; have a heavy penetrating odor. Capsule triangular, usually distinctly lobed, slightly crested, $3 / 16$ inch broad; secds mature in late August and September.

In the northern range of this species the plants often assume a clecumbent spreading habit. The plants growing singly sometimes have a diancter spread of 12 feet, or they may form a continuous ground cover over large areas. During the flowering period the alsundant white flowers often cause slopes to appear snow covered.

Distribution (map on page 106). This species occupies open flats, rocky ridges, or open pine forests from 3,500 (1) $9,(0)(0)$ fect elevation. It oceurs in the higher mountains in sonthern California, in the Sierra Nevada, and in the north Coast Ranges from Lake to . Vendocino comnties northward to Siskiyon Comnty and into Oregon.

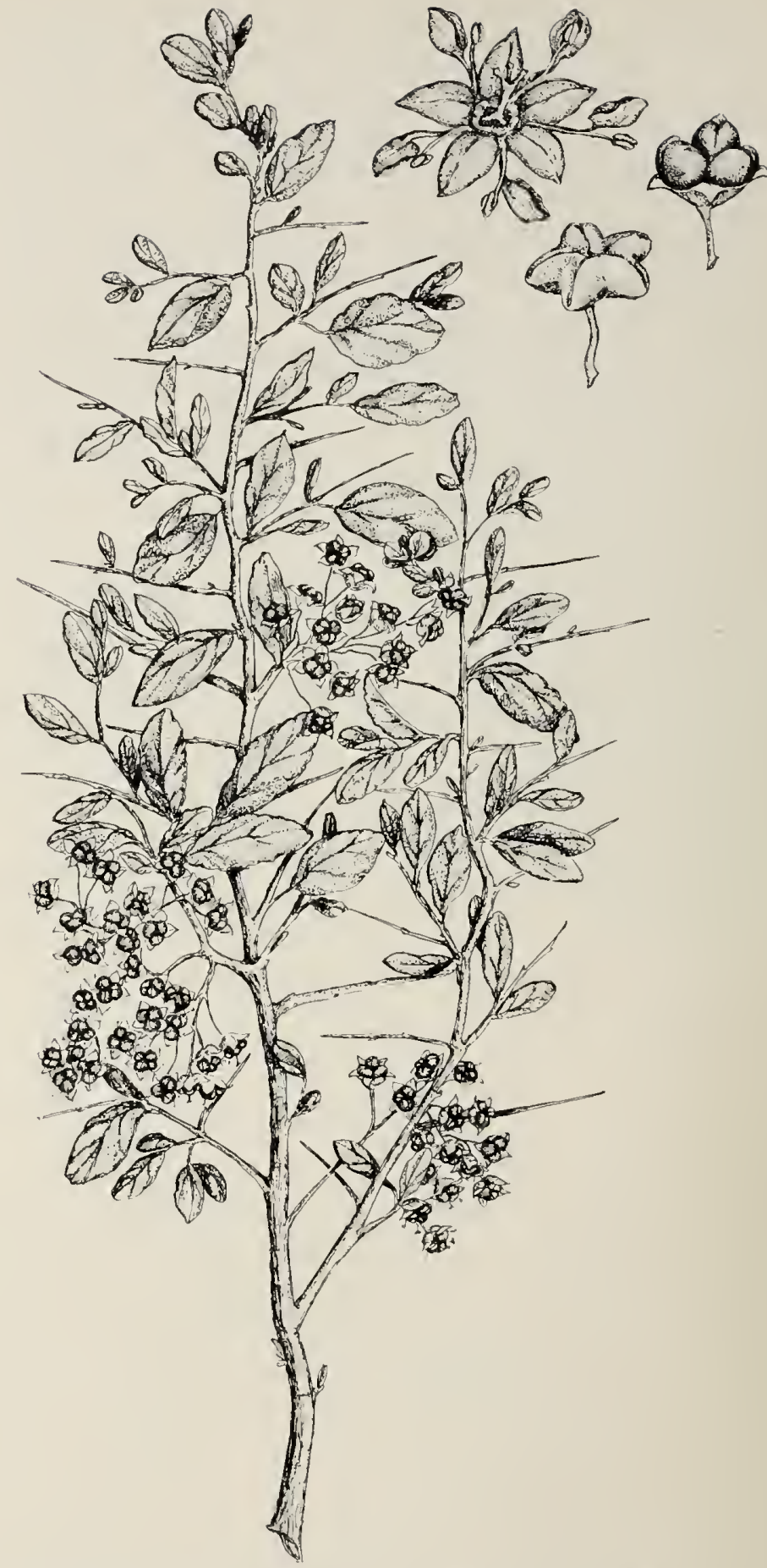

Mountain whitethorn (Ceanolhus cordulatus). Thorny flowering branehlet showing oharaeteristie small leaves; flower; and fruit.

This species sprouts vigorously after a fire. As browse it rates is medium to low for domestic livestock but is cropped rather closely by deer. Its nutritive values are similar to those of other evergreen ceanothus species.

Economic value. Domestic livestock eonsume the leafage of mountain whitethorn sparingly; decr crop it somewhat closely. It was one of the most important somrees of deer food in the summer and fall months on the experimental deer range in Tehama Comnty ${ }^{(1)}$. Here it constituted 33.2 per cent of the diet and was found in 78.4 per eent of the stomachs of the 37 deer analyzed.

The palatability of momntain whitethom differs markedly in the different localities, probably depending 


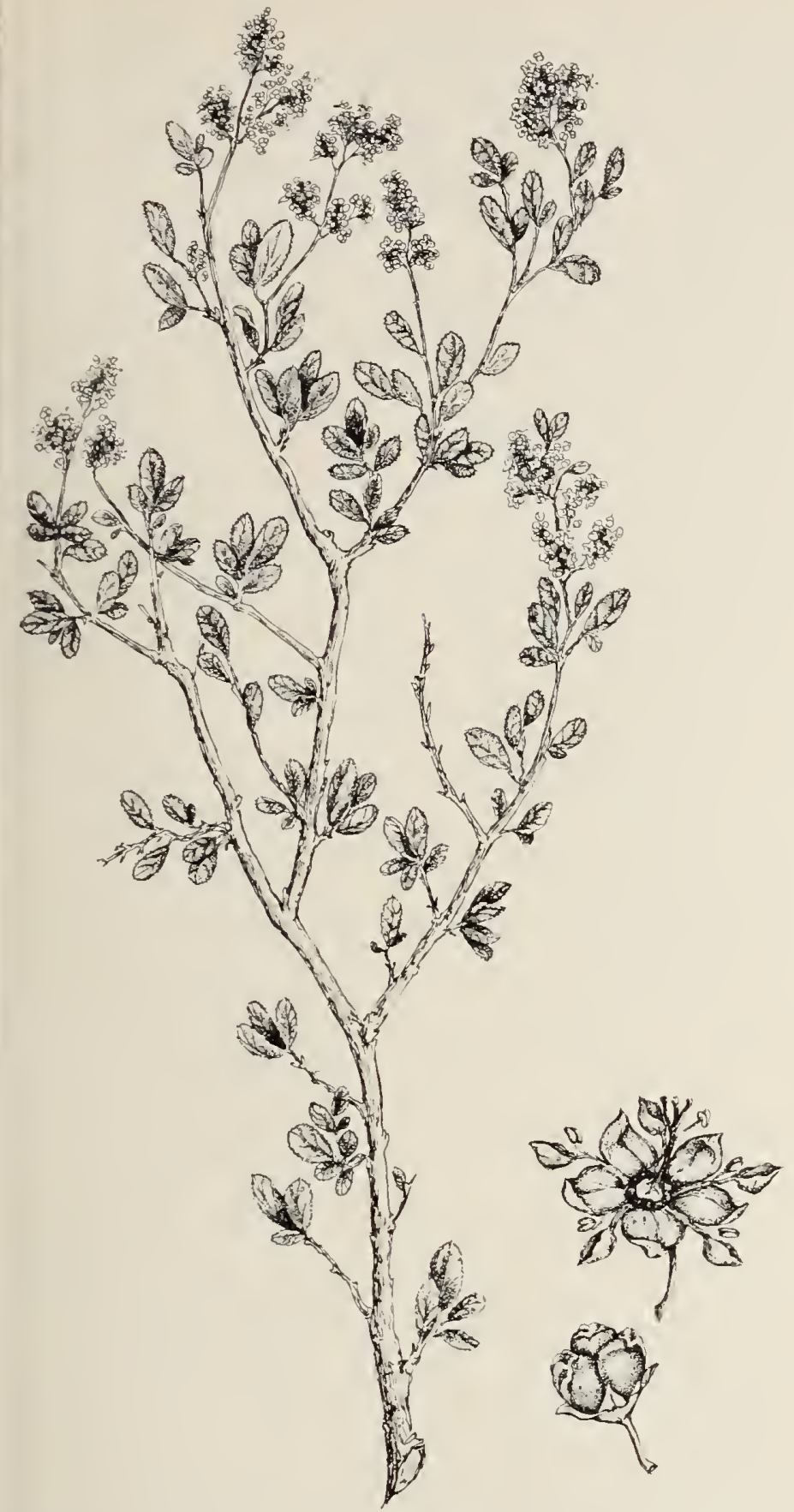

Lemmon ceanothus (Ceanothus lemmonii). Flowering branchlet; flower; and fruit.

Although a browse of secondary importance, the numerous sprouts on recent burns are generally cropped closely by sheep, goats, and deer Cattle, on the other hand, seldom feed closely upon this plant.

on the composition of associated species and on site quality. Deer crop the sprouts and current leafage closely on some newly burned areas, indeed somctimes to the extent of weakening or killing individual plants. On other areas deer seek out the young growth discriminately but do not over-utilize it. On the Jawbone summer range in central Tuolumne County this species comprised the largest single item ( 31.4 per cent) in the diet of California mule deer ${ }^{(02)}$. In few localities close cropping by livestock does occur.

Its crude protein content compared favorably with that of various other California evergreen shrubs. Analy- ses showed the highest protein levels, about 15 per ccnt, were recorded in July whon the new lcaves had attained full growth, and the lowest in late winter and early spring when it dropped to about 6 per cent ${ }^{(11)}$. It is reported that the principal diet for deer on much of the Nevada summer range is mountain whitethorn.

Browse rating. Excellent to good for deer; good to fair for goats; fair for shcep; poor for cattle; and useless for horses.

\section{Secondary Ceanothus Species}

SQUAW CARPET (Ceanothus prostratus), also called mahala mat. Evergreen prostrate shrub 2 to 6 inches high, or occasionally to $1 \frac{11}{2}$ feet; stems root at the joints spreading and forming dense mats 2 to 8 feet across. Leaves opposite, roundish or broadly elliptical, wedge shaped at the base, ${ }_{1 / 4}^{10}$ inch to ${ }_{5 \%}^{5}$ inch wide, thick and leathery, dark green and smooth above or sometimes gray-green, paler and finely hairy beneath, margins usually with a few coarse teeth near the tip, or with 4 to 7 finer teeth on each side, rarely almost entire. Flowers deep or light blue, often becoming pinkish in age, borne in umbels; April and May. Capsule roundish, $1 \frac{16}{4}$ inch wide, with large wrinkled horns and intermediate crests.

Distribution. Squaw carpet occurs in the ponderosa pine and red-fir forests of the ligher mountains of the north Coast Ranges, cxtending eastward through the Siskiyou Mountains to Modoc County, southward in the Sierra Nevada to Calaveras County; usually forming carpets under pines between 2,100 and 7,800 feet elevation. It extends northward to Washington and eastward into Nevada.

Economic value. Squaw carpet is cropped little by domestic grazing animals but is rather important for deer. Its crude protein levels are typical of evergreen shrubs and range from 5.4 per cent in January, 6.5 per cent in April, and from 7.5 to 9.8 per cent from June to October $^{(\mathrm{al1}}$. Food items eaten by 96 black-tailed deer taken from the Tehama winter range showed that squaw carpet accounted for 1.5 per cent, by volume, of the stomach contents in October and 10.4 per cent in December. On the summer range of this area the stomach content of 37 deer accounted for 7.3 per cent. In this study deer utilized squaw carpet, in addition to other brush species found on the lower portions of the summer ranges, until snow forced them to the lower ranges ${ }^{(537)}$.

Among the food items eaten by 327 Rocky Mountain mule decr collected on the Lassen-Washoe winter range, squaw carpet accounted for 5.8 per cent of the stomach content in September, less than 1 per cent in October and November, and from 0.6 to 5.9 per cent from December to April. It contributed most to the diet in the early months of the winter. Because of the light utilization of these secondary species, the all-important bitterbrush was available over a longer period of time ${ }^{(s)}$.

Browse rating. Good to poor for deer; fair to poor for goats; poor to useless for sheep; uscless for cattle, horses.

Lemmon Ceanotius (Ceanothus lemmonii) (drawing on this page). Low, evergreen, spreading, sprouting 


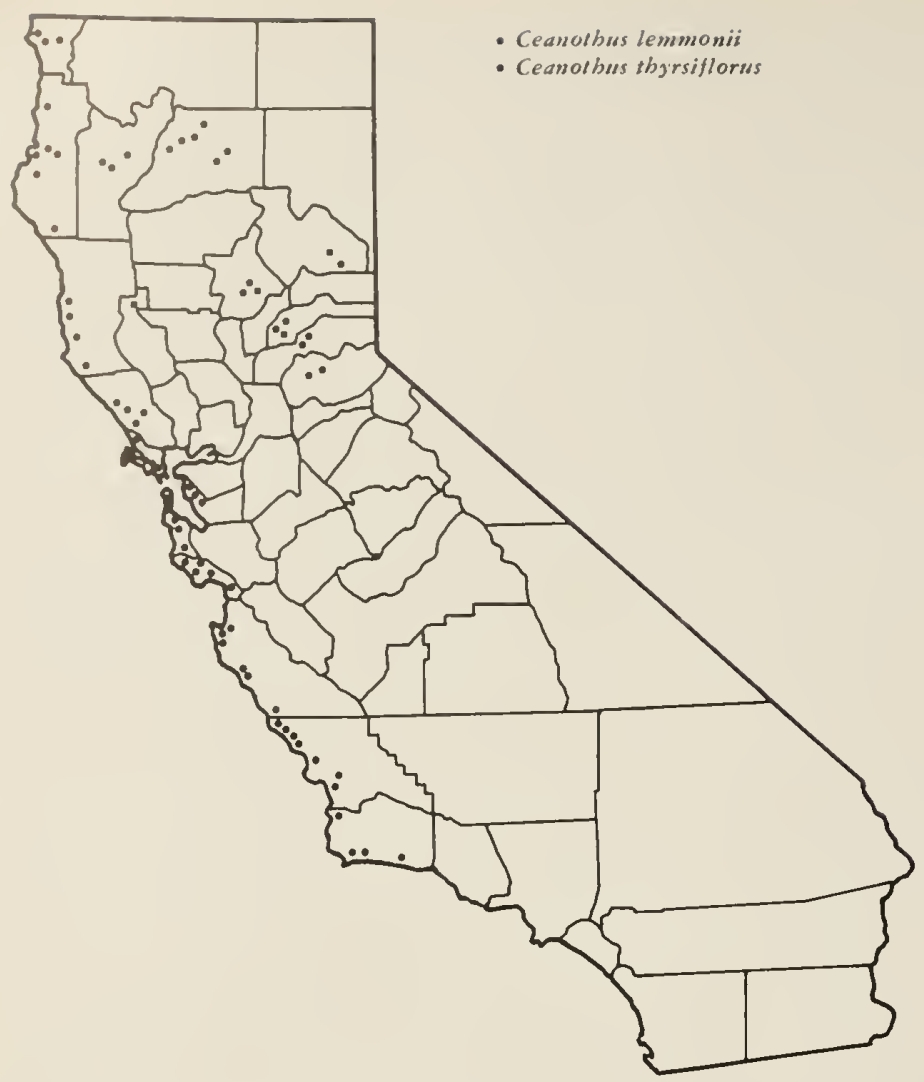

Distribution of lemmon ceanothus (Ceanothus lemmonii) and blueblossom ceanothus (Ceanothus thyrsiflorus).

shrub, 1/1/2 to 3 feet high, with gray or whitish hairy branches and branchlets. Leaves alternate, eliptical, or oblong-elliptic, $\frac{1 / 2}{2}$ inch to $1 \frac{1}{1}$ inches long, ${ }_{1 / 4}^{1 / 4}$ to ${ }_{4}^{3 /}$ inch wide, finely hairy to smooth, bright green and waxen above, paler and densely hairy beneath, margins usually glandular toothed. Flowers pale blue, in simple clusters, $1 / 2$ incl to 1 inch long; April to May. Capsule somewhat triangular, distinetly depressed and lobed at the summit, erested at the top.

Distribution (map above). This speeies grows on open wooded slopes or on burned-over areas, from 1,500 to 3,500 feet elevation. It is confined to northern California, in the Sierra Nevada foothills from Eldorado north to Shasta counties, and in the inner north Coast Ranges in Humboldt, Trinity, and northern Lake eounties.

Economic value. Beeause of its restricted distribution it is not regarded lighly as browse. Its selectivity varies considerably ${ }^{(45)}$. However, the young sprouts are often cropped rather closely by slieep, goats, and deer, and occasionally by cattle, especially on recently burned-over lands.

Browse rating. Fair to poor for sheep, goats, and deer; poor to uscless for cattle; and useless for liorses.

bi,ueblossom ceanothus (Ceanothus thyrsiflorus) (drawing on the right). Varies greatly in growth halbit; shape, size, and pubescence of leaves. Ifeight growth from 4 fect highl on poor sites to 20 feet or more on fertile soils. Usually a large, evergrecon shmb, or sometimes treelike, with green angled branches. Leaves oblong-ovate to broadly elliptieal, 3-veined, ${ }_{4}^{3}$ ineh to 2 inehes long, dark green, paler beneath, margins more or less glandular toothed or oceasionally inrolled. Flowers light or deep blue, rarely whitish, in compound elusters, 1 to 3 inches long; March to June. Capsules roundish, smooth, about $1 / 16$ inch wide, only slightly lobed at the top, glandular, black in age. Two varieties oeeur in California ${ }^{(105)}$.

Distribution (map on the left). This species is confined to wooded hills and eanyon slopes in the outer Coast Ranges from Monterey County to Del Norte County, north into Orcgon. It oeeurs from sea level to about 1,500 feet elevation in mixed evergreen and redwood forests. The stands arc generally seattered.

Blueblossom ceanothus (Ceanothus thyrsiftorus). Flowering branchlet; fruit showing three-lobed capsule; leafy branchlet and fruit.

This is a fairly important sccondary browse plant.
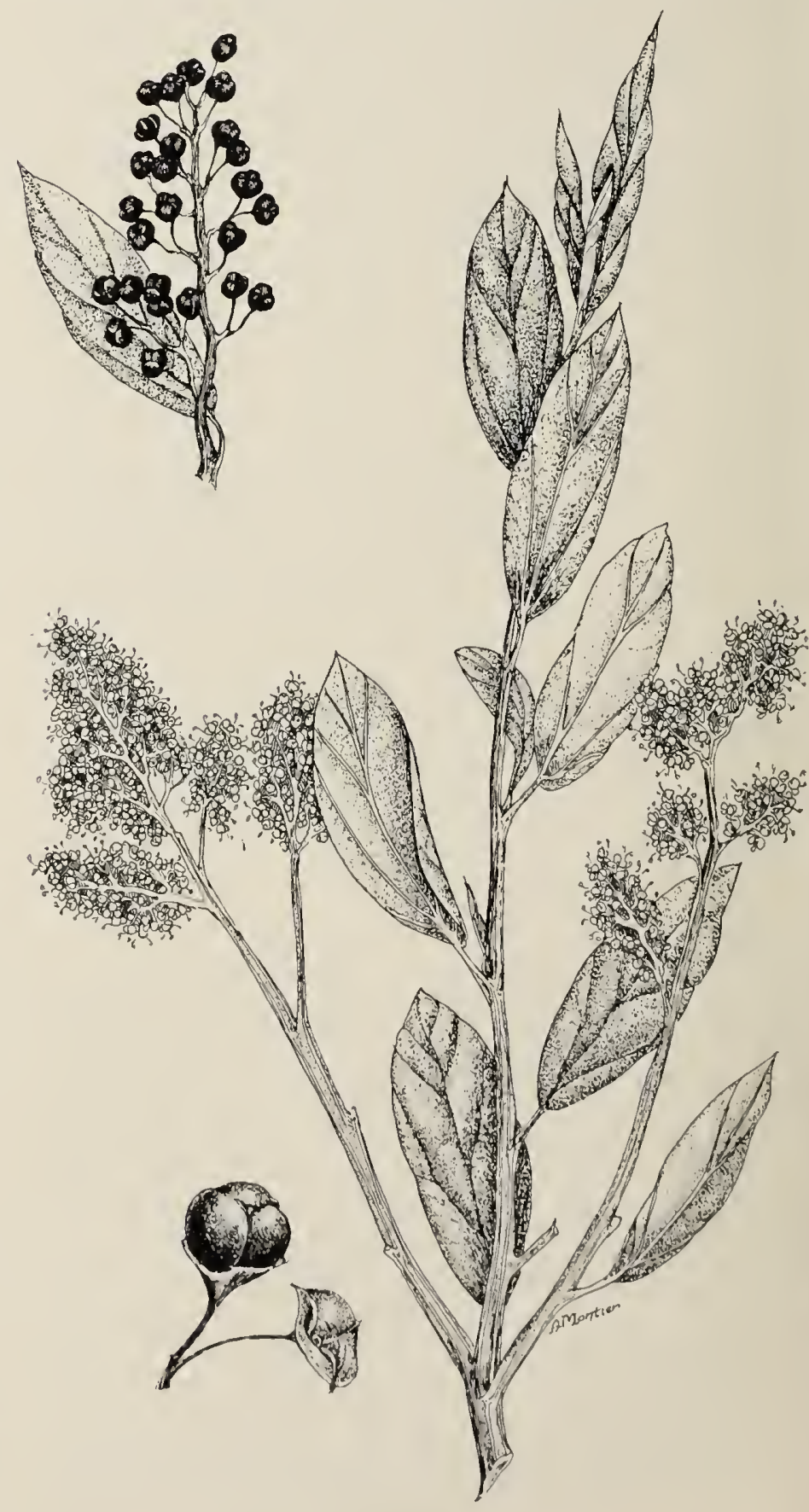
Economic value. Even though blueblossom ceanothus does not sprout it is persistent, and provides fairly important feed, especially for deer. Nutritive values of ground-up stems and leaves of blueblossom ceanothus were reported to be satisfactory for grazing animals and were strikingly similar to those of certain common hars ${ }^{(\hat{s+t})}$. Large numbers of seedlings come in the first year after areas are cut or burned. They are palatablc to all grazing animals while young and succulent.

Brouse rating. Good to fair for sheep and deer; good to poor for goats; fair to poor for cattle; and useless for horses.

trailing CEAnothus (Ceanothus diversifolius). Nonsprouting, low, prostrate, evergreen shrub, not exceeding 1 foot in height, 2 to 4 feet wide, with soft-hairy, flexible, roughened branches. Leaves alternate, soft, rather thin, ovate, round, elliptical, or broadly oblong, $1 \frac{1}{2}$ inch to $1 \frac{1}{2}$ inches long, pale bluish-green and finely hairy above, pale and densely hairy below, margins glandular toothed, or sometimes way. Flowers blue to nearly white, in small simple clusters, $1 / 2$ inch long; May to June. Capsule roundish, about 3/16 inch wide, smooth, distinctly crested at the top.

Distribution. Trailing ceanothus inhabits draws, flats, and hillsides in oak and ponderosa pine forests, between elevations of 3,000 and 6,000 feet. It occurs from northern Lake County northward into Trinity County, eastward to Siskiyou County and southward in the Sierra Nevada from Shasta County to Kern County. While it often forms a dense carpet in favorable sites it is nowhere abundant over large areas.

Economic value. Although trailing ceanothus is not highly palatable to any browsing animal, it provides considerable feed because of its wide distribution and the fact that it is an evergreen. It is cropped over a long period with good results.

Browse rating. Good to fair for deer; fair to poor for sheep, goats; poor to useless for cattle; useless for horses.

WAVYLEAF CEANOTHUS (Ceanothus foliosus). Low, spreading, evergreen shrub, 1 to 3 feet high, or up to 12 feet high when crowded by other shrubs, with diffuse, straight, slender branches. Leaves alternate, often with smaller leaves clustered in the axils, elliptical to oblong, usually undulate, $3 / 16$ to $\frac{3 / 4}{4}$ inch long, $\frac{1}{8}$ to $\frac{1}{2}$ inch wide, dark green and often waxen above, to whitish beneath, margins wavy, minutely glandular toothed. Flowers pale to dark blue, in simple clusters, $x_{4}^{\prime}$ to 1 inch long; March to May. Capsule roundish, about $1 / 16$ inch wide, smooth, sometimes distinctly lobed or crested.

Distribution. This species occupies dry ridges and rocky brushy slopes from 200 to 5,000 feet elevation, mainly in the Coast Ranges from Mendocino County southward to the Santa Cruz Mountains, and away from the coast to San Luis Obispo County, and limitedly in the Cuyamaca Mountains of San Diego County.

Economic value. Because of its restricted distribution and sparse stands generally, wavyleaf ceanothus does not have high rank as browse for all animals. However in some locations the lcafage is consumed closcly.

Browse rating. Excellent to good for deer; fair to poor for sheep and goats; poor to useless for cattle; and useless for horses.

SNOwBrush CEANOTHus (Ceanothus velutinus), also known as snowbush, mountain balm, sticky laurel, and tobacco bush. Spreading, round topped, evergrecn shrub, 2 to 5 feet high, rarely tree-like up to 20 feet high, with several to many stems from the base. Leaves alternate, with a strong cinnamon or balsam-like odor, broadly elliptical, or elliptical-ovate, $1 \frac{1}{2}$ to $2 \frac{1}{2}$ inches long, ${ }_{4}^{3 /}$ inch to $1 \frac{11}{4}$ inches wide, 3-veined from the base, smooth, dark green, usually varnished above, paler and finely hairy beneath, margins finely toothed or glandular toothed. Flowers in compound clusters, 2 to 4 inches long, white, fragrant; May to August. Capsule roundish or triangular, $1 / 8$ to $1 / 16$ inch wide, sticky glandular, distinctly lobed at the top.

Distribution. This shrub inhabits open wooded mountain slopes and ridges between 3,500 to 10,000 feet elevation in the Sierra Nevada from Tulare to Modoc counties, westward to Shasta, Trinity, Siskiyou, and Del Norte counties. In favorable habitats it often forms impenetrable thickets, probably because it is a strong sprouter.

There are two varieties of this species: Var. lorenzenii, with smaller leaves that are scarcely varnished above, and smaller flower clusters; occurs occasionally in the Sierra Nevada from Kern Canyon northward to the Mount Shasta region. Var. laevigatus (usually called varnishleaf ceanothus), a tall shrub or tree-like, 6 to 20 feet high, with leaves highly varnished above, but not hairy beneath, grows in the north Coast Ranges near the coast from Marin County to Del Norte County, northward to British Columbia.

Economic value. Snowbrush ceanothus is fairly high in crude protein-about 17 per cent in the young leavesyet it is not onc of the preferred foods ${ }^{(82)}$. Goats and deer browse considerably upon the young sprouts, and more limitedly on the cument young twigs. An experiment to eradicate this shrub and species of manzanita on the Lassen National Forest by excessive goat browsing, without first removing the top growth, was wholly unsuccessful ${ }^{(\theta 7)}$.

Browse rating. Fair for deer; fair to poor for goats; poor for sheep; and useless for cattle and horses.

COAST WHITETHORN (Ceanothus incanus.) Tall evergreen shrub, 5 to 12 feet high, with numerous grayglaucous branches, and stout thorn-like branchlets. Leaves alternate, broadly ovate to elliptic, 1 to $2 \frac{1}{2}$ inches long, $1 / 2$ inch to 1 inch wide, 3-veined, dull gravish green above, paler beneath; margins entire or somctimes toothed. Flowers creamy white, in short dense compound clusters, 1 to 3 inches long; April to May. Capsule triangular, slightly lobed at the smmmit, about $1 / 4$ inch wide, warty roughened.

Distribution. This species inhabits valley flats, moist slopes, and ridges of the redwood region of the Coast 
Ranges from the Santa Cruz Mountains northward to Humboldt County, and into southwestern Siskivou County. It does not endure shade but oeeurs on open ridges and exposed flats, eommonly on logged-over and bumed arcas. It spronts vigorously after a fire.

Ecomomic value. The young leafage and twigs, and especially the tender sprouts, are cropped with moderate relish by shcep, goats, and deer during spring and early summer.

Browse rating. Good to fair for deer; fair to poor for goats; poor for sheep; and useless for eattle and horses.

LITTLELEAF CEANOTHUS (Ceanothus parvifolius). Low, spreading, deciduous, flat-topped shrub, 1 to 3 feet tall, with flcxible olive-green branches. Leaves altemate, oblong elliptie to elliptie, $\frac{1 / 4}{14}$ to 1 ineh long, $\frac{1}{4}$ to $\frac{1 / 2}{12}$ ineh wide, 3-veined, smooth and light green above, pale beneath, margins usually entire. Flowers mostly in simple elusters, 1 to 3 inches long, pale to deep blue; June and Julv. Capsule globose, less than 将 ineh wide, smooth.

Distribution. This beautiful shrub inhabits wooded mountain slopes and flats at intcrmediate elevations. It oceurs in the Sierra Nevada from Tulare County northward to El Dorado County.

Economic value. Livestoek and big game feed limitedly on the older stands and somewhat closely on newly burned areas while the sprouts are tender. The diminutive leaves and the restricted distribution reduee its usefulness as a food plant.

Browse rating. Good for decr; good to fair for sheep, goats; poor to useless for cattle; useless for horses.

\section{BUCKTHORNS (Rhammus)}

This genus includes deciduous or evergreen shrubs or small trees. Leaves are alternate and pinnately veined. Flowers arc greenish in small axillary elusters. Sepals are 4 or 5 ; petals 4,5 , or none; stamens 4 or 5 . The fruit is a berry-like drupe with 2 to 4 nutlets.

Although the native California speeies of this genus have not achieved the status of good garden plants as have Ceonothus, some of them could actually become splendid ornamentals. One California grower is pioncering with a new selection of Rhammus californica, a very handsome ground eover form ealled 'Sea View.

The primary members of the genus that provide browse are: California coffeeberry and hollyleaf redbcrry. Caseara sagrada ranks as secondary browse.

\section{Key to Browse Species and Varieties}

1. Deciduous shrubs; Icaves thin, 3 to 8 inches long

CASCARA SAGRADA

(Rhammus purshiana)

Evorgreen shrubs; leaves thick, usually less than 3 inclues louge

2. Branclilets flexible, not spiny; leaves oblong-elliptic, longer than loreacl, dark green above, paler beneath, marguns fincly tootherd to nearly contire, of ten inrolled;

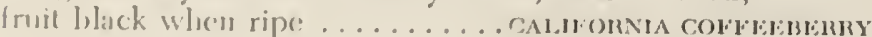
(Rhamnus californica)

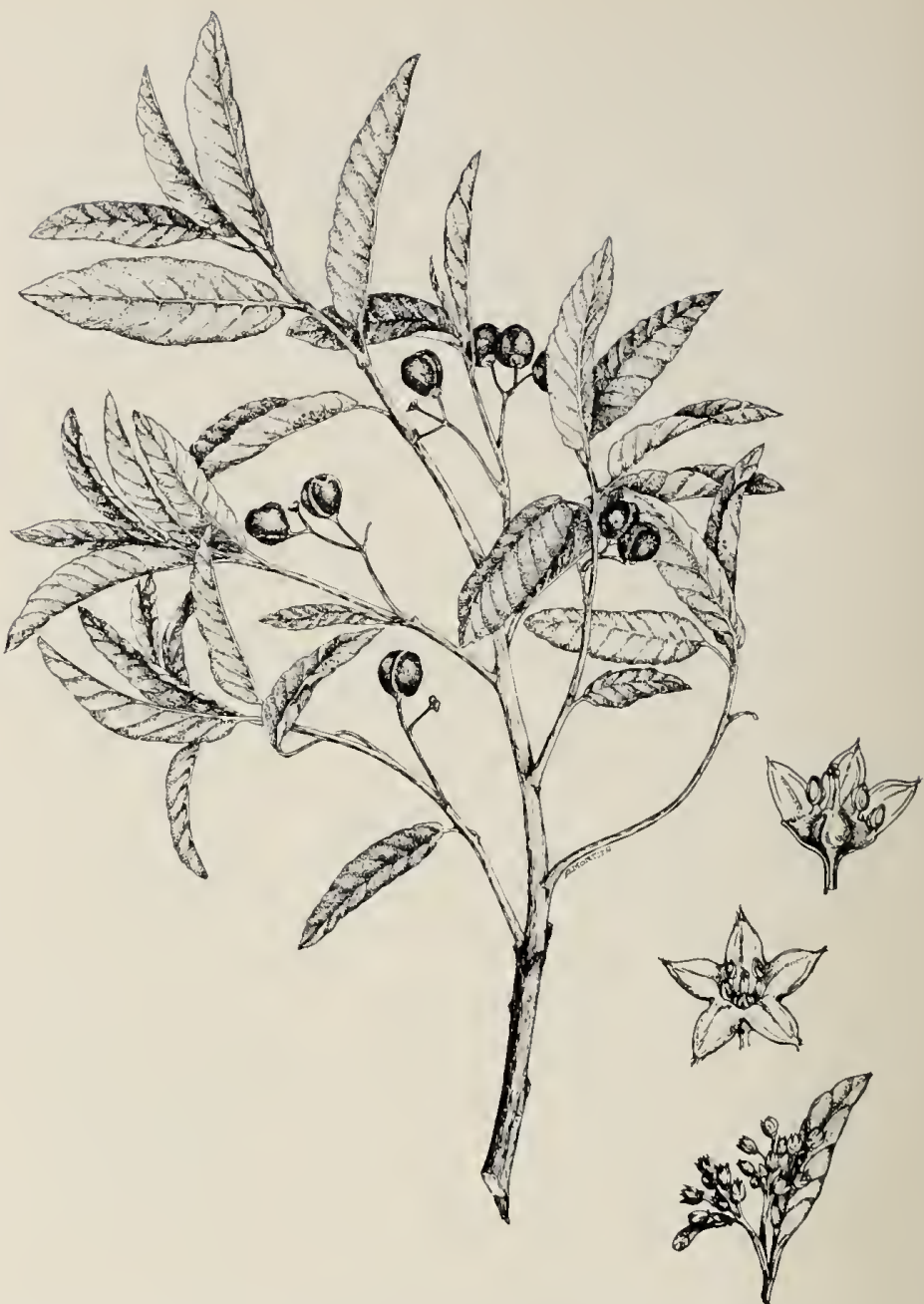

California coffeeberry (Rhamnus californica). Leafy branchlet in fruit; twig with flowers; flower; flower showing structural details.

Sheep, goats, and deer browse upon this plant more closely than cattle. Howcver, the tender leafy shoots that appear after a fire are relished by all grazing animals. Nutrient constituents appear to be satisfactory, the protein content being highest during spring and summer months.

2. Branchlets short, rigid, or spiny; leaves ovate to almost round, usually as broad, dark green above, paler or brownish beneath, margins usually spiny (hollylike); fruit red when ripe .......... HOLLYLEAF REDBEURY (Rhamnus crocea var. ilicifolia)

\section{Primary Rhamnus Species}

CALIFORNAA COFFEEBERRY (Rhamnus californica) (drawing shown above), also ealled pigeon herry. Evergreen shrub 4 to 6 feet high, or sometimes to 10 feet high, with gray, brown, or reddish branehes. Lcaves oblong-elliptic, 1 to 3 inches long, $1 / 2$ ineh to 1 inel wide, dark green above, paler beneath, margins toothed to nearly entirc, of ten rolled inward. (Leaves vary from small and thiek in dry sites to large and thin in moist shady places.) Flowers small, greenish, in umbels; June and July. Berry globular or oval, about $x_{1}$ inch wide, green when young, turning red or recklish, black when mature in September and Octolber.

The species is so variable, notably in leaf form, and 
degree of hairiness, that some five varieties have been described ${ }^{(10)}$.

Distribution (map shown below). This common species is found on dry flats, moist slopes, or rocky ridges in the coastal shrub, mixed evergreen forest, redwood forest, and chaparral, from sea level to about 5,500 feet elevation. It occurs in the Coast Ranges from Siskiyou County to San Luis Obispo County and Trinity County southward to the San Gabriel and San Bernardino mountains of southern California. Varicties occur intermingled with the species in the foothills of the Sierra Nevada and the Tehachapi mountains.

Economic value. California coffeeberry is browsed more by sheep, goats, and deer than by cattle. The young tender sprouts that appear after a fire are the most palatable. Although domestic livestock utilize this shrub rather sparingly, there are exceptions. On the San Joaquin Experimental Range, for example, the current growth was browsed closely by cattle (photo on this page). In contrast, in the foothills east of Berkeley and in various localities northward cattle utilize it rather lightly.

On the Inyo winter range in Owens Valley, Inyo County, this shrub accounted for 2.4 per cent of the total volume of food ingested by mule deer in February, and a somewhat lesser amount in $\mathrm{March}^{(80)}$. The crude protein content of the leafage from November to March was low, averaging about 7.5 per cent, whereas in the young to fully developed current leafage, as from April to August, it averaged approximately 19 per cent ${ }^{(11,80)}$. The fiber content, ranging from about 13.5 per cent in the young spring leaves to 15 per cent in the mature

Distribution of California coffeeberry (Rhamnus californica).

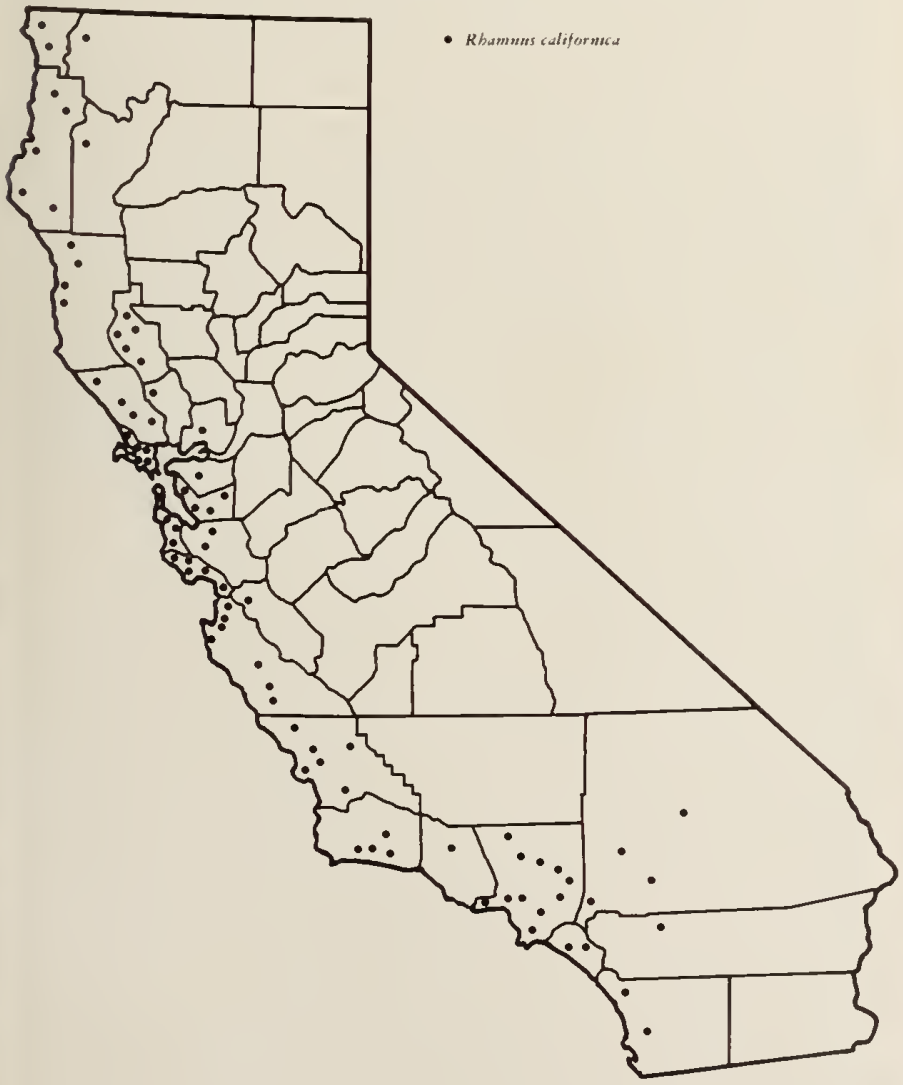

autumn foliage, tended to be somewhat higher than in such associated evergreen spccies as wedgeleaf ceanothus and chaparral whitethorn. The mineral constituents compared favorably with that of these two specics.

Browse rating. Good to poor for shecp, goats, and deer; fair to poor for cattle; and uscless for horses.

HOLLYLEAF REDBERRY (Rhamnus crocea var, ilicifolia) (drawing on page 114). Stout evergreen shrub, or often tree-like, 3 to 15 feet high, with numerous short branchlets. Leaves ovate, or almost round, $\frac{1 / 2}{12}$ inch to $1_{1 / 4}^{1 / 4}$ inches long, $\frac{12}{2}$ inch to 1 inch wide, dark green and smooth above, palcr or brownish beneath, spiny toothed, or rarely only deeply toothed to entire. Flowers small, in stalkless umbels; February to April. Fruit oval, red, about $\frac{1 / 4}{4}$ inch long; seeds ripen from August to October.

Hollyleaf redberry is a strong sprouter. This variety intergrades with the species but typically is larger and more open and spreading. The lcaves are larger and more holly-like.

Distribution (map on page 114). This variety occurs on dry lower slopes and flats in the middle and inner Coast

California coffeeberry (R/ummus californica) showing heavy browsing by cattle on the San Joaquin Experimental Range Such close utilization most commonly occurs where cattle encounter the plants more frequently than over the range generally.

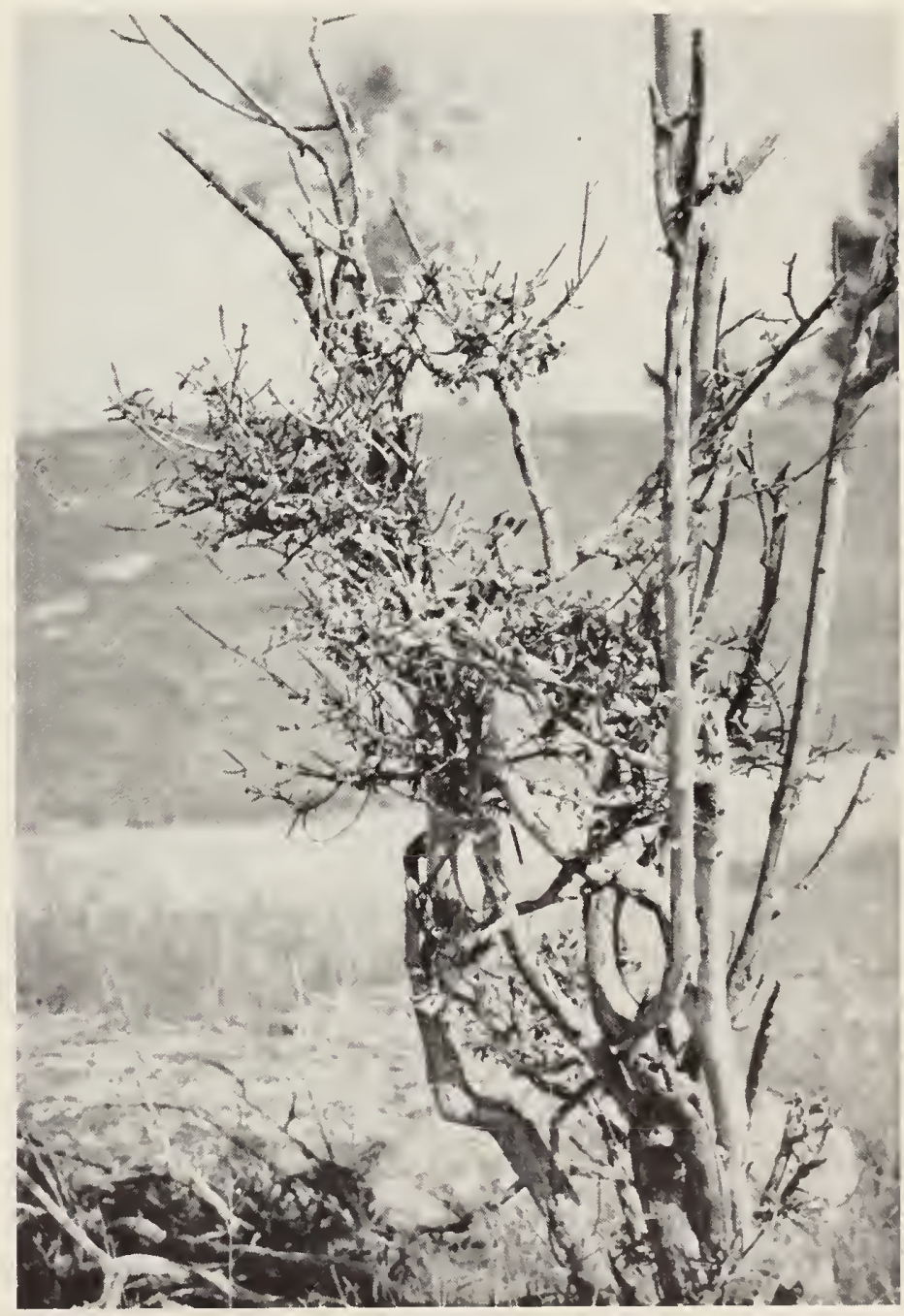


Ranges from Humboldt, Siskiyou, and Trinity counties to the foothills and mountains of southern California, where it grows commonly in the chaparral in the Upper Sonoran Life Zone. It also oecurs in the Sierra Nevada foothills from Shasta County southward to Tularc County, and more limitedly in the mountains of the Mojave Desert. Common associates are fremontia, western mountain-malogany, Ceanothms species, and oaks.

Economic value. Holly leaf redberry is primarily a deer and goat fecd but is of some value for cattle and sheep. On the basis of the protein content alone it is less nutritious than the closely rclated species, California coffeeberry ${ }^{(11)}$. The highest protein levels were recorded in May, with 16.3 per cent, as compared to 19 per cent for California coffeeberry. During the autumn and winter months the protcin contents of these two are much the samc, ranging from about 7 to 9 per cent. Its protein pattcrn is similar to that of other evergreen species of the buckthorn family

Utilization of hollyleaf redberry tends to vary rather widely in different localities. In some areas sheep, goats, and deer crop a large proportion of the current leaves, twigs, and sprouts. In other areas utilization is relatively light cven on deer range. Association with other plant species may largely account for this variability. On the

Hollyleaf redberry (Rhammus crocea var. ilicifolia). This species is best known for its high palatability to goats and deer. It is utilized somewhat less closely by cattle and sheep. The extent of its utilization varies rather widely in different localities.

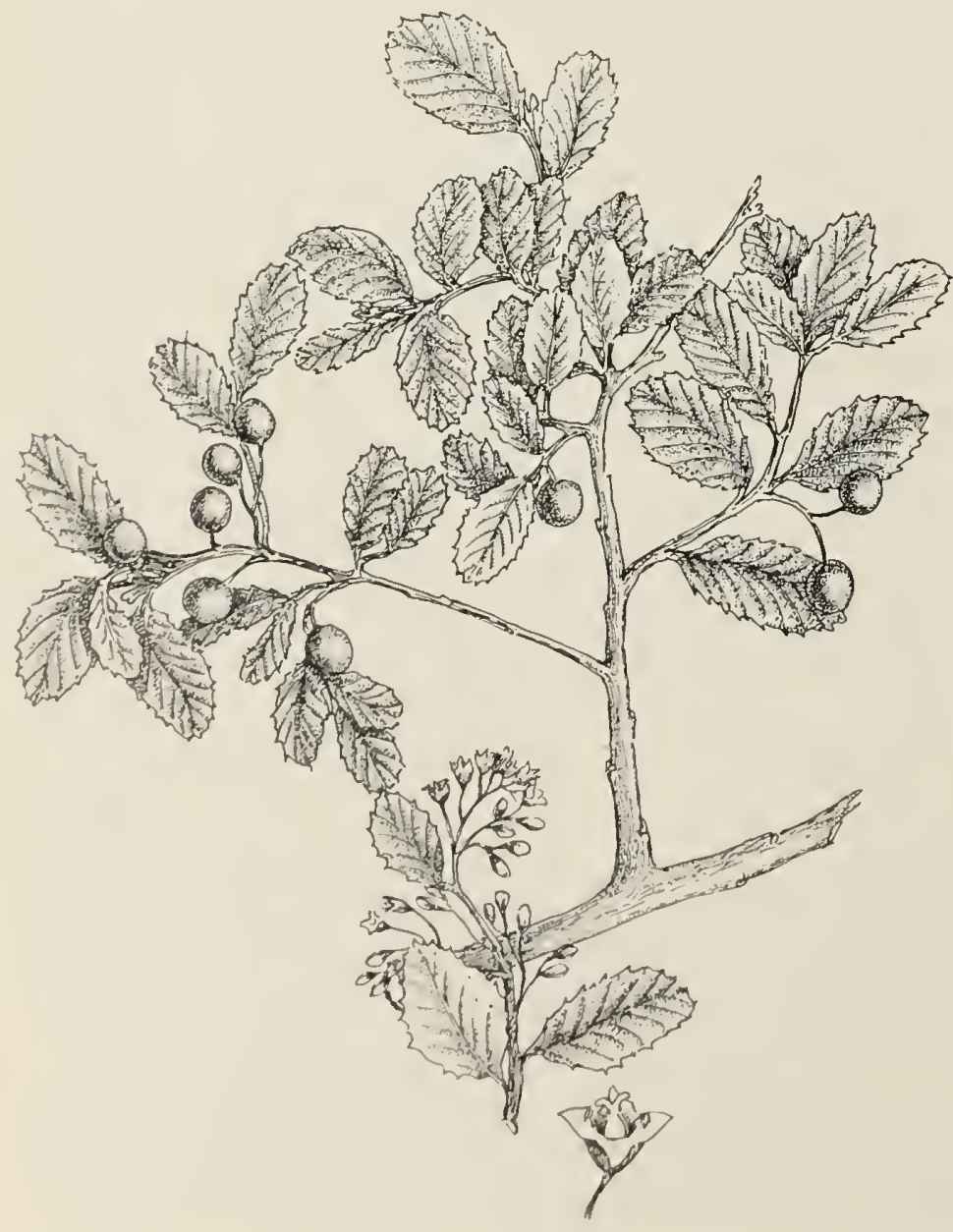

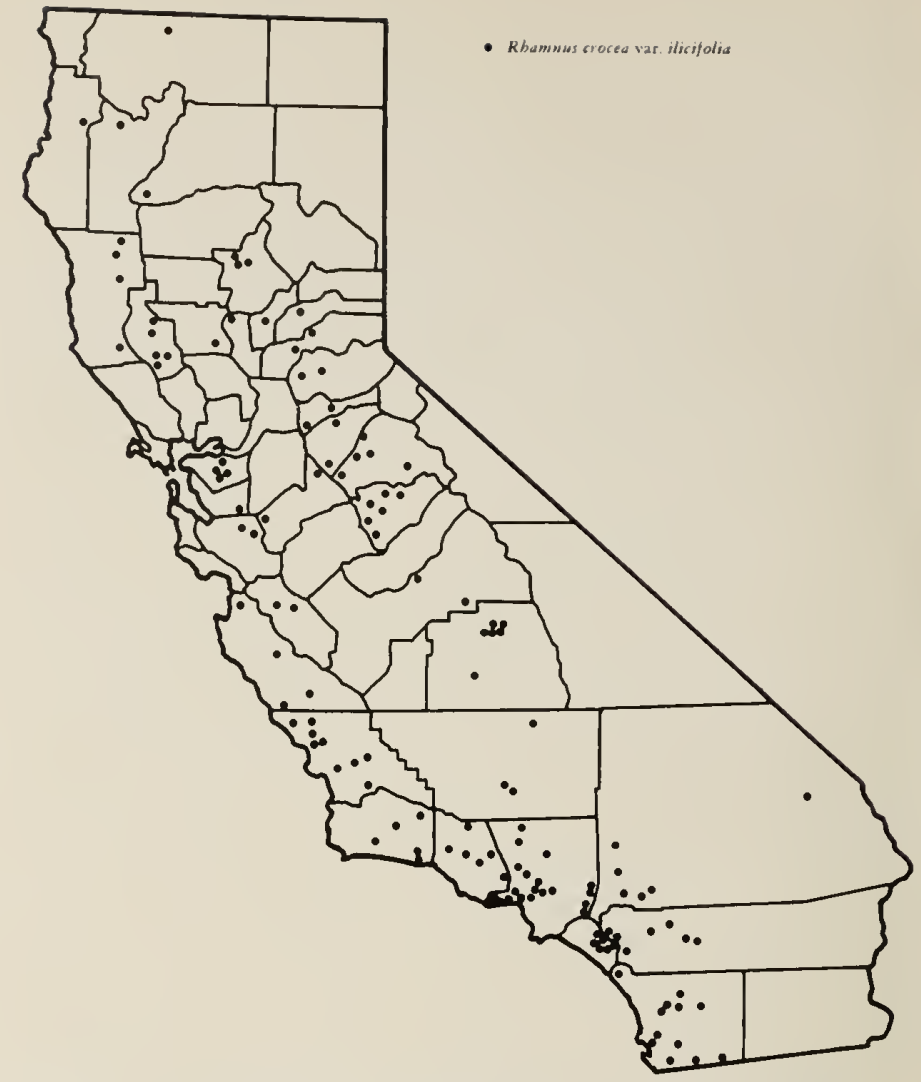

Distribution of hollyleaf redberry (Rhamnus crocea var. ilicifolia).

Sequoia National Forest in southeastern Fresno and northeastem Tulare counties the Barton Flat deer herd showed high preference for this shrub. In 1954 its summer utilization by deer was 5.8 per cent and in 1955 it was 7.6 per cent. During the winter periods of these years its utilization was 29.5 and 46.6 per cent, respectively. These utilization data far exceed those of any other browse spccies on the area concerned. On dcer winter range on the Sierra National Forest east of North Fork, hollyleaf redberry ranked next to western mountain-mahogany and fremontia in preference and degree of utilization (photo on page 115). Since it was less abundant on the range than these two assoeiated species, however, it was a less valuable deer feed.

Browse rating. Excellent to good for goats and deer; good to fair for cattlc and shecp; and uselcss for horses.

\section{Secondary Rhammus Species}

CASCARA SAGRADA (Rhamnus purshiana), also called cascara, chittimwood, and various local names. Large deciduous shrub or small tree, 6 to 20 feet high, with smooth gray or brownish bark. Leaves nsually bornc close together at cnds of the branchlets, oblong-elliptic, 3 to 8 inches long, 3 inch to $2 \frac{12}{2}$ inches wide, rather thin, deep green and smooth above, paler and brownish hairy on the veins beneath, margins cntire or finely toothed. Flowers greenish, numerons, small, in axillary umbels; April and May. Frut globose, 将 to $\frac{1}{2}$ inch wide, black.

This species intergrades with California coffecherry (R. californica) and some specimens of the two speeies are difficult to distingnish. Commercially this species is 
important because of the medicinal qualities of the bark, referred to as sacred bark, which yields the drug, cascara sagrada, that is used as a cathartic or laxative.

Distribution. Cascara sagrada inhabits canyons and lower mountain slopes. It occurs mostly near the coast in Sonoma County northward to Mendocino, and Humboldt counties, thence eastward into Trinity, Siskivou, and Shasta counties, southward in the Sierra Nevada to Butte County in the lower ponderosa pine belt; also on Snow Mountain in Lake County. It extends northward to British Columbia and eastward to Idaho.

Economic value. Cascara sagrada is cropped sparingly by most grazing animals. Its relatively low palatability may be accounted for by the exceedingly bitter taste of the bark, leaves, and twigs. It is browsed most by goats and deer.

Browse rating. Fair to poor for deer and goats; poor to useless for cattle and sheep; and useless for horses.

\section{Grape Familly (Vitaceae)}

Although this is a small family, it assumes tremendous stature commercially when one thinks of the grape (Vitis). Grapes of many famous varieties are grown throughout the world to produce fine red and white wines. California, too, contributes her share of excellent wines from the Napa Valley, the Livermore Valley, Cucamonga in southern California, and other areas.

Most of the members of this family are woody climbers that climb by tendrils or attach to wood and walls by little disks that perform like suction cups. Two wellknown, hardy, deciduous ornamental vines belong to the latter class--the Boston ivy (Parthenocissus tricuspidata)

Hollyleaf redberry (Rhamnus crocea var. ilicifolia) showing heavy browsing by deer of lower and intermediate branches. San Joaruin winter deer range.

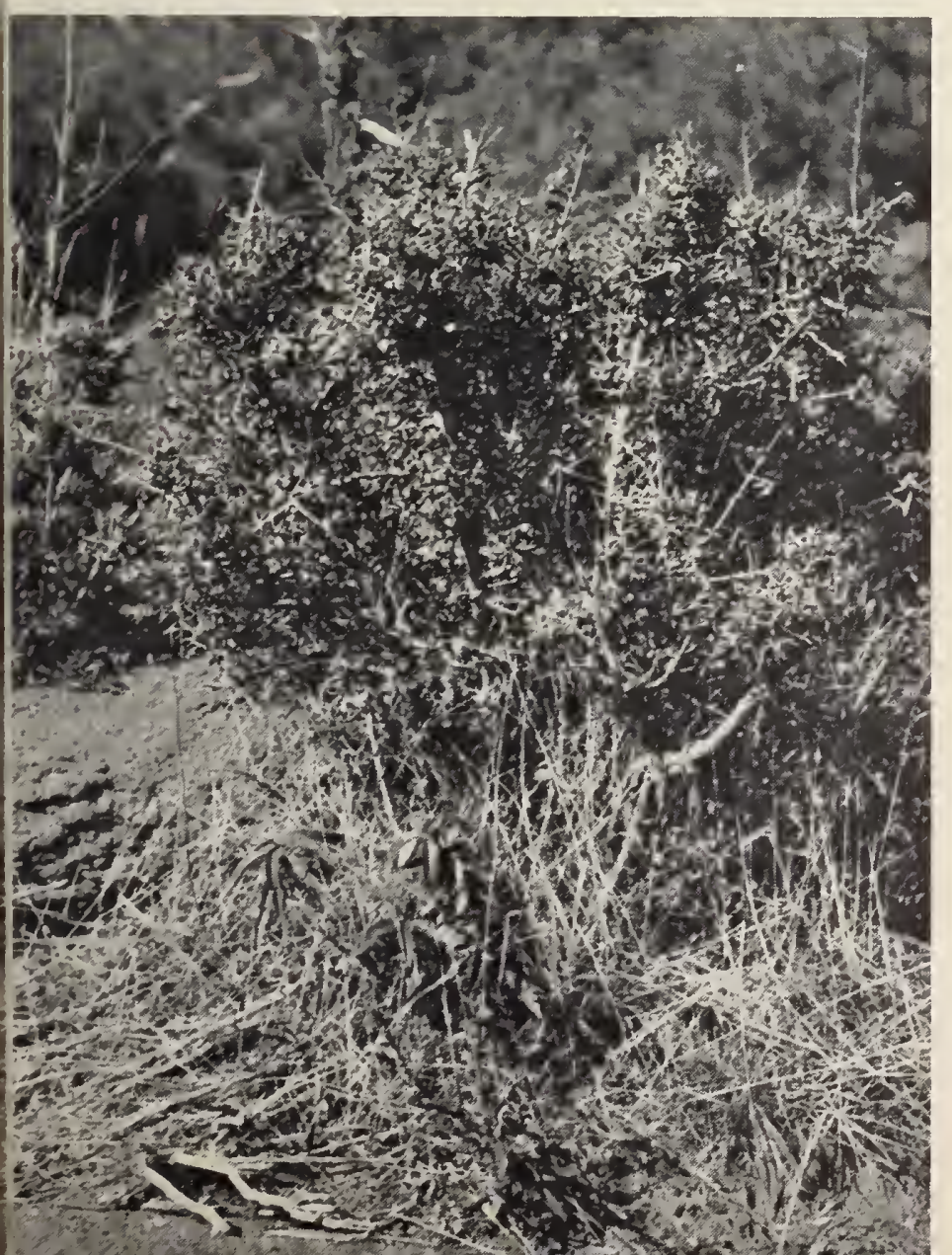

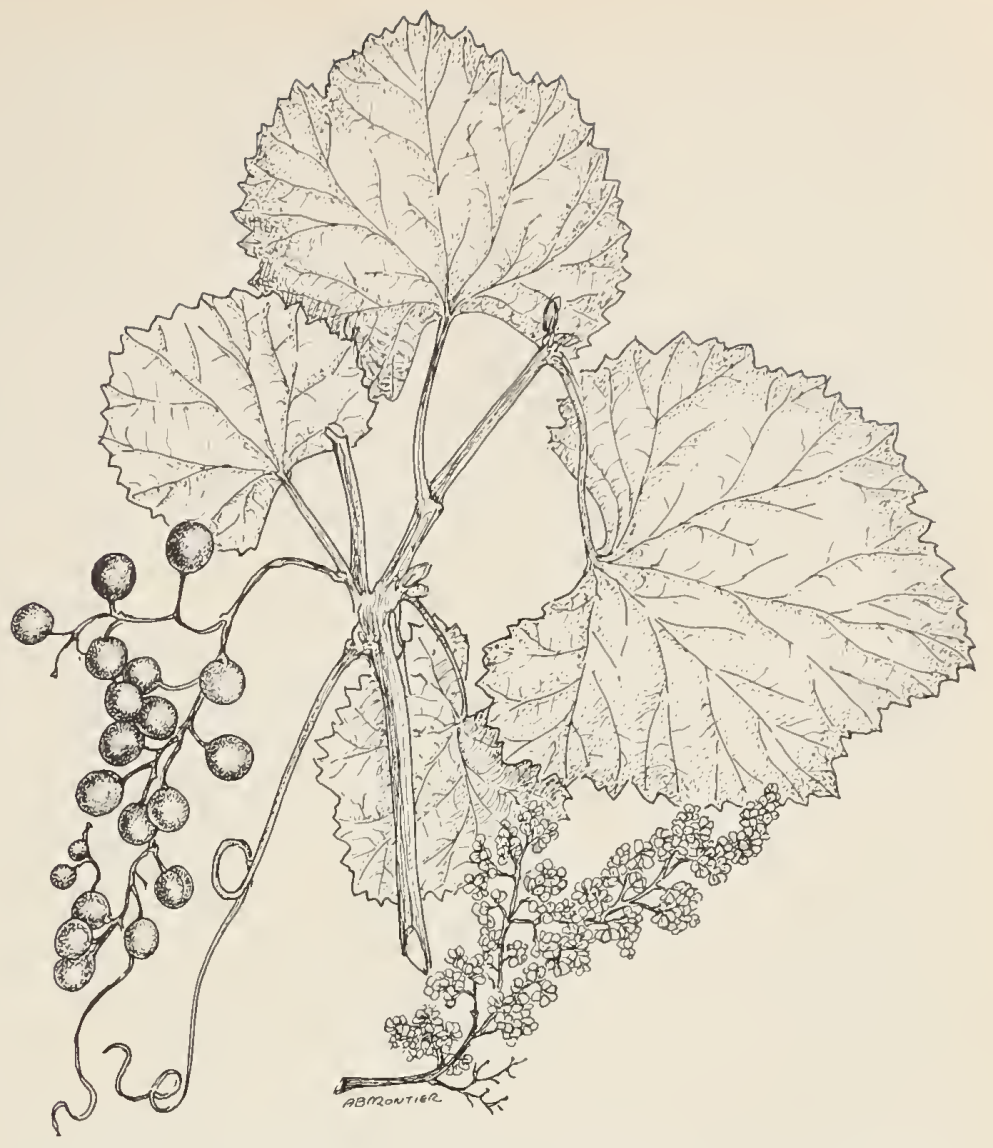

California wild grape (Vitis californica) is browsed with moderate relish by all livestock and by deer. It is regarded as a filler or a variant rather than as first-class forage.

and the Virginia creeper (Parthenocissus quinquefolia). Both contribute a wealth of fiery fall color especially in cold-winter areas.

In spite of this family's economic importance, it contributes little to California ranges as a browse crop. Only one genus (Vitis) and two species occur natively but only the California wild grape warrants discussion.

CALIFORNIA WILD GRAPE (Vitis californica) (drawing shown above). Deciduous woody vine climbing to 5 to 50 feet high, or sprawling and bush-like when not finding support. Young leaves and branches commonly densely white-hairy. Leaves opposite, roundish, 2 to 5 inches wide, commonly 3 to 5-lobed, heart-shaped at the base, finely hairy becoming smooth above, thinly cobwebby hairy beneath. Tendrils and flowers clusters opposite the leaves. Male and female flowers often on separate plants, numerous, fragrant, greenish, in compound clusters; May to July. Berry roundish, 将 to $\frac{1}{2}$ inch wide, purplish, covered with a whitish bloom.

California wild grape climbs high and wide, and when in full foliage, often completely covers large trees, or festoons over low shrubs along stream banks. In the fall the leaves turn scarlet, orange, and gold.

Distribution (map on page 116, top). This species occurs along streams and in canyons throughout the Coast Ranges from San Luis Obispo County northward to Siskiyou County; in the Great Valley; and the foothills of 


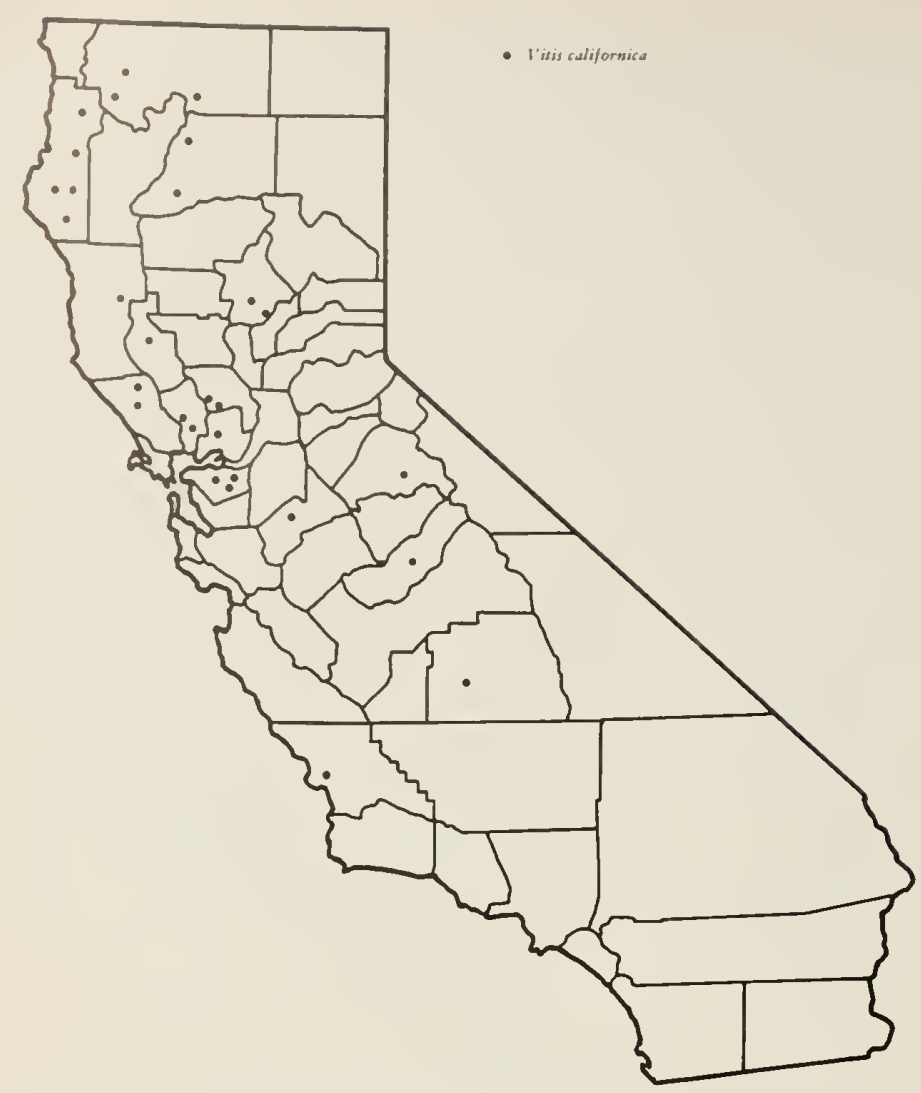

Distribution of California wild grape (Vitis californica).

the Sicrra Nevada from Kern County northward to Shasta County.

Economic value. California wild grape, although not a first-rate browse plant, is cropped with some relish by all domestic livestock, and by deer, throughout most of the grazing season. The lcafage and young stems are often cropped somewhat closely as high as deer can rcach. Even after the leaves have shed they are eaten to some extent.

Browse rating. Fair to poor for sheep, goats, and decr; and poor to uscless for cattle and horses.

\section{Cacao or Sterculia Family (Sterculiaceae)}

The gencrally recognized common name of this family-cacao family-is taken from the species that is most economically important, Theobroma cacao, native to Central and South America, the secds of which are the basis for chocolate and cocoa. The kemels of the fruit of another species, Cola acuminala, are used in making drinks and medicines. Nost of the members of this family are tropical or subtropical.

Two genera are native to California. One genus, with one species-Ayenia pulsilla-is a small subshrub, so rare in California that it has no browse value. The other genus, Fremonlia, that occurs in California is named in honor of Ceneral John C. Fremont who discovered the plant. It inchuckes two species. Fremonlia mexicama occons only in San Diego Comnty, and is usually the one frecpuently secon in cultivation. The more widespread
Fremontia californica, which has several varieties ${ }^{(108)}$, is the only species that is useful as a browse plant.

FREMONTIA Or FLANNEL BUSH (Fremontia califormica) (photo page 117, left). Evergrecn, loosely branched shrub or small tree, 6 to 15 feet high, with long, tough, dark colored branchlets covered with stiff hairs. Leaves thick and leathery, round-ovate to elliptic-ovate, ${ }_{4}^{1 / 4}$ inch to $1^{1 / 2}$ inches long, dark green and rough above, covered with grayish or brownish rough felt beneath, entire to slightly lobed or sometimes maple-like. Flowers lemon-ycllow, showy, 1 to $1 \frac{11}{2}$ inches broad, with 5 sepals which are petal-like and united at the base; May to June. Capsules roundish, ${ }_{8}^{5}$ to 1 inch long, densely brown bristly hairy; seeds brown, dull.

Distribution (map below). Fremontia inhabits dry chaparral foothills, the ponderosa pine forest, and woodland-juniper association with some seepage, from 5,000 to 6,000 feet elevation. It occurs on the western slopes of the Sierra Nevada from Kern County northward to Tehama County and southward in the inner and middle Coast Ranges in scattered locations from Lake to San Luis Obispo counties. In southern California it is found in the Tehachapi, San Gabriel, and San Bernardino mountains; occasionally in the Topatopa Mountains, and the eastern slope of Mount Pinos, Ventura County; in the San Jacinto Mountains, and rarely in San Diego County.

Economic value. This species is cropped readily and with considerable relish by all kinds of range livestock and big-game animals. The young leaves and twigs are often browsed closely. The cvergreen characteristic ac-

Distribution of fremontia or flannel bush (Fremontia californica) and fremont silktassel (Garrya fremontii).

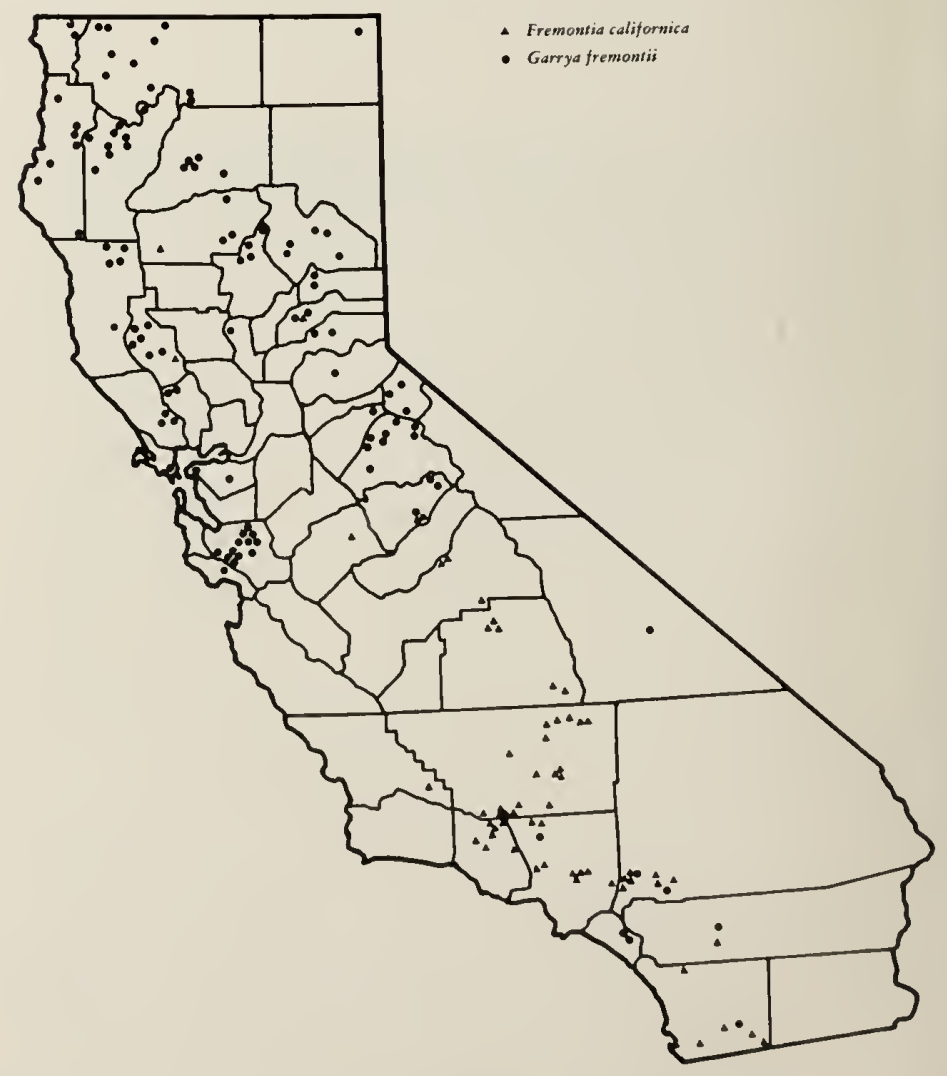



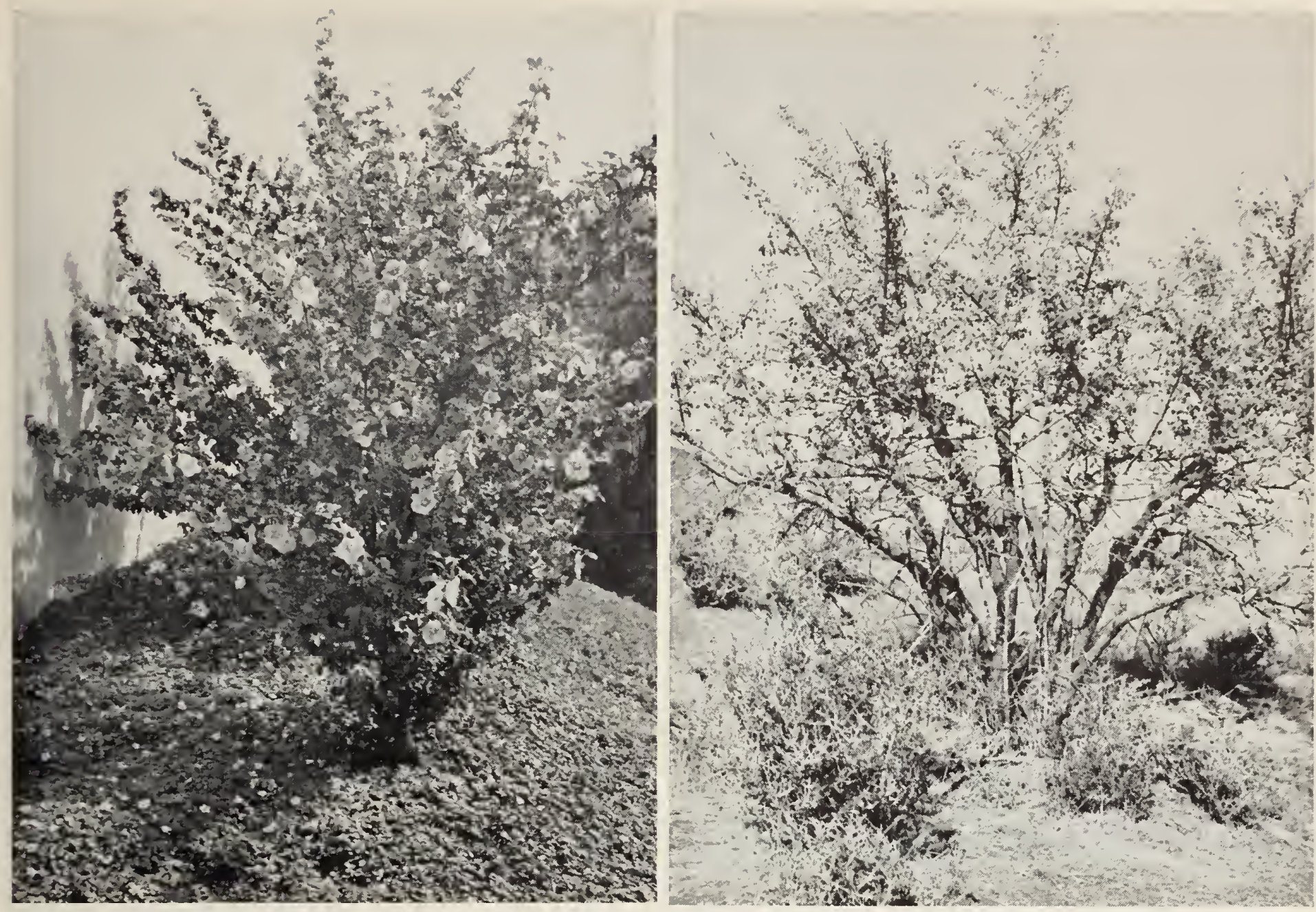

Left. A protected fremontia or flannel bush (Fremontia californica) in full foliage and flower. It is browsed with relish by most livestock and by deer at practically all seasons. Seldom, however, does it grow densely in any habitat.

Right. This loosely branched specimen of fremontia (Fremontia californica) is about fifteen feet high. Deer have nearly completely destroyed the lower branches by close cropping. The low, heavily cropped growth is wedgeleaf ceanothus (Ccanothus cuneatus).

counts for the fact that it provides some feed year-long. Best utilization occurs on recent burns where great numbers of sprouts spring from the crowns of the old charred plants. During the spring months of the first two years after a burn, cattle, sheep, and goats seldom leave more than a few inches of the more woody basal portions of the young sprouts. Deer tend to utilize the sprout growth even more closely than domestic livestock (photo on this page, right).

Browse rating. Excellent for deer; good to fair for sheep and goats; fair to poor for cattle; and useless for horses.

\section{Oleaster Family (Elafagnaceae)}

This family of evergreen or deciduous shrubs and small trees includes only three genera and about 30 species. Many of the species have silvery scales on the leaves that cause them to glint in the sun.

One genus and one species are native to California. Although the leaves are smaller, and it grows more shrub-like, it is somewhat reminiscent of the ornamental Russian olive (Elaeagnus angustifolia), because of its sil- very gray willow-like foliage. Occasionally the native is planted as an ornamental shrub.

SILver bUFFALOBERRY (Shepherdia argentea) (drawing on page 118). Erect deciduous shrub or small trec, 4 to 20 feet high, with shaggy bark, and brown or silveryscurfy twigs, branches terminating in sharp thorns. Leaves simple, opposite (some alternate), oblong-lanceolate, ${ }_{4}^{3 /}$ inch to $1_{4}^{3 / 4}$ (rarcly up to 3 ) inches long, ${ }_{1 / 4}^{1 / 4}$ to ${ }_{5}^{5}$ inch wide, silvery scurfy on both sides. Male and female flowers borne on scparate plants, usually in clusters at the nodes of the twigs; April to May. Fruit drupe-like, ovoid, $1 \frac{1}{4}$ inch or less long, red, sour, edible.

Distribution. This species grows along strcams in a few localities in California, occurring in Modoc, Alpine, Mono, Kern, Santa Barbara, Ventura and San Bernardino countics in the sagcbrush scrub and the piñon-juniper woodland. It extends northward in Oregon and east to the Rocky Mountains.

Economic value. Silver buffaloberry is occasionally cropped closely, but more often only limitedly by all kinds of domestic livestock and by deer. The thomy 


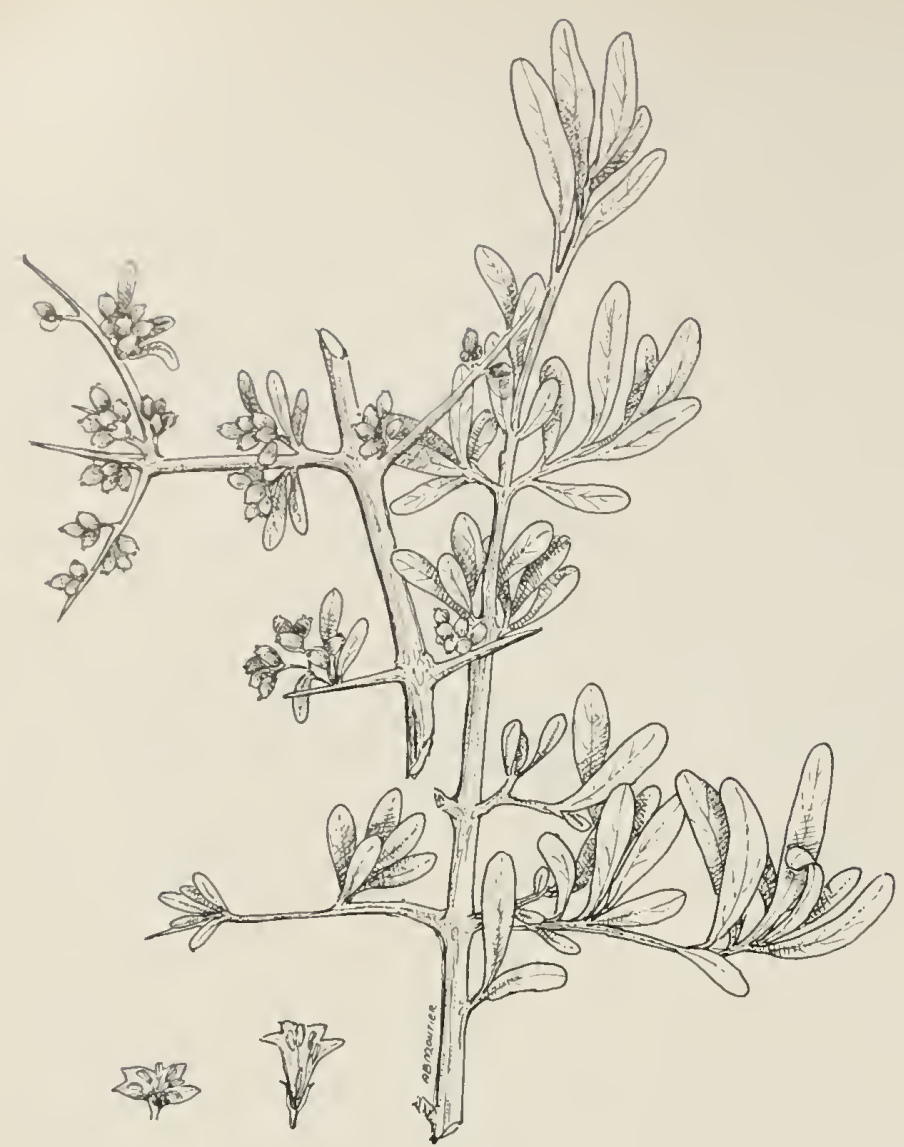

Silver buffaloberry (Shepherdia argentea). Largely a streambank shrub of limited distribution. It is occasionally browsed closely by sheep, goats, and decr. Cattle feed but little upon it, possibly because of the thorny twigs.

twigs and the rather small scurfy leaves make it less attractive to cattle than to the smaller-nosed grazing animals.

Browse rating. Fair to poor for sheep, goats, and deer; and poor to uscless for cattle and horses.

\section{Silktassel Family (Garryaceae)}

The silktassel family consists of a single genus Garrya which is limited to the western United States, Mexico, and the West Indies. The common name of the family refers to the showy pendulous flower tassels produced in January or February. Six species are native to California. The coast silktassel (Garrya elliptica) is sometimes seen in gardens as a dense foliaged, dark green, tall sercen. It grows well in shade and part shade. The sumloving Carrya fremontii is also desirable for cvergreen shmblery because of its abmant glossy yellow-green foliage, and showy flower clusters. Both species are relatively immune from scale and other pests. Sometimes the nane guninine bush is applied to some of the species becanse of the bitter bark, leaves, and fruits. 'They contain an alkaloid, garrvine, which is used as a tonic.

These harge shrouls or small trees, typified by thick leathery leaves, are characteristic of the broad scleroplivll vegetation gronp which is a pronninent component of the trice chaparal associations. Fromont silktassel is the most inportant browse species.
FrEMONT SILKTASSEL (Garrya fremontii) (drawing shown below), also ealled bear brush, California fever bush, and flamnel bush. Erect evergreen shrub, 5 to 10 feet high, usually of a yellowish-grecn cast. Lcaves oblong-clliptical, $3_{4}^{3}$ inch to $2^{\frac{1}{2}}$ inches long, $1 / 2$ inch to $1 \frac{1}{2}$ inches wide, shiny yellow-grcen above, paler boneath, young foliage often gray hairy, margins entire. Male and female flowers borne on separate plants, the flowers small, without petals, borne in catkin-like clusters. Male catkins 2 to 8 inches long, slender, rather loose, vellow, 2 to 5 in a cluster; female catkins 1 to 2 inches long, thick, and more compact, gray-green; January to April. Berry usually smooth, about $\frac{14}{4}$ inch wide, purple to black, with dark juicy pulp, borne in clusters like small grapes; seeds 2,3 , or 4 , horny.

Distribution (map on page 116, bottom). This species is found in the chaparral and forest associations from 2,500 to 7,000 elevation. It occurs in the Sierra Nevada, north to Modoc County, the immer Coast Ranges south to Montercy County, and in the mountains of Riverside, Orange, and San Diego counties of southem California. The most common habitats are the dry inner ranges where it is often a prominent member of the brush fields. It extends northward to Washington.

Economic value. Fremont silktassel, while not of the highest browse rank, is a strong sprouter. This growth on new burns is cropped with relish from spring until late fall by both domestic livestock and deer. The current crop of leaves and stems of adult stands is also some-

Fremont silktassel (Garrya fremontii). A valuable browse plant for deer at various seasons of the year. Sheep, goats, and deer are particularly fond of the numerous young sprouts that appear on burned areas.

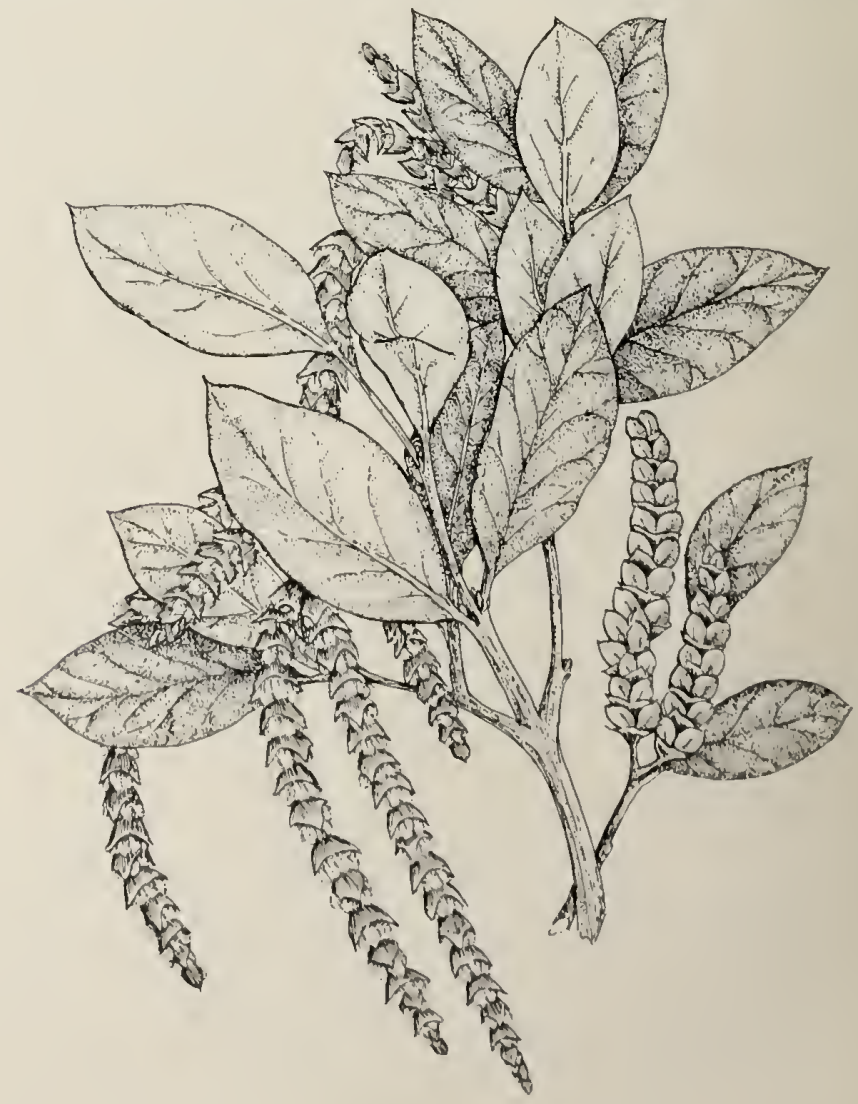


times utilized closely by livestock and big game (photo below). On the Tehama deer winter range, fremont silktassel accounted for $12,14,22.6$, and 2.7 per cent, respectively, of the food in 96 stomachs examined of black-tailed deer in December, January, February, and March. In other months this shrub was not utilized, except in October when it accounted for 1 per cent ${ }^{(k i)}$. Forage utilization checks showed that silktassel and associated shrubs had been croppcd heavily. The transition from a diet of grasses and forbs to one largely of browse was most pronounced in April and May, when silktassel and associated shrubs had produced new leafage. The deer then quickly switched to this food.

In Lake County the volume of Fremont silktassel in stomachs of black-tailed deer amounted to 5.8 per cent in April. 3.3 per cent in May, traces in June and July, 0.9 per cent in August, 3.1 per cent in September, mere traces in October and November, and 1.1 per cent in December ${ }^{(1)}$. The pattern of crude protein was typical of that of evergreen shrubs, though somewhat higher than in some species. It was 7.9 per cent in January, 8.4 per cent in February, 9.3 per cent in March, 12 per cent in April, about 10.3 in May and June, 6.9 per cent in July, and from 5.1 to 6.4 from August to December.

Birds are particularly fond of the fruit. One observer, who has this plant in his garden, states that just as soon as the fruit is ripe, the robins clean up every berry.

Brouse rating. Good to fair for sheep, goats, and deer; poor to useless for cattle; and useless for horses.

Fremont silktassel (Garrya fremontii). The numerous sprouts, as on new burns, are cropped with relish from spring to late fall by sheep, goats, and deer. The current twigs and leaves of adult plants are aiso sometimes eaten closely by livestock and deer. The protein content of current leaves and stems is fairly high for an evergreen plant. Madera County:

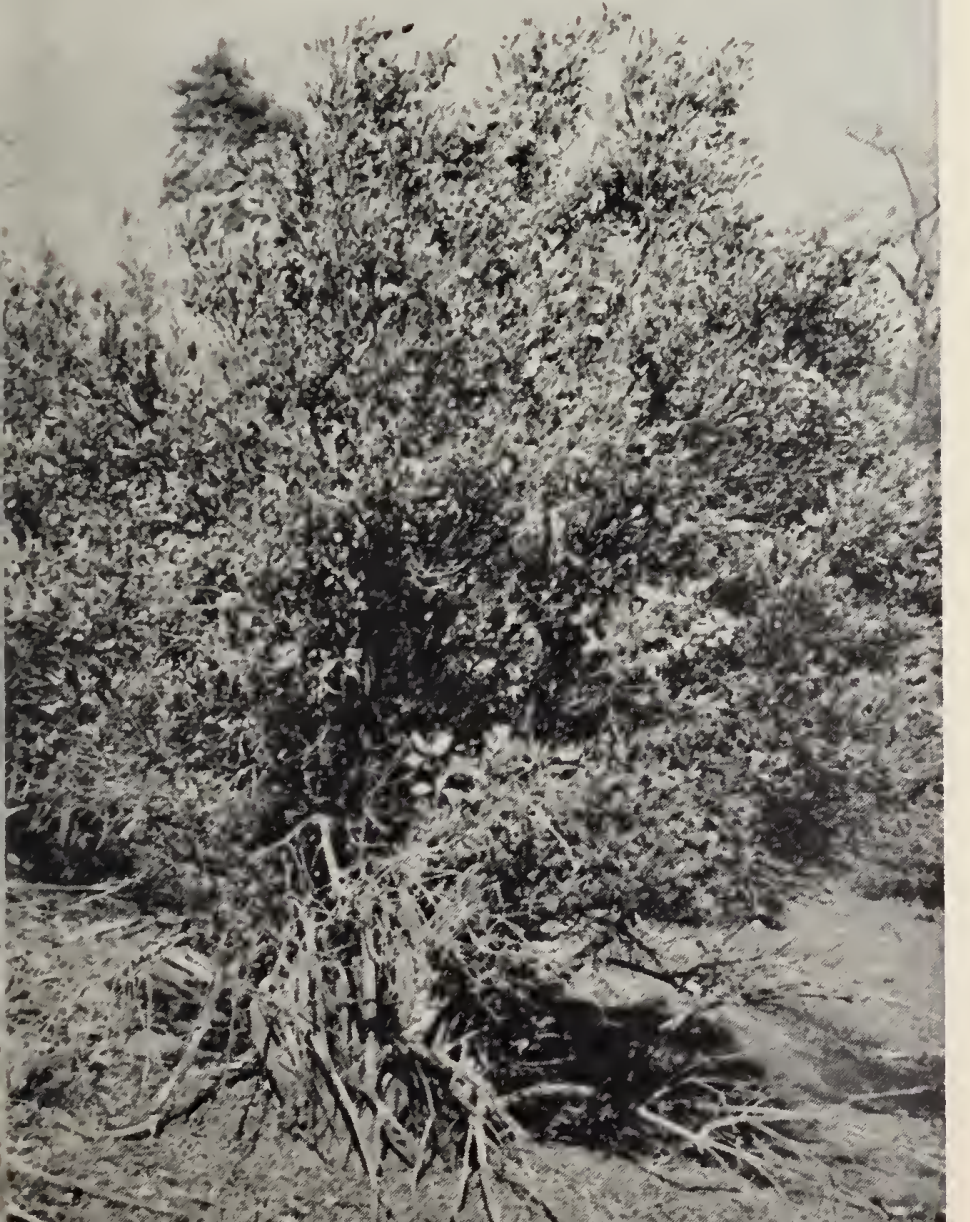

\section{Dogwood Family (Cornaceae)}

The dogwood family is probably best known for the genus Cornus, although there are approximately 16 genera and some 80 spccies included in this family. Cornus, popularly known as dogwood, is the most important genus as far as browse is concerned, and it also contributes a number of beautiful ornamental species.

\section{DOGWOODS (Cornus)}

This genus includes deciduous or evergreen shrubs and trees, rarely herbs, with usually opposite leaves. The small flowers are bisexual, regular, and borne in compact heads or open clusters. In some species where the flowcrs are in heads, these are subtended by showy bracts that are petal-like. The sepals, with white or yellowish petals, and stamens, are four in number. The fruit is an ovoid or roundish drupe.

The species most prized for ornamental use are the large shrub or tree forms that bear the showy white or creamy white, pctal-like flower bracts in the spring; supply colorful red fruits, and give splendid autumn color. The California and Northwest native, Pacific dogwood (Cornus nuttallii), is one of these. Another plant worth mentioning in this group is the little herbaceous bunchberry (Cornus canadensis) that grows in northern California, forming an attractive ground cover under coniferous trees. Other dogwoods are useful for their colorful bare stems such as the native, Cornus stolonifera, with its dark blood red branches.

The genus Cornus became well known early in England, where a solution prepared by boiling the bark of bloodtwig dogwood (Cornus sanguinea) in water, was used for treating mangy dogs ${ }^{(3)}$. The bitter foliage and bark is quinine-like chemically. Flowering dogwood (Cornus florida) yields a useful substitute for quinine that is reputed to produce virtually the same effect in the treatment of fever.

About six species and one variety of Cornus occur natively in California. They occupy moist wooded habitats, mostly as understory of conifers, maples, and oaks, and often grow along streams, on fertile bottom lands, in moist or wet meadows, and near springs. They are effective in stabilizing stream banks and as shade for livestock and big game, but their browse valucs are rather low, in part, perhaps, because of their distinctly bitter cell sap. They are cropped most in the autumn after the soil has dried. Thrce species and one variety will serve to illustrate the browse values of the genus.

\section{Key to the Browse Species and Varieties}

1. Small tree 10 to 40 feet high; flowers yellowish-green crowded in a compact head-like cluster, this cluster subtended by usually 6 white obovate to oblong petallike bracts 2 to 3 inches long; fruit scarlet; mountain woods

PACIFIC DOGWOOD (Cormus nuttallii)

1. Shrubs 5 to $\mathbf{1 5}$ feet high; small flowers in flattish less compact clusters, not subtended by petal-like bracts; mature fruit not red 
2. Leaves thin; flowers few in stalkless elusters; mature fruits shiny black; moist eanvons in northern California foothills

13LACKFRUIT DOGWOOD

(Cornus sessilis)

2. Leaves thiek, prominently veined; flowers numerous in stalked roundish elusters; mature fruits white or sometimes blue

3. Leaves with few to numerous straight 2-branehed hairs on the under surface; mountains from Humboldt County, eastward to the Warner Mountains of Modoe County, Sierra Nevada, oeeasional in San Bernardino Mountains, usually above 5,000 feet elevation

AMERICAN DOGWOOD (Cornus stolonifera)

3. Leaves with many long, bent, eurled hairs on under surface of leaf; eommon along streams in the foothills of the Sierra Nevada and Coast Ranges, and the Great Valley from sea level to 6,000 feet elevation. . CREEK DOGwood (Cornus stolonifera var. californica)

AMERICAN DOGWOOD (Cornus stolonifera) (drawing on page shown below), also called American dogberry, redbrush, red osier dogwood, and various other local names. Deciduous, erect, spreading shrub, 6 to 15 feet high, with smooth purplish or reddish branches. Leaves oval or elliptical, pointed at the apex, rounded at the base, $1 \frac{1}{2}$ to $3 \frac{11}{2}$ inches long, ${ }^{3}$ inch to 2 (rarcly 3 ) inches wide, pale

Ameriean dogwood (Cornus stolonifera). Although this is not a highly palatable species for any kind of grazing animal, the young sprouts are cropped with fair relish by both domestic livestock and deer.

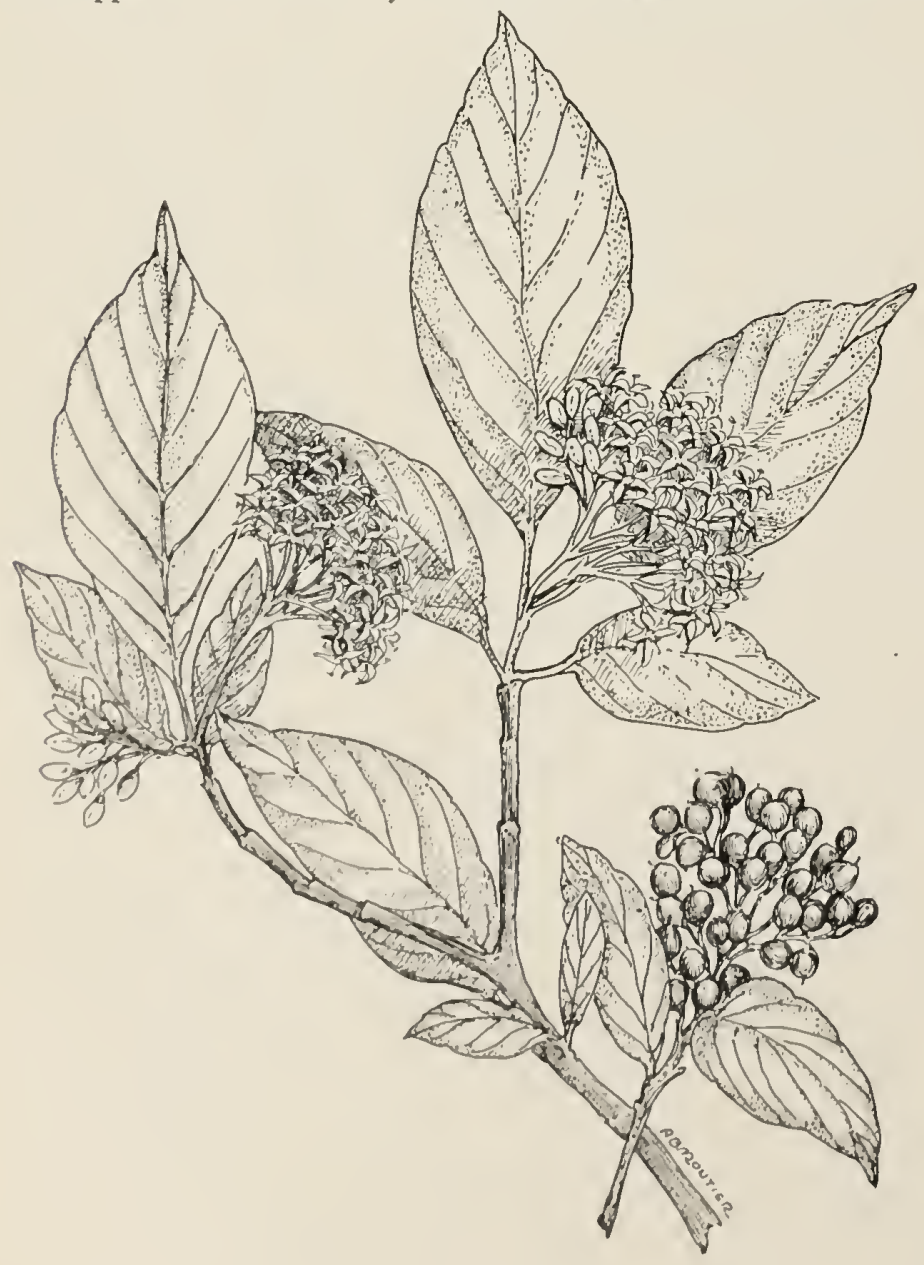

beneath with few to numerous straight, 2-branehed hairs. Flowers white or eream colored, numerous, small, in branched round-topped elusters about 2 inches across; April to November. Fruit nearly round, about ${ }_{1}^{1 /}$ inch wide, smooth, white, or blue.

Distribution (map page 121, left). This species inhabits canyons and moist flats mostly below 9,000 feet elevation. It occurs in the mountains from Humboldt County eastward to the Warner Mountains of Modoe County, southward in the Sierra Nevada, usually above 5,000 feet elevation to Tulare County, and occasionally in the San Bernardino Mountains of southern California. It commonly grows in association with elderberries, alders, and willows.

Creek dogwood (Cornus stolonifera var. californica) differs from the species in that it has many long, bent, curled hairs on the under surfaces of the leaf. Some botanists indicate that this plant is a hybrid between Cornus stolonifera and Cornus occidentalis and shows intermediate stages between the two ${ }^{(108)}$. Creek dogwood usually occurs at lower elevations than the American dogwood, inhabiting stream banks or moist flats from near sea level to 6,000 feet elevation in the mountains of northern California, southward in the Coast Ranges; along streams in the Great Valley, and the lower slopes of the Sierra Nevada.

Economic value. The bitter herbage, twigs, and bark of American and creek dogwoods may partly account for the low palatability of these shrubs. Nowhere are they cropped closely except when feed is scarce. Young sprouts, however, are sometimes cropped with fair relish both by livestock and big game.

Browse rating. American dogwood rates fair to poor for goats and deer; poor for sheep; poor to useless for cattle; and useless for horses. Creek dogwood has the same rating.

PACIFIC DOGwOOD (Cornus nuttallii), also called western dogwood, and mountain dogwood. Deciduous tree 10 to 30 (or sometimes up to 45 ) feet high, the twigs black in age. Leaves usually elliptic-obovate, 3 to 5 inches long, minutely hairy above, paler and hairy beneath. Flowers small, yellowish green, erowded in a head, surrounded by 6 showy petal-like braets, white, sometimes tinged with pink, 2 to 3 inehes long. Fruit about $1 / 2$ inch long, searlet.

Distribution (map page 121, right). This species is widely distributed in the mountains up to about 6,000 feet elevation. It oeeurs in the Sierra Nevada from T1lare County north; in the Coast Ranges from the Santa Lucia Mountains, Monterey County, northward to British Columbia, eastward to Idaho. It is oecasionally found in the mountains of southern California from San Diego County to Los Angeles County.

Economic value. The browse values of Pacifie dogwood are essentially the same as those for Ameriean and ereek dogwood, except that the more eommon habitats are somewhat less moist and therefore more congenial to visitation by browsing animals. 


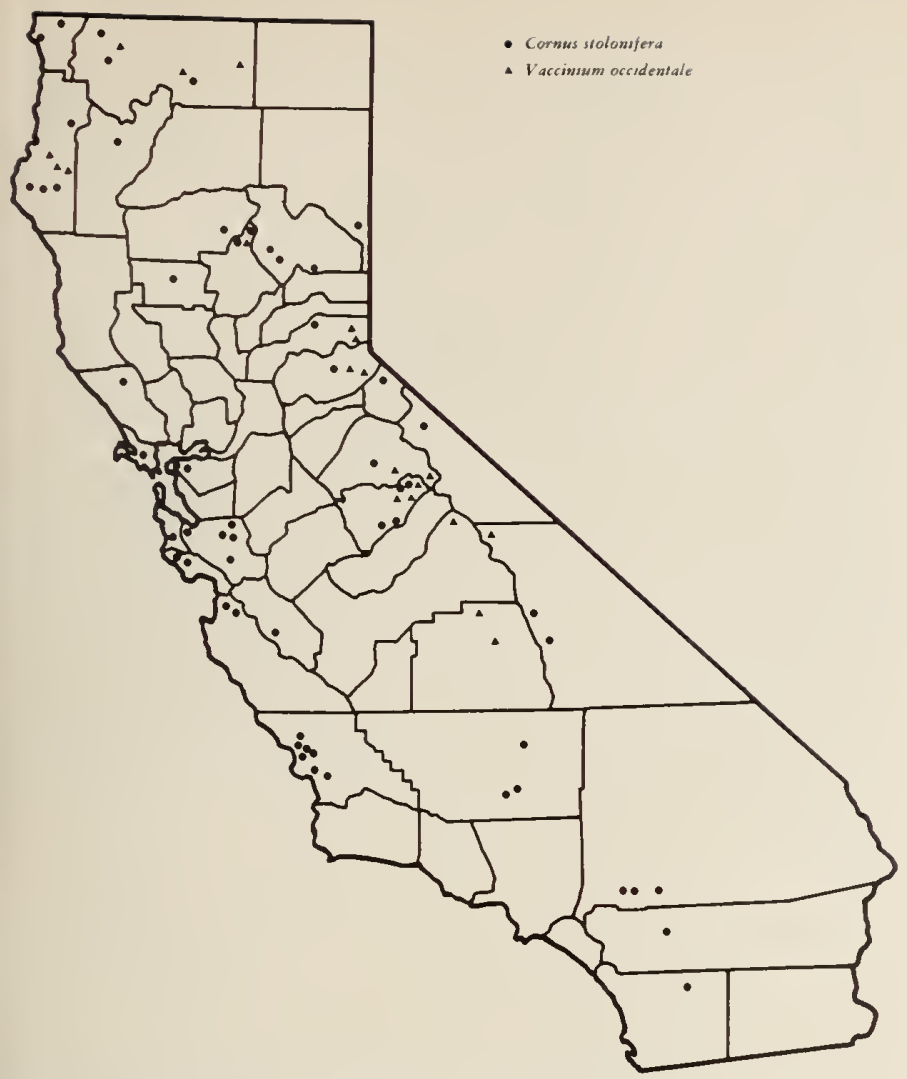

Distribution of American dogwood (Cornus stolonifera) and western blueberry (Vaccinium occidentale).

Browse rating. Fair to poor for sheep, goats, and deer; and useless for cattle and horses.

BLACKFRUIT DOGWOOD (Cornus sessilis). Deciduous spreading shrub, 5 to 10 (or up to 20) feet high, with green bark. Lcaves ovate or broadly elliptical, $1_{4}^{3 \prime}$ to 4 inches long, ${ }^{3 / 4}$ inch to $1_{4}^{3 / 4}$ (sometime $2_{4}^{1 / 4}$ ) inches wide, thin, light green and smooth above, with scattered hairs beneath. Flowers yellowish, few to several in stalkless umbels, appearing with or before the leaves in April and Mav. Fruit ovoid or ellipsoidal, about ${ }_{8}^{5 \%}$ inch long; at first greenish white, then yellow, to red, and finally black and shining.

Distribution. This species inhabits moist ravines in the lower mountains of northern California, from 1,800 to 4,000 feet elevation. It occurs from Amador County northward in the Sierra Nevada through El Dorado, Placer, Butte, eastern Tehama, and Shasta counties, westward into Trinity and Humboldt counties.

Economic value. Blackfruit dogwood is cropped to a moderate degree in the fall after the foliage loses some of its bitter taste. It is utilized little earlier in the season by any grazing animal.

Browse rating. Fair to useless for deer; poor to useless for sheep and goats; and useless for cattle and horses.

\section{Heather Family (Ericaceae)}

The heather family includes deciduous or evergreen shrubs, trees, and some subshrubs. The simple leaves may be alternate, opposite, or whorled. The bisexual

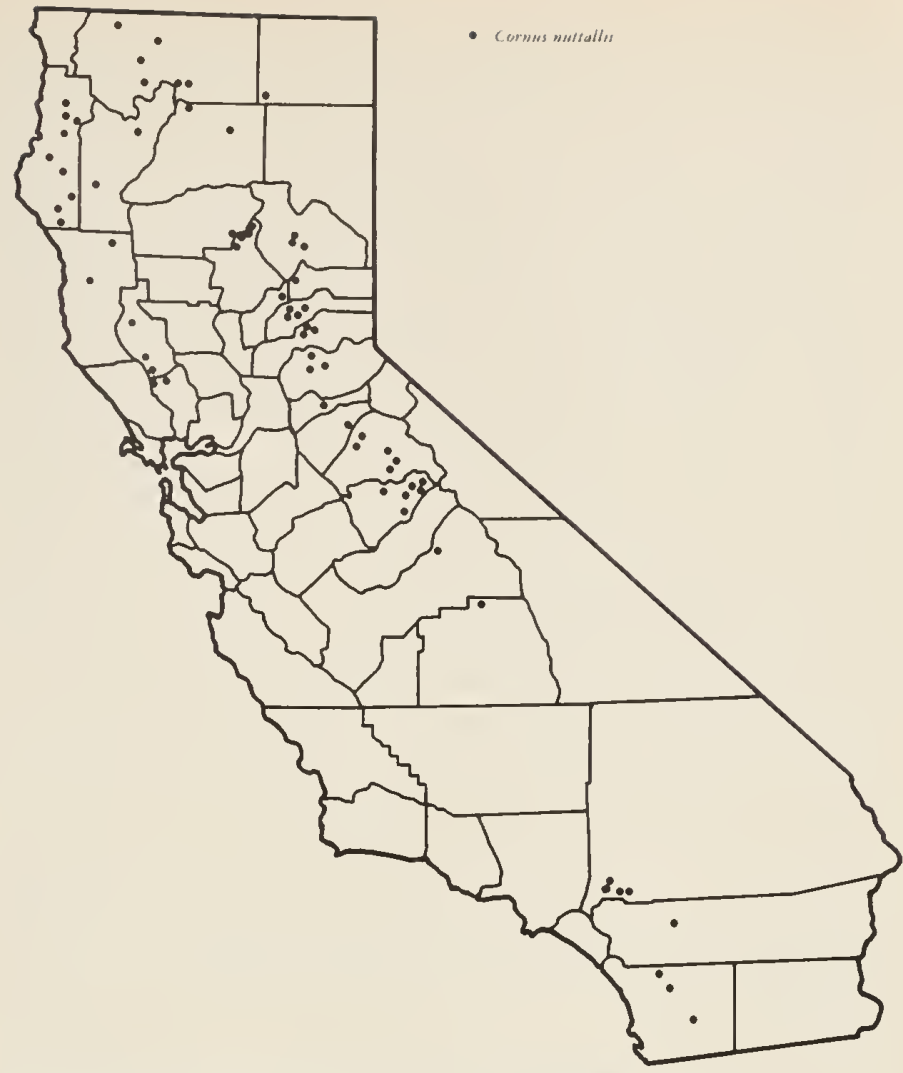

Distribution of Pacific dogwood (Cornus muttallii).

flowers are regular or slightly irregular, borne singly, or in axillary or terminal racemes or panicles. The sepals and usually the petals are united, with 4 or 5 lobes. The stamens are as many or twice as many as the number of corolla lobes. The fruit is a capsule, a berry, or a drupe.

This family, consisting of about 70 gencra and some 1,500 species, contributes many plants that are considered garden aristocrats. Even many California natives in this family rate high as ornamentals. For magnificent displays of flower color, few genera can compete with members of the genus Rhododendron which also includes the azaleas. The heaths (Erica, Daboecia) and heathers (Calluna) comprise another large group of ornamentals. Although their flowers are not as spectacular as the rhododendrons and azaleas, thcy are borne in such profusion that they make a good mass of color. Many other genera could be singled out for their excellent garden performance but the list is long. A few morc will be mentioned along with the discussion of the genera that follow.

A number of the plants included in this family are poisonous to stock. In California some of these are western Labrador tea (Ledum glandulosum), western azalea (Rhododendron occidentale), alpinc laurel (Kalmia polifolia var. microphylla), black laurel (Leucothoe davisiae), and rustyleaf (Menziesia ferruginea). Thev have no browse value at any season.

Most of the members of the heather family grow in areas where there is an abundance of moisture and the soils are highly acid. Of the 13 genera and some 75 species in California, only a few grow on drier sites. 
These plants are considered the true range plants, but all are relatively low in palatability. Most important are the manzanitas, huckleberries, salal, and madrone.

\section{MANZANITAS (Arctostaphylos)}

The manzanitas are cvergreen woody plants that vary from prostrate ground covers to small trees. Usually they have very crooked branches with smooth purplish or reddish brown bark that may become shreddy on old branches. The leaves are simple and alternate. The small, white or pinkish, biscxual flowers are urn-shaped, and bome in simple or compound clusters. The berry-like or drupe-like fruits consist of several hard nutlets surrounded by a soft pulp.

Although the manzanitas are highly ornamental plants becausc of their warm bark color, their dense foliage, and attractive flowers and fruits, they have not as yet been singled out as popular garden shrubs. Probably the one best known in horticulturc, and widely available in nurserics, is the kinnikinnick or bear berry (Arctosta- phylos wea-ursi). It is circumpolar in distribution, and in California ranges as far south as Marin County. A few growers in California are offering selected forms of taller growing ground cover types of manzanitas, especially forms of the native Hooker manzanita (A. hookeri), and Sonoma manzanita (A. densiflora).

Manzanitas arc among the most common and characteristic constituents of the chaparral association in California. A recent California flora ${ }^{(10)}$ recognizes 43 species and 29 varieties. These plants occupy a variety of soil types and sites, including thin soils and dry hot areas to fairly decp productive sites. A number of species crown sprout after a fire, or when the top growth is cut off, and are a prominent constituent of the "fire type" chaparral, so-called because of the rapidity with which they reclaim such disturbed areas. In contrast, the nonsprouting species are killed by a single hot fire, or when cut to the ground surface. Many areas of non-sprouting species can be transformed to vegetation more desirable for grazing.

Greenleaf manzanita (Arctostaphylos patula). Branchlet showing growth habit, leafiness, and infloreseenee; twig with mature fruits; flower with some petals removed exposing sepals, stamens, and pistil.

A shrub of low palatability to all grazing animals. The tender young shoots and seedlings, however, are eropped in varying degrees by foraging animals for the first two years after a fire. Chemieal studies show that the crude protein and nutritive values generally are low.

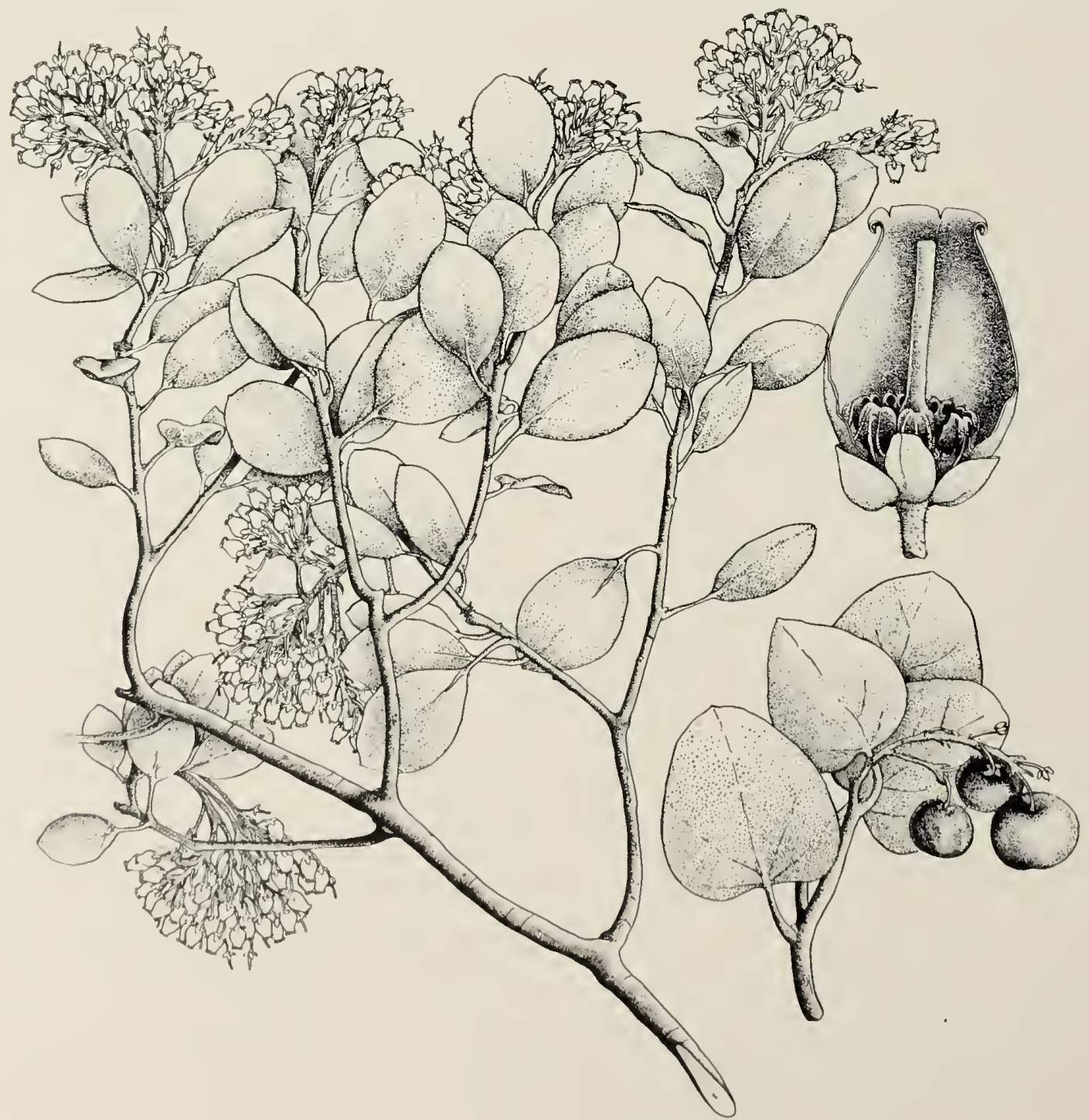



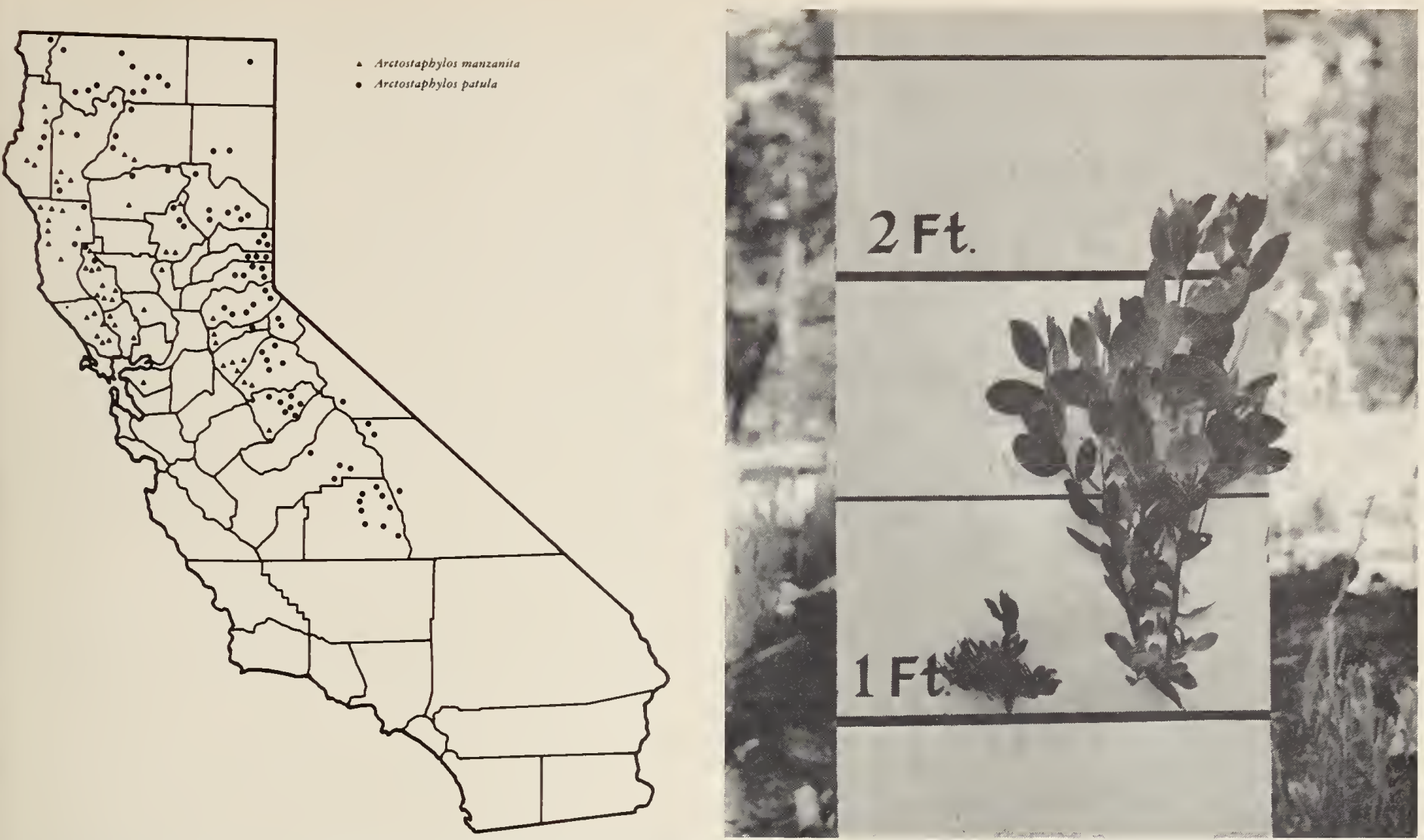

Left. Distribution of common manzanita (Arctostapluylos manzanita) and greenleaf manzanita (Arctostapluylos patula). Right. Conmon manzanita (Arctostaphylos manzanita) showing two-year-old seedling severely browsed by deer and, next to it, a protected two-year-old manzanita seedling. Many manzanita seedlings had been destroyed by repeated close deer browsing. Hobergs' recreation center, Lake County, where the deer population is very heavy.

No manzanita species provide high-quality browse or a large volume of season-long feed. The mature fruits are eaten by various birds, bear, rodents, and deer. Best grazing utilization is obtained from a few species whose sprouts on new burns are cropped in varying degrees by sheep, goats, and deer. Also the young seedlings of some species are browsed rather closely, whereas they are barely nibbled on burns after the third year. Two widely distributed species are selected to represent the browse values of the manzanitas, one a sprouter, the other a non-sprouter.

\section{Key to the Browse Species}

1. Plants with burl at base of stem; branchlets usually

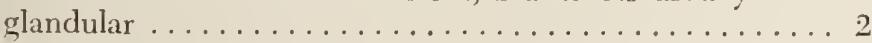

1. Plants without burl at base of stem; branchlets finely

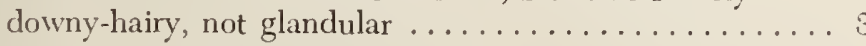

2. Branchlcts usually finely glandular-hairy with yellowish-green glands; bracts of unfolding inflorescence scale-like; fruit smooth; open pine forests, 2,000 to 8,200 feet elevation, Sierra Nevada, higher inner north Coast Ranges ............ GREEnLEAF Manzanita (Arctostaphylos patula)

2. Branchlets usually coarsely glandular-hairy, glands not yellow-green bracts of unfolding inflorescence leafy; fruit usually gummy; dry chaparral areas of lower elevations, Coast Ranges southward to the mountains of southern California.....EASTwOOD MANZANITA (Arctostaphylos glandulosa)
3. Leaves pale gray-green, velvety hairy; bracts of unfolding inflorescence leafy .......... HOARY MANZANita (Arctostaphylos canescens)

3. Leaves darker green, not velvety-hairy; bracts of unfolding inflorescence scale-like....... COMMON MANZANITA

(Arctostaphylos manzanita)

GREENLEAF MANZANita (Arctostaphylos patula) (drawing on page 122), sometimes called buckbrush and Indian tobacco. Much branched shrub, 3 to 7 feet high, sprouting from a prominent swollen base or "burl." Limbs crooked, with smooth reddish brown bark bccoming shreddy on old stems and branches. Branchlets finely glandular hairy with yellowish green glands. Leaves broadly ovate or nearly round, 1 to $1 \%$ inches long, ${ }^{33}$ to 1\%2 inches wide, bright green or yellow-green, smooth. Bracts of the unfolding inflorescence scale-like. Flowers small, pinkish, about $\frac{1}{4}$ inch long, in terminal clusters; May to Jume. Fruit berry-like, ${ }_{1 / 4}^{\prime}$ to $\frac{1 / 2}{2}$ inch wide, smooth, dark brown or nearly black when ripe.

Distribution (map above). This species occurs in open pine forests from 2,000 to 5,000 (occasionally up to 8,000 ) feet elevation, commonly growing in association with Jeffrey pine (Pinus jeffreyi), canyon live oak (Quercus clirysolepis), and mountain whitethorn (Ceanothus cordulatus). It occurs in the Sierra Nevada Mountains from Siskivou to Kern counties, and in the higher inner north Coast Ranges from northeastern Lake to Humboldt counties and into Oregon. 
Economic value. The leafage of greenleaf manzanita is generally of low palatability for domestic livestock, bnt is utilized by deer to a considerable extent in winters of light snowfall. Both livestock and deer feed on the tender young shoots and seedlings for the first two vears or so after a fire. On the Great Basin winter range grecnleaf manzanita and squaw earpet (Ceanothus prostratus) composed 3.2 per cent of the diet of the Rocky Mountain mule deer in November, 1951, and a somewhat lesser amount in December and January, 1952 $2^{(80)}$. During the summer and fall months this speeies was largely ignored. In a study on a good condition range in the Verdi arca, located in Truckee River Canyon along the California-Nevada border, greenleaf manzanita contributed materially to the diet of Roeky Mountain mule deer during January, February, and Mareh, 1951. In Deecmber of that vear this shrub composed 53.8 per ecnt of the diet based on 36 mulc deer stomachs examined, and lesser amounts in other months.

Chemical studies showed that the erude protein eontent of greenleaf manzanita was relatively low throughout the year, ranging from 6 per eent from January to Mav, around 6.7 per eent for June and July, 7.8 per cent for Angust and September, 6.8 per cent in Oetober, and 6.3 in December ${ }^{(11)}$. On the other hand, the foliage was fairly high in mineral matter but was apparently low in over-all nutritive value ${ }^{(2)}$.

Experiments designed to determine if greenleaf and other speeies of manzanita could be eradieated by heavy browsing with goats to improve the forage erop were undertaken on the Lassen National Forest in northern California $^{\left({ }^{(8)}\right.}$. These experiments failed beeause the goats nearly starved to death after having consumed all herbaceous and other vegetation in the enclosure that was more palatable than the manzanita. They did, however, pecl the bark of some bushes and girdled some plants. Deer, more than any other animal, browse limitedly npon the young sprouts and seedlings. In localities of unusually heavy deer populations manzanita seedlings are sometimes destroyed by browsing. Surviving plants are greatly reduced in size and badly distorted.

Browse raling. Fair to poor for deer; poor to worthless for slieep and goats; and worthless for cattle and horses.

(ommon maNzantTa (Arctostaphylos manzonita). Tall, up)right, non-sprouting shrul), or tree-like, 6 to 20 feet ligh, the base not swollen. Branches crooked, with reddish brown lark; lranchlets nostly downy hairv. Leaves broadly ovate or (elliptic to ollong, thick and firm, 1 to 2 iuches long, $3_{1}^{\prime}$ to $1 \frac{11}{2}$ inches wide, dark green or pale, usually downy hairy when voung. Bracts of unfolding inflorescenee scale-like. Flowers white or pale pink, about 18 inch long, in drooping open clusters; Feloruary to April. Fonit roundish, about $\frac{1}{4}$ to $\frac{1 / 2}{2}$ inch wide, white

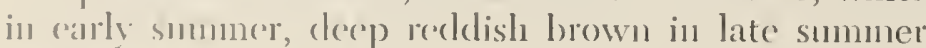
ind fall.

Distribulion (unap) on page 123). This sprecies inlabits dry, gravelly, or recky slopes where it is associated with Digerer pinc and occasionally with ponderosat pine in the upper elevations. It oceurs at elevations of from 250 to 4,000 feet in the inner north Coast Ranges from . Mount Diablo, Contra Costa County, northward to Tehama, Trinity, and Shasta counties, thence south in the Sierra Nevada foothills to Mariposa County.

Economic value. Common manzanita seems to typify the low browse value of the non-sprouting manzanitas. Aside from the somewhat close browsing by deer of the young seedlings on burns on heavily-stoeked deer range, this spccies is of little value as a food plant (photo on page 123).

Browse rating. Poor to useless for goats and decr; and useless for eattle, sheep, and horses. The palatability of hoary manzanita (A. canescens), a non-sprouter, and Eastwood manzanita (A. glandulosa), which is a sprouter, is low and essentially of the same rating (summary table, page 146).

\section{HUCKLEBERRY, BLUEBERRY (Vaccinium)}

This genus includes evergreen or deciduous shrubs or shrublets with simple alternate leaves. The flowers are urn-shaped, much like those of the manzanitas. The fruit is usually berry-like.

To many this genus is not well-known as Vaccinium but better reeognized by the edible fruit eertain species produce, whether they are ealled blueberries, huckleberries, bilberries, or whortleberries. And the best known of all is the traditional holiday accompaniment to the turkey-the cranberry (Vaccinium macrocarpum). In the wild the fruits of several of this genus are considered delicacies by bear and other wild life. Other than the commereial deciduous kinds that are grown in gardens for fruit production, they are not too often planted as ornamentals. Nevertheless, the native evergreen huckleberry (Vaccinium ovatum) makes an exeeptionally attractive hedge. The foliage is also used for Christmas decoration.

Some species have thick leathery leaves, others are thin leafed. The latter speeies are the most palatable to grazing animals. Of the seven native California species, the following three best illustrate their browse value.

\section{Key to the Browse Species}

1. Leaves thick and leathery, evergreen; flowers in 1 to 5-flowered racemes ........... EVERGHEEN HUCKLEBEMIY (Vaccinim ovatum)

1. Leaves thin and deciduous; flowers solitary or 2 to 4

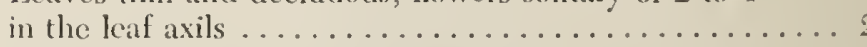

2. Low compact shrul) 1 to $2 \frac{1}{2}$ feet high, or almost prostrate; branchlets romded; leaves 礁 to $x^{\prime}$ inch long, margins cntire, slightly inrolled; flowers white or

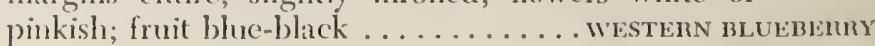

(Vaccinium occidentale)

2. More upright shrub) I to 4 feet ligh; branchlets angled; leaves 1 to 2 inches long, margins funcly toothed; flowers greenish white; fruit black or winc-

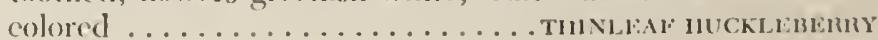
(Vaccininm mombranacenm) 


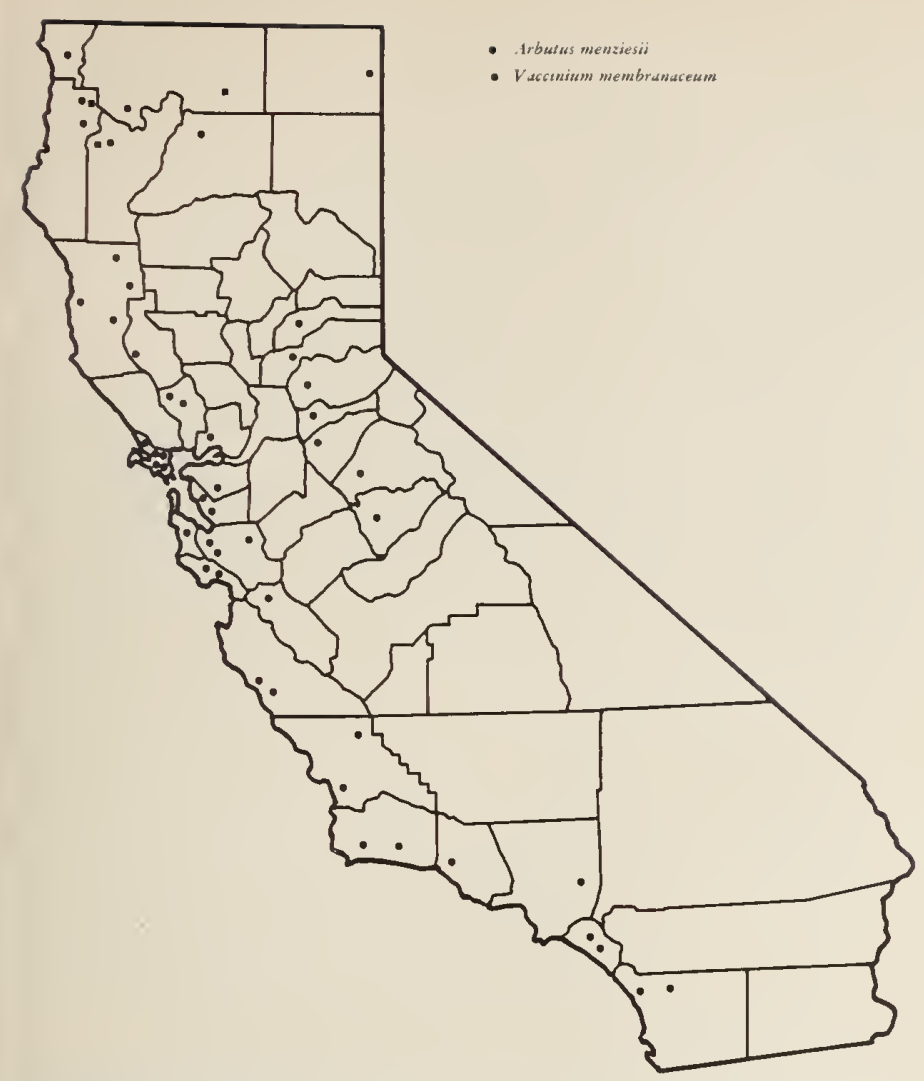

Distribution of madrone (Arbutus menziesii) and thinleaf huckleberry (Vaccinium membranaceum).

THINLEAF HUCKLEBERRY (Vaccinium membranaceum). Erect deciduous shrub, 1 to 4 feet high, with widely spreading, slightly angled branches. Lcaves thin, ovate to roundish, 1 to 2 inches long, ${ }_{8}^{3 /}$ to ${ }^{3} / 4$ inch wide, smooth, and pale green, margins finely toothed. Flowers solitary, greenish white; May to July. Berry spherical, 14 inch or more wide, black or wine-colored, sweet; ripen from mid-August into October.

Distribution (map shown above). Thinleaf huckleberry is somewhat rare in California, being confined to a few localities in Humboldt and Siskiyou counties. It extends northward into British Columbia and eastward into Idaho, Montana, and Michigan. It grows on both wet and dry sites and on all slopes but is most abundant on north facing slopes, frequently occurring in almost pure stands. It is commonly associated with such woody plants as white fir, coast hemlock, lodgepole pine (on open burns), snowberry, mountain-ash, wild rose, serviceberry, currant, and thimbleberry. Among the more common associated herbs are arnica, lupine, penstemon, and various perennial grasses.

Economic value. The palatability of thinleaf huckleberry varies greatly according to the amount of other desirable forage in the stand. Evidently, because of the animals' liking for a variety of forage, nearly pure stands of this species are low to almost worthless as browse, whercas mixed covers, with a goodly scattering of palatable grasses and other plants, they are utilized moderately or even closely by sheep, goats, and deer, and more limitedly by cattle. Best utilization is in early spring and late fall, but its selectivity varies from one place to another. Deer feed limitedly upon the leafage and current twigs at all seasons but it is browsed most closely in early spring. It contributes materially to forage of Rocky Mountain elk in Montana and Wyoming.

Browse rating. Fair for decr; fair to poor for sheep and goats; poor for cattle; and uscless for horses.

WESTERN BLUEBERRY (Vaccinium occidentale) (drawing shown below), also called swamp blueberry. Low, compact, deciduous shrub, 1 to 2/2 feet high (sometimes nearly prostrate) with smooth rounded branches. Leaves thin, oblong-elliptic, or oval to roundish, $\frac{1 / 8}{8}$ to ${ }_{4}^{3 / 4}$ inch long, $1 / 8$ to $\frac{3 / 8}{8}$ inch wide, pale green and smooth above, paler beneath, margins entire and slightly inrolled. Flowers white or pinkish, solitary or 2 to 4 in a cluster; June to July. Berry elliptic, about $\frac{11}{14}$ inch long, blue-black, with a whitish bloom.

Western blueberry (Vaccinium occidentale). A thin-leaved species ranking among the more palatable of the blueberry group. It is utilized most by sheep, goats, and deer.

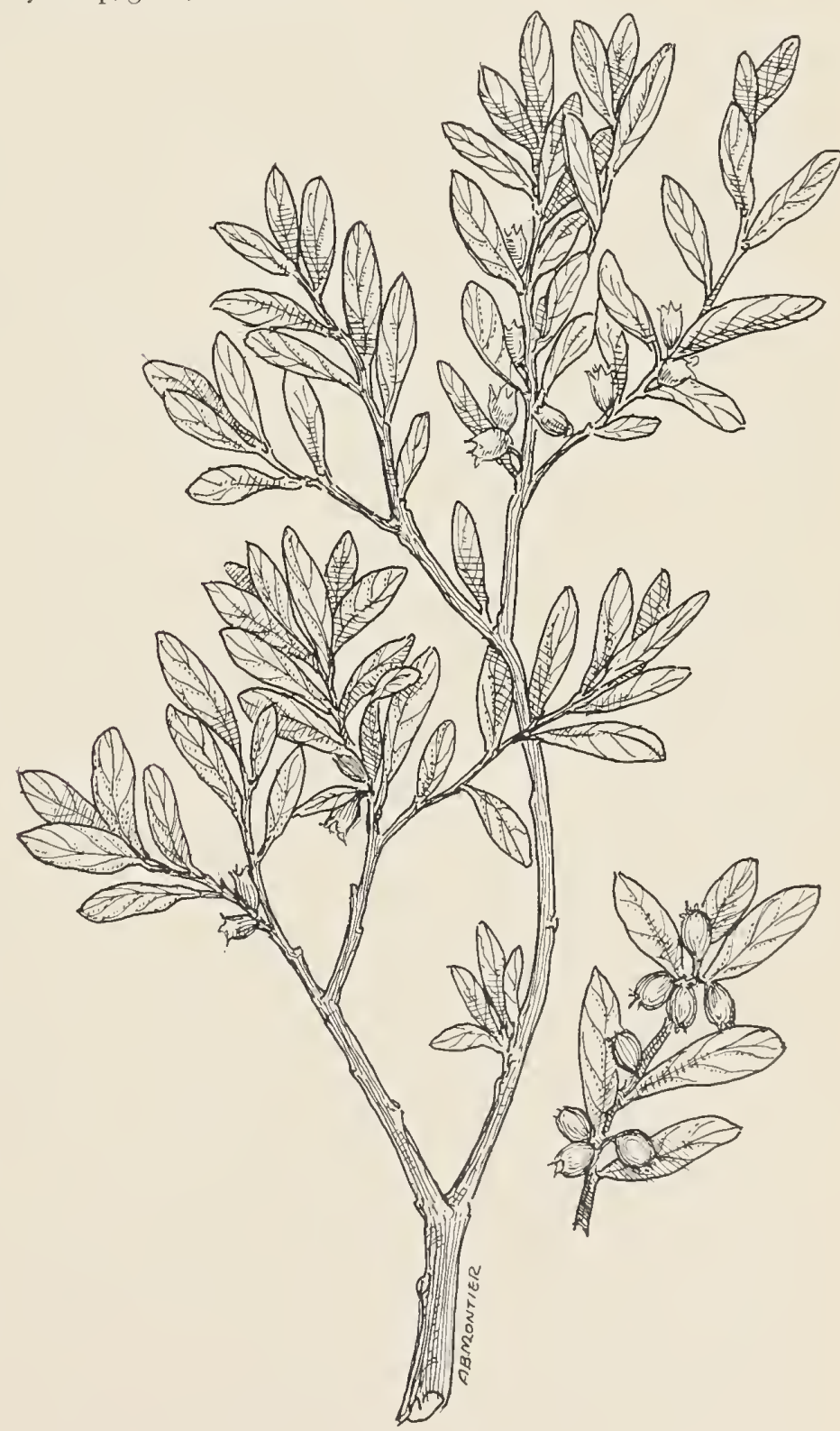


Distribution (map page 121, left). Western bheberry inhabits open moist or wet meadows and borders of streams, largely in the lodgepole pine and subalpine forests, between 3,000 and 7,000) feet elevation; in the Sierra Nevada from Tulare Countr northward to Modoc and Siskivou counties, and westward to Humboldt County. It extends northward to British Columbia and eastward to Utah and Montana.

Economic value. This is one of the more palatable species of the genus ${ }^{(t)}$. The leafage and tender current twigs are sometimes cropped closely in autumn when the ground dries out sufficiently for grazing animals to walk orer the area. Its relatively short usable season is reflected in its overall browse rating.

Brouse ruting. Good to fair for goats and deer; fair to poor for shcep; poor for cattle; and useless for horses.

EVERGREEN HUCKLEBERRY (Vaccinium ovatum). Erect, evergreen shrub, 2 to 8 feet high. Leaves thick and

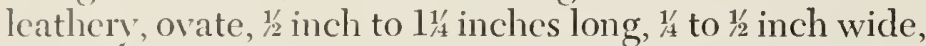
rich dark green, smooth, shining above, paler beneath, margins finely toothed. Flowers white or pinkish, bellshaped, about ${ }_{1}^{1 /}$ inch long, in 1 to 5 -flowered clusters; April to May. Berry broadly ovoid, about $\underset{4}{14}$ inch long, black, usually without bloom; mature from late July to October.

Distribution. Evergreen huckleberry inhabits moist, semi-shaded, timbered or wooded areas from sea level to 2,500 feet elevation. It occurs in the Coast Ranges from Santa Barbara County northward to Del Norte County. It is often the most abundant shrub under redwood and Douglas-fir stands where it is commonly associated with salal (Gaultheria shallon), coast rhododendron (Rhododendron macrophyllum), sweet vernal grass (Anthoxenthum odoratum), and annual grasses.

Economic value. In some localities goats and deer crop evergreen huckleberry rather closely, utilizing 30 to 40 per cent of the leafage and current twigs. Sheep crop it somewhat less closely but it enters into their diet to a considerable extent in late summer and autumn.

Browse rating. Fair to poor for sheep, goats, and deer; poor to uscless for eattle; and useless for horses.

\section{SALAL (Gaultheria)}

Within this genus are several species that are considered high quality ground covers for small areas under trees in rich moist soil, or they are useful in rock gardens and containers. The western wintergreen (Ganltheria lumifusa) and Oregon wintergreen (Gaultheria ovatifolia) are California natives. Some species of Gaultheria yicld an aromatic oil (oil of wintergreen) that is used as a flavoring.

Of the three species that occur in Califonia, salal, described lockow, is the most important browse plant. It is occasionally grown in garckens for its handsome foliage. Florists call it lemon leaf and use it as a foliage backgromud for floral arrangements.

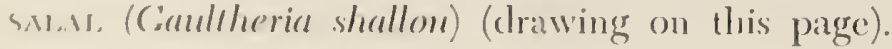

Evergreen shrub with erect or spreading stems, 1 to 6 feet high, or occasionally taller when growing in shade; branchlets stoutish, glandular hairy. Leaves glossy, ovate to nearly round, $1_{4}^{3 / 4}$ to 4 inches long, ${ }_{4}^{3 / 4}$ inch to $1_{1 / 4}^{1 / 4}$ inches wide, margins finely toothed. Flowers white or pinkish, urn-shaped, borne in terminal or axillary racemes, 3 to 6 inches long; March to June. Fruit roundish, about $\underset{1 / 4}{1 / 4}$ inch wide, black.

Distribution. Salal is a common shrub in the redwood belt along the coast from Del Norte County southward to Monterey County and occasionally in the woods of the Santa Ynez Mountains of Santa Barbara County. The redwood forest understory is often dominated by this low growing shrub. It is commonly associated with Oregon grape (Mahonia aquifolium), evergreen huckleberry, willows, and various ferns.

Economic value. The browse value of salal is not high, but sheep, goats, and deer do crop this shrub. It is of greatest importance to these animals on burned-over areas, where the tender sprouts are cropped in varying degrees. Deer feed moderately upon this plant, espeeially in the winter, when its evergreen foliage is particularly attractive to them. Both browsing animals and birds eagerly eat the spicy aromatic fruits. They were also an important source of food for the aborigines.

Browse rating. Fair to poor for goats and deer; poor for sheep; poor to useless for cattle; and useless to horses.

Salal (Gaultheria shallon). This is a low-grade browse plant growing in the redwood forest. Because of its abundance, however, the volume of feed which it produces is fairly large. It is cropped most by sheep, goats, and deer.

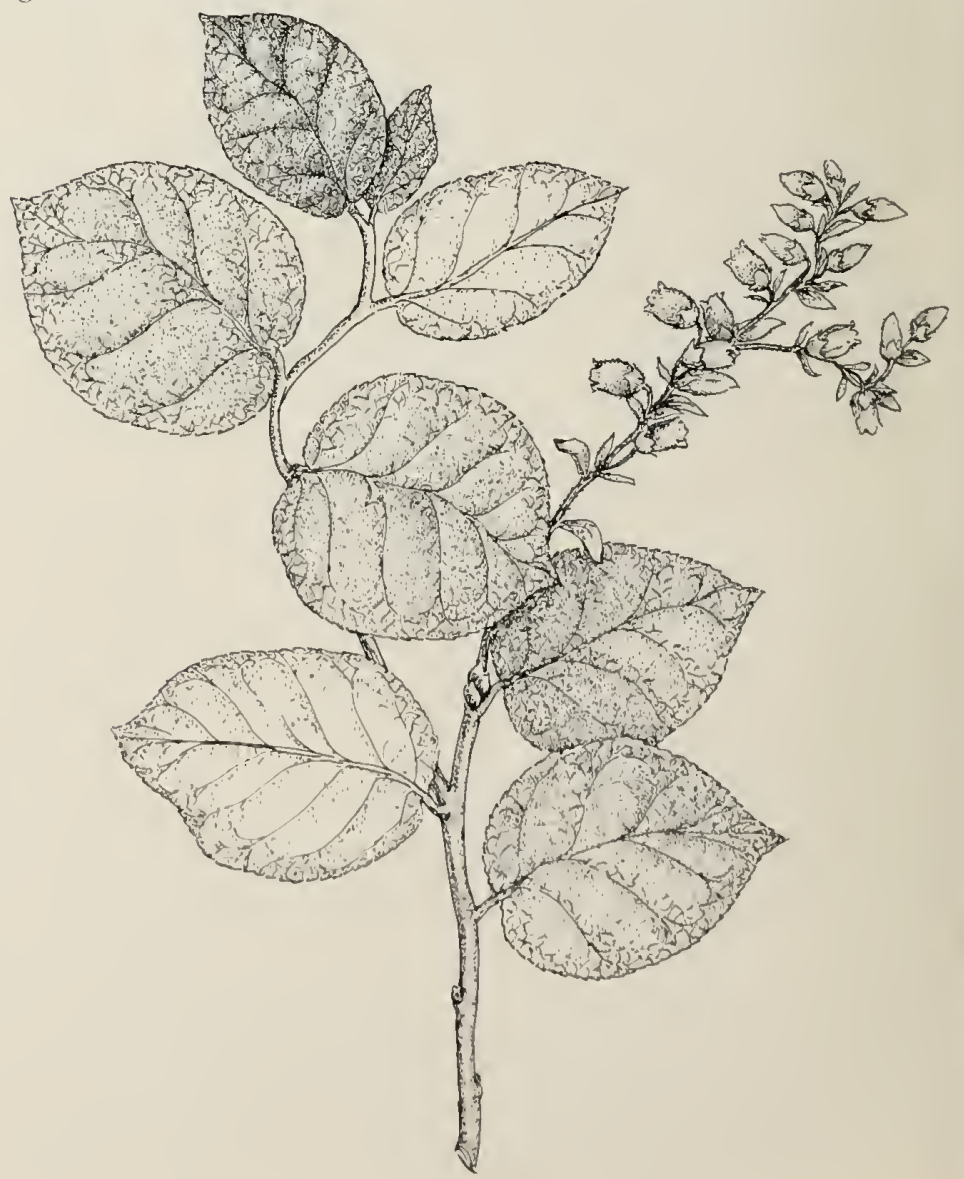




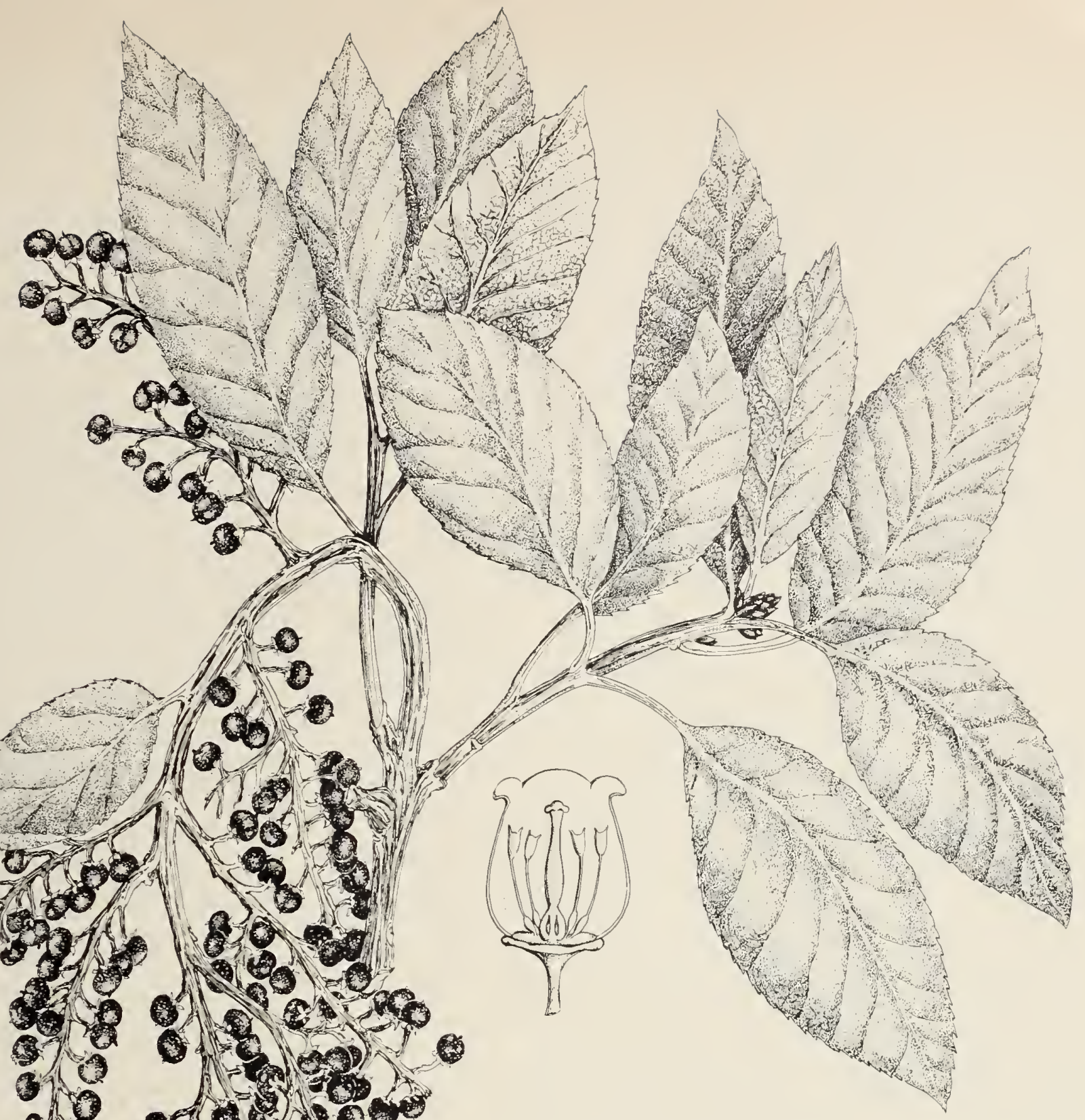

\section{MADRONE (Arbutus)}

Although only one species of this genus is native to California-the handsome madrone, described belowthe strawberry tree (Arbutus unedo) is commonly planted in gardens. The native madrone is occasionally seen in cultivation but it usually grows too large for the average garden and the continual leaf drop causes a litter problem.

MADRONE (Arbutus menziesii) (drawing on this page), also called madroño. Widely branched evergreen tree, 20 to 125 feet high, with crimson or tcrra cotta polished bark, or on old trunks dark brown and peeling into small flakes. Leaves narrowly elliptic or ovate, 3 to 6 inches

Madrone (Arbutus menziesii). This species ranks from low to moderate in palatability for all grazing animals. The young leafy sprouts, as on new burns, are eaten rather closely by sheep and deer-but tess so by cattle-for the first two years. The mature fruits are eaten by many birds.

long, dark green and polished above, smooth and paler beneath. Flowers white, in large, dense, terminal clusters; March to May. Berry roundish, $\frac{12}{2}$ inch wide, fleshy, bright red or yellowish red with a granular or warty surface.

Distribution (map on page 125). This species occupies a variety of sites on foothill and mountain slopes, from 300 to 4,000 feet elevation. It is a common understory plant in the redwood, Douglas-fir, and live oak forests, and occasionally in ponderosa pine. Throughout the Coast Ranges from San Diego to Del Norte counties, and in the Sierra Nevada from Tuolumne to Shasta counties, and extends northward into British Columbia.

Economic value. Madrone ranks from low to moderately high in palatability, depending upon conditions. The mature leaves are almost wholly ncglected by browsing animals, whereas the young lcafy sprouts, where the top growth has been killed by firc, are eatcn 
elosely for the first two years by sheep, goats, and deer, and more limitedly by eattle. The fruit is eaten by deer and, when fully mature, is a farorite food of many birds.

Brouse rating. Fair to useless for deer; poor to useless for eattle, sheep, and goats; and useless to horses.

\section{Ash or Olive Family (Oleaceae)}

More representatives of this family are seen in California gardens than grow natively. Historieally, perhaps the most interesting is the European olive (Olea curopaca). In the early colonization of California the Spaniards introdueed these trees to supply them with olives and olive oil. Olive trees are still grown eommereially in California.

In California three genera represent this familyForestiera, Menodora, and Fraxinus. Of the three, however, the genus Fraxinus is the only one that has appreciable browse value.

\section{ASH (Fraxinus)}

These are trees or shrubs, mostly deeiduous, with opposite eompound (rarely simple) leaves. The ineonspieuous flowers are bisexual or unisexual, borne in elusters. The fruit is a one-seeded samara, winged either at the tip or all around.

There are about 40 speeies of ash. Several are well known shade trees and some are highly valued for their strong wood. Others are eommonly used for fuel. The ash that is seen throughout California, planted as a street tree or patio tree, is a form of the native ash (Fraxinus velutina), usually sold in nurseries as Modesto ash.

Four speeies of ash are native to Califomia, two of them shrubs. They provide browse of some importanee and furnish shade for livestock and big game. Some stockmen contend that large amounts of ash leaves eaten ly domestic livestock may eause seours ${ }^{(* 3)}$.

\section{Key to the Browse Species}

1. Leaves 6 to 12 inches long, leaflets 2 to $5 \frac{1}{2}$ inches long, 1 inch to $1 \frac{1}{2}$ inches wide, without stalks, or the terminal leaflet short stalked, margins entire or ol)scurely toothed above the middle; flower panicles sinooth

. OHEGON ASH (Fraxinus latifolia $[F$. oregona])

1. I.caves 4 to 8 inches long, leaflets 2 inches to 4 inches long, 惢 to 1 inch wide, all with stalks, margins fincly trothed albove the middle; flower panicles finely hairy

ARIZONA ASII

(Fraximus velutina)

omban asu (Fraximus latifolia) (drawing on this page). Tree 30 (0) 80 feet higli. Leaves 6 to 12 inehes long; leaflets 5 to 7 , ohlong to oval, 2 to $5 \frac{1}{2}$ inches long, 1 inch to $1 \frac{1}{2}$ inches wide, almouptly short pointed, usually stalkless except the terminal one; margins entire or toothed alowe the midlde. Male and fenale flowers atre borne on separate plants, in small, croweled, smooth panickes, appeatring before the leaves. Simnarat olblong-lanceolate, $1 \because 6102$ incises loug.

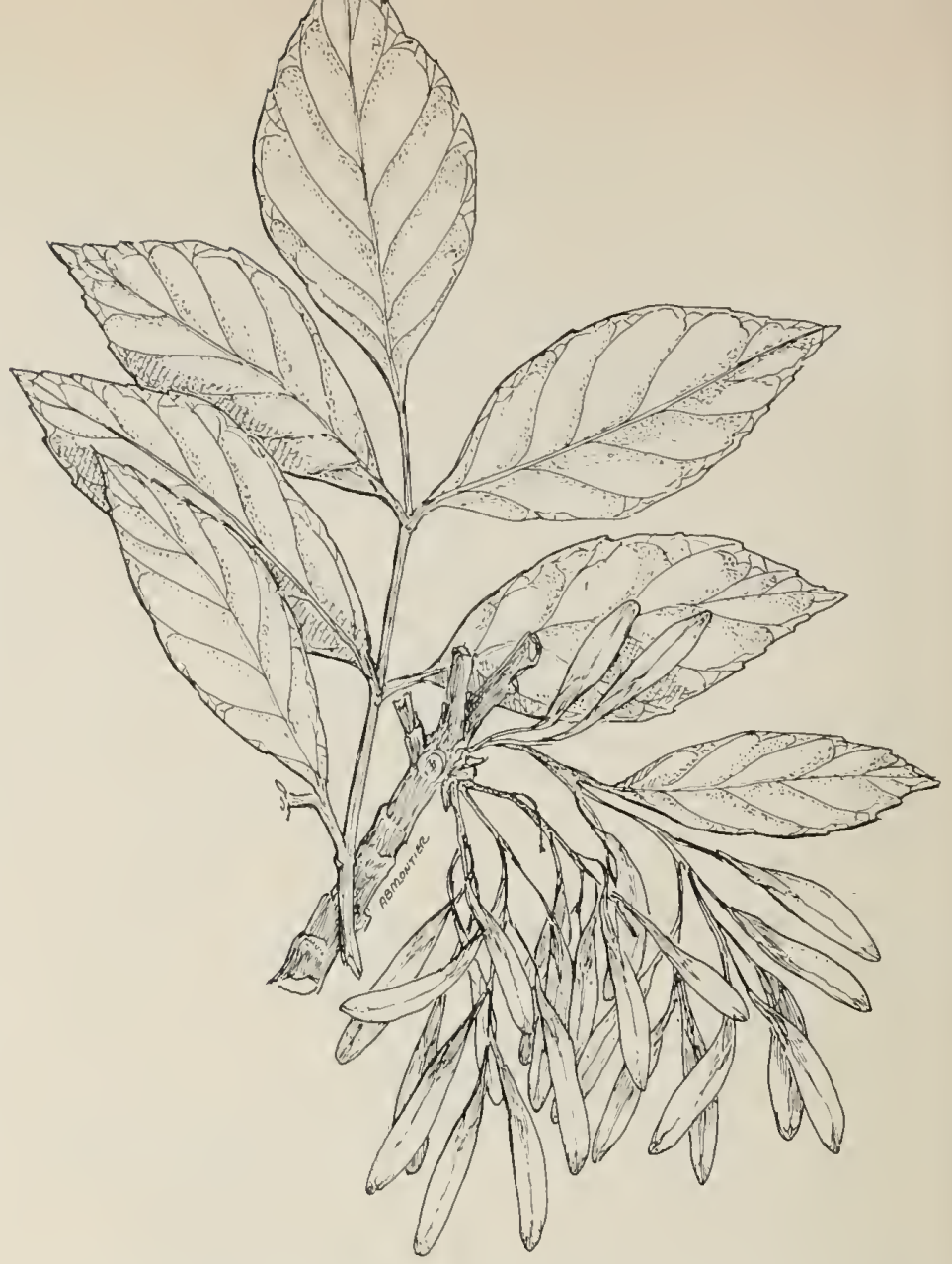

Oregon ash (Fraxinus latifolia). This species supplies a fair volume of browse which in many localities is cropped with fair relish by cattle, sheep, and goats. It also supplies some forage for deer.

Distribution of Oregon ash (Fraxinus latifolia) and Arizona ash (Fraxinus velutina).

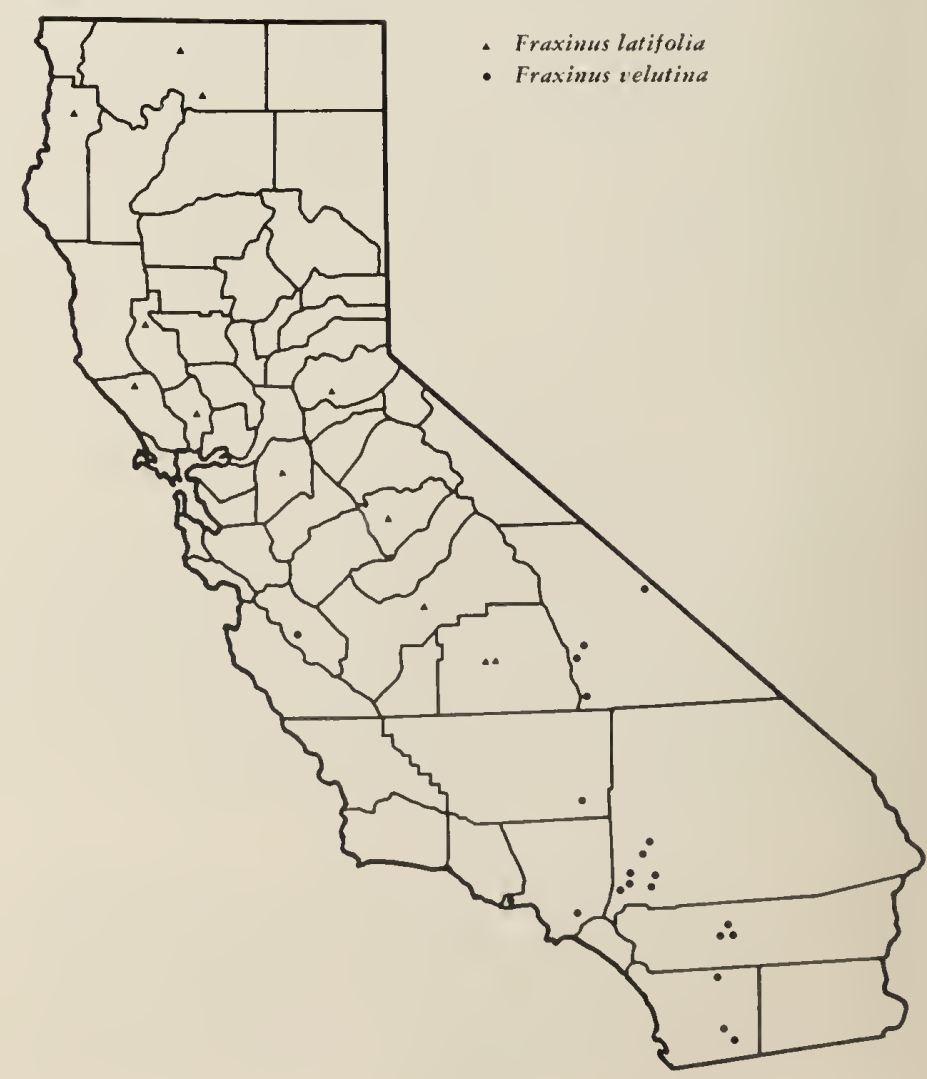

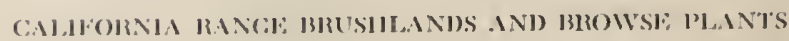


Distribution (map on page 128). This species is found along streams or in valleys, from sea level to 5,500 feet elevation in many plant conmunities. It occurs on the west base of the Sierra Nevada from northern Kern County to Modoc County; the Coast Ranges from Santa Clara County northward to British Columbia.

Economic value. Oregon ash supplies a fair volume of browse for domestic livestock and deer in spite of its height. The shrubbier forms are often cropped rather closely by all grazing animals. In Modoc County this species is taken readily by cattle, sheep, and goats.

Browse rating. Fair for sheep and goats; fair to poor for cattle; and poor to useless for horses and deer.

ARIZONA ASH (Fraxinus velutina) (drawing shown below). Tree 15 to 30 feet high. Leaves 4 to 8 inches long, leaflets 5, 2 to 4 inches long, lanceolate to narrowly ovate, the lateral ones stalked; margins finely toothed above the middle. Male and female flowers borne on separate plants, appearing before the leaves, flower panicles finely hairy. Samaras 1 inch long, the wing about ${ }_{1 / 4}$ inch wide.

Distribution (map on page 128). Arizona ash inhabits desert stream banks, valleys, or borders of lakes or springs at middle to low elevations. It is confined to southern California and oecurs at Owens Lake; in the Panamint Range; the southwest base of Mount San Jacinto; also between Campo and Jacumba; thence eastward to Texas.

Economic value. Arizona ash is somewhat less palatable than Oregon ash, yet it fumishes browse of some value over most of its range. Much of the foliage, however, is out of reach of grazing animals.

Brouse rating. Fair to poor for goats; poor for sheep; poor to useless for deer; and useless for cattle and horses.

Arizona ash (Fraxinus velutina). This plant is cropped with moderate relish by sheep, goats, and deer. The more shrubly forms of this species obviously provide more browse than do the taller species.

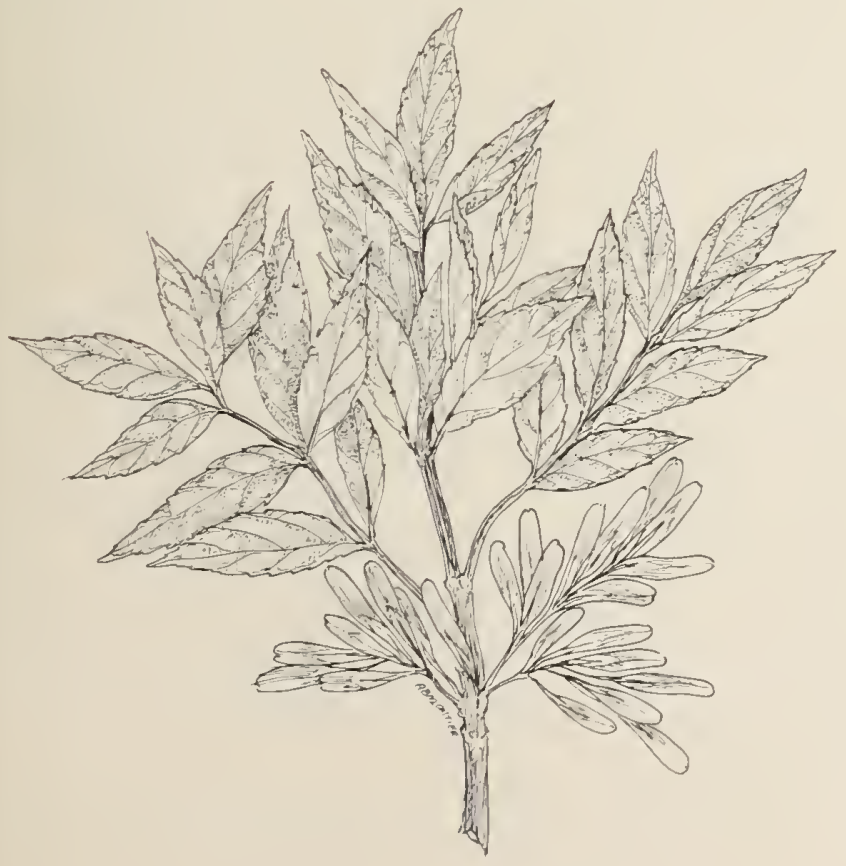

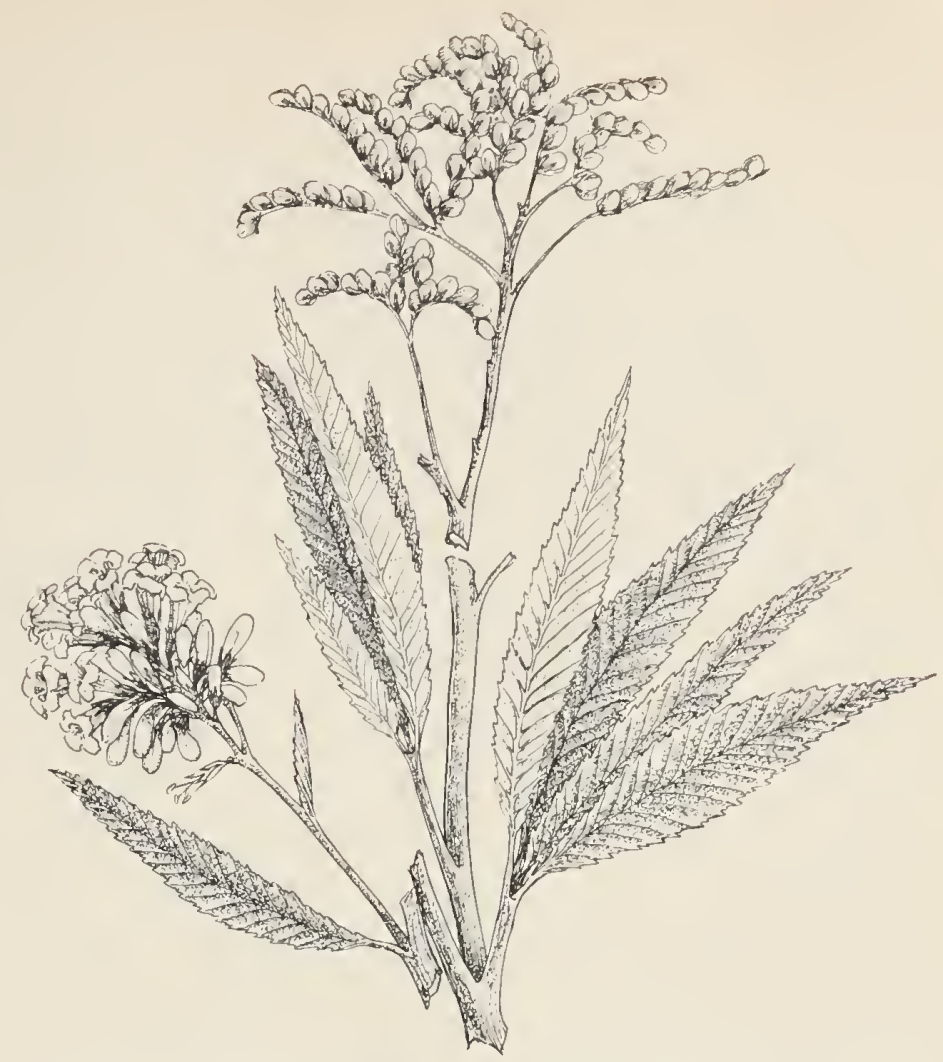

California yerba santa (Eriodictyon californicum). Adult plant is usually cropped little or not at all by any kind of domestic livestock. On recent burns the numerous sprouts are eaten, usually to a moderate degree, by deer, especially in the spring.

\section{Phacelia or Waterleaf Family (HydROPHYLLACEAE)}

This family includes about 25 genera and 300 species mostly native to western America. Few members of this group are seen in California gardens although some of the native speeies are definitely garden potentials. In general the family includes mostly annuals and herbaceous perennials, with a few shrubby plants. Of the 25 genera, 14 are native to California. However, only the genus Eriodictyon, whieh eontains about 8 speeies with several varieties and many intermediate forms, provides plants that eontribute some value. California verba santa, described below, is the most important species in this respeet.

CALIFORNIA YERBA SANTA (Eriodictyon californicum) (drawing shown above), also called mountain balm. Aromatic, strongly sprouting, crect, many branched, evergreen shrub, 2 to 8 feet high. Branehes usually smooth and glutinous or resinous. Lcaves simple, alternate, linear-lanceolate to laneeolatc, rarely roundish, 2 to 6 inches long, $\frac{1 / 2}{2}$ inch to $1 \frac{1}{2}$ inches wide, dark green, smooth and gummy above, grayish beneath with fine felt betwcen the prominent network of veins; the margins finely toothed and sometimes inrolled. Flowers lavender, pale blue, or sometimes nearly white, short tubular, ${ }_{s}^{3,}$ to ${ }^{5 \prime s}$ inch long, densely hairy on the outside, borne in loose elusters; May to July. Fruit is a 4-valved eapsule. 
tant browse plants. Desert sage, described below, is fairly representative of their browse value.

DESERT SAGE (Salvia carnosa) (drawing at right), often called blue sage. Low, aromatic, compact shrub $3 / 4$ foot to $2 \frac{1}{2}$ feet high, and about as broad, with leafy grav or white-hairy branches. Leaves broadly obovate,

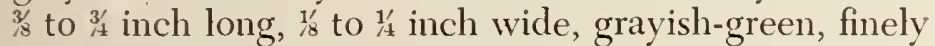
hairy; margins entire or slightly scalloped. Deep blue flowers in dense clusters, usually arranged in interrupted spikes subtended with rose or purple colored papery bracts; May to July. Fruit is 4 nutlets that separate in age.

Distribution (map on this page). This is the most widely distributed species of the shrubby sages in the West. The typical form occurs on rocky bluffs along the Klamath River in Siskiyou County, northward into Oregon, Washington, and Idaho, between elevations of about 3,000 to 5,000 feet. There are also varieties which extend along the eastern slope of the Sierra Nevada from Lassen County to Kern County; in Los Angeles, San Bernardino, and Riverside counties. It extends eastward to Arizona, Nevada, and Utah, northward to Idaho.

Economic value. Desert sage is not a high quality browse plant, but all kinds of domestic livestock as well as deer, feed to a limited extent upon the leafage and current twigs. It serves chiefly as a variant or "filler," being most utilized on the winter ranges.

Browse rating. Fair for goats; fair to poor for sheep and deer; poor to useless for cattle; and useless for horses.

Distribution of desert salvia (Salvia carnosa) and blue witch (Solanum umbelliferum).

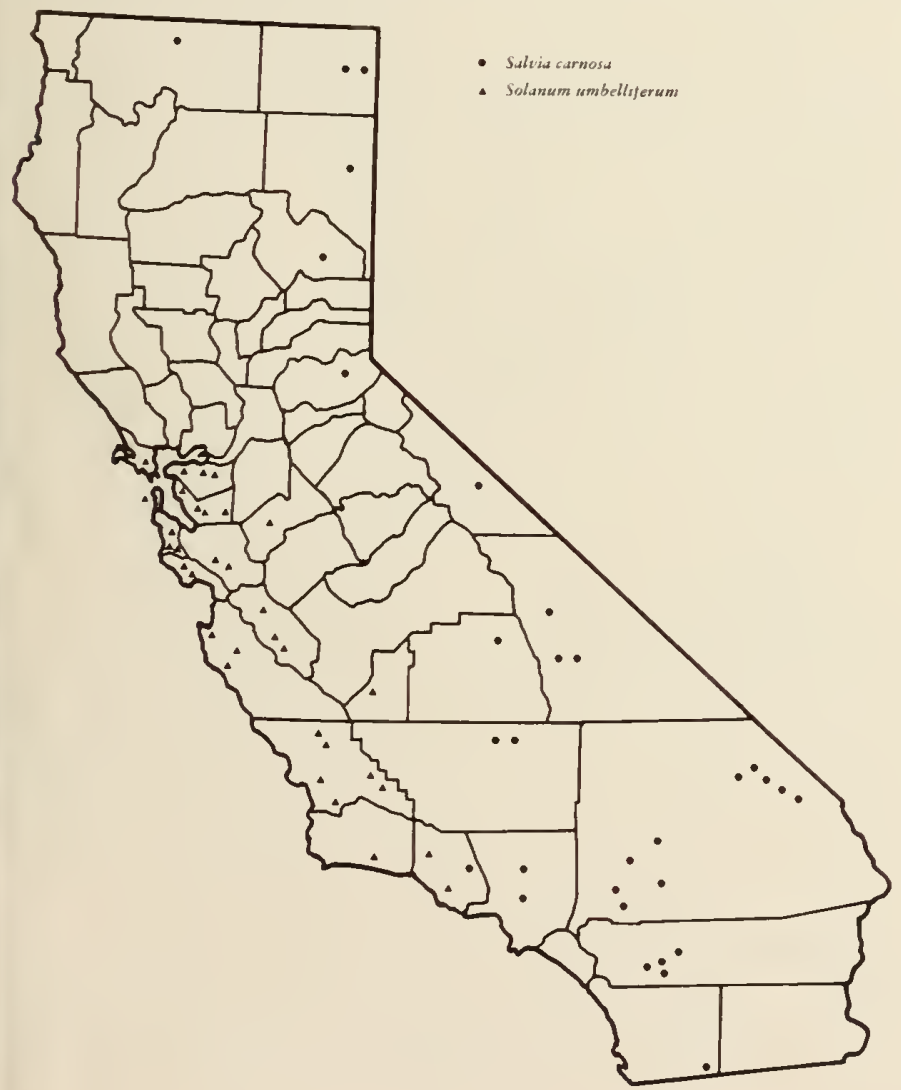

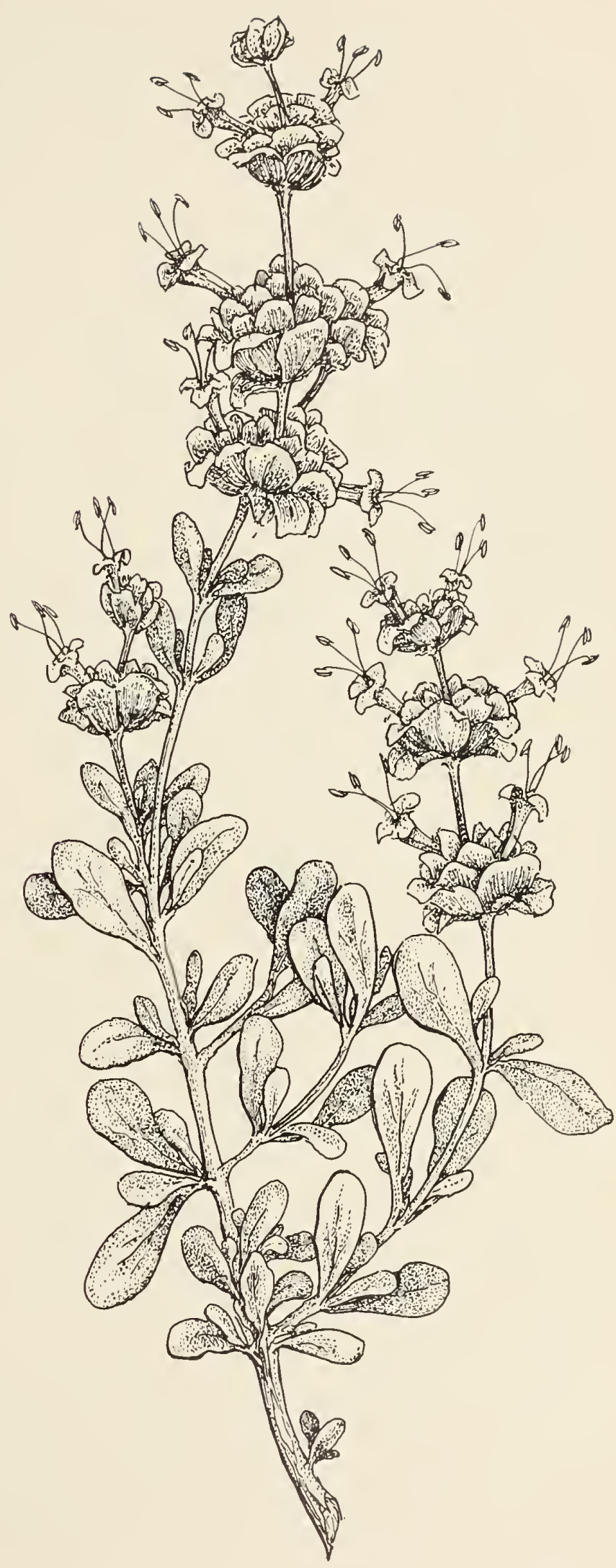

Desert salvia (Salvia carnosa). This widely distributed species, like most other shrubby salvias, is a fairly important secondary browse plant for sheep, goats, and deer. It serves chiefly as a variant or "filler." 


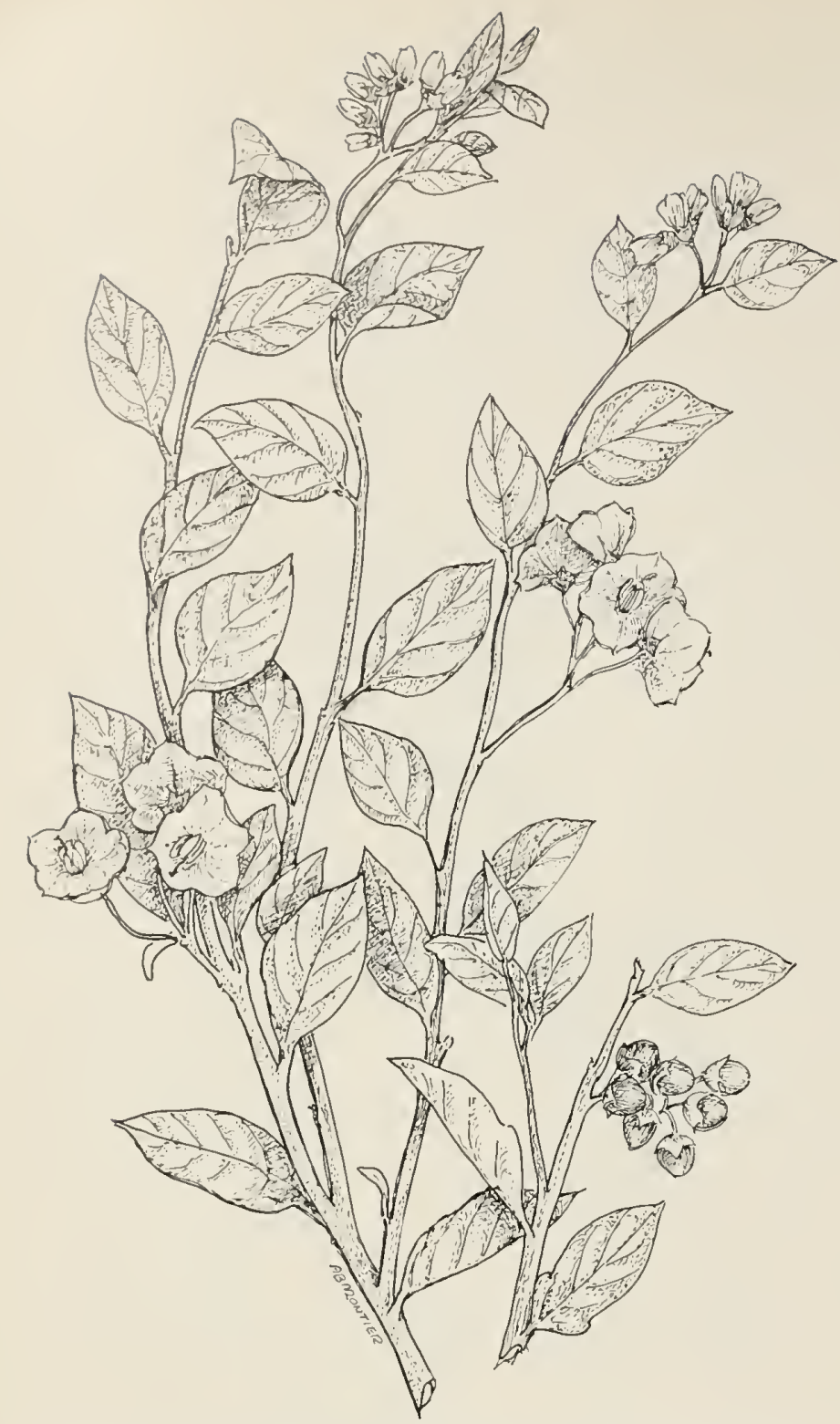

Blue witch (Solanum umbelliferum). A moderately palatable plant to all kinds of browsing animals. Deer are espeeially fond of the young tender shoots, as on new burns.

\section{Nightshade Family (Solanaceae)}

This is a well known family from three standpoints. It is probably best known for its eeonomie importance, providing potatoes, tomatoes, eggrlant, peppers, and tobaeco. A few members of the family, such as the deadly nightshadc, are poisonous ${ }^{(12 x)}$. And this family is well represented in California gardens. One of the most widely known garden plants is the petunia.

Although this family contains about 100 genera and some 2,000 species, only 9 genera are represented in Califonia. These include mainly anmual and perennial herbs and shrubs. The genus Solanum, with some 20 species, is the largest group, and l,he witeh, described below, is selected to represent the browse values of this fanily.

II,UE WTrear (Solanum umbelliferum) (drawing on this page). Erect or spreading evergreen subshrub, 2 to $3 \frac{1}{2}$ feet high, with gray-green, 5-angled or ridged, herbaceous stems. Leaves alternate, elliptie-ovate, $1 / 2$ to 2 inches long, gray-green; margins entire or sometimes pinnatifid at base. Flowers usually purplish blue, violet, or sometimes white, wheel-like, or sancer shaped, $1 / 2$ inch to 1 inch wide, with 5 green glands at the base; bloom most abundant from April to July, but some flowers throughout the year. Berry greenish-white, about $1 / 2$ inch wide.

Distribution (map on page 131). This species is common in wooded hill eountry along gulehes and eanyons, and or brushy slopes. It occurs in the Coast Ranges from Santa Barbara County northward to Mendocino County, and up to about 2,500 feet elevation.

Economic value. Blue witeh is moderately palatable to all kinds of browsing animals. The leafage is cropped most elosely on recent burns where the sprouts are utilized at any season of the year. Deer feed somewhat more extensively upon the sprouts and tender current stem growth than do domestic livestock.

Browse rating. Exeellent to fair for deer; good to fair for goats; fair to poor for sheep; and poor to useless for cattle and horses.

\section{Honeysuckle Family (Caprifoliaceae)}

This family includes trees, shrubs, and vines that may be evergreen or deciduous, with opposite leaves. The flowers are bisexual, regular or irregular. The fruit may be an achene, a capsule, a berry, or a drupe.

The eommon name of this family is appropriate beeause probably the best known genus is that of the honeysuckles. The Asian speeies, Japanese honeysuckle (Lonicera japonica) and its varieties, has long been used as a vine or as a ground cover for banks. In fact, it has become so well adapted in the Southeast that it has escaped eultivation and elambers over much of the native vegetation. Even in some areas of California it has oceasionally eseaped ${ }^{(108)}$.

Five genera and approximately 22 speeies are native to California; all are woody exeept one (Linnaea). Of these genera, only three contribute a eonsiderable volume of browse to livestoek and big game. The most important genera are the elderberries (Sambucus) and the snowberries (Symphoricarpos). Of much less valne are the honeysuckles or twinberries (Lonicera).

\section{Primary Species}

\section{ELDERBERRIES (Sambucus)}

Elderberries are deeiduous small trees or shrubs with very pithy branches. Leaves are opposite, compound, and odd-pinnate. The flowers are bisexual, small, borne in componnd flattish or conical clusters at the ends of the branchlets. The fruit is a 3 to 5 -celled berry-like drmpe eontaining 3 to 5 one-seeded nutlets.

They are typieal of moist sites or where there is subirrigation and are found over a wide elevational range. The young foliage is rather pungent and strong-scented when crnshed, and somewhat low in palatability, but 
sweetens in the fall, notably after the first frosts come; hence the browse value of these plants is largely, though not entirely, confined to the autumn season. The mature fruits of elderberries are either blue, black, or red. Those that are blue or black are edible for humans when cooked, and are relished, especially when ripe, by birds, big game, and other wild life, and sometimes by domestic livestock. On the other hand, the fruits of some of the red berried species are more or less toxic. Numerous cases of illness have occurred among children and others from eating them. Birds and other native animals seem to avoid those species with red fruits ${ }^{45)}$.

Three species and one variety of elderberries occur in California, all of which are valuable browse plants.

\section{Key to the Browse Species and Varieties}

1. Flowers in dome-shaped clusters; fruit bright red.......2

1. Flowers in flat-topped clusters; fruit bluish-black cov-

ered with a whitish bloom ............... 3

Blue elderberry (Sambucus caerulea). A much-branched and leafy species that rates from high to moderate in palatability for all grazing animals. It is devoured most extensively and closely in late summer and autumn.

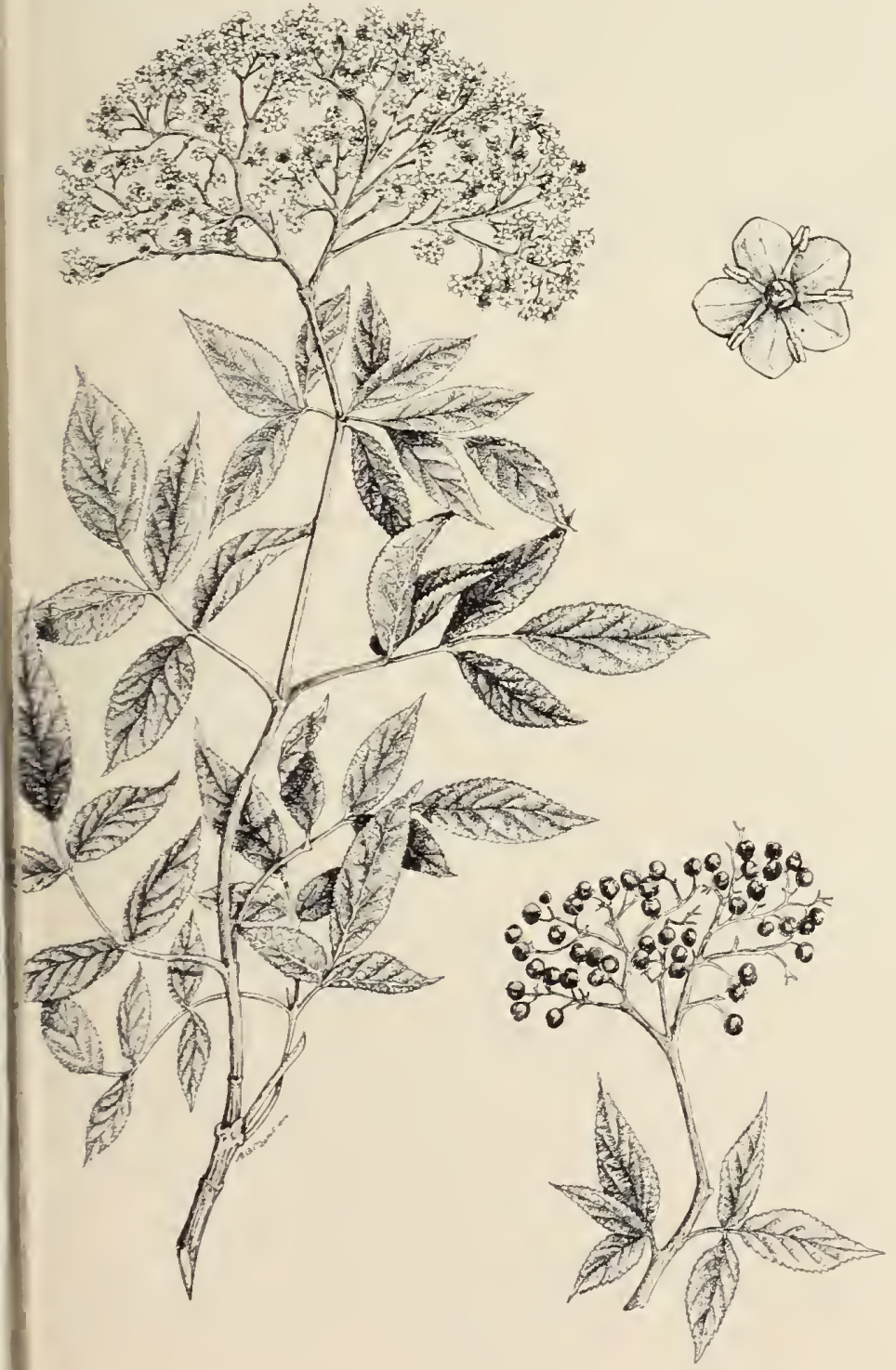

2. Shrub 2 to 6 feet high; flower clusters $1 \frac{11}{2}$ to 2 inches broad; Sierra Nevada and San Bernardino Mountains

from 6,000 to 11,800 feet elevation. . . . . . RED ELDERBERRY (Sambucus racemosa)

2. Tall shrub or small tree 8 to 20 feet tall; flower clusters 2 to 5 inches broad; outer Coast Ranges from San Mateo County to Del Norte County, eastward to Sis-

kiyou County, at low elevations.... . COAST RED ELDERBERRY

(Sambucus callicarpa)

3. Leaflets usually smooth.

BLUE ELDERBERRY (Sambucus caerulea)

3. Leaflets usually soft-hairy or somewhat coarsely hairy HAIRY BLUE ELDERBERRY (Sambucus caerulea var. velutina)

BLUE ELDERBERRY (Sambucus caerulea) (drawing on this page). Many-stemmed shrub, or occasionally a small tree, 4 to 10 , and occasionally up to 30 feet high, with smooth or softly hairy branches and branchlets. Leaves 5 to 8 inches long, with 5 to 9 narrowly oblong or ovatelanceolate, to nearly round leaflets, 1 to 6 inches long, $1 / 2$ inch to 2 inches wide, usually smooth but vary to soft hairy; margins sharply toothed. Flowers numerous, white or cream color, in flat topped clusters 2 to 8 inches wide; April to August. Fruit blue to nearly black, about ${ }_{11}^{1}$ inch wide, usually covered with a whitish bloom; ripen during August to October.

Distribution (map on this page). This widely distributed species occupies moist places in open woods, canvons or flats, and stream banks from sea level to about

Distribution of blue elderberry (Sambucus cacrulea) and red elderberry (Sambucus racemosa).

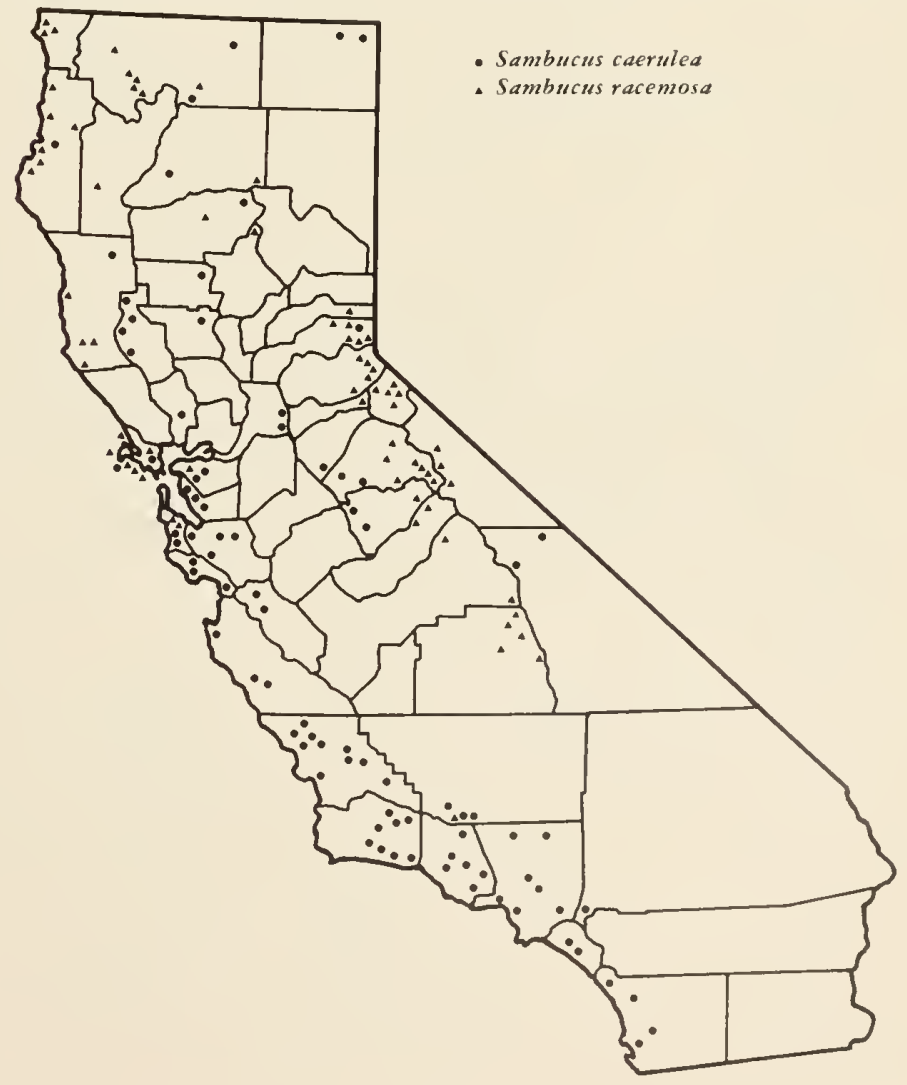




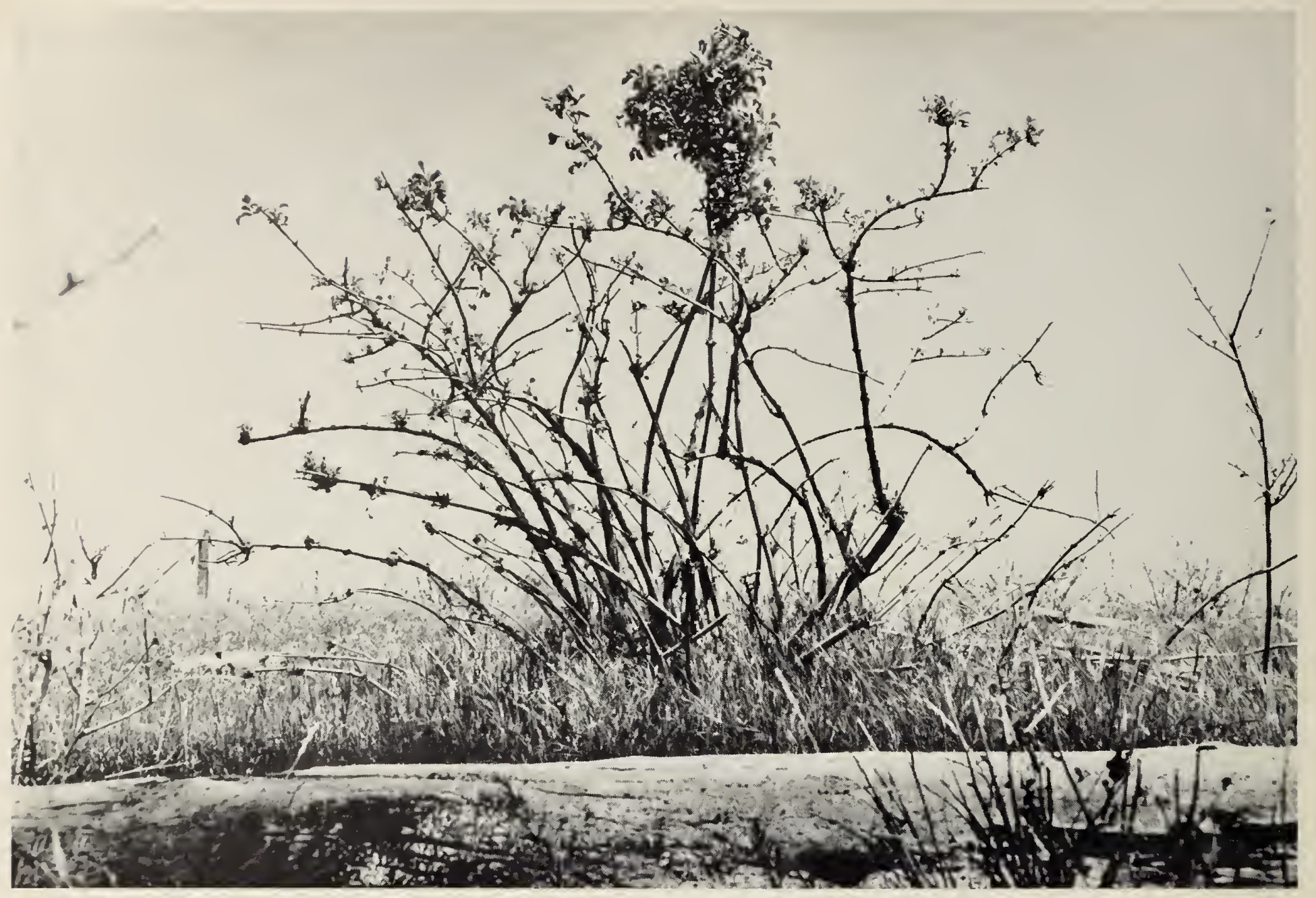

A closely browsed bush of blue elderberry (Sambucus caerulea). The tall uppermost leafy branches protect the plants from destruction. San Joayuin winter deer range.

5,500 feet elevation. It oeeurs in the Sierra Nevada, the Coast Ranges, and the mountains of southern California. Northward to British Columbia, eastward to the Roeky Mountains, and southward to Lower California.

Economic value. Blue elderberry is a useful range plant but is not equally palatable at all seasons. It is usually browsed limitedly in the spring and to a mueh greater extent in late summer and in the fall. The leafage is eagerly devoured after the first heavy frost in the fall, when the leaves turn black but remain sueeulent. Because many branehes are beyond the reaeh of the animals, utilization is seldom destructive (photo above).

Browse raling. Good for goats; good to fair for sheep; good to poor for decr; fair for eattle; and fair to poor for horses.

HAHY BLUE RLABRBERMY (Sambucus caerulea var, velu(ina) is distinguished from the species primarily by the densely soft-hairy branches and by the leaflets, which are very unecual at the base, and soft-hairy or stiff-hairy and harsh to the tonch. The distinction between the blue olderlerry and its variety is not clean-ent.

Distribution. This variety ocenrs in the Sierra Nevada ancl monutains of southem California, but usually at somewhat higher elevations than the species.
Browse rating. Essentially the same as for the speeies. (See summary table, page 148.)

RED ELDERBERRy (Sambucus racemosa). Shrub 2 to 6 feet high, with the young stems and branehes green, the pith brownish. Leaves 3 to 6 inehes long; leaflets, usually 5 or 7 , ovate to ovate-laneeolate, $1 \frac{1}{2}$ to 5 inehes long, 3 ineh to $1 \frac{1}{2}$ inehes wide, smooth or sometimes finely hairy; margins sharply toothed exeept at the apex. Flowers eream eolored or nearly white, in dome-shaped elusters $1 \frac{11}{2}$ to 2 inehes broad; May to July. Fruit bright red, about $3 / 16$ ineh in diameter; late July to Oetober.

Distribution (map on page 133). Red elderberry inhabits moist plaees in the Sierra Nevada between 6,000 and 11,800 feet clevation from Tulare to Nevada eounties, and in the San Bernardino Mountains of southern California. It extends northward to British Columia, eastward to Newfoundland, and south to Georgia.

Economic value. The browse value of red elderberry is fairly good for all kinds of domestie livestoek and is readily cropped by deer. Like blıe elderberry, it is browsed with greatest relish after the first heavy frost in the fall when the foliage has turned blaek. The berries are reputed to be poisonous to lumans but livestock and deer eat them with impunity ${ }^{(4 *)}$. 
Brouse rating. Excellent to good for deer; good for goats; fair for cattle and horses; and fair to poor for sheep.

COAST RED ELderberRy (Sambucus callicatpa). Tall shrub or small tree 8 to 20 feet high. Very similar to Sambucus racemosa except that the leaves are usually hairy beneath and often above, and the margins are usually toothed to the apex. Flower clusters are 2 to 5 inches broad.

Distribution. This species occurs in moist canyons and on flats in the outer Coast Ranges from San Mateo County northward to Del Norte County and eastward to Siskivou County, commonly in the coastal scrub, redwood forest, and Douglas-fir forest. It also extends northward to Washington.

Economic value. Coast red elderberry is cropped with considerable relish by both livestock and deer, but much of the foliage is beyond the reach of grazing animals. There are no reports of livestock poisoning from consuming the berries.

Browse rating. Good to fair for sheep, goats, and deer; fair to poor for cattle; and poor for horses.

\section{SNOWBERRIES (Symphoricarpos)}

This genus includes low or medium height deciduous shrubs that often spread by suckers. The leaves are simple and opposite. The bisexual, bell-shaped, or tubular flowers are pink or white, and borne in small axillary or terminal clusters. The fruits are roundish berries that are white in the California native species.

The snowberries, sometimes called Indian currant, waxberry, wolf-berry, and other vernacular names, are represented by 10 to 15 variable species, all native to North America. Four species are native to California. Some forms are valued as ornamentals because of their large waxy snow-white berries. They occupy dry to moist fairly deep soils and are found on all slopes, growing both in full sun and in shade.

All species of snowberries are grazed more or less by livestock and deer, some being moderately high in palatability. Because of their shrubby growth most of the leafage is available to the animals, yet they cndure grazing well. Because of their abundance, snowberries are an important factor in the forage crop on many ranges.

The nutritive values of snowberries secms to compare favorably with those of many other equally palatable deciduous shrubs. Analyses in Utah of Symphoricarpos vaccinoides, a common species on the mountain ranges, gave crude protein values for the leaves of about 14.5 per cent in the early summer season, 11 per cent in the midseason, and 10.25 in the late season ${ }^{(30)}$. The cellulose content was typically high for deciduous shrubs, averaging about 32 per cent in the leaves in the early season, 16 per cent in mid-season, and about 15 per cent in the late season. The levels of other constituents indicated this species as wholesome and nutritious feed.

Common snowberry and mountain snowberry are of greatest browse value in California.

\section{Key to the Browse Species}

1. Branchlets and foliage usually finely hairy; flowers tubular, $\frac{1}{4}$ to $\frac{3 / 8}{8}$ inch long; higher mountains, 5,000 feet to 10,000 feet elevation .............. . . (Symphoricarpos rotundifolius)

1. Branchlets and foliage usually smooth; flowers bellshaped, 兑 to ${ }^{1 / 2}$ inch long; lower slopes usually at elevations below 2,000 feet.

COMMON SNOWBERRY (Symphoricarpos albus)

COMMON SNOWBERRY (Symphoricarpos albus) (drawing shown below). Slender branched shrub, 2 to 6 feet high, with shreddy gray or brown bark on the older branches.

Common snowberry (Symplioricarpos albus). A fairly abundant species that is most palatable to sheep, goats, and deer. Cattle also feed upon it. Heaviest utilization is in late summer and fall. It is a valuable browse plant.

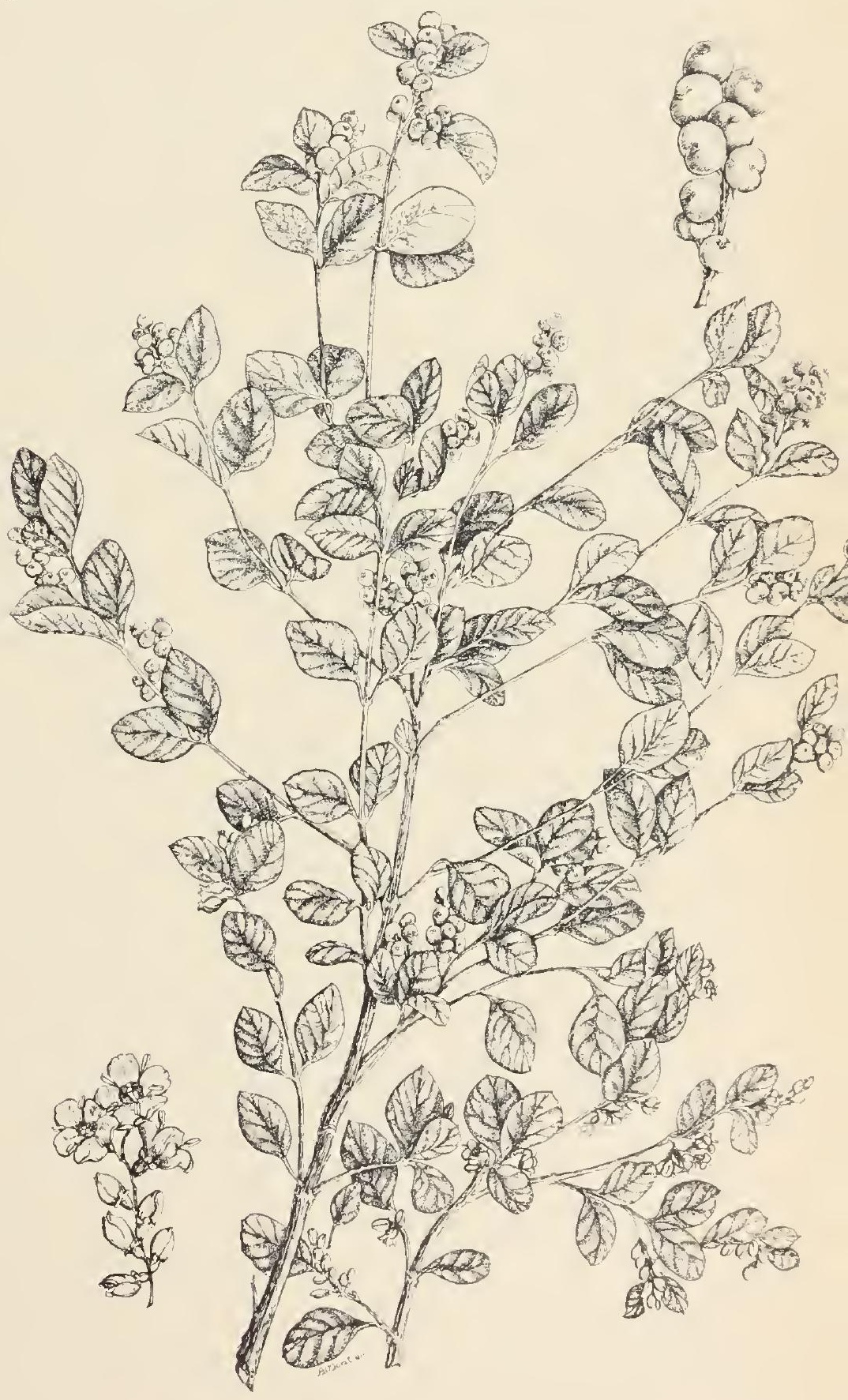


Leaves ovate, oval, or nearly round, ${ }_{34}^{3 \prime}$ inch to 2 inches long (sometimes to 4 inches on sterile shoots growing in shade), dull green and smooth above, paler and smooth or slightly hairy beneath, entire or lobed. Flowers bell-

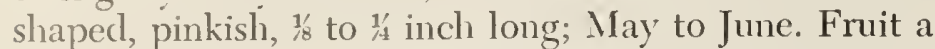
fleshy white berry, globose, about $\frac{3}{8}$ to $1 / 3$ inch wide; ripen in August and September.

Distribution (map shown below). This species inhabits slopes and valley flats in the foothills of the Coast Ranges, the Sierra Nevada, and the mountains of southern California, usually below 2,000 feet elcvation, commonly in the foothill woodland community. It extends eastward to Pennsylvania and the New England states and northward to British Columbia.

Economic value. Common snowberry is frequently abundant and the dominant shrub over fairly extensive areas. It is readily eaten by sheep and deer and to a lesser degree by cattle and horses. Its heaviest utilization occurs in late summer and early fall. Stands of this species tend to give way somewhat under continuous heavy utilization. However, it reproduces both by sprouts and seed, and responds well to rational management.

Browse rating. Good to fair for sheep and goats; fair to poor for cattle and deer; and poor for horses.

MOUNTAIN SNOWBERRY (Symphoricarpos rotundifolius). Spreading shrub, 1 to 4 feet high, with reddish brown bark on the new growth and shreddy grayish or brown bark on the older branches. Foliage and branchlets are

Distribution of common snowberry (Symphoricarpos albus) and mountain snowberry (Symphoricarpos rotundifolius).

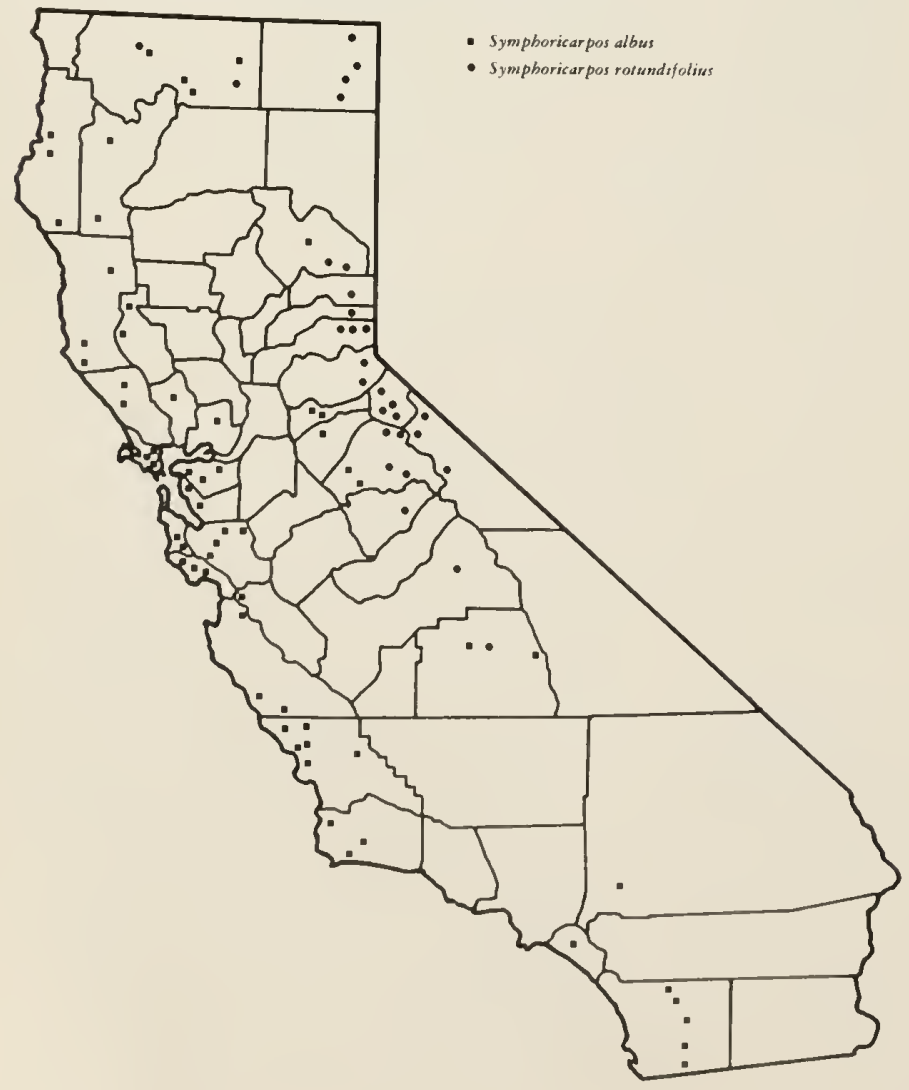

usually finely hairy. Leaves ovate to almost round, $\frac{1}{2}$ inch to 1 inch long, ${ }_{18}^{1}$ inch to ${ }_{4}^{3 /}$ inch wide, usually dull green; the margins entire or rarely irregularly toothed or slightly lobed. Flowers white, yellowish, or pink, tubular, ${ }_{1 / 4}^{1 /}$ to ${ }_{1 / 8}^{3 /}$ inch long, in pairs or small clusters; June and July. Fruit white, ovoid, about ${ }^{3 /} / \mathrm{inch}$ long.

Distribution (map on this page). This species occupies moderately moist woodcd sitcs, associated with ponderosa pine, aspen, and fir. It occurs in the higher mountains of the north Coast Range from northern Lake County to Humboldt, Shasta, and Siskiyou counties, eastward in Modoc County, and southward in the Sierra Nevada to Tulare County, and in the mountains of southern California. The elevational range is between 5,000 and 10,000 feet.

Economic value. Mountain snowberry is a valuable plant for all browsing range animals. In most of its habitat it ranks favorably with the associated shrubs in palatability and in the volume of browse which it produces.

Browse rating. Good for goats; good to fair for sheep; fair to poor for cattle and deer; and poor for horses.

\section{Secondary Species}

\section{HONEYSUCKLE (Lonicera)}

Some members of this large and widely distributed genus of erect shrubs and twining vines are frequently referred to as twinberries. The genus includes about 100 spccies, chiefly in the north temperate zone. Of the 30 species or so found in the United States, 10 are native to California. Some species are sometimes browsed by all domestic livestock and big game but ordinarily these plants are unpalatable to grazing animals. Occasionally stockmen have reported them to be poisonous to livestock but investigators have concluded that more study is needed to determine whether they may be mildly toxic under some conditions ${ }^{(115)}$. Evidently the fruits of all species are cmetic and cathartic, yet birds frequently consume them without apparent ill effects. Twinberry is selected to represent the genus.

TWINBERRY (Lonicera involucrata) (drawing on page 137), known also as bearberry, fly honeysucklc, and inkberry. Upright, much branched, deciduous shrub 2 to 10 feet high. Branches of the scason angled. Leaves simple, opposite, ovate or obovate, 2 to 5 inches long, ${ }^{3 /}$ inch to $2 \frac{1}{2}$ inches widc, dark green and smooth above, paler and hairy beneath, becoming smooth; margins entire, often with thread-like hairs (ciliate). Flowers yellow or reddish, glandular hairy, 12 inch long, in axillary pairs on stalks $1 / 2$ to 1 inch long, subtended by 2 rounded bracts that become reddish in age; March to July. Fruit black, oval or globose, about $1 / 3$ inch wide.

Distribution. This species is common along shady mountain strcams and moist canyon flats and bottoms in the Sierra Nevada from Modoc County southward to Tulare Conmty and in the Coast Ranges from Del Norte Comnty sonthward to Santa Barbara County, from sca 


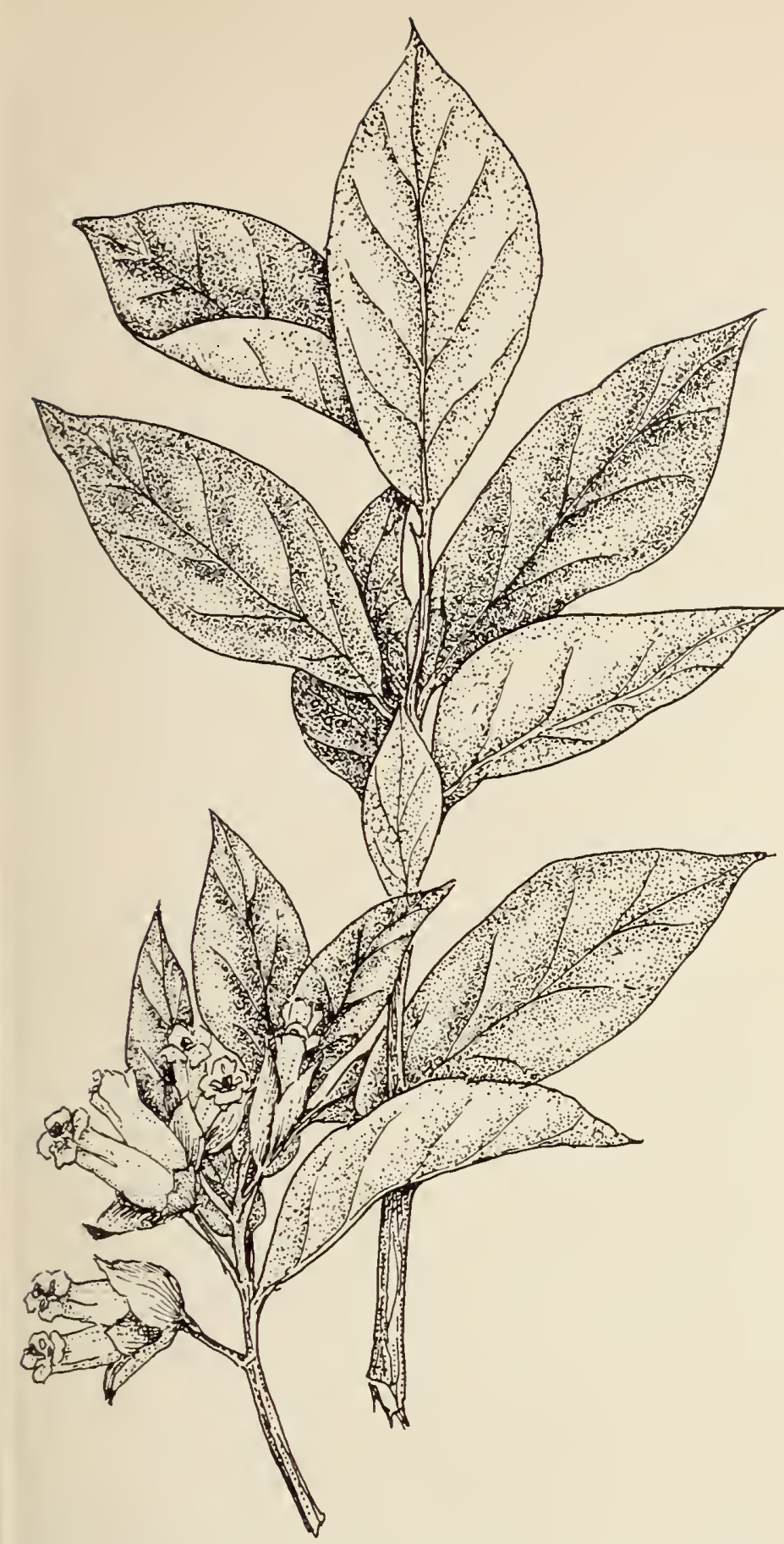

Twinberry (Lonicera involucrata). Although twinberry is low in palatability, it is cropped moderately by livestock and deer in most localities. It is relished most by goats and deer. Claims that it is occasionally poisonous to livestock have not been substantiated.

level to 9,500 feet elevation. It is also widely distributed across North America from Quebec to Alaska and British Columbia, as well as in Colorado, Utah, and Arizona.

Economic value. Twinberry is low in browse value for domestic livestock but in some localities it is cropped more or less by cattle and sheep. Goats and deer consume the succulent leafage somewhat closely over most of its range.

Browse rating. Good to fair for deer; fair to poor for goats; poor for sheep; poor to useless for cattle; and useless for horses.

\section{Sunflower Family (Compositae)}

This is the largest family of flowering plants, including approximately 950 genera and some 20,000 species. Usually they are annual or perennial herbs, shrubs, occasionally trees. A few are vines. The leaves are usually alternate or opposite, rarely whorled. The flowers are borne in heads on a receptacle surrounded by a cup-like involucre of bracts. These heads are usually many flowered but occasionally fcw, or even one-flowered. Heads may be made up of marginal ray flowers (strapshaped) and central tubular disk flowers. Or there may be disk flowers only or ray flowers only. The fruit is an achene.

As this is the largest family of flowering plants it also contributes a large share of garden plants-too many, in fact, to point out individually. Nevertheless, many of our summer and fall color annual or perennial bedding and border plants belong to this family. Also a number of extremely pestiferous weeds are members of the Compositae such as the dandelion, star thistle (Centaurea solstitialis), Canadian thistle (Cirsium canadensis), and many others.

Of the native California members of this family, relatively few of the woody species contribute high-quality browse, whereas many of the forbs are palatable and abundant forage plants. Of the shrubby genera, sagebrushes (Artemisia spp.) are the most important members of the Compositae family. They supply the primary source of winter food to Rocky Mountain mule deer and to antelope in the Great Basin areas of California. The other important genera of this family are rabbitbrush (Chrysothamnus); Baccharis; and the horsebrushes (Tetradymia).

\section{SAGEBRUSHES (Artemisia)}

This genus includes herbs or shrubs that have aromatic or bitter foliage. The leaves are simple and alternate, either entire or variously lobed and dissected. All of the flowers are tubular, either yellow or purplish. The outer flowers are female or sometimes bisexual. The inner disk flowers are bisexual, fertile or sterile. The small nodding or erect heads are borne in panicled spikes or racemes. The cup-like involucre is made up of 2 to 4 series of dry, papery bracts that are closely overlapping. The obovoid or oblong achenes are usually smooth or resinous-granuliferous. Usually there is no pappus.

This is a large genus of about 250 species native to both hemispheres, but most abundant in the arid regions of the northern hemisphere. Many of the species are called sage or sagebrush, especially in the west. However, the names mugwort and wormwood are also applied both to the sagebrushes and certain other species both in this country and abroad.

Several Old World artemisias are of economic importance. In Europe Artemisia absinthium is the chief source of absinthe. In Spain Artemisia barrelieri is used in the preparation of Algerian absinthe. Artemisia cina is used in the Orient in the preparation of santonica, a vermi- 


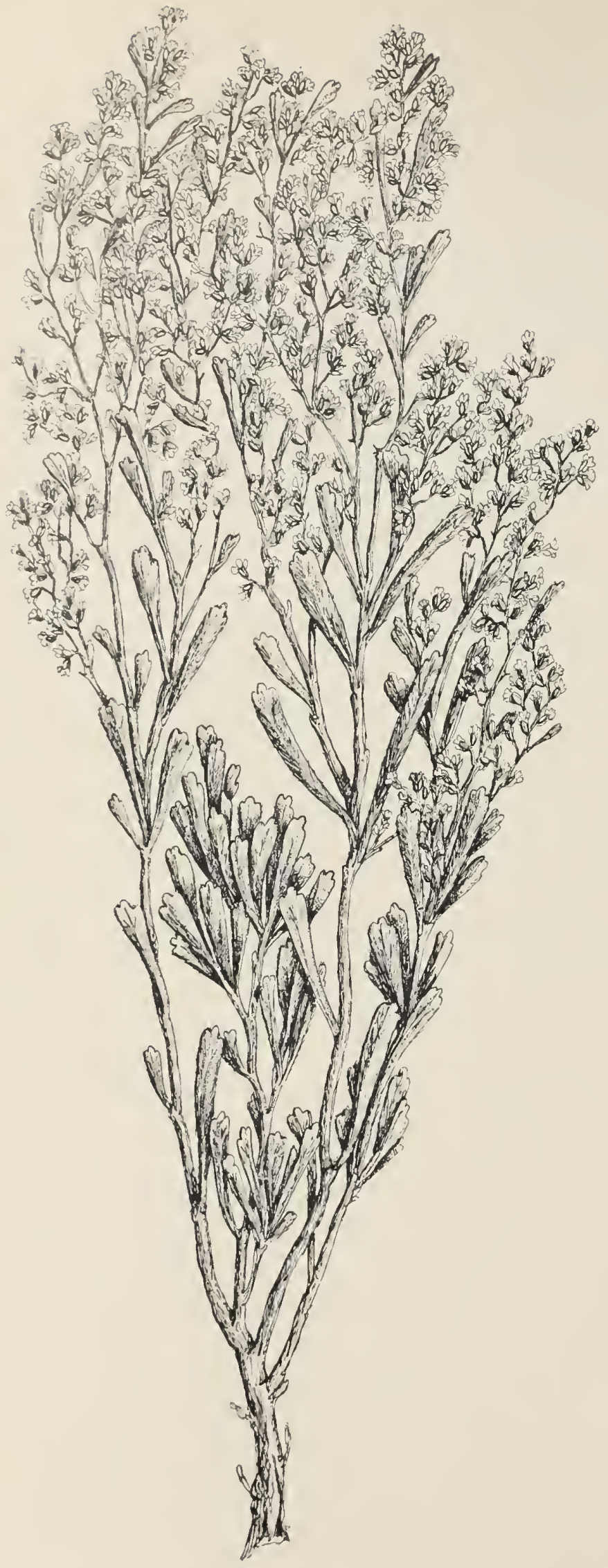

Big sagebrush (Artemisia tridentata complex). This widely distributed and alundant species and its varicties provide browse of limited palatability and usefulness for domestic livestock. In coutrast, it is a highly valuable plant for derer and antelope. These animats feed extensively upon big sagebrush witlı good results during the winter months, especially where other forages are unavailable. For prong-horn antelope it is a stiple: food throughiont the year. fuge. Tarragon (Artemisia dracunculus) is used as a seasoning and especially to flavor vinegar. This European species is also found in dry waste places in southern and central California.

Scveral of the perennial artemisias are useful in California gardens because of their interesting leaf pattern and silvery foliage. One of the most attractive is the California coastal native Artemisia pycnocephala which has, in the last few years, bcen accepted as an unusual and beautiful landscape plant.

\section{Key to the Browse Species and Varieties}

1. Plants very spiny $\ldots \ldots \ldots \ldots \ldots \ldots$. BUd SAGEBRUSH (Artemisia spinescens)

1. Plants not spiny $\ldots \ldots \ldots \ldots \ldots \ldots \ldots \ldots \ldots \ldots$

2. Leaves divided into thread-like lobes..... COAST SAgEBrush (Artemisia californica)

2. Leaves usually 3 -toothed, rarely 4 or 7 -toothed at the

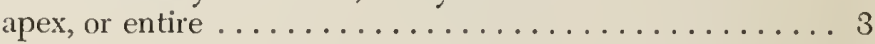

3. Leaves usually 3-toothed, rarely 4 - or 7 -toothed at the apex, only some, or just the upper leaves entire...... 4

3. Leaves all entire, rarely with 1 or 2 teeth or lobes

HOARY SAGEBRUSH

(Artemisia cana)

4. Shrubs $1 \frac{1}{2}$ to 15 feet high; flower clusters ${ }_{4}^{3 / 4}$ inch to 4 inches broad; common shrub of the Great Basin area. In California: Siskiyou County, eastward to Modoc County, southward on eastern slopes and flats of the Sierra Nevada to Inyo County, westward in the Tehachapi Mountains to the desert slopes of Ventura County, and south into San Diego County.... Big Sagebrush (Artemisia tridentata)

4. Shrubs less than 1/3 feet tall; flower clusters less than 11/4 inches broad; Bear Valley, San Bernardino Mountains, New York, Clark, Panamint, and Inyo-IVhite mountains, Benton Range ............ BLACK SAGEBRUSH (Artemisia arbuscula var. nova)

\section{Primary Sagebrush Species}

BIG SAGEBRUSir (Artemisia tridentata) (drawing on this page), also known as black sage and common sagebrush. Ereet, much branched, evergreen shrub, $1 \frac{1 / 2}{2}$ to 15 feet high, usually with distinct trunk and shreddy bark. Leaves gray, narrowly cuneate, ${ }_{1 / 8}^{3 /}$ to ${ }_{4}^{3 /}$ ineh long, occasionally to $1 \frac{1}{2}$ inches long, 3 (or 4 , sometimes more) toothed at the apcx, or the upper leaves linear of oblanceolate and entirc. Heads (of 4 to 6 disk flowers) many in clense leafy panicles, up to 4 inehes wide; late July to November. Involueral bracts 8 to 15 , gray hairy. Aehencs resinous-granuliferous.

Distribution (map on page 139). This species inhabits a variety of soils on the high plains and arid mountain slopes, from 1,500 to 8,000 feet or more elevation. It is often the dominant plant in the main part of its range. It is remarkably tolcrant of salinity, but attains optimum growth in deep, rieh, moist, alluvial loams ${ }^{(134)}$. In California it occurs in Siskiyou County, eastward to Modoe Comty, southward on the eastern dry slopes of the Sierra 


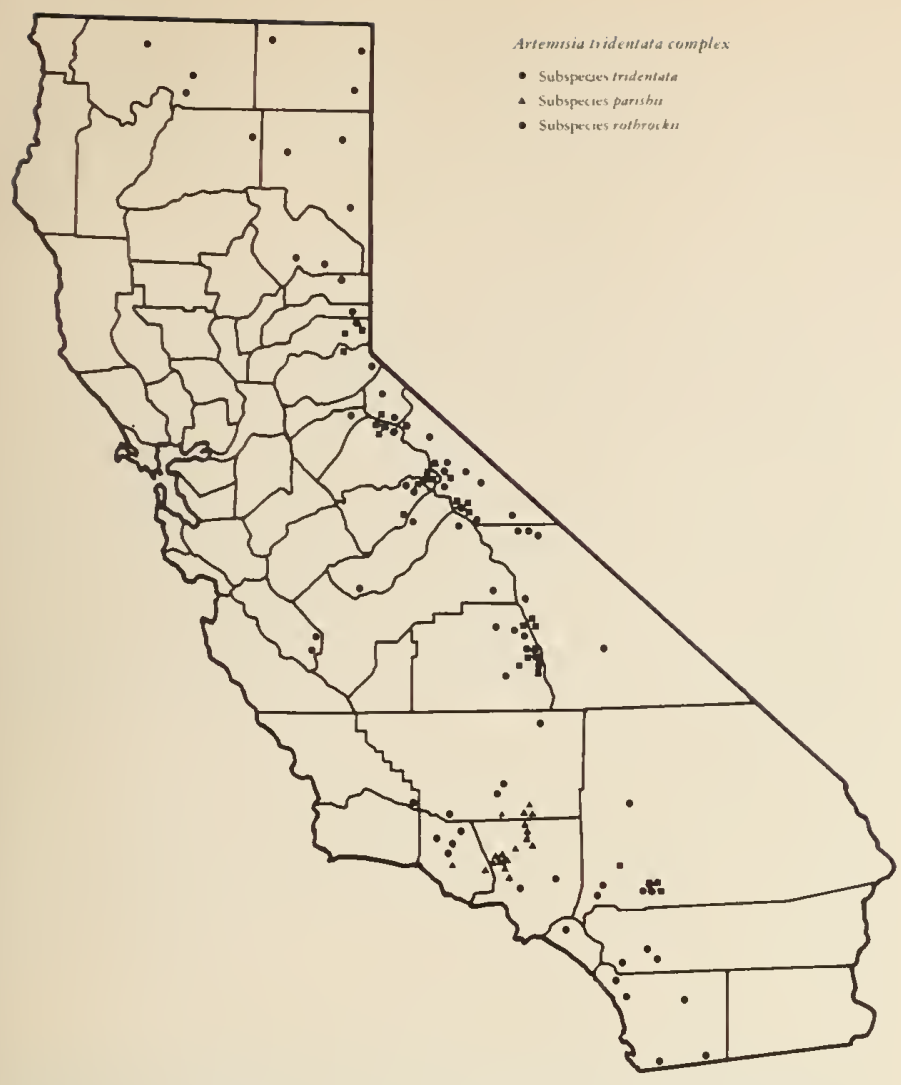

Distribution of subspecies of big sagebrush (Artemisia tridentata complex).

Nevada to Invo County, aeross the Tehachapi Mountains to Ventura County, and south into San Diego County. Considering the West as a whole, it is more widely distributed than most shrubs. Actually, it is the common shrub of the Great Basin Area of western North America.

Economic value. Although big sagebrush is generally of considerable importance as winter browse to grazing animals, it is not lighly regarded by most stockmen in California. It is looked upon essentially as an emergency feed, primarily for sheep. On the other hand, this species is an exceedingly important food plant for Roeky Mountain mule deer and for antelope. On the Interstate winter range in northern California it accounted for an average of 19 per cent of the Rocky Mountain mule deer diet during the winter ${ }^{(47)}$. In a dietary study of the Interstate deer herd, big sagebrush replaees bitterbrush as the latter declined in palatability. In December, January, and February, it composed 12.2, 26.3, and 25.2 per cent of the diet. This heavy consumption of big sagebrush continued into March but decreased sharply in April ${ }^{(8 \infty)}$.

In California big sagebrush proved to be a staple food for the prong-horn antelope throughout the year, aceording to stomach analyses ${ }^{(32)}$. The degree of its utilization by these animals was as follows: 95.2 per cent, by volume, in December; 40.8 per cent in May and June; and 35.9 per cent in August and September. The crude protein levels were never high, varying from 9.9 per cent in August, 12.7 per cent in October, and 10.9 per cent in December. Such protein levels should be adequate to maintain deer, yet they die off in considerable numbers during periods of abnormal winter stress. Studies in Utah, where deer were subsisting almost wholly upon a diet of sagebrush and a trace of juniper, showed that deer dicd in large numbers perhaps because of insufficient protein ${ }^{(123)}$. On the other hand, where sagebrush provided a substantial part, but by no means all of the winter diet, the nutrition of the deer herd was generally satisfactory $^{(38)}$. Its energy-furnishing qualities, howcver, were found to be relatively low and somewhat under recommended standards ${ }^{(20)}$. The prong-horned antelope, on the other hand, seemed to be maintained in satisfactory condition primarily on a winter diet of big sagebrush.

Because of the extensive areas occupied by big sagebrush on the big game winter ranges, the production or maintenance of antelopc in California is apparently not a limiting factor for winter forage to nearly the extcnt that it is with the migratory deer herds.

Big sagebrush has encroaehed on large acreages of grassland and has seriously decreased their grazing capacity for domestic livestoek in various parts of its distribution. Such infestations are most serious in Oregon, Idaho, Utah, and Nevada, but control of this shrub also poses a problem of some importance in California. Overly dense big sagebrush stands appear to be largely the result of overgrazing, together with periodic protracted droughts ${ }^{(10,}{ }^{1777}$. Control of big sagebrush is recommended primarily on ranges used by domestic livestock, notably on spring and on summer-fall ranges. Its control is less of a problem on the livestock winter range because this shrub is most palatable at that scason. Its extensive removal is not recommended on important big-game ranges where it is a primary food plant. Eradication or control of grassland infested with big sagebrush is accomplished by spraying with suitable herbicides, by meehanical means, and by prescribed burning. In California, spraying with 2,4-D cster from late May to midJune, when the new twigs are 3 to 4 inehes in length, has given best results ${ }^{(40,41)}$.

Browse rating. Good to poor for deer; fair to poor for sheep and goats; poor to useless for cattle; and useless for horses.

BLACK SAGEBRUSH (Artemisia arbuscula var. nova), also called dwarf sagebrush. Low growing, spreading evcrgreen shrub, 5 to 20 inches high. Leaves broadly cuneate to fan-shaped, ${ }_{11}^{1 /}$ to ${ }_{8}^{5 /}$ ineh long, ${ }_{18}^{1 / 8}$ to ${ }_{8}^{3 /}$ inch wide, usually 3 to 5 -toothed at the tip. Heads of 3 to 5 flowers in a narrow panicle less than 1/4 inehes wide. Bracts of the involucre 8 to 12, greenish yellow. Achenes smooth.

Blaek sagebrush is regarded as a distinct species by some authors. Others have considered it so smilar to big sagebrush morphologically that they have trated it as a variety of that speeies. Two reeent floras ${ }^{(1,105)}$, and a work by Ward ${ }^{(155)}$, relate black sagebrush more closely to Artemisia arbuscula because of its low growth habit and narrow inflorescencc.

Distribution (map on page 140). Black sagebrush inhabits dry roeky hillsides, ridges, and plateaus in the San Bernardino Mountains, New York, Clark, Panamint, and 


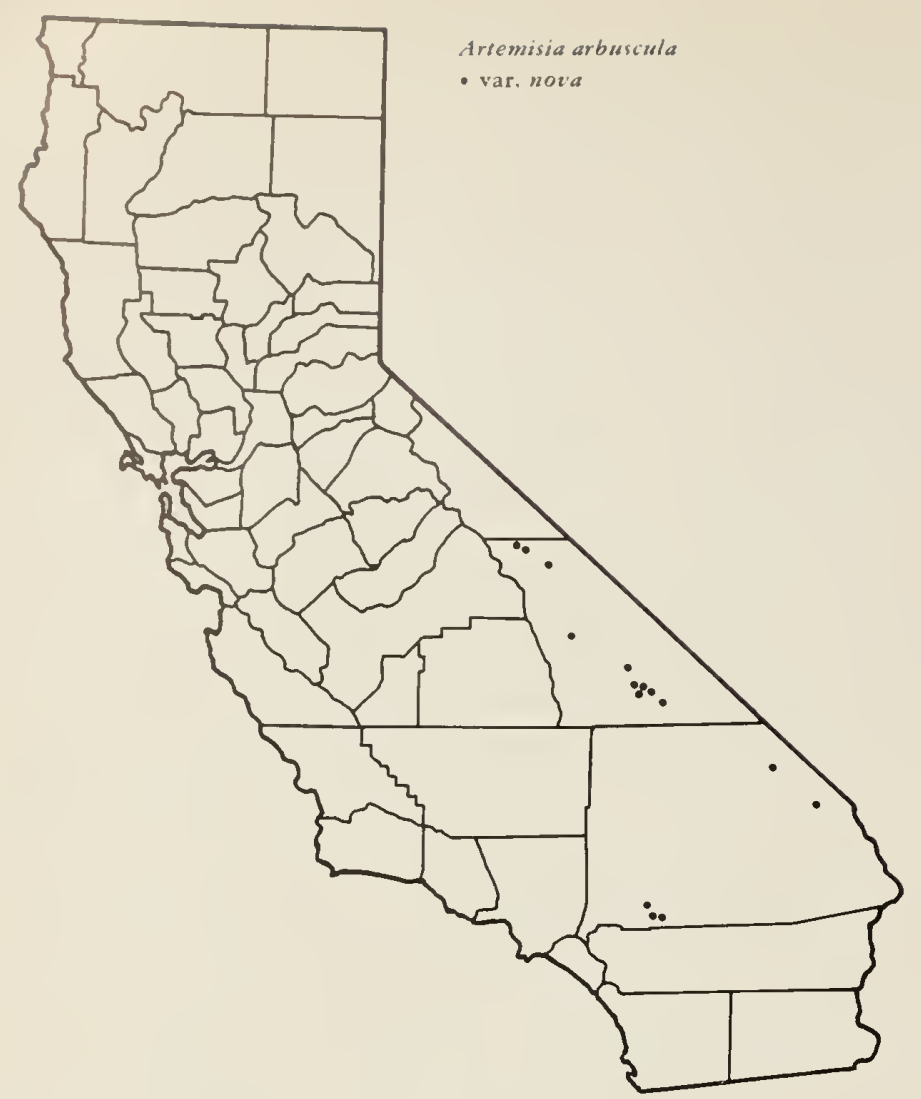

Distribution of Artemisia arbuscula, var. nova.

Inyo-IVhite mountains, Benton Range. Also eastward to Arizona and Wyoming, northward to Idaho.

Economic value. In California, black sagebrush is somewhat more palatable than big sagebrush. Black sagebrush is especially notieeable on the open flats beeause of its low growth and the gray-white east of leaves and stems. Antelopes seem to prefer black sagebrush habitat to higher-growing big sagebrush. Perhaps this is because black sagebrush can be seen better by the animals. It is browsed with eonsiderable relish by sheep and goats in late autumn and in the winter, and is an important winter feed for deer. Cattle also feed upon it to a limited extent. On winter range in Utah, Colorado, and New Mexico it is held in high repute as browse for sheep, goats, and deer. Studies of the ehemical composition of black sagebrush in Utah showed that it is a good source of phosphorus and vitamin $\mathrm{A}^{(35)}$. Also its digestible coefficients were comparable to those of big sagebrush, but the energy-fumishing constituents were elearly deficient. The rather high fractions of essential oils were suspeeted of being toxic when this plant composed a large part of the dict over extended periods of time.

Browse rating. Good to fair for deer; fair to poor for sheep and goats; poor for cattle; and useless for horses.

\section{Secondary Sagebrush Species}

The only seeondary species of the Sunflower Family worthy of mention are tlic sagebrushes. Of the 15 species of sagebrushes in California, including their several varieties, none ranks as highly as the one species and the one varicty previonsly diseussed. Others that are worthy of mention are: Hoary sagebrush (Artemisia cana) and bud sagebrush (A. spinescens). It is not probable that these species eolleetively provide nearly as mueh browse for livestock or big game as does big sagebrush. The over-all browse values of these species are given in the summary table on page 146.

Coast sagebrush (Artemisia californica), a eommon shrub on exposed slopes and dry hills from San Franciseo Bay southward in the Coast Ranges, has a pungent sage odor. It is grazed little or not at all by range livestock, and perhaps limitedly by deer; however, only limited study has been earried out on coastal deer. Mention is made here of coast sagebrush beeause of its abundance on many southern eoastal areas and the fact that frequent inquiries are made eoncerning its worth as browse.

It is well known that not all plants with high erude protein eontent are good forage speeies. Coast sagebrush, for example, has relatively high protein levels for a shrub of its growth characteristies. The protein averages about 3 per eent higher than in big sagebrush, yet the latter has fair to good forage rank ${ }^{(11)}$. The bitter taste and penetrating aroma peculiar to eoast sagebrush may tend to repel grazing animals.

\section{RABBITBRUSHES (Chrysothamnus)}

These are evergreen shrubs or subshrubs with smooth or tomentose foliage that is often resinous or aromatie. The leaves are simple, alternate, and entire. Heads have 4 to 20 yellow disk flowers that are bisexual and fertile. No ray flowers are present. The heads are usually borne in panieles or eymes, rarely solitary. The firm leathery involueral bracts are elosely overlapping and in more or less distinet vertical rows. The achenes are rounded or somewhat angled, smooth to densely hairy. The pappus consists of dull white or brownish soft bristles.

Rabbitbrush is the name sometimes applied to other woody plants of the west but in general it usually applies to members of the genus Chrysothamnus. Other eommon names that are frequently used are rabbitsage, rayless goldenrod, and yellow brush.

The genus Chrysothamnus eontains about 12 speeies with many varieties. They are confined to North Ameriea, mainly in western United States. Approximately 9 species and 18 varieties oecur in California. The latex of some speeies yields rubber whieh is said to be of good quality. In fact, during the seeond World War a special study was made of Chrysothamnus nauseosus at the University of California as a possible emergeney souree of rubber ${ }^{(4)}$. It was found to eontain rubber of high quality that vuleanized readily.

The ehief importanee of the genus is its abundance and the faet that all species and varieties seem to make good growth on poor sites. The palatability of the rabbitbrushes varies from nearly worthless to fairly good. The terminal portion of the flower stalks, the eurrent leaves, and more linitedly, the flower heads are the most palatable parts. They are eropped most in late fall and winter, notalyly after a rain or heavy frost. Rubber rabbitlonsh and rabbitbrush are chosen to represent the genus. 


\section{Key to the Browse Species}

1. Branches only covered with a permanent dense feltlike mat of hairs; leaves thread-like to broadly linear, more or less finely hairy, not gummy, gray-green to light yellow-green ............. RUBBER RABBITBRUSH

(Chrysothamnus nauseosus)

1. Branches without dense felt-like mat of hairs, smooth or slightly finely hairy; leaves narrowly linear to oblong or lanceolate, often twisted, smooth or somewhat hairy, usually gummy, bluish-green......... RABBitBRUSH (Chrysothamnus viscidiflorus)

RUBBER RABBITBRUSH (Chrysothamnus nauseosus) (drawing on this page), also called rubber yellowbrush and white sage, including its several varieties, is probably the best known species. Shrub with numerous stems originating from the base, 1 to 7 feet high, with pliable leafy branchlets covered with gray-green or white felt-

Rubber rabbitbrush (Chrysothamnus nauseosus). This plant is cropped but lightly by domestic livestock except occasionally in the winter when sheep and goats, and to a lesser extent cattle, in some localities feed more closely on the flower tops and current leafage. Deer crop this plant in winter commonly and it is an item of some importance in their diet.

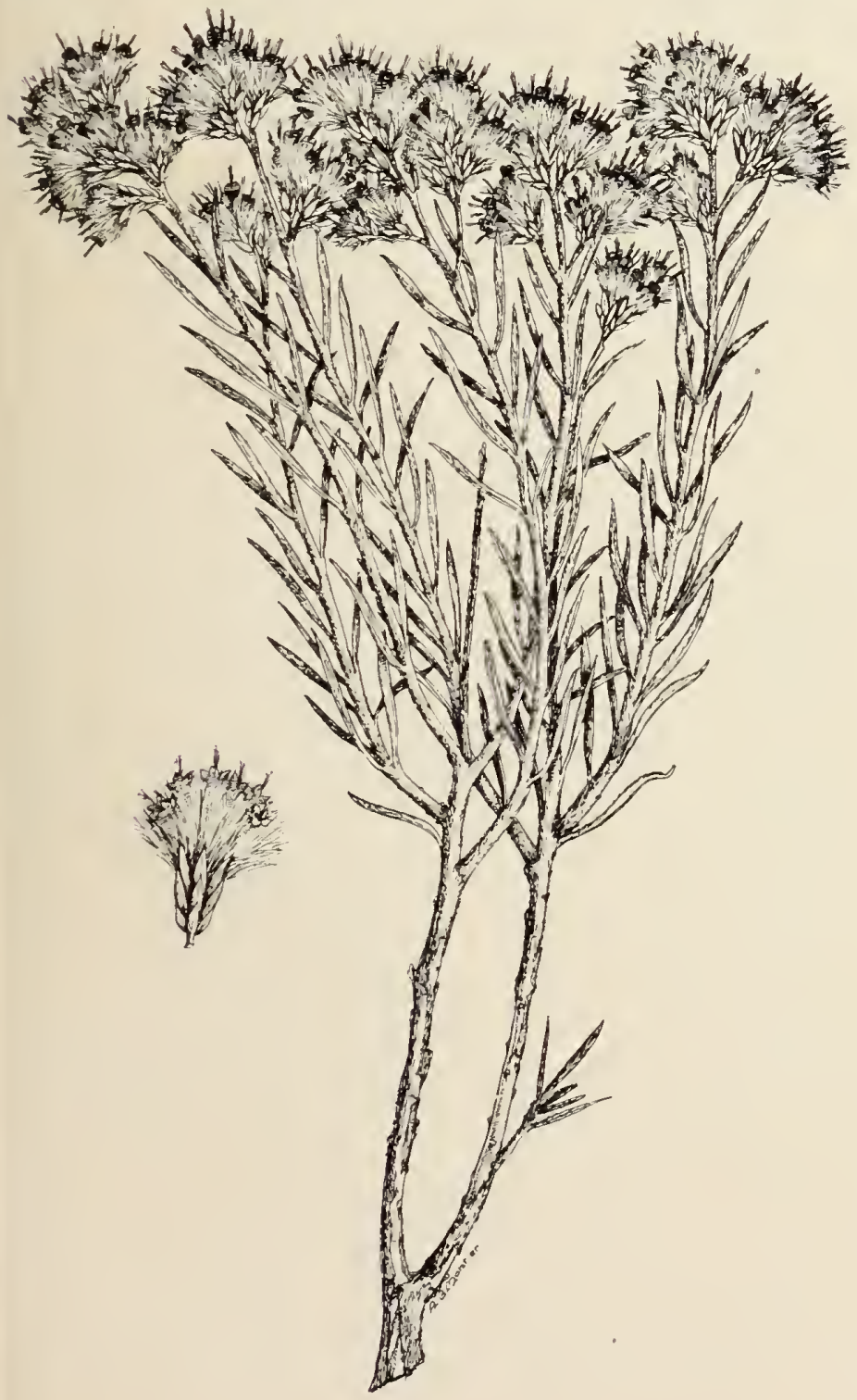

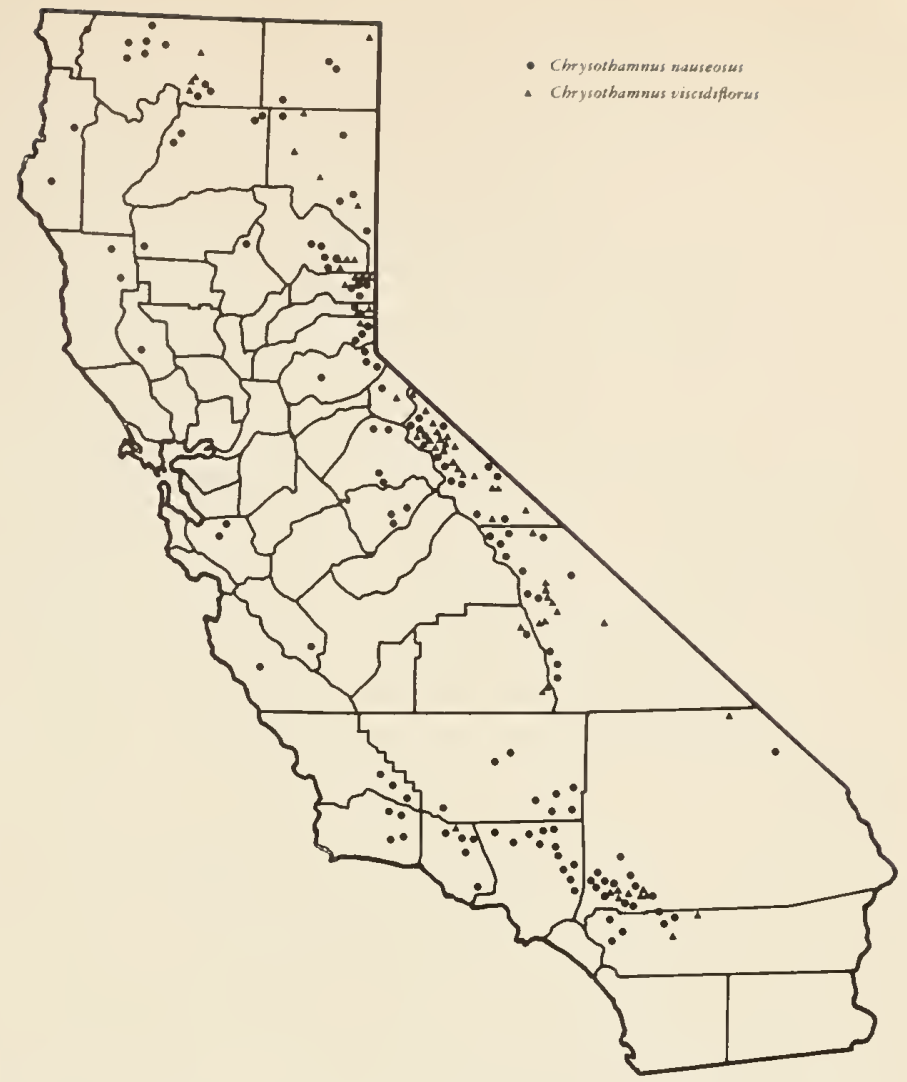

Distribution of rubber rabbitbrush (Chrysothamnus nauseosus) and rabbitbrush (Chrysothamnus viscidiflorus).

like hairs. Leaves thread-like or broadly linear, ${ }_{4}^{3}$ inch to $2 \frac{1}{2}$ inches long, usually hairy. Flower heads in terminal rounded or conical clusters. Involucral bracts usually 20 to 25; flowers commonly 5 to 6 . Achenes 5-angled, smooth or covered with long hairs. This species is highly variablc, some 11 varieties being recognized in California.

Distribution (map on this page). Rubber rabbitbrush and its complexity of forms inhabits gravelly dry slopes or flats, and alkalinc sites between 500 to 9,000 feet elevation. It is common on the castcrn slope of the Sierra Nevada and in the southern California mountains. It occurs scattered throughout the Coast Ranges and occasionally on the western slope of the Sierra Nevada.

Economic value. The herbagc of rubber rabbitbrush has a somewhat disagreeable odor and taste. It is cropped but lightly by domestic livestock except seasonally, or on overgrazed range. In late fall and winter sheep, goats, and antelopes, and less extensively cattle, feed somewhat closely on the flower tops and the current leafage. On winter deer range in Owens Valley, Inyo County, rubber rabbitbrush, together with roundleaf rabbitbrush (Chrysothamnus teretifolius) were found in as much as 48 per cent of the deer stomachs examined ${ }^{(s)}$. The volume of this feed was usually small, however, never exceeding more than about 6 per cent of the total food ingested. Even so, rubber rabbitbrush and other species of the genus are an item of some importance, especially to deer. Also, antelope appear to prefer rabbitbrush and roundleaf rabbitbrush. The crude protein 
content of rabbitbrush, and big sagebrush were found to be strikingly similar, ranging from a minimum of about 9 per cent during the dormant months to 11.8 per cent in April after the yormg leares had formed. In Utah, ellowbrush (Chrysothamnus stenophyllus) was found to contain fairly satisfactory levels of carotine but was rather low in phosphorus and protein ${ }^{(37)}$.

Browse rating. Fair to poor for sheep, goats, and deer; poor to useless for cattle; and useless for horses.

12. АBBтвRUSH (Chrysothomnus viscidiflorus), also called rabbitsage, vellow sage, and yellowbrush. Shrub of exceedingly diverse habit, with variable foliage, 6 inches to 8 feet high, with numerous leafy smooth or sometimes hairy branches. Leaves narrowly linear to oblong, or lanceolate, sometimes twisted, ${ }_{4}^{3 \prime}$ inch to $2^{\frac{1}{2}}$ inches long, 1 to 5-nerved, smooth or hairy, usually gummy, bluish green. Heads in terminal rounded or flat-topped clusters. Involueral bracts about 15 . Flowers usually 5 in a head. Several varicties have been deseribed.

Distribution (map on page 141). Rabbitbrush occupies dry slopes and benches between elevations of about 3,000 to 8,500 feet elevation. It oecurs on the north and east sides of the Sierra Nevada from Siskivou County to Inyo County, southward to Lower California, northward to Montana, and eastward to Arizona.

Economic value. Rabbitbrush is similar in palatability for domestic livestock and big game animals to that of rubber rabbitbrush in that neither species accounts for more than a small part of the total feed ingested. It is cropped mostly in late fall and winter. The results of a large number of stomach analyses of mountain mule deer on the Devils Garden Interstate herd in 1946, for example, revealed that the frequency of occurrence in the stomachs varied from 10 per cent to 14.8 per cent from October to January, respectively ${ }^{(88)}$. These wcre the highest stomach frequency figures recorded for that year, but they accounted for only a trace of the total volume of food ingested. Even so, utilization of this speeies may oceasionally be rather close on areas with exeeptionally heavy concentrations of deer or when snow covers up other desirable feed.

Browse rating. Fair to poor for goats and decr; poor to useless for cattle and sheep; and useless for horses.

\section{BACCIARIS (Baccharis)}

These are usually resinous or glutinous, sometimes hairy, evergreen shrubs, altlough some are herbaceous perennials. Leaves are simple and alternate. The whitish or yellowish flowers are all disk flowers, the malc and female borne in separate heads on different plants. The involucral bracts are listinctly overlapping. The achenes are slighly flattenced, 5 to 10-nerved. Pappus bristles in male flowers are scanty; in the fertile female flowers copious and long.

This genus includes alont 300 species native to Ancrica, mostly in South America. Nine species, 6 shrmbloy and 3 peremuials, are native to California. The browse value of this gromp is low yet it provides needed forage variety and vitamin A on dry grass ranges. All western species are wholesome to animals so far as known, whereas on the Atlantic South American Coast, Baccharis cordifolia, called mio mio, contains baceharin, an alkaloid, which is toxic to all kinds of domestic livestock $^{(58,115)}$.

Chaparral broom and mule fat are selected to represent the browse values of the genus.

\section{Key to the Browse Species and Varieties}

1. Leaves willow-like, 1 inch to $3 \frac{1}{2}$ inches long, pale green, margins usually entire or occasionally slightly toothed; shrubs along water courses and moist waste places in the Sacramento and San Joaquin valleys and adjacent valleys of low elevation to the Coastal and foothill areas of southern California........... MULE FAT

(Baccharis viminea)

1. Leaves broad, not willow-like, $\frac{1}{2}$ inch to $1 \%$ inches long, dark green, margins usually coarsely and irregularly toothed, sometimes entire; common shrub on low open hills and lower mountain slopes..... CHAPARRAL BROOM (Baccharis pilularis var. consanguinea)

CHAPARRAL BROOM (Baccharis pilularis var. consangninea) (drawing on page 143), also known as baceharis, chaparral brush, coyote bush, kidneywort, and kidneyroot. Upright, compact shrub, 2 to 10 feet high, with a spread of 2 to 10 feet, the new growth with green angular branches. Leaves ovate, roundish, or rarely oblongelliptical, $1 / 2$ inch to $1 \frac{1}{2}$ inches long, leathery, dark green, not hairy, margins coarsely and irregularly toothed, or sometimes entire. Heads about $\frac{1 / 4}{4}$ inch long, mostly solitary in the leaf axils or in terminal clusters on leafy branches; August to October.

Because of its spreading habit this variety makes a good protective soil cover. It also forms a good hedge if properly pruned. The coastal species (Baccharis pilularis), known as dwarf ehaparral broom, or dwarf coyote brush, is a prostrate spreading plant 6 to 12 inches high that is now being used as a ground cover in southern California gardens.

Distribution (map on page 143). This is eommon on open low hills and lower mountain slopes from Monterey County northward in the coastal counties to southern Oregon, commonly in the coastal scrub, chaparral, and foothill woodland communities. It also oceurs in mneh less abundance to northern San Diego County and on the west slopes of the Mount Hamilton Range, in the foothills of the Central Sicrra Nevada comties, and on the islands off the coast of southern California.

Economic value. Although chaparral broom, like other members of the genus, is low in palatability to all browsing animals, it provides some browse, especially for goats, and nore limitedly for eattle, sheep, and deer. This variety of ten encroaches upon lightly stocked or on overutilized grasslands to measurably lower the grazing capacity. All species are susceptible to destruetion by hornone sprays, notably 2,4-D ester or anine ${ }^{(10)}$. Soon after such treatment grass nsually recaptures the area. Occasional burning, followed by sheep or goat grazing to 


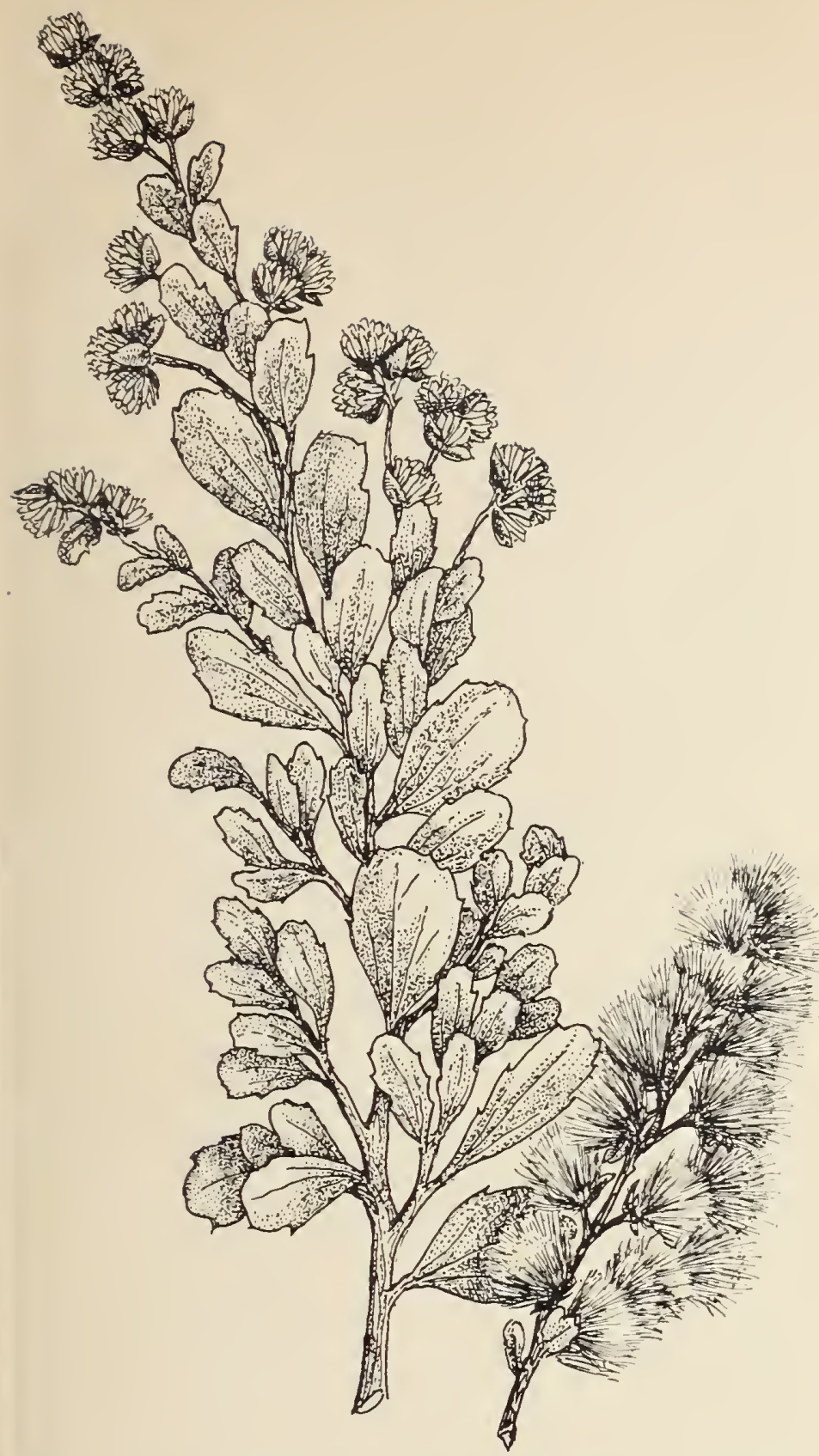

Chaparral broom (Baccharis pilularis var. consanguinea). Although this plant is low in palatability it provides some uscful browse for all domestic livestock and for deer. Unfortunately it tends to encroach on grasslands where it may measurably lower the grazing capacity. It is readily destroyed by hormone sprays.

destroy the sprouts and seedlings, is also effective in maintaining an open grass cover.

Brouse rating. Fair to poor for sheep and goats; poor to useless for cattle and decr; and useless for horses.

MULE FAT (Baccharis viminea). Erect, spreading, leafy shrub with many loosely branched stems, 6 to 12 feet high, usually with many short lateral flowering branchlets. Foliage scarcely glutinous. Leaves narrowly lanceolate to oblong, 1 to $3 \frac{1}{2}$ inches long, pale green; margins entire or slightly toothed. Heads rather numerous, in compact flattish clusters at the ends of the lateral branches; May to June. Achenes 5-nerved.

Distribution (map on this page). This willow-like shrub is common in moist areas and along water courses from sea level to about 1,500 feet elevation. It occurs from the

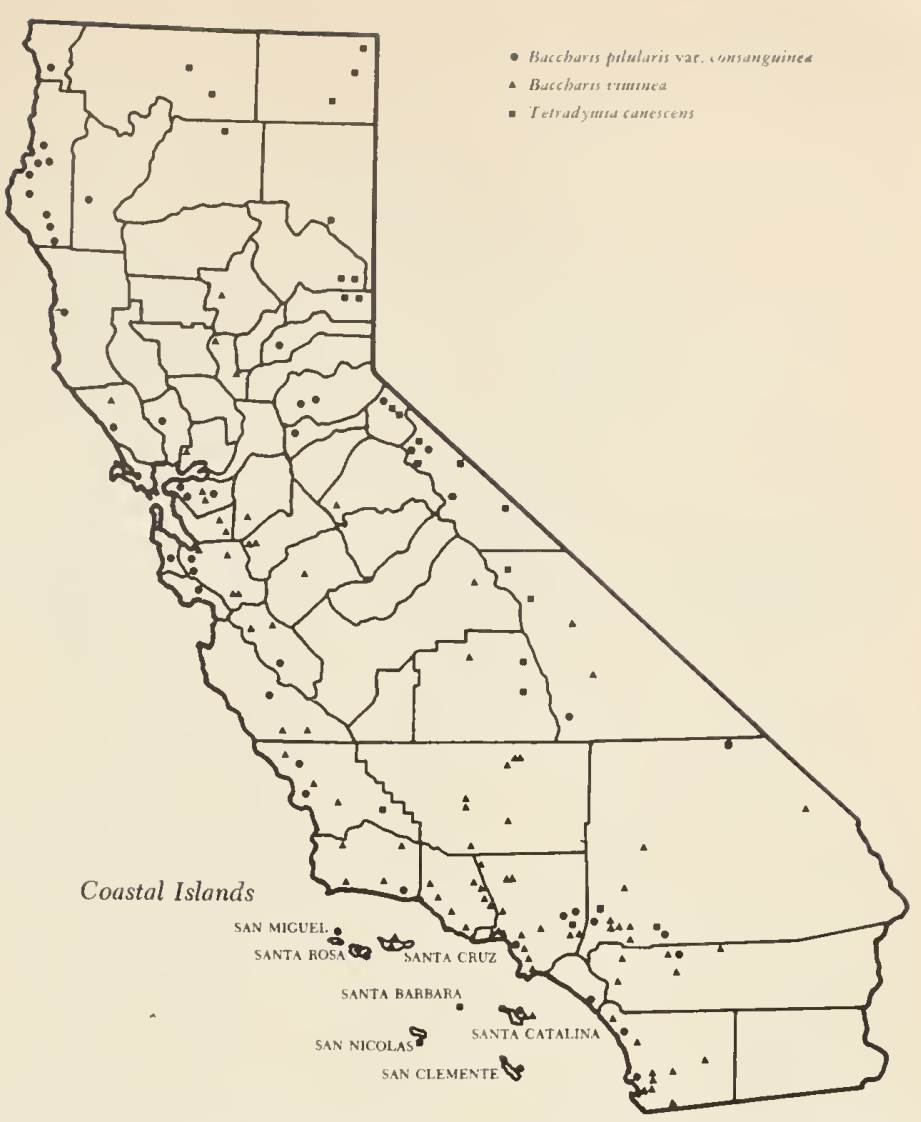

Distribution of chaparral broom (Baccharis pilularis var. consanguinea), mule fat (Baccharis viminea), and gray horsebrush (Tetradymia canescens).

Sacramento and adjacent valleys; southward along the coastal vallcys; the San Joaquin Valley, and the lower valleys of the Sierra Nevada to the coastal and foothill areas of southern California in the coastal sage scrub, grassland, and foothill woodland communities. It is commonly associated with valley and certain other species of oaks, maples, poison-oak, and various grasses and forbs.

Economic value. The herbage has a bitter resinous taste that is typical of most plants in this genus, and is of relatively low palatability. It is cropped mostly during the late fall months after the grass cover is dry and bleached, and to a somcwhat lesser extent in winter and early spring. On overutilized grasslands, as well as on areas long protected from livestock grazing, mule fat often encroaches so heavily as to shade out most of the grass. In such instances spraying with 2,4-1D amine, when applied between May and July, has proven effective ${ }^{(8)}$.

Browse rating. Fair to poor for goats; poor to useless for cattle, shecp, and deer; and useless for horses.

\section{HORSEBRUSHES (Tetradymia)}

This is a small genus of some six spccies native to the arid region of westem North America. They are low rigid shrubs, the foliage usually covered with a dense matted pubescence. Some species have spiny branches. In general the horsebrushes are low to useless as browse, exccpt on desert ranges in winter and spring or on overgrazed areas. Gray horscbrush, described below, typifics the browse values of the genus fairly well. 


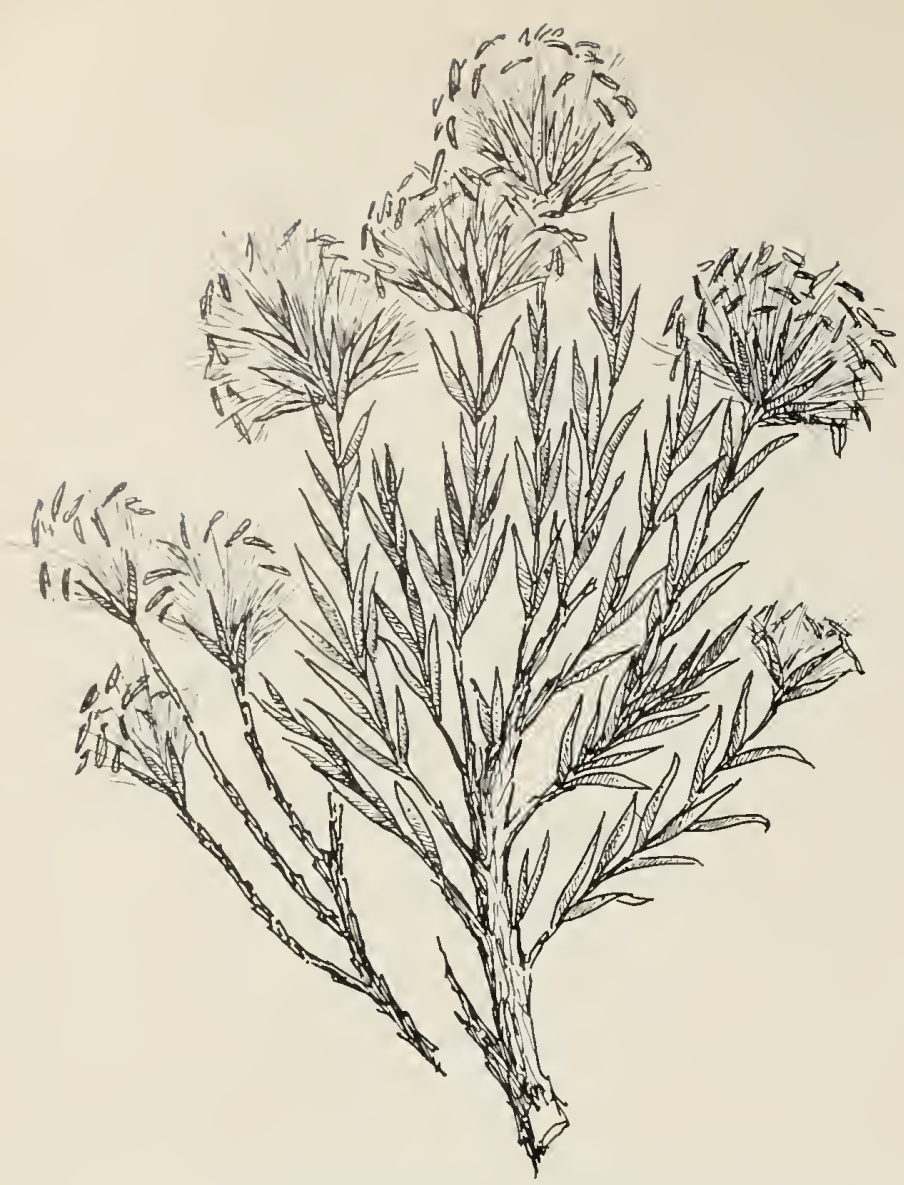

Gray horsebrush (Tetradymia canescens). This species, like other horsebrushes, is of low palatability. The young leaves and stems, however, are browsed in varying degrees by sheep, goats, and deer. Poisoning of livestock may oceur where large quantities of leaves and twigs are ingested.

GRAY HORSEBRUSH (Tetradymia canescens) (drawing shown above), often called black sage. Spineless, much branched shrub, 4 inches to 1 foot high. Leaves linear lanceolate, $\frac{1}{2}$ to $7 / 8$ ineh long, crowded on the branches, whitc hairy. Heads yellow, in short stalked elusters at the ends of short branchlets, 4-flowered; June to August. Involueral braets 4 or 5 . Achenes smooth or hairy; mature in Scptember and Oetober.

Distribution (map on pagc 143). It is widely distributcd on dry hills and flats from 4,000 to 8,000 fect elevation in the southern California mountains northward cast of the Sierra Nevada crest to Modoc and Siskiyou counties in the sagebrush scrul), piñon-juniper woodland, and the ponderosa pine communities. It extends northward and eastward into adjacent territory

Economic value. Gray horschrush, like the other speeics of the genus, is of low palatability to all grazing animals. The buds and yoming leaves, however, are frequently cropped during spring and fall months by sheep, goats, and deer, but the volnme taken is generally small'sss. When large quantities of the leafage are eaten this species, as well as little horselnush (Tetradymia glalorata), may cause poisoning of livestock ${ }^{(125)}$.

Browse raling. Fair to useless for decr; poor to useless for cattle, she'p, and goats; and nus(eless for horses.

\section{Conifers}

This group is included in this manual more beeause of the importance of managing forest range so as to prevent serious damage to timber reproduetion by wildlife and domestic livestoek than for their value as food plants.

A large proportion of the pines (Pinus), spruces (Picea), firs (Abies), and Douglas-fir (Pseudotsuga menziesii) are of great economic importance in the lumber industry. Excessive browsing upon young coniferous seedlings and saplings, or injury to the reproduction by trampling during wet weather, must obviously be corrected on all important timber-producing areas. Some browsing upon conifers by livestock, notably by sheep and goats, and cropping and rubbing at eertain seasons by deer, oceurs under the best management practices. Where the range is overgrazed, or cropped at the wrong season of the year, or if the livestock finds the forage unsuitable, they will feed upon the seedling conifers. This damage to the reproduction may cause deformity of the young trees and failure to obtain a desired new stand after a logging operation $^{(31,42,123)}$.

Although species of the pine family (Pinaceae) and other conifers are not espeeially palatable to any grazing animal and consequently contribute little to the annual food supply, some species are browsed more than others. On the Inyo and certain other mule deer ranges, for example, singleleaf piñon pine (Pinus monophylla) and ponderosa pine (Pinus ponderosa) composed from a trace to 2 per cent of the stomach eontents, by volume, of the deer in February and March ${ }^{(86,87)}$, and were also cropped on some summer ranges. White fir (Abies concolor), Douglas-fir (Pseudotsuga menziesii), and ineense cedar (Libocedrus decurrens) were also browsed lightly to fairly heavily by decr. Among domestic livestock goats are by far the heaviest browscrs of conifers. Junipers (Juniperus) are often cropped so extensively by big game as to constitute an important winter food item.

Resins, terpenes, and other oleoresins of the pines and other conifers tend to repel grazing animals. These chemicals also have an irritating effeet on the digestive tract, and cases of scours and abortion have been attributcd to them ${ }^{(115)}$. These substanees, however, do not prevent deer from sevcre or destruetive browsing upon coniferous plants in localities where their food supply is inadequate (photo on page 145). Even where an excessive population of decr exists, howcver, an oecasional secdling will escape scvere browsing and develop into a wcll formed sapling.

In the Paeific Northwest, the North Central area, in the East, and South, wildlife anmully eausc severc damage to conifcrous reprodnction. Recognition of this faet is inducing various timber organizations to cstablish departments of wildlife management to minimize damage to tree reproduction. Roy ${ }^{(122)}$, working in northcastem California, conchuded that the severity of the damage to young coniferous growth by deer was closely related to the anount of preferred browse species which the 
area supports. Deer seem to reach maximum densities of populations on newly logged or otherwise disturbed areas where the food supply is temporarily much increased. Later, as this vegetation becomes less palatable or is out of reach of the animals, they consume less desirable plants, including various species of coniferous reproduction. Damage is most keenly felt on plantations where deer congregate while the seedlings are young.

It is important that the deer-timber reproduction problem be studied more intensely. This should inclucle more knowledge of the habits of deer, the foods that they prefer, and how they may be lured away from localities where they are not wanted.

Only limited studies of the nutritive values of conifers as food plants have been made. Evidently none of our conifers are poisonous to browsing animals. Western yew (Taxus brevifolia), which occurs from Alaska to western Montana and into California, has not been reported to poison grazing animals. The yews (Taxus) of the old W'orld, however, have long been known to be poisonous to livestock and deer. English yew (Taxus baccata) is the worst offender. Numerous cattle, horses, sheep, deer, rabbits, and even humans have died from eating the foliage or fruit of this species. Cattle, sheep, and goats sometimes crop fairly large amounts of the leafage and young twigs of Douglas-fir, white fir, and incense cedar with no apparent ill effects. The seeds of piñon pines (Pinus edulis and Pinus monophylla) and Digger pine (Pinus sabiniana) are eaten by livestock, humans, and rodents with no ill effects.

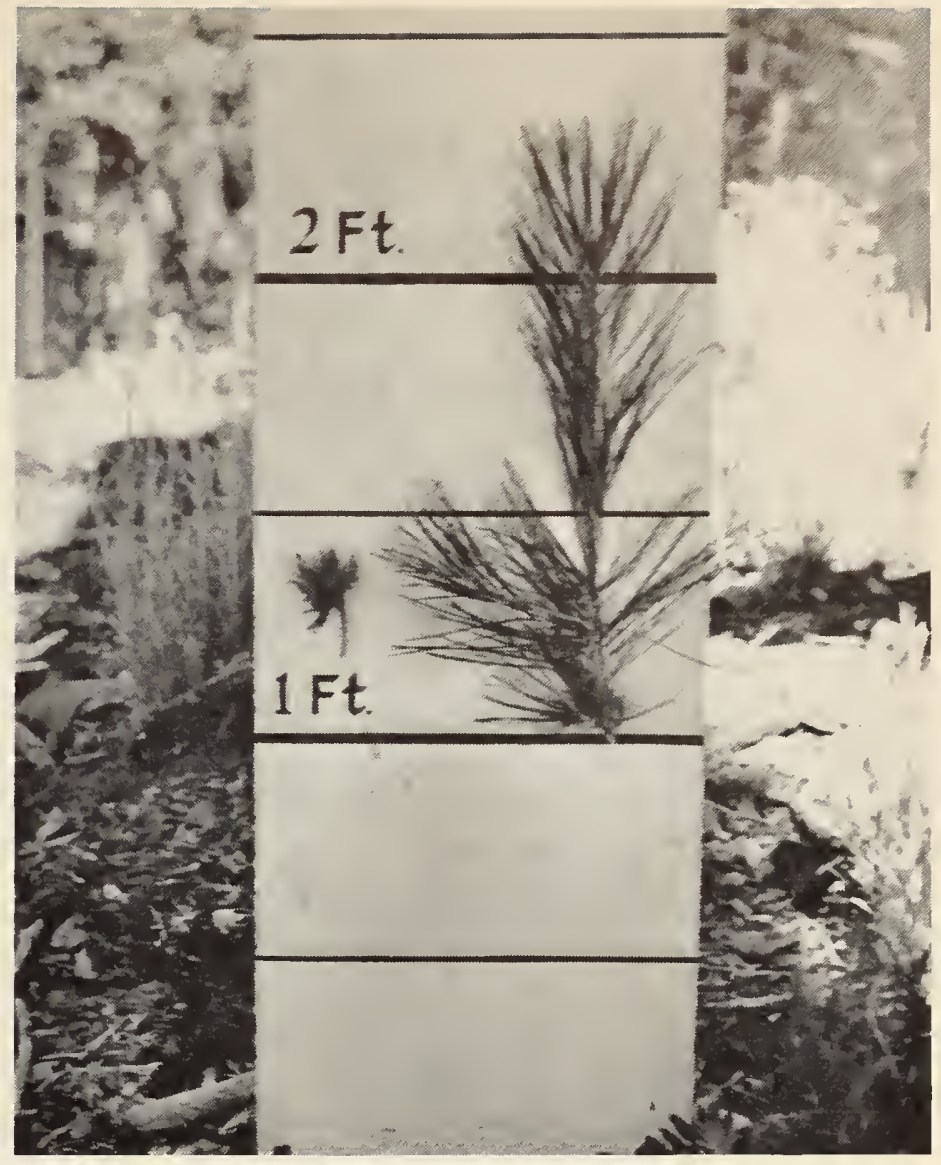

Left: Severely browsed three-year-old ponderosa pine seedling on a heavily populated deer range. Right: Seedling of same age protected from browsing. Hobergs' recreation property. Lake County.

For a summary of the ratings of browse species discussed in this manual, see pages 146 to 148. 


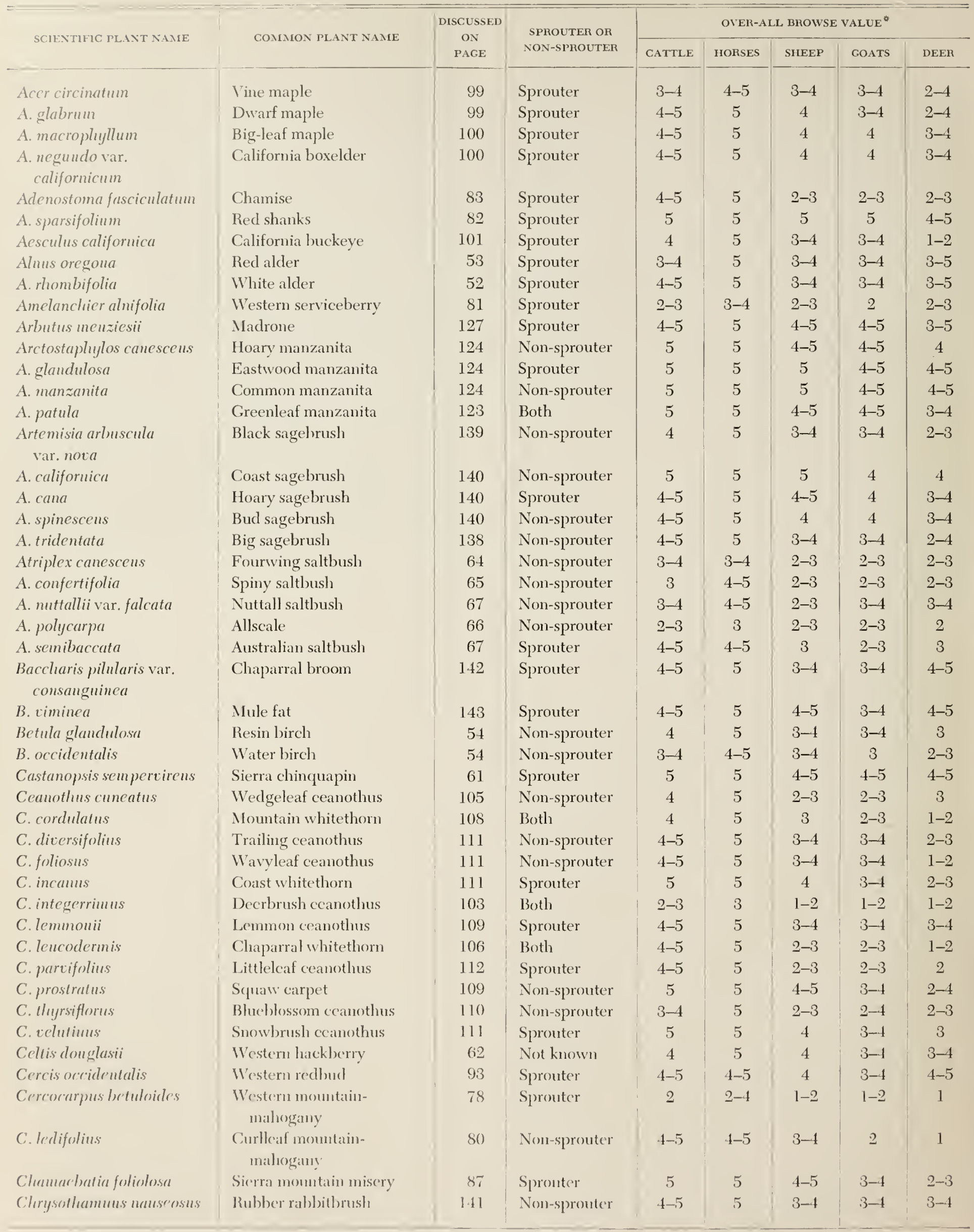

- llir. ower-all rating symbols are: $1=$ excedlent; $2=$ good; $3=$ fair; $4=$ poor; $5=$ useless. 


\begin{tabular}{|c|c|c|c|c|c|c|c|c|}
\hline \multirow{2}{*}{ SCIENTIFIC PLANT NAMIE } & \multirow{2}{*}{ COMMON PLANT NAME } & \multirow{2}{*}{\begin{tabular}{|} 
DISCUSSED \\
ON \\
PAGE
\end{tabular}} & \multirow{2}{*}{$\begin{array}{l}\text { SPROUTER OR } \\
\text { NON-SPROUTER }\end{array}$} & \multicolumn{5}{|c|}{ OVEJ-ALL BROWSE VALUE ${ }^{\circ}$} \\
\hline & & & & Cattlee & HORSES & SHEEP & GOATS & DEER \\
\hline C. teretifolius & Roundleaf rabbitbrush & 141 & Non-sprouter & $4-5$ & 5 & $3-5$ & $3-4$ & $3-4$ \\
\hline C. viscidiflorus & Rabbitbrush & 142 & Non-sprouter & $4-5$ & 5 & $4-5$ & $3-1$ & $3-4$ \\
\hline Coleogyne ramosissima & Black bush & 86 & Non-sprouter & 4 & 5 & $3-4$ & $2-4$ & $2-4$ \\
\hline Cornus nuttallii & Pacific dogwood & 120 & Sprouter & 5 & 5 & $3-4$ & $3-4$ & $3-4$ \\
\hline C. sessilis & Blackfruit dogwood & 121 & Sprouter & 5 & 5 & $4-5$ & $4-5$ & $3-5$ \\
\hline C. stolonifera & American dogwood & 120 & Sprouter & $4-5$ & 5 & 4 & $3-4$ & $3-4$ \\
\hline $\begin{array}{l}\text { C. stolonifera var. } \\
\text { californica }\end{array}$ & Creek dogwood & 120 & Sprouter & $4-5$ & 5 & 4 & $3-1$ & $3-4$ \\
\hline $\begin{array}{l}\text { Corylus cornuta var. } \\
\text { californica }\end{array}$ & California hazelnut & 5.5 & Sprouter & $4-5$ & $4-5$ & 4 & $3-4$ & $3-4$ \\
\hline $\begin{array}{l}\text { Cowania mexicana var. } \\
\text { stansburiana }\end{array}$ & Cliffrose & 85 & Non-sprouter & $3-4$ & $4-5$ & $2-3$ & 2 & $1-2$ \\
\hline Crataegus douglasii & Western blachlhaw & 93 & Sprouter & $4-5$ & $3-4$ & 4 & 4 & $3-4$ \\
\hline Dendromecon rigida & Bush poppy & 71 & Sprouter & $4-5$ & 5 & $3-4$ & $3-4$ & $3-4$ \\
\hline Epledra nevadensis & Nevada ephedra & 48 & Non-sprouter & $3-4$ & 5 & $3-4$ & $2-3$ & $3-4$ \\
\hline E. viridis & Green ephedra & 48 & Non-sprouter & $3-1$ & 5 & $3-1$ & $2-3$ & $3-4$ \\
\hline Eriodictyon californicum & California yerba santa & 129 & Sprouter & 5 & 5 & $4-5$ & $4-5$ & $3-4$ \\
\hline Eriogonum fasciculatum & California buckwheat & 63 & Both & $3-1$ & $4-5$ & $3-1$ & 3 & $2-3$ \\
\hline Eurotia lanata & Winter fat & 67 & Non-sprouter & $1-2$ & 3 & $1-2$ & $1-3$ & $2-3$ \\
\hline Fraxinus latifolia & Oregon ash & 128 & Sprouter & $3-4$ & $4-5$ & 3 & 3 & $4-5$ \\
\hline F.velutina & Arizona ash & 129 & Sprouter & 5 & 5 & 4 & $3-4$ & $4-5$ \\
\hline Fremontia californica & $\begin{array}{l}\text { Fremontia or } \\
\quad \text { flannel bush }\end{array}$ & 116 & Sprouter & $3-4$ & 5 & $2-3$ & $2-3$ & 1 \\
\hline Garrya fremontii & Fremont silktassel & 118 & Sprouter & $4-5$ & 5 & $2-3$ & $2-3$ & $2-3$ \\
\hline Gaultheria shallon & Salal & 126 & Sprouter & $4-5$ & 5 & 4 & $3-4$ & $3-4$ \\
\hline Grayia spinosa & Spiny hop-sage & 68 & Non-sprouter & $3-4$ & $4-5$ & $2-3$ & $2-3$ & $2-3$ \\
\hline $\begin{array}{l}\text { Heteromeles (Photinia) } \\
\quad \text { arbutifolia }\end{array}$ & Toyon & 92 & Sprouter & 5 & 5 & $4-5$ & $2-3$ & $2-3$ \\
\hline Juniperus californica & California juniper & 45 & Sprouter & 5 & 5 & $4-5$ & $3-4$ & $3-4$ \\
\hline J.occidentalis & Western juniper & 46 & Non-sprouter & 5 & 5 & $4-5$ & $4-5$ & $3-4$ \\
\hline J. osteosperma & Oneseed jumiper & 45 & Not known & 5 & 5 & $4-5$ & $4-5$ & $3-4$ \\
\hline Kochia americana & Green molly & 69 & Non-sprouter & 5 & 5 & $3-1$ & $3-4$ & $4-5$ \\
\hline Larrea divaricata & Creosote bush & 95 & Non-sprouter & 5 & 5 & $4-5$ & $4-5$ & $4-5$ \\
\hline $\begin{array}{l}\text { Lithocarpus densiflora } \\
\text { var. echinoides }\end{array}$ & Dwarf tanoak & 61 & Sprouter & 5 & 5 & 5 & $4-5$ & $1-2$ \\
\hline Lonicera involucrata & Twinberry & 136 & Non-sprouter & $4-5$ & 5 & 4 & $3-4$ & $2-3$ \\
\hline Lotus scoparius & Deerweed & 94 & Non-sprouter & $4-5$ & 5 & 4 & 4 & $3-4$ \\
\hline $\begin{array}{l}\text { Philadelphis lewisii var. } \\
\quad \text { californica }\end{array}$ & Wild mockorange & 74 & Both & $4-5$ & 5 & $3-4$ & $3-4$ & $3-4$ \\
\hline Physocarpus capitatus & Western ninebark & 92 & Not known & $4-5$ & $4-5$ & $3-1$ & 4 & $4-5$ \\
\hline Pickeringia montana & Chaparral pea & 94 & Sprouter & 4 & 5 & $3-4$ & $3-4$ & $1-2$ \\
\hline Populus fremontii & Fremont cottonivood & 51 & Sprouter & 4 & 5 & $3-4$ & $2-3$ & $3-4$ \\
\hline P. tremuloides & Aspen & 51 & Sprouter & $3-4$ & $3-4$ & $2-3$ & $2-3$ & 1 \\
\hline P. trichocarpa & Black cottonwood & 52 & Sprouter & $3-4$ & $4-5$ & $3-4$ & $2-3$ & $3-4$ \\
\hline Potentilla fruticosa & Shrubby cinquefoil & 92 & Non-sprouter & 5 & $4-5$ & $3-4$ & 3 & 3 \\
\hline Prunus emarginata & Bitter cherry & 89 & Sprouter & 3 & 5 & $3-1$ & 3 & $1-2$ \\
\hline P. subcordata & Sierra plum & 89 & Sprouter & $2-3$ & 5 & $2-3$ & $2-3$ & $1-2$ \\
\hline P. virginiana var. demissa & Western chokecherry & 89 & Sprouter & $2-3$ & 5 & $3-4$ & $3-4$ & $1-2$ \\
\hline Purshia glandulosa & Desert bitterbrush & 77 & Both & 3 & $3-5$ & $1-2$ & $1-2$ & $1-2$ \\
\hline$P$. tridentata & Bitterbrush & 75 & Both & $2-3$ & $2-3$ & 1 & $1-2$ & 1 \\
\hline Quercus agrifolia & Coast live oak & 61 & Sprouter & 5 & 5 & $4-5$ & $4-5$ & $3-4$ \\
\hline Q. chrysolepis & Canyon live oak & 61 & Sprouter & 5 & 5 & 5 & 5 & $3-4$ \\
\hline Q. douglasii & Blue oak & 59 & Sprouter & 4 & $4-5$ & $3-4$ & $3-4$ & $1-2$ \\
\hline Q. dumosa & California scrub oak & 58 & Sprouter & $4-5$ & 5 & 4 & $2-4$ & $1-2$ \\
\hline
\end{tabular}


O. garryana

O. kelloggii

O. lobata

Q. vaccinifolia

Q. uislizenii var. frutescens

Rhammus californica

R. croce'a var, ilicifolia

R. purshiana

Rhus diversilolo

$R$. trilobata

Ribes californicum

R. cereum

$R$. divaricatum var. inerme

R. menziesii

$R$. nevadense

R. roezlii

R. sanguineum var. glutinosum

R. speciosum

R. riscosissimum

Rosa californica

Rubus parviflorus

Salix breweri

S. exigua

S. hindsiana

S. lasiandra

S. lasiolepis

S. lemmonii

S. scouleriana

Salvia carnosa

Sambucus caerulea

S. cacrulea var. velutina

S. callicarpa

S. racemosa

Sarcobatus vermiculatus

Shepherdia argentea

Simmondsia chinensis

Solanum umbelliferum

Sorbus sitchensis

Symphoricarpos albus

S. rolundifolius

Tetradymia canescen.s

Umbellularia californica

Vaccinium membranaceum

V. occidentale

V. ovatum

Vitis californica
Oregon white oak

California black oak

Valley white oak

Huckleberry oak

Scrub interior live oak

California coffeeberry

Hollyleaf redberry

Cascara sagrada

Poison-oak

Squaw bush

Hillside gooseberry

Wax currant

White-stemmed gooseberry

Canyon gooseberry

Mountain pink currant

Sierra gooseberry

Pink flowering currant

Fuchsia flowering

gooseberry

Sticky flowering currant

Califomia wild rose

Thimbleberry

Brewer willow

Narrowleaf willow

Valley willow

Yellow willow

Arroyo willow

Lemmon willow

Nuttall willow

Desert sage

Blue elderberry

Hairy blue elderberry

Coast red elderberry

Red elderberry

Greasewood

Silver buffaloberry

Goatnut

Blue witch

Western mountain-ash

Common snowberry

Mountain snowberry

Gray horselorush

California laurel

Thinleaf hucklelserry

Western bluelerry

Evergrcen huckleberry

California wild grape

\begin{tabular}{|c|c|c|c|c|c|c|}
\hline \multirow{2}{*}{$\begin{array}{c}\text { DISCUSSED } \\
\text { ON } \\
\text { PAGE }\end{array}$} & \multirow{2}{*}{$\begin{array}{l}\text { SPROUTER OR } \\
\text { NON-SPROUTER }\end{array}$} & \multicolumn{5}{|c|}{ OVER-ALL BROWSE VALUE* } \\
\hline & & CATTLE & HORSES & SHEEP & GOATS & DEER \\
\hline 61 & Sprouter & $4-5$ & 5 & $4-5$ & $4-5$ & $2-3$ \\
\hline 60 & Sprouter & $2-4$ & $4-5$ & $3-4$ & $3-4$ & $1-2$ \\
\hline 61 & Sprouter & 4 & 5 & $4-5$ & $4-5$ & $3-4$ \\
\hline 61 & Sprouter & $4-5$ & 5 & $4-5$ & $4-5$ & $3-4$ \\
\hline 57 & Sprouter & 4 & 5 & $3-5$ & $3-4$ & $1-2$ \\
\hline 112 & Sprouter & $3-4$ & 5 & $2-4$ & $2-4$ & $2-4$ \\
\hline 113 & Sprouter & $2-3$ & 5 & $2-3$ & $1-2$ & $1-2$ \\
\hline 114 & Not known & $4-5$ & 5 & $4-5$ & $3-4$ & $3-4$ \\
\hline 97 & Sprouter & $3-4$ & $2-3$ & $3-4$ & $3-4$ & $2-3$ \\
\hline 98 & Sprouter & $4-5$ & 5 & 4 & 4 & $3-4$ \\
\hline 74 & & 4 & $4-5$ & 3 & $2-3$ & $3-4$ \\
\hline 74 & Sprouter & $3-4$ & $4-5$ & 3 & $2-3$ & $3-4$ \\
\hline & $\begin{array}{l}\text { Nearly all } \\
\text { Ribes are }\end{array}$ & $4-5$ & $4-5$ & 3 & 3 & $3-5$ \\
\hline 74 & non-sprouters, & 4 & $4-5$ & 3 & 3 & $3-5$ \\
\hline 14 & crown is left & 4 & $4-5$ & $3-4$ & $3-4$ & $3-5$ \\
\hline & after digging the & 4 & $4-5$ & 3 & 3 & $3-5$ \\
\hline & plants will grow & 4 & $4-5$ & 3 & 3 & $3-5$ \\
\hline 74 & Both & 4 & $4-5$ & 3 & 3 & $3-5$ \\
\hline 72 & Both & 4 & $4-5$ & $3-4$ & $3-4$ & $3-5$ \\
\hline 91 & Sprouter & 4 & $4-5$ & $3-4$ & 3 & $3-4$ \\
\hline 92 & Sprouter & 5 & 5 & 4 & $3-4$ & $3-4$ \\
\hline 50 & Sprouter & $4-5$ & $4-5$ & $3-4$ & 3 & 3 \\
\hline 50 & Sprouter & $4-5$ & $4-5$ & $3-4$ & $3-4$ & 3 \\
\hline 50 & Sprouter & $4-5$ & $4-5$ & $3-4$ & 3 & 3 \\
\hline 50 & Sprouter & $4-5$ & 5 & 3 & $2-3$ & 3 \\
\hline 50 & Sprouter & $2-4$ & $4-5$ & $2-3$ & $2-3$ & 3 \\
\hline 50 & Sprouter & 4 & 5 & 4 & 3 & 3 \\
\hline 49 & Sprouter & 3 & 4 & $2-3$ & $2-3$ & 3 \\
\hline 131 & Non-sprouter & $4-5$ & 5 & $3-4$ & 3 & $3-4$ \\
\hline 133 & Sprouter & 3 & $3-4$ & $2-3$ & 2 & $2-4$ \\
\hline 134 & Sprouter & 3 & $3-4$ & $2-3$ & 2 & 2 \\
\hline 135 & Non-sprouter & $3-4$ & 4 & $2-3$ & $2-3$ & $2-3$ \\
\hline 134 & Sprouter & 3 & 3 & $3-4$ & 2 & $1-2$ \\
\hline 68 & Non-sprouter & $3-5$ & 5 & $3-4$ & $3-4$ & 4 \\
\hline 117 & Sprouter & $4-5$ & $4-5$ & $3-4$ & $3-4$ & $3-4$ \\
\hline 96 & Sprouter & $3-4$ & $4-5$ & $2-3$ & 2 & 2 \\
\hline 132 & Sprouter & $4-5$ & $4-5$ & $3-4$ & $2-3$ & $1-3$ \\
\hline 93 & Non-sprouter & $4-5$ & $4-5$ & $4-5$ & $2-3$ & $2-3$ \\
\hline 135 & Sprouter & $3-4$ & 4 & $2-3$ & $2-3$ & $3-4$ \\
\hline 136 & Non-sprouter & $3-4$ & 4 & $2-3$ & 2 & $3-4$ \\
\hline 144 & Non-sprouter & $4-5$ & 5 & $4-5$ & $4-5$ & $3-5$ \\
\hline 70 & Sprouter & $3-4$ & 5 & $3-4$ & $3-4$ & $2-3$ \\
\hline 125 & Not known & 4 & 5 & $3-4$ & $3-4$ & 3 \\
\hline 125 & Not known & 4 & 5 & $3-4$ & $2-3$ & $2-3$ \\
\hline 126 & Sprouter & $4-5$ & 5 & $3-4$ & $3-4$ & $3-4$ \\
\hline 115 & Sprouter & $4-5$ & $4-5$ & $3-4$ & $3-4$ & $3-4$ \\
\hline
\end{tabular}




\section{A Long-Range Suggestion for Browse Improvement}

Most range research has centered on attempts to replace brushy covers with grass; only recently, some research effort has been aimed at reestablishing choice shrubby plants as deer food in critical areas.

None of the improvement methods used on fruit and cereals, such as selection of desirable forms, or hybridization, has been extended to browse species. The grazier still has at his disposal merely the original wild forage plants and a few introduced domesticated herbaccous species. Yet, natural variation and hybrids could be used by plant breeders to improve the local browse crop.

Brushlands also could be improved by world-wide explorations to find superior browse species or species of low inflammability. Explorations of this nature have accounted for most of the best domesticated grasses and cereal plants.

Research of this nature must obviously be set up on a long-time basis, carried out by highly qualified personnel, and be assured of adequate funds. Most satisfactory, perhaps, would be the establishment of a "Foundation for World-Wide Browsc Improvement," in which interested countries would participate and in which research institutes of various countries and the Food and Agricultural Organization of the United Nations or some independent foundation would cooperate in a concentrated effort of range rcsearch. 


\section{Literature Cited}

1. Abrans, L., and R. S. Ferris

1960. Illustrated flora of the Pacific States-Washington, Oregon, and California. Stanford Univ. Press, Stanford, Calif. 4:1-732.

2. Ariold, R. K., L. T. Burchai, R. L. Fenner, and R. F. GRAH

1951. Use of fire in land clearing. Reprint from Calif. Agr. $\mathbf{5}(3-7): 1-23$.

3. BAILEY, L. H

1919. The standard cyclopedia of horticulture. Macmillan Co. New York, 2:603-1200 (see especially page 852).

4. BAKer, F. S., and CommitTeE

1945. Forest cover types of western North America. Rept. of the Com. on Western Forest Types. Soc. Amer. Foresters. Washington:1-35.

ว. BEDELl, T. E., and H. F. HEAdy

1959. Rate of twig elongation in chamise. J. Range Mgmt. 12(3): 116-121.

6. Bentley, J. R., and M. W. Talbot

1951. Efficient use of annual plants on cattle ranges in the California foothills. U. S. Dept. Agr. Circ. 870: 1-52.

7. Bentley, J. R., and L. R. Green

19.54. Stimulation of native annual clovers through application of sulfur on California foothill ranges. J. Range Mgmt. 7(1):25-30.

8. Bentley; J. R., M. W. Talbot, and R. L. Fenner

1957. Conversion of selected brushland areas to grass range in California. U.S. Forest Serv. File Report, Southwest Forest and Range Expt. Sta., Berkeley.

9. Bissell, H. D.

1952. Chemical analyses of some California deer browse. Mimeo. Progress Report. State of California, Dept. of Fish and Game Lab., Berkeley, Calif.:1-32.

10. Bissell, H. D., B. Harris, H. Strong, and F. James

1955. The digestability of certain natural and artificial foods eaten by deer in California. Calif. Fish and Game 41(1):57-78.

11. Bisselt, H. D., and H. Strong

1955. The crude protein variations in the browse diet of California deer. Calif. Fish and Game 41(2):145-55.

12. BisSELL, H. D., and W. C. WEIR

1957. The digestabilities of interior live oak and chamise by deer and sheep. J. Animal Sci. 16(2):476-80.

13. Biswell, H. H., R. D. TABer, D. M. Hedrick, and A. M. SCHULTZ

1952. Management of chamise brushland for game in the north coast region of California. Calif. Fish and Game 38:453-84.

14. Biswell, H. H., A. M. Schultz, and D. W. Hedrick

1953. A possible method of increasing western mountainmahogany on game ranges. Calif. Fish and Game $39(2): 187-89$.

15. Biswell, H. H.

1954. The brush control problem in California. J. Range Mgmt. 7(2):57-62.

16. Biswell, H. H., J. L. Launchibaugh, and A. M. Schultz 1954. Reseeding control burns. Calif. Agr. 8(10): 11 .

17. Black, O. F., and J. W. Kelly

1927. Pseudo ephedrine from Ephedra alata. Am. J. Pharm. 99:748-51.

18. Black, W. H., L. H. TASh, J. M. Jones, and R. J. Kleberg

1949. Comparison of methods of supplying phosphorus to range cattle. U. S. Dept. Agr. Tech. Bull. 981:1-22.
19. Blaisdell, J. P.

1953. Ecological effects of planned burning of sagebrushgrass range on the upper Snake River plains. U. S. Dept. Agr. Tech. Bull, 1075:1-39.

20. Buechner, H. K.

1947. Livestock-antelope relations in west Texas. The Cattleman 34(2):80-84.

21. Burcham, L. T., and F. F. Cameron

1955. An analysis of the use of fire under controlled conditions in California. Calif. Div. of Forestry, Sacramento, Calif. 1-33. Processed.

22. Burcham, L. T.

1957. California range lands. Calif. Div. of Forestry, Dept. of Nat. Resources, Sacramento, Calif.: 1-261.

23. Burcham, L. T., and R. E. Storie

1957. Soil-vegetation survey information in range management planning and administration. Soil Sci. Soc. of Amer. Proc. 21(1): 108-11.

24. Burcham, L. T., and P. B. Furbush

1958. Livestock feed may be made from ground brush. Calif. Livestock News 34(12):36.

25. Burd, J. S.

1919. Rate of absorption of soil constituents at successive stages of plant growth. J. Agr. Research 18:51-72.

26. Cailfonnia Crop and Livestock Reporting Service

1957. Calif. Ann. Livestock Rept., Sacramento, Calif., 129. Multilithed.

27. California, State of

1947, 1957. Soil-vegetation: Glenn, Lake, and Mendocino counties. Dept. of Nat. Resources, Div. of Forestry, in co-operation with Univ, of Calif., and U. S. Forest and Range Expt. Sta. Sacramento and Berkeley.

28. California, State of

1951. Upland soils of Mendocino County. Dept. of Nat. Resources, Div, of Forestry in co-operation with U. S. Dept. of Agr., Forest Service, Calif. Forest and Range Expt. Sta. Map.

29. California State Board of Forestry

1886. First biennial report of the California State Board of Forestry for the years 1885-86, to Governor George Stoneman:1-182. J. D. Young, Supt., State Printing, Sacramento.

30. Califonnia State Boand of Forestry

1888. Second biennial report of the California State Board of Forestry for the years 1887-88, to Governor R. W. Waterman: 1-182. J. D. Young, Supt., State Printing. Sacramento.

31. Chapline, W. R.

1919. Production of goats on far Western ranges. U. S. Dept. Agr. Bull. 749:1-35.

32. Chilson, E. W.

1955. Economic aspects of livestock-big game relations as viewed by a livestock producer. J. Range Mgmt. 8(4): $145-48$.

33. Clark, E. C.

1956. The Great Basin tent caterpillar in relation to bitterbrush in California. Calif. Fish and Game 42(2): $131-42$.

34. Clawson, A. B., and H. MARsh

1919. Oak-leaf poisoning in domestic animals. U. S. Dept. Agr. Bull. 767:1-36. 
35. Cole, G. F

1956. The piong-horn antelope; its range use and food habits in Central Montana with special reference to alfalfa. Mlont. Agr. Expt. Sta. Bull. 516:1-63.

36. Cook, C. IT., and L. E. HARris

1950. The nutritive content of the grazing sheep's diet on the summer and winter ranges of Utah. Utah Agr. Expt. Sta. Bull. 342: I-66.

37. Cook, C. II. A. L. Stoddart, and L. E. Harris

1954. The nutritive value of winter range plants in the Great Basin. Utah Expt. Sta. Bull. 372:1-56.

38. Cook, C. IV

1956. Range livestock nutrition and its importance in the Intermountain Region. Utah State Agr. College, 17th Ann. Fac. Research Lecture: 1-28.

39. CoOper, W. S.

1922. The broad-sclerophyll vegetation of California. Carnegie Inst. Wash., D.C., Publ. 319:1-124.

40. Cornelius, D. R., and M . W. Talbot

1955. Rangeland improvement through seeding and weed control on east slope Sierra Nevada and on southern Cascade Mountains. U. S. Dcpt. Agr., Forest Serv. Agr. Handbook 88:1-51.

41. Cornelius, D. R., and C. A. Graham

1958. Sagebrush control with 2,4-D. J. Range Mgmt. $11(3): 122-25$.

42. Coville, F. V.

1898. Forest growth and sheep grazing in the Cascade Mountains of Oregon. U. S. Dept. Agr., Div. Forestry, Bull. 15:1-14.

43. Cronemiller, F. P., and P. S. Bartiolomew

1950. The California mule deer in chaparral forest. Calif. Fish and Game 3(4):343-65.

44. Cronemiller, F. P.

1953. Deerbrush (sweet birch) in California. U. S. Forest Serv. Region V, San Francisco, Calif.:1-16. Processed.

45. Cronemiller, F. P.

1959. The life history of deerbrush-a fire type. J. Range Mgmt. 12(1):21-25.

46. DAlims, W. G., and G. H. James

1955. Brush control on forest lands. U. S. Forest Serv., Pac. Northwest Forest and Range Expt. Sta. Research Paper 13:1-81. Multigraphed.

47. Dasmann, W. P.

1949. Deer-livestock forage studies on the Interstate Winter Deer Range of California. J. Range Mgmt. 2(4): 206-12.

48. DaYTon, W. A.

1931. Important western browse plants. U. S. Dept. Agr. Misc. Publ. 101:1-213.

49. Dixon, J. S.

1934. A study of the life history and food habits of mule decr in California. Part I-Life history. Calif. Fish and Game 20(3):181-282. Part II-Food habits. Calif. Fish and Gamc 20(4):315-54.

50. Evanko, A. B.

1959. Manipulation of brush cover on California national forests. U. S. Forest Serv., Region 5, San Francisco: 1-70. Processed.

51. FeNNer, R. L., R. K. AnNold, and C. C. BuCK

1955. Area ignition for brush burning. U. S. Forest Serv, Calif. Forest and Range Expt. Sta., Tech. Paper 10: 1-10. Proeessed.

52. Fentel, C. M., and H. R. LEACH

1950). Food habits of a California decr herd. Calif. Fish and Game 36(3):235-40.

53. Frikis, C. M., and H. R. Liscil

1952. The prong-hom antelope of California. Calif. Fish and Came $38(3): 285-93$.
54. Furbush, P. B., C. E. Carlson, and N. Dalporte

1960. Cattle feeding trials using pelleted brush roughage. Range Improvement Studies. Calif. Div. of Forestry $4: 1-13$.

55. Gardner, R. A., and A. E. Wieslander

1957. The soil-vegetation survey of California. Soil Sci. Soc. of Am. Proc. 21(1):103-05.

56. Garrison, G. A.

1953. Effects of clipping on some range shrubs. J. Range Mgmt. 6(5):309-17.

57. Gilbert, F. A.

1951. The place of sulfur in plant nutrition. Bot. Rev. 17: 671-91.

58. Girola, C. D.

1925. Plantas toxicas para animales. Argentine Min. Agr. Circ. 472:1-19.

59. Gleason, C. H.

1953. Indicators of erosion on watershed land in California. Trans. Am. Geophys. Union 34(3):419-26.

60. Gordon, A., and A. W. Sampson

1939. Composition of common California foothill plants as a factor in range management. Calif. Agr. Expt. Sta. Bull. 627:1-95.

61. Gullbert, H. R., and G. H. Hart

1951. California beef production. Calif. Agr. Expt. Sta. Ext. Serv. Manual 2, Section 3:1-28.

62. Hagen, H. L.

1953. Nutritive value for deer of some forage plants in the Sierra Nevada. Calif. Fish and Game 39(2):163-75.

63. Hall, H. M., and H. S. Yates

1915. Stock poisoning plants of California. Calif. Agr. Expt. Sta. Bull. 249:217-47.

64. Hall, H. M., and T. H. Goodspeed

1919. A rubber plant survey of Western North America. Univ. Calif. Publ. Bot. 7:159-278.

65. Hart, G. H., H. R. Guilbert, and H. Goss

1932. Seasonal changes in the chemical composition of range forage and their relation to nutrition in animals. Calif. Agr. Expt. Sta. Bull., 543:1-62.

66. Hart, G. H., H. R. Gullbert, K. A. Wagnon, and H. Goss

1947. Acorn calves. Calif. Agr. Expt. Sta. Bull. 699:1-24.

67. Hatton, J. H.

1913. Eradication of chaparral by goat grazing. Lassen Natl. Forest. U. S. Dept. Agr. Review of Forest Serv. Invest. 2:25-28.

68. Hellmers, H.

1940. A study of monthly variations in the nutritive value of several natural winter deer foods. J. Wildlife Mgmt. 4(3):315-25.

69. Hesselman, $\mathrm{H}$.

1918. Soil nitrification in relation to forest production. Skogsvardsforeningens Tidskrift:104 pp. Reviewed in: J. Forestry 17:69-73.

70. HollenbeCK, H. D., and J. MuIR

1951. Converting brushland to grass in Monterey County, California. Calif. Agr. Ext. Serv.:1-7. Processed.

71. Hormay, A. L.

1943. Bittcrbrush in California. U. S. Forest Serv., Calif. Forest and Range Expt. Sta., Forest Rescarch Note 34:1-13. Mimco.

72. Honmax, A. L.

1943. A method of estimating grazing use of bitterlorush. U. S. Forest Serv., Calif. Forest and Range Expt. Stil. Rescarch Note 35:1-4. Mimeo.

73. Honton, J. S., and C. J. Kinaebel.

1955. Development of vegctation after firc in the chamise chaparral of southom Calif. Ecology 36:244-62.

74. Hun13Aา1, R. L.

1956. The effects of plant competition upon the growtl and survival of bitterbrush secrlings. U. S. Forest 
Serv., Calif. Forest and Range Expt. Sta. Forest Research Note 109:1-5. Mimeo.

75. Hubbard, R. L.

1958. How water bath and thiourea break dormancy of wedgeleaf ceanothus seed. U. S. Forest Serv., Calif. Forest and Range Expt. Sta. Forest Research Note 143:1-4. Processed.

76. Hubband, R. L., E. C. Nond, and L. L. Brown

1959. Bitterbrush reseeding- a tool for the game range manager. U. S. Forest Serv. Pac. Southwest Forest and Range Expt. Sta. Berkeley Misc. Paper 39:1-14. Processed.

77. Hubbard, R. L., and H. R. Sanderson

1960. Herbage production and carrying capacity of bitterbrush. U. S. Forest Serv. Pac. Southwest Forest and Range Expt. Sta., Reseach Note 157:1-6. Processed.

78. Hunter, G. N

1945. Methods of determining trends in big game numbers and range conditions. Trans, of 10th North Am. Wildlife Conf.:234-41.

79. Imperial Agricultural Bureaux

1947. The use and misuse of shrubs and trees as fodder. Aberystwyth, Wales. Joint Publ. 10:1-231. (See especially pp. 186-231).

80. JENSEN, H. A.

1947. A system for classifying vegetation in California. Calif. Fish and Game 33(4):199-266.

81. Jepson, W. L.

1925. Flowering plants of California. Assoc. Students Store, Univ. Calif., Berkeley: 1-1238.

82. Julavder, O.

1937. Utilization of browse by wildlife. Trans. of 2nd North Am. Wildlife Conf.:276-87.

83. Julander, O.

1955. Deer and cattle range relations in Utah. Forest Sci. l(2): 130-39.

84. JULANDER, O.

1958. Techniques in studying competition between big game and livestock. J. Range Mgmt. 11(1): 18-21.

85. Lassen, R. W., C. M. Ferrel, and H. Leach

1952. Food habits, productivity and condition of the Doyle mule deer herd. Calif. Fish and Game 38(2):211-24.

86. LEACH, H. R.

1956. Food habits of the Great Basin deer herds of California, Calif. Fish and Game 42(4):243-93.

87. LeACH, H. R., and J. L. Hiehle

1957. Food habits of the Tehama deer herd. Calif. Fish and Game 43(3): 161-78.

88. LeONard, O. A.

1956. Studies of factors affecting the control of chamise (Adenostoma fasciculatum) with herbicides. Weeds 4(3): $241-54$.

89. Leonard, O. A., and C. E. Carlson

1955. Chemical brush control techniques on California rangelands. (Rev.), Calif. Div. of Forestry, Sacramento, Calif.: 1-12. (Processed).

90. Leonard, O. A., and IV. A. Harvey

1956. Chemical control of woody plants in California. Calif. Agr. Expt. Sta. Bull. 755:1-40.

91. Leopold, A. S., T. Riney, R. McCain, and L. T. Travis, Jr.

1951. The Jawbone deer herd. Calif. Div. Fish and Game. Game Bull. 4:1-139.

92. Longhurst, W. M., S. Leopold, and R. F. DasmanN

1952. A survey of California deer herds, their range and management problems. Calif. Dept. Fish and Game. Game Bull. 6:1-136.

93. Longhurst, W. M., and W. E. Howard

1956. Managing deer on private land. Calif. Agr. I0(5):4, 10.
94. Love, R. M., and B. J. Jones

1952. 1mproving California brush ranges. Calif. Agr. Expt. Sta. Circ. $371: 1-38$.

95. MACKIE, WV. W.

1903. The value of oak leaves as forage. Calif. Agr. Expt. Sta. Bull. 150:1-21.

96. Madson, B. A.

1952. University of Califomia College of Agriculturerange research program. Assembly Interim Com. on Agr. Public lands, grazing and forest practices, first prog. rept: $32-34$

97. Mankins, J. V.

1956. The Barton's Flat deer herd. Calif. Dept. of Fish and Game:1-50. Mimeo.

98. Marion, P. T., C. E. Fisher, and E. O. Robinson

1959. Feed ground mesquite to fattening steers. Western Livestock J., Nov.:24-25.

99. Marsh, C. D., A. B. Clawison, and J. F. Couch

1923. Greasewood as a poisonous plant. U. S. Dept. Agr. Circ. 279:1-4.

100. MArsh, C. D

1929. Stock-poisoning plants of the range. U. S. Dept. Agr. Bull. 1245:1-75.

101. Martin, W. E., and L. J. Berry

1954. Will range fertilization pay? Calif. Ext. Serv.:1-31. Processed.

102. McAllister, H. M.

1923. California's large game animals. Calif. Fish and Game 9(2): 1-49.

103. MCLEan, D. D.

1944. The prong-horned antelope of California. Calif. Fish and Game 30(4):221-41.

104. McMinn, H. E.

1939. An illustrated manual of California shrubs. J. W. Stacey, Inc, San Francisco, Calif.:1-689.

105. Mirov, N. T., and C. J. Kiraebel

1936. Collecting and handling seeds of wild plants. U. S. Forest Serv. Calif. Forest and Range Expt. Sta., Civilian Cons. Corps Publ. 5:1-42.

106. Mirov, N. T.

1950. Simmondsia. Chemurgic digest 2(7):7-9.

107. Mormison, F. B.

1937. Feeds and feeding. The Morrison Publ. Co., 1thaca, N.Y.: 1-1050 (see especially p. 109).

108. Munz, P. A., and D. D. KecK

1959. A California flora. Univ. Calif. Press, Berkeley and Los Angeles: 1-1681.

109. Murneek, A. E.

1932. Growth and development as influenced by fruiting and seed formation. Plant Physiol. 7:79-90.

110. NeLson, E. W.

1925. Status of the prong-horned antelope, 1922-24. U. S. Dept. Agr. Bull. 1346:1-64.

111. Nord, E. C.

1956. Quick testing bitterbrush seed viability. J. Range Mgmt. 9(4):193-94.

112. Nord, E. C., and J. E. Whitacre

1957. Germination of fourwing saltbush seed improved by scarification and grading. U. S. Forest Service, Calif. Forest and Range Expt. Sta. Research Note 125: 1-5.

113. Nord, E. C.

1959. Bitterbrush ecology-some recent findings. U. S. Forest Serv. Calif. Forest and Range Expt. Sta. Research Note 148: 1-8. Processed.

114. Offord, H. R., C. R. Quick, and V. D. Moss

1958. Blister rust control aided by the use of chemicals for killing ribes. J. Forestry 56(1):12-18.

115. Pamiel, L. H.

1911. A manual of poisonous plants, chiefly in eastern North America, with brief notes on economic and 
medicinal plints. The Torch Press, Cedar Rapids, Iowa: $1-977$.

116. Pearson, B. O

1957. Bitterbrush seed dormaney broken with thiourea. J. Range Mlgt. 10(1):41-42.

117. Pechanec, J. F., G. Stewart, A. P. Plummer, J. H. Robertson, and C. H. Hull, Jk.

1954. Controlling sagebrush on grasslands. U. S. Dept. Agr. Farmers' Bull. 2072:1-36.

118. Petersox, R. A.

1953. Comparative effect of seed treatments upon seedling emergence in seven brotvse species. U. S. Forest Serv., Northern Rocky Mountain Forest and Range Expt. Sta. Research Note 114:1-11. Processed.

119. Plumier, A. P., R. L. Jensen, and H. D. Stapley

1957. Job completion report for game forage revegetation project W-82-R-2. Utah State Dept. Fish and Game: 1-128. Processed.

120. Reynolds, H. G., and A. W. Sampson

1943. Chaparral crown sprouts as browse for deer. J. Wildlife Mgt. 7(1): 119-23.

121. Riondan, L. E.

1957. Some results of a ten-year study of deer-livestock eompetition for range forage. Colo. Dept. Game and Fish, Denver:1-14. Mimeo.

122. Roy, D. F

1960. Deer browsing and Douglas-fir seedling growth in Northwestern California. J. Forestry 58(7):518-22.

123. Sampson, A. W., and W. A. Dayton

1913. Relation of grazing to timber reproduetion, Shasta National Forest. U. S. Dept. Agr., Review of Forest Serv, Invest. 2:18-24.

124. SaMipson, A. W.

1919. Effect of grazing upon aspen reproduction. U. S. Dept. Agr. Bull. 741: 1-29.

125. Sanipson, A. W., and H. E. Malmisten

1942. Stock-poisoning plants of California. Calif. Agr. Expt. Sta. Bull. 593:1-90.

126. Sampson, A. W.

1944. Plant succession on burned chaparral lands in northern California. Calif. Agr. Expt. Sta. Bull. 685:1144.

127. Sampson, A. W.

1952. Range management, principles and practices. John Wilcy \& Sons, Inc., New York: 1-570.

128. Sampson, A. W., and L. T. Burcham

1954. Costs and returns of range improvement in northern California. Calif. Div. of Forestry, Range Improvement Studies 1: 1-41.

129. Sampson, A. W., and A. M. Schultz

1956-1957. Control of brush and undesirable trees. Unasylva 10(1): 19-29; II. Unasylva 10(3):117-29; III. Unasylva 10(4):166-82, 1956; IV. Unasylva 11(1): $17-25,1957$.

130. Sanison, A. W., and C. H. Gleason

1957. Change in burning technology. J. Range Mgmt. 10 (3): 103 .

131. SCHNEIDER, A.

1912. Pharmacal plants and their eulture. Calif. State Bd. Forestry Bull. 2: 1-175.

132. SCHULT\%, A. M., and H. H. BisweLL

1952. Competition between grasses reseeded or burned brushlands in California. J. Range Mgmt. 5:338-45.

133. Schult\%, A. M., J. L. I aunchilaugh, and H. H. Biswell

19.5.5. Relationship between grass density and brush secdling survival. Ecology $36(2): 226-38$.

131. SHANT\%, H. I.

1911. Natural vegetation as an indieator of the capalsilities of lands for crop production in the Creat Plains area. U. S. Dept. Agr., Bur. Plant Indus. Bull. 201:1-100.
135. Shantz, H. L.

1947. Fire as a tool in the management of the brush ranges in California. Calif. Dept. of Nat. Resourees, Div. of Forestry, Sacramento: 1-156.

136. SмITH, A. D.

1950. Sagebrush as a winter food for deer. J. Wildlife Mgmt. 14(3):285-89.

137. Sмітн, J. G

1900. Fodder and forage plants, exclusive of the grasses U. S. Dept. Agr., Div. Agros, Bull 2. Rev. ed.:1-86.

138. Stanley, P. C.

1920. Trees and shrubs of Mexico. U. S. Natl. Herbarium 23, Part 3. (See page 517).

139. Stoddart, L. A., and D. I. Rasmussen

1945. Deer management and range livestoek production. Utah Agr. Expt. Sta. Circ. 121:1-17.

140. Stoddart, L. A.

1950. The stockman: his importanee in management of lands and big game. Trans. of 15th North Am. Wildlife Conf.: $83-93$.

141. Stoddart, L. A., and A. D. Smith

1955. Range management. McGraw-Hill Book Co., Inc. New York: 1-433.

142. Storie, R. E., and W. W. Weir

1953. Generalized soil map of California. Calif. Agr. Expt. Sta. Ext. Ser., Manual 6:1-47.

143. Sweeney, J. R.

1956. Responses of vegetation to fire. University of Calif. Press. Berkeley, Calif. Publ. in Botany 28(4): 143250 .

144. TABER, R. D.

1956. Deer nutrition and population dynamics in the North Coast range of California. 21st Am. Wildlife Conf. Trans.: 159-72.

145. Taber, R. D., and R. F. Dasmann

1958. The black-tailed deer in the chaparral. Calif. Dept. of Fish and Game. Game Bull. 8:1-163.

146. UpCHURCH, M. L.

1954. Economic aspects of livestock-big game relationships. J. Range Mgmt. 7(6):245-49.

147. U. S. Census of Agriculture

1950. Vol. 1. Counties and state, economic areas, Part 33, 1952. U. S. Gov't Printing Off., Washington, D.C.: $1-296$.

148. U. S. Fonest Service

1948. Woody plant seed manual. U. S. Dept. Agr. Mise. Publ. 654:1-416.

149. U. S. Forest Service, Calif. Forest and Range Expt. Sta.

1942. An analysis of national forest range problems in northern California. Berkeley, Calif.:1-49. Proeessed.

150. VANSELL, G. H.

1926. Buckeye poisoning of the honey bee. Calif. Agr. Expt. Sta. Cire. 301:1-12.

151. VerhMEYER, F. J

1949. Runoff, erosion and soil moisture from vegetated and burned plots in typical brush areas in California. In: Miller, M. D. (Editor) What we know about brush. land management in California:8-14. Agr. Ext. Service, Univ. of Calif. Mimeo.

152. VeHIMEYLi, F. J.

1953. Wasted aeres. Univ. Bull. Berkelcy:2(1):3.

153. Voonnies, E. C., and A. B. KougmaN

1928. Economic aspeets of the bcef eattle industry. Calif. Agr. Expt. Sta. Bull. 461:1-128.

154. Voomines, E. C., and W. E. SCIINEIDEI

1929. Economic aspects of the sheep inclustry. Calif. Agr. Expt. Stil. Bull. 473:1-173. 
155. WARD, G. H.

1953. Artemisia, Section Seriphidium, in North America, a cytological study. Contrib. from Dudley Herbarium. Nat. Hist. Mluseum of Stanford Univ., Stanford, Calif. Volume 4, Part 6:155-205.

156. Watkins, V. M., and H. DE Forest

1941. Growth in some chaparral shrubs in California. Ecology 22:79-83.

157. Weaver, J. E., and F. E. Clements

1938. Plant ecology. McGraw-Hill Book Co., New York, N.Y.: 1-601.

158. Weeks, D. A., A. E. Wieslander, H. R. Josephson, and C.

L. HILL

1943. Land utilization for the northern Sierra Nevada. Calif. Agr. Expt. Sta. Spec. Publ., Giannini Foundation of Agr. Econ. : 1-127.

159. Wieslander, A. E., and H. A. Jensen

1946. Forest areas, timber volumes, and vegetation types in California. U. S. Forest Serv., Calif. Forest and Range Exp. Sta. Forest Survey Release 4:1-66.
160. Wieslander, A. E., and R. E. Storie

1952. The vegetation-soil survey in California and its use in the management of wildlands for yield of timber, forage, and water. J. Forestry 50:521-26.

161. Wieslander, A. E., and C. H. Gleason

1954. Major brushland areas of the coast ranges and SierraCascade foothills of California. U. S. Forest Serv., Calif. Forest and Range Expt. Sta. Misc., Paper 15: $1-9$.

162. Woodman, H. E., D. B. Norman, and M. H. French

1931. Nutritive value of pasture. VII. The influence of the intensity of grazing on the yield, composition and nutritive value of pasture herbage, Pt. 3. J. Agr. Sci. 21:267-321.

163. WOOLFOLK, E. J.

1959. Improving California deer ranges to meet increasing demands for hunting. Proc. Soc. Amer. Foresters: $170-72$. 



\section{Index}

Page numbers in bold type refer to species descriptions, including distribution, economic value, browse rating.

Abies, 144

concolor, 144

Acer, 99

circinatum, 99

glabrum, 4, 99

macrophyllum, 100

negundo var. californicum, 100

Aceraceae, $98-100$

Adenostoma, 27, 38, 82

fasciculatum, 3, 15, 16, 20, 83

sparsifolium, 82 map, 83

Aesculus californica, 3, 4, 10, 18, 101

nap, 99

Agropyron, 6

inerme, 33

Alder, see Alnus

Oregon, see $A$. oregona

red, see $A$. orcgona

white, see A.rhombifolia

Alders, see Alnus

Allscale, see Atriplex polycarpa

Alnus, 4, 52

oregona, 53

rhombifolia, 52

melanchier, 8

alnifolia, $5,11,81$

seed germination, 2.5

utahensis, 33

Anacardiaceae, 97-98

Antelope, prong-horn, 13-15

diet, 16-17, 20-21

grazing-forage competition, $16-17$

population, 14

range (map), 14

Arbutus, 127

menziesii, 3, 127

map, 125

Arctostaphylos, 3, 4, 5 (illus.), 15, 27, 122-23

canescens, 124

glandulosa, 124

manzanita, 124

map, 123

mariposa, 4 (illus.), 10

patula, 5 (illus.), 123

Aristida, 7

Artemisia, 6, 15, 38, 137

arbuscula var. nova, 6, 139

californica, $6,15,140$

cana 17,140

frigida, 17

species, primary, 138

species, secondary, 140

spinescens, 140

spraying of, 29

tridentata, $6,16,17,138$

protein digestion coefficient, 84

Ash, see Fraxinus

Arizona, see $F$. velutina

family, see Oleaceae

Modesto, see $F$. velutina

Oregon, see $F$. Latifolia

Aspen, see Populus tremuloides

quaking, see $P$. tremuloides

Aspens, see Populus

Atriplex, 6, 7, 64

canescens, 64

map, 64

seed germination, 26 confertifolia, 16, 65

map, 64

grazing, 35,38

nuttallii var. falcata, 67

polycarpa, 66

semibaccata, 67

Avcna, 3

barbata, 2 (illus.), 18,

Baccharis, 142

pilularis, 142

pilularis var. consanguinea, 6,142 spraying of, 29

viminea, 143

Balsam root, see Balsamorhiza

Balsamorhiza, 16

Basin tent caterpillar, sce Malacosoma fragilis

Bay, California, see Umbellularia californica

Bearberry, see Lonicera involucrata

Bear brush, see Garrya fremontii

Bear-clover, see Chamaebatia foliolosa

Bear-mat, sce Chamaebatia foliolosa

Beech family, see Fagaceae

Beetles, see Clirysolina

Betula, 53

glandulosa, $\mathbf{5 4}$

occidentalis, $\mathbf{5 4}$

Betulaceae, 52-55

Biological control of brush, 29-30,32

advantages, 31

by animals, 29-30

by insects, 29

measurement of results, 32-33

Birch, see Betule

family, see Betulaceae

mountain, see $B$. occidcntalis, $B$. glandulosa

red, see B. occidentalis

resin, see $B$. glandulosa

water, see $B$. occidcntalis

Bitter aloes, see Cowania mcxicana var. stansburiana

Bitterbrush, see Purshia, P. tridentata, Cowania mexicana var. stansburiana

desert, see $P$. glandulosa

protcin digestion coefficient, 84

waxy, see $P$. glandulosa

Bitterbrush-sagebrush association, 6 (illus.)

Black bush, see Colcogyne ramosissima

Blackhaw, western, see Cratuegus douglasii

Blueberry, see Vaccinium

swamp, see V. occidcntale

western, see $V$. occidcntale

Bluc brush, see Ceanothus integcrimus

Bluegrass, see Poa

Blue witch, see Solanum umbellifcrum

Bouteloua, 7

Box family, see Buxaceae

Boxelder, California, see Acer ncgundo var. californicum

Brome, see Bromus

Bromus, 3, 6

mollis, 18

rigidus, 18

Broom, chaparral, see Bacclaris pilularis var. consanguinca

Broom snakeweed, see Gutierrczia sarothrae

Browse

animal preferences for, $10,35,38$

chemical composition, 18-20 definition, 1

description of individual species, 44-145

families with lesser browse value (table), 39

ground up for fced, 3.3

management studies, 3.3

nutritional values, $17-18$

palatability, $35,37-38$

principal families, 38

ratings, $38-39,146-48$

utilization, 32-33, 35, 38

winter browse specics, 20-21

Browsing for brush control, 29-30

advantages, 31

disadvantages, 31

Brusl

definition, 1

desirable control, acreage, 22

harvesting for feed, 33

on foothill ranges, 23

planting, 25

Brush control

by browsing, 29-30

chemicals, 28

fire, $27-28$

insects, 29

mcchanical, 28, 30

reseeding with grass, 30,31

costs, 23, 28, 32

foothill area, 22,23

selection of method, 30-31

Brushland

cost of conversion to range land, 32

improvement, 26-32

suitability for range improvement, 23

Brushland communities

distribution map, 3

Buck brush, see Ceanothus cuneatus

Buckeye, California, see Aesculus californica

Buckthorn family, see Rhamnaceae

Buckthorns, see Rlammus

Buckwheat

California, see Eriogonum fasciculatum

family, see Polygonaceae

wild, see Eriogonum

Buffaloberry, silver, see Shcplierdia argentea

Bur clover, see Medicago hispida

Burns, controlled, 27-28

acreage, 1945-1961, table, 27

advantages, $30-31$

condition afterward, 23, 24, 26

converted to permanent grazing land, 23

costs, $27-28$

danger of escape fires, 27

disadvantages, 31

grazing capacity, 23

heavy burning, 27

light burning, 27

reseeding, 23, 26

Burrobrush, white, see Hymenoclea salsola

Burro-weed, see Franseria dumosa

Buxaceae, 96-97

Cacao family, see Sterculiaceae

Cactoblastis cactorum

control of Opuntia spp., 29

Calocedrus decurrens, 144

Caltrops family, see Zygophyllaceae

Caprifoliaceae, 38, 132-37

Caraway, false, see Carum 
Carum, 16

Casciara, see Rhamnus purshiana vagrada, see $R$. purshiana

Cashew family, see Anacardiaceae

Castanopsis sempertirens, 61

Cittlo, 9-11

browsing behavior, 9-11

browse preference, table, 10

control of brush by $29-31,33$

dict, 20-21

distribution, map, 9

Sec also Livestock

C.canotluus, 2 (illus.), 4, 16, 38, 102

blichlossom, see C. thyrsiflorus

cordulatus, $5,18,108$

map, 106

cuneatus, 3,4 (ilhus.), 10, 18, 20, 105

deerbnush, see $C$. integerrimus

diversifolius, 111

foliosus, 111

incanus, 111

integerrimus, 4, 5, 103

Lemon, see $C$. lemmoni

lemmonii, 109

lencodermis, 3,4 (illus) $10,18,106$

littleleaf, see C. parvifolius

parvifolius, 112

prostratus, 16,109

redstem, see C. sanguineus.

seed germination, 25

snowbrush, see $C$. velutinus

snowbush, see $C$. velutinus.

species, primary, 103-09

species, secondary, 109-12

thyrsiflorus, 110

utilization, 33

trailing, see $C$. diversifolius

varnishleaf, see $C$. vclutinus var. laevigatus

velutinus, 5 (illus.), 111

browsing, 33

seed germination, 25

velutinus var. laevigatus, 111

velutinus var. lorenzenii, 111

wavyleaf, see $C$. foliosus

wedgeleaf, see $C$. cuncatus

Celtis donglasii, 62

inap, 5.5

Cercis; 93

occidentalis, $3,4,93$

Cercocarpus, 38,78

betuloides, $3,4,11,15,16,78$

grazing, 38

regeneration, 26

ledifolius, $5,16,80$

browsing, 3.3

inap, 79

montanus, 79

browsing, 3.3

Chamachatia, 87

grazing, 3.5

foliolosa, $5,15,87$

map, 86

Chamise, see Adenostome

Chaparral, 1, 2, 3 (illus.), 3-5

definition, 3

foxthill range area, 22, 23 (tal)le's)

regencration, 5

stability, 4

irsefulness, 5

See also Timber chauparral

Chaparral breom, see Baccharis pilularis var comsansuinea

dwart, sce. Bacclaaris pilularis

Ciliparral lorush, sec Bacelaris pilutaris var. remsernguine

(iliniculs for Jumsli control, 28-29), 31

advantise's, 28,31

atpplication, 29)

disidflvantigges, 31 growth regulating herbicides, 28

hormones, 28

Chenopodiaceae, 38, 64-70

Cherries, see Prunus

Cherry, see Prunus

bird, see $P$. emarginata

bittcr, see $P$. emarginata, $P$. virginiana var. demissa

narrowleaf, see $P$. emarginato

pin, see $P$. emarginata

quinine, see $P$. emarginuta

western choke, see $P$. virginiana var, demissa

wild, see Prunus

Chess, soft, see Bromus mollis

Clitopsis linearis, 7

Chinguapin, 61, 62

Chittimwood, see Rhamnus purshiane

Christmas berry, see Heteromeles arbutifolia

Clorysolina

control of Klamath weed, 29

Clurysotluamnus, $6,16,38, \mathbf{1 4 0}$

nauseosus, 7,141

stenophyllus, 142

teretifolius, 141

iscidiflorus, 142

map, 141

Cinquefoil, shrubby, see Potentilla fruticosa

Clidemia hirto

controlled by insects, 29

Cliffrose, see Cowania, C. mexicana var. stansburiana

Coffeeberry, California, see Rhamnus californica

Coleogyne, 86

ramosissima, 86

Competition, grazing-forage, 15-18, 21

definition, 15

livestock and antelope, 16-17

livestock and deer, 15-16

livestock and other big game, 17

Compositae, 16, 38, 137-144

Conifers, 144-145

deer damage, 15

minor, foothill region, 22,23

Controlled burns and burning, see Burns, controlled

Cornaceae, 119-21

Cornus, 119

muttallii, 120

sessilis, 121

stolonifera, 120

map, 121

seed germination, 25

stolonifera var. californica, 120

seed gcrmination, 25

Corylus, $\mathbf{5 5}$

cornuta var. californica, $\mathbf{5 5}$

Cottonwood, see Populus

black, see $P$. trichocarpe

common, sec $P$. fremonti

Fremont, sce $P$. fremontii

Cottonwoods, sce Populus

Cow lettuce, see Atriplex polycarpa

Couania, 85

grazilig, 35

mexicana var stansburiana, 16, 33, 85

Coyote bush, see Baccharis pilularis var. con sanguince

dwarf, see Baccluaris pilularis

Crataegus douglasii, 93

Creosote bush, sec Larrea divaricata

Cinpressace'ac, 44-40

Ciurrant, se' Ribes

hairy, sec $R$. viscosissimum

indian, see Symplioricarpos

mountain pink, sce $R$. nevadense

pink flowering, see: $R$. sanguincum var, glutinosim sandbox, see $R$. viscosissimum

sticky flowering, see $R$. viscosissimum

wax, see $R$. cereum

Currants, see Ribes

Cypress family, see Cupressaceae

Deciduous species

chemical composition, 18, 19 (graphs)

Deer, 11-13

browse ratings for, 146-48

bucks killed in 1955 (map), 11

bucks killed 1927-1960 (graph), 12

California mule, 16

Columbian black-tailed, 16

competition with livestock for forage, 15 16,33

control of brush by, 29-30,31

deer tag sales (graph), 12

dict, 16, 20-21

Inyo mule, 16

population, 12-13

correlation with overgrazing, 9

population excess, 17

Rocky Mountain mule, 16

Southern mule, 16

Deerbrush, see Ceanothus integerrimus

Deemut, see Simmondsia chinensis

Deer range, 13 (illus.)

improvement, $16,25,26,29-30$

Deerweed, see Lotus, L. scoparius

Defoliation

by animals, $29-30$

by insects, 29-30

Dendromecon rigida, 71

Desert shrub brushland community, 2, 7

Desert-willow, see Clilopsis linearis

Diablo clay, 8

Digger pine, see Pinus sabiniana

Distichlis stricta, 7

Dogberry, American, see Cornus stolonifera

Dogwood, see Cornus

American, see C. stolonifera

blackfruit, sec $C$. sessilis

creek, see C. stolonifera var. californica

family, see Cornaceae

mountain, see C. nuttallii

pacific, see C. nuttallii

redosier, see $C$. stolonifera

western, see $C$. nuttallii

Dogwoods, see Cornus

Douglas fir, see Pseudotsuga menziesi

Dulzura stony sandy loam, 8

Echinocereus engelmannii, 7

Elaeagnaceae, $117-18$

Elderberries, see Sambucus

Elderberry, see Sambucus

blue, see S. caerulea

coast red, see S. callicarpa

hairy bhue, see $S$. caerulea var. velutina red, see $S$. racemosa

Elk, 15, 17

tule, 17

Roosevelt, 17

Elm family, sce Ulmaceac

Elymuss, 6

Ephedra, 47

grcen, sce E. eiridis

Nevadin, see E. nevadensis

nevadensis, 48

virid is, 48

Ephedracear, 46-48

Ericaceac, 121-28

Eriodictyon, 4

culifornicum, 3, 4, 21, 129

map, 130

Eriogonum, 4

fasciculatum, 6, 63

fasciculatum var. flavoviride, 63 
Eriogonum, cont.

fasciculatum var. foliolosum, 63

fasciculatum var. polifolitum, 63

Erodium, 3

cicutarium, 2 (illus.)

Eurotia, 38, 67

lanata, 7,67 map, 64

Evergreen species

chemical composition, 18, 19 (graphs)

Fagaceae, 38, 55-62

Feed pellets, 33

Fences, 17

Fern-bush, see Chamaebatia foliolosa

Fertilization, see Fertilizers; Germination

Fertilizers, 31

Fescue, see Festuca

foxtail, see $F$. megalura

Festuca, 3,6

megalura, 18

Fever bush, California, see Garrya fremontii

Filaree, see Erodium

redstem, see $E$. cicutarium

Filberts, see Corylus

Fir, white, see Abies concolor

Fire, see Burns, controlled

Firs, see Abies

Flannel bush, see Fremontia californica, Garrya fremontii

Foliage palatability, 35,38

Food preferences, see palatability of plants

Foothill range, 1, 2, 18

acreage, $22-23$

grazing management, 31

increased grazing capacity, 24

soil, 22

Fouquieria splendens, 7

Franseria dumosa, 7

Fraxinus, 128

latifolia, 128

velutina, 129

map, 128

Fremontia, see Fremontia californica

Fremontia californica, 4, 116

Galleta, big, see Hilaria rigida

Game

competition for forage, $15-17$

reliance on browse, $9,11,38$

Game ranges

management studies, 33

restoration, 26

Garrya fremontii, 118

map, 116

Garryaceae, 118-19

Gaultheria, 126

shallon, 126

Germination, 25

Glossary of scientific terms, illustrated, 36-37

Gnetum family, see Ephedraceae

Goatnut, see Simmondsia chinensis

Goats, 9

control of brush by, 29-30, 31, 29 (illus.), 38

diet, 20

rating of browse plants for, 38

Goldenrod, rayless, see Chrysothamnus

Gooseberries, see Ribes

Gooseberry, see Ribes

canyon, see $R$. menziesii

fuchsia flowering, see $R$. speciosum

hillside, see R. californicum

Sierra, see $R$. roezlii

white-stemmed, see $R$. divaricatum var. inerme

Goosefoot

family, see Chenopodiaceae genera, primary, 64

genera, secondary, 68

Gorse, see Ulex curopaeus

Gramagrass, see Bouteloua

Gramineae

grazing, 38

Grape

California wild, see Vitis californica

family, see Vitaceae

Grass, conversion to, 1, 3, 8, 21-22

Grass-woodland, see Woodland-grass brushland community

Grasses

chemical composition, 18, 19 (graphs)

reseeding with, 30,31

Grayia, 68 spinosa, 7, 68 map, 63

Grazing

capacity on burned over areas, 23, 24

for brush control, 29-30

management, 31-32

preferences by animals, 35, 38

Greasebush, see Ceanothus cuneatus

Grcasewood, see Sarcobatus, S. vcrmiculatus Adenostoma fasciculatum, Larrea divaricata

Grossularia, see Ribes

Gutierrezia sarothrae, 7

Hackberry, western, see Celtis douglasii

Haplopappus squarrosus, 6

Hardtack, see Cercocarpus betuloides

Hay, alfalfa

protein digestion coefficient, 84

Hazelnut, Califormia, see Corylus cormuta var californica

Hazelnuts, see Corylus

Heatlier family, see Ericaceac

Heliantheae, 16

Henneke stony clay, 7,8

Herbicides, see Chemicals

Heteromeles, 92

arbutifolia, 20,92

Hilaria rigida, 7

Hippocastanaceae, 101

Hog-fennel, see Lomatium

Holly, California, see Heteromeles arbutifolia

Honey mesquite, see Prosopis clilensi.

Honeysuckle, see Lomicera

family, see Caprifoliaceae

family, primary species, 132

family, secondary species, 136

fly, see L. involucrata

Hop-sage, see Grayia spiny, see G. spinosa

Hormones, see Chemicals

Hornbrush, see Ceanotlaus cuneatus

Horscbrush, see Tetradymia

gray, sec $T$. canescens

little, see $T$. glabrata

shortspine, see $T$. spinosa

Horsebrushes, see Tetradymia

Horsebush, see Grayia spinosa

Horse-chestnut family, see IIippocastanaceae

Horses

rating of browsc plants for, 38

Huckleberry, see Vaccinium

evergreen, see $V$. ovatum

thinleaf, see $V$. membranaceum

Hugo loam, 8

Hunting

fees, 17

policy, 13

See also Deer

Hydrophyllaceae, 129-30

Hymenoclea salsola, 7 (illus.)

Hypericum perforatum

control by insects, 29
Identification keys for browse plants, 39-44, 44-145

Incense cedar, see Calocedrus decurrens

Indian tobacco, see Arctostaphylos patula

Inkberry, see Lonicera involucrata

Insects

control of brush by, 29, 30

damage to browse plants, 29

Ironwood

desert, see Olneya tesota

mountain, see Cercocarpus betuloides

Jojoba, see Simmondsia chinensis

Joshua tree, see Yucca brevifolia

Judas tree, see Cercis occidcntalis

Juneberry, western, see Amelanchier alnifolia

Juniper, see Juniperus

California, see J. californica

oncseed, see J. osteospcrma

Utah, see J. osteosperma

western, see J. occidentalis

Junipers, see Juniperu.

Juniperus, $6,7,15,16,44,144$

californica, $38, \mathbf{4 5}$

communis var. saxatilis, 44

occidentalis, 16, 46

osteosperma, 45

Ket-ket-dizze, see Clamaebatia foliolosa

Key area, definition, 32

Key species, 32-33

definition, 32

Key to browse plants, 39-44, 44-145

Kidney-root, see Baccharis pilularis var. consanguinea

Kidneywort, see Baccharis pilularis var. consanguinea

Klamath weed, see Hypericum perforatum

Kochia, 69

americana, 69

map, 63

californica, 69

Koster's weed curse, see Clidemia hirta

Labiatae, 130-31

Lantana camara

control by insects, 29

Larrea divaricata, 7 (illus.), 95

Laughlin soil series, 24

Lauraceae, $70-71$

Laurel

California, see Umbellularia californica

family, see Lauraceae

sticky, see Ceanothus velutinus

Laurel sumac, see Rhus laurina

Legume family, see Leguminosae

Leguminosae, 93-95

Lemon leaf, see Gaultheria shallon

Lemonadeberry, sec Rhus integrifolic

Light burning, see Burns, controlled

Lilac, wild, see Ceanothus integcrrimus

Lithocarpus densiflora var. cchinoides, 61

Livestock

browse ratings for, 146-48

competition for forage, $15-17$

history and distribution, 9 (map)

nutritional requirements, 20,21

population trends (graph), 9

See also Cattle; Goats; Sheep

Lomatium, 16

Lonicera, 136

involucrata, 136

Los Gatos soil, 8, 24

Los Gatos stony clay loam, 8

Lotus, 94

scoparius, 15, 18, 94

Lupine, silver, see Lupinus albifrons

Lupinus albifrons, 10 
Madrone, see Arbutus, A. menziesii

Madroño, see Arbutus menzicsii

Mahala mat, see Ceanothus prostratus

Mahogany, desert, see Cercocarpus ledifolius

Valacosoma fragilis

defoliation of bitterbrush by, 29

Management, $13,16,17,31$

balanee of animal species, 21

dual use of public lands, 17 game, 12, 17

Manzanita, see Arctostuphylos

common, see A. manzanito

Eastwood, see A. glandulosa

grecnleaf, see A. patula

hoart; sce A. canescens

Mariposa, sec A. mariposu

Manzanitas, see Arctostap/rylos

Maple

big-leaf, see Acer macrophyllum

dwarf, see Acer glabrum

family, see Aceraceae

mountain, see Acer glabrum

species, primary, 99

species, secondary, 100

vine, see Acer circinatum

Maymen stony loam, $7,8,24$

Mechanical brush removal, 28, 30

advantages, 30

disadvantages, 30

Medicago hispida, 3

Mediterranean annuals, 3

Melica, 6

Meliegrass, see Melica

Minor conifer plant community

foothill range area, 22-23

Mint family, see Labiatae

Mockorange, see Philadelphus

wild, see $P$. lewisii var. californicus

Iolly, see Kochi

desert, see $K$. americana

grecn, sce $K$. americana

rusty, sec $K$. californicu

Mountain-ash, western, sce Sorbus sitchensis

Mountain balm, see Coanothus velutimus, Eriodictyon californicum

Mountain-mahogany, see Cercocurpus

birchleaf, see $C$. betuloides

eurlleaf, see C. ledifolius

desert, see $C$. ledifolius

true, sec C. montanus

western, see $C$. betuloides

Mountain misery, Sierra, see Chamaebatia, C. foliolosa

Mountain range, 2

forage competition, 16

forage conditions, 12

Mugwort, sce Artemisia

Mule fat, see Baccharis viminea

Mvrtle, Oregon, see Umbellularia californica

Needlegrass, see Stipa

Nightshade family, sece Solanaceae

Ninchark, western, see Physorarpus capitatus

\section{Oak, see Ouercus}

blue, sce Q. douglasii

Brewer, see $Q$. garryana var. breceri

California black, see $O$. kellogoii

California scruls, see $Q$. dumoses

canyem live, see (). chirysolepis

(raist live, see (). angrifolia

dwarf interior live, see $Q$. wislizenii var. frutescens

dwarf tanbark, sce Lithocarpuss densiflore var. echinoides

faunily, see liagaciate

(iirry, si. (). garryanu

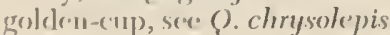

hickory, see Q. chrysolepis

huckleberry, see $Q$. vaccinifolia

interior live, see Q. wislizenii

iron, see $Q$. douglasii

leather, see $Q$. durata

maul, see $Q$. chrysolepis

mountain, see $Q$. douglasii

mountain live, see $Q$. chrysolepis

Oregon white, see Q. garryana

other genera, 61

pin, see Q. chrysolepis

post, see $Q$. garryana

Sadler, see O. sadleriana

serub interior live, see $Q$. wislizenii var. frutescens

species, primary, 57

species, secondary, 61

valley white, see $Q$. lobuto

white live, see Q. chryssolepis

Oaks, see Quercus

Oat, wild, see Avena

slender, see A. barbata

Ocotillo, see Fouquieria splendens

Oleaceae, 128-29

Oleaster family, see Elaeagnaceae

Olive family, sce Oleaceae

Olneya tesota, 7

Opuntia

control by insects, 29

bigelovii, 7

echinocarpa, 7

Oryzopsis hymenoides, 6

Palatability of plants, 35, 37-38

definition, 35

Papaveraceae, 71

Pea

chaparral, sce Pickeringia montuna

family, see Leguminoseae

Pear, prickly, see Opuntia

Pelleted feed, 33

Pepperwood, see Umbellularia californica

Phacelia fanily, see Hydrophyllaceae

Philadelphus, 74

lewsii var. californicus, 74

lewsii var, gordonianus, 75

Phlox, 16

Photinia arbutifolia, see Heteromeles arbutifolia

Phussocarpus capitatus, 92

Picea, 144

Pickeringia, 94

montuna, 94

Pigeon berry, see Amelanchier alnifolia Rhamnus californica

Pignut, see Simmondsia chinensis

Pinaceac, 144

Pine, see Pinus

Digger, see $P$. saliniana

family, see Pinaceace

piñon, see $P$. edulis

ponderosa, see $P$. ponderosa

singleleaf piñon, see $P$. monophylla

Pinus, 144

edulis, 145

monophylla, 144, 145

pourderosa, 5,144

sabiniana, 3, 4 (illus.), 10, 145

Plant suceession, 4

Plum, see Prunus

Klamath, see $P$. subcordata

Pacific, see P. subcordata

Sierra, see P. subcordata

Pou, 6, 15, 33

ganure-livestock compctition for, 33

Poison-oak, see: Rhus diversilobu

Polygonaceac, 62-6.3

Ponderosa pine, see Pinus ponderosa

Poplars, sec Populus:
Poppy

bush, see Dendromecon rigida

family, see Papaveraceae

Populus, 38, 50

fremontii, 51

tremuloides, $\mathbf{5 1}$

browsing, 33

trichocarpa, $\mathbf{5 2}$

Potentilla fruticosa, 92

Primary browse families, 38

Prosopis chilensis, 7

Prunus, 4, 5, 88

emarginata, 5 (illus.), 89

map, 90

subcordata, 89

map, 87

virginiana var, demissa, 89

seed germination, 25

Pseudotsuga menziesii, 144

Purshia, 38, 75

glandulosa, 77

planting, 25

seed germination, 26

grazing, 35

planting, 25

seed germination, 25, 26

tridentata, $6,11,15,16,20,75$

browse utilization study, 32 (table)

browsing of, 32,33

defoliation by insects, 29

game-livestock competition for, 33

map, 77

planting experiments, 25

seed germination, 26

Quail brush, see Atriplex polycarpa

Quercus, 10, 16,55

agrifolia, 3, 61

chrysolepis, 3, 61

douglasii, 3,4 (illus.), 10, 18, 59

dumosa, 3, 20, 58

durata, 3

garryana, 3, 61

garryana var. breweri, 5, 11, 61

kelloggii, 60

lobata, 3,61

sadleriana, 5

vaccinifolia, 61

wislizenii, 3,10

wislizenii var. frutescens, $3,20,57$

Quinine bush, see Garryaceae

Quinine-bush, see Cowania mexicana var. stansburiana

Quinine plant, see Simmondsia chinensis

Rabbitbrush, see Chrysothamnus, C. viscidiflorus

roundleaf, see C. terctifolius

rubber, see C. nauseosus

Rabbitbrushes, see Chrysothamus

Rabbitsage, see Chrysothamnus, C, viscidiflorus

Ragweed, see Senecio jacobea

Range improvement, 13, 23-24 costs, 23,28

estimate of success, 23-24

factors necessary for, 24, 26-32

selection of method, 30-32

surveys, 22

Range land

brush land converted into, 23

Range types, table, 2

Redberry, hollyleaf, see Rhummus crocea var. ilicifolia

Redbrush, see Cormus stolonifera

Redbut, see Cercis

westem, see C. occidentalis

Red shanks, sec Adenostona sparsifolium

Reseceling, see Secling 
Rhamnaceae, 38, 102-15

Rhamnus, 38, 112

californiea, 3, 4 (illus.), 10, 18, 112

grazing, 38

map, 113

crocea var. ilicifolia, 3, 4 (illus.), 10, 113

map, 114

purshiana, 114

species, primary, 112

species, secondary, 114

Rluus, 97

diversiloba, 4, 10, 18, 97

map, 87

integrifolia, 6

laurina, 6

trilobata, 4, 98

Ribbonwood, see Adenostoma sparsifolium

Ribes, 72

californicum, 74

cereum, 74

divaricatum var. inerme, 74

menziesii, 74

nevadense, 74

roezlii, 74

sanguineum var. glutinosum, 74

species, primary, 72

species, secondary, 74

speciosum, 74

viscosissimum, 72

viscosissimum var. hallii, 72

Ricegrass, Indian, see Oryzopsis hymenoides

Ripgut, see Bromus rigidus

Rosa , 4, 91

californica, 91

Rosaceae, 38, 75-9:3

Rosaceous species

other, 92

primary, 75

secondary, 8.5

Rose, see Rosa

California wild, see $R$. californica

family, see Rosaceae

wild, see Rosa

Roses, see Rosa

Rubus parviflorus, 4, 92

Running oak, see Chamaebatia foliolosa

Rye, cereal

seeding, 30 (illus.)

Ryegrass, annual

seeding, 30 (illus.)

Sage

black, see Artemisia tridentata, Salvia mellifera, Tetradymia canescens

blue, see Salvia carnosa

desert, see Salvia carnosa

feather, see Eurotia lanata

purple, see Salvia leucopliylla

red, see Koehia amcricana

spiny, see Grayia spinosa

white, see Chrysothamnus nauscosus, Eurotia lanata, Salcia apiana

winter, see Eurotia lanata

yellow, see Chrysothamnus viscidiflorus

Sagebrush, see Artemisia

big, see A. tridentata

black, see A. arbuscula var. nova

bud, see A. spinescens

California, see A. californica

coast, see A. californica

common, see A. tridentata

dwarf, see A. arbuscula var. nota

fringed, see A. frigida

hoary, see A. cana

species, primary, 138

Sagebrushes, see Artemisia

St. Johnswort, see Hypericum perforatum

Salal, see Gaultheria, G. shallon

Salicaceae, $38,48-52$
Salix, 4, 38, 48

breweri, 50

exigua, 50

liindsiana, 50

lasiandra, 50

lasiolcpis, 50

lemmonii, 50

scouleriana, 49

Saltbush, see Atriplex, A. confertifolia

Australian, see A. semibaccato

family, see Chenopodiaceae

fourwing, see $A$. canescens

Gray's see Grayia spinosa

nuttall, see A. unttallii var. falcato

species, primary, 64

species, secondary, 67

spiny, see A. confertifolia

Saltbushes, see Atriplex

Saltgrass, desert, see Distichlis stricta

Saltsage, see Atriplex confertifolia

Salvia

apiana, 6

carnosa, 131

leucophylla, 6

mellifera, 6

Sambucus, 4, 38, 132

caerulea, 10, 18, 133

caerulea var. velutina, 134

eallicarpa, 135

grazing, 35

racemosa, 134

map, 133

Sarcobatus, 68

vermiculatus, 68

Sarvisberry, sce Amelanclier alinifolia alderleaf, see Amclancliier alnifolia

Sawtooth golden bush, see Haplopappus squarrosus

Saxifragaceae, $71-75$

Saxifrage family, see Saxifragaceae

Secondary browse plants, 39 (table)

Seeding, 25, 31

artificial, 31

selecting suitable grasses, 31

Senecio jacobea control by insects, 29

Serviceberry, see Amelanchier

Utah, see A. utahensis

western, see A. alnifolia

Shadlscale, see Atriplex confertifolia

Shadscales, see Atriplex

Sheep

bighorn, 17

domestic, 9

control of brush by, 29-31, 33

diet, 20-21

Sheepnut, see Simmondsia chinensis

Sheplerdia argentca, 117

Silktassel

family, see Garryaceae

Fremont, sec Garrya fermontii

Simmondsia chinensis, 96 map, 93

Sites, 26-27

Skunk bush, see Rhus trilobata

Snowberries, see Symplioricarpos

Snowberry, see Symphoricarpos

common, see S. albus

mountain, see $S$. rotundifolius

Snowbrush, see Ceanothus velutinus

Snowbush, see Ceanothus velutinus

Soil-vegetation surveys, 22, 24

necessity for, 24

Soils

brushland

classification, 7-8

table, 8

grassland, 23, 27

necessity for greater knowledge of, 24 productivity, $8,30,31$

wildlands, 24

woodland-grass, 23

Solanaceae, 132

Solanum umbelliferum, 132 map, 131

Sorbus sitchensis, 9.3

Spanish bayonet, see Yucca baccata

Spraying, see Chemicals

Spruces, see Picea

Squaw bush, see Rhus trilobata

Squaw carpct, see Ceanothus prostratus

Sterculia family, see Sterculiaccae

Sterculiaceae, 116-117

Stipa, 6

Sumac, sce Rlius

family, see Anacardiaceae

laurel, see $R$. Jaurina

Sumacs, see Rhus

Sunflower family, see Compositae, Hcliantheae

Sweet birch, sce Ceanothus integerrimus

Sweet brush, see Cercocarpus betuloides

Symplioricarpos, 38, 135

albus, $4,15,16,135$

rotundifolius, 136

vaccinoides

nutritive values, 135

Syringa, vild, sec Pliiladelplus lewisii var. californicus

Taxus, 145

brevifolia, 145

Tetradymia, 143

canescens, 6,144 map, 143

glabrata, 144

spinosa, 6

Thimbleberry, see Rubus parciflorus

Threeawns, see Aristide

Timber chaparral, 2, 5

See also Chapparral

Tobacco bush, see Ccanothus velutinus

Tobacco plant, see Chamaebatia foliolosa

Toyon, see Ileteromeles, H. arlutifolia

Trefoil, bird's-foot, see Lotus

Twinberry, see Loniccra involucrata

Ulex europaeus, 29

Ulmaceae, 62

Umbcllularia californica, 4, 20,70

Use standards, 3.3, 35

Utah serviceberry, see Amelanchier utuhensis

Utilization of plants

definition, 35

Vaccinium, 124

membranaceum, 125

occidentalc, 125

map, 121

ovatum, 126

Vallecitos loan, 8

Vegetal belts, 1

Vitaceae, 115-16

Vitis californica, 115

Waterleaf family, see Hydrophyllaceae

IVaxberry, see Symphoricarpos

Weevil

control of gorse seed by, 29

Western serviceberry, see Anclanchier alnifolia

Wheatgrass, see Agropyron

bluebunch, see A, inerme

Whitethorn

chaparral, sec Ceanothus leucodermis

coast, see Ceanothus incanus

mountain, sce Ceanotlus cordulatus 
IVjld-]azel, see Simmondsia chinensis

IVild lands inventory, 24

Wildrie, see Elymus

Willow, sce Salix

arroyo, see S. lasiolepis

black, see S. scouleriana

Brewer, sce S. breweri

fanily, see Salicaceae

fire, see S. scouleriana

Lemmon, see S. lemmonii

narrowleaf, see S. exigua

Nuttall, see S. scouleriana

species, other, 50 species, primary, 49

valley, see S. hindsiana

vellow, see S. lasiandra

Willows, see Salix

Winter fat, see Eurotia, E. lanata

Wolf-berry, see Symphoricarpos

Woodland-grass brushland community, 1, 2 (illus.)

conversion to agricultural lands, 4

description, $2-3$

distribution, 2

foothill range area, 22-23 (tables)

Wormwood, see Artemisia
Yellow brush, see Chrysothamnus

Yellowbrush, see Chrysothamnus stenophyllus, Chrysothamnus viscidiflorus

rubber, see C. nauseosus

Yerba santa, see Eriodictyon

California, see $E$. californicum

Yew, western, see Taxus brevifolia

Yews, see Taxus

Yucca

baccata, 7 (illus.)

brevifolia, 7 (illus.)

Zygophyllaceae, 95-96 
Co-operative Extension work in Agriculture ond Home Economics, College of Agriculture, University of Colifornio, and United Stotes Deportment of Agriculture co-operoting. Distributed in furtheronce of the Acts of Cangress of May 8, and June 30, 1914. George B. Alcorn, Director, Colifornio Agriculturol Extension Service. 




